UNIVERSIDADE DE SÃo PAULO

FACULDADE DE FILOSOFIA, LETRAS E CIÊNCIAS HUMANAS

PROGRAMA DE Pós-GRADUAÇÃo EM HISTÓRIA SOCIAL

FÁbio Augusto MoRALES SOARES

\title{
Atenas e o Mediterrâneo romano espaço, evergetismo e integração
}

[versão corrigida]

São Paulo

2015 


\section{Atenas e o Mediterrâneo romano espaço, evergetismo e integração}

Tese apresentada ao Programa de PósGraduação em História Social da Faculdade de Filosofia, Letras e Ciências Humanas para obtenção do título de Doutor em História.

Área de Concentração: História Antiga.

Orientador: Prof. Dr. Norberto Luiz Guarinello

[versão corrigida]

São Paulo

2015 
Autorizo a reprodução e divulgação total ou parcial deste trabalho, por qualquer meio, para fins de estudo e pesquisa, desde que citada a fonte. 


\section{Cerâmica}

Os cacos da vida, colados, formam uma estranha xícara.

Sem uso,

ela nos espia do aparador.

(Carlos Drummond de Andrade)

\section{Urbana}

Diante da ingrata cidade, verdade

Irradia o pedido de amor, favor Interrompendo a ordem caótica, robótica

Do insano mar de automóveis, imóveis

Pedido cego e oculto, insulto?

No urbano caos invisível, risível Quer torna-se grito mas para, e cala

Sem socorro e sem sentido, olvido

Palco da dádiva marginal, Radial

Persiste a majestosa figura, candura

Simplória entrega o coração, absolvição

Transformando o conforto da dor, em Amor!

(Cynthia Oliveira) 
À Cynthia,

À Cleusa, Clarice e Leonor. 


\section{Agradecimentos}

Muitas pessoas colaboraram, direta ou indiretamente, para a elaboração desta pesquisa; uma tese é obra de muitos, e qualquer agradecimento, por mais extenso que fosse, não faria justiça a todo apoio que recebi.

Primeiramente, agradeço à Cynthia, pelo amor e pelo privilégio da convivência, fonte infinita de inspiração.

Agradeço profundamente à minha família e amigos de longa data, por suportar as longas ausências e mesmo as presenças preocupadas, como se tornou habitual desde o mestrado. Agradeço à Cleusa, ao Junior, ao Ricardo, à Leonor, à Clarice, à Stephanie, à Patrícia, ao Matheus, ao Marcos, ao César, à Elaine, ao Júlio, ao Rafael, à Franci, ao Levy e à Lia; e também à Rosa, ao Rafael Fortes, ao Cristiano, ao Thiago, ao René, ao Rafael Prado, ao Marcius, ao Mani, ao Daniel, ao Manolo, à Joice, ao Junior, e com uma imensa saudade, ao Moacir, in memoriam.

Agradeço ao CNPq pela concessão da bolsa que tornou esta pesquisa possível, assim como a Universidade de São Paulo, pela formação desde o início da graduação, à École Française d'Athènes, por colaborar com as duas imprescindíveis estadias em Atenas e pelo seminário de formação doutoral, e à American School of Classical Studies at Athens, pela ampla disponibilização do material escavado na ágora. Agradeço ainda aos funcionários das bibliotecas "Florestan Fernandes" (FFLCH/USP), da biblioteca do Museu de Arqueologia e Etnologia (MAE/USP) e das bibliotecas das supracitadas escolas francesa e americana de Atenas.

Agradeço ao meu orientador, Norberto Luiz Guarinello, por sua generosidade sem limites, demonstrada seja nas leituras devoradoras de pressupostos assentados, seja na confiança (algumas vezes temerária) depositada em mim. Sua liberdade intelectual, sem concessões, é uma das melhores demonstrações da autenticidade no trabalho do historiador, e permanece, para mim, uma meta. Agradeço também aos muitos professores que participaram da minha formação como pesquisador e professor, das bancas de qualificação às conversas em simpósios, das salas de aula aos debates etílicos; Maria Beatriz Borba Florenzano, pelos cursos de pós-graduação, textos e conversas que me iniciaram na pedregosa estrada da Arqueologia; Carlos Augusto Ribeiro Machado, 
por sua disposição, em conversas, cursos e bancas, em me oferecer caminhos (práticos e teóricos) que eu (eventualmente) não aceitaria, mas que permanecem me atormentando/inspirando mesmo após de terminada a tese; Breno Battistin Sebastiani, cujo curso de grego antigo esteve na base da minha jornada na pós-graduação; Fábio Faversani, pela disposição crítica e bem humorada de desmontar seguranças teóricas; Maria Isabel d'Agostino Fleming, cujo curso sobre romanização (com ou sem aspas) me indicou o tamanho do problema assim como as vias de superá-lo; Elaine Farias Veloso Hirata, cujo curso de pós-graduação em teoria arqueológica me possibilitou palmilhar esta estrada com mais propriedade; Jorge da Silva Grespan, cujo materialismo permaneceram como horizonte teórico muito após os cursos iniciais; Nicolau Sevcenko, in memoriam, pela capacidade de transtornar a sisudez dos rituais acadêmicos pela análise rigorosa da cultura; Haiganuch Sarian, pelo apoio indispensável em minhas missões atenienses; Ístvan Jancsó, também in memoriam, pela introdução primeira às ciências históricas; Patrick Marchetti, Jean-Charles Moretti e Jean-Yves Marc, pelo curso de formação doutoral na $E F A$, cujo rigor e capacidade de síntese estabeleceram um novo patamar em minha pesquisa; Emanuele Greco, pelas perspicazes sugestões para a solução de alguns dos mais complexos enigmas da topografia ateniense tratados na tese; e, finalmente, Ulpiano Toledo Bezerra de Meneses, por ter instituído em mim uma absolutamente nova relação com as fontes históricas e arqueológicas.

Agradeço também aos professores e alunos das diversas sedes do Laboratório de Estudos sobre o Império Romano (LEIR) pelo Brasil, em cujos encontros tive o privilégio de contar com as críticas e sugestões a diversos aspectos da pesquisa. Destes, agradeço em particular à Margarida Maria de Carvalho, à Helena Papa, à Semíramis Corsi, ao Gilvan Ventura da Silva, à Ana Teresa Marques Gonçalves, ao Lucas Sousa, ao Fábio Duarte Joly e à Juliana Bastos Marques (responsável, aliás, pelo desafio que originou a tese). No âmbito do Laboratório de Estudos sobre o Império e o Mediterrâneo Antigo (LEIR-MA/USP), cujas reuniões anárquicas funcionaram como uma segunda (e terceira, e quarta, e quinta...) orientação, não tenho palavras suficientes para agradecer a convivência aos colegas Gilberto da Silva Francisco, Uiran Gebara da Silva, Gustavo Junqueira, Sarah Azevedo, Camila Zanon, Bruno dos Santos Silva, Ivana Teixeira, Juliana Monzani, Francisco Sabadini, Alan Nicolaev, Pedro Piza, Tatiana Bina, Ygor Belchior, Alex Degan, Rafael Costa Campos, Aline Rodrigues e Gaya Gicovate. 
Também agradeço aos professores e alunos de diversos laboratórios, núcleos de pesquisa no Brasil cujo convívio e colaboração foram de grande importância para o amadurecimento da pesquisa, tais como o Laboratório de Estudos sobre a Cidade Antiga (LABECA) e do Laboratório de Arqueologia Romana Provincial (LARP), ambos no MAE-USP, e do Laboratório de Arqueologia Pública (LAP) da Unicamp, do Núcleo Interdisciplinar de Estudos e Pesquisas sobre Marx e o Marxismo - Pré-Capialismo (Niep-PréK), da UFF, o Laboratório de História Antiga (LHIA) da UFRJ, o Núcleo de Estudos da Antiguidade (NEA) da UERJ; agradeço, em particular, à Maria Cristina Kormikiari, ao Vagner Porto, à Irmina Doneaux Santos, ao Felipe Perissato, à Lilian Laky, ao Estevam de Argos, Pedro Paulo Funari, ao Zé Knust, ao Fábio Frizzo, ao Gabriel Melo, à Maria Tereza David João, ao Mario Jorge Bastos, ao Júlio César Oliveira, à Maria Regina Cândido, ao Carlos Eduardo Campos, à Cláudio Beltrão, a Airan Borges, à Regina Bustamante, à Marta Mega de Andrade.

Agradeço também ao professor Arjan Zuiderhoek e demais participantes do workshop sobre as identidades imperiais realizado na Universidade de Ghent (Bélgica), pelas sugestões e pela ampliação das perspectivas.

Agradeço ainda aos colegas da PUC-Campinas pelo fundamental apoio durante a escrita da tese, em particular aos professores Lindener Pareto Jr., João Miguel Godoy, Janaína Camilo, Ana Rosa Cloclet, Ester Sartori, Roberto Donato, Breno Campos, Glauco Barsalini, Ana Paula Bolfe, Artur Vitorino, Geraldo Sabino; e a todos os alunos com os quais eu pude fabricar estas obras coletivas, chamadas por alguns de "aulas". 


\section{Resumo}

MORALES, Fábio Augusto. Atenas e o Mediterrâneo romano: espaço, evergetismo e integração (200 a.C. - 14 d.C.). 2014. 429 f. Tese (Doutorado) - Faculdade de Filosofia, Letras e Ciências Humanas, Universidade de São Paulo, São Paulo, 2015.

Esta tese discute a produção do espaço urbano em Atenas de 200 a.C. a 14 d.C., analisando a interação entre práticas evergéticas, propaganda dinástica/imperial, e tradições e demandas locais. Após um extensivo levantamento dos estudos sobre o tema, assim como suas fontes e paradigmas, os capítulos que seguem discutem as intervenções espaciais em Atenas realizadas por ou em associação a reis helenísticos, potentados romanos e a casa imperial. Argumenta-se que estas intervenções formaram diferentes programas urbanos com lógicas espaciais específicas; e cada programa urbano deveria dialogar com os anteriores para afirmar sua própria lógica. Mais do que uma mera metáfora da história política, a história espacial de Atenas tardo-helenística e romana é tomada como parte da cultura material pela qual as estruturas políticas locais e imperiais se (re)produziam, no contexto de processos de integração mediterrânicos específicos.

Palavras-Chave: Atenas Pós-Clássica; Evergetismo; Integração; Espacialidade; Romanização. 


\section{Abstract}

MORALES, Fábio Augusto. Athens and the Roman Mediterranean: space, euergetism and integration (200 B. C. - 14 A. D.). 2014. 429 f. Thesis (PhD) - Faculdade de Filosofia, Letras e Ciências Humanas, Universidade de São Paulo, São Paulo, 2015.

This thesis discusses the production of the Athenian urban space from $200 \mathrm{BC}$ to $14 \mathrm{AD}$, analyzing the interaction between euergetic practices, dynastic/imperial propaganda, and local traditions and demands. After a extensive survey of the studies on this subject and their sources and paradigms, the following chapters discuss the Athenian spatial interventions made by or in association with Hellenistic kings, Roman rulers and the imperial family. It is argued that these interventions formed different urban programs with specific spatial logics; and each urban program must dialogue with the earlier ones to assert its own logic. More than a mere metaphor of political history, the spatial history of Late Hellenistic and Early Roman Athens is taken as part of the material culture by which imperial and local political structures (re)produced themselves, in the context of specific Mediterranean's process of integration.

KEY-WORDS: Post-classical Athens; Euergetism; Integration; Spatiality; Romanization. 


\section{Sumário}

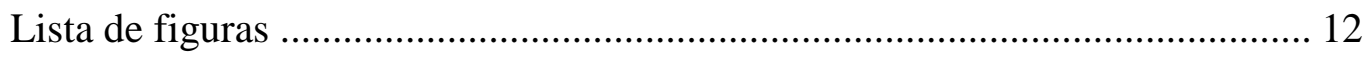

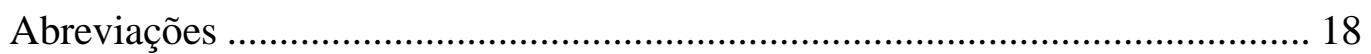

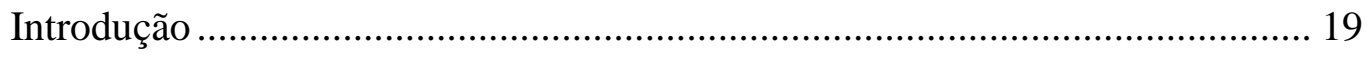

Espaço urbano na Atenas pós-clássica: formas e paradigmas ......................... 28

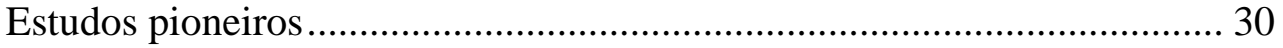

A revolução documental (1930-1990) ………………………………….... 36

Revoluções teóricas e metodológicas (1990-2010) ...................................... 49

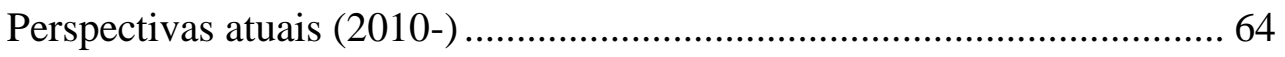

Capítulo 1. A cidade tardo-helenística............................................................... 73

As destruições de Filipe e a criação da tribo Attalis......................................... 88

A presença atálida na acrópole ...................................................................... 102

A Dedicação Atálida na acrópole e os "pequenos bárbaros" .................... 102

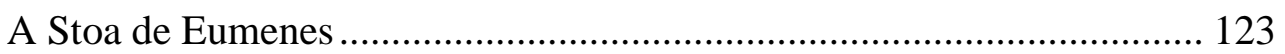

Os pilares "atálidas" ............................................................................... 129

A reforma do Erechtheion …………………………………………….... 131

A ágora tardo-helenística.......................................................................... 134

A praça Sul, as demolições e o Ptolemaion ................................................. 134

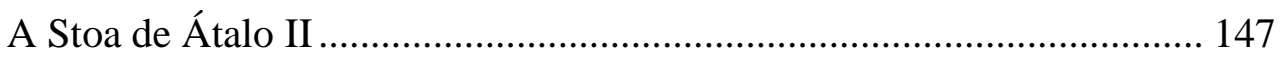

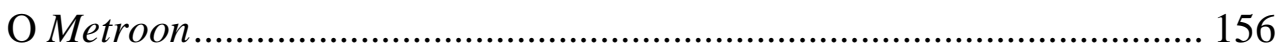

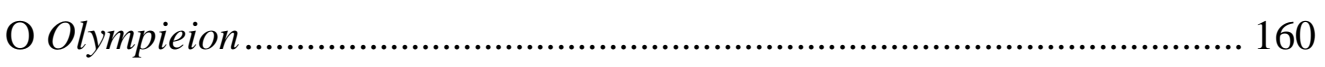

O Banho Sudoeste e o Horologium ………………………………………... 164

Capítulo 2. A formação da "Atenas romana" ....................................................... 170

Antes do saque: as primeiras intervenções "romanas" ................................... 174 
O Rhomaion

O santuário do Demos, das Graças e de Roma ........................................ 177

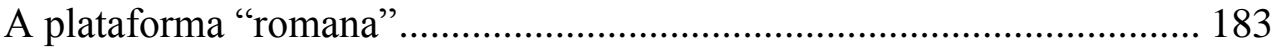

O saque de 86: destruições e recomposições ............................................. 197

Filosofia e tirania em Posidônio/ ............................................................ 199

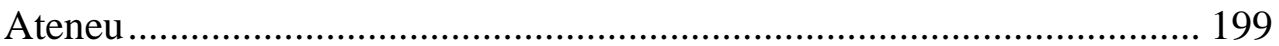

Plutarco, entre Atenas e Roma................................................................ 213

Apiano, entre Atenas e Alexandria .................................................... 217

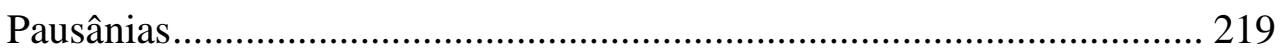

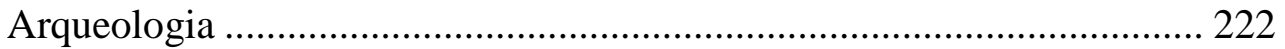

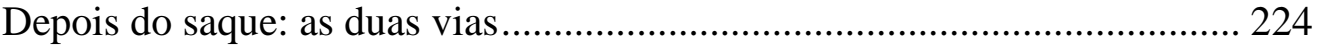

Ático, Cícero e o antiquarianismo romano em Atenas ............................ 225

Pompeu e Ariobarzanes em Atenas: novos e antigos bárbaros ................ 235

Atenas na guerra civil: César, os cesaricidas e Antônio ............................ 248

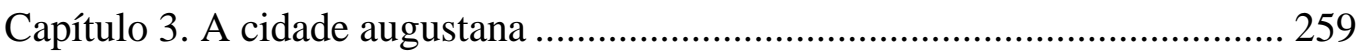

Augusto e a acrópole de Atenas............................................................... 262

O monóptero de Roma e Augusto na acrópole ......................................... 262

Reforma do Asklepeion ......................................................................... 279

O santuário de Apolo Hypoakraios............................................................ 282

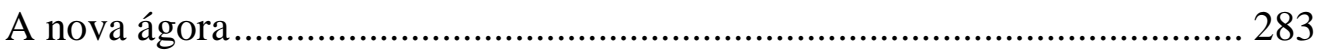

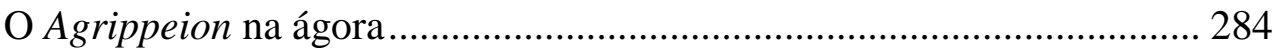

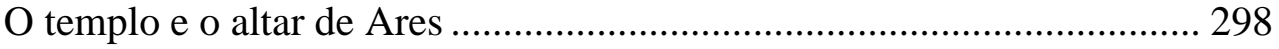

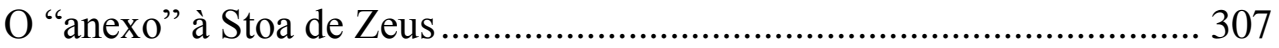

O novo recinto do Tholos-Bouleuterion-Strategion e outras reformas..... 312

Intervenções no norte da ágora ........................................................... 315

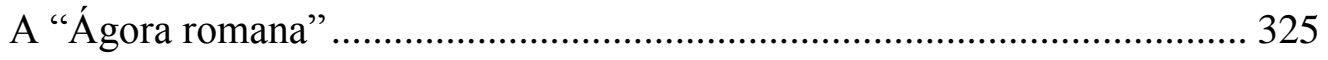

A restauração dos santuários da Ática (IG II2 1035).................................. 335 
Conclusão

As lógicas do programa urbano tardo-helenístico

Urbanismo antiquário e comemoração monárquica 352

As lógicas do programa augustano 356

Bibliografia ...... 360

Fontes literárias:. 360

Estudos: 361 


\section{Lista de figuras}

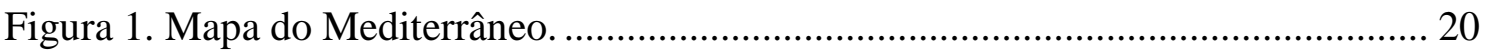

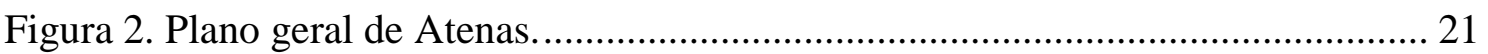

Figura 3. Proposta de reconstituição da planta da acrópole no período imperial ........... 22

Figura 4. Proposta de planta da ágora no período imperial (II d.C.) ............................. 23

Figura 5. Fotografia da arcada posterior da Stoa de Eumenes. ..................................... 31

Figura 6. Desenho dos vestígios da Stoa de Átalo II.................................................. 31

Figura 7. Fotografia do Olympieion a partir do oeste................................................... 31

Figura 8. Desenho da "Torre dos Ventos"..................................................................... 31

Figura 9. Fotografia da arquitrave do monóptero de Roma e Augusto .......................... 32

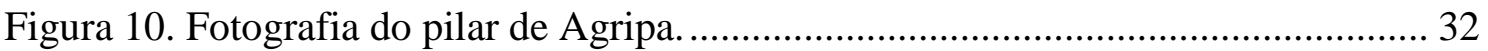

Figura 11. Desenho da vista do propileu ocidental da Ágora Romana a partir do oeste.33

Figura 12. Fotografia dos fragmentos A e C da estela com a inscrição IG II2 1035. .... 33

Figura 13. Proposta de reconstituição da ágora em meados do século II d.C. ............... 39

Figura 14. Fotografia da Stoa de Átalo II reconstruída a partir do sudoeste................... 40

Figura 15. Fotografia aérea da área da Praça Sul. ......................................................... 40

Figura 16. Fotografia aérea da área escavada do Metroon........................................... 40

Figura 17. Fotografia das bolas de pedra lançadas por catapulta no Aiakeion ............... 41

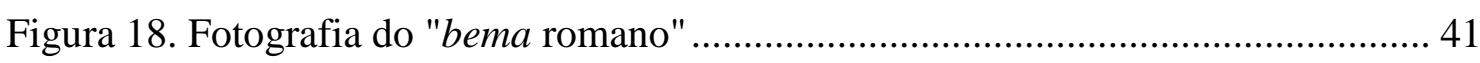

Figura 19. Fotografia das escavações na área do Agrippeion a partir do sul ................. 41

Figura 20. Fotografia do templo e altar de Ares a partir do nordeste ............................ 42

Figura 21. Fotografia do altar de Zeus Agorarios a partir do noroeste ......................... 42

Figura 22. Fotografia das escavações do anexo à Stoa de Zeus a partir do norte ........... 42

Figura 23. Detalhe da fotografia aérea da região sudoeste da ágora ............................. 42

Figura 24. Detalhe da proposta de planta da ágora........................................................ 54

Figura 25. Fotografia do altar arcaico e do Templo Noroeste a partir do sul................. 54

Figura 26. Fotografia aérea do área noroeste da ágora com detalhe para o limite oriental

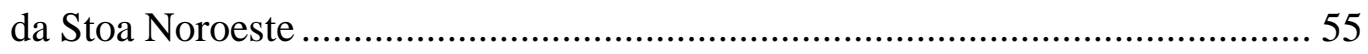


Figura 27. Fotografia dos vestígios da Stoa Nordeste a partir do oeste

Figura 28. Proposta de planta da ágora e arredores em 86 a.C., mostrando edifícios e monumentos destruídos ou danificados por Sula 59

Figura 29. Proposta de reconstituição da ágora antes da divisão tardo-helenística......... 70

Figura 30. Comparação entre as áreas livres da ágora na época romana com a Pnix e o teatro de Dioniso. 71

Figura 31. Planta do estado atual do edifício identificado como "Arsenal helenístico".76

Figura 32. Detalhe da proposta de planta da ágora por volta do ano 100 76

Figura 33. Proposta de reconstituição da planta baixa da área noroeste da ágora no século II d.C.

Figura 34. Detalhe da proposta de Maria Chiara Monaco para a reconstituição da planta do noroeste da ágora no século II a.C. 80

Figura 35. Altar a Afrodite Hegemone e às Graças exposto no Museu Arqueológico Nacional de Atenas 80

Figura 36. Fotografia aérea do monumento dos Heróis Epônimos 85

Figura 37. Proposta de reconstituição da planta baixa e da elevação frontal e lateral da fase IV do Monumento dos Heróis Epônimos. 85

Figura 38. Fragmentos de estátua de bronze folheada a ouro, encontrada em poço 3 metros ao norte do recinto da encruzilhada. 94

Figura 39. Visão aérea da região norte/noroeste da ágora, com o recinto da encruzilhada no centro-direita da imagem, com o poço sagrado logo acima 94

Figura 40. Planta do estado atual da região noroeste da ágora..................................... 96

Figura 41. Proposta de reconstituição da esquina noroeste da ágora ............................. 96

Figura 42. Detalhe da proposta de planta da ágora no século II d.C.......................... 100

Figura 43. Planta do estado atual do Períbolo Retangular........................................... 100

Figura 44. Fotografia da estátua plena do "gigante" .................................................. 110

Figura 45. Fotografia da estátua plena da "amazona" ................................................... 110

Figura 46. Fotografia de estátua plena de "persa" ...................................................... 110

Figura 47. Fotografia de estátua plena de "gaulês" ....................................................... 111

Figura 48. Fotografia das estátuas plenas dos "gauleses" do Museu Arqueológico Nacional de Veneza.

Figura 49. Fotografia da estátua plena do "persa" no Museu do Vaticano ................... 114

Figura 50. Fotografia da estátua plena do "gaulês" do Museu Granet ......................... 115

Figura 51. Fotografia da estátua plena do "gaulês" do Museu do Louvre..................... 115 
Figura 52. Proposta de planta baixa e seção da acrópole na (altura da fachada leste do Pártenon) após as escavações de 1885-90, por P. Kavvadias e G. Kawerau .... 118

Figura 54. Proposta de reconstituição da perspectiva das bases da Dedicação Atálida vista do leste, por M. Korres.

Figura 55. Proposta de reconstituição da elevação da área sudeste da acrópole no período helenístico vista do norte

Figura 56. Fotografia do bloco do friso meridional do templo de Atena Nike exposto do British Museum. 120

Figura 57. Fotografia da estátua plena do guerreiro moribundo do frontão oriental do templo de Afaia em Egina.

Figura 58. Fotografia de estátua plena de "gaulês" 121

Figura 60. Fotografia da estátua plena de "gaulês" 122

Figura 61. Proposta de reconstituição da planta da acrópole no período imperial

Figura 62. Propostas de elevação e de planta baixa da Stoa de Eumenes

Figura 64. Detalhe de proposta de reconstituição da planta da acrópole de Pérgamo . 128

Figura 65. Fotografia do pilar de Agripa

Figura 66. Desenho do estado atual da superfície do "pilar de Agripa" 129

Figura 67. Desenho do estado atual do pilar ao nordeste do Pártenon. 130

Figura 68. Proposta de reconstituição do "pilar atálida" junto ao Pártenon, 130

Figura 69. Fotografia do lintel da porta norte do Erechteion 133

Figura 71. Proposta de reconstituição da elevação parcial da "Praça Sul" 135

Figura 72. Proposta de reconstituição da planta da região ao norte da acrópole após a invasão dos hérulos em 267 d.C.

Figura 73. Proposta de reconstituição da planta dos três níveis da Stoa de Átalo II.... 148

Figura 74. Fachada reconstruída da Stoa de Átalo II 149

Figura 75. Planta com proposta de reconstituição da ágora e arredores e indicação dos lotes ocupados por edifícios modernos. 151

Figura 76. proposta de reconstituição da planta da ágora em c. 100. 155

Figura 78. Proposta de elevação parcial do Metroon no século II 157

Figura 79. Proposta de reconstituição da elevação da fachada do Olympieion no século VI 162

Figura 80. Proposta de reconstituição da planta do Olympieion no século VI 162

Figura 81. Proposta de reconstituição da elevação da fachada do Olympieion no século II. 162 
Figura 82. Proposta de reconstituição da planta baixa do Olympieion no século II..... 162

Figura 83. Moeda de prata, Antioquia, c. 169/8-164 ................................................... 164

Figura 84. Planta do estado atual do "banho helenístico". .......................................... 165

Figura 85. Fotografia debanheira de mármore encontrada próximo ao "banho

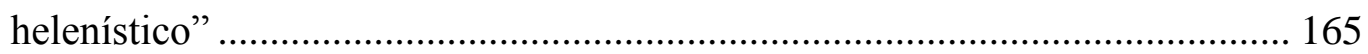

Figura 86. Proposta de reconstituição da planta do "edifício em poros" ...................... 167

Figura 87. Proposta de reconstituição da elevação do "edifício em poros" .................. 167

Figura 88. Fotografia da "Torre dos Ventos" a partir do noroeste ............................... 168

Figura 89. Planta da Torre dos Ventos, segundo Stuart e Revett em 1767 .................. 168

Figura 90. Detalhe da proposta de reconstituição da ágora ateniense no século II a.C.180

Figura 91. Detalhe da proposta de reconstituição da região noroeste da ágora............. 180

Figura 92. Estatueta identificada como "Afrodite Urânia" encontrada no noroeste da

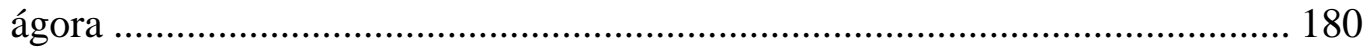

Figura 93. Detalhe de planta com curvas de nível da ágora e arredores. ..................... 184

Figura 94. Comparação das propostas de planta do Odeion de Péricles (esquerda) e da Sala do Trono de Persépolis.

Figura 95. Fotografias de bases de estátua dedicadas a Júlio César encontrada na ágora ateniense. 251

Figura 97. Fotografia da cópia romana do grupo de Harmódio e Aristogiton 255

Figura 98. Fotografia da cópia romana em mármore da estátua de Aristogiton encontrada no Capitólio 255

Figura 100. Reconstituição da planta do monóptero de Roma e Augusto .................... 264

Figura 101. Proposta de reconstituição da elevação do monóptero .............................. 264

Figura 103. Fotografia de detalhe da fachada oriental do Erechtheion e detalhe de coluna jônica do Erechtheion 265

Figura 104. Moeda de bronze, Atenas, c. 264-267 d.C............................................ 266

Figura 105. Gravura da região diante da fachada leste do Pártenon ............................. 266

Figura 106. Moeda de ouro, Espanha (Caesaraugusta?), c. 19/8................................ 271

Figura 108. Fotografia da estátua em mármore de Augusto de Prima Porta, c. 20..... 275

Figura 109. Representação das relações métricas entre o Pártenon e o monóptero. .... 276

Figura 110. Proposta de reconstituição da disposição dos edifícios e monumentos do santuário de Atena Nikephoros em Pérgamo no início do século II.

Figura 111. Detalhe da proposta de reconstituição da planta da acrópole ateniense.... 277

Figura 112. Proposta de reconstituição de planta do Asklepieion .................................. 280 
Figura 113. Planta baixa do estado atual do Agrippeion ........................................... 285

Figura 114. Reconstituição das plantas do Odeion..................................................... 286

Figura 115. Reconstituição da seção norte-sul do Odeion ........................................... 286

Figura 116. Reconstituição da seção leste-oeste do Agrippeion .................................. 286

Figura 117. Maquete do Agrippeion, visto a partir do noroeste ................................. 286

Figura 118. Maquete do Agrippeion, visto a partir do noroeste .................................. 286

Figura 120. Proposta de reconstiuição da elevação do Bouleuterion de Mileto............ 290

Figura 121. Proposta de reconstituição da planta do "pequeno teatro" de Pompéia.... 291

Figura 122. Proposta de reconstituição da planta do templo de Ares............................ 300

Figura 123. Proposta de restauração da seção longitudinal da elevação do templo de Ares..... 300

Figura 124. Imagem de satélite das fundações do templo de Athena Pallenis ............. 301

Figura 125. Estado atual das fundações do Santuário de Atena Pallenis ...................... 301

Figura 127. Métopa I do friso leste do templo de Hefestos na ágora ateniense ........... 305

Figura 128. Métopa IV do friso sul do templo de Hefesto na ágora ateniense ............ 305

Figura 129. Planta do estado atual e reconstituição do limite setentrional da Stoa de Zeus Libertador 308

Figura 130. Fragmento de estátua de Vitória alada atribuído aos acrotérios da Stoa de Zeus Libertador 308

Figura 131. Detalhe da proposta de reconstituição dos edifícios do lado ocidental da ágora.

Figura 132. Proposta de reconstituição da planta da Stoa de Zeus Libertador em época romana.

Figura 133. Fotografia dos fragmentos de base de monumento encontrados no ambiente meridional do anexo da Stoa de Zeus Libertador. 309

Figura 134. Fragmento inscrito da base do monumento localizado em ambiente medional do anexo da Stoa de Zeus Libertador, inserido no perfil do pilar..... 309

Figura 135. Detalhe da proposta de reconstituição do lado ocidental da ágora no período imperial

Figura 136. Comparação da localização da Stoa Pintada (indicada pela seta azul) no detalhe das propostas de reconstituição da planta da ágora. 316

Figura 138. Fotografia dos fragmentos ósseos de cães encontrados no depósito G 5:3. 
Figura 140. Fotografia de fragmento da parte superior de placa em ágata (quartzo) marrom com perfil de Otávio e caduceu em baixo relevo.

Figura 141. Detalhe da proposta de reconstituição da planta da região norte da ágora.

Figura 142. Fotografia dos fragmentos arquiteturais associados à Stoa Nordeste ........ 324

Figura 143. Proposta de reconstituição da planta da Ágora Romana........................... 325

Figura 144. Desenho da vista do propileu ocidental da Ágora Romana a partir do oeste, segundo J. Stuart e N. Revett em 1767. 326

Figura 145. Proposta de reconstituição da fachada do propileu (interpretado como um templo), segundo J. Stuart e N. Revett em 1767 326

Figura 146. Fotografia das cavidades "de medida" no intercolúnio da colunata jônica exterior do pórtico sul.

Figura 147. Fotografia de equipamento para extração de azeite encontrado na ágora romana 330

Figura 148. Fotografias do capitel dórico da fachada oriental do propileu da acrópole e do capitel do propileu da Ágora Romana 334 


\section{Abreviações}

Agora I - Agora Inscriptions

ASCSA - American School of Classical Studies at Athens

BSA - British School at Athens

CID - Corpus des inscriptions de Delphes

CIG - Corpus Inscriptionum Graecarum

CIL - Corpus Inscriptionum Latinarum

DAI - Deutsches Archäologisches Institut

EFA - École Française d'Athènes

FD - Fouilles de Delphes

ID - Inscriptions de Délos

IG - Inscriptiones Graecae

IvP - Die Inschriften von Pergamon

LIMC - Lexicon Iconographicum Mythologiae Classicae

SAIA - Scuola Archeologica Italiana di Atena

SEG - Supplementum Epigraphicum Graecum

SIG - Sylloge inscriptionum Graecarum 


\section{Introdução}




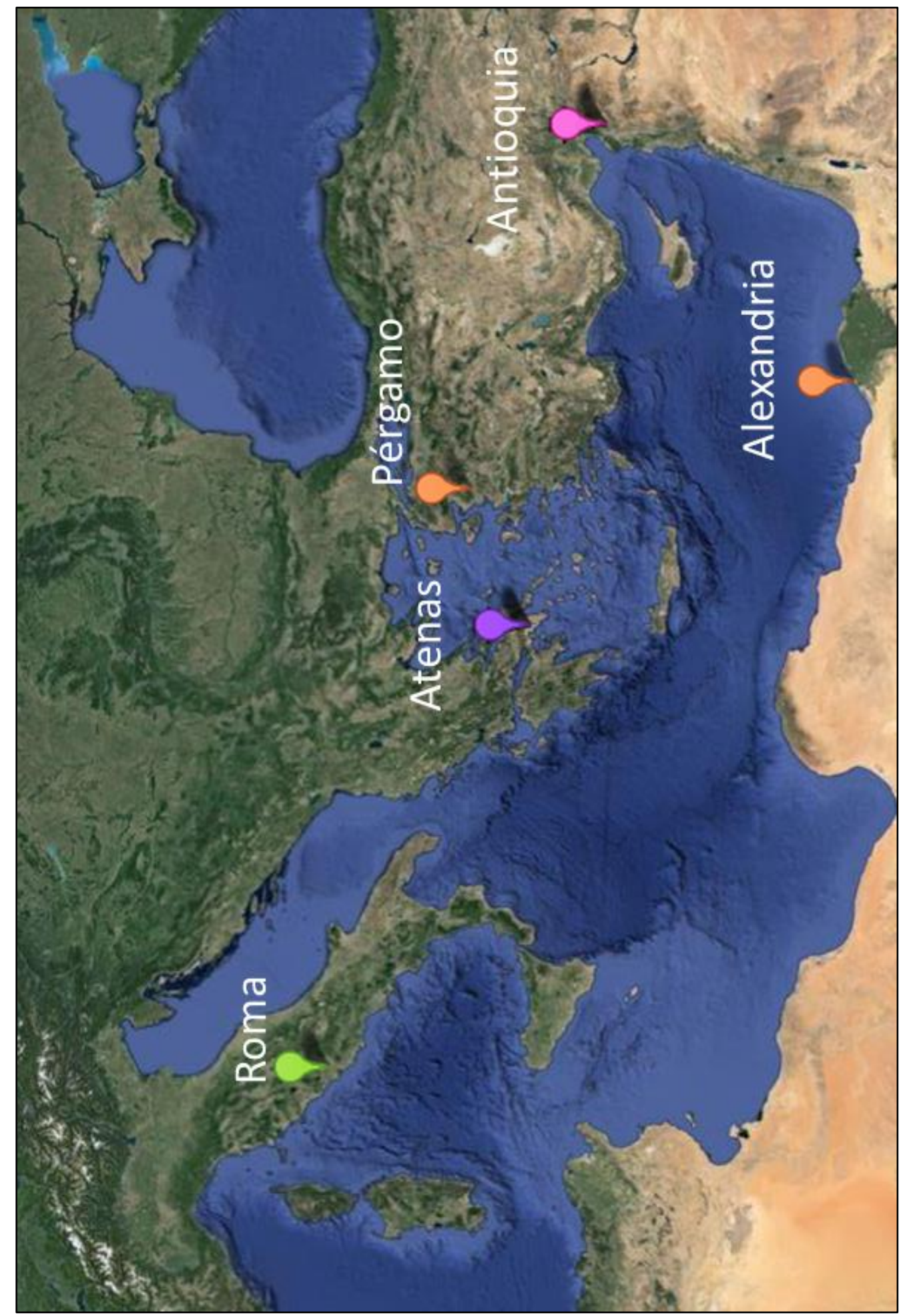

Figura 1. Mapa do Mediterrâneo (Google Earth). 


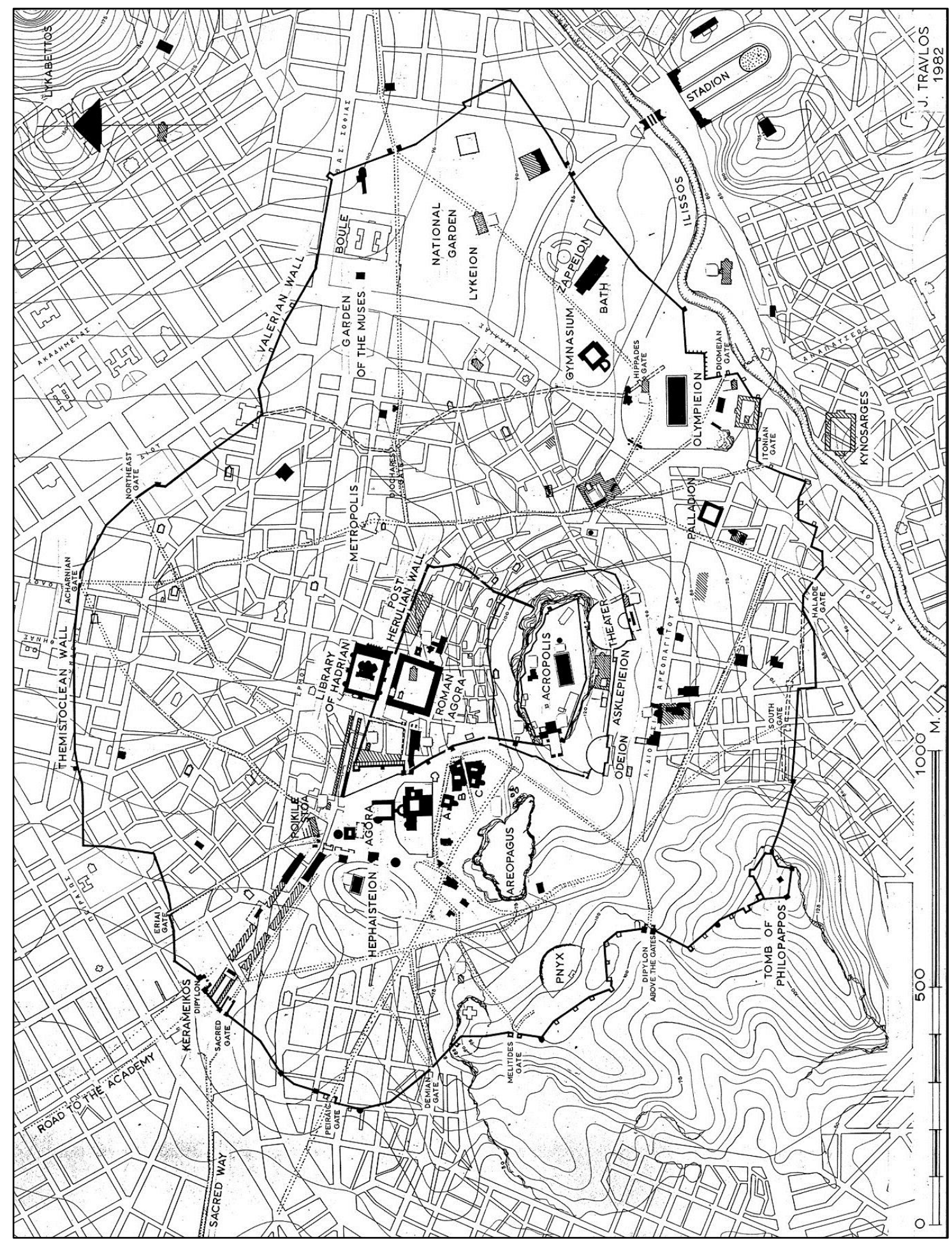

Figura 2. Plano geral de Atenas, feito por J. Travlos em 1982 (ASCSA ${ }^{1}$ ).

\footnotetext{
${ }^{1}$ Disponível em: http://agora.ascsa.net/id/agora/image/2002.01.2661.
} 


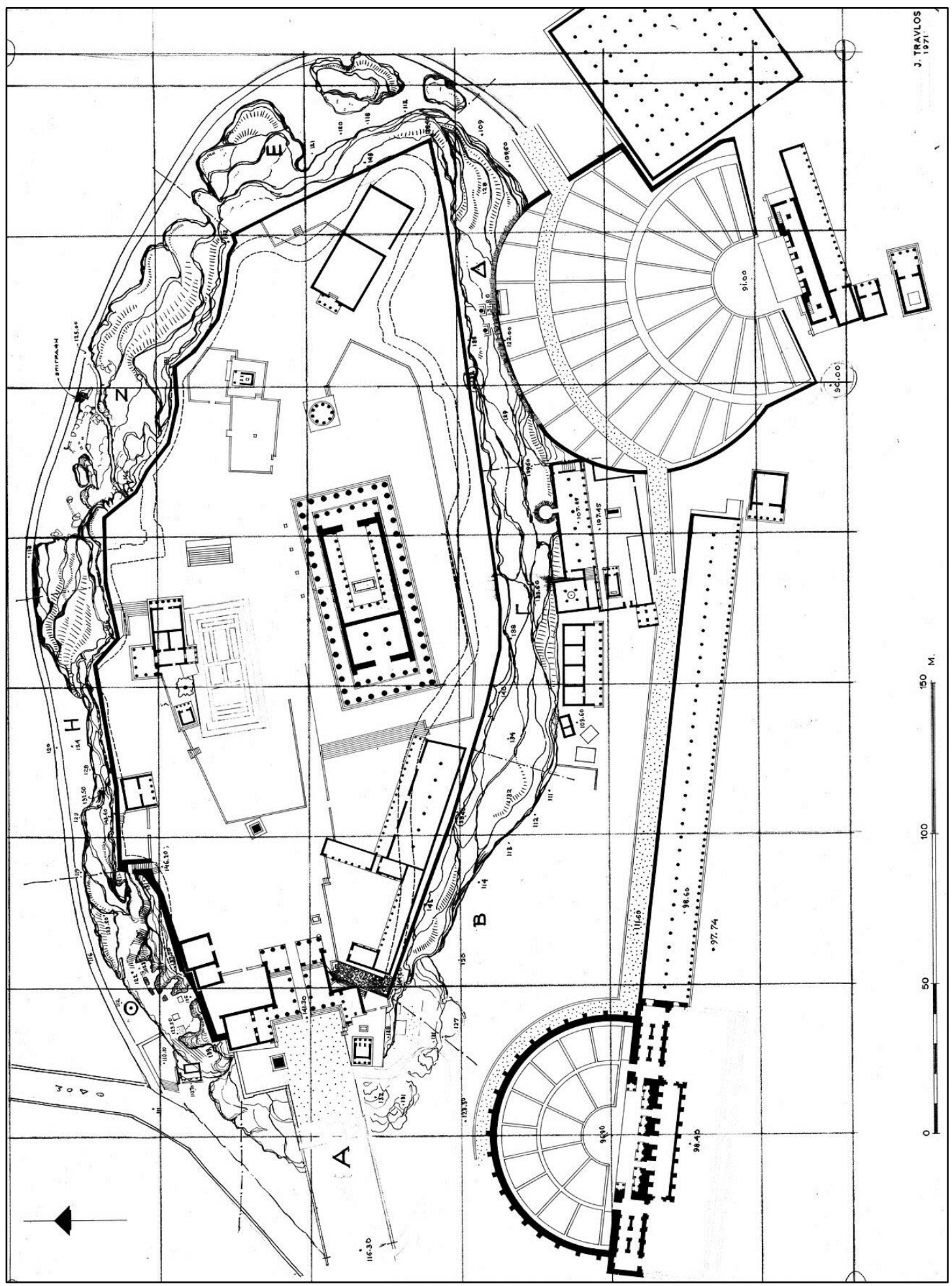

Figura 3. Proposta de reconstituição da planta da acrópole no período imperial, segundo Travlos em 1971 (ASCSA $\left.{ }^{2}\right)$.

\footnotetext{
${ }^{2}$ Disponível em: http://agora.ascsa.net/id/agora/image/2002.01.2201.
} 


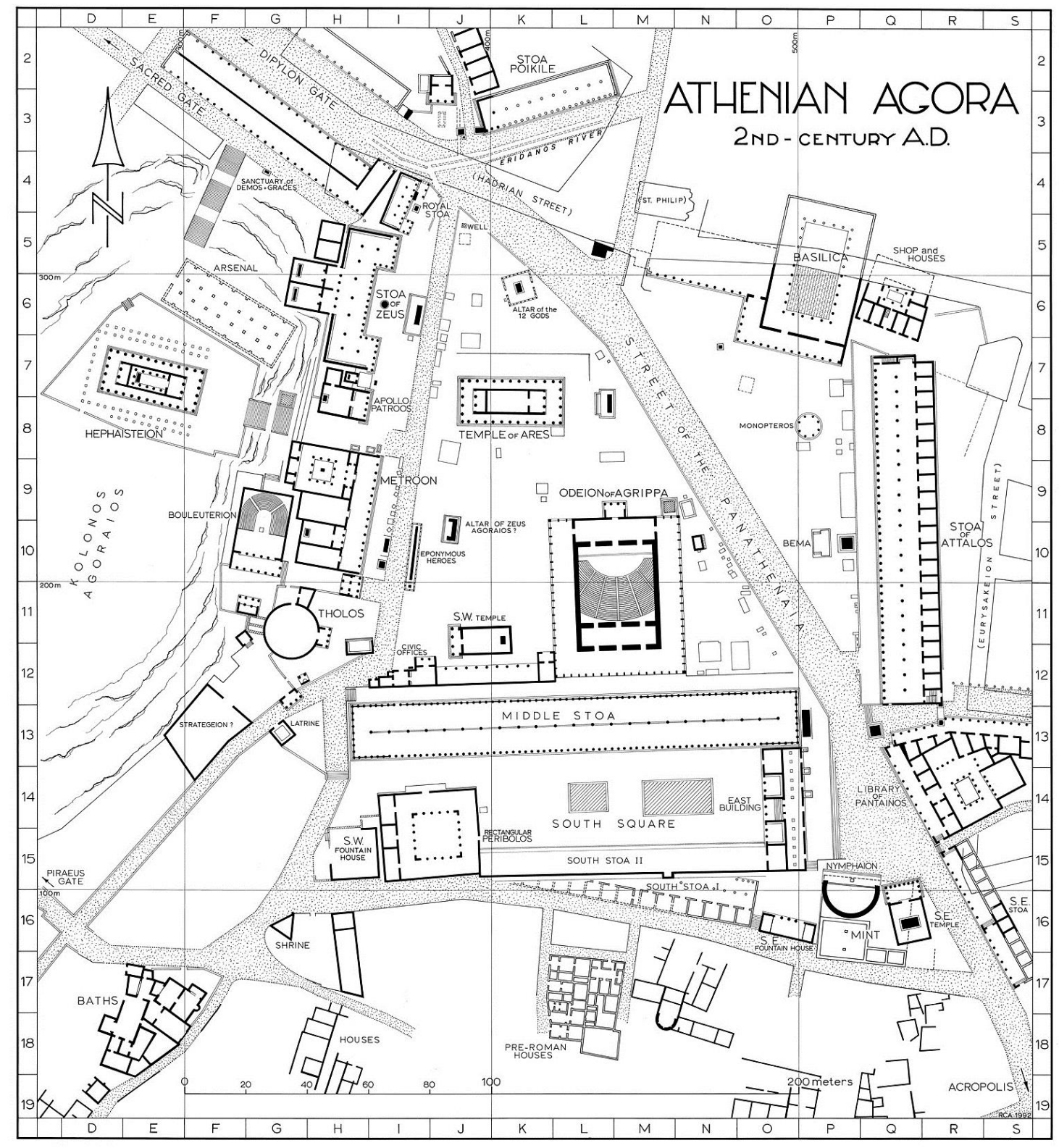

Figura 4. Proposta de planta da ágora no período imperial (II d.C.), feita por R. Anderson em $1992\left(\mathrm{ASCSA}^{3}\right)$.

${ }^{3}$ Disponível em: http://agora.ascsa.net/id/agora/image/2002.01.2671. 
Como um espelho distorcido, a história de Atenas é boa para pensar nossas experiências urbanas. A velocidade das transformações espaciais, impulsionada tanto pelo desenvolvimento tecnológico quanto pela posição específica da espacialidade na (re)produção social da vida, projeta diante dos sujeitos uma miríade de questões urgentes, entre as quais a urbana é fundamental. O que é a cidade? Em primeiro lugar, a natureza da cidade é, hoje em dia, uma questão disputada (Aristóteles, Política, 1274b). Por um lado, enquanto uns afirmam que a cidade é praticamente um sujeito histórico, para além do caráter de palco ou terreno dos acontecimentos (a cidade como sujeito histórico, fetichicizado), outros afirmam que a cidade é objeto das ações sociais, e seu segredo deve ser buscado nos projetos de poder dos diferentes grupos sociais envolvidos com sua produção. Por outro lado, vemos que atividade do legislador, do urbanista, do morador, do cidadão e todos aqueles envolvidos com a vida urbana, é ao mesmo tempo produtora e produzida pela cidade. Em suma, a produção social da cidade resulta de um modo específico de estabelecimento de uma ordem, não apenas entre os habitantes, mas do mundo: a posição da cidade em relação a outras, a articulação dos grupos sociais em conflito ou em aliança, a situação material do espaço construído em relação aos seus usos e descartes. A cidade é uma realidade complexa, e, justamente por isso, não pode ser reduzida a uma "multidão de cidadãos". Pelo contrário: as diferentes representações da cidade, inclusive as produzidas no âmbito mesmo da cidade analisada (Meneses, 1996), longe de servirem como pressuposto da investigação, devem ser explicadas do ponto de vista de sua materialidade. O estudo da (re)produção social do espaço urbano é ao mesmo tempo explicação e compreensão (Lefebvre, 1974).

Esta tese é um estudo sobre a (re)produção social do espaço ateniense, mas com recortes específicos: foram analisadas apenas as intervenções em espaços públicos monumentais intramuros, o que significa que casas, necrópoles e vias marginais não serão consideradas; o período analisado se estende da tentativa de invasão macedônica em 200 a.C. ao fim do principado de Augusto em 14 d.C., tendo o saque de Sula em 86 a.C. como um marco fundamental. O recorte temporal foi definido em função do recorte espacial: os ritmos da produção e reprodução dos espaços públicos monumentais apontam para uma periodização própria, relacionada mas não redutível à história estatal ateniense. Assim, eventos como a libertação da Macedônia em $229^{4}$ e a criação da

\footnotetext{
${ }^{4}$ Todas as datas no texto são "a.C.", exceto quando indicação diversa ou no caso de referência óbvia: por exemplo, os séculos XIX e XX. No caso da proximidade, na frase, entre datas "antes de Cristo" e "depois de Cristo", ambas serão indicadas.
} 
província aquéia em 146, centrais para a história da Grécia como um todo, tiveram um impacto relativamente reduzido na produção do espaço monumental; já a tentativa de invasão de 200 a.C. e o consequente fortalecimento dos laços com a dinastia atálida de Pérgamo, a grande destruição promovida pela invasão de Sula em 86 a.C. e o ciclo construtivo iniciado no período augustano, são marcos fundamentais para a transformação das atitudes em relação ao espaço e, paralelamente, das intervenções materiais no espaço.

A estrutura dos capítulos, mais do que à cronologia, diz respeito aos diferentes programas urbanos realizados em Atenas ao longo deste período: o programa urbano tardo-helenístico (cap. 1), o tardo-republicano (cap. 2) e o augustano (cap. 3). O peso do nome atribuído a cada um dos programas não deve ser exagerado: "programa tardohelenístico" não envolve apenas os edifícios doados pelos monarcas gregos, assim como "tardo-republicano" não diz respeito somente à atividade dos generais romanos e “augustano" não se refere necessariamente à iniciativa de Augusto. Pelo contrário, uma impossibilidade documental impede tais atribuições, e entre as questões centrais discutidas ao longo da tese está, justamente, a da colaboração entre agentes locais e estrangeiros na produção do espaço.

A categoria de programa foi tomada como uma tentativa de superar a visão que limita a produção do espaço a uma consciência superior ou poder único, normalmente externo, que em um momento inaugural criaria e limitaria as possibilidades da vida em uma cidade (Bruneau, 1976). Na medida em que a cidade é um ser social, ela é construída ao longo de sua história - muito além dos planos urbanísticos. Programa, pois, se distingue de projeto ou planejamento, na medida em que os incorpora. Um programa urbano é o resultado de um conjunto de intervenções materiais e simbólicas ${ }^{5}$ sobre o espaço, considerando os diferentes momentos de sua produção: o projeto, a manufatura, o uso e o descarte ${ }^{6}$. O fato de que estes momentos seguem padrões específicos, e que tais padrões respondem a lógicas dominantes, permite que tais intervenções sejam compreendidas em sua articulação. No caso da história urbana de Atenas de 200 a.C. a 14 d.C., a natureza evergética claramente documentada em boa parte das intervenções levou os estudiosos a privilegiarem, muitas vezes de modo absoluto, a categoria de propaganda como chave explicativa dos programas urbanos. $\mathrm{O}$

\footnotetext{
${ }^{5}$ Sobre a indissociabilidade dos suportes materiais e imateriais da cultura, cf. Meneses (1983).

${ }^{6}$ A categoria de programa, aqui, se articula à de cadeia comportamental ou lifehistory (Schiffer, 1972; Hodder, 2012), envolvendo tanto os aspectos materiais quanto simbólicos intrínsecos à produção da cultura material.
} 
evergetismo, entendido aqui como prática ritual $^{7}$, no entanto, não pode ser limitado à iniciativa ou à doação, isoladas de uma estrutura. Por um lado, o próprio contrato evergético pressupõe a participação ativa da comunidade presenteada em, ao menos, um dos dois momentos fundamentais - o agradecimento à doação. Quando as doações assumem a forma de edifícios ou monumentos, por exemplo, é fundamental que eles carregam, de alguma maneira, as marcas da doação (seja com inscrições em arquitrave ou base, seja no hábito social de nomear a intervenção a partir do doador) devem ser incorporadas nos usos do edifício, e isto parte, necessariamente, da comunidade local. Ou seja, o contrato evergético não se limita ao eventual aperto de mãos, mas ele é reiterado - ou não - ao longo de toda a história daquela intervenção espacial, inclusive no momento de seu descarte. Por outro lado, a densidade histórica materializada em monumentos e edifícios atenienses será considerada, ainda que não da mesma maneira, em praticamente todas as intervenções. A "propaganda" do evergeta não se impunha de modo absoluto, mas sim de modo relativo, em função dos significados e usos associados a determinado local. Neste sentido, a dicotomia entre "propaganda" e "resistência" quando a historicidade local era determinante -, que dominou o debate sobre a produção do espaço da Atenas pós-clássica, não tem fundamentos nem na documentação nem na construção teórica do evergetismo.

Antes da discussão direta dos programas urbanos, vale a pena uma revisão bibliográfica detalhada dos estudos realizados sobre o espaço ateniense pós-clássico. Tais estudos estiveram, desde o princípio, vinculados a dois fatores relacionados mas relativamente autônomos: a ampliação da documentação disponível ligada à história das escavações em Atenas, especialmente a partir do final do século XIX, e as transformações dos paradigmas e das formas historiográficas nos quais os estudiosos posicionavam seus estudos ${ }^{8}$.

A ampliação da documentação esteve vinculada aos projetos de escavação em Atenas que se estenderam ao longo dos séculos XIX e XX. Antes, alguns edifícios e monumentos construídos entre 200 a.C. e 14 d.C. eram conhecidos total ou parcialmente, tais como o Olympieion - reestruturado no século II a.C. e terminado somente no século II d.C. - e a Stoa de Átalo II, de meados do século II a.C. A fundação das sociedades arqueológicas gregas, associadas à organização das missões

\footnotetext{
${ }^{7}$ Sobre o conceito de evergetismo e suas transformações, cf. Veyne (1969, 1976), Andreau, Schnapp e Schmitt-Pantel (1978), Gauthier (1985) e, com a bibliografia mais recente, Zuiderhoek (2009).

${ }^{8}$ Para a categoria de forma historiográfica, cf. Guarinello (2003); para a relação entre paradigmas e formas, cf. a discussão em Silva (2009).
} 
estrangeiras em escolas arqueológicas ${ }^{9}$, promoveu os primeiros grandes projetos de escavação ainda no século XIX, tais como: a liberação da área de Stoa de Átalo II pela Sociedade Arqueológica entre 1859 e 1862; a escavação do Olympieion entre 1889 e 1896 pela Escola Britânica de Atenas; a grande escavação da acrópole dirigida por P. Kavvadias e G. Kawerau entre 1885-1890, que revelou edifícios como o monóptero de Roma e Augusto e o pilar de Agripa; as escavações conduzidas pelo Instituto Alemão de Atenas na área que seria então identificado como a parte ocidental da ágora entre 1891 e 1898, relevando edifícios como o Metroon, de meados do século II; e o grande projeto de escavação da ágora ateniense conduzido pela Escola Americana de Estudos Clássicos de Atenas a partir de 1930, que não somente explorou com mais detalhe os vestígios da Stoa de Átalo II e do Metroon, como também relevou o grande complexo da chamada "Praça Sul", o Agrippeion e os "templos flutuantes". Ao longo deste percurso, centenas de inscrições foram incorporadas às primeiras coletâneas, iluminando diversos aspectos da história ateniense mencionada apenas de passagem quando muito - pela historiografia da Grécia pós-clássica ${ }^{10}$.

As formas e os paradigmas que estruturaram os estudos sobre esta documentação, por sua vez, passaram também por grandes transformações, influenciadas seja pelo ambiente político e acadêmico dos pesquisadores, seja pela ampliação da documentação acima mencionada. Em linhas gerais, até a segunda metade do século XX os estudos estiveram fortemente vinculados a duas formas historiográficas principais, a "História da Grécia" e a "História de Roma". Na primeira, o paradigma dominante era aquele que equacionava uma forma social (pólis) a uma situação geopolítica (autonomia), gerando como consequência a visão de que as poleis gregas, após Alexandre, não era propriamente poleis - daí o relativo desinteresse pela história de Atenas pós-clássica, vista como uma sombra do que havia sido no período

\footnotetext{
${ }^{9}$ Em particular com a fundação da École Française d'Athènes em 1846, do Deutsches Archäologisches Institut em 1874, da American School of Classical Studies at Athens em 1881, e da British School at Athens em 1886. Para a discussão das relações entre arqueologia, identidade e imperialismo na Grécia idependente, cf. Dyson (2006), Diaz-Andreau (2007, pp. 79-13), Hamilakis (2007 e 2008), e Athanassoglou-Kallmyer, 2008.

${ }^{10}$ A produção de documentação e de interpretações é objeto de uma acirrada disputa entre as missões estrangeiras ainda hoje, especialmente com a publicação dos primeiros volumes da Topografia di Atene, pela Escola Italiana de Atenas, cujos pesquisadores, sem terem para si quaisquer projetos de escavação, tem corrigido e problematizado uma série de interpretações produzidas pela hegemônica Escola Americana. Para a história editorial das escavações em Atenas, cf. Morales (2013a).
} 
clássico $^{11}$. Na segunda, os estudiosos eram confrontados com o paradigma da romanização, que caracterizava, por um lado, as culturas provinciais ocidentais como duplos da cultura romana, e por outro, inversamente, as culturas provinciais orientais (especialmente as de matriz grega) como expressões da resistência cultural de povos culturalmente superiores mas militarmente inferiores a Roma; a Atenas imperial, neste paradigma, era o símbolo do orgulho nostálgico da cultura clássica. A partir da segunda metade do século XX, transformações de ordem política e social, tais como as descolonizações na África e na Ásia e os movimentos pelos direitos civis de mulheres e negros, e de ordem acadêmica, como a ascensão dos chamados Estudos Culturais, quando incorporadas na História Antiga e na Arqueologia Clássica, demonstraram com clareza a insuficiência dos paradigmas e formas tradicionais. Vejamos.

\section{Espaço urbano na Atenas pós-clássica: formas e paradigmas}

Os estudos escolhidos para este balanço foram todos aqueles que tomaram como objeto - mesmo que não exclusivamente - as intervenções urbanas realizadas em Atenas entre 200 a.C. e 14 d.C., oferecendo interpretações de conjunto, e não apenas sobre intervenções individuais ${ }^{12}$. Raras vezes, no entanto, as intervenções do século II foram interpretadas em conjunto com as intervenções da época de Augusto. Isto se explica, para além de questões pessoais, pela vinculação do estudo às formas e subformas historiográficas hegemônicas. Assim, os que tiveram por objeto as intervenções do século II situavam seu estudo dentro da subforma "Grécia helenística", e usavam como marco final ou o saque de Sula em 86, ou o início do principado de Otávio em 31 (esta diferença é importante, como veremos). A "Grécia helenística" se relacionava a duas formas historiográficas principais, que entre si tinham um relacionamento complexo: a História da Grécia, estruturada em torno do paradigma da

\footnotetext{
${ }^{11}$ Para uma crítica profunda - e talvez exagerada - da centralidade da categoria de "pólis" na estruturação narrativa da História da Grécia, cf. Vlassopoulos (2007), com as críticas em Morales (2010). Para a discussão da historiografia da Grécia helenística, cf. van Nijf e Alston (2011).

12 Não serão considerados, portanto, os estudos nos quais as intervenções aparecem apenas marginalmente, como o de Geagan (1989) para a Atenas romana e o de Habicht (1997) para Atenas helenística, obras de resto fundamentais para a compreensão do período; ou os estudos monográficos voltados para uma intervenção em particular, sem contudo promover uma interpretação de conjunto.
} 
"pólis autônoma", e a História do Helenismo, e seu paradigma da "fusão cultural"13. Quando confrontados com a História da Grécia, que tinha como referências principais Atenas e Esparta do século V, a grande questão a ser respondida pelos estudiosos era a do "declínio da pólis": quando e como a pólis começou a declinar, e quais as consequências para a vida cívica? Quando confrontados com a História do Helenismo, cuja referência espacial era mais ampla que o mundo grego - todas as regiões conquistadas por Alexandre e seus sucessores - a grande questão colocada era: como a pólis se relacionava com as monarquias helenizadoras e, por meio delas, com as culturas não gregas dos povos dominados? Apesar do descompasso geográfico, as duas formas poderiam ser combinadas: a decadência da pólis poderia ser explicado em função da ascensão das monarquias helenísticas, as quais, por sua vez, teria dervituado as poleis tanto por seus valores monárquicos quanto por suas culturas miscigenadas.

Já os estudos que tiveram como objeto as intervenções da época de Augusto situaram seu texto dentro da subforma "Grécia imperial", caso tomassem como marco o início do principado em 31, ou da "Grécia romana", caso o marco fosse o saque de Sula em 86. Neste ponto, mesmo que ainda presente, a questão da decadência da pólis já não era central: no período imperial as cidades gregas já teriam acumulado muitos séculos de "declínio" para que alguém buscasse pelas marcas características da pólis clássica: acima de tudo, a autonomia externa. A questão central estava vinculada não à História da Grécia, mas à História de Roma. Esta, estruturada a partir de uma generalização da história da cidade de Roma como história das regiões dominadas pelo império sediado em Roma (i.e., o "romanocentrismo"), incluía o estudo das regiões dominadas a partir de uma divisão mais ou menos nítida: por um lado, a análise dos instrumentos administrativos e militares para a manutenção da dominação (a romanização política ou militar); por outro, a discussão do processo de aculturação dos povos bárbaros dominados (a romanização cultural) ${ }^{14}$. Quando as provinciais analisadas eram aquelas ocupadas por cidades gregas, a questão se tornava mais complexa: se por um lado a romanização política poderia ser semelhante àquela das regiões bárbaras, por outro a romanização cultural dificilmente daria conta da persistência da cultura grega (na língua, na literatura, na religiosidade, na organização políade) nas províncias gregas parte oriental do império. Como explica-la? Já no início do século XX se constituiria o

13 Tal como formulado por G. Droysen no século XIX (Caldas e Sant'Anna, 2008; Fox, 2010; Vlassopoulos, 2013, pp. 278-290).

${ }^{14}$ Sobre os descompassos entre estas duas "romanizações", a política e a cultural, cf. Woolf, 1994. 
paradigma do descompasso entre "superioridade cultural" e "inferioridade militar", o qual, utilizando o verso de Horário como máxima (“a Grécia conquistada conquistou o feroz vencedor e as artes / introduziu no agreste Lácio" ${ }^{15}$ ), influenciaria diretamente a interpretação dos achados arqueológicos e epigráficos relativos ao período imperial em Atenas.

\section{Estudos pioneiros}

Até o início das escavações da Escola Americana na ágora ateniense, na década de 1930, as intervenções espaciais do período entre 200 a.C. e 14 d.C. eram conhecidas a partir dos vestígios total ou parcialmente escavados ao longo do século XIX, com registros de qualidade variável ${ }^{16}$, além de algumas inscrições e diversas referências na tradição clássica literária. Do século II, eram conhecidas: a Stoa de Eumenes (fig. 5), já conhecida por uma menção em Vitrúvio (5.9.1) por sua ligação ao teatro de Dioniso e associada ao rei Eumenes II de Pérgamo (197-159), foi escavada em 1877-1878 pela Sociedade Arqueológica de Atenas (Travlos, 1971, p. 523); a Stoa de Átalo II (fig. 6), construída durante o reinado deste em Pérgamo entre 158 e 148 e parcialmente de pé (inclusive com sua inscrição dedicatória na arquitrave) no século XIX, já havia sido escavada pela Sociedade Arqueológica de Atenas em 1859-1862 e 1898-1902 (Travlos, 1971, p. 505; Thompson e Wycherley, 1972, p. 220); o Olympieion (fig. 7), sobre o qual Vitrúvio (7.15) mencionava a participação de um arquiteto romano, Cossutius, no projeto de reestruturação financiado por Antíoco IV (rei da Síria entre 175 e 164), já analisado por J. Stuart e N. Revett em 1767, foi escavado sistematicamente por F. Penrose entre 1883 e 1886 (Travos, 1971, p. 402; Baldassarri, 1998, p. 75-76, n. 2); a Dedicação Atálida na acrópole (figs. 44-51) composta por quatro grupos escultóricos (gigantomaquia, amazonomaquia, maratonomaquia e galatamaquia), mencionada por Pausânias como um presente de um certo Átalo, já era objeto das reconstituições dos escavadores da acrópole e tema de grandes controvérsias na história da arte (Stewart, 2005, pp. 11-62); finalmente, um dos monumentos mais preservados de Atenas era o Horologium (fig. 8), conhecido como "Torre dos Ventos" em função dos relevos de seu

\footnotetext{
${ }^{15}$ Horácio, Epist. II.1.156-7: Graecia capta ferum uictorem cepit et artes / intulit agresti Latio.

${ }^{16}$ Compare-se, por exemplo, as escavações realizadas na acrópole nas décadas de 1840 e 1850 por K. Pittakis e no norte da ágora por conta da construção da linha férrea do Pireu em 1890-1891, com escassos registros estratigráficos e contextuais, com as grande escavações na acrópole entre 1885 e 1890 por P. Kavvadias e G. Kawerau. Cf. Dyson (2006, pp. 65-85) e Korres (2008).
} 
friso, já conhecido por Stuart e Revett em 1767, ainda hoje é objeto de controvérsias quanto a sua datação, ainda que geralmente se aceite que tenha sido construído no final do século II (Kienast, 1997). Algumas intervenções já eram conhecidas no século XIX por meio da tradição literária, mas ainda hoje não foram identificadas: o exemplo maior é o ginásio de Ptolomeu, cuja localização e datação ainda é objeto de grandes polêmicas (cf. cap. 1).

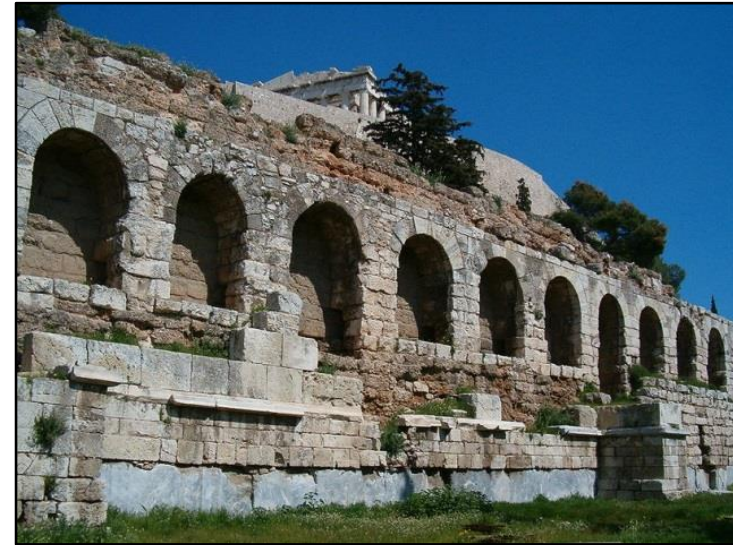

Figura 5. Fotografia da arcada posterior da Stoa de Eumenes, tirada por Macok em 2005 (Wikipedia Commons ${ }^{17}$ ).

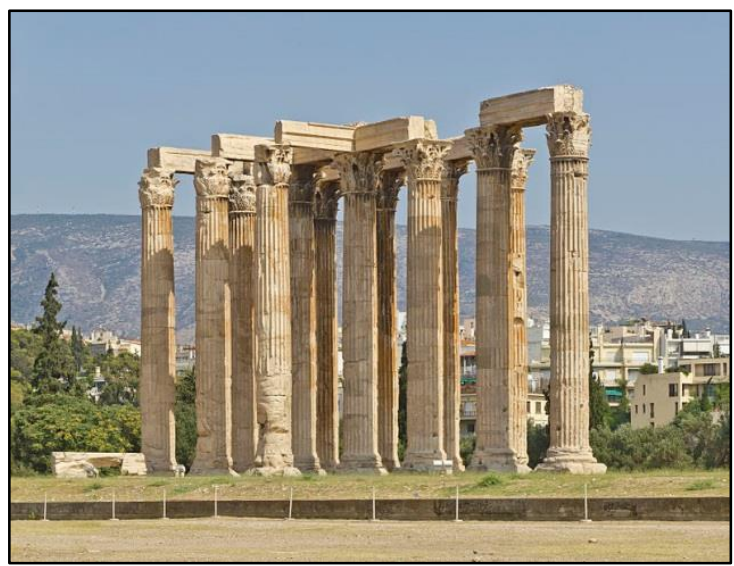

Figura 7. Fotografia do Olympieion a partir do oeste, tirada por A. Savin em 2013 (Wikipedia Commons $^{18}$ ).

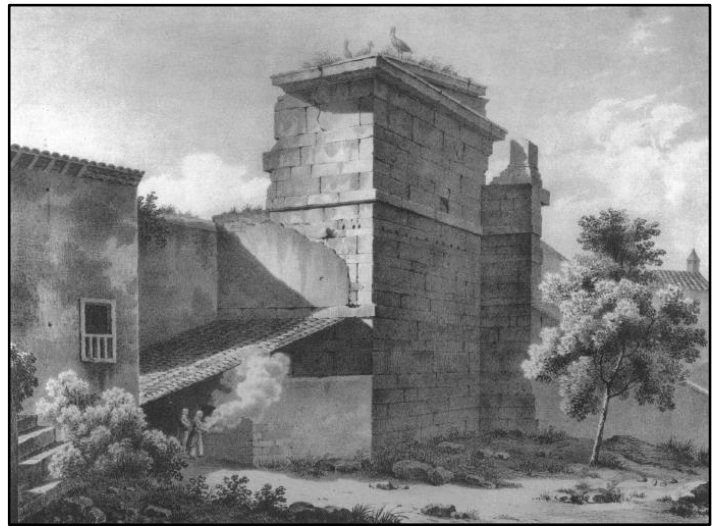

Figura 6. Desenho dos vestígios da Stoa de Átalo II, segundo E. Dodwell em 1834 (Thompson e Wycherley, 1972, pl. 56).

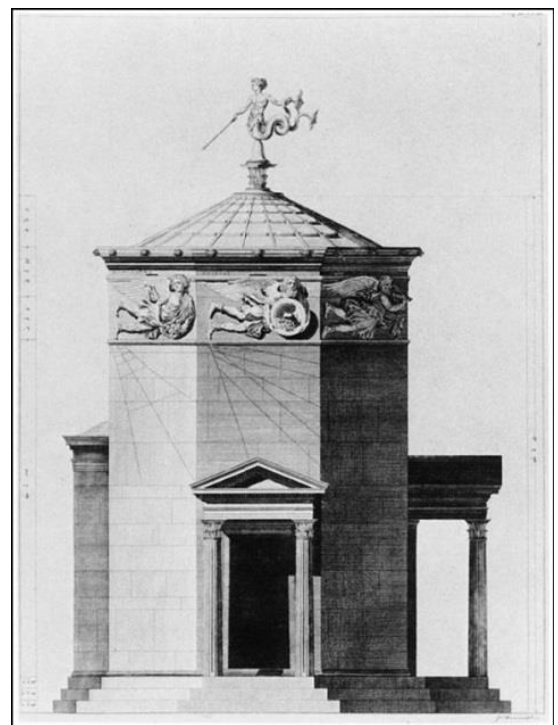

Figura 8. Desenho da "Torre dos Ventos", por J. Stuart e N. Revett $(1767$, v. 1, cap. 3, pl. 3).

\footnotetext{
${ }^{17}$ Disponível em:

http://commons.wikimedia.org/wiki/File:Teatro_di_Erode_Attico_mar05_03.jpg.

${ }^{18}$ Disponível em:

http://commons.wikimedia.org/wiki/File:Attica_06-13_Athens_25_Olympian_Zeus_Temple.jpg
} 
As intervenções do início do século I, em particular as destruições de Sula, eram conhecidas majoritariamente pela tradição literária, sem contar com qualquer paralelo arqueológico (estabelecido somente após as escavações americanas na ágora na década de 1930). As intervenções do período augustano eram mais bem documentadas: o monóptero de Roma e Augusto (fig. 9), cuja arquitrave continha a inscrição dedicatória, já havia sido atribuído às fundações ao leste do Pártenon escavadas por Kavvadias e Kawerau em 1885-1890 (Travlos, 1971, p. 494); o pilar de Agripa (fig. 10), com cerca de 4 metros de altura e situado diante do propileu da acrópole, era bastante visível mesmo antes das grandes escavações; a Ágora Romana (fig. 11), uma grande praça murada e porticada de cerca de $10 \mathrm{mil} \mathrm{m}^{2}$, dotada de duas entradas monumentais, uma das quais (a oeste) continha a inscrição dedicatória que menciona a dedicação à deusa Atena Fundadora e o financiamento realizado primeiro por César e depois por Augusto (assim como os gestores atenienses), já havia sido observada por J. Stuart e N. Revett em 1787, mas foi sistematicamente escavada pela Sociedade Arqueológica de Atenas somente em 1890 (Travlos, 1971, p. 28); a estela com a inscrição IG II 1035 (fig. 12), que continha um decreto de restauração de dezenas de santuários e recintos sagrados da Ática, atribuído comumente à época augustana, foi publicado em 1884 por C. Tsoudas (Baldassarri, 1998, p. 242, n. 1).

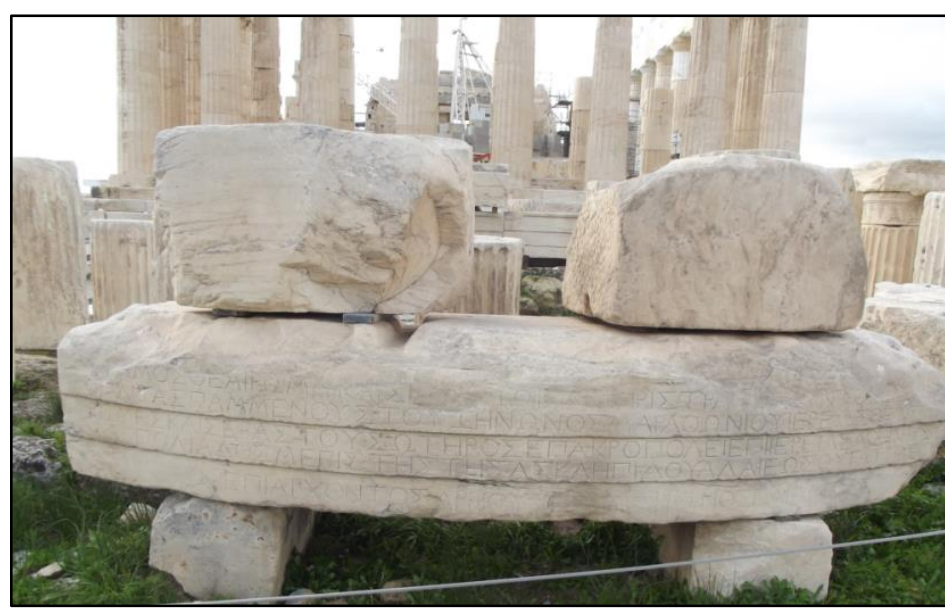

Figura 9. Fotografia da arquitrave do monóptero de Roma e Augusto, tirada em 2011 (Acervo Pessoal).

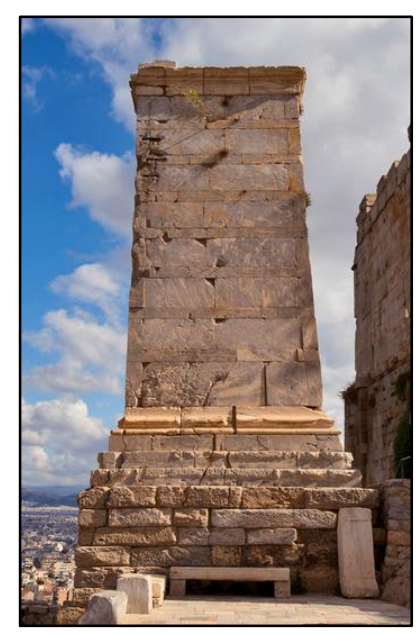

Figura 10. Fotografia do pilar de Agripa, tirada por Curtis Perry em 2013 (Flickr ${ }^{19}$ ).

\footnotetext{
${ }^{19}$ Disponível em: https://www.flickr.com/photos/curtisperry/13991458055/.
} 


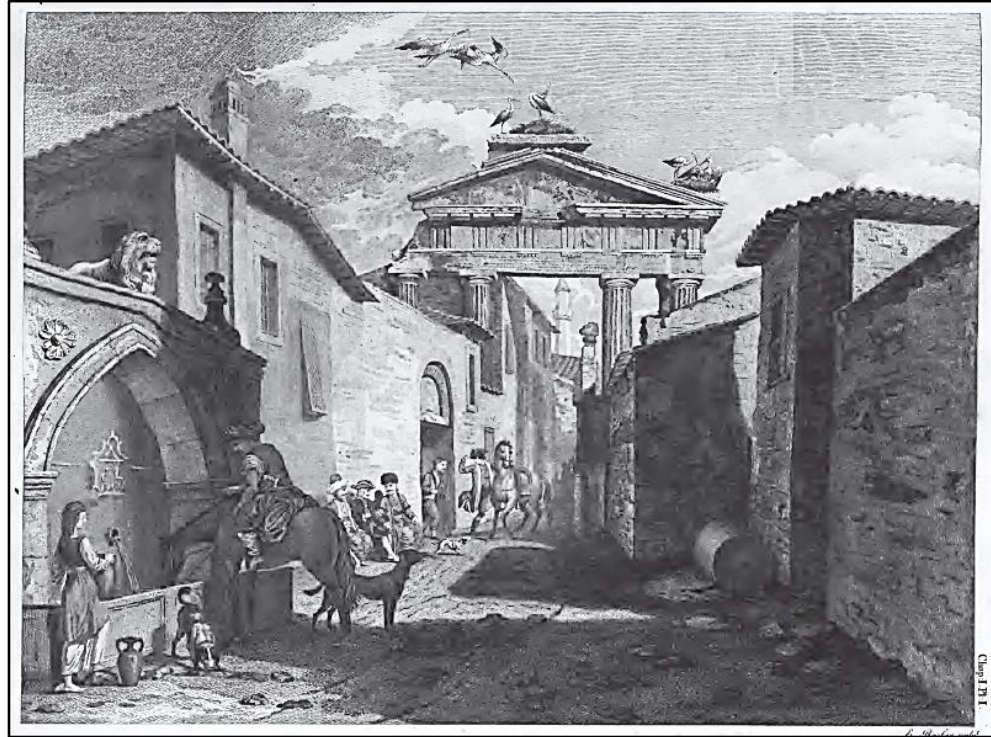

Figura 11. Desenho da vista do propileu ocidental da Ágora Romana a partir do oeste, segundo J. Stuart e N. Revett em 1767 (v. 1, cap. 1, pl. 1).

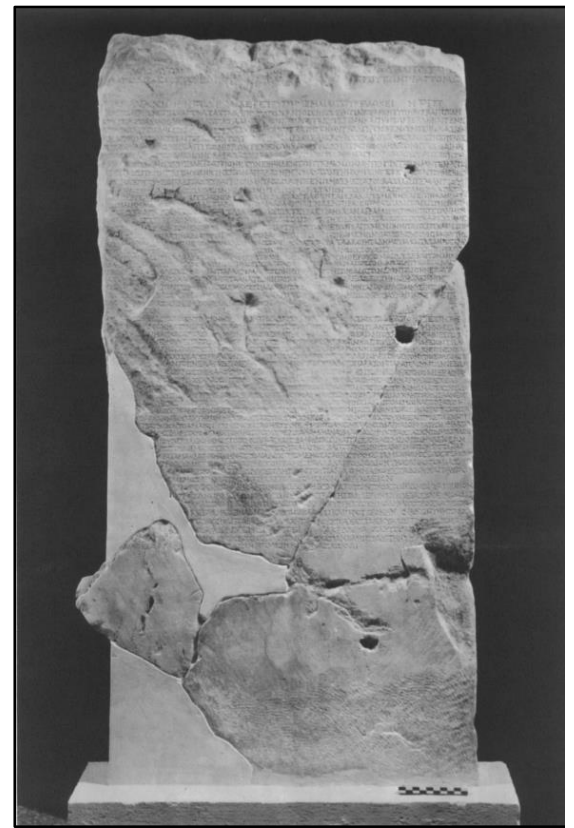

Figura 12. Fotografia dos fragmentos A e C da estela com a inscrição IG II2 1035 (Culley, 1975, pl. 45).

Um estudo pioneiro sobre o conjunto das intervenções helenísticas (do final do século IV ao início do século I) em Atenas aparece em 1911: trata-se do Hellenistic Athens, de W. Ferguson ${ }^{20}$. De início, o autor, professor de História Antiga em Harvard, repele a hipótese de que no período helenístico está a chave para a explicação do declínio de Atenas: o declínio começou antes, ainda no século $\mathrm{V}$, com a derrota na Guerra do Peloponeso. A história da Atenas helenística é a da transformação de uma pequena cidade-estado em uma municipalidade de grandes impérios territoriais, "o tema central do Helenismo" (Ferguson, 1911, p. ix). A especificidade de Atenas é ela ser considerada, interna e externamente, o centro da cultura helênica, o que se mantem até o início do século II, quando a abertura cultural e a incorporação de estrangeiros no corpo cívico marcou o início de "um movimento que era a destruição do que era mais distintivo na vida ateniense" (ou seja, sua cidadania restrita), o que seria reprovado por Políbio e geraria preocupação mesmo entre os romanos, admiradores dos atenienses (Ferguson, 1911, p. 311).

\footnotetext{
${ }^{20} \mathrm{O}$ autor faz referência, em sua primeira página, ao estudo de um autor russo chamado S. Shebelew, voltado para a história de Atenas entre 229 e 31 a.C., publicado em russo em 1898. Infelizmente, não obtive notícia nem da localização deste livro nem do conteúdo - relativo ou não às intervenções urbanas e portanto ele não será considerado aqui.
} 
A Atenas helenística de Ferguson é uma cidade esmagada entre poderes muito maiores que o seu, mas que encontra, com a libertação em relação à Macedônia em 229 e a instituição de uma democracia conservadora (controlada pela elite fundiária culta e urbana), um caminho promissor para a sobrevivência: a proteção de reis evergetas. A participação destes reis nos jogos e festivais atenienses é interpretada como parte da diplomacia ateniense; a discussão sobre o espaço construído em associação aos monarcas helenísticos é uma derivação desta análise. As intervenções espaciais discutidas por Ferguson se limitam às stoas de Eumenes na encosta sul da acrópole e de Átalo na ágora, ao Olympieion, e aos colossos dedicados a Eumenes e Átalo no topo da acrópole; todas elas são discutidas majoriamente a partir de fontes literárias e epigráficas. O autor ecoa Vitrúvio na interpretação da Stoa de Eumenes como um anexo do teatro; a Stoa de Átalo II, por sua vez, é interpretada como uma adaptação da ágora ateniense aos "bazares helenísticos, embelezando a praça central da cidade e associando o nome de Átalo à metrópole da cultura grega" (Ferguson, 1911, p. 301). As stoas estariam na base da dedicação dos colossos na acrópole como agradecimento aos reis pergamenos. Quanto ao Olympieion, Ferguson o interpreta como parte da política de Antíoco pela helenização da Síria (assim como Roma havia latinizado a Itália); a indicação de um arquiteto romano, Cossutius, como responsável pela reconstrução, se explicava pelo fato de Roma ser o maior canteiro de obras de então, o que produzira arquitetos de alta qualidade (Ferguson, 1911, p. 307).

Por que os reis buscavam Atenas para doar edifícios? A explicação de Ferguson se baseia em dois argumentos centrais: em primeiro lugar, Atenas era um centro cultural grego superior às outras metrópoles gregas por ter mantido a "pureza de sangue e de língua por mais de um século após a morte de Alexandre” (Ferguson, 1911, p. 308), e já havia encontrado na cultura a salvação diante derrota na Guerra do Peloponeso; em segundo lugar, os reis helenísticos, ao venerarem a cultura de uma cidade insignificante militarmente, ao mesmo tempo competiam entre si (Atenas era maior que Alexandria para pergamenos e maior que Pérgamo para os alenxadrinos) e reforçavam seus laços com a população grega de seus reinos, o que permitia a eles "manter sua posição contra a população nativa" (Ferguson, 1911, pp. 309-310).

Para Ferguson, o século II marca a contradição segundo a qual Atenas, ao usar o prestígio cultural, incorpora os evergetas (no corpo cívico e na paisagem urbana) e arrisca-se, assim, a perder a pureza que lhe conferia prestígio. Desse modo, o autor se posicionava, ainda que não explicitamente, junto aos autores que criticaram o otimismo 
com o diálogo cultural entre gregos e orientais defendido na obra fundadora dos estudos helenísticos, a Geschichte des Hellenismus de J. G. Droysen, publicada entre 1836 e $1843^{21}$. Ao lado deste argumento, Ferguson mantem o paradigma dominante da "História da Grécia" de um inelutável declínio das cidades gregas pós-clássicas, que resultaria na veneração do passado, tanto pelos atenienses quanto pelos estrangeiros: a veneração da tradição clássica se explica nos termos do declínio atual. De todo modo, deve-se reconhecer que, em sua síntese inaugural, Ferguson estabelece as bases para uma abordagem "evergética" da história urbana ateniense, pelo qual a consideração do contexto geopolítico é fundamental para a interpretação das intervenções.

Quase duas décadas depois do livro pioneiro de Ferguson, é publicado no Egito o primeiro estudo compreensivo sobre Atenas no período imperial. Trata-se de Athènes sous Auguste, escrito pelo belga Paul Graindor enquanto professor da Universidade do Cairo, em 1929. Fortemente baseado nas fontes epigráficas, o autor procura preencher algumas das lacunas de uma história da Atenas augustana apenas baseada nas fontes literárias. No entanto, o autor não considerava ser possível escrever uma "História": como escreve na Introdução, “este título seria muito ambicioso para um período cujo tempo poupou apenas raros escombros" (GRAINDOR, 1927, p. vi). Ainda assim, o enquadramento da obra dentro da tradição historiográfica totalizante das "histórias da civilização" - que englobavam economia, sociedade, política, literatura, artes, história factual etc - mantem o livro de Graindor como leitura obrigatória ainda hoje.

A justificativa da obra se dá dentro de uma tradição "ocidentalista": no período de Augusto os atenienses teriam moldado o gosto e a mentalidade dos romanos, e por meio destes o gosto e a mentalidade dos renascentistas e o "nosso" (Graindor, 1927, pp. vi e 246). Mas o que era essa Atenas responsável pela preservação da tradição clássica, sob Augusto? Se por um lado Atenas era uma cidade provincial, sem autonomia ou importância militar, por outro, era um centro cultural importante, cuja atração era a base para o "turismo intelectual" praticado por romanos como Cícero e Antônio. Esta dicotomia submissão/admiração explicava as flutuações da moralidade ateniense - da bajulação dos potentados romanos à revolta contra a dominação. Internamente, Atenas era governada por uma oligarquia intimamente ligada ao poder imperial, cuja

\footnotetext{
${ }^{21}$ Sobre a bibliografia favorável e e contrária às teses de Droysen, cf. Moyer (2011, pp. 11-36), com ênfase para as consequências para os estudos sobre o "Egito helenístico"; de um ponto de vista mais geral, cf. Vlassopoulos (2013, pp. 278-282).
} 
dominação foi consolidada no contexto da reconstrução da cidade após as longas guerras civis romanas. E por fim, a cidade estava imersa em um "espírito arcaizante", o qual estruturaria as intervenções augustanas (como o dórico do propileu da Ágora Romana inspirado nos propileus da acrópole, ou o jônico do templo de Roma e Augusto inspirado no Erechtheion, por exemplo) e outras manifestações culturais, como o tipo de letras nos preâmbulos de determinados decretos ou as cópias das esculturas clássicas na tradição chamada de "neo-ática". Infelizmente, a ideia de um "arcaísmo como projeto" não é trabalhada com profundidade pelo autor - ela aparece cá e lá, ao sabor das análises particulares.

As obras de Ferguson e Graindon construíram um modelo da Atenas pósclássica com algumas características centrais: a submissão aos poderes estrangeiros (cidade provincial), o prestígio cultural (centro do helenismo), a democracia formal controlada por uma oligarquia, e o espírito modernizante/descaracterizador (período helenístico) ou arcaizante/nostálgico (romano). Em um primeiro momento, a verdadeira revolução documental das décadas seguintes seria processada dentro deste paradigma; seriam necessárias revoluções conceituais e metodológicas para que uma nova visão pudesse ser formulada.

\section{A revolução documental (1930-1990)}

O livro de Graindor foi publicado quatro anos antes do início das escavações que transformariam radicalmente o conhecimento sobre Atenas, especialmente para o período pós-clássico. A região da ágora antiga já havia sido objeto de escavações anteriores, como as dirigidas por W. Dörpfeld, pesquisador do Instituto Arqueológico Alemão, ou as realizadas pelos arqueólogos gregos quando da construção do trem urbano, em 1890/1891 (Dörpfeld, 1937; Thompson e Wycherley, 1972, pp. 220-224); no entanto, a topografia do antigo centro da cidade era ainda quase exclusivamente baseada nas descrições de Pausânias. A partir da década de 1920, com as pressões geradas pela valorização do solo no centro de Atenas no pós-Primeira Guerra, as instituições arqueológicas gregas buscaram soluções para a aquisição definitiva da área. Em 1924, a recusa do Parlamento Grego a uma proposta para a compra da área pelo governo abriu o espaço para que as escolas arqueológicas estrangeiras competissem pela compra de um terreno valiosíssimo para o conhecimento da arqueologia grega, que 
poderia até superar as aquisições de Delos e Delfos pela École Française, de Olímpia pelo Deutsches Institut, ou de Cnossos pela British School, todas no século XIX. A vencedora da disputa pela ágora foi a até então marginal American School of Classical Studies at Athens, a qual, com apoio do International Education Board, financiado por R. Rockfeller, adquire o terreno em 1929 (Meritt, 1947, pp. 200-205; Hamilakis, 2013; Morales, 2013a). Em 1931 tem início o Agora Excavation Project.

Já nos primeiros anos de escavação foram descobertos depósitos que iam do neolítico ao período medieval; entretanto, os edifícios e monumentos datados dos períodos helenístico e augustano talvez tenha sido as mais surpreendentes (fig. 13). As descobertas relacionadas a intervenções do período tardo-helenístico incluíam, além de uma nova escavação sistemática da Stoa de Átalo II e dos edifícios que a precederam que redundou na decisão de reconstruir a stoa para sediar o novo Museu da Ágora (fig. 14) - duas importantes intervenções do século II, sem qualquer menção epigráfica ou literária até então conhecida, foram identificadas: o grande complexo de edifícios conhecido como a Praça Sul (fig. 15), formada pela Stoa Média, o edifício Leste e a Stoa Sul II, cuja construção teve início pouco depois de 183, o que implicou na demolição de uma série de edifícios do período clássico, e cuja função ainda é objeto de polêmicas (Travlos, 1971, p. 233); e a reestruturação do complexo Antigo BouleuterionMetroon (fig. 16), datada de meados do século II, cuja função é identificada como sede do culto da deusa Mãe, do arquivo e de magistraturas atenienses (Travlos, 1971, p. 352).

Do século I a.C., foram encontrados diversos vestígios de destruição datáveis, com maior ou menos segurança, ao saque de Sula em 86 - incluindo bolas de catapulta encontradas no edifício atualmente identificado como Aiakeion, no limite ocidental da Praça Sul (fig. 17). De um período provavelmente não muito anterior ao saque, data a construção de uma plataforma (fig. 18) para oradores construída diante da Stoa de Átalo II, e identificada à "bema para os generais romanos" mencionada por Posidônio (Ateneu, Banquete dos Sofistas, 5.50). Quanto à época augustana, o mais imponente edifício é o Agrippeion ou Odeion de Agripa (fig. 19), um grande teatro coberto de aprox. 2 mil $\mathrm{m}^{2}$, cujo auditório tinha capacidade para cerca de mil espectadores, com dois andares circundantes, e que já era conhecido pela menção em Filóstrato como espaço para apresentações musicais e retóricas (Travlos, 1971, p. 356). Ainda na década de 30 é descoberto o templo de Ares (fig. 20), um templo dórico hexastilo, cujos vestígios apresentam marcas dos construtores em quase todos os blocos, argumento 
central para a interpretação segundo a qual o templo foi "transplantado"22 de uma área rural (então indeterminada) para a ágora na época augustana (Travlos, 1971, p. 104). Outras intervenções contem vestígios de transposição, como o altar de Zeus Agorarios (fig. 21) e os templos Sudoeste e Sudeste; aos dois últimos, no entanto, os estudos mais recentes atribuem uma datação no final do século I d.C. (Thompson e Wycherley, 1972, pp. 160-168; Baldassarri, 1998). A Stoa de Zeus Libertador, escavada parcialmente no início do século XX por W. Dorpfeld, foi objeto de uma análise sistemática: descobriuse que em época augustana a stoa recebeu a adição de um anexo (fig. 22) em seu lado posterior, onde foram encontrados fragmentos de uma base de estátuas, com marcas dos pés e parte da inscrição, que levaram os arqueólogos a interpretarem o anexo como uma adaptação da stoa ao culto imperial (Travlos, 1971, p. 357). Finalmente, o complexo do Tholos e do Strategeion (fig. 23) foi reformado com a construção de dois novos propileus, duas fontes e uma exedra, todas datadas, com maior ou menor segurança, do período augustano.

A primeira síntese sobre a história da Atenas romana a incorporar os achados recentes foi, não obstante, feita por um pesquisador sem ligação com a Escola Americana: trata-se do livro An economic history of Athens under Roman domination, J. Day, publicado em 1942. O livro nasce da sugestão de M. Rostovtzeff para um volume sobre a história econômica da Grécia romana, limitada por J. Day para Atenas. A influência do historiador russo não se limitaria à sugestão: tanto a abordagem quanto a periodização são extremamente próximas do projeto de Rostovtzeff. Day faz uma história econômica alinhada à abordagem "modernista", discutindo questões como o balanço entre exportações e importações, o valor da mão-de-obra, os períodos de prosperidade e crise, a política econômica e os interesses comerciais nos contatos entre estados etc; além disso, Day, apesar do título do livro, não trata apenas do período romano: a análise começa no final do século IV a.C., no longo capítulo intitulado "Before Sula", para então se dividir em capítulos que tratam da história de Atenas até o século III d.C.

\footnotetext{
${ }^{22}$ A tese do transplante é amplamente aceita atualmente, com a importante exceção de E. Lippolis (2001, pp. 178-205), que enfatiza as incertezas derivadas dos dados arqueológicos.
} 


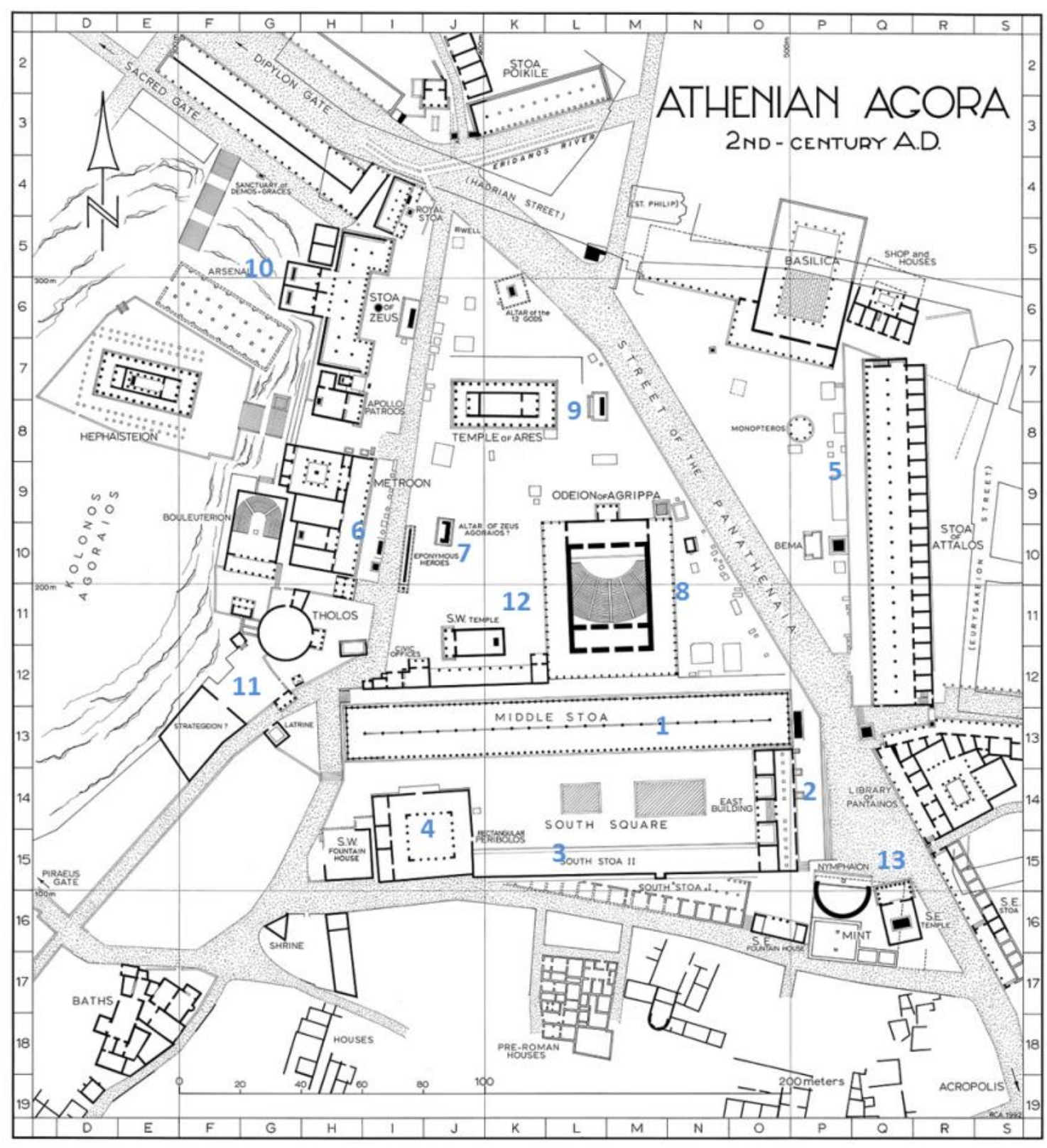

Figura 13. Proposta de reconstituição da ágora em meados do século II d.C., feita por $R$. Anderson em 1992 (ASCSA), com numeração (minha dos achados das décadas 1930-1950. 1. Stoa Média. 2. Edifício Leste. 3: Stoa Sul II. 4. Aiakeion reformado. 5. Stoa de Átalo II. 6. Novo Metroon. 7. Altar de Zeus Agoraios. 8. Agrippeion. 9. Templo e altar de Ares. 10. Anexo da Stoa de Zeus. 11. Reformas no Tholos-Strategeion. 12. Templo sudoeste. 13. Templo sudeste. 


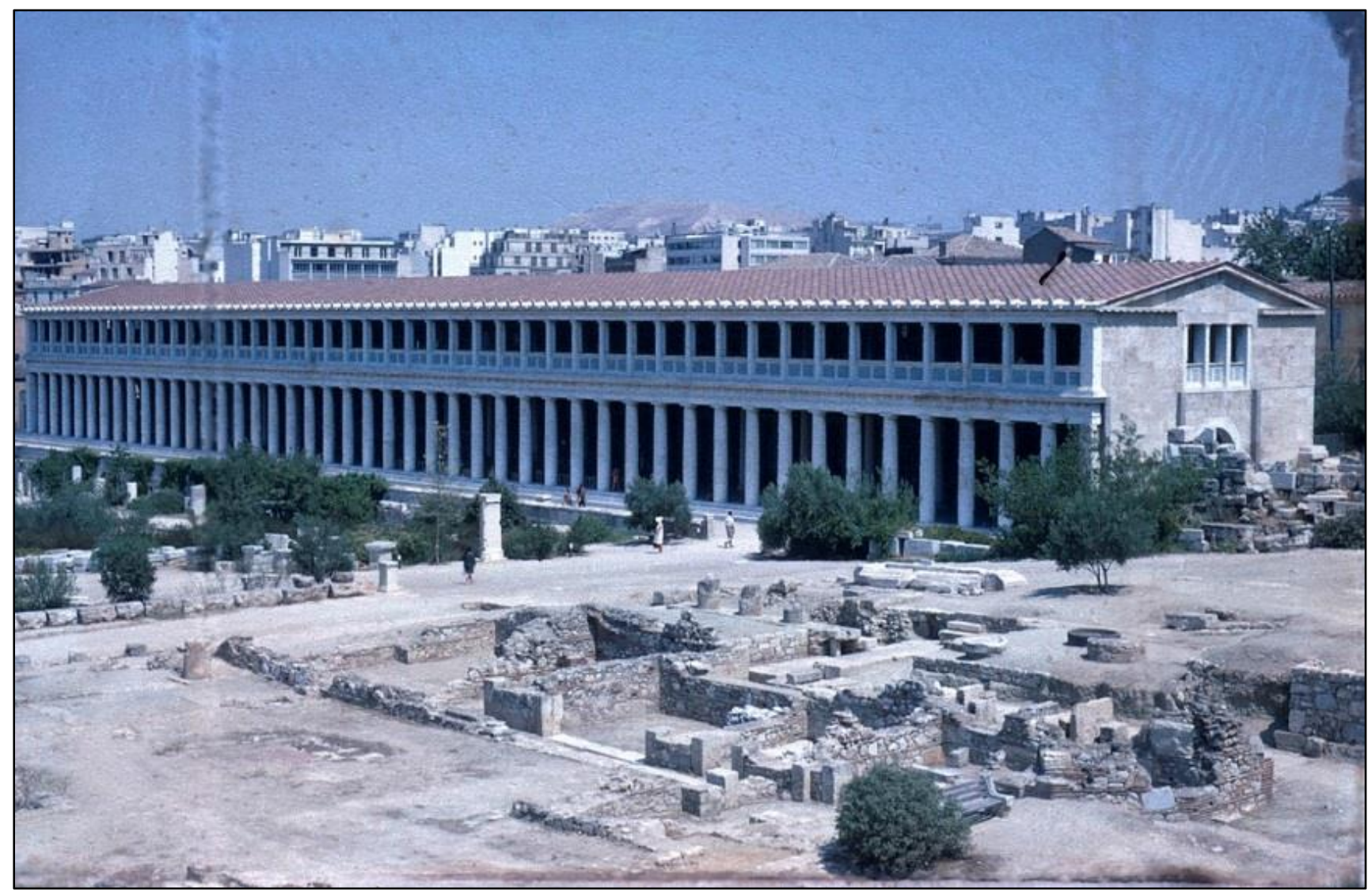

Figura 14. Fotografia da Stoa de Átalo II reconstruída a partir do sudoeste, tirada por E. Vanderpool em 1967 $\left(\mathrm{ASCSA}^{23}\right)$.

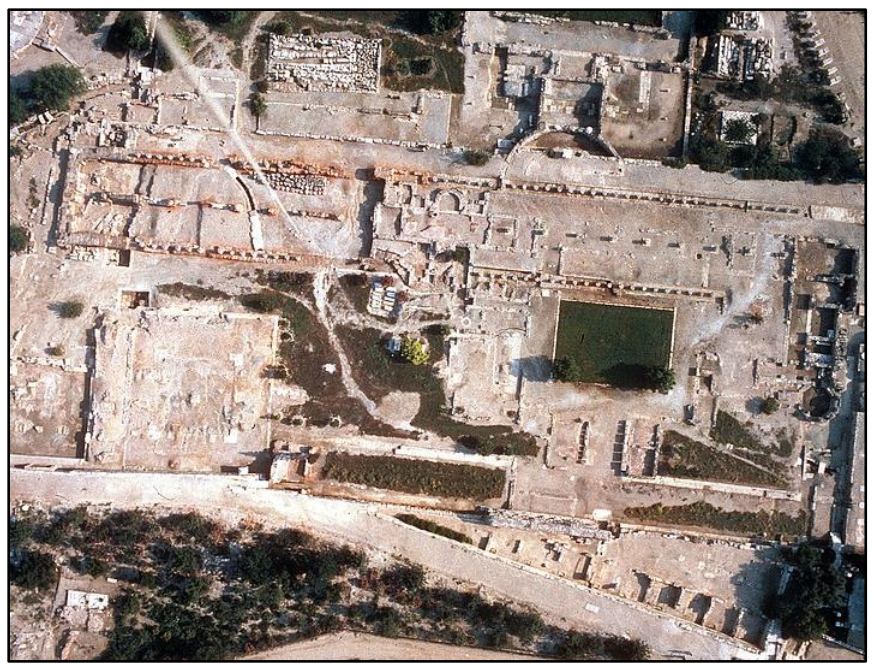

Figura 15. Fotografia aérea da área da Praça Sul, tirada em 1975 (ASCSA $\left.{ }^{24}\right)$. 1. Stoa Sul I. 2. Stoa Sul II. 3. Edifício Leste. 4. Stoa Média.

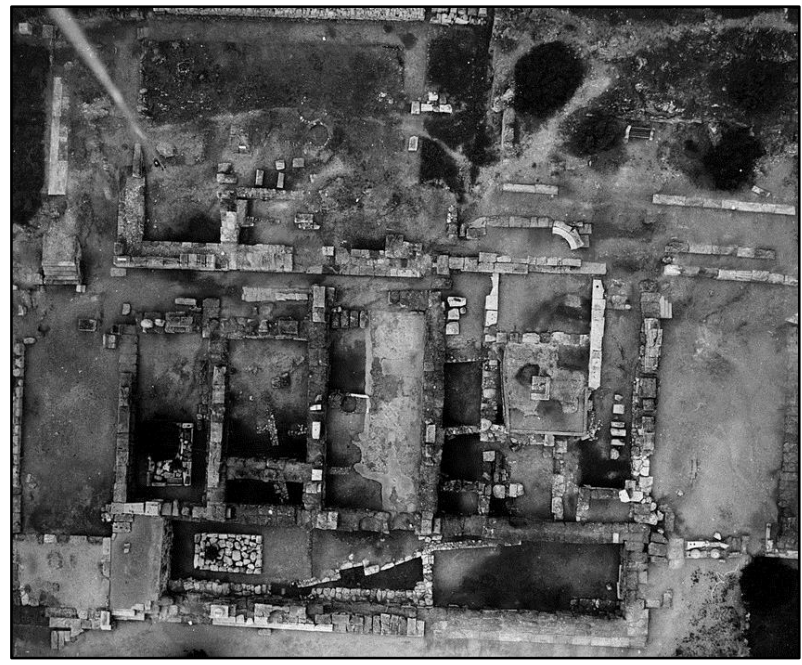

Figura 16. Fotografia aérea da área escavada do Metroon, tirada em 1975 (ASCSA $\left.{ }^{25}\right)$.

\footnotetext{
${ }^{23}$ Disponível em: http://agora.ascsa.net/id/agora/image/2004.01.2033.

${ }^{24}$ Disponível em: http://agora.ascsa.net/id/agora/image/2000.03.0010.

${ }^{25}$ Disponível em: http://agora.ascsa.net/id/agora/image/1997.03.0411.
} 


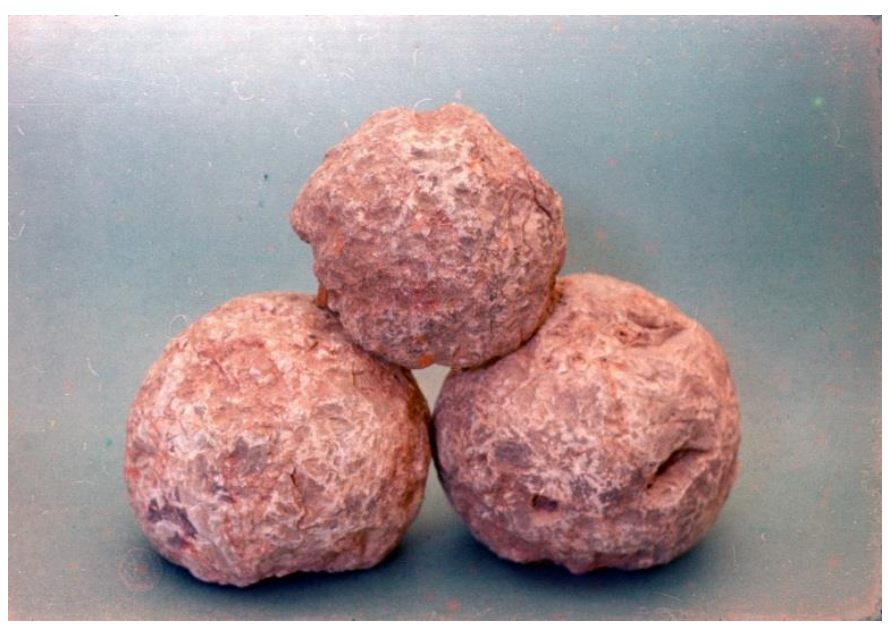

Figura 17. Fotografia das bolas de pedra lançadas por catapulta encontradas no Aiakeion, tirada em 1960 $\left(\mathrm{ASCSA}^{26}\right)$.

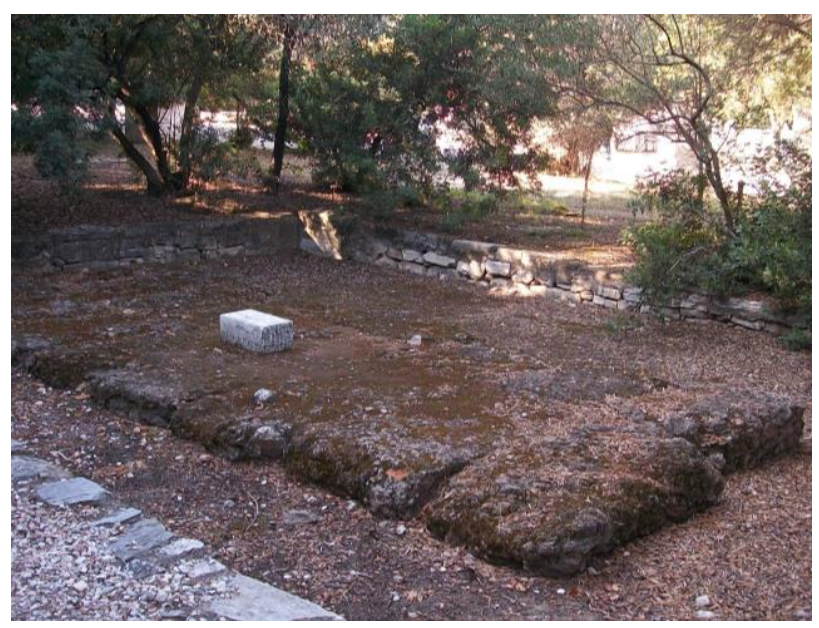

Figura 18. Fotografia do "bema romano", tirada pelo autor em 2011 (Acervo Pessoal).

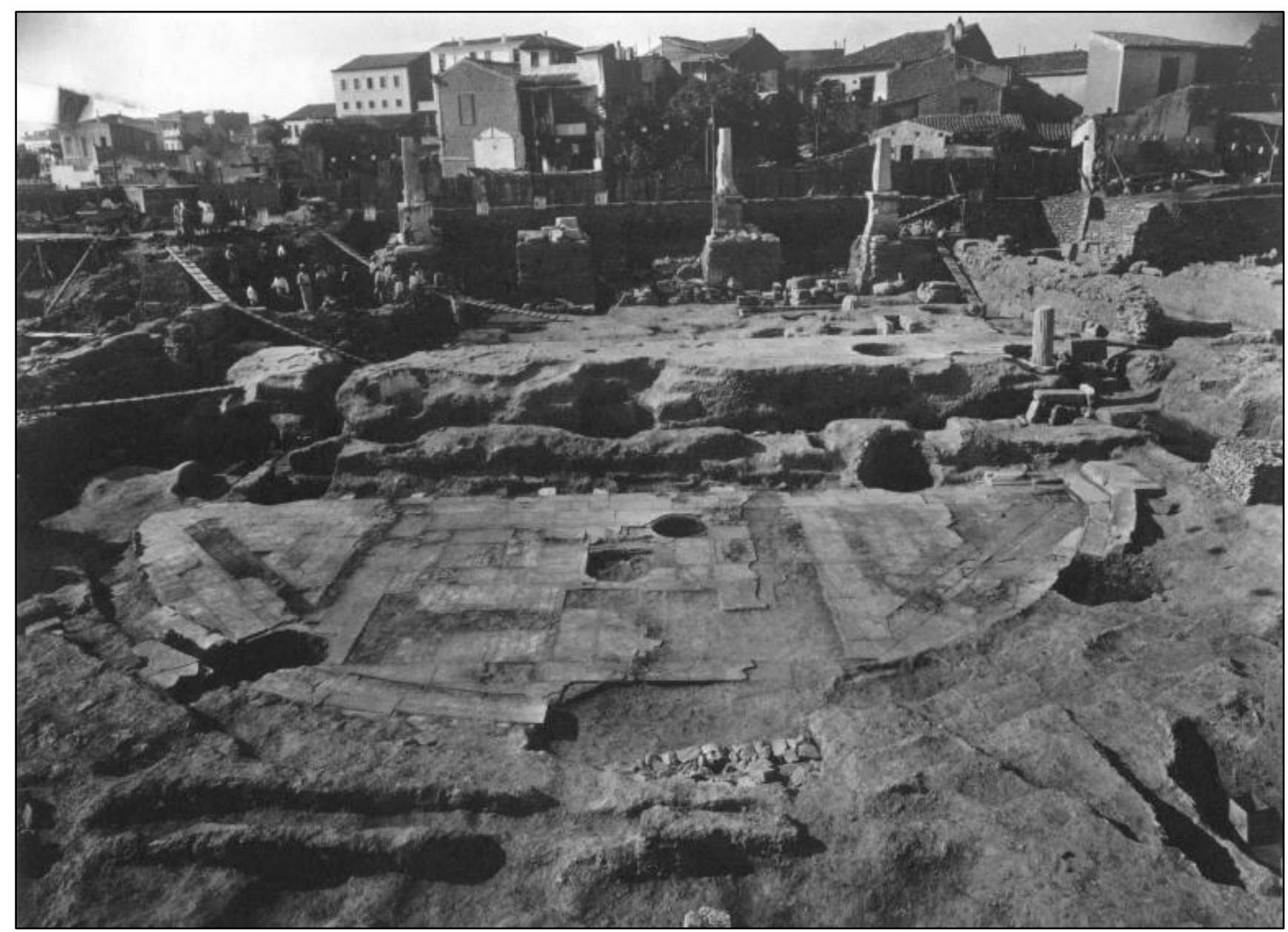

Figura 19. Fotografia das escavações na área do Agrippeion a partir do sul, tirada em 1935 (Thompson e Wycherley, 1972, pl. 58).

${ }^{26}$ Disponível em: http://agora.ascsa.net/id/agora/image/2004.01.1727. 


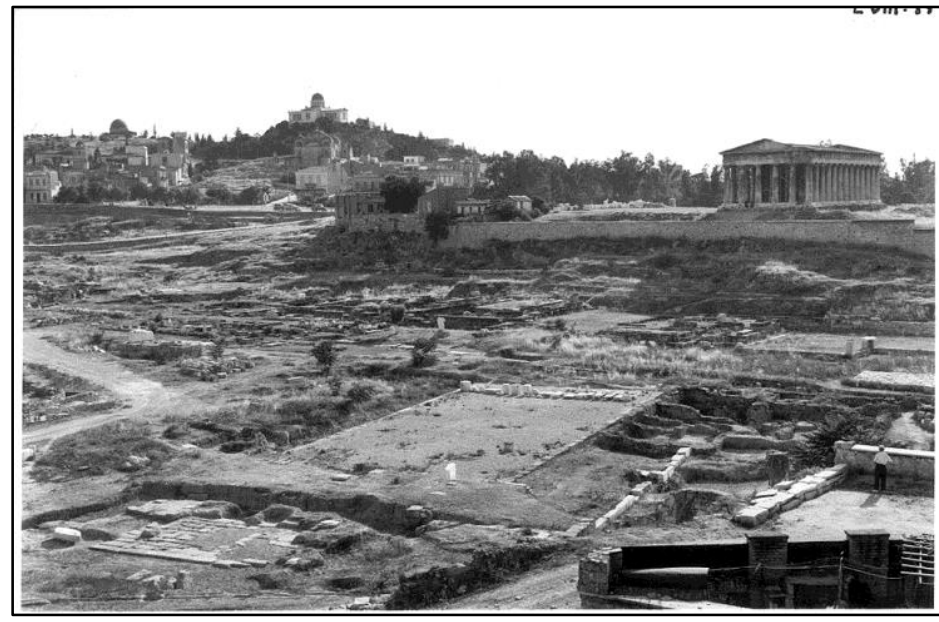

Figura 20. Fotografia do templo e altar de Ares (primeiro plano) a partir do nordeste, tirada em $1853\left(\operatorname{ASCSA}^{27}\right)$.

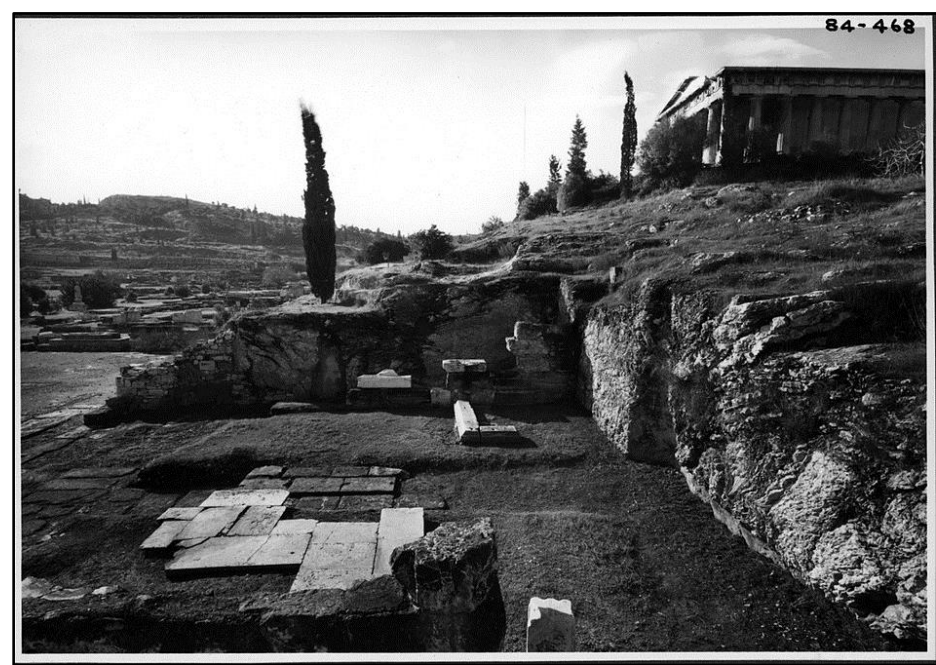

Figura 22. Fotografia das escavações do anexo à Stoa de Zeus a partir do norte, tirada em $1932\left(\mathrm{ASCSA}^{29}\right)$.

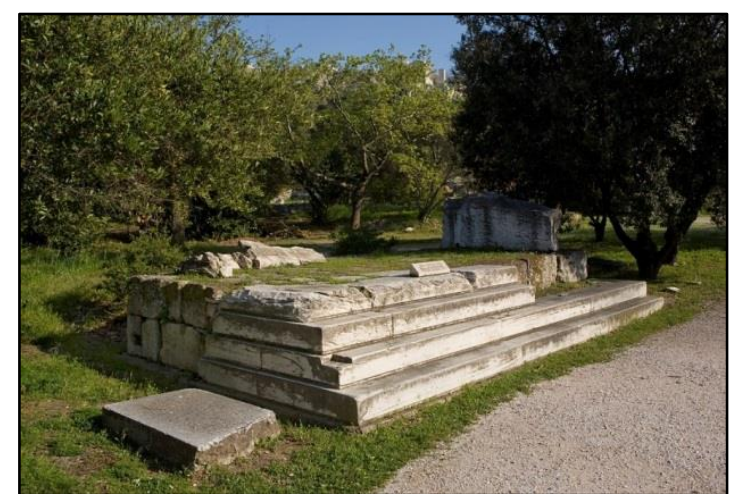

Figura 21. Fotografia do altar de Zeus Agorarios a partir do noroeste, tirada por $\mathrm{C}$. Mauzy em $2009\left(\operatorname{ASCSA}^{28}\right)$.

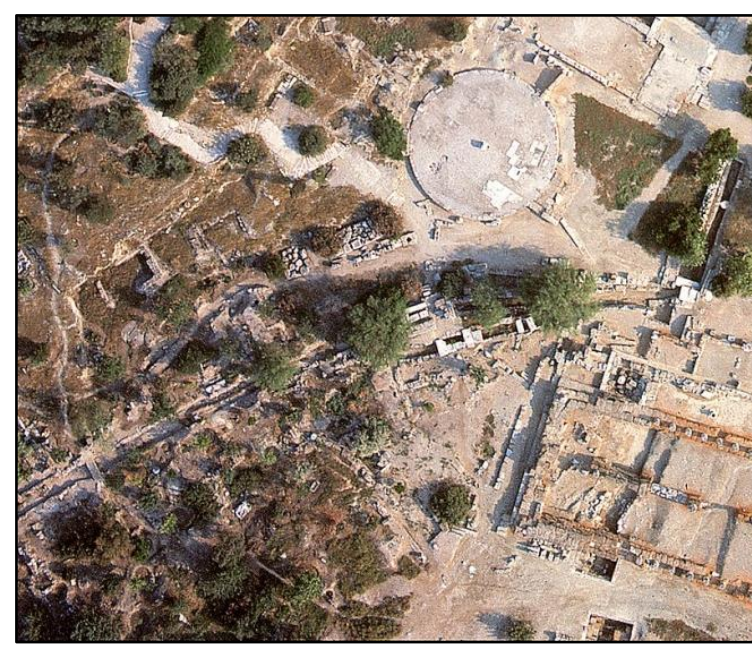

Figura 23. Detalhe da fotografia aérea da região sudoeste da ágora, tirada em 1975 $\left(\operatorname{ASCSA}^{30}\right)$.

Apesar de incorporar na análise os achados das escavações na ágora ateniense, o autor não está preocupado com questões espaciais: as intervenções aparecem no texto em função de suas motivações e consequências econômicas. Desse modo, após apresentar as bases históricas da formação da elite fundiária ateniense - a crise econômica após a perda do império marítimo, o encarecimento do trigo e consequente ascensão dos grandes proprietários de terra das planícies férteis da Mesogéia e Maratona - o autor cita os edifícios financiados pelos reis helenísticos (as stoas atálidas, o

\footnotetext{
${ }^{27}$ Disponível em: http://agora.ascsa.net/id/agora/image/1997.10.0478.

${ }^{28}$ Disponível em: http://agora.ascsa.net/id/agora/image/2011.04.0052.

${ }^{29}$ Disponível em: http://agora.ascsa.net/id/agora/image/1997.03.0178.

${ }^{30}$ Disponível em: http://agora.ascsa.net/id/agora/image/2000.03.0004.
} 
Olympieion) para discutir as razões que levaram às doações. Além dos argumentos de Ferguson, Day (1942, pp. 42-45) sugere motivações econômicas: os reis buscariam o apoio de Atenas no acesso às redes comerciais do Egeu, nas quais Atenas era um centro redistribuidor importante, ainda mais com a aquisição da ilha de Delos, cedida aos atenienses pelos romanos em 167/6. As doações helenísticas ainda teriam consequências benéficas para a ampliação das oportunidades aos trabalhadores livres, cada vez menores em função do aumento da escravidão na produção cerâmica e na mineração.

O período pós-Sula também aparece no livro de Day: a restauração do Odeion de Péricles, financiada por Ariobarzanes da Capadócia, as doações de Pompeu para reconstrução da cidade e o primeiro financiamento da Ágora Romana por César são utilizadas para relativizar a tese de uma crise econômica radical após o saque de Sula. O autor argumenta que mesmo se a iniciativa estrangeira apontasse para a fraqueza das contas públicas atenienses, sua realização teria gerado movimentação econômica, o que é demonstrado pela demanda comercial local implícita na construção da Ágora Romana (Day, 1942, p. 51). Este movimento é reforçado pelas construções da época augustana: a intensa atividade construtiva, visível no Agrippeion, na Ágora Romana e no transplante dos "templos itinerantes", mesmo que não financiada pelo estado ateniense, tinha um efeito estimulante na economia da cidade; a natureza comercial da Ágora Romana é um exemplo claro de uma "clara necessidade de comércio e negócios em Atenas" (Day, 1942, p. 153$)^{31}$.

Na conclusão do capítulo sobre o período inicial da dominação romana (de Sula a Augusto), o autor menciona as oportunidades oriundas do "capital cultural" ateniense (Day, 1942, p. 175), e com isso aborda, citando Graindor, o problema do "arcaísmo". Para o autor, boa parte do bem-estar da cidade repousava na atração exercida sobre estudantes, turistas e patronos ricos. Esta atração era estimulada por um "arcaísmo consciente", visível na cunhagem, na arte, na arquitetura e nas inscrições, o que fazia com que "nem os próprios atenienses nem os visitantes estrangeiros pudessem perder de vista a herança cultural da cidade" (Day, 1942, p. 176). Aqui era esboçada a ideia do arcaísmo não como decorrência natural da "decadência da pólis", mas como projeto, o que seria uma das bases da renovação da década de 1990 .

\footnotetext{
${ }^{31}$ A hipótese da "demanda comercial" da elite ateniense permaneceria marginal dos estudos sobre Atenas augustana, aparecendo com força somente na dissertação de J. Burden (1999), como se verá ainda neste capítulo.
} 
As escavações da ágora ateniense só receberiam uma obra de síntese com a publicação do décimo quarto volume das monografias oriundas das escavações: The agora of Athens, publicado em conjunto por H. Thompson e R. Wycherley. Antes disso, ambos autores haviam publicado uma grande quantidade de artigos sobre questões ou monumentos específicos e alguns poucos livros gerais. É o caso, por exemplo, do influente manual de urbanismo grego How the Greeks built cities (1962), publicado por R. Wycherley originalmente em 1949, ou o artigo de síntese "The agora at Athens and the Greek Market", publicado por H. Thompson em 1954 no Journal of the Society of Architectural Historians. Nestes textos - e nos diversos relatórios de escavação, artigos e monografias sobre intervenções específicas - aparecem, pela primeira vez de modo sistemático, interpretações propriamente espaciais, constituindo as bases de uma abordagem que se tornaria fundamental para qualquer discussão das intervenções urbanas na Atenas pós-clássica.

As intervenções da época helenística tem um papel fundamental na reflexão dos dois autores. Wycherley (1962) desenvolve uma interpretação da construção das stoas helenísticas na ágora a partir de uma categoria já formulada em estudos anteriores, mas que se tornaria então central na leitura das ágoras helenísticas: com a Stoa Média, a Stoa de Átalo II e o novo Metroon, a ágora ateniense se compararia (ainda que para se diferenciar) do modelo da "ágora jônica" ${ }^{32}$, caracterizada por uma combinação de stoas em ângulos retos que delimitariam a ágora dentro da estrutura retangular da estrutura viária, formando "esquemas impressionantes e efetivos" (Wycherley, 1962, p. 71). A ágora ateniense não se adequaria plenamente a este modelo, em função da irregularidade de seu sistema viário e da antiguidade dos edifícios na área oeste; mas de qualquer modo, na construção da Stoa Média, da Stoa de Átalo II e da fachada colunada do novo Metroon, havia uma preocupação com a "regularização do espaço", com forte influência pergamena (visível, por exemplo, na semelhança entre as plantas da biblioteca de Pérgamo e do novo Metroon; Wycherley, 1962, p. 86).

H. Thompson, diretor das escavações entre 1946 e 1967, no artigo de 1954 explora as consequências funcionais da construção das intervenções helenísticas: o novo Metroon, mais adaptado a funções administrativas (arquivo e sede de magistrados, além de santuário), serviria para isolar o Bouleuterion, onde se reunia o conselho ateniense, da ruidosa ágora, enquanto que a Stoa de Átalo II e a Stoa Média funcionariam como

\footnotetext{
32 Para a bibliografia precedente e uma crítica radical da aplicação do conceito de "ágora jônica", cf.
} Dickenson (2012, pp. 500-507). 
plataformas para espectadores dos jogos e festivais realizados na ágora. Mais importante, as novas intervenções regularizariam a ágora por meio da divisão entre um espaço exclusivamente comercial (a Praça Sul, então interpretada por Thompson como um grande mercado) e a ágora principal, ao norte; tal divisão atualizaria a ágora ateniense às cidades helenísticas, onde também se buscava a "separação de funções" (Thompson, 1954, p. 13). Os edifícios da época augustana são interpretados a partir da romanidade implícita na ordenação axial entre o Agrippeion e o templo de Ares e mesmo na verticalidade do primeiro, o mais alto da ágora, além das implicações religiosas ligadas ao culto imperial sugeridas pelos indícios associados a tais edifícios (Thompson, 1954, p. 14).

No manual escrito por ambos, Wycherley e Thompson, em 1972, as teses são discutidas detalhadamente na apresentação de cada intervenção; uma síntese, bastante sucinta, aparece somente introdução. As intervenções helenísticas são interpretadas como criadoras de uma "interessante mistura entre o antigo e o novo": apesar do novo Metroon, o lado ocidental e setentrional da ágora mantinha o caráter clássico, enquanto que as novas stoas faziam com que os lados meridional e oriental se tornassem "profundamente helenísticos" (Thompson e Wycherley, 1972, p. 23). Quanto às intervenções augustanas, se a construção da Ágora Romana trouxe um novo espaço para o "mercado" ateniense, a antiga ágora rompeu sua longa tradição de um espaço central aberto, por conta da construção do Agrippeion e da transposição dos templos itinerantes (explicada tanto pelo abandono do culto nos locais originais, quanto pelo projeto de embelezamento da ágora). O aspecto de "forum romano" da ágora ateniense é atribuído ao "patronato da família imperial, para quem os atenienses demonstravam sua gratidão e homenagem pela instalação de cultos apropriados, com numerosos altares e estátuas" (Thompson e Wycherley, 1972, p. 23).

As escavações da ágora e os estudos seminais publicados por Thompson, Wycherley e outros membros da Escola Americana fizeram com que os edifícios e plantas reconstituídas da ágora ateniense se tornassem, em especial a partir dos anos 1970, quase onipresentes nos trabalhos que tratavam de arqueologia, arquitetura, arte ou história das poleis no período helenístico e romano. Junto deste repertório, a abordagem espacial, que enfatizava as relações entre os edifícios, fez da ágora ateniense um terreno fértil para intervepretações da visualidade e dos projetos envolvidos nas intervenções espaciais. Um exemplo precoce da apropriação das questões e interpretações produzidos no âmbito da Escola Americana é o estudo sobre a arquitetura das ágoras gregas 
publicado por Roland Martin em 1951, intitulado Recherches sur l'Agora grecque. O autor se ocupa da ágora ateniense somente de passagem, mas vale aqui destacar sua discussão sobre a influência da Ásia Menor na ágora helenística de Atenas: se por um lado ela se aproxima da "ágora jônica", ainda que sem as "stoas em ferradura" de Wycherley, a influência de Pérgamo é visível na articulação dos edifícios tanto na planta, pela ortogonalidade, quanto na elevação, com a construção de amplos terraços ao norte da Stoa de Átalo II e ao oeste da Stoa Média. O sistema de terraços é o fundamento do que o autor denominará como "urbanismo cenográfico", característico de Pérgamo (Martin, 1951, pp. 433, 506-507), e que execerceria em Atenas uma forte influência.

Outra apropriação, que estará na base de um interessante desenvolvimento da interpretação das intervenções helenísticas na ágora, é o livro Art and thought in the Hellenistic Age, publicado pelo historiador da arte inglês J. Onians, em 1979. A ágora ateniense aparece duas vezes nesta obra: na primeira, como aplicação de linhas imaginárias na concepção do espaço, na medida em que as stoas helenísticas criavam uma orientação cardeal até então inexistente na ágora; na segunda, como aplicação de eixos visuais a partir de pontos definidos, tal como o monumento diante da Stoa de Átalo II, que criava linhas de visão articulando o altar do Metroon e a fachada do Hephaisteion; o espaço deixado livre entre o Metroon e o templo de Apolo, justamente, não colocava obstáculos à linha visual que partia do altar da Stoa de Átalo II até o Hephaisteion.

A semântica visual do espaço de J. Onians é o mote para um texto que ao mesmo tempo o critica e o aprofunda: trata-se do artigo "Die hellenistische Umgestaltung der Athener Agora im 2. Jh. v.Chr.-Ausdruck von Rationalitat oder Entpolitisierung?" de H.-J. Schalles, publicado em 1982. O autor começa o texto pela crítica da abordagem excessivamente axial e geométrica de Onians, inclusive demonstrando alguns equívocos geométricos cometidos em função de plantas inadequadas (Schalles, 1982, p. 100-101, fig. 3). Contra uma visão geometrizante do espaço, Schalles explora os significados históricos das intervenções e das relações entre os edifícios implicadas nas intervenções helenísticas.

Para o autor, as intervenções devem ser situadas dentro de um momento particularmente agressivo da política externa pergamena no início do reinado de Átalo II, que procurou intervir na Capadócia, na Síria e na Bitínia, apesar das restrições estabelecidas por Roma contra seu irmão e antecessor Eumenes II (Schalles, 1982, p. 
103). Neste contexto, a construção da Stoa de Átalo II, com características que remetiam imediatamente à arquitetura pergamena (o jogo dos capitéis e a interrupção das caneluras das colunas, cujas referências eram os pórticos do santuário de Atena Nikephoros em Pérgamo), significa a imposição sobre a ágora ateniense de uma arquitetura atálida. A reforma do Metroon, realizada na década de 140, novamente remete à dinastia atálida: para além da semelhança com a Biblioteca de Pérgamo, é significativo o envolvimento do culto à deusa Mãe, realizado sob a proteção da monarquia pergamena em território gálata (Pessino), era fundamental na política religiosa atálida - basta lembrar que o culto foi introduzido em Roma por meio de Átalo I, que colaborou com os embaixadores romanos na obtenção da imagem de culto da deusa (Tito Lívio, 29.10-11). A Stoa de Átalo II, por sua vez, estava intimamente associada ao Hephaisteion: o eixo visual ligava o monumento atálida ao templo ateniense decorado com as vitórias de Héracles, herói pan-helênico e pai de Télefo, herói fundador de Pérgamo, e de Teseu, herói ateniense, sobre as forças do caos, da natureza e da barbárie, o que formaria um paralelo à comemoração atálida anti-bárbara após a vitória sobre os gálatas (os novos bárbaros), presente, por exemplo, na Dedicação Atálida na acrópole; além disso, sendo santuário da manufatura, o Hephaisteion se ligava à própria Stoa de Átalo II como espaço comercial. O eixo visual estabelecido entre a Stoa de Átalo II, o Hephaisteion e o Metroon, dessa forma, condensava os interesses da dinastia atálida e dos mercadores e artesãos atenienses (Schalles, 1982, pp. 107-108). A relação entre as stoas helenísticas e o Metroon é interpretada por Schalles dentro de um processo mais amplo de diferenciação e identificação da ágora. A diferenciação se realizava por meio da especialização de funções: a Praça Sul, ao sul, subtraía um amplo espaço da ágora e se especializava como complexo judiciário; a Stoa de Átalo II, ao leste, demarcava a ágora e se especializava como complexo comercial; o Metroon, ao oeste, reunia as atividades cultuais à administração cívica, coerente com os edifícios do lado oeste da ágora. A identificação era dada pelo cercamento da área central da ágora por grandes sequências de colunas, ininterruptas no sul (Stoa Média) e no leste (Stoa de Átalo II), e descontínua no lado oeste (Metroon, templo de Apolo e Stoa de Zeus) (Schalles, 1982, 108-109).

Este amplo processo é compreendido não como exemplo de racionalidade, com em Onians, mas como um símbolo do enfraquecimento da democracia ateniense, cuja assembleia não mais controla a produção do espaço: as novas stoas na ágora criam uma moldura estético-formal e apolítica (unpolitischen, formalästhetischen Rahmen), 
construídas com forte influência da autorepresentação (Selbstdarstellung) de uma monarquia helenística na concepção da nova ágora, que relega a democracia cada vez mais ao museu (Schalles, 1982, p. 111). Desse modo, o paradigma da "decadência da pólis", ainda dominante, recebia com o texto de Schalles uma nova fundamentação.

Uma leitura das intervenções augustanas como musealização da ágora ateniense havia sido proposta um ano antes da publicação do estudo de Schalles, em um texto que seria a primeira tentativa de interpretação global das intervenções espaciais da época romana em Atenas após as escavações americanas na ágora; trata-se do influente artigo "Athens: From City-State to Provincial Town", escrito pelo então diretor de escavações da Escola Americana T. L. Shear Jr., publicado em 1981 na revista Hesperia.

Neste texto, o autor apresenta uma leitura das transformações urbanas da Atenas romana a partir de uma matriz política. Para Shear Jr., a nova formatação da ágora ateniense é ao mesmo tempo símbolo e resultado do fim de Atenas como "cidadeestado" para tornar-se uma "cidade provincial". O Agrippeion, edifício sem precedentes em Atenas (filiado aos teatros cobertos italianos) era um "monumento para uma cidade onde sofistas e filósofos substituíram os generais e os oradores como os mais notáveis cidadãos" (Shear Jr., 1981, p. 361). Os templos itinerantes, o templo de Roma e Augusto na acrópole e o anexo à Stoa de Zeus Eleutherios são interpretados como marcas do culto imperial na cidade, forma de manifestação da lealdade das elites locais para com o imperador, assim como instrumento de romanização (SHEAR JR., 1981, pp. 362-3). O preenchimento da ágora sintetizava a nova situação política de Atenas, na medida em que "uma cidade conquistada tem pouca necessidade de assembleias democráticas [na ágora] e um cidadão-súdito tem pouca voz na determinação de seu destino" (Shear Jr., 1981, p. 361). Finalmente, os templos transplantados dariam para a ágora, em meados do século I d.C., "algo do aspecto de um museu” (Shear Jr., 1981, p. $362)$.

Identificando "política" a "autonomia militar" e a "democracia", o texto de T. L. Shear Jr. é um eloquente exemplo de como uma massa enorme de documentação nova pode ser enquadrada em um paradigma construído antes dessa documentação, a saber, o paradigma da decadência da pólis, ainda dominante na subforma da "Grécia helenística", sintetizado na passagem, indicada no título, de Atenas como "cidadeestado" para "cidade provincial". Com relação à subforma "Grécia romana", o paradigma dominante da "resistência à romanização" é nuançado, mas não abandonado: 
a multidão de evidências da influência romana na ágora augustana impedia a defesa de uma resistência simples, de uma manutenção integral ${ }^{33}$. Não obstante, a cultura clássica, para o autor, ainda tinha na época romana sua "força fertilizante" (Shear Jr., 1981, p. 356), manifestada no "profundo conservadorismo" na escolha dos materiais, métodos de construção e desenho das intervenções do período (Shear Jr., 1981, p. 368).

Os paradigmas do "declínio da pólis" e da "resistência à romanização", com os estudos de Shear Jr. e Schalles publicados em 1981 e 1982, respectivamente, estava assegurado na interpretação das intervenções urbanas pós-clássicas em Atenas. Isso mudaria radicalmente duas décadas depois, a partir de transformações teóricas e metodológicas da década de 1990.

\section{Revoluções teóricas e metodológicas (1990-2010)}

Nas décadas de 80 e 90, profundas transformações afetaram as ciências humanas em diversos níveis, reformulando tanto seus procedimentos metodológicos quanto a eleição de seus objetos de pesquisa. Os estudos sobre as intervenções urbanas da época de Augusto em Atenas não ficariam ilesos: a partir seja da História Antiga, seja da Arqueologia Clássica, em seus diferentes enquadramentos nacionais, tais estudos seriam confrontados com questões derivadas de movimentos como o cultural turn, o pósprocessualismo, os estudos pós-coloniais, os estudos de gênero, a nova história política, e os estudos de cultura material, entre outros (Shanks, 1996; North, 2009; Guarinello, 2010, pp. 117-118) - daí a quase onipresença de termos como "semântica do espaço", "imagem urbana", "história cultural da arquitetura", "ideologia/propaganda imperial", "cultura política" etc, como veremos.

Dentre as grandes questões que atravessaram os estudos de História Antiga e Arqueologia Clássica neste período, vale destacar a importante mutação no estudo das culturas provinciais no Império Romano, fortemente vinculada à experiência histórica da descolonização na África e Ásia. Tal mutação faria com que o "balanço bibliográfico da questão da romanização" se tornasse quase um gênero literário próprio, com

\footnotetext{
${ }^{33}$ Um caso particularmente interessante é a recusa na aplicação do termo "romanização" às províncias gregas no clássico Augustus and the Greek World, de G. Bowersock: apesar de não utilizar o termo (que seria cada vez mais esconjurado nas décadas seguintes), o autor discute profundamente a influência da nobreza romana na origem dos "revivals" arcaizantes e classicizantes na retórica, na epigrafia e na literatura do período augustano na Grécia (Bowersock, 1966, pp. 74-75), no quadro da formação de uma cultura greco-romana como fundamento da aliança entre a elite imperial e as elites provinciais no Oriente (Bowersock, 1966, p. 140).
} 
protagonistas e enredos permanentes e figurantes em função dos compromissos acadêmico-políticos de cada autor ${ }^{34}$. Contra os paradigmas eurocêntricos que viam na romanização cultural um complemento quase natural da dominação política, uma série de estudos explorará a documentação literária, epigráfica e arqueológica provincial em busca da agência das populações conquistadas a partir de múltiplos paradigmas: a preservação de traços culturais, interpretada como resistência à cultura estrangeira; a adoção da cultura do dominante como forma de inserção no sistema de poder; o hibridismo cultural, que promoveria a criação de formas culturais novas; a multiculturalidade, a partir da ideia de que a adoção de uma nova cultura se sobrepõe à anterior, sem necessariamente se mesclar; etc. Estas novas abordagens produziram uma verdadeira revolução nos estudos das culturas provinciais ocidentais, em consonância com a nova postura acadêmica derivada da expansão dos estudos pós-coloniais. Neste contexto, os gauleses, que a historiografia anterior romanizara, ainda eram gauleses, ou, no máximo, galo-romanos.

Diante desta mutação, a história das províncias gregas parecia figurar como um modelo para os estudos sobre as províncias ocidentais: a permanência da cultura grega, e mesmo sua influência sobre a cultura romana - numa espécie de "imperialismo cultural reverso" da cultura grega sobre Roma (Jones, 1963, p. 3). No entanto, ironicamente, no mesmo momento em que as resistências à romanização das provinciais ocidentais começam a protagonizar a produção acadêmica, um efeito inverso ocorre nos estudos sobre as províncias gregas: a ênfase recai sobre o impacto cultural e econômico da dominação romana, ainda que nem sempre rotulada como "romanização".

Fundamental neste movimento é a publicação do livro de S. Alcock, Graecia Capta, em 1993, fruto da tese de doutorado da autora defendida em Cambridge, e fortemente influenciada pela arqueologia de A. Snodgrass e J. Bintliff. A autora, a partir fundamentalmente dos resultados dos surveys, analisou o impacto da integração da Grécia ao Império Romano para além da problemática da romanização; um dos objetivos do livro, fundado na longa duração braudeliana, era construir uma história do

${ }^{34}$ Dentro deste "gênero", se enquadram tanto as dezenas de introduções de monografias dedicadas ao tema quanto os artigos e colóquios voltados justamente para o balanço. Um estudo sobre estes balanços, apesar de correr o risco de levar uma discussão por muitos considerada inútil a um segundo nível - que poderia ser um segundo nível de inutilidade - nos parece uma tarefa interessante para uma antropologia da produção acadêmica contemporânea, muito mencionada mas pouco explorada em profundidade. Entre os "balanços", se incluem: Millet (1990), Woolf (1998), Hingley (2000, 2005), Mattingly (2001), Keay e Terrenato (2001), Le Roux (2004), e o debate recente publicado no Archaeological Dialogues (2014), em especial o artigo de Versluys (2014a e 2014b) e os comentários de Hingley (2014), van Domelen (2014) e Woolf (2014). No Brasil, destacam-se Pinto (2003), Bustamante (2006) e Silva (2011). 
espaço rural, ignorada pela narrativa militar e política tradicional. O impacto da dominção romana se revelava no reforço das práticas oligárquicas e no enfraquecimento das instituições cívicas, o que levava à concentração da propriedade fundiária e ao consequente êxodo rural e declínio demográfico; neste contexto, as cidades se engajam em uma série de conflitos territoriais, procurando resistir ao declínio de suas instituições diante da dominação romana. Alinhada à tendência da época, a autora criticava o termo "romanização": a relação dominação imperial/resposta provincial era mais complexa do que o processo de mão única que o termo poderia indicar. Mas de qualquer modo, a Grécia se transformara profundamente sob a influência do Império ${ }^{35}$.

A discussão sobre o impacto cultural da dominação romana sobre as províncias gregas seria retomada em um breve artigo de Greg Woolf, publicado em 1994, intitulado "Becoming Roman, Staying Greek" ${ }^{36}$. Neste texto, após enumerar as resistências culturais gregas - tanto no campo da literatura quanto na cultura material o autor parte para a discussão do projeto romano específico para os gregos e das diferentes estruturas cognitivas entre as duas culturas. Os romanos buscavam regenerar a Grécia, considerada por eles como o berço da civilização, mas que então apresentava sinais de decadência moral. Mas o fariam a partir de seus próprios critérios: a associação entre cultura material e moralidade, central na cultura romana, não era estruturante, segundo o autor, na cultura grega. Assim, a adoção de elementos materiais da cultura romana, em especial a arquitetura (tipos de edifícios, ornamentação, técnicas), não afetava o modo como os próprios gregos se entendiam; eles poderiam participar dos jogos gladiatoriais e se reunir em banhos públicos e ainda assim continuariam se identificando como gregos. Considerando a reverência romana diante do passado grego e a permissão do uso da língua grega como uma das línguas administrativas, as características definidoras da identidade grega não foram afetadas: "os gregos permaneceram gregos, ao menos em parte, porque os romanos o permitiram" (Woolf, 1994, p. 131).

\footnotetext{
35 A aparente contradição entre impacto territorial e econômico de Roma sobre a Grécia e resistência literária dos gregos sob Roma (a Segunda Sofística) é abordada pela autora no final da década de 1990 (Alcock, 1997), o que marcará uma importante mudança em seus estudos, cujos desenvolvimentos aparecerão a partir de novo livro publicado no início da década de 2000 (Alcock, 2002), como veremos adiante.

${ }^{36} \mathrm{O}$ título faz referência à tese do autor, defendida anos antes mas só publicada em 1998 (Woolf, 1998), intitulada Becoming Roman: the origins of provincial civilization in Gaul, na qual o autor discute os processos de aculturação e hibridismo na Gália num contexto de transformações da própria cultura romana, caracterizado como uma "revolução cultural".
} 
Com o livro de S. Alcock e o artigo de G. Woolf, o impacto de Roma sobre a vida social e a cultura grega passaria a ser cada vez mais considerado no debate sobre a romanização; o desenvolvimento e a incorporação dos estudos de caso, e em particular daqueles voltados para o espaço urbano ateniense, seriam fundamentais na radicalização desta postura. Antes de tratar mais detidamente destes estudos - e desta radicalização -, é preciso destacar um movimento paralelo, mas intimamente relacionado ao debate da romanização, que se desenvolverá principalmente no campo dos estudos helenísticos: a crítica ao paradigma do "declínio da pólis". Tal crítica tem origens principalmente nos estudos epigráficos, acima de tudo pelos numerosos artigos e notas publicados por L. Robert entre 1930 e 1980. O epigrafista francês demonstrou a vitalidade política das cidades gregas até o fim do Império Romano, mas com especial ênfase para o período helenístico; a batalha de Queronéia ou a morte de Alexandre deixariam de ser vistas como os marcos definitivos para a experiência da pólis, depois dos quais esta agonizaria até sua provincialização sob Roma. Pelo contrário, a riqueza e a diversidade da documentação relativa ao período pós-clássico demonstrava a relevância da pólis enquanto forma de organização social (van Nijf e Alston, 2011; Dickenson, 2012, pp. 36-45). A crítica ao "declínio e queda" seria reforçada pelo grande projeto de inventário das poleis arcaicas e clássicas gregas realizado no Copenhagen Pólis Centre, publicado somente em 2004 mas fruto de um trabalho iniciado em 1993, e que teve nos artigos e livros de M. H. Hansen sua principal divulgação ${ }^{37}$. Uma das mais importantes contribuições do inventário foi a de, justamente, demonstrar que as categorias de "independência" ou "autonomia" não podem ser utilizadas como critérios de definição do que era uma pólis: a esmagadora maioria das poleis arcaicas e clássicas estava submetida, de modo mais ou menos intenso, a alguma forma de dominação; sustentar que a pólis, em geral, declinara após o estabelecimento dos reinos helenísticos ou do império romano, significava assumir que a pólis declinara praticamente desde seus princípios. Ao contrário de um retorno a Fustel de Coulanges - para quem, de fato, a pólis declinara a partir do século VIII a.C. - o movimento foi o de justamente situar o fim da pólis junto do fim do Império Romano, estivesse ele situado no período do "Baixo Império" (séculos III-V) ou na "Antiguidade Tardia" (séculos III-VIII) ${ }^{38}$.

\footnotetext{
${ }^{37}$ Cf. Hansen (1995), com o eloquente título "The "autonomous city-state". Ancient fact or modern fiction?”, além do próprio inventário (Hansen e Nielsen, 2004).

${ }_{38}$ Sobre os paradigmas do "declínio e queda do Império Romano" e da "Antiguidade Tardia", cf. Silva (2008, pp. 17-47), com bibliografia anterior.
} 
Os movimentos de crítica à "não-romanização dos gregos" e ao "declínio da pólis" foram absorvidos nos estudos de modo desigual e em ritmos diferentes. Assim, o reconhecimento da romanização das cidades gregas promoveu, algumas vezes, a ideia de que, se não foi após a batalha de Queronéia em 338, foi após a batalha do Ácio em 31 que a pólis declinou; só recentemente tem se consolidado uma historiografia que insiste na permanência da vitalidade das poleis gregas pelo período imperial adentro, apesar dos estudos pioneiros de L. Robert (Heller, 2009; van Nijf e Alston, 2011). O problema estava em compreender o aparente paradoxo pelo qual "mais romanização" não significaria "menos atividade cívica" - ainda que fora dos moldes anacrônicos da pólis autônoma e democrática do período clássico. A mesma questão se colocava para a relação entre as monarquias helenísticas e as cidades gregas: como conjugar a presença cada vez maior, via evergetismo, das dinastias na paisagem urbana e geopolítica das cidades com a intensificação das atividades cívicas? A discussão abrangente destes problemas, aplicados ao caso ateniense, só ocorreria recentemente; não obstante, a reflexão sobre a vitalidade ou declínio da pólis perpassou os estudos que rediscutiriam a romanização na época augustana, questão que concentrou boa parte da bibliografia sobre a Atenas pós-clássica até a década de $2010^{39}$.

O interesse sobre as intervenções espaciais do período 200 a.C.-14 d.C. em Atenas cresceu gradativamente a partir do final dos anos 80 e ao longo dos 90, levando a reflexão a um novo patamar. A explicação de tal impulso deve ser procurada tanto na efervescência dos debates acima mencionados quanto na maior divulgação dos resultados das escavações na ágora ateniense, que são inteiramente incorporados nos estudos sobre urbanismo na Antiguidade. Os achados mais revolucionários foram feitos ainda na década 30, mas a ampliação da área escavada no final dos anos 70 acrescentou novas intervenções para a lista. A nova área escavada englobava o limite noroeste da ágora, ao norte da rua Adrianou: enquanto edifícios já conhecidos tiveram finalmente seu traçado precisamente determinado, como foi o caso da Stoa Pintada (ou Stoa

\footnotetext{
${ }^{39}$ É digno de nota, neste sentido, que nenhum estudo abrangente sobre a produção do espaço ateniense exclusivamente no período tardo-helenístico tenha sido publicado desde 1982, quando surgiu o artigo de H.-J. Schalles, até os anos 2010. Uma possível excessão, que infelizmente ainda não foi publicada e à qual não tive acesso, é a tese de Luca Mercuri (2007). O único autor a considerar com mais detalhe as intervenções helenísticas, com o objeto de melhor interpretar as intervenções augustanas, foi Torelli (1995). Mesmo a publicação do manual sobre Atenas helenística de Chr. Habicht (1997), que substituiu o livro já ultrapassado de Ferguson (1911), trata do espaço urbano apenas tangencialmente, pela enumeração das práticas evergéticas, sem considerar a espacialidade destas intervenções. Os manuais de arqueologia de Atenas publicados por Camp (2001) e Étienne (2004), apenas de serem obras importantíssimas, não avançam muito além de sua condição como manuais: o livro de Camp se limita à descrição e narrativa, enquanto o de Étienne sintetiza interpretações elaboradas nas décadas anteriores.
} 
Poikile), novos edifícios foram trazidos à luz, muitos deles datando do período pósclássico (fig. 24). É o caso de três edifícios datados da época augustana: o primeiro e mais importante é o chamado Templo Noroeste (fig. 25), construído sobre podium, identificado pelo escavador T. L. Shear Jr. como o templo de Afrodite Urânia mencionado por Pausânias (1.14.7), mas, após as duras críticas dos arqueólogos italianos, hoje melhor interpretado como um templo de Hermes ${ }^{40}$; os dois seguintes são as stoas que se estendiam ao longo de ambos os lados da Via Panatenaica de algum ponto depois do Dípilo até a entrada noroeste da ágora, e por isso nomeadas Stoas Noroeste (fig. 26), das quais apenas a meridional é (relativamente) bem conhecida. Finalmente, um edifício que já era conhecido desde 1938 mas solenemente ignorado foi integrado às interpretações: trata-se da Stoa Nordeste (fig. 27), de época augustana, e que seria incorporada em uma basílica do século II d.C. (Shear Jr., 1981, p. 376, n. 79).

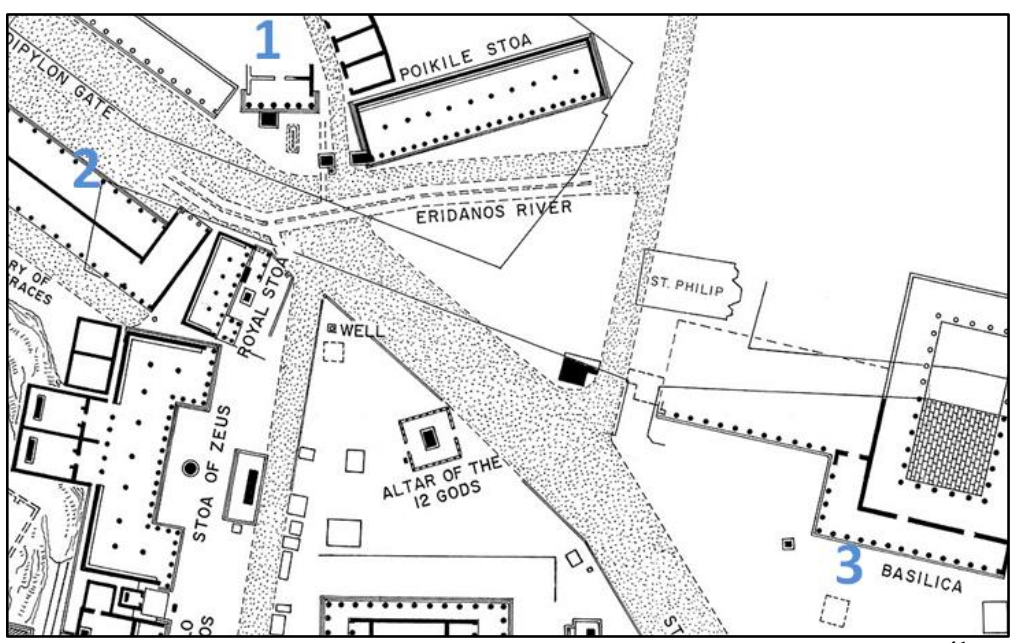

Figura 24. Detalhe da proposta de planta da ágora $\left(\mathrm{ASCSA}^{41}\right)$, com numeração (minha) dos achados/releituras das décadas 19702000. 1. Templo Noroeste. 2. Stoas Noroeste. 3. Stoa Nordeste.

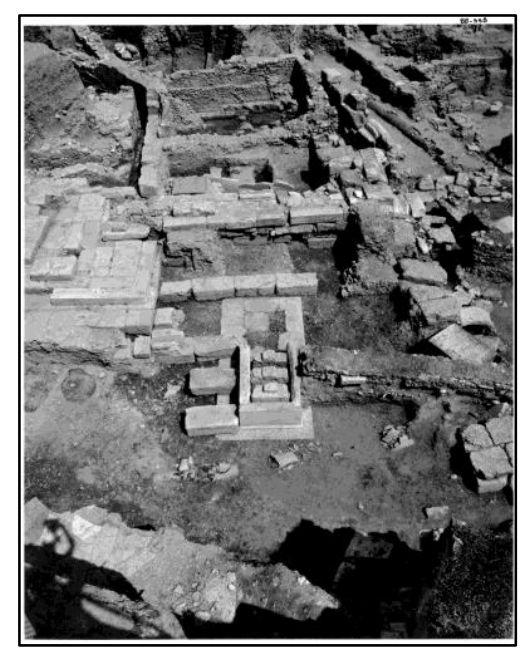

Figura 25. Fotografia do altar arcaico e do Templo Noroeste a partir do sul, tirada em $1991\left(\operatorname{ASCSA}^{42}\right)$.

\footnotetext{
${ }^{40}$ Cf. Shear Jr. (1984) para a identificação como templo de Afrodite Urânia; contra, Osanna (1988-1989), Torelli (1995, pp. 29-30) e Baldassarri (1998, pp. 182-197). A identificação inicial, não obstante, se mantém nos materiais de divulgação produzidos pela escola americana, ainda que isto implique em uma série de dificuldades topográficas.

${ }^{41}$ Disponível em: http://agora.ascsa.net/id/agora/image/1997.01.0420.

${ }^{42}$ Disponível em: http://agora.ascsa.net/id/agora/image/1997.06.0216.
} 


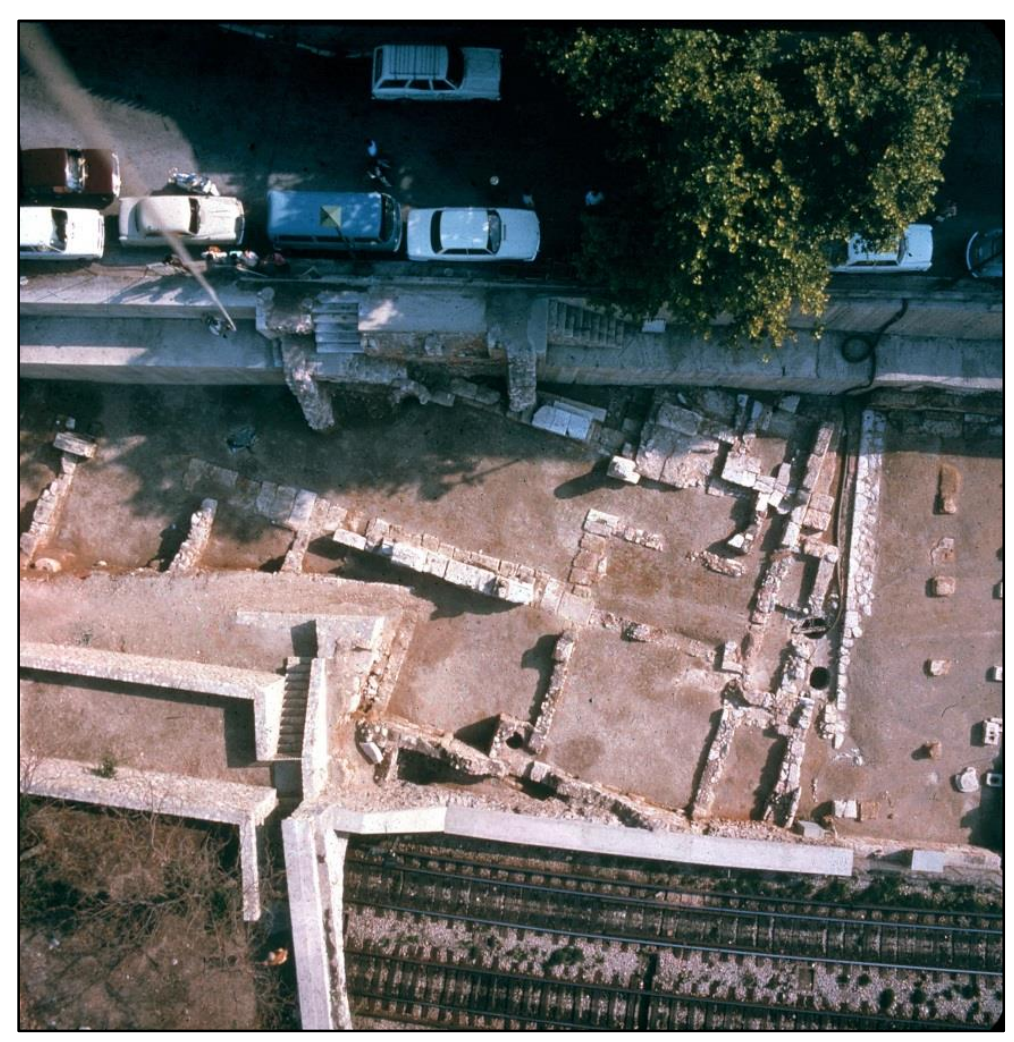

Figura 26. Fotografia aérea do área noroeste da ágora com detalhe para o limite oriental da Stoa Noroeste, tirada em 1975 $\left(\mathrm{ASCSA}^{45}\right)$.

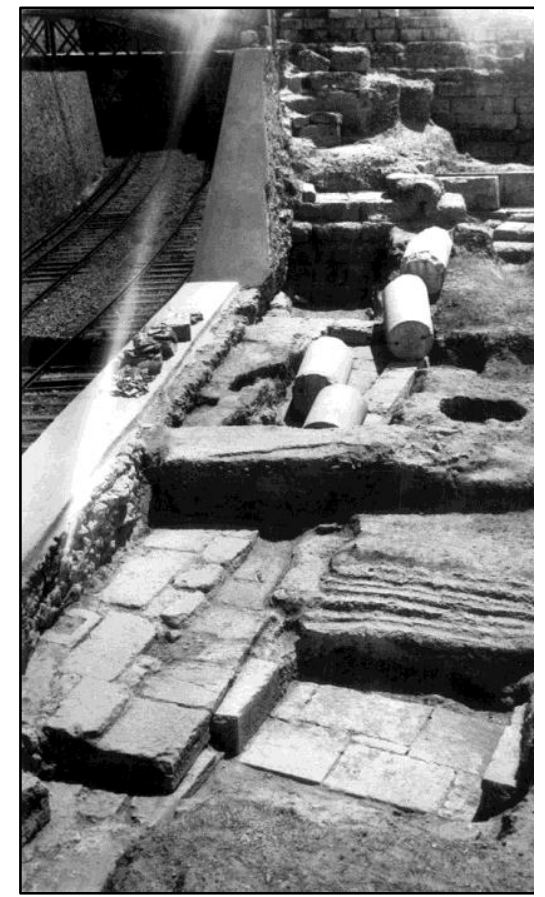

Figura 27. Fotografia dos vestígios da Stoa Nordeste a partir do oeste, tirada em $1950\left(\mathrm{ASCSA}^{46}\right)$.

Um texto pioneiro deste novo momento da reflexão sobre a produção do espaço na Atenas pós-clássica - em particularmente, augustana - é o curto artigo de P. Gros, Nouveau paysage urbain et cultes dynastiques, fruto de um colóquio realizado em 1985 mas publicado somente em 1991. Ainda que as teses do autor estejam em consonância com o paradigma do "declínio da pólis" "47, duas novidades de método são apresentadas. A primeira é a proposição de uma "semântica" do espaço urbano, pela qual o aspecto simbólico dos edifícios passa a ser essencial para a construção dos significados dos espaços. Por exemplo, oAgrippeion era, por sua semelhança com o edifício do Conselho (auditório semicircular em edifício retangular), um símbolo do fim da liberdade política; por sua função, um tributo à tradição cultural ateniense; por sua decoração (segundo Pausânias, estátuas de monarcas ptolomaicos), monumento da vitória de Augusto sobre Antônio; e por seu alinhamento com o templo de Ares, um reforço da propaganda

\footnotetext{
${ }^{45}$ Disponível em: http://agora.ascsa.net/id/agora/image/2000.03.0016.

${ }^{46}$ Disponível em: http://agora.ascsa.net/id/agora/image/1997.01.0097.

47 O sentido do programa augustano, para Gros, é a transformação da "velha praça comercial e administrativa em um verdadeiro santuário da família imperial” (Gros, 1991, p. 131).
} 
dinástica (devido às associações de Augusto e Caio César com Mars Ultor em Roma). A segunda novidade é o uso do método comparativo dos esquemas urbanísticos de cidades do Império que também sofreram intervenções na época augustana: Gros compara Atenas a uma cidade do oriente (Thasos) e duas do ocidente (Nîmes e Arles), demonstrando que as intervenções nas cidades no oriente ao mesmo tempo respeitavam e transformavam as tradições locais, cooptando o contexto monumental, dominando os alinhamentos e alterando das hierarquias.

Junto do texto de P. Gros, um dos textos fundadores desta nova fase é o artigo de Mario Torelli, intitulado L'immagine dell'ideologia augustea nell'agorà di Atene, publicado em 1995 na revista Ostraka, mas originalmente apresentado em jornada de estudos realizada em Cortona dois anos antes. Uma importante inovação de Torelli é começar a análise no período helenístico para compreender a lógica do espaço recebido pelos construtores da época de Augusto. A partir do início do século II a.C., a ágora ateniense seria equipada com um ginásio ao sul $^{48}$, uma luxuosa stoa ao leste e por edifícios reformulados no lado oeste, intimamente relacionados ao evergetismo dos reis de Pérgamo, que com alterações radicais no espaço da ágora, a adaptariam à maneira helenística de ágoras inteira ou parcialmente porticadas. As intervenções helenísticas teriam forte influência no programa augustano, especialmente nas intervenções associadas a Agripa. Torelli divide a ágora da época de Augusto em duas regiões: a noroeste, apropriada por Augusto (anexo à Stoa de Zeus, do período clássico, e o Templo Noroeste, identificado como dedicado a Hermes, na região tradicionalmente associada a Roma), e a sudoeste, apropriada por Agripa (Agrippeion como anexo ao ginásio helenístico, Templo Sudoeste ${ }^{49}$ como atribuído a Netuno/Agripa); enquanto Augusto teria respeitado as tradições urbanísticas locais, articulando suas intervenções aos edifícios já existentes, o segundo comportara como um monarca helenístico, alterando radicalmente a lógica do espaço. Se por um lado a interpretação de Torelli é a primeira que considera as intervenções tardo-helenísticas para a compreensão das intervenções augustanas, por outro sua análise se vinculava de modo exclusivo à propaganda imperial, situando a explicação mais em Roma do que em Atenas.

\footnotetext{
${ }^{48}$ A "Praça Sul". Torelli retoma a identificação do complexo como um ginásio, proposta pela primeira vez por Thompson em 1966 e logo depois abandonada, a favor da identificação como complexo jurídico ou comercial.

${ }^{49}$ Tornou-se consenso que este templo data de época posterior ao período augustano; cf. Baldassarri (1998, pp. 202-208).
} 
Uma perspectiva diferente é proposta pela dissertação de G. Schmalz, Public building and civic identity in Augustan and Julio-Claudian Athens (1995), o primeiro estudo abrangente dedicado quase exclusivamente ao período de Augusto após o livro de Graindor de 1927. Caracterizada pelo autor como uma "história cultural e arquitetural da atividade construtiva" (Schmalz, 1995, p. 1), esta dissertação insere as transformações urbanas de Atenas dentro das relações entre o poder imperial e a elite local, estruturadas pelo evergetismo. O modelo é o seguinte: cidades e indivíduos buscavam honra e prestígio, criando um ambiente extremamente competitivo; no período pós-31 a.C., o prestígio das cidades era obtido pela valorização do passado cultural; o prestígio dos indivíduos era obtido pelas honras concedidas pelas cidades, dadas em troca de doações; estas doações assumiam a forma de edificações e monumentos, associados à tradição da cidade e reforçando, assim, seu prestígio cultural. Nesta perspectiva, Schmalz historiciza a nostalgia integrando a uma história do evergetismo: a valorização do passado é compreendida "não simplesmente como uma fuga para uma 'fantasia nostálgica', mas como um importante recurso local que poderia ser manipulado e convertido em prestígio cultural valioso" (SCHMALZ, 1995, p. 2).

Dos quatro capítulos da dissertação, os três primeiros tratam do período de Augusto. O primeiro trata do "período formativo" das relações entre Augusto e Atenas: das incertezas após 31 a.C. à construção do templo de Roma e Augusto entre 20 e 19 a.C., interpretado como comemoração da "vitória diplomática" de Augusto sobre os partas, indício portanto da adesão irrestrita de segmentos da elite ao projeto augustano. Os dois capítulos seguintes tratam do período posterior a estes "anos formativos", e se dividem tematicamente: o capítulo 2 trata principalmente das restaurações de edifícios cívicos e santuários, o capítulo 3 das novas construções associadas à família imperial. $\mathrm{O}$ autor vê lógicas diferentes nos vários projetos de restauração (comemoração das vitórias sobre os persas, culto imperial, ornamentação da Via Panatenaica), enquanto que nas construções novas a tônica é, mais do que o culto imperial, o culto dinástico, por meio das figuras de Agripa e seus filhos (Caio e Lúcio César), netos de Augusto tornados herdeiros após a adoção imperial.

Das principais novidades apresentadas pela dissertação de Schmalz, destacamos o amplo uso da comparação de edificações atenienses com edificações semelhantes em outras cidades (ainda que não tenha feito comparações entre esquemas urbanos como um todo), as associações de diferentes contextos para resolver problemas específicos (como a associação do templo de Roma e Augusto com a "vitória" parta) e uma 
primeira explicitação do quadro conceitual básico para análise do objeto (evergetismo e ideologia imperial). Outra novidade importante, ainda que de outra ordem, é a realização de um pequeno catálogo de todas as edificações e monumentos do período analisado, seguido de uma coletânea das principais inscrições.

Em 1997, é publicada a coletânea The Romanization of Athens, organizada por M. Hoff e S. Rotroff. Dividida em 5 seções ("introdução", "história e prosopografia", "arquitetura e escultura", "cerâmica e cunhagem" e "literatura e culto"), a coletânea reúne textos apresentados em conferência realizada na Universidade de Nebraska, nos Estados Unidos, 1996. Dos 13 capítulos, apenas dois se dedicam à produção do espaço ateniense: o primeiro, de M. Hoff, analisa os vestígios materiais do saque de Sula em 86; o segundo, de S. Walker, se volta para o programa urbano augustano colocado em perspectiva.

O capítulo "Laceratae Athenae: Sulla's siege of Athens in 87/7 B. C. and its aftermath", de M. Hoff (1997), reconstrói, com base em fontes literárias e epigráficas, os principais momentos do saque, para então discutir seu impacto material no primeiro levantamento sistemático dos vestígios. A partir da planta produzida com marcação dos edifícios afetados (fig. 28), Hoff propõe que as destruições seguiam alguma racionalidade. Foram afetados edifícios situados na intersecção de rotas ou próximo das bases de operação do exército romano (Stoa Real, Prisão, Strategeion, Odeion de Péricles, Asklepieion), edifícios militares (Arsenal helenístico) e monumentos ligados à memória ateniense (Base dos Heróis Epônimos), enquanto edifícios da administração cívica (Bouleuterion) e religiosos (Metroon, Hephaisteion, Apolo Patroos) foram poupados. O autor conclui o texto apontando para as dificuldades materiais na reconstrução da cidade, evidenciadas pela dependência em relação a doações de potentados estrangeiros para tanto. 


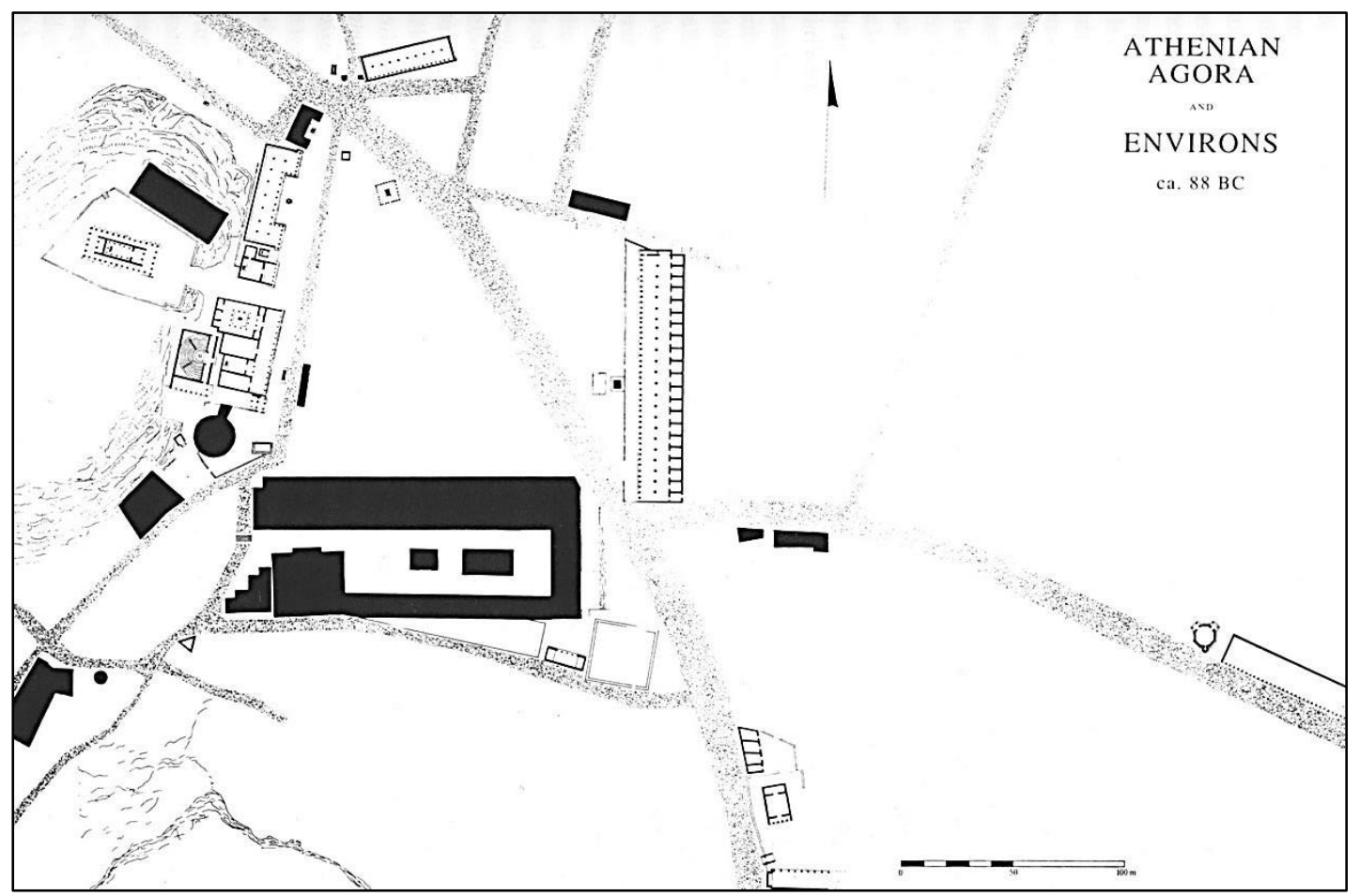

Figura 28. Proposta de planta da ágora e arredores em 86 a.C., mostrando edifícios e monumentos destruídos ou danificados por Sula, realizado por M. Hoff (1997, p. 39, fig. 1).

O texto de S. Walker (1997) realiza uma comparação dos esquemas urbanísticos (método já utilizado por P. Gros) das ágoras de Atenas, Cirene e Éfeso. O pressuposto da comparação é a idéia de que a passagem da república para a monarquia em Roma foi uma experiência universalmente sentida no mundo romano (Walker, 1997, p. 68), e isto produziu fenômenos urbanos comparáveis. S. Walker identifica as linhas gerais dos programas construtivos nestas três cidades no período augustano: são observáveis o reforço do aspecto religioso das ágoras associados ao culto imperial (eventualmente preenchendo o espaço central), a conservação e/ou realocação de monumentos ligados à origem da cidade, o registro proeminente dos benfeitores, e a construção de áreas porticadas a alguma distância da ágora (e sem ligação construída), com entradas monumentais. Deste quadro, Atenas apresenta duas especificidades: (1) seus "homens proeminentes" são atenienses sem cidadania romana, e (2) somente em Atenas ocorre a transposição de templos e monumentos de outros locais para a ágora. Se para a primeira especificidade a autora não avança hipóteses, para a segunda uma interessante solução é sugerida. Para Walker, a transposição de templos, como o de Ares, por exemplo, deve ser compreendida dentro das transformações urbanas ligadas à propaganda moral de Augusto, perceptíveis também em Roma: se na capital imperial Augusto preenche o 
centro de Roma com obras de arte gregas (carregadas com forte apelo moral), em Atenas esta "propaganda moral" poderia ser realizada não apenas com as estátuas, mas também com os edifícios inteiros que conteriam estas obras. Retorna, assim, a tese da musealização: “a razão para criar [...] um museu sagrado de arte e arquitetura religiosa em Atenas pode ser vista no papel exercido pela pólis clássica na propaganda moral augustana" (Walker, 1997, p. 72).

Em 1998 aparece o livro que se tornaria referência básica para os estudos posteriores sobre a Atenas augustana: Sebastoi Soteri: edilizia monumentale ad Atene durante Il saeculum augustum, de Paola Baldassarri. Fruto de uma tese de doutorado defendida em 1994 (mesmo ano de defesa da não-publicada dissertação de Schmalz), o livro de P. Baldassarri está centrado no extenso catálogo das “intervenções monumentais" augustanas (mais de 200 páginas), composto por detalhadas análises arqueológicas, arquitetônicas e epigráficas e extensos levantamento bibliográficos de cada uma das 18 intervenções catalogadas; uma introdução histórica e uma conclusão interpretativa completam a obra.

Baldassarri, além de considerar o conjunto de intervenções espaciais pós-sulanas - inovação que também aparece na quase contemporânea tese de J. Burden (abaixo) e que será retomada em estudos posteriores -, refina a periodização das intervenções de época augustana propondo quatro momentos. O primeiro (21-19 a.C.) é marcado, por um lado, pela associação de Augusto com a tradição anti-oriental ateniense, na construção do templo de Roma e Augusto e na reforma do Erechtheion, e por outro lado, pelo início do culto imperial, ligado ao financiamento da Ágora Romana e ao projetode término da construção do Olympieion pelos "reis amigos" de Augusto (mencionado por Suetônio, Vida de Augusto, 60). O segundo (por volta de 16/5 a.C.) é marcado pela ação de Agrippa e a formação do culto dinástico, visível na construção do Agrippeion e do anexo àStoa de Zeus, dedicados a Augusto e seus netos, filhos de Agripa. O terceiro (por volta de 2 a.C.) é o do reforço do culto dinástico com a presença de Caio César, herdeiro de Augusto, visível na transposição do templo de Ares e na associação Ares-Caio César. O quarto (pouco antes de 14 d.C.) tem a última intervenção religiosa augustana, com a construção do templo de Hermes ao lado da Stoa Pintada, também associado a Augusto. Quanto à interpretação geral, apesar de em algumas passagens enfatizar as referências locais e/ou mediterrânicas dos arquitetos e pedreiros envolvidos nas construções, a autora funda sua interpretação na periodização da propaganda augustana em Roma, reforçando a visão romanocêntrica. 
Uma alternativa consistente é apresentada na dissertação Athens remade in the age of Augustus: a study of the architects and craftsmen at work, de Jeffrey Burden, defendida no ano de 1999 em Berkeley, ainda não publicada. A dissertação de Burden busca "a visão do arquiteto", dentro de uma proposta de reconstrução dos projetos arquitetônicos (Burden, 1999, p. 3); com uma introdução metodológica, um capítulo sobre o contexto urbano pré-Augusto de Atenas, três capítulos divididos por região (acrópole, ágora, ágora romana), um capítulo interpretativo, a obra ainda inclui um catálogo ricamente ilustrado dos 14 "vestígios arquitetônicos" analisados.

A alternativa de Burden ao romanocentrismo parte da ideia de que a ação construtiva no centro urbano ateniense diz sim respeito à propaganda augustana, mas não somente: é possível observar dois projetos contraditórios. De um lado, a propaganda religiosa augustana, estruturada pelo arcaísmo e pelo reforço das tradições cívicas, cujas principais manifestações são a proibição da venda da cidadania ateniense por Augusto (Dio Cássio, 54.7.2) e o embelezamento do trajeto percorrido pela procissão das Grandes Panatenéias ${ }^{50}$. De outro lado, as demandas práticas de uma burguesia comercial ateniense que, mais do que a restauração/transposição de edifícios veneráveis, buscava a construção de uma nova ágora. Com isso, Burden interpreta o "prodígio" da estátua de Atena cuspindo sangue na direção de Roma (Dio Cássio, 54.7.2-3) como uma manifestação deste conflito $^{51}$, tendo sido apaziguado com a construção da Ágora Romana por Augusto.

Com a publicação deste conjunto de obras na década de 90, a pesquisa sobre a Atenas augustana disporia de uma imensa quantidade de material organizado e analisado (especialmente nas obras de Baldassarri e Burden): as interpretações de conjunto dominariam os novos estudos, deixando a discussão minuciosa das fontes para um segundo plano. Também em função deste novo patamar, as interpretações do espaço

\footnotetext{
${ }^{50} \mathrm{O}$ papel do festival na propaganda augustana, apenas indicado em Graindor, é longamente analisado por Burden. $\mathrm{O}$ argumento é que as intervenções augustanas, com a exceção dos anexos à stoa de Zeus, se situam todos no percurso da procissão: as stoas e templos no noroeste da ágora, o templo de Ares e o Agrippeion formando uma quina com a via panatenaica; o pórtico da Ágora Romana dedicado a Atena, visto da via panatenaica na saída da ágora; a quadriga de Agripa, a reforma do Erechtheion e o templo de Roma e Augusto, já no topo da acrópole, marcariam o último trecho da procissão antes do Partenon. Como argumento adicional, Burden, seguindo Graindor, interpreta a procissão representada no Ara Pacis, construído em Roma por Augusto, como uma procissão panatenaica (BURDEN, 1999, pp. 210-25).

${ }^{51}$ Cf. a discussão pormenorizada em Hoff (1989).
} 
ateniense pós-clássico produzidas na década de 2000 tiveram como objeto central as intervenções augustanas; nenhum estudo tomará exclusivamente como objeto as intervenções tardo-helenísticas até a década de 2010. Não obstante, o recuo cronológico para o período pré-augustano, tal como efetuado por Torelli (1995), por vezes tomando o saque de Sula como marco, por vezes mesmo a libertação contra a Macedônia em 229, tornou-se prática corrente. Neste contexto, se consolida a oposição entre uma abordagem romanocêntrica, que explica a ação construtiva em Atenas quase que exclusivamente em função das transformações em Roma, e uma abordagem helenocêntrica, que busca integrar as intervenções romanas nas tradições e projetos locais e/ou mediterrânicos. Os estudos mais recentes tendem a se aproximar mais de um ou de outra perspectiva.

Após seu estudo seminal sobre as "paisagens" da Grécia Romana (Alcock, 1993), no qual a Grécia emergia como uma "província comum” diante do poder romano (especialmente no âmbito da produção agrícola e dos assentamentos rurais e urbanos), S. Alcock passa a abordar o tema da resistência cultural dos gregos, base da imagem da Grécia como uma "província singular" e até culturalmente dominante no império ${ }^{52}$. O elemento central, para a autora, é a relação de romanos e gregos com o passado da Grécia: daí o papel estruturador da memória em Archaeologies of the Greek Past: landscapes, monuments, and memories, publicado em 2002. Neste livro, o espaço urbano ateniense é apenas um entre diversos exemplos, mas a nova orientação da análise tem grande destaque. Para Alcock, a interpretação do conjunto das novas construções, das reformas e das transposições na ágora de Atenas no período de Augusto não pode ser limitada à propaganda imperial: diferentes atores sociais, tanto romanos quanto gregos, construiriam diferentes relações com o espaço; se por um lado as intervenções poderiam significar a total dominação romana, por outro poderiam se tratar de referências à tradição local ateniense, como no caso dos templos transpostos.

S. Alcock não propõe uma interpretação de conjunto para o espaço urbano ateniense pelo simples motivo de que, em seu livro, o argumento central é justamente que não há "uma" interpretação, mas múltiplas, em função das diferentes experiências dos sujeitos históricos. O grande obstáculo para esta abordagem, que, consequentemente, mantem seu caráter ainda demasiadamente propositivo, é a raridade

\footnotetext{
${ }^{52}$ Um texto que marca a passagem de uma visão materialista (de sujeição) a uma culturalista (de resistência) da Grécia romana foi publicado na célebre coletânea Dialogues in Roman Imperialism, organizada por D. Mattingly (1997).
} 
de fontes que apresentem estas múltiplas leituras. De qualquer modo, já se tem com o estudo de Alcock um grande passo no sentido de uma história social das relações da cidade com o passado por meio do espaço construído, para além das intenções dos projetistas/financiadores.

Em 2008 é publicada coletânea Athens during the Roman Period, organizada por Stavros Vlizos, primeira obra sobre Atenas romana predominantemente composta por textos escritos em grego e por autores gregos. Dos quase 30 capítulos dedicados à arquitetura, escultura, numismática e cerâmica, apenas dois têm como objeto a produção do espaço na Atenas augustana; não obstante, ambos reforçam a tendência de crítica da “iniciativa imperial" no conjunto das intervenções urbanas em Atenas, procurando ressaltar a presença e participação de agentes e tradições locais em determinados aspectos das intervenções.

O primeiro, Tradition and romanization in the monumental landscape of Athens, de Theodosia Stefanidou-Tiveriou, reforça o papel das tradições locais na composição da paisagem da Atenas augustana. Após um breve levantamento da presença visual de Roma na paisagem urbana ateniense desde o século II a.C., Stefanidou-Tiveriou distingue duas categorias de intervenções: o respeito às tradições urbanísticas e arquitetônicas locais seria indício de planejamento local (com ou sem financiamento imperial), sendo o caso na Ágora Romana, nos anexos à Stoa de Zeus, no templo de Roma e Augusto e nos reparos do Erechtheion, dos edifícios públicos da ágora e do Asklepeion na acrópole, e da construção das stoas bordeando a Via Panatenaica. Quando não há este respeito, se tratarim de projetos externos, imperiais, como no caso do Agrippeion e da transposição do templo de Ares.

Ainda que este critério seja interessante, ele não é decisivo: como os muitos estudos já enfatizaram, o arcaísmo era parte fundamental da propaganda augustana, e por consequência o respeito às tradições locais pode ser integrado às intervenções imperiais; ademais, o argumento anti-romanização das "múltiplas leituras" de S. Alcock poderia ser usado contra o localismo. Independente disto, entretanto, o texto de Stefanidou-Tiveriou traz duas valiosas inovações: em primeiro lugar, uma recuperação das intervenções romanas pré-Augusto na paisagem urbana, adicionando mais uma camada na análise das intervenções augustanas; em segundo lugar, a crítica de interpretações desnecessariamente romanizantes do estilo arquitetônico de alguns edifícios, como no caso da Ágora Romana, inserida na tradição helenística de ágoras fechadas. 
O segundo, Athen in der frühen Kaizerzeit - ein Werkdes Kaisers Augustus?, de Ortwin Dally, discute o problema da iniciativa imperial da reestruturação global do espaço urbano ateniense: para o autor, a partir das evidências literárias, epigráficas e arqueológicas, não há fundamento para a defesa desta tese. Dois exemplos são eloquentes: no caso do templo de Roma e Augusto na acrópole, o nome de Augusto não aparece no nominativo - pelo contrário, o sujeito da dedicação é o demos, e são mencionados na inscrição os nomes de magistrados locais; no caso da Ágora Romana, a quantidade e disposição das métopas do propileu fazem uma paráfrase dos propileus da acrópole, indicando assim a presença da tradição arquitetural local. A indeterminação nas fontes quanto ao problema da iniciativa leva o pesquisador alemão a propor um modelo que integre a influência imperial e a ação decisiva das elites locais na atividade construtiva ateniense, ainda que tal modelo não seja desenvolvido, em seu curto texto, a ponto de dar conta das ambiguidades estruturantes do programa.

\section{Perspectivas atuais (2010-)}

As idas e vindas da romanização de Atenas ao longo das últimas décadas, oscilando dos indícios de resistência e até conflito das tradições e/ou agentes locais com a imposição romana à total colaboração com a propaganda imperial, fortaleceram a ideia de que uma das chaves de compreensão das intervenções augustanas, mais do que a determinação da essência do programa imperial, é a eventual colaboração entre elites locais e casa imperial. No entanto, isto não resolvia todos os problemas: colaborar em quê, como, com quais objetivos, e desde quando? Fundamental para o tratamento adequado destas questões foi contextualizar as intervenções de época augustana no conjunto das intervenções romanas em Atenas, o que fez com que os pesquisadores reforçassem o movimento de recuo cronológico à história urbana ateniense dos séculos II e I a.C. Este retorno tem acrescentado novas dimensões na análise, e as consequências deste adensamento para a imagem geral da cidade são particularmente interessantes. Aos poucos, os desenvolvimentos do final da década de 2000, no que diz respeito tanto à questão da romanização quanto à vitalidade da pólis pós-clássica, seriam absorvidos nos estudos sobre Atenas. 
Em 2010 é publicada a coletânea Die Akropólis von Athen im Hellenismus und in der römischen Kaiserzeit, organizada por R. Krumeich e Chr. Witschel. Apesar do livro ter como objeto central as intervenções na acrópole, dois capítulos procuram analisar as intervenções romanas como um todo, refinando uma das propostas do texto de Stefanidou-Tiveriou, qual seja, a retomadada história das intervenções romanas préaugustanas em Atenas.

No capítulo “Von Lucius Aemilius Paullus zu Augustus - Stiftungen von Römern in Athen", Caroline Rödel (2010) procura compreender a relação entre a posição dos "benfeitores" no sistema e nas circunstâncias políticas romanas e o modo como as intervenções romanas pré-augustanas se estruturam. Assim, partindo da discussão do significado político da "plataforma (bema) romana" na ágora de Atenas até as intervenções augustanas, a autora propõe uma periodização das intervenções urbanas romanas em Atenas em três períodos: no século II a.C., os magistrados estavam submetidos ao Senado, e agiam conforme suas determinações, fazendo com que as doações a Atenas estivessem em segundo plano; ao longo do século I a.C., o poder extraordinário concedido pelo Senado e pelo povo aos generais gerou a competição, simultaneamente, pelo poder em Roma e pelo maior número de clientes, o que motivou a prática do evergetismo romano nas cidades gregas, como Atenas; após a vitória de Augusto em 31 a.C., o fim da competição entre generais alterou as formas de evergetismo, que passariam a estar associadas ou à família imperial, ou às elites locais, às quais, em virtude da pax Augusta, se motivariam a participar do desenvolvimento da cidade. O quadro geral da interpretação é, pois, a passagem da república para o principado de um ponto de vista simultaneamente global e local, discutindo o modo como esta passagem se manifestou no espaço urbano ateniense.

Em "Tanta vis admonitionis inest in locis - Zur Veränderung von Erinnerungsräumer im Athen des 1. Jahrhunderts v. Chr.”, Elena Mango (2010) faz um movimento semelhante ao de C. Rödel, mas com uma preocupação específica: analisar o papel dos "espaços de memória" na relação entre romanos e atenienses. Fundamental na noção de "espaço de memória" é a consideração do uso dos espaços, para além da discussão limitada às intencionalidades do projeto; além disso, e retomando a proposta de P. Graindor e P. Gros, a autora incorpora na análise as estátuas e sua inserção espacial. O argumento básico é que, apesar de alguns importantes descompassos no século I a.C., no período augustano ocorre uma fusão entre as expectativas romanas e os interesses da elite e do povo: as intervenções se integram nas estruturas econômicas, 
sociais, políticas e culturais locais. Exemplos são a Ágora Romana e o Odeion de Agripa: se a primeira une a propaganda imperial às atividades econômicas populares, a segunda o faz simultaneamente como espaço para atividades artísticas e (possivelmente) de representação das elites locais (Odeion de Agrippa).

As duas autoras, portanto, enfatizam a colaboração entre elites locais e a casa imperial, buscando ver, no caso de C. Rödel, as transformações nas relações entre romanos e atenienses do ponto de vista de Roma (passagem da República ao Principado) e, no caso de E. Mango, as acomodações das intervenções romanas nas estruturas locais do ponto de vista das tradições atenienses (a produção e uso dos lugares de memória).

O retorno ao século II a.C. é também a estratégia metodológica de um pequeno mas rico texto publicado em 2012, intitulado Métamorphoses de l'agora d'Athènes à l'époque augustéenne, de Patrick Marchetti (2012). O autor belga, cujos insights topográficos, associações mítico-históricas e a ênfase na ágora o colocam na mesma seara do texto de M. Torelli (1995), apresenta novas articulações das intervenções da época augustana com as tradições espaciais locais, em particular aquelas criadas no período helenístico: a continuidade, pelo aproveitamento imperial do prestígio dos espaços, é a chave de leitura. Para isso, o autor reabre a questão das intervenções atálidas e ptolomaicas na ágora, em particular a Stoa de Átalo II e a chamada "Praça Sul", identificada pelo autor como o ginásio de Ptolomeu mencionado por Pausânias e diversas outras fontes. A continuidade, no caso da Stoa de Átalo II, é marcada pela posição da plataforma romana exatamente diante da stoa, tornando-a uma "stoa dos romanos" (Marchetti, 2012, p. 218); no caso do ginásio de Ptolomeu ("Praça Sul”), a continuidade se dá pela construção do Agrippeion como um anexo do ginásio, uma “extensão monumental do ginásio real” (Marchetti, 2012, p. 220). Em síntese, a tese central do autor é que Atenas se torna "uma vitrine do poder imperial", que, ao invés de alterar ou destruir o espaço, exploram e utilizam o "potencial [...] que os lugares altamente simbólicos e prestigiosos" de Atenas fornecem à propaganda imperial. Em um sentido mais urbanístico, a ágora de Atenas, com um ginásio e uma série de associações religiosas com a família imperial, se torna um equivalente do Campo de Marte de Roma, "praças públicas que serão invadidas por novas construções características do império", conscientemente tornando inviáveis as reuniões do povo, então "venerado como entidade abstrata, o Demos, mas privado de toda possibilidade de 
ação direta [...]" (Marchetti, 2012, p. 220-1). Retorna-se deste modo, ainda que com um maior refinamento e novas associações, ao paradigma do "declínio da pólis" enunciado por T. Leslie Shear Jr. em 1981 e reforçado por P. Gros em 1991.

No mesmo ano da publicação do capítulo de Marchetti, aparecem duas obras que incorporarão os mais recentes desenvolvimentos nos dois principais debates que nos acompanharam até aqui: a questão da "romanização x resistência" da cultura grega sob o império está no centro do argumento de Greece and the Augustan Cultural Revolution, de A. Spawforth (2012), enquanto o que estrutura a tese de Christopher Dickenson, "On the Agora: power and public space in Hellenistic and Roman Greece" (2012), é a questão do “declínio ou permanência” da pólis. Vejamos.

O livro de Spawforth é fortemente influenciado pelo modelo proposto por Andrew Wallace-Hadrill (2008) para a análise das transformações culturais na Itália entre os séculos II a.C. e I d.C., cujo impacto para a questão da romanização das províncias ainda não foi totalmente avaliado ${ }^{54}$. Em linhas muito gerais, Wallace-Hadrill defende que em Roma no século I a.C., além da ascensão social e política das elites italianas dentro do sistema imperial romano, ocorreu uma revolução cultural marcada pela subversão das tradições aristocráticas romanas em nome de um novo sistema cognitivo, baseado na cultura grega (em especial o antiquarianismo), mas levado a Roma por elites italianas helenizadas ao longo do século II a.C. (ao final do qual chegaram a forjar uma identidade anti-romana, engajada na Guerra dos Sócios do início do século I a.C.); um dos principais objetos deste sistema cognitivo seria a própria definição de romanidade. A ressignificação da identidade romana seria o paralelo cultural da ascensão das elites italianas nas estruturas de poder romanas analisada por R. Syme; com a mesma inspiração, Wallace-Hadrill interpreta o principado de Augusto como a vitória, não sem ambiguidades, desta revolução cultural, pela qual os romanos passaram a definir a si e aos outros em termos gregos (ou a interpretação italiana dos termos gregos). Não se trata, com o livro de Wallace-Hadrill, da discussão sobre a romanização ou não das culturas provinciais; a própria referência da romanização, a cultura romana, é analisada no jogo de sua instalibilidade e estabilização: os romanos já

\footnotetext{
54 Apesar de ser incorporado no mais recente balanço sobre a romanização como um dos principais teóricos da "romanização 2.0" (Versluys, 2014, p. 9).
} 
não seriam mais pura e simplesmente romanos. O autor chega a propor uma metáfora cardíaca, pela qual Roma é o coração que recebe o sangue vindo do oriente e o bombeia para todo o império; neste sentido, a romanização é inseparável da helenização.

O livro de Spawforth discute as implicações desta "revolução cultural de Roma" para a Grécia: qual a ideia de identidade grega que os romanos manejam em seu contato com a Grécia, e qual o impacto disso na auto-representação dos gregos provinciais? A tese do autor é de que a "revolução cultural augustana", em Roma e na Grécia, estava baseada em algumas oposições estruturais: masculino/feminino, gregos do passado/gregos do presente, Europa/Ásia. Dentro deste quadro, os romanos se identificavam como os verdadeiros herdeiros dos gregos do período clássico, cuja masculidade militar e retidão moral havia lhes dado a vitória sobre os bárbaros persas, amolecidos pelas amenidades asiáticas; os gregos do presente haviam perdido suas qualidades (por influências asiáticas), e cabia aos romanos a re-helenização (arcaica e clássica) dos gregos de então. Alguns elementos desta campanha restauradora dos romanos na Grécia eram imediatamente visíveis nas intervenções augustanas no espaço urbano ateniense: é o caso da celebração das vitórias gregas sobre os persas (templo de Roma e Augusto na acrópole, santuários restaurados pelo decreto IG II $^{2}$ 1035), da celebração da disciplina militar (templo de Ares na ágora) e da retórica clássica ateniense (Agrippeion). Quanto à resposta das províncias, o autor enfatiza a adesão das elites locais ao projeto augusto, visível na proliferação dos cultos imperiais. Em síntese: a retomada do passado clássico ateniense, longe de ser uma resistência à dominação imperial, é uma das marcas centrais da romanização de Atenas, que age na forma de helenização (em termos ítalo-romanos) pela iniciativa imperial e/ou local. A metáfora para a romanização e seus ritmos, utilizada pelo autor, é clara: a romanização é como um "moinho de vento", que sopra mais ou menos forte em função dos projetos dos diferentes imperadores (Spawforth, 2012, p. 130). Resistir, neste sentido, seria negar a valorização do passado clássico ateniense, algo particularmente improvável em Atenas dominada por Roma. Na conclusão, o autor explicita claramente sua abordagem: "o estado imperial não procurou negociar esta romanidade com súditos de língua grega. $\mathrm{Na}$ análise final, esta era uma romanidade sinalizada de cima e emergindo do ocidente" (Spawforth, 2012, p. 274).

A sutil diferença na qualificação das "revoluções culturais" de A. WallaceHadrill (Rome's Cultural Revolution / Roma como um "coração") e de A. Spawforth (Augustan Cultural Revolution / casa imperial como um "moinho de vento") é 
importante: Spawforth parte da desestabilização da romanidade para reforçar uma perspectiva romanocêntrica e mesmo imperatocêntrica da história da Grécia, e em particular do espaço urbano ateniense. Contrariamente à perspectiva exposta por autoras como S. Alcock e Th. Stefanidou-Tiveriou, em Spawforth a tradição local, mais do que ser considerada, é sequestrada, na medida em que é resultado de uma seleção realizada a partir dos termos estabelecidos pelos romanos durante sua revolução cultural; em outras palavras, quanto mais ateniense, mais romano. As categorias de "propaganda" e de "corte" - que não estão isentas de dificuldades conceituais, muito pelo contrário - são alçadas a um novo patamar.

Ainda em 2012, aparece a tese de C. Dickenson sobre as ágoras gregas dos períodos helenístico e romano, On the Agora. Trata-se de uma exaustiva discussão sobre a documentação literária, epigráfica e arqueológica das ágoras, além dos fundamentos teóricos e metodológicos da análise desta documentação; e Atenas é tomada mais de uma vez como objeto privilegiado de análise. O debate central da tese é, justamente, aquele que aparecia marginalmente e como que resolvido nos estudos até aqui considerados: a da decadência ou permanência da pólis. Seja diante da ideologia monárquica helenística, seja diante da propaganda imperial, Atenas foi representada como uma espécie de vitrine, uma arena cultural onde se disputava a proeminência das tradições locais ou das demandas dos soberanos estrangeiros; as intervenções eram tomadas como suportes para inferências a respeito da falência do modelo democrático de produção do espaço (p.ex. em Schalles). A decadência da pólis e das atividades políticas era dada como certa.

A tese de Dickenson se situa em um estágio em que a crítica da decadência da pólis, iniciada, como dito acima, pelos estudos de L. Robert, já se encontra em uma fase de grande maturidade. Após os estudos precursores de Eric Gruen (1984), Philippe Gauthier (1985) e Maurice Sarte (1991), uma nova geração de estudiosos tem rediscutido a relação entre monarcas helenísticos e imperadores demonstrando o modo como as cidades não apenas mantiveram sua atividade política, como também a cultura da pólis ainda estrutura as relações delas com os soberanos ${ }^{55}$. No caso específico de Dickenson, a ágora é interpretada como um “espaço público" não apenas em sua

${ }^{55}$ Cf. John Ma (1999) e os desenvolvimentos em Sviatoslav Dmitriev (2005), Anna Heller (2009), Arjan Zuiderhoek (2009) e Onno van Nijf e R. Alston (2011), entre outros. 
materialidade, mas também do ponto de vista das práticas sociais que reiteram ou questionam a ordem e a hierarquia social.

A partir desta abordagem, o autor enfatiza os aspectos locais das intervenções, como é claro no caso da discussão sobre as dimensões da ágora nos períodos clássico e helenístico. O autor retoma e desenvolve a hipótese, enunciada algumas vezes (Marchetti, 2001, pp. 142-146; Hoff, 2001, p. 583; Sourlas, 2008, p. 99 e 2012), de que a ágora clássica se extendia da Kolonos Agoraios até a área do Horologium, e que teria sido dividida pela Stoa de Átalo II em duas (fig. 29). As evidências que apontam para esta direção, além da construção, na época augustana, da Ágora Romana, são os vestígios de lojas do período clássico encontradas no limite nordeste da ágora, cuja orientação segue o traçado das ruas que percorrem a região ao norte da acrópole, além, é claro, da construção do Horologium, que poderia ter funções ligadas ao controle do tempo na atividade comercial. A divisão da ágora, operada em meados do século II, responderia ao critério helenístico de divisão de funções: a ágora ocidental seria dedicada à administração e a oriental, atrás da Stoa de Átalo II, ao comércio. Uma subdivisão ainda existiria na ágora ocidental: a Praça Sul, recém-construída, criava um complexo jurídico e administrativo específico, que se comunicava mas se diferenciava do resto da ágora (Dickenson, 2012, pp. 156-182).

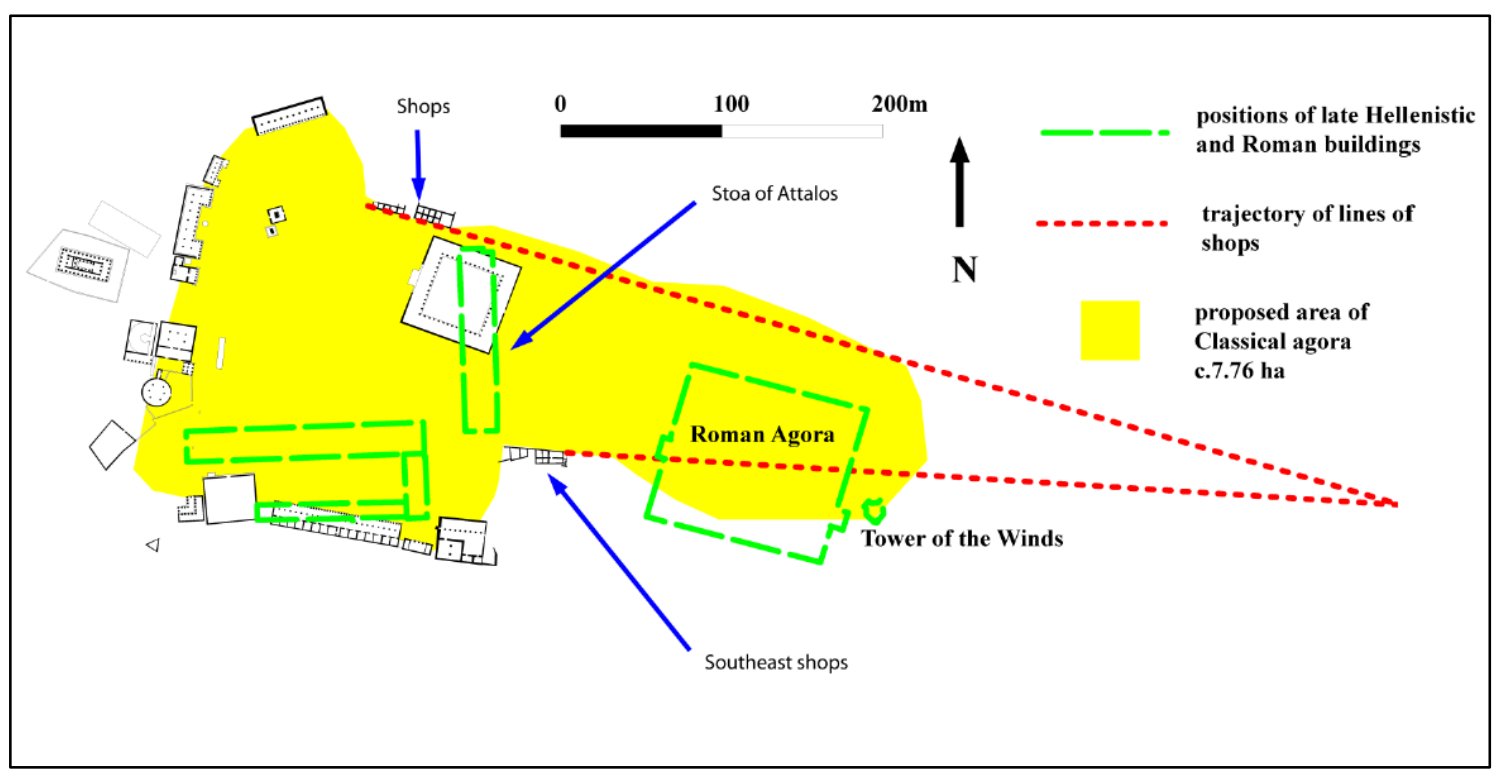

Figura 29. Proposta de reconstituição da ágora antes da divisão tardo-helenística, segundo Dickenson (2012, p. 174, fig. 23). 
A crítica radical ao modelo da decadência da pólis se dá na discussão das intervenções de época romana. Contra as interpretações que tomavam as intervenções na ágora ateniense pós-clássica como sinal inequívoco da decadência da pólis, Dickenson argumenta que mesmo no período de maior ocupação da área central, o espaço livre disponível ainda era equivalente ao espaço da Pnix, onde ocorriam as assembléias da democracia (fig. 30); além disso, edifícios dedicados a atividades político-institucionais, tais como o Bouleuterion, o Tholos, o Metroon e a própria Praça Sul (interpretada como complexo administrativo), seriam objeto de importantes intervenções, o que pode ser tomado como indício da vitalidade das instituições cívicas. Em uma interessante inversão do argumento de Shear Jr., para quem a romanização de Atenas era simbolizada pela ocupação e pelo fim do uso da ágora como espaço de reunião, Dickenson demonstra que não há documentação suficiente para a ideia de que a ágora fosse usada como espaço de assembléia no período clássico, e, inversamente, a prática da reunião política na praça pública era uma marca da política romana, coerente com a construção da plataforma para os generais romanos na ágora; a ágora passa a ser utilizada como espaço para assembléia, justamente, por influência romana.
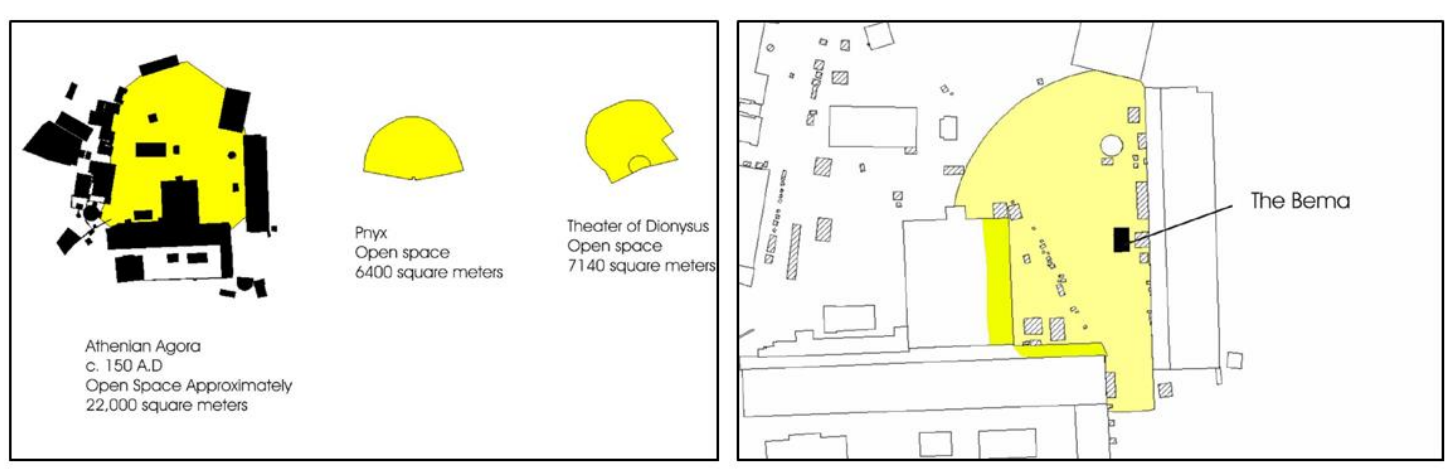

Figura 30. Comparação entre as áreas livres da ágora na época romana com a Pnix e o teatro de Dioniso (Dickenson, 2012, p. 405, fig, 50) e destaque da área livre diante do bema romano (Dickenson, 2012, p. 406, fig. 51).

A tese de Dickenson, ao analisar detidamente a documentação relativa às ágoras gregas e, em particular, a(s) ateniense(s), realiza uma profunda crítica às abordagens que partiam do pressuposto da decadência da pólis e da equivalência democracia/política para interpretar as intervenções espaciais; pelo contrário, as intervenções são tomadas como atestação da vitalidade da atividade políticoinstitucional. Esta inversão não significa abandonar por completo a problemática da 
romanização: ela é situada dentro de contextos mais delimitados, nos quais os padrões espaciais locais são determinantes.

Os estudos sobre a produção do espaço urbano ateniense, ao longo do século XX, tiveram que lidar com profundas mutações tanto dos conjuntos documentais quanto dos paradigmas e formas historiográficas; desta trajetória, vale destacar três pontos fundamentais para a presente pesquisa. Em primeiro lugar, a formulação de questões propriamente espaciais consolidou-se como um procedimento fundamental para impedir o reducionismo das análises "políticas", que tomam o espaço simplesmente como metáfora das relações internacionais atenienses. Ora, as novas intervenções dialogam com as tradições espaciais locais tanto quanto com as motivações e limitações políticas; reestabelecer estes diálogos é fundamental para uma apreciação mais complexa das relações entre espaço, política e sociedade. Em segundo lugar, e em decorrência do anterior, o retorno aos programas construtivos que antecederam o programa augustano é a melhor forma de evitar o reducionismo romanocentrista, que se por um lado explica as intervenções urbanas por meio da propaganda imperial em Atenas, expõe a propaganda imperial por meio das intervenções urbanas - o risco do argumento circular é evidente. Assim, é preciso considerar cada uma das intervenções dentro de seus contextos espaciais específicos, ressaltando o modo como cada novo programa urbano engaja (pela afirmação ou negação) os programas anteriores. Diante da multiplicidade de camadas históricas que, interpenetrando-se, compõem a paisagem urbana ateniense, é necessária uma delimitação básica. O recorte aqui escolhido - e este é o terceiro ponto se articula com a consideração do aspecto estrutural dos programas urbanos realizados a partir do século II a.C., qual seja, o evergetismo, que passa a ser a lógica dominante, ainda que não exclusiva, da atividade construtiva monumental da cidade até, pelo menos, o século III d.C., e que tem na época de Augusto e de Adriano o seu ápice. 
Capítulo 1. A cidade tardo-helenística 
Os primeiros sessenta anos do século II em Atenas são marcados por uma grande transformação no espaço urbano público: intervenções espaciais, direta ou indiretamente associadas a monarcas helenísticos, produzem uma nova paisagem urbana, rompendo com o período de mais de um século de baixa atividade construtiva (após as intervenções associadas a Licurgo entre 336 e 324). O conjunto destas intervenções foi interpretado, usualmente, a partir de referenciais estrangeiros: ou a construção de novas stoas na ágora e na encosta da acrópole significavam "atualizações" do espaço urbano ateniense aos padrões espaciais do período (tendo como referência principal as cidades gregas da Ásia Menor), ou a cidade se tornava uma espécie de vitrine da propaganda monárquica helenística, em particular dos reinos de Pérgamo, da Síria e do Egito; no mais da vezes, as duas interpretações se integravam, variando a ênfase nos aspectos urbanísticos ou ideológicos ${ }^{56}$. Estudos mais recentes, entretanto, tem enfatizado o papel das demandas e tradições locais na concepção e utilização das intervenções; mais do que apenas restringir-se à antiguidade da cidade (por oposição à liberdade concedida aos planejadores no caso das cidades recém-fundadas), as intervenções incorporavam padrões espaciais anteriores e respondiam a demandas locais, ligadas tanto a atividades administrativas quanto ao desenvolvimento comercial $^{57}$. O objetivo deste capítulo é discutir a relação entre o local e o estrangeiro nas intervenções helenísticas, aprofundando as pistas lançadas nos estudos anteriores para a construção de uma imagem mais complexa da história urbana ateniense no período, que dê conta das ambiguidades e contradições inerentes à nova modalidade de produção do espaço: o evergetismo construtivo.

O marco para o início desta nova modalidade será o ano de 200, quando Atenas declara guerra contra a Macedônia e se insere/é inserida de modo efetivo no novo contexto geopolítico do Mediterrâneo Oriental, ou seja, o processo de construção da hegemonia romana. A história das relações internacionais atenienses do século IV ao século I foi exaustivamente discutida em Habicht (1997), mas alguns elementos devem ser lembrados aqui. Após a derrota de Queronéia, em 338, a capacidade militar ateniense foi consideravelmente reduzida; mesmo assim, a cidade foi protagonista na guerra contra a dominação macedônica após a chegada da notícia da morte de Alexandre, em 323. A derrota para o general macedônico Antípatro, um ano depois,

\footnotetext{
${ }^{56}$ Tais interpretações são onipresentes nos grandes manuais dedicados ao urbanismo ateniense ou grego em geral, tanto os mais antigos, como os de Wycherley (1962, p. 84-85) e Martin (1951, pp. 433, 506507), quanto os mais recentes, de Camp (2001, pp. 161-182) e Étienne (2004, pp. 154-162).

${ }^{57}$ Cf. especialmente as discussões em Kohl (2001), Mercuri (2004) e Dickenson (2012, pp. 156-184).
} 
marcou o início da ocupação do Pireu por uma guarnição macedônica, que duraria, com um curto intervalo (301-295), até 229. O governo ateniense assumiria uma feição oligárquica e pró-macedônica da morte de Alexandre até 318, quando a restauração da democracia precipitaria a instalação de uma tirania liderada pelo ateniense Demétrio de Falero, protegido do rei macedônico Cassandro, filho de Antipatro. A tirania de Demétrio de Falero, de grandes consequências para a formação da paisagem urbana e fúnebre ateniense ${ }^{58}$, teria fim com a libertação da cidade comandada por Demétrio Poliorcetes ("Toma-Cidades"), filho do general e postulante ao trono macedônico Antígono Monoftalmos (“Caolho”), no ano de 307/6. A libertação é ocasião para a dedicação de honras divinas a Demétrio e seu pai: o rei e o príncipe macedônios recebem estátuas ao lado dos tiranicidas na ágora, tem seus retratos bordados no peplos $^{59}$ de Atena, são nomeados Heróis Epônimos de duas novas tribos atenienses (Demetrias e Antigonis), entre outras homenagens (Mikalson, 1999, pp. 75-104). A primeira fase do domínio de Demétrio sobre Atenas duraria até 301, quando, após a derrota dele e de seu pai na batalha de Ipsos, Atenas rompeu com o príncipe. Por volta de 298/7, a cidade seria governada por uma nova tirania, capitaneada pelo ateniense Lachares; Demétrio Poliorcetes também derrubaria esta tirania em 295, quando recebeu, dos arrependidos atenienses, a posse do porto do Pireu, que permaneceria sob domínio macedônico até 229 (Habicht, 1997, p. 124). A cidade conquistaria, com apoio do Egito, sua independência em 288/7, mas seria novamente subjugada à dominação direta em 262, já sob o reinado de Antígono II Gonatas, filho de Demétrio Poliorcetes. Da época da independência deve datar a construção do edifício conhecido como o Arsenal Helenístico (figs. 31 e 32), construído ao norte do Hephaisteion. Após 262, e ainda que as instituições democráticas continuassem em vigor, as proclamações de lealdade à casa real macedônica são quase onipresentes na epigrafia estatal ateniense; mais do que demonstrar sua lealdade, Atenas ainda participaria dos conflitos macedônios comandados por Antígono II Gonatas e seu filho e sucessor, Demétrio II, rei a partir de 239 (Habicht, 1997, p. 164).

\footnotetext{
${ }^{58} \mathrm{Na}$ tradição literária, há referências para a legislação suntuária de Demétrio, que teria limitado as honras fúnebres a apenas uma coluna, ao mesmo tempo em que teria disposto nos espaços públicos centenas de estátuas suas (Étienne, 2004, pp. 146-147).

${ }^{59}$ Manto bordado dedicado a Atena na acrópole durante o festival das Panatenéias.
} 


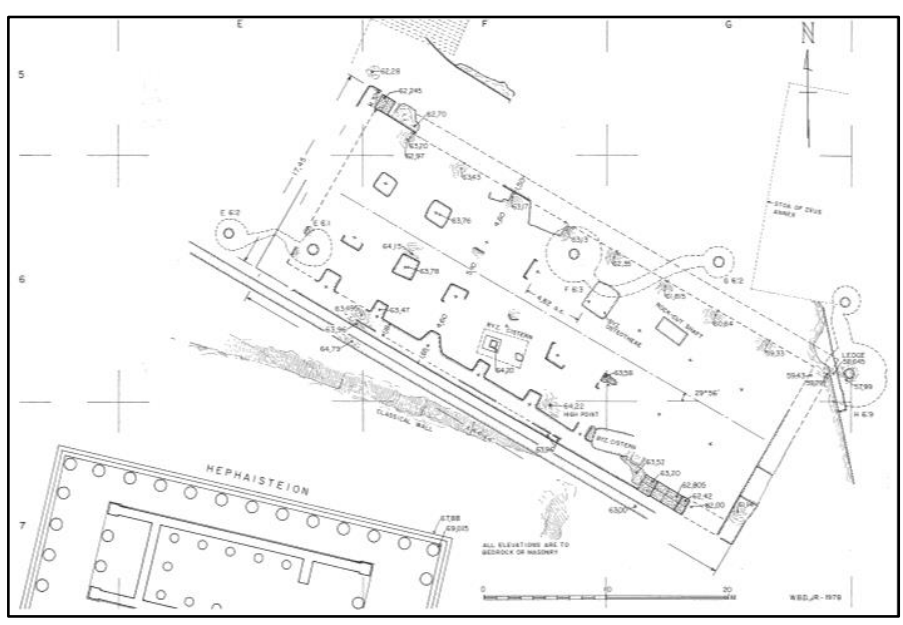

Figura 31. Planta do estado atual do edifício identificado como um Arsenal helenístico, feita por W. B. Dinsmoor em $1978\left(\operatorname{ASCSA}^{60}\right)$.

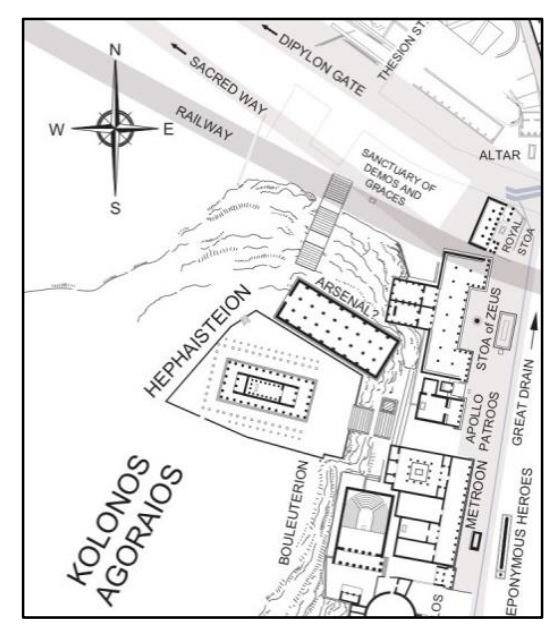

Figura 32. Detalhe da proposta de planta da ágora por volta do ano 100, feita por W. B. Dinsmoor em $1982\left(\mathrm{ASCSA}^{61}\right)$.

A morte de Demétrio II em 229 foi aproveitada pelos atenienses como uma oportunidade de recuperar a independência e a posse do Pireu; com a liderança dos irmãos Euricleides e Mícion do demos de Cefísia, Atenas iniciou uma política de alianças com o Egito de Ptolomeu III (que seria incorporado como herói epônimo em 224/3 de uma nova tribo, a Ptolemais) e a Liga Aquéia, liderada por Aratus de Sicião; tais personagens foram fundamentais na obtenção dos fundos requeridos pelo general macedônio Diógenes, comandante da guarnição ocupante no Pireu, para liberar a tropa e devolver o porto à cidade (Habicht, 1997, pp. 173-185). Diogenes se fixaria em Atenas, recendo honras divinas e sendo incorporado no clã dos Eteobutadai, responsável pelos cultos de Poseidon e Atena na acrópole (Mikalson, 1998, pp. 171-172). Atenas iniciaria em 229 uma política de estrita neutralidade nas questões militares no continente, sustentada, acima de tudo, pelo suporte da monarquia egípcia, até que a guerra eclodisse novamente em solo Ático no ano de 200, contra o rei Filipe V da Macedônia (Habicht, 1997, pp. 185-204).

Ao longo do século III, a geopolítica do Mediterrâneo Oriental passou por uma profunda reorganização. Após as reviravoltas dos primeiros anos da "Era dos Sucessores" (Will, 2003, t. I, pp. 19-84), no século III consolidaram-se as dinastias antigônida na Macedônia, selêucida na Síria e ptolomaica no Egito (Ager, 2003). Estes últimos foram eleitos pelos atenienses como seus principais protetores, o que se explica, mais do que por qualquer predileção ocasional, pela contínua oposição egípcia à casa

\footnotetext{
${ }^{60}$ Disponível em: http://agora.ascsa.net/id/agora/image/2002.01.2437.

${ }^{61}$ Disponível em: http://agora.ascsa.net/id/agora/image/2011.04.0041.
} 
real macedônica e pela distância segura do Egito em relação a Atenas, perigosamente próxima à Macedônia. A partir da segunda metade do século III, consolida-se uma nova dinastia que seria importantíssima na história de Atenas no século II: os atálidas de Pérgamo $^{62}$. A dinastia tem início com a traição de Filetairo, eunuco encarregado por Lisímaco, então soberano sobre a Ásia Menor, de proteger seu tesouro na cidadela de Pérgamo; em 282 Filetairo se associa a Selêuco, rei da Síria e rival de Lisímaco, e torna Pérgamo uma espécie de protetorado selêucida. O reinado do sucessor de Filetairo, Eumenes (263-241), reforça o movimento no sentido da independência de Pérgamo contra a Síria, que só é obtida com Átalo I (241-197), proclamado rei provavelmente no contexto de suas vitórias contra os gauleses (que haviam invadido a Ásia Menor em 278/7, fixando-se na Galátia e extraindo tributos das cidades gregas) e as tropas selêucidas nos primeiros anos de seu reinado. Átalo I continuaria a política, iniciada ainda por Filetairo, de doação de presentes não apenas às cidades da Ásia Menor, mas também de centros filelenos, como Delos e Delfos (Étienne, 2003). Mas um passo decisivo na entrada de Pérgamo no cenário fíleleno seria dado em 200, no início da chamada Segunda Guerra Macedônica, em Atenas.

O ano de 200 também marcou uma nova etapa na participação de Roma na vida militar do Mediterrâneo Oriental $^{63}$. Roma já havia guerreado contra Filipe V da Macedônia, em um conflito motivado pelas intervenções romanas na Ilíria nas décadas de 220 e 219. Aliado a Aníbal de Cartago, Filipe V declara em 214 uma guerra que se prolongaria até o tratado de paz em 205, sem grandes conquistas para nenhum dos lados. A vitória romana na Segunda Guerra Púnica em 201 coincidiu com o início das hostilidades entre Filipe V e Atenas; sob forte influência de Roma e de Pérgamo, que já haviam sido aliadas na Primeira Guerra Macedônica, Atenas declara guerra contra Filipe V, que organizaria o cerco ao longo do ano de 200, no que seria a Segunda Guerra Macedônica.

A aliança de Atenas com Roma e Pérgamo, poderes relativamente recentes no cenário geopolítico, pode ser explicada em função da profunda crise em que se encontrava a monarquia egípcia desde 204, quando a morte de Ptolomeu IV Filopator levou ao trono Ptolomeu V Epifanes, ainda com seis anos de idade (Habicht, 1997, pp. 196-197; Eckstein, 2008). Esta circuntância, associada às rebeliões da população

\footnotetext{
62 Para a história geral do reino atálida de Pérgamo, sumarizada aqui, cf. Hansen (1971), Allen (1983) Habicht (1989, pp. 324-334 e 373-380) e Kosmetatou (2007).

${ }^{63}$ Cf. Eckstein (2006a, 2006b e 2008), com bibliografia anterior.
} 
egípcia e os interesses de anexação de Antíoco III da Síria, tornaram absolutamente improvável a proteção egípcia a Atenas contra a Macedônia. É revelador da leitura ateniense da situação que tenha sido Átalo I, e não um general romano, que tenha recebido honras divinas em 200/199, quando, sitiados pelo exército macedônico, os atenienses decidem abolir as duas tribos macedônicas (Demetrias e Antigonis) e criam uma nova tribo dedicada ao monarca pergameno (Attalis).

As relações entre Atenas e Pérgamo se tornariam cada vez mais próximas nas décadas seguintes, mesmo quando a aliança entre Pérgamo e Roma dava sinais de desgaste. Quanto à aliança com Roma, Atenas manteria sua fidelidade ao longo de todo o século em todas as guerras travadas por Roma no Mediterrâneo Oriental, sendo grandemente recompensada: se o apoio na guerra contra Antíoco III, em 198, rendeu relativamente poucos benefícios, o apoio na Terceira Guerra Macedônica, travada contra Perseu da Macedônia entre 171 e 168, rendeu a Atenas a posse de Delos e outras ilhas do Egeu. A posse de Delos seria a base de um grande período de prosperidade econômica e efervescência cultural para Atenas, administradora daquele que se tornaria o principal entreposto comercial do Mediterrâneo Oriental ${ }^{64}$. A aliança seria quebrada somente em 88, no trágico apoio ateniense a Mitrídates VI do Ponto, que resultaria no saque de Sula em 86 (cf. cap. 2).

Trataremos aqui das intervenções nos espaços públicos atenienses a partir de 200, tomando como marco fundamental a declaração ateniense de guerra contra Filipe $\mathrm{V}$ da Macedônia e o consequente cerco à cidade. Obviamente, no entanto, as novas intervenções não são rupturas absolutamente radicais, mas dialogam tanto com tradições urbanas preexistentes em Atenas quanto com repertórios urbanísticos disponíveis às monarquias helenísticas, particularmente na Ásia Menor. Por isso, o capítulo começa com uma breve discussão de quatro intervenções espaciais do final do século III, três construtivas e uma discursiva, com o objetivo de destacar algumas linhas de força que servirão de referência para as novas intervenções.

A primeira é a construção do modesto santuário do Demos e das Graças, no final do dromos que ligava o Dípilo ao limite noroeste da ágora (figs. 33 e 34). O santuário, já conhecido por fontes literárias e epigráficas ${ }^{65}$, foi localizado durante as escavações prévias à construção de uma nova linha férrea em Atenas, que ligaria a cidade ao porto

\footnotetext{
${ }^{64}$ Sobre o novo período de dominação ateniense sobre Delos e suas consequências econômicas, políticas e culturais, cf. Roussel (1916), Day (1942, pp. 50-119), Bruneau (1970), Solin, Coareli e Musti (1983), Habicht (1997, pp. 246-263) e Mikalson (1998, pp. 207-241).

${ }^{65}$ Cf. discussão e bibliografia anterior em Monaco (2001).
} 
do Pireu, na área ao norte da ágora - e que não havia ainda sido identificada como tal. As escavações, feitas às pressas, se por um lado revelou uma série de importantes achados, que se mostrariam fundamentais para a posterior identificação da ágora, por outro não foram acompanhadas da elaboração de relatórios e plantas detalhadas da área destruída. ; o conhecimento da disposição extada do santuário do Demos e das Graças foi profundamente comprometido por essa ausência (Monaco, 2004). Durante as escavações, foi encontrado um altar dedicado pela Boule a Afrodite Hegemone ("Líder

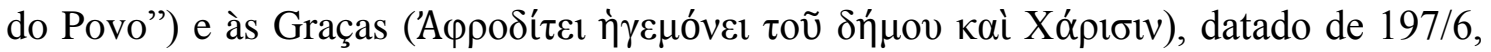
mencionando Mikion, filho de Euricleides de Kefisia, como sacerdote (IG II2 2798; fig. 35). A famosa família de Kefísia ${ }^{66}$ é documentada na tradição literária e epigráfica como personagens centrais da política ateniense no final do século III: os irmãos Euricleides e Mikion foram fundamentais para a negociação pela libertação da cidade da guarnição macedônica sediada no Pireu; aparentemente, a família de Kefísia manteve o sacerdócio do santuário do Demos e das Graças de modo hereditário. As inscrições em bases de estátua e decretos honoríficos encontradas no local indicam com clareza que o santuário era usado como espaço de exposição do agradecimento a práticas evergéticas em relação a Atenas, mas com uma peculiaridade: os evergetas honrados no santuário não são os reis helenísticos, mas os membros de elites locais que facilitavam o acesso a estes reis pelos embaixadores atenienses (Monaco, 2004, pp. 120-129). Em algum momento no século II, ao culto ao Demos, às Graças e a Afrodite Hegemone será acrescentado o culto à Roma (ver discussão no cap. 2). Além disso, é atestada a ligação, por meio do culto às Graças, do santuário ao processo de formação dos efebos atenienses, que realizavam anualmente um juramento às Graças no Pritaneu, supervisionado, entre outros, pelo sacerdote do Demos e das Graças (SEG 15.104; Habicht, 1997, p. 181; Breitenberger, 2007, pp. 105-115).

\footnotetext{
${ }^{66}$ O mais amplo estudo foi feito por Habicht (1982, pp. 179-185), completado por Monaco (2004, pp.
} 112-114). 


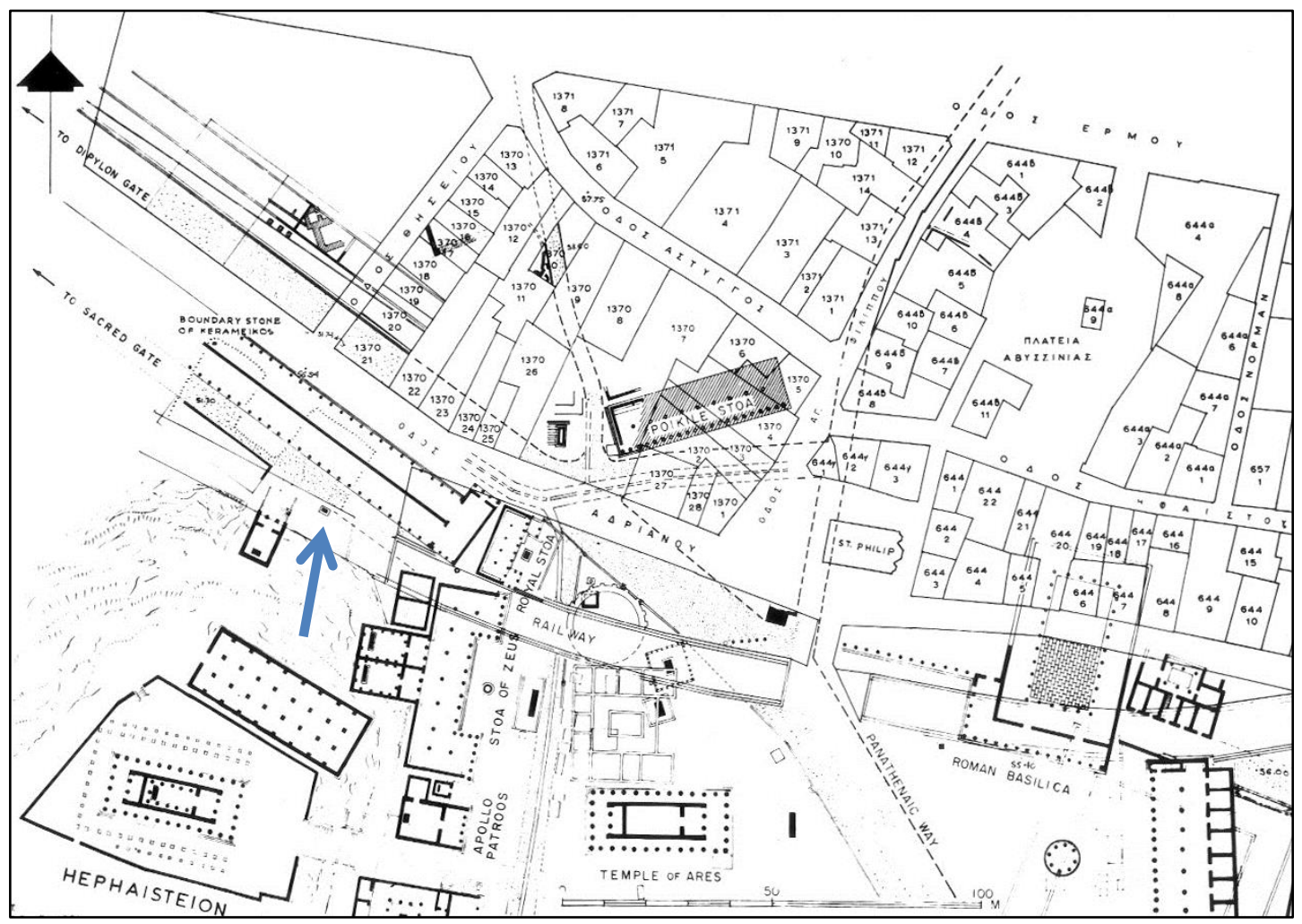

Figura 33. Proposta de reconstituição da planta baixa da área noroeste da ágora no século II d.C., com destaque para o santuário do Demos e das Graças, por J. Travlos e W. B. Dinsmoor em $1981\left(\operatorname{ASCSA}^{67}\right)$.

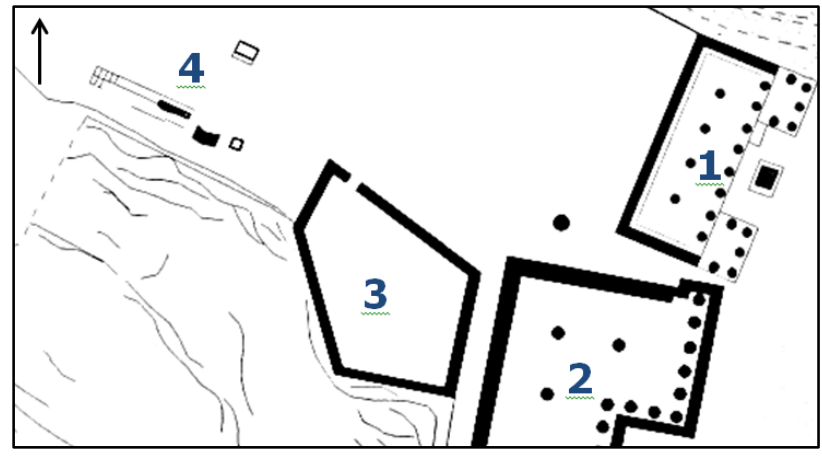

Figura 34. Detalhe da proposta de Maria Chiara Monaco para a reconstituição da planta do noroeste da ágora no século II a.C. (Monaco, 2001), com numeração (minha): 1. Stoa Real. 2. Stoa de Zeus. 3. Santuário da Democracia. 4. Santuário do Demos e das Graças.

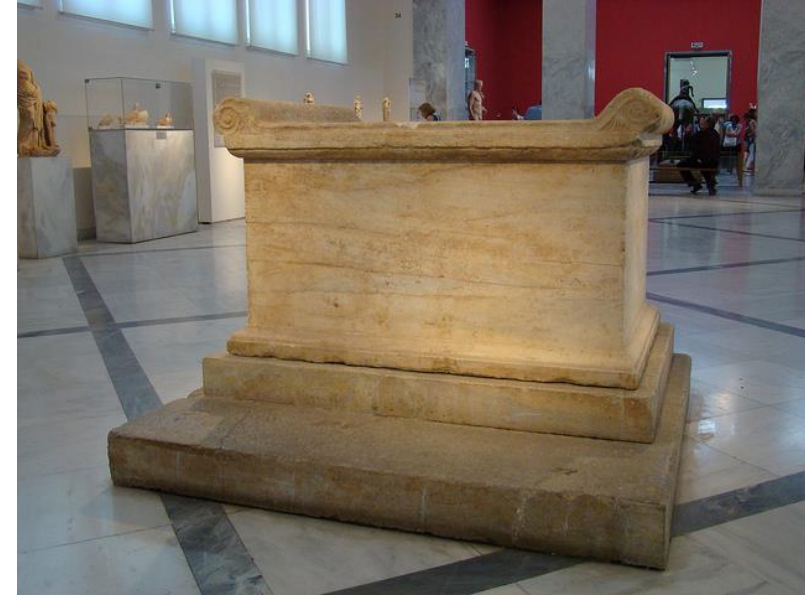

Figura 35. Altar a Afrodite Hegemone e às Graças exposto no Museu Arqueológico Nacional de Atenas. Fotografia de F. Tronchin, tirada em 22 de maio de 2011 (Flickr ${ }^{68}$ ).

\footnotetext{
${ }^{67}$ Disponível em: http://agora.ascsa.net/id/agora/image/1997.01.0420.

${ }^{68}$ Disponível em: https://www.flickr.com/photos/frenchieb/5922652063.
} 
A disposição exata do santuário - o altar, as estátuas e decretos honoríficos não pode ser determinada com exatidão (como dito acima), mas parece claro que não havia um muro de isolamento do recinto sagrado. O recinto ficava fora da ágora, o que é indicado por sua relação com a Stoa Real, que voltava seu muro posterior ao santuário. Ao lado do santuário do Demos e das Graças, e junto ao muro posterior da Stoa de Zeus, estava localizado um recinto de formato pentagonal cujas escavações não conseguiram estabelecer sua história construtiva e muito menos sua identidade; é possível que se trate de um santuário da deusa Demokratia, cuja estátua é mencionada em associação ao Eurysakeion, santuário localizado próximo à Colina da Ágora mas ainda não identificado (Wycherley, 1957, pp. 91 e 210), e que seria coerente com sua proximidade ao santuário do Demos das Graças: os dois santuários seriam os últimos monumentos para o visitante que acabara de entrar em Atenas pela porta principal (o Dípilo) e se dirigia para a ágora. O estado atual dos conhecimentos, no entanto, impede uma sugestão com bases mais sólidas.

O santuário do Demos e das Graças, por seu local e visibilidade, cumpria uma função de marcar a passagem entre o fora e o dentro da ágora; as inscrições no altar, nas bases e nos decretos, para além de suas funções religiosas, funcionavam como legendas da situação política e militar da cidade, cuja liberdade - ou seja, a autonomia em relação à Macedônia - dependia do apoio externo conseguido por meio de intermediários influentes. Era, portanto, um espaço de representação que sintetizava a estrutura evergética em vias de afirmação sobre a produção do espaço ateniense.

A segunda intervenção também estava diretamente relacionada à libertação em 229: trata-se da construção de um edifício nomeado pelas fontes como Diogeneion, construído em homenagem a Diógenes, comandante macedônico que promoveu a retirada da guarnição macedônica sob sua responsabilidade do porto do Pireu. O Diogeneion é objeto de uma grande polêmica entre os estudiosos: tradicionalmente identificado como um ginásio, com base especialmente na tradição epigráfica, é mais provável que tenha sido apenas um santuário, construído de modo independente ou associado ao ginásio de Ptolomeu ${ }^{69}$. Uma inscrição encontrada na acrópole $\left(\mathrm{IG} \mathrm{II}^{2}\right.$ 3474) indica que Diógenes se integrou de tal modo na sociedade ateniense a ponto de

69 Esta questão está vinculada ao problema da datação do ginásio de Ptolomeu, o Ptolemaion: os estudiosos se dividem entre atribui-lo ao reinado de Ptolomeu III Evergeta (246-222) ou a Ptolomeu VI Filometor (186-145). Mais adiante, será defendida a datação mais baixa, associando o Ptolemaion aos vestígios da estrutura chamada de "Praça Sul" pelos arqueólogos americanos; deste modo, o santuário de Diógenes é interpretado aqui como uma construção anterior e independente do ginásio ptolomaico em Atenas. Cf. Guidi (1921-1922), Miller (1995, pp. 207-209) e Lippolis (1995, p. 65). 
ser incorporado em uma das famílias de maior prestígio na cidade, o clã Eteobutadai, cujo ancestral seria Butes, sacerdote de Atena e Poseidon e irmão de Erechtheus, um dos primeiros reis de Atenas (Apolodoro, 3.15.1), e da qual nasceria, no século IV, o estadista Licurgo ${ }^{70}$. Entre as honras que recebeu dos atenienses, estavam, além do santuário, o direito de proedria (IG II $^{2}$ 5080), sacrifícios de dois bois pelos efebos e um festival próprio, a Diogeneia (IG II ${ }^{2}$ 1011.14-15, 1028.23-24, 1029.14, 1039.55-57, 1040.2, 1043.48-49; Mikalson, 1998, pp. 171-172). A localização do Diogeneion, fosse ele um ginásio, parte de um ginásio ou um santuário, não é conhecida - de fato, o Diogeneion é um dos pivôs do principal buraco negro da topografia ateniense. De qualquer modo, é necessário destacar que o culto a um evergeta macedônico em Atenas não é uma completa novidade, tendo em vista os rituais e monumentos estabelecidos em honra a Demétrio Poliorcetes e seu pai, Antígono Monoftalmos, no final do século IV, além das proclamações oficiais em honra à família real macedônica ao longo do século III (Habicht, 1997, p. 166-170). Diógenes, desse modo, se inseria ao mesmo tempo na tradição gentílica e na tradição evergética ateniense, ao mesmo tempo em que se tornava epônimo de um santuário central nas atividades da efebia ateniense - que a partir do século IV se tornara uma via privilegiada para o acesso à elite local. $\mathrm{O}$ aprendizado da cidadania se tornava, assim, indissociável do aprendizado do evergetismo.

A terceira intervenção, ainda que tímida materialmente, era muito mais profunda e ampla que a criação dos dois santuários acima mencionados, na medida em que reorganizava o modo como os cidadãos atenienses se relacionavam entre si e com as instituições cívicas e militares: trata-se da adição de mais um herói epônimo no panteão ateniense, no caso, o rei Ptolomeu III Evergeta, em 224/3 (fig. 36). A adição implicava, em primeiro lugar, a ampliação do número de estátuas no monumento dos Heróis Epônimos na ágora, composto por um Períbolos e uma longa base retangular de mármore que sustentava, originalmente, as estátuas dos dez Heróis Epônimos da reforma clistênica. A base já havia sido ampliada, em 307/6, para abrigar as estátuas dos dois novos Heróis Epônimos, os macedônios Demétrio Poliorcetes e Antígono Monoftalmo - homenageados desta forma pela derrubada do regime de Demétrio de Falero, apoiado por Cassandro, então rei da Macedônia. A solução encontrada para a adição de uma nova estátua, segundo T. Leslie Shear Jr., foi a substituição do trípode meridional pela estátua de Ptolomeu, sem ampliar a base. Quando, em 200, as duas

\footnotetext{
${ }^{70}$ Sobre a família e sua ligação com as tradições atenienses, cf. Osborne (1981-1983, v. 2, pp. 187-188).
} 
tribos macedônicas foram abolidas e foi criada uma nova, em homenagem ao rei pergameno Átalo I, o número voltou a ser o de doze tribos, a estátua de Ptolomeu foi deslocada e o trípode foi novamente colocado em sua posição original (Shear Jr, 1970, p. 199; fig. 37).

A nova tribo também demandava a criação de novos sacerdócios para os cultos ao herói recém-chegado, além de mais 50 assentos no Conselho, que passaria a ser composto por 650 membros (Habicht, 1982, pp. 105-112; 1997, pp. 182). O equilíbrio numérico para a composição da nova tribo foi buscado por meio da rearticulação das afiliações demóticas: alguns deme foram cedidos das outras doze tribos para aquela recém-criada, e, adicionamente, um novo demos foi criado com o nome de Berenicidae, em referência à rainha egípcia Berenice. A rainha, junto do rei, seriam cultuados por um sacerdote próprio, cujo papel certamente seria central na realização do festival em homenagem a Ptolomeu - a Ptolemaia. No entanto, não está claro se o festival e o culto ao rei e a rainha se identificavam ao culto tribal a Ptolomeu, que dependia de sacerdotes e santuários escolhidos pela própria tribo.

A existência de um santuário da nova tribo é controversa; ainda que se possa argumentar, como faz Habicht (1982, pp. 112-117), que o ginásio de Ptolomeu, mencionado por Pausânias (1.17.2), tenha sido construído ainda nos anos 220 e teria sido utilizado, para além das atividades ginasiais, como santuário da tribo ptolomaica, é possível argumentar que o culto da tribo Ptolemais era realizado em santuários compartilhados com outros cultos tribais, especialmente no caso de sacerdotes de tribos mais antigas terem sido designados para o culto da nova tribo.

O impacto da criação de uma nova tribo na organização da religião políade era um problema já enfrentado, de modo mais dramático, na reforma de Clístenes. Nesta ocasião, a despeito da inovação do sistema, as dez novas tribos também se adequaram a estruturas já existentes (Parker, 1997, pp. 112-113), seja em relação à escolha dos sacerdotes $^{71}$, seja na utilização de santuários já existentes. Neste último aspecto, é significativo o caso do culto a Ajáx, herói epônimo da tribo Aiantis. Uma estela encontrada em um poço ao sul do Hephaisteion nas escavações de 1936 (Agora I 3625) continha um decreto honorífico relativo à tribo Aiantis, datado de 327/6; sua localização

\footnotetext{
${ }^{71}$ Em pelo menos dois casos (Cecropis e Erechtheis) ocorreu a escolha, para o culto do herói epônimo, de um sacerdote que não estava registrado na tribo; de acordo com R. Schlaifer, isto se explica pelo fato dos sacerdotes pertencerem a clãs que realizavam o culto dos heróis antes destes se tornaram epônimos Aminandridas para Cécrops, e Eteobutades para Erechtheus. Cf. Schlaifer (1940); Parker (1997, pp. 285 e 293), com evidencia adicional.
} 
- onde também foram encontradas estelas com inscrições relativas ao genos dos Salaminioi, clã responsável pelo culto de Eurisace, filho de Ajáx, em seu santuário na colina da ágora, o Eurysakeion (Wycherley, 1957, pp. 90-93) - sustenta a hipótese de que o santuário de Eurisace era a sede tanto do culto de Ajáx como herói epônimo quanto de Eurisace pelo clã dos Salaminioi ${ }^{72}$. Caso a hipótese esteja correta, o parentesco mítico legitimaria os cultos sunnaoi de Ajáx e seu filho ${ }^{73}$.

Um inscrição (Agora I 6827), encontrada no sudeste da ágora, coloca o Eurysakeion em associação desta vez à tribo Ptolemais. O decreto honorífico, datado de cerca de 200, determina que Democles, filho de Filistion, do demos de Afidna, deverá ser honrado com uma coroa e uma estátua de bronze por seus serviços como magistrado da tribo Ptolemais; ao final do texto, o decreto determina que a estela deverá ser colocada no Eurysakeion. Na primeira edição da inscrição, B. Meritt (1963, p. 14) já apontava o fato de que o demos de Afidna pertencia à tribo Aiantis, antes da criação da tribo Ptolemais; mesmo assim, defende em seu comentário que a nova tribo "herdou" as ligações com o santuário de Eurísace (Meritt, 1963, p. 15; também Mikalson, 1998, p. 179); Parker (1997, p. 265) sugere que isto poderia significar uma resistência à nova tribo, por meio da manutenção do local de exposição do decreto no santuário utilizado pela tribo antiga ${ }^{74}$.

Finalmente, a inclusão de uma estátua de Ptolomeu III na base dos Heróis Epônimos na ágora não implicou na ampliação da base, mas no rearranjo das estátuas sobre ela; aproveitou portanto a ampliação realizada no final do século IV, com a inclusão de Antígono e Demétrio Poliorcetes. Deste modo, os atenienses, se por um lado reforçavam seus laços com a monarquia ptolomaica, grande fiadora da neutralidade política e militar perseguida pelos irmãos Euricleides e Mikion no final do século III,

\footnotetext{
72 Apesar de que outras inscrições fazem referência a um Aianteion sem mencionar a contiguidade do Eurysakeion (Agora I 286; IG II2 1008). Os estudiosos tendem a associar os dois nomes com mesmo santuário, situado no sul da colina da ágora. Cf. Wycherley (1957, p. 91); Kearns (1989, p. 82); Parker (1997, p. 119).

${ }^{73}$ Kearns sugere que os cultos de Ajáx e Eurísace já estavam estabelecidos conjuntamente no Eurysakeion antes mesmo da reforma de Clístenes: Eurísace, um herói ligado originalmente a um escudo

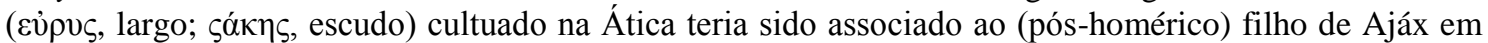
algum momento do século VI, quando o culto de ambos heróis foi usado na disputa pela ilha de Salamina entre Atenas e Mégara (Kearns, 1989, p. 82).

${ }^{74} \mathrm{O}$ que faria sentido considerando-se o pouco tempo entre a criação da nova tribo (224/3) e o decreto (c. 200): seria mais importante expor o decreto honorífico diante de grupos mais tradicionais. Se esta hipótese estiver correta, invalidará o argumento de que a tribo Ptolemais tem seu culto realizado no Eurysakeion, e não no ginásio de Ptolomeu (Mikalson, 1998, p. 179). Por outro lado, a eventual datação tardia da construção do ginásio, a ser associada à Praça Sul na ágora, seria coerente com a não realização do culto tribal no ginásio.
} 
por outro não rompiam com a Macedônia inteiramente, na medida em que as tribos macedônicas permaneceriam.

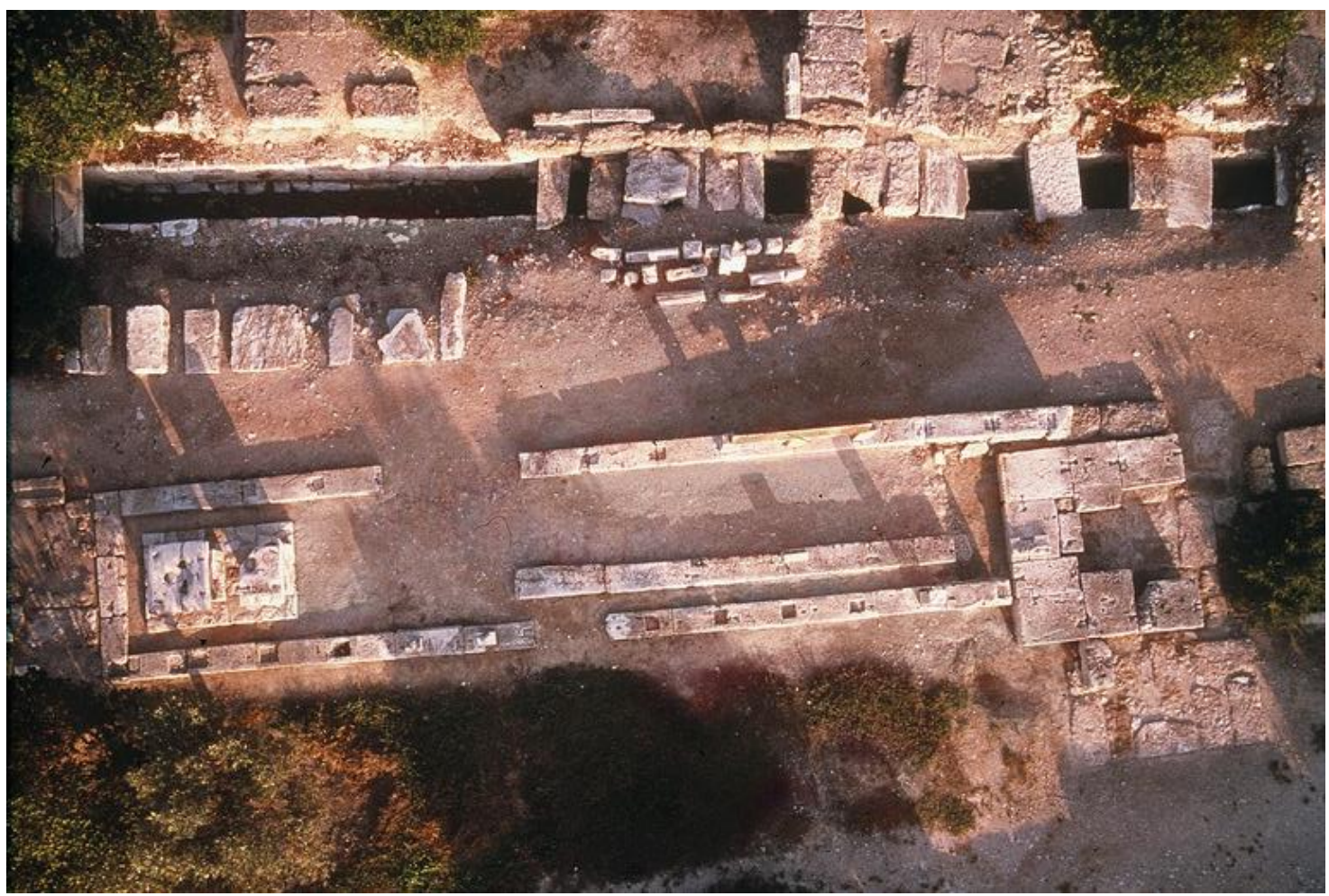

Figura 36. Fotografia aérea do monumento dos Heróis Epônimos, em maio de 1975 (ASCSA ${ }^{75}$ ).
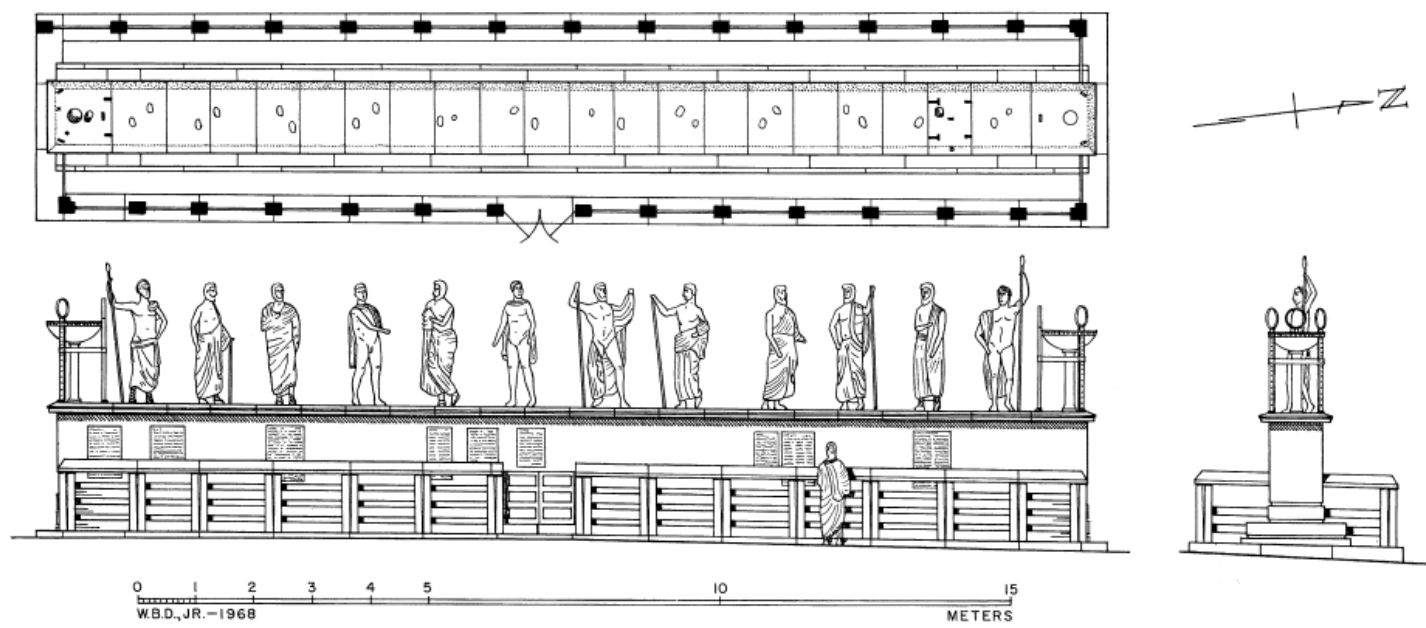

Figura 37. Proposta de reconstituição da planta baixa e da elevação frontal e lateral da fase IV do Monumento dos Heróis Epônimos (Shear Jr, 1970, pl. 44).

${ }^{75}$ Disponível em: http://agora.ascsa.net/id/agora/image/2000.03.0008. 
Em suma, as três intervenções estabeleciam com clareza uma hierarquização do evergetismo: o monarca evergeta se tornaria herói epônimo, receberia culto oficial e festival cívico; um evergeta importante, mas não monarca, como Diógenes, receberia um culto oficial, um festival e um santuário, mas não se tornaria herói epônimo; um evergeta intermediário entre a cidade e os evergetas maiores seria honrado de modo mais modesto, seja com proclamações nos festivais, coroas ou, de modo bastante eloquente, com uma inscrição acompanhada ou não de uma estátua no santuário do Demos e das Graças, logo antes da entrada da ágora.

A quarta intervenção, por sua vez, é o relato de um certo Heráclides ${ }^{76}$, que visitou Atenas no século III e deixou uma brevíssima descrição da cidade, parte de sua obra maior "Sobre as cidades de Grécia". A datação do relato é bastante polêmica: alguns estudiosos viram no texto referências à ocupação macedônica, enquanto outros defendem que a vivacidade cultural da cidade seria mais plausível após a libertação em 229; a escassez de referências impede uma datação mais precisa, ainda que seja consenso entre os estudiosos que o texto tenha sido escrito na segunda metade do século III $^{77}$. Quanto ao estilo, Heráclides já foi considerado o "primeiro blogueiro" (McInerney, 2012, p. 245) por seu tom bem humorado, erudito e antiteórico; do ponto de vista de sua inserção na tradição textual de relatos de viagem, Heráclides pode ser associado às observações e descrições de Heródoto e Pausânias, considerando a presença de notas sobre o próprio processo da viagem, o que o diferencia da tradição de descrição sobre lugares e culturas de Hecateu ou Estrabão (Pretzler, 2009, pp. 357-358).

Heráclides atenta para sete aspectos em sua descrição da cidade: a paisagem rural e os produtos do campo, as festas e espetáculos, o casario e o traçado das ruas, o saneamento básico, os monumentos (edifícios e estátuas), os hábitos dos habitantes e a relação de Atenas com as outras cidades. O autor afirma que o campo é cultivado, mas reitera o topos da pobreza do solo ático, incapaz de abastecer sua população ou seus visitantes $^{78}$. Isto é compensado pela profusão de "espetáculos e prazeres aos cidadãos", graças aos quais "a cidade não percebia a fome, fazendo-a esquecer dos benefícios do

\footnotetext{
${ }^{76}$ Nomeado ora como "Heráclides o crítico" (Arenz, 2006; McInerney, 2012), ora como "Heráclides de Creta" (Perrin, 1994; Étienne, 2004, p. 150). A indefinição vem do termo no manuscrito de Apolônio,

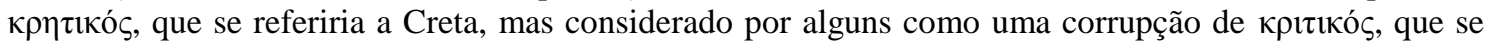
referiria à atividade ou estilo literário do autor.

${ }^{77}$ Cf. a discussão em Pfister (1951, pp. 44-45) e Perrin (1994, p. 194, n. 8); o primeiro propõe a uma datação ampla entre 275 e 200, enquanto o último sugere o período pós-229.

${ }^{78}$ Sobre a construção do topos e suas ressonâncias na época romana, cf. Spawforth (2012, pp. 229-230).
} 


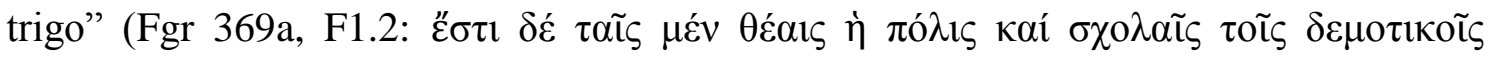

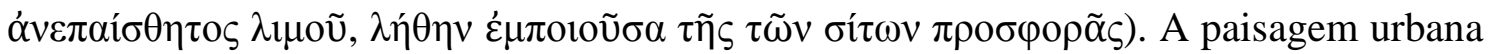
é marcada por uma oposição entre, por um lado, a aparência simples das casas e a desordem das ruas e quarteirões, e por outro, os monumentos atenienses como o teatro, o santuário de Atenas (especialmente o Partenon), o templo de Zeus Olímpico e os ginásios. Esta oposição se realiza, do ponto de vista do visitante, no contraste entre a fama da cidade e sua aparência ${ }^{79}$, no qual os monumentos tem um efeito legitimador da memória: o teatro, o Pártenon, o Olympieion atestam que se trata da famosa Atenas, apesar de suas simples casas. Os habitantes são divididos entre "áticos" e os "atenienses": os primeiros são intrometidos e trapaceiros, enquanto os últimos são generosos, gentis e amantes da $\operatorname{arte}^{80}$. A exposição contínua aos espetáculos explica a superioridade dos atenienses sobre os áticos, o que ao mesmo tempo faz com que Atenas torne as cidades vizinhas em seu subúrbio, as quais, apesar de superarem Atenas pelos produtos do campo, não a superam pelos prazeres urbanos.

A retomada de diversos topoi presentes na literatura ática - a superioridade da cidade sobre o campo, a pobreza do solo ateniense, a abundância de espetáculos e obras de arte - traz uma série de dificuldades para quem procura no texto de Heráclides uma descrição objetiva das condições econômicas e culturais de Atenas no século III. Aqui, é importante destacar a presença de duas imagens diferentes da cidade: a cidade dos prazeres e a cidade da memória. As duas cidades se completam, ainda que seja a primeira que chame a atenção de Heráclides: a fama de Atenas e a memória de sua grandiosidade são questionadas diante do casario porém reforçadas diante do teatro, cujos espetáculos estruturam tanto a oposição alimentação/arte quanto a oposição campo/cidade. Os espetáculos eliminam a fome, produto de uma produção agrícola pobre, e diferenciam o citadino do camponês, condenado à pobreza agrícola não compensada pela riqueza artística.

As intervenções discutidas acima - o santuário do Demos e das Graças, o Diogeneion, a criação da tribo Ptolemais e a descrição de Heráclides - apontam para algumas estruturas fundamentais da produção do espaço urbano ateniense. Em primeiro lugar, o evergetismo, que tomará a cidade, num primeiro momento, como lugar necessário da exposição do agradecimento ao evergetismo (espaço de representação), e

\footnotetext{
${ }^{79}$ Contradizendo, com isso, a famosa passagem de Tucídides sobre a memória da grandeza de Atenas e de Esparta (1.10.2).

${ }^{80}$ Oposição que será fundamental no argumento da "pureza" dos atenienses de Ferguson (1911).
} 
em seguida, como próprio objeto das práticas evergéticas, com a doação de dinheiro, materiais e/ou mão-de-obra para a construção civil local (prática espacial), em função da imagem de Atenas como centro da helenidade. Em segundo lugar, o prestígio cultural ateniense, reforçado pela consolidação da cidade como centro da cultura helênica na tradição literária construída e difundida nos centros helenísticos na Ásia e na África (representação do espaço); prestígio este que canalizará, por sua vez, os objetivos e interesses das práticas evergéticas e das doações que alterarão radicalmente a paisagem urbana local. Trata-se, de todo modo, do evergetismo no presente e do prestígio cultural no presente que estruturam esta produção; se não se pode ignorar a força das tradições que dialogarão com as novas intervenções, mas não se verá, contudo, no século II, a veneração quase acadêmica pelo passado tal como é observável nas intervenções do século I, já associadas mais diretamente à influência romana (cf. caps. 2 e 3). O "renascimento" de Atenas no século II é diferente do "renascimento" no século I: se no primeiro visou-se, em linhas gerais, a atualização de Atenas (a cidade dos prazeres), no segundo tratou-se de um retorno à cidade clássica (a cidade da memória) com todas as ambiguidades que a ideia de renascimento traz em si. Ambos começam com eventos traumáticos - o cerco de Filipe V em 200, o saque de Sula em 86 - e o

modo como cada um ocorreu e, principalmente, terminou, foi fundamental para a determinação das diferenças entre os dois padrões de intervenção. Comecemos, pois, do princípio.

\section{As destruições de Filipe e a criação da tribo Attalis}

As destruições ocorridas na cidade e nos arredores em função deste cerco são mencionadas somente no livro 31 do Ab Urbe condita de Tito Lívio - o que se deve, em grande medida, ao fato do livro 17 das Histórias de Políbio não ter sido preservado.

A relação de Tito Lívio com suas fontes gregas e latinas foi objeto de uma enorme bibliografia; se até a década de 1960 era hegemônica a linha da "pesquisa das fontes" (Marques, 2008, pp. 28-31), atualmente é consenso que Tito Lívio não apenas reproduz suas fontes, mas as ordena em função de princípios retóricos. Um exemplo disso é a própria estruturação da obra, ou ao menos dos livros remanescentes (1-45). T. J. Luce (1977) defende que os 45 livros podem ser divididos em três grandes conjuntos - 1-15: história primitiva de Roma; 16-30: Guerras Púnicas; 31-45: conquista do 
Oriente - sendo cada um deles divididos em blocos menores de cinco ou dez livros com temas coerentes. O livro 31 assume um papel estratégico nesta composição, marcando a passagem do enfoque do ocidente para o oriente, de Cartago para a Macedônia. Neste sentido, não por acaso a diferenciação dos dois conflitos aparece logo no prefácio:

\footnotetext{
A paz púnica foi sucedida pela guerra macedônica, a qual, embora não comparável no perigo, na virtude do líder ou no poderio militar, mas em função da celebridade dos antigos reis, da fama de sua nação e da extensão de seu império, que pelas armas obteve domínio sobre grande parte da Europa e Ásia, é quase mais celebrada (Lívio, 31.1.6-7).
}

Assim situada a guerra macedônica, o livro 31 alterna as narrativas das deliberações, preparativos e conflitos dos romanos e aliados (especialmente Rodes e Pérgamo) contra Filipe V da Macedônia, com as narrativas da sublevação gaulesa liderada pelo cartaginês Amílcar, prodígios religiosos e situações ligadas à distribuição de terra aos veteranos romanos, às dívidas públicas e aos jogos e rituais cívicos romanos. No centro da narrativa estão os debates de macedônios, romanos e atenienses na assembléia da Confederação Etólia (31.29-32).

$\mathrm{Na}$ estruturação do livro, a narrativa do cerco de Atenas oferece um contraponto a duas outras histórias de cerco: o de Calcis, na Eubéia, e de Abidos, no Quersoneso. Atenas resistiu ao cerco macedônico em três situações (a primeira liderada por um general de Filipe, Nicanor, a segunda e terceira pelo próprio rei), em parte pela prontidão das tropas de cidadãos e mercenários, e em parte pelo rápido socorro de tropas ródias, pergamenas e romanas. Abidos caiu diante do cerco macedônico, contando com pouquíssima ajuda de Rodes e Pérgamo (31.16-18); Cálcis caiu diante do cerco romano, na medida em que o socorro macedônico chegara tarde demais (31.2324). Além desta tripla oposição (Atenas socorrida por ródios, pergamos e romanos / Abidos desprotegida por ródios e pergamenos / Cálcis desprotegida pelos macedônios), o autor realiza o que Luce definiu como "equilíbrio textual" (1977, p. 55) na narrativa da chegada de Caio Cláudio Cento a Atenas $(31.14,22)$ e depois a Calcis (31.23), e então a chegada de Filipe a Cálcis (31.24) e depois a Atenas (31.24). E finalmente, às estatuas de Filipe destruídas pelos invasores na derrotada Cálcis (31.23), se opõem as estátuas de Filipe destruídas pelos cidadãos na defendida Atenas (31.44). 
Assim, se por um lado Tito Lívio é fortemente influenciado por suas fontes latinas e gregas, e entre as últimas, Políbio acima de todas - isto não esgota suas possibilidades estilísticas, na medida em que o autor busca adequar a narrativa aos padrões da historiografia latina do século I a.C. Não obstante, no caso do livro 31, na medida em que diversas passagens fazem referência literal a Políbio, é de se esperar que a narrativa do cerco de Atenas esteja baseada no perdido livro 17 das Histórias do historiador megalopolitano.

Duas passagens do livro 31 fazem referência a destruições em Atenas: o cerco à cidade comandado pelo próprio rei macedônico (31.24), em meados do ano 200 a.C., e a reação dos atenienses após as primeiras derrotas macedônicas (31.44) em meados de 199 a.C. $^{81}$. O contexto da primeira passagem é a retaliação de Filipe diante da destruição de Cálcis. Após a tentativa frustrada de um ataque surpresa, Filipe promove um enfrentamento regular que o faz chegar até o Dípilo, sem conseguir, no entanto, ultrapassar as muralhas defendidas pelos atenienses com apoio de mercenários e de um destacamento pergameno na cidade. Então,

[...] Filipe, dando sinal para a retirada, montou acampamento junto ao Cinosárges, onde havia um templo de Hércules, um ginásio e um bosque sagrado ao redor. Mas o Cinosárges, o Liceu e qualquer local sagrado ou ameno nos arredores da cidade foram incendiados: não somente os edifícios como também as tumbas foram destruídas, e nem a lei divina ou humana foi salva de sua incontrolável paixão (Tito Lívio, 31.24.17-18).

Dos ginásios mencionados pelo historiador apenas o Liceu não foi localizado com precisão. Todos eles ficam, certamente, fora das muralhas: a Academia foi encontrada em um sítio a cerca de $3 \mathrm{~km}$ a noroeste da acrópole (Travlos, 1971, pp. 4243; Caruso, 2013), e o Cinosarges foi encontrado em um sítio a pouco mais de $1 \mathrm{~km}$ a sudeste da acrópole, próxima à antiga porta Dioméia (Travlos, 1971, p. 340); a localização do Liceu ainda é debatida, mas certamente se situava pouco ao norte do Cinosarges, próximo da atual praça Syntagma (Travlos, 1971, p. 345). Nos três casos, também, o nome do santuário ou da região passou a ser associado ao ginásio, que era apenas um dos edifícios de cada complexo . A Academia era composta pelo ginásio, por um recinto murado, o peripatos, por exedras para suporte de estátuas, ao menos uma

\footnotetext{
${ }^{81}$ Aqui sigo as datas estabelecidas por A. Hus (1977, p. 1xxxi-lxxxii).
} 
biblioteca, além de diversos santuários e altares dedicados ao culto de Atena, Héracles, Hermes, Zeus, as Musas, e do herói Academo. No caso do Cinosárges, como mencionado em Tito Lívio, havia junto ao ginásio um templo de Héracles. No caso do Liceu, além de edifícios próprios a atividades de ensino, havia ao menos um dromos para atividades atléticos dos efebos, e associado ao ginásio, um santuário das Musas. Além disso, associado aos três santuários também se situavam necrópoles, em particular de filósofos que lecionaram na escola. Na narrativa de Lívio, Filipe ordena a destruição dos complexos como um todo, incorrendo na impiedade da destruição de espaços sagrados - topos recorrente na literatura diplomática que reforça a representação dos macedônios como bárbaros, e, em particular, como os novos persas, como será discutido mais abaixo.

A segunda passagem que menciona destruições desta vez tem os próprios atenienses como sujeitos (31.44). Após narrar as atividades militares terrestres e navais de romanos e macedônios, Tito Lívio afirma:

Então, a cidade dos atenienses, cujo ódio por Filipe era moderado pelo medo, deu-lhe total vazão na esperança do socorro em vista. Não faltam ali línguas prontas para levantar a plebe; essa espécie de gente existe em todas as cidades livres, mas sobretudo em Atenas, onde a palavra tem imenso poder junto à multidão. Propuseram imediatamente, com a aceitação da plebe, que todas as imagens e estátuas de Filipe, assim como de seus ancestrais, homens e mulheres, fossem destruídas com as inscrições; que os feriados, as festas religiosas e os sacerdotes entronizados em sua honra ou de seus ancestrais deveriam ser suprimidos; que os locais onde algum monumento tivesse sido erigido ou alguma inscrição gravada em sua honra se tornassem objetos de maldição, e se decidiu de não mais os colocar ou dedicar onde a religião permite que se coloque ou dedique algo em um lugar puro. [...] Assim os atenienses faziam a guerra contra Filipe com golpes de letras e palavras, no que unicamente eram valorosos.

No relato de Tito Lívio, a datação das medidas antimacedônicas é ambígua. Esta passagem segue o relato das operações navais datadas tradicionalmente em 199 (Ferguson, 1911, p. 268, n. 4; Hus, 1977, p. 1xxxii). No entanto, é possível ler este trecho como uma retomada de um aspecto da narrativa iniciada em 31.14. Na primavera de 200, Átalo I e os embaixadores de Rodes, na perseguição a Filipe que voltava para a Macedônia após a guerra na Ásia Menor, foram a Atenas para confirmar e renovar a 
aliança (31.14.11). Após o discurso dos ródios na assembleia ateniense e da leitura de uma carta de Átalo (que não quis se dirigir diretamente à assembléia), a cidade decide pela guerra contra Filipe, que então apoiava os ataques do exército acarnânio na Ática (31.14.9-10). Além disso, os atenienses conferiram uma série de honras a Átalo e aos ródios, incluindo, para os últimos, a concessão da cidadania ateniense, e ao primeiro, a honra de tornar-se um herói epônimo de uma tribo ateniense, que seria adicionada "às dez tribos antigas" (31.15.6: ad decem veteres tribus addenda). A referência a apenas dez tribos é problemática: em 307/6 foram adicionadas duas tribos em honra aos reis macedônicos, Antigonis (Antígono Monophtalmos) e Demetrias (Demétrio Poliorcetes); em 224/3 uma nova tribo foi criada em honra a Ptolomeu III Evergetes, Ptolemais. Ou seja, no final do século III, Atenas tinha 13 tribos; mesmo que a eliminação da presença macedônica na cidade ocorresse antes da criação da tribo Attalis, ainda haveria 11 remanescentes. Quando comparado ao relato de Políbio (16.2526), apesar de uma diferença significativas (quando relata a recepção de Átalo na cidade, Políbio menciona a presença de embaixadores romanos no Pireu e em Atenas os quais também teriam sido, embora em menor grau, honrados pelos atenienses enquanto Tito Lívio não faz qualquer menção ${ }^{82}$ ), ambos não fazem referência à extinção das tribos macedônicas.

Duas hipóteses plausíveis para a referência das "dez tribos antigas” são: (1) Tito Lívio supôs a destituição das tribos macedônicas simultaneamente à declaração da guerra em 200, e ignorava a existência da tribo Ptolemais em Atenas; (2) quando Tito Lívio faz referência às tribos atenienses, distingue as "dez tribos antigas", ou seja, as criadas pela reforma de Clístenes no século VI, e as tribos "recentes", criadas nos séculos IV e III. De todo modo, após a descoberta e interpretação de uma série de inscrições, em particular da IG II2 2362 (Prichett, 1954), é consenso que já em 200 as tribos macedônicas haviam sido abolidas (Habicht, 1995, p. 197, n. 10).

Caso o relato da execração dos macedônios em 31.44 não seja uma retomada retórica e, de fato, indique um acontecimento datado de quase um ano após o início das hostilidades (199), surge a questão de por que os atenienses não haviam tomado tais medidas antes, especialmente quando o próprio rei comandava as destruições de santuários, túmulos e plantações na Ática, conforme relatado por Tito Lívio e

\footnotetext{
${ }^{82}$ A questão da "omissão" dos embaixadores romanos em Atenas no relato de Tito Lívio foi discutida por diversos autores, cujas hipóteses vão da omissão consciente por parte do autor, em função do papel secundário dos romanos na ocasião da recepção de Átalo, à sugestão de um equívoco de Tito Lívio na organização de informações derivadas de fontes latinas e de Políbio. Cf. Luce, 1977.
} 
argumentado pelos atenienses em discursos diplomáticos. Ferguson sustentava que era preciso separar os três eventos: a abolição das tribos macedônicas ainda em 201, em função do apoio macedônico aos ataques acarnânios à Ática; a criação da tribo Attalis e a declaração de guerra à Macedônia em 200; e as medidas antimacedônicas mencionadas por Tito Lívio em 199 (Ferguson, 1911, p. 268-9, n. 4). Habicht, por outro lado, sustenta que todos estes acontecimentos são contemporâneos à declaração de guerra em 200, que levaria a uma reforma geral do sistema tribal ateniense (Habicht, 1995, p. 197).

Algumas evidências arqueológicas podem ser associadas às medidas antimacedônicas mencionadas por Tito Lívio. O primeiro grupo de evidências é composto por uma série de inscrições do século III a.C., levantadas por S. Dow (1937, pp. 48-50) e Chr. Habicht (1982, p. 148, n. 137), que apresentam marcas de apagamento deliberado do nome das tribos ou de membros da casa real macedônica ${ }^{83}$. As inscrições foram encontradas basicamente em dois locais: na ágora e nos escombros da muralha pós-herúlea próximos à igreja de Demétrio Katefores (hoje demolida). A localização das inscrições na ágora ou em contexto de reuso em muralhas muito posteriores ao apagamento indica que as estelas continuaram sendo expostas com as marcas de raspagem, o que pode ser explicado por dois fatores: por um lado, a raspagem do nome das tribos ou de menções da família real macedônica não invalidaria a função da inscrições, em sua maioria honoríficas (tribais e/ou efébicas); por outro, a raspagem faria parte da paisagem ateniense, ironicamente, como memorial de uma drmática damnatio memoriae, pelo qual se lembraria do gesto público de esquecimento ${ }^{84}$.

O segundo grupo de evidências é composto por quatro fragmentos de uma estátua equestre de bronze, encontrados nas escavações de 1971 na região noroeste da ágora ateniense (Shear Jr., 1973, pp. 165-168): a parte inferior da perna esquerda, da

${ }^{83}$ IG II $^{2} 665,677,681,682,766,775,780,781,790,791,798,825$; Hesperia, IV (1935), p. 526, no. 39; Hesperia, II (1933), p. 497, no. 13; Hesperia, II (1933), p. 500, no. 15; Hesperia 30 (1961), p.11 n.7.1; Hesperia 34 (1965), p. 90 n. 3.2; Hesperia 23 (1954), p. 287, n.182.37; Hesperia 30 (1961), p. 11, n. 7.6; Hesperia 34 (1965), p. 90, n. 3.8; Hesperia 16 (1947), p. 186, n. 92.2; A.J.A., XXXVII (1933), p. 46; Agora 15.57, 61, 89, 111, 135. Inscrições com possíveis marcas de apagamento: IG II2 1299; BCH 54 (1930), p. 268; Hesperia 23 (1954), p. 287, n. 182; Moretti, Inscrizioni 7, 13-14; Hesperia 42 (1973), pp. 165-168, t. 36; Hesperia 50 (1981), p. 354.

${ }^{84}$ Algumas inscrições, no entanto, não foram raspadas, o que parece ser explicável por lapsos da ação de raspagem, mas não há elementos suficientes para se afirmar que existia ou não um padrão. São elas: IG II $^{2}$ 784; 776; 793 (SEG 3:100); 1225.3; Agora 15. 85; Hesperia 52 (1983) 52, 1. 23-25. A última delas se trata da famosa inscrição do Aglaureion; sua colocação em uma caverna, com visibilidade restrita aos que poderiam entrar no santuário, pode indicar que esta era a variável para a raspagem ou não. 
metade da coxa até o pé, ligeiramente flexionada, com marcas de vestimenta na parte superior da coxa e uma sandália amarrada ao pé, cujas tiras rodeiam o tornozelo até o início da canela; dois pequenos fragmentos de vestimenta, com tecido drapejado em ambos; e uma espada dentro de uma bainha com ponta circular (fig. 38). Em todos os fragmentos, mas especialmente na sandália e na bainha da espada, existem marcas que indicam a anexação de finas folhas de ouro que cobririam toda a estátua.

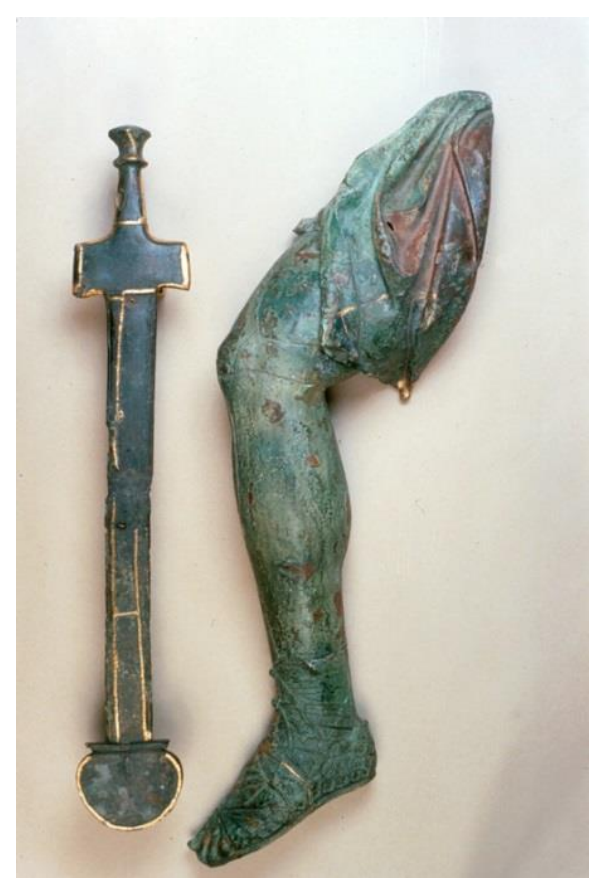

Figura 38. Fragmentos de estátua de bronze folheada a ouro, encontrada em poço 3 metros ao norte do recinto da encruzilhada (ASCSA $\left.{ }^{85}\right)$.

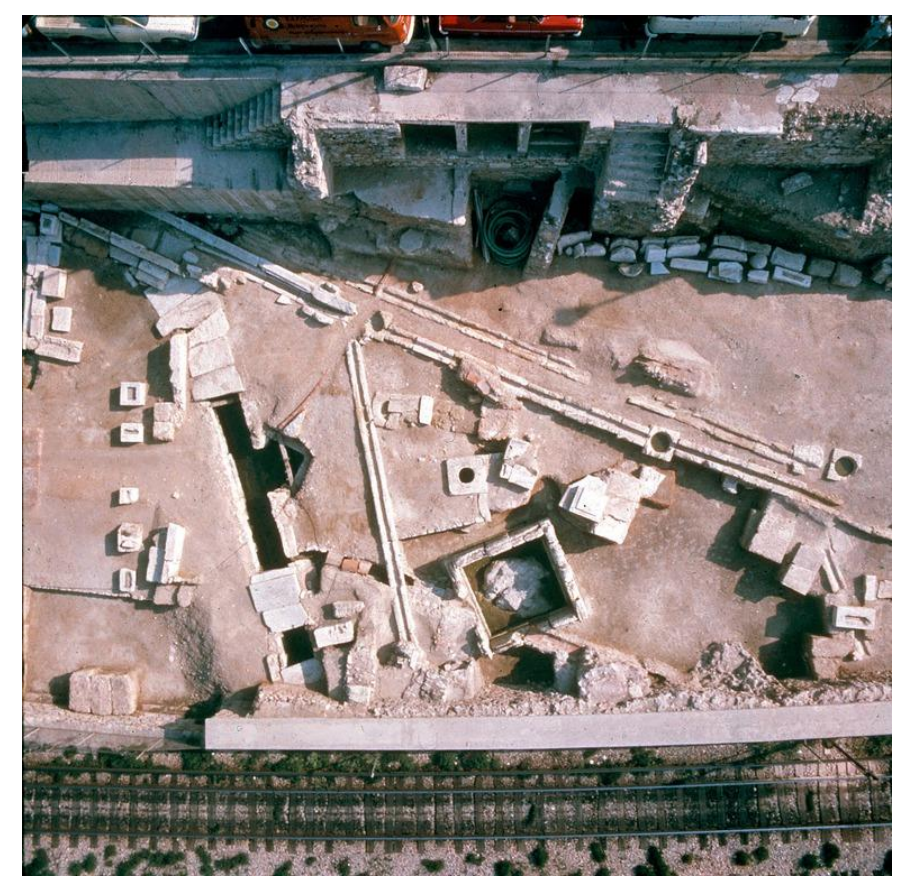

Figura 39. Visão aérea da região norte/noroeste da ágora, com o recinto da encruzilhada no centrodireita da imagem, com o poço sagrado logo acima. Fotografia de maio de $1975\left(\operatorname{ASCSA}^{86}\right)$.

Os quatro fragmentos foram encontrados juntos em um estreito poço próximo ao limite noroeste da ágora (fig. 39), 3 metros ao norte do chamado "recinto da encruzilhada", um pequeno santuário usado para o depósito de material votivo e restos de sacrifícios cercado por baixos parapeitos de calcário, cuja utilização começa no final do século $\mathrm{V}$ e segue até o final do século IV. No poço foram encontrados centenas de objetos, de jóias a inscrições da cavalaria ateniense; a grande quantidade de material votivo similar ao encontrado no recinto sagrado indica uma articulação entre os dois espaços; diferentemente do recinto, no entanto, o poço foi utilizado para o

\footnotetext{
${ }^{85}$ Disponível em: http://agora.ascsa.net/id/agora/image/2000.02.0833.

${ }^{86}$ Disponível em: http://agora.ascsa.net/id/agora/image/2000.03.0018.
} 
armazenamento (ou descarte) de material até o final do século III ou início do II. Neste último estrato foram encontrados os fragmentos da estátua equestre (Shear Jr., 1973, pp. 126-134).

A datação da modelagem dos fragmentos, com base em dados estilísticos (os detalhes da sandália, o drapejado do tecido, e acima de tudo o tipo da espada) foi sugerida para o início do período helenístico (Shear Jr., 1973, p. 166). A partir da escassez de referências a estátuas equestres na ágora de Atenas, o que significaria uma honra excepcional (especialmente considerando-se a cobertura dourada), e a datação para o final do século IV, Leslie Shear Jr. sugeriu a identificação do personagem retratado como sendo um dinasta macedônico: especificamente, Antígono ou Demétrio Poliorcetes, tornados Heróis Epônimos em 307/6. Neste sentido, o estado fragmentário e a deposição no poço se explicariam pelas medidas antimacedônicas de 200: mais do que derreter a estátua, os atenienses teriam preferido quebra-la e enterrá-la, aos pedaços.

No momento de sua descoberta, havia poucas indicações da localização original da estátua, para além do local da própria encruzilhada. Uma pista apareceu com as escavações de 1980-82 (Shear Jr., 1984, pp. 22-24): três conjuntos de blocos de calcário, dois deles paralelos, com soluções de encaixe semelhantes e separados por um espaço de cerca de 3 metros, e um deles, formado por apenas dois blocos, colocado na extremidade sul do conjunto ocidental (fig. 40). Estes três conjuntos foram interpretados como bases para uma "entrada monumental" (dois conjuntos paralelos) e uma base de estátua (blocos ao sul do conjunto oeste), localizados na entrada norte da ágora entre a Stoa Pintada e os edifícios alinhados à rua que vinha do Dípilo. A datação, com base na cerâmica encontrada nas camadas de preenchimento abaixo dos blocos das bases, foi fixada em fins do século IV. Com isso, a entrada e a base foram combinadas com a passagem onde Pausânias (1.15.1) menciona, logo antes de falar da Stoa Pintada, uma estátua de bronze de Hermes Agoraios e um portão que expunha um troféu de uma vitória da cavalaria ateniense contra Plistarco, irmão do rei Cassandro da Macedônia, que teria ocorrido no final do século IV. 


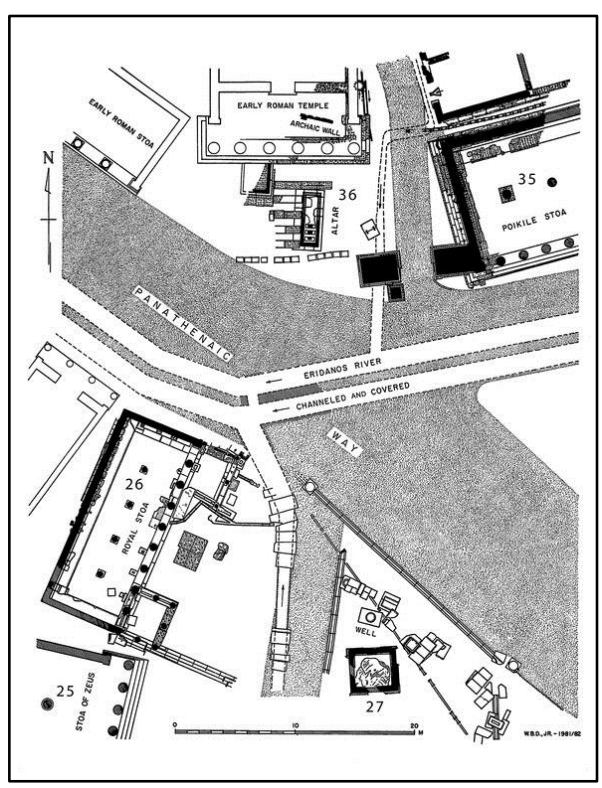

Figura 40. Planta do estado atual da região noroeste da ágora, feita por $W$. B. Dinsmoor Jr. em 1981/82 $\left(\mathrm{ASCSA}^{87}\right)$.

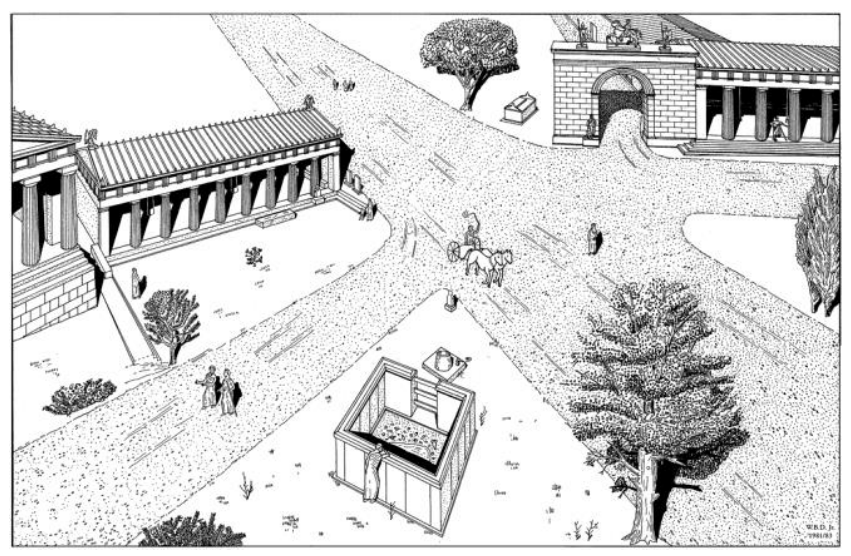

Figura 41. Proposta de reconstituição da esquina noroeste da ágora, feita por W. B. Dinsmoor Jr. em $1981 / 3\left(\operatorname{ASCSA}^{88}\right)$.

Raciocinando que um portão monumental dificilmente seria erigido, em uma posição tão destacada, para homenagear uma batalha mencionada em apenas uma fonte (Pausânias), Leslie Shear Jr. (1984, pp. 22-24) sugere que esta entrada estava articulada às homenagens atenienses a Antígono e Demétrio Poliorcetes, especialmente porque este último estaria no comando das ações militares atenienses após 307/6. Sendo assim, Leslie Shear Jr. conjectura que sobre o portão seria colocada uma estátua de Demétrio, cujos vestígios seriam, justamente, os fragmentos da estátua equestre de bronze folheada a ouro encontradas no poço a cerca de 20 metros ao sul da entrada monumental (fig. 41). O fato de Pausânias não mencioná-la em sua descrição se deveria, justamente, à sua destruição em 200/199 no contexto das medidas antimacedônicas.

Os vários argumentos da proposta de Shear Jr. apresentam graus diferentes de segurança. A identificação dos fragmentos a uma estátua equestre de Demétrio Poliorcetes é provável, considerando-se a datação da camada onde foi encontrada (c. 200) e o fato dos fragmentos não terem sido derretidos ${ }^{89}$. Já a localização da estátua no

\footnotetext{
${ }^{87}$ Disponível em: http://agora.ascsa.net/id/agora/image/2011.04.0089.

${ }^{88}$ Disponível em: http://agora.ascsa.net/id/agora/image/2008.20.0077.

${ }^{89}$ Ainda que outras possibilidades não possam ser descartadas, em particular a de que era uma estátua equestre ligada ao Hipparcheion (Bugh, 1988, pp. 219-220), o quartel general da cavalaria ateniense, em virtude de uma expressiva quantidade de documentos da cavalaria ter sido encontrada no mesmo poço onde foram achados os fragmentos da estátua (Shear Jr., 1973, pp. 176-178)
} 
topo do portão da "entrada monumental" no nordeste da ágora não tem tanta solidez, especialmente em virtude de sua datação no século IV. O primeiro portão usado para monumentalizar a entrada de uma ágora conhecido é aquele de Priene, possivelmente em forma de arco, construído na entrada nordeste da ágora em meados do século II (Winter, 2006, p. 38); à diferença do "portão ateniense", o portão de Priene era cercado por muros dos dois lados - sendo portanto a única abertura naquele lado - e não apresentava decoração escultórica. Por ter sido aparentemente independente no lado ocidental, o portão ateniense se aproximaria dos arcos triunfais em Roma, cujos exemplares mais antigos, atestados apenas literariamente, são os arcos de L. Stertinius em 196 (Tito Lívio, 37.27.4). Além disso, a proximidade do poço (cerca de 30 metros) não é conclusiva, ademais pelo fato do uso do poço não ter sido estabelecido claramente: nos diversos estratos escavados, foram encontrados jóias, vasos, figurinhas e documentos oficiais, não tornando claro se o poço era usado como local de deposição de material votivo ou apenas como descarte.

As destruições macedônicas e atenienses da virada do século III para o II, longe de serem aleatórias, fazem parte de programas coerentes, articulados por contingências e lógicas específicas. As destruições macedônicas estavam vinculadas, em primeiro lugar, ao desequilíbrio entre a defesa intra e extramuros, determinada pela muralha e pelos contingentes militares (entre atenienses, pergamenos e mercenários), e em segundo lugar, pela valorização dos locais de memória atenienses, sejam eles os ginásios, referências do prestígio das escolas filosóficas e da efebia ateniense, as necrópoles, elemento fundamental da memória cívica, ou os santuários, também ligados aos mitos fundadores e à identidade cívica.

As destruições atenienses, por sua vez, estavam vinculadas à (in)capacidade militar ateniense e à identificação dos locais de memória macedônicos na cidade, especialmente as manifestações visuais do evergetismo. Assim, impossibilitada de promover ataques efetivos aos territórios macedônicos ou aliados, os atenienses se limitaram a destruir o que a própria cidade havia criado - decretos e monumentos honoríficos. A raspagem de inscrições e a destruição de estátuas satisfizeram a demanda destrutiva ateniense, e ao mesmo tempo adicionaram um capítulo à história da damnatio memoriae ateniense iniciada cem anos antes, com a destruição das centenas de estátuas de Demétrio de Fálero após sua derrubada por Demétrio Poliorcetes em 307/6 (Habicht, 1997, p. 65) - cujas estátuas seriam, em 200/199, alvo da mesma prática. 
O que se observa neste dramático período é uma transformação radical na memória urbana ateniense, que terá consequências também para a relação da cidade com o espaço. Se por um lado as destruições geraram oportunidades de reconstrução (novos ginásios e santuários / novos locais para a dedicação de estátuas honoríficas), elas também renovam o uso do espaço como memória do inimigo, realocando assim os até então evergetas macedônios como os novos persas do espaço urbano ateniense algo que a Dedicação Atálida na acrópole ateniense reforçará de um modo mais ou menos direto.

Diretamente associado a este episódio está a criação da tribo Attalis em Atenas, como homenagem ao rei Átalo I de Pérgamo (Políbio, 16.26; Tito Lívio, 31.15). A criação de uma tribo "honorífica" não é novidade em Atenas, como já foi dito: três novas tribos já haviam sido criadas em 307/6 e 224/3. Como nos casos precedentes, tal criação não se limitava a uma homenagem. Uma nova tribo pressupunha uma reorganização de ao menos cinco dimensões diferentes da organização cívica ateniense: estatal, ligada à composição dos conselhos; religiosa, ligada aos rituais vinculados aos Heróis Epônimos e aos membros da tribo; militar, no que diz respeito à formação dos batalhões; educacional, em função da estrutura tribal da efebia; e agonística, na medida em que diversas competições dos festivais atenienses eram disputadas pelos atletas divididos por tribo. As consequências para a produção do espaço não são desprezíveis.

A primeira, mais evidente, é a reforma no monumento dos Heróis Epônimos. A inclusão da estátua de Átalo I não implicou em uma alteração radical do monumento: o espaço vago deixado pela abolição das tribos macedônicas permitiu a inclusão da nova estátua sem grandes problemas. No entanto, é preciso destacar que, mesmo que o monumento tenha continuado o mesmo, a inclusão de uma estátua de Átalo significa, até onde as fontes permitem saber, a primeira estátua atálida em Atenas. A colocação da estátua no monumento dos Heróis Epônimos, inserindo Átalo I no conjunto de personagens da tradição mítica e democrática ateniense (os dez heróis da época de Clístenes, escolhidos pelos sacerdotes de Delfos) e do evergetismo recente (Ptolomeu III), é uma atestação das esperanças depositadas no rei pergameno. A importância do gesto pode ser resgatada tendo em mente o fato de que, em cerca de 600 anos de história, as estátuas foram alteradas somente quatro vezes (Shear Jr., 1970).

A segunda, cuja importância fica evidente nas inscrições apagadas acima mencionadas, é a presença do nome da tribo Attalis em inscrições ligadas às atividades das instituições cívicas atenienses. A disposição das inscrições nos espaços públicos da 
cidade, como a ágora, a acrópole e o pritaneu, poderia funcionar como uma espécie de marcação temporal e espacial do novo contexto, como um duplo, epigráfico, da aliança com a Macedônia pela aliança com Pérgamo.

A terceira consequência, que será discutida com maior detalhe, está ligada à realização dos rituais tribais. Não há notícia nem epigráfica nem literária de um Attaleion em Atenas, como é indicado para outros locais ${ }^{94}$. Os candidatos mais prováveis do estabelecimento de um culto atálida seriam a Stoa de Eumenes ao sul da acrópole (c. 180), a Stoa de Átalo II I (c. 150) ou o novo Metroon (c. 140) na ágora: no entanto, a construção de todos é posterior demais à instituição da nova tribo para serem considerados. Poderíamos questionar, neste sentido, se Átalo I não foi cultuado como sunnaos em um santuário já estabelecido na cidade. Assumindo o caráter hipotético da proposta, é possível sugerir o culto de Átalo I no Aiakeion de Atenas.

O Aiakeion era um santuário contruído no final do século VI e dedicado ao herói Éaco, filho de Zeus fundador de Egina e na linhagem que contaria, entre outros heróis, com Ajáx e Aquiles. A construção do santuário foi motivada por um oráculo de Delfos, que aconselhava aos atenienses, então em guerra contra a ilha de Egina, que construíssem o santuário como forma de abreviar o sofrimento da guerra e obter a vitória (Heródoto, 5.89). Recentemente, o Aiakeion foi localizado no edifício conhecido pelos escavadores como Períbolo Retangular (figs. 42-43), localizado próximo ao limite sudoeste da ágora, e identificado alternativamente como santuário de Teseu ou sede dos tribunais atenienses ${ }^{95}$.

A ligação de Átalo com o Aiakeion é indicada por três elementos. O primeiro é o fato de que é o fato de que Egina, desde 210, era uma possessão atálida, comprada junto à liga Etólia no contexto da Primeira Guerra Macedônica (Políbio, 22.8.10), e que seria uma importante base para experimentos imperiais da dinastia atálida fora da Ásia Menor (Allen, 1971). A colaboração na defesa de Atenas contra o cerco de Filipe V, em 200, foi feito a partir da base pergamena em Egina, inserindo, ironicamente - haja vista a intensa rivalidade entre Egina e Atenas no período tardo-arcaico (Watson, 2011) - a ilha no sistema de defesa da cidade já sem uma frota própria de tamanho significativo.

\footnotetext{
94 Há indícios da existência de Attaleia em Egina (SEG 53.272; Polinskaya, 2013, pp. 211), em Teos (OGIS 326) e em Pérgamo (IvP 222).

95 Conferir a discussão historiográfica e documental completa em Stroud (1998, pp. 85-108), que argumentou fortemente para a identificação do Peribolo Retangular como a sede do Aiakeion.
} 


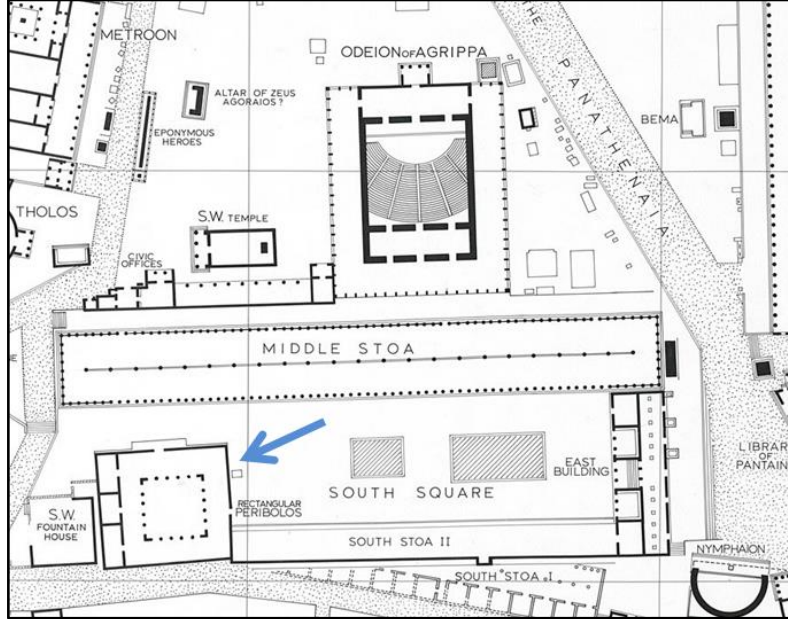

Figura 42. Detalhe da proposta de planta da ágora no século II d.C., feita por R. Anderson em 1992 $\left(\mathrm{ASCSA}^{96}\right)$, com indicação do Períbolo Retangular.

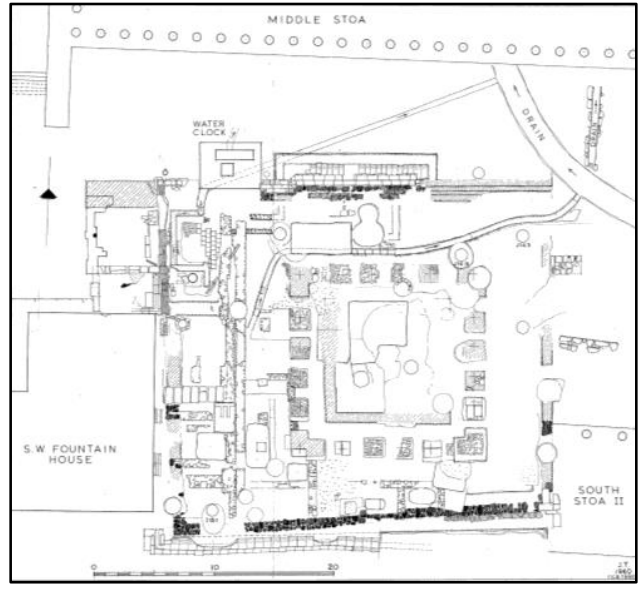

Figura 43. Planta do estado atual do Períbolo Retangular, identificado atualmente ao Aiakeion, feita por $\mathrm{J}$. Travlos em 1980 e corrigida por $R$. Anderson em 1990 (ASCSA ${ }^{97}$ ).

O segundo é a associação entre Átalo I e Egina no campo da narrativa mítica. A mitologia era uma ferramenta comumente empregada pela diplomacia pergamena (Gruen, 2000; Étienne, 2003), e de ao menos três formas a mitologia de fundação de Pérgamo poderia ser relacionada com personagens ligados à ilha de Egina. A primeira é pelo parentesco entre Éaco, herói fundador de Egina, e Héracles, pai do herói fundador da dinastia atálida, Télefo; ambos são filhos de Zeus, o primeiro com a ninfa Egina, o segundo com Alcmena (Gruen, 2000, pp. 22-23). A segunda é pela narrativa do conflito entre Télefo, filho de Héracles e rei da Mísia, e Aquiles, neto de Éaco: por conta de alianças com Priamo, Télefo decide não revelar o caminho para Troia, mas é forçado a fazê-lo após ser ferido em combate contra Aquiles (Heres, 1997). O terceiro se dá pela ascendência do herói epônimo da cidade microasiática: após a queda de Tróia, Andrômaca, esposa de Heitor, é tomada como cativa por Neoptolemo, filho de Aquiles, e levada para Epiro; lá, será mãe, dentre outros, de Pergamus, que partirá para a Ásia Menor onde fundará a cidade nomeada a partir de seu nome (Gruen, 2000, pp. 23-24). Assim, nos três contextos os personagens da linhagem pergamena se colocam em oposição a Tróia (ainda que de modo ambíguo nos dois últimos casos): Héracles combateu Laomedon na chamada primeira guerra de Tróia - narrativa comemorada no frontão do templo de Aphaia, em Egina (Watson, 2011); Télefo, ainda que aliado de Tróia, mostrou o caminho para os gregos começarem a chamada segunda guerra de

\footnotetext{
${ }^{96}$ Disponível em: http://agora.ascsa.net/id/agora/drawing/da\%203912

${ }^{97}$ Disponível em: http://agora.ascsa.net/id/agora/image/2002.01.1299.
} 
Tróia; o nascimento de Pergamus é resultado da queda de Tróia e, nascido na Grécia, conquistará um reino na Ásia Menor.

Que a associação mítica entre Pérgamo e Egina tenha sido uma prática consciente, é indicado por uma inscrição fragmentária encontrada em Atenas (IG II2 885). R. Allen (1971) sugeriu que o decreto era originário de Egina (com base no tipo de letra), e propôs uma reconstituição ${ }^{98}$ que destacava Átalo I como compartilhando o

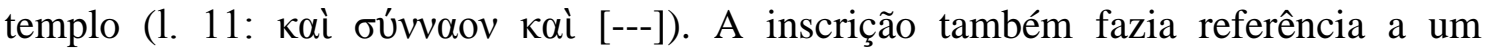

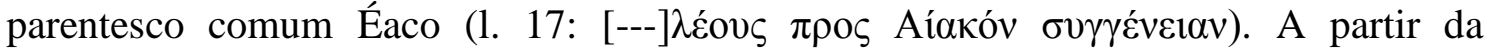

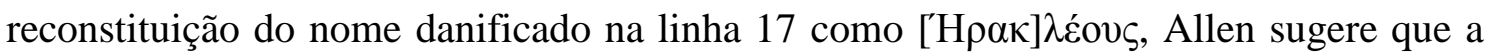
indicação de parentesco comum entre Éaco e Héracles estava relacionada ao mito de

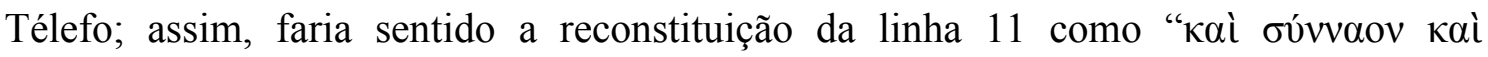

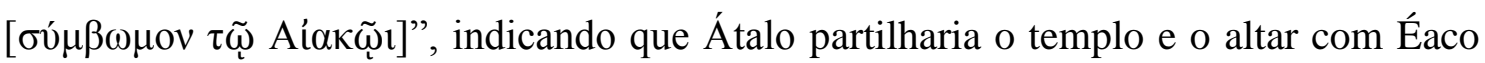
em Egina, e tornando plausível que este santuário compartilhado fosse, justamente, o Aiakeion egineta, mencionado por Pausânias (2.29.6; Allen, 1971, p. 10).

O terceiro elemento é dado pelos fortes indícios de participação pergamena na construção da Praça Sul, conjunto arquitetônico articulado ao - e talvez, pelo Aiakeion. A discussão desta participação será realizada mais adiante, mas é importante aqui destacar o papel estruturante do Aiakeion, santuário de Éaco construído na ágora ateniense no final do século VI, reformado durante a construção dos edifícios da Praça Sul, na primeira metade do século II. Então, o único edifício da ágora que apresentava uma orientação próxima dos eixos cardinais era o Aiakeion, o qual, conforme será discutido, pode ter sido a referência para a regularização cardeal da ágora tardohelenística, completada em meados do século II pela - sem dúvida pergamena - Stoa de Átalo II. A ligação da Praça Sul com Egina, além da contiguidade com o Aiakeion, se nota pela utilização de calcário egineta na construção da Stoa Média, iniciada pouco depois de 183: a possessão atálida de Egina torna plausível que parte da construção da Stoa Média tenha sido custeada por Pérgamo, por meio, ao menos, da doação de materiais. A localização do culto da tribo Attalis no Aiakeion seria coerente tanto com as ligações entre a mitologia pergamena e egineta, quanto com a provável participação pergamena na construção da Praça Sul, durante o reinado do sucessor de Átalo, Eumenes II: o Aiakeion/Attaleion seria então a chave para a regularização cardeal da

\footnotetext{
98 Geralmente aceita pelos estudiosos de Egina; p.ex., Figueira (1993, pp. 396-397). Ressalvas são
} apontadas em Robert e Robert (1973, pp. 92-93) e Polinskaya (2013, p. 211, n. 304). 
ágora. Infelizmente, o estado atual dos conhecimentos não oferece bases mais sólidas do que as apontadas acima para sustentar esta hipótese.

\section{A presença atálida na acrópole}

Após o trauma de 200, tem início um importante ciclo construtivo na cidade; não por acaso, as intervenções mais antigas são aquelas associadas à acrópole ateniense, tanto no topo quanto na encosta. A escolha pela acrópole é reveladora do modo como as intervenções construtivas tardo-helenísticas se relacionarão com a cidade: a acrópole era o santuário mais prestigioso da cidade, dedicado ao culto de Atena Políade e de diversas outras divindades; além disso, era repleto de monumentos importantíssimos para a identidade e a memória cívica ateniense. A articulação ao santuário do Demos e das Graças promove um interessante jogo de oposições: enquanto que pelo pequeno santuário do Demos e das Graças a cidade homenageia evergetas menores, as grandes intervenções na acrópole são elas próprias presentes dados pelos monarcas à cidade. Tal articulação, para além dos usos e apropriações cotidianas do espaço, era reiterada de modo ritual durante a procissão panatenaica, realizada de quatro em quatro anos ao final das Grandes Panatenéias: iniciando o percurso no Dípilo, a procissão passava pelo santuário do Demos e das Graças ainda antes de entrar na ágora, para terminar diante da Dedicação Atálida junto ao muro sul da acrópole (Shear, 2001).

As intervenções tardo-helenísticas na acrópole ateniense, como se verá, eram diretamente associadas à monarquia de Pérgamo, que com a impactante Dedicação Atálida iniciaria um período de seis décadas de intensa atividade construtiva, introduzindo um novo programa na produção do espaço urbano ateniense.

\section{A Dedicação Atálida na acrópole e os "pequenos bárbaros"}

A última intervenção urbana associada a Átalo I em Atenas (após a defesa da cidade e a criação da tribo Attalis) é a famosa "Dedicação Atálida"99. Cinco fontes estão relacionadas à dedicação: a descrição de Pausânias (1.25.2), a menção no decreto

\footnotetext{
99 A bibliografia usa igualmente as expressões "pequena doação atálida" ou "presentes atálidas". A escolha do termo "dedicação" aqui se deve ao caráter religioso da intervenção, como é indicado também em Pausânias quanto no decreto augustano da restauração dos santuários (IG II ${ }^{2}$ 1035.25-26). Um levantamento bibliográfico exaustivo pode ser encontrado em Stewart (2004, pp. 11-80).
} 
augustano de restauração dos santuários (IG II $^{2}$ 1035.25-6), as nove estátuas dos "pequenos bárbaros" (atualmente identificadas como cópias romanas dos originais atenienses; Stewart, 2004), a plataforma artificial da acrópole construída no século V, que serviria de fundação para a dedicação no século II (Korres, 2004), e os blocos encontrados em diversos locais da acrópole, identificados por M. Korres (2004) como partes das bases da dedicação.

Comecemos por Pausânias. Escrevendo em meados do século II a.C., o periegeta descreve o que seria um grupo escultórico localizado na acrópole de Atenas:

\footnotetext{
Junto ao muro sul [estão] a famosa guerra dos gigantes, os quais habitaram então no istmo de Palene na Trácia, a guerra dos atenienses contra as amazonas, o conflito em Maratona contra os medas e a destruição dos gálatas na Mísia, [que] Átalo dedicou, grande dois pés cada um (Pausânias, 1.25.2).
}

Diferenciemos de início as três temporalidades presentes na descrição de Pausânias. A primeira é a do próprio ato descritivo: meados do século II d.C., inserida no projeto da redação da Periegesis. A segunda é a da dedicação dos conjuntos: Pausânias diz que um Átalo dedicou, mas, se a identificação como um rei pergameno é obvia, não é certo qual dos três reis homônimos é o Átalo em questão. A terceira é a dos temas dos conjuntos: a gigantomaquia, a amazonomaquia, a persianomaquia e a galatomaquia. Cada uma destas temporalidades tem uma lógica própria, é preciso descortina-las antes de passarmos à análise dos vestígios materiais da dedicação.

A primeira temporalidade leva em consideração a interação entre experiência e descrição, na medida em que estes elementos estruturam a composição da obra. Duas posições antagônicas quanto à interpretação do projeto do autor podem ser sintetizadas a partir das obras de J. Elsner $(1992,2001)$ e K. Arafat (1996). Elsner defende que a Periegesis é um relato de peregrinação, pois é a experiência religiosa - da visita/visualilzação dos santuários - que estrutura o percurso do periegeta; para o autor, Pausânias é um grego falando das coisas gregas, centrando a atenção no caráter panhelênico das tradições religiosas do passado independente da Grécia, por oposição ao presente da dominação romana. Arafat, por sua vez, defende que a Periegesis foi composta como um guia cultural e artístico da Grécia balcânica, escrita por um estrangeiro (um grego da Ásia Menor); sua preocupação é entender as tradições locais 
em seus contextos específicos, preocupado não com a memória, mas com a realidade tangível, a Grécia de então.

As oposições peregrinação/turismo, nativo/estrangeiro, pan-helênico/local e passado/presente em Pausânias, no entanto, podem ser nuançadas (Rutherford, 2001). De fato, se tomarmos apenas a descrição da acrópole de Atenas (1.22.4-28.4), onde está a menção à Dedicação Atálida, rapidamente percebe-se a fusão entre os extremos. Logo depois de discutir as questões de autoria e qualidade técnica de determinadas pinturas e estátuas, Pausânias descreve os rituais ligados aos cultos representados naqueles suportes. Se por um lado Pausânias considera-se grego, e, portanto, integrante daquele ambiente cultural, por outro, diante de tradições absolutamente locais, ele deve se apoiar, como estrangeiro, em informantes ou na tradição literária. No mesmo sentido, na medida em que Pausânias está preocupado em identificar com acuidade os monumentos e narrar com precisão os mitos que justificam certos rituais, ele tem de lançar mão de uma tradição literária que era, simultaneamente, local e pan-helênica. E, por fim, se Pausânias busca constantemente o passado em suas descrições - o que se deve, em grande medida, ao gênero e à filiação literária do autor (Bowie, 2001) - ele só o faz a partir do presente, do que vê ou ouve, e isto se torna mais premente quando o tipo de objeto selecionado são monumentos que, em si, estão intimamente vinculados ao passado.

É nessa interação entre passado e presente, memória e vestígio, que a experiência assume um lugar central. A obra está estruturada pela experiência: os monumentos são mencionados na medida em que são vistos e julgados "dignos de serem vistos" ( $\theta \dot{\varepsilon} \alpha \varsigma$ $\left.\alpha \xi_{10 \imath}\right)$ pelo autor em seu percurso. No caso da Dedicação Atálida, os dados apresentados são a localização, o tema das representações, o dedicante e a dimensão das figuras; nada é dito acerca do suporte das imagens, do(s) escultor(es), estilo(s), quantidade de figuras, dimensões do monumento etc. A ênfase no tema - a gigantomaquia, a amazonomaquia, a persianomaquia e a galatomaquia - pode ser compreendida como uma síntese da articulação entre pan-helênico/local e religiosidade/erudição que estrutura a Periegesis. No entanto, a dedicação não serve de suporte para as características digressões mitográficas ou historiográficas de Pausânias, como será o caso para a descrição seguinte, da estátua de Olimpiodoro (e a digressão sobre as relações da cidade com a Macedônia no final do século IV e início do III; 1.25.2-.26.4). A brevidade da descrição da Dedicação Atálida se explica, possivelmente, pelo fato de estas batalhas já terem sido mencionadas por ocasião da descrição de outros 
monumentos na Ática, antes da chegada do periegeta à acrópole: logo após a entrada da cidade pelo Dípilo, Pausânias descreve um grupo escultórico de Poseidon combatendo o gigante Polibotes (1.2.4); a invasão das amazonas em Atenas já havia sido mencionada na descrição de uma estátua de Antíope diante do Dípilo (1.2.1) e nas pinturas do Theseion (1.17.2); a vitória dos atenienses sobre os persas já havia sido mencionada na descrição do templo de Eukleia (1.14.5) e das pinturas na Stoa Pintada, na ágora (1.15.3); a vitória de Átalo sobre os gauleses havia sido mencionada na digressão de Pausânias diante do grupo dos Heróis Epônimos na ágora (1.5.5). O que é específico da figuração da galatomaquia na acrópole é a ausência de atenienses na batalha. Vale a comparação com uma outra representação de galatomaquia em Atenas: Pausânias escreve que dentro do edifício do Conselho havia um retrato de Calipo, general ateniense presente na expulsão dos gauleses da Grécia (1.3.5) - aqui, o retrato do general funcionava como metonímia para a batalha, e este é o gancho para a digressão acerca da invasão gaulesa na Grécia (1.4.1-6). Assim, a conjunção entre lógica panhelênica e lógica local equipara a dedicação ao próprio projeto da Periegesis, servindo nesta passagem como uma espécie de reiteração das narrativas antibárbaras.

Passemos à segunda temporalidade, a do momento da dedicação do conjunto escultórico. O debate está centrado sobre a identidade do rei pergameno mencionado por Pausânias. Dos três Átalos que reinaram em Pérgamo ${ }^{100}$, somente os dois primeiros tiveram contatos mais intensos com a cidade: Átalo I esteve em Atenas em 200 a.C., quando foi decisivo para a declaração da guerra contra a Macedônia, além de ter sido comandante da galatomaquia representada na dedicação ${ }^{101}$; Átalo II também esteve em Atenas diversas vezes, e foi o doador de uma custosa stoa de dois andares na ágora ateniense, que carregava seu nome na arquitrave, construída ao longo da década de 150.

Ainda que não se possa descartar Átalo II de maneira definitiva ${ }^{102}$, diversos argumentos apontam para a iniciativa de Átalo $\mathrm{I}^{103}$. Em primeiro lugar, Átalo II não guerreou contra os gálatas, em virtude da interdição romana (OGIS 315.6; Will, 2003, t.

\footnotetext{
100 Átalo I (241-197), Átalo II (159-138) e Átalo III (138-133).

${ }^{101}$ Sobre a discussão das batalhas e sua datação, cf. Will (2003, t. II, pp. 296-297).

102 Como é o caso para Átalo III, cujas relações com Atenas, se existiram, não deixaram vestígios inequívocos (1990, p. 575).

103 Os defensores da datação mais baixa se baseiam principalmente nos aspectos formais das estátuas identificadas como cópias romanas de originais da Dedicação Atálida em Atenas: elas apresentariam elementos, na história da arte pergamena, ao Altar de Pérgamo, erigido por Eumenes II (197-159). No entanto, a descoberta de paralelos anteriores, associada à crítica tanto da periodização da arte pergamena com base somente nas obras quanto da desconsideração dos problemas ligados às cópias, tem enfraquecido esta posição. Cf. Stewart, 2004, pp. 11-80.
} 
II, p. 382). Em segundo lugar, Átalo I, após vencer os gálatas, dedicou um grupo escultórico representando a batalha no santuário de Atena Nikephoros em Pérgamo (Stewart, 2004, p. 191 e 197) o que faria com que a dedicação na acrópole de Atenas fosse um paralelo adequado. Em terceiro lugar, a referência no decreto augustano de restauração dos santuários da Ática às "dedicações e estátuas dedicadas pelo rei Átalo para a segurança da cidade" (IG II2 1035.25-27; Schmalz, 2007-2008), é paralela à inscrição dedicatória do monumento à galatomaquia dedicado por Átalo I em Pérgamo, "Rei Átalo [dedica] a Atena para a segurança da cidade" (Stewart, 2004, p. 226). Em quarto lugar, a dimensão das honras concedidas pela cidade ao rei em 200, à época da declaração de guerra contra a Macedônia, e que incluíam a criação de uma nova tribo, torna plausível a dedicação de um monumento comemorando, entre outras, uma vitória de Átalo. E finalmente, o clima antimacedônico na cidade, reforçado pelas destruições nos arredores de Atenas causadas por Filipe V, seria o combustível para a realização de um monumento com tema militar e antibárbaro, inserindo os macedônios - então inimigos dos atenienses e de Átalo - na mesma categoria dos gigantes, das amazonas, dos persas e dos gauleses. Neste sentido, é indicativa a referência de Pausânias à origem dos gigantes no "istmo de Palene na Trácia", onde ficava a antiga cidade de Potidea, rebatizada no final do século IV como Cassandrea pela iniciativa de Cassandro, rei da Macedônia e instaurador da tirania de Demétrio de Fálero em Atenas. Ademais, a diplomacia ateniense reforçará estas associações na continuidade da guerra (Stewart, 2004, pp. 223-224).

Aceitando-se a hipótese de Átalo I como o sujeito da dedicação, não está claro, de qualquer maneira, em qual momento o conjunto foi dedicado. A referência a "presentes anteriores" na mensagem do rei à assembleia ateniense em 200 (Políbio, 16.26) poderia indicar que, entre os presentes, estaria a Dedicação Atálida. No entanto, o prestígio envolvido na dedicação de conjuntos contendo a representação de uma batalha na qual, até onde se sabe, não houve envolvimento ateniense (contra os gálatas na Mísia), ocupando cerca de metade do espaço junto ao muro sul, faria mais sentido após a colaboração pergamena na defesa da cidade contra o cerco de Filipe V em 200/199. Assim, se as dificuldades decorrentes do cerco tornariam impraticável um trabalho de tal dimensão, parecem candidatos mais prováveis os anos subsequentes ao cerco, tendo como terminus ante quem a morte de Átalo I em 197 (Will, 2003, t. II, p. 159). 
À terceira temporalidade - do tema dos grupos escultóricos - se articulam duas oposições básicas: pan-helênico/ local, mitológico/ histórico. Contrariamente ao número relativamente reduzido de referências literárias, a gigantomaquia é amplamente representada em suportes materiais, especialmente na decoração escultórica de templos e na cerâmica pintada (Vian e Moore, 1988). De acordo com Apolodoro (1.6.1-2), os gigantes, seres monstruosos nascidos do contato da Terra com o sangue que jorrou de Urano após sua castração, foram instados pela própria Terra a guerrearem contra os deuses olímpicos, após estes terem vencido e aprisionado os titãs; os deuses, agindo de acordo com um oráculo, segundo o qual só venceriam os gigantes com a ajuda de um mortal, trazem para a batalha Héracles, e após diversos combates, obtém a vitória. Ao mesmo tempo cosmogônico, pois o que está em discussão é a ordem olímpica, o mito também se situa no tempo dos heróis, como demonstra a participação de Héracles. Fundamental no mito é a atuação de Atena, responsável pela entrada do herói no conflito e pela vitória diversos gigantes: sua participação era representada na acrópole ateniense ainda no século VI, no frontão do templo arcaico, e mais claramente nas métopas do friso leste do Pártenon, na segunda metade do século V (Étienne, 2004, p. 46-47, 90).

A amazonomaquia diz respeito à invasão de Atenas pelas amazonas, expedição punitiva ao rapto de Antíope por Teseu, quando este acompanhou Héracles em sua expedição à terra das amazonas. $\mathrm{Na}$ acrópole ateniense, uma das mais célebres representações da invasão das amazonas estava no escudo da estátua criselefantina de Atena no Pártenon (Harrison, 1966), além das métopas ocidentais do Pártenon e no frontão ocidental do templo de Atena Nike (Étienne, 2004, p. 90-93). Na Dedicação Atálida, se por um lado a lógica defensiva da gigantomaquia se mantém, por outro a espacialização do conflito (a invasão de Atenas) reforça o localismo ateniense, articulado à dimensão pan-helênica pelo discurso anti-bárbaro.

A persianomaquia se refere à batalha de Maratona entre atenienses e persas. A memória das guerras médicas estava presente na acrópole em pelo menos duas maneiras: nos vestígios das destruições persas, como nas famosas "fundações Dörpfeld", e nos relevos do friso sul do templo de Atena Nike (Hurwitt, 1999, pp. 111, 212-13). No entanto, a historicidade da batalha de Maratona não era percebida, necessariamente, como laica: o relato da participação de Teseu ao lado dos atenienses (Plutarco, Teseu, 35), demonstra a contiguidade dos fundamentos míticos e históricos do discurso antibárbaro. 
Finalmente, a galatomaquia se refere à vitória do exército liderado pelo rei pergameno Átalo I sobre os gauleses, que invadiram a Ásia Menor em 278/7 (Pausânias, 10.23.14) e se estabeleceram próximo à Mísia, realizando repetidos saques às cidades da Ásia Menor. A situação específica desta vitória não é clara. Duas vitórias de Átalo sobre contingentes gauleses são datadas da década de 230: uma sobre a tribo dos tolistoages no vale do rio Caico, e outra sobre as tribos dos tolistoages e tectosarges aliados a Antíoco Hierax. A cronologia das duas batalhas não é precisa, mas há um consenso segundo o qual a vitória sobre os tolistoages antecedeu aquela sobre Antíoco e aliados, ocorrendo por volta de 237, quando Átalo I já teria assumido o título de rei ${ }^{104}$. Existem diversas referências a monumentos comemorando suas vitórias sobre os gauleses: em Pérgamo, uma pintura cuja localização é desconhecida (Pausânias, 1.4.6), e dois monumentos dedicados no santuário de Atena Nikephoros, o de base circular (IvP 20), provavelmente associado a uma estátua colossal de Atena e datado em cerca de 237, e a chamada "dedicação múltipla" (IvP 21-28), composta por diversas batalhas travadas por Átalo I, datada de pouco depois de 223 (Marszal, 2000, p. 206); em Delos, em monumento no limite norte da "Stoa Sul” (IG XI.4 1110); em Delfos, em monumento diante da Stoa de Átalo II (SIG3 682); e em Atenas, a Dedicação Atálida na acrópole, mencionada por Pausânias. A escolha de dois santuários pan-helênicos (Delfos e Delos) e Atenas torna evidente o caráter propagandístico das dedicações. Ainda que na batalha no vale do Caico não haja notícia de participação de qualquer ateniense, é importante lembrar das pinturas no Bouleuterion, na ágora, que comemoram a participação do general ateniense Calipo na guerra gálica na Grécia (Pausânias, 1.3.5). Dessa maneira, ainda que "estrangeira", a galatomaquia pergamena se torna "local" tanto por meio do discurso antibárbaro, equiparando a Ásia Menor (Pérgamo) e a Grécia (Atenas) sendo invadidas pelos bárbaros (gálatas/persas), quanto por meio da participação ateniense na resistência em 279/8.

A articulação dos elementos pan-helênicos e locais, mitológicos e históricos, é feita de modo complexo, e seu pressuposto é a identificação dos quatro inimigos como parte de uma mesma categoria - a barbárie. Esta identificação já tinha uma longa

\footnotetext{
104 Allen (1983, pp. 33-34) acredita que a vitória sobre os tolistoages é anterior àquela sobre Antíoco Hierax e aliados, argumentando que os tectosarges teriam se engajado no conflito após a derrota dos tolistoages, e a vitória sobre Antíoco teria sido decisiva, tornando improvável um novo ataque gaulês pouco tempo depois. Estes argumentos não são decisivos: não há informação sobre a proporção das forças gaulesas em nenhuma das batalhas, sendo impossível medir o impacto das derrotas em sua organização geral. Sobre o título de rei de Átalo I, cf. a discussão em Will (2003, t. I, p. 298) e Allen (1983, p. 195199).
} 
tradição, que tem como marco as guerras médicas do início do século V a.C. e os persas como eixo fundamental. Os gigantes são associados aos persas já no século $\mathrm{V}$, representações da selvageria (reforçada pela pele de leão e pela forma de luta, por pedradas) que se opõem a ordem instituída pelos deuses olímpicos (Carpenter, 2007, p. 403). A representação das amazonas sofre uma inflexão com as guerras médicas: se até o início do século $\mathrm{V}$ o episódio representado nos vasos áticos era o rapto - reforçado pelas operações atenienses durante a revolta jônia na Ásia menor -, a partir de 490 este episódio será substituído pela invasão da cidade pelas amazonas, claramente influenciado pela batalha de Maratona: as amazonas se tornam predecessoras dos persas, invasores da Ática (Walker, 1995, p. 55). E segundo Pausânias, os gauleses usaram o mesmo expediente dos persas em 480 para atravessar a passagem das Termópilas - o atalho de Efialtes - e derrotaram os gregos em 279 (desta vez, atenienses), e do mesmo modo que os persas invadiram a Grécia e foram finalmente expulsos (Pausânias, 1.3.5-1.4.2).

Identificado os oponentes, identificam-se simultaneamente os vencedores, dispostos ao mesmo tempo em uma sequência cronológica e em uma hierarquia de prestígio: os deuses olímpicos e o herói pan-helênico na guerra cosmogônica; o rei mítico local e os ancestrais na defesa do território nos tempos heróicos; os defensores históricos da Grécia e de Atenas contra os persas; e o rei evergeta contra os novos bárbaros invasores. Importante destacar que, nas quatro batalhas, os vencedores são acima de tudo defensores, seja da ordem (gigantomaquia), seja do território/autonomia (amazonomaquia, persianomaquia, galatomaquia). A dedicação pergamena, assim, incorpora os grandes feitos mitológicos e históricos da grande narrativa anti-bárbara pan-helênica, coerente com a tendência à mitologização dos monumentos do período helenístico (Marszal, 2000, p. 212).

Os vestígios materiais da Dedicação Atálida foram objeto de uma imensa bibliografia, que tem como marcos principais a publicação do estudo pioneiro de $\mathrm{H}$. Brunn (1870), quando pela primeira vez os “pequenos bárbaros” (estátuas de cerca de 1 metro de altura espalhadas por museus da Itália e França) foram associadas à dedicação; e a publicação do estudo de M. Korres sobre os vestígios das bases da dedicação, em 2004. No estudo mais abrangente sobre o tema (Stewart, 2004), dez estátuas são associadas à Dedicação Atálida: quatro estão no Museu Arqueológico de Nápoles, três no Museu Arqueológico de Veneza, uma no Museu Vaticano (Roma), uma no Museu do Louvre (Paris) e uma no Museu Granet (Aix-em-Provence). Encontradas em Roma, 
na região do Campo de Marte, em 1514, representam apenas os derrotados. Este fato, associado a um significativo conjunto de características comuns à escultura romana do final do século I e início do II d.C., aponta para a identificação das estátuas como cópias romanas do período do principado de Trajano ou Adriano; sua localização indicaria que as estátuas fariam parte dos projetos de restauração dos edifícios augustanos realizado por Adriano no Campo de Marte (Stewart, 2004, pp. 136-180).

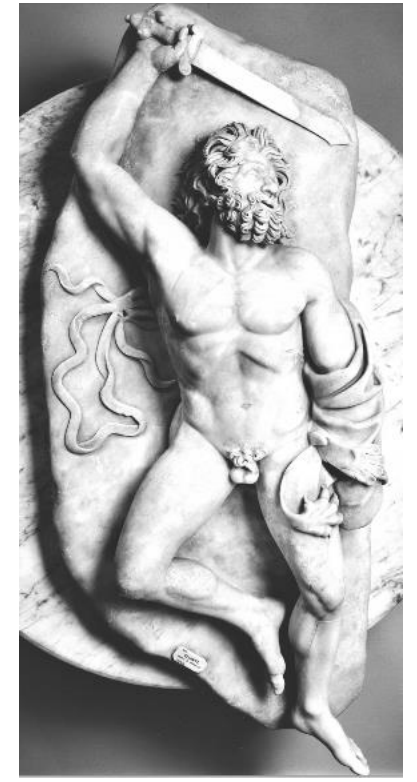

Figura 44. Fotografia da estátua plena do "gigante" (Museu Arqueológico Nacional de Nápoles ${ }^{105}$ ).

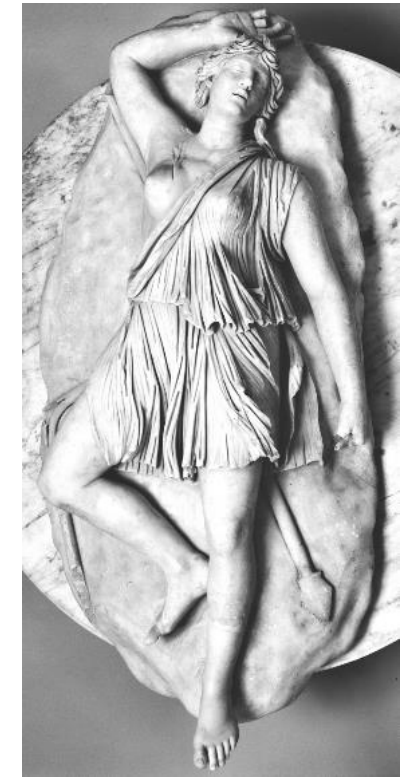

Figura 45. Fotografia da estátua plena da "amazona" (Museu Arqueológico Nacional de Nápoles ${ }^{106}$ ).

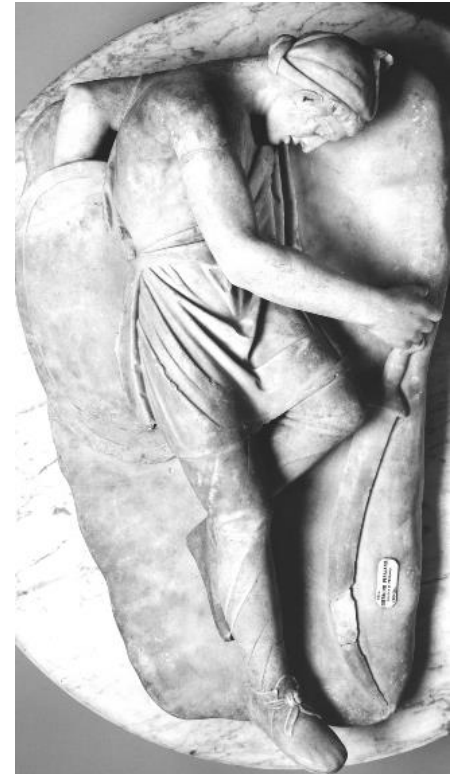

Figura 46. Fotografia de estátua plena de "persa" (Museo Arqueológico Nacional de Nápoles ${ }^{107}$ ).

105 Disponível em: http://cir.campania.beniculturali.it/museoarcheologiconazionale/percorso/nelmuseo/P_RA8/RIT_RA306.

106 Disponível em: http://cir.campania.beniculturali.it/museoarcheologiconazionale/percorso/nelmuseo/P_RA8/RIT_RA263

107 Disponível em: http://cir.campania.beniculturali.it/museoarcheologiconazionale/percorso/nelmuseo/P_RA8/RIT_RA325. 




Figura 47. Fotografia de estátua plena de "gaulês"

(Museu Arqueológico Nacional de Nápoles ${ }^{108}$ ).

Os "bárbaros" do Museu Arqueológico Nacional de Nápoles (figs. 44-47) foram fundamentais para a identificação do grupo, pois representam, cada um, um dos grupos escultóricos mencionados por Pausânias. O gigante morto de Nápoles (fig. 44) representa um homem nu, em decúbito dorsal, com o braço e a perna direita flexionada e o braço e perna esquerdos estendidos, olhos e boca entreabertos, testa levemente franzida; cabelos e barba longos divididos em mechas grossas, onduladas e revoltas, feitas com incisões profundas. Segura uma espada com a mão direita enquanto um manto com pele de leão envolve o braço esquerdo e repousa sobre parte da perna esquerda; à direita, está um laço esculpido em relevo sobre a base; um ferimento aberto jorra sangue no flanco esquerdo. A tensão na musculatura do abdômen, o sangue jorrando do ferimento e a mão segurando a espada se opõem à expressão da face, já em relaxamento com a testa sutilmente franzida, que se volta para o lado esquerdo. A pele de leão, a nudez heroica e os cabelos e barbas asseguram a identificação como um gigante, ou ao menos uma de suas variações, tendo em mente, por exemplo, as 108 Disponível em: http://cir.campania.beniculturali.it/museoarcheologiconazionale/percorso/nelmuseo/P_RA8/RIT_RA291. 
representações de gigantes como hoplitas, seres alados imberbes ou seres com pernas em forma de serpente (Vian e Moore, 1988). A amazona morta de Nápoles (fig. 45) representa uma mulher vestida com chitoniskos drapejado preso no ombro esquerdo, deixando o seio direito visível; como o gigante, está deitada em decúbito dorsal com o braço e a perna direita flexionada, olhos e boca entreabertos; tem cabelos compridos presos aparentemente com um laço. Está sobre duas lanças quebradas, e tem um ferimento aberto jorrando sangue no seio direito. O arranjo dos membros, a posição da cabeça, a representação dos cabelos em mechas grossas com incisões profundas e a expressão em relaxamento da face indicam o mesmo modelo do gigante. O seio visível e o a túnica asseguram identificação como uma amazona. O persa morto de Nápoles (fig. 46) representa um homem vestido com barrete frígio, túnica presa no ombro esquerdo e na cintura, deixando o ombro direito visível, calças de pele e botas leves; está deitado em decúbito lateral (esquerdo), perna direita estendida e esquerda flexionada, braço esquerdo flexionado e recuado para trás do corpo. Tem cabelos curtos saindo em mechas em sequência sob o barrete, sem barba, com rosto arredondado, olhos e boca entreabertos, e expressão da face menos relaxada que a amazona ou o gigante, talvez ainda indicando agonia. Um escudo oval é segurado pela mão esquerda por trás do corpo, e uma espada curva solta está próxima à mão direita; não há ferimentos visíveis. O barrete frígio, as calças, o calçado e a espada curva reforçam a identificação como um persa, como atestam paralelos no friso de Atena Nike ou no mosaico de Alexandre. Diferentemente do gigante e da amazona, a escultura é estruturada por formas curvas: aquela das costas e pescoço na parte superior, do braço esquerdo logo abaixo, da espada diante das pernas, e do escudo oval atrás do corpo. O gaulês moribundo (fig. 47) do Museu Arqueológico Nacional de Nápoles representa um homem nu com capacete pseudo-ático (restauração), reclinado para a esquerda se apoiando no braço esquerdo, pernas e braços ligeiramente flexionados; dois ferimentos profundos no flanco esquerdo e abaixo da omoplata direita, jorrando sangue; as cavidades nas costas e no abdomem indicam que uma lança, provavelmente de bronze, estava fixada à estátua. A identificação com um gaulês parte da similaridade com a estátua em tamanho natural do "Gaulês capitolino". 


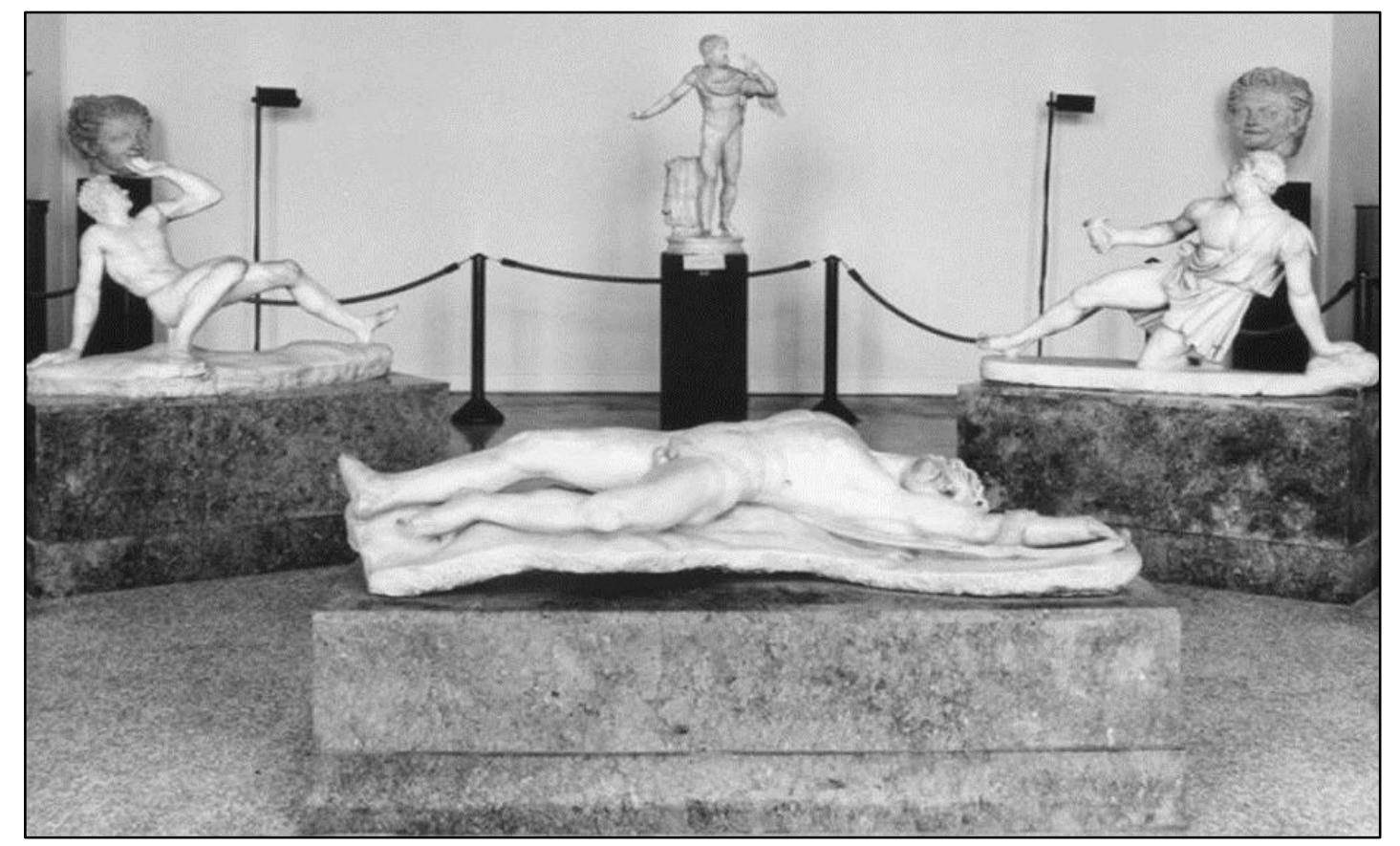

Figura 48. Fotografia das estátuas plenas dos "gauleses" do Museu Arqueológico Nacional de Veneza, tirada no local por O. Böhm (Stewart, 2004, p. 2, fig. 2).

Os "bárbaros" do Museu Arqueológico Nacional de Veneza, por sua vez, são todos identificados identificados como gauleses mais pela ausência do que pela presença de elementos característicos. O gaulês ajoelhado de Veneza (fig. 48, à direita) representa um homem vestido com túnica presa no ombro esquerdo e na cintura, deixando o lado direito do dorso à mostra; olhos arregalados e boca entreaberta, cabelo e barba longos; apoiado sobre o joelho esquerdo, o tornozelo direito e o braço esquerdo, que se apoia sobre uma pedra; o braço direito que segura espada é uma restauração. $\mathrm{O}$ gaulês "break-dancer" de Veneza (fig. 48, à esquerda) representa um homem nu, com dorso torcido para a direita (pernas e braços são restaurações); olhos arregalados e boca entreaberta; cabelo curto e nenhuma barba; sua postura, reclinada para trás no movimento de queda, pode indicar que o personagem estivesse associado a um cavalo. O gaulês morto de Veneza (fig. 48, em primeiro plano) representa um homem nu com cinto de metal na cintura; deitado em decúbito dorsal, com braço esquerdo estendido para cima e direito paralelo ao corpo, pernas ligeiramente flexionadas; olhos e boca entreabertos; cabelo de tamanho mediano, sem barba; braço esquerdo sobre escudo hexagonal, e mão direita segurando cabo de espada; ferimentos no peitoral e nos dois flancos laterais, jorrando sangue.

Mais três estátuas estão espalhadas por museus europeus. O persa ajoelhado do Museu do Vaticano (fig. 49) representa um homem nu vestindo apenas um barrete 
frígio; corpo flexionado, flanco direito estendido, apoiado sobre o braço esquerdo estendido e o joelho flexionado, cabeça inclinada voltada para a direita; olhos arregalados e boca entreaberta; cabelo curto, sem barba; sem ferimentos. A identificação como persa é assegurada pelo barrete frígio, além das dimensões do nariz e dos lábios. O persa ajoelhado do Museu Granet (fig. 50) representa um homem vestido com túnica presa no ombro esquerdo, deixando parte direita do dorso à mostra, também com barrete frígio, calça de pele de calçado leve; apoiado sobre o joelho direito, a mão direita e o pé esquerdo; cabeça voltada para cima; olhos arregalados e boca entreaberta; cabelo e barba curtos; sem ferimentos. O gaulês ajoelhado do Museu do Louvre (fig. 51) representa um homem nu, apoiado sobre o joelho esquerdo e o pé direito (braços são restaurações); cabeça voltada para a esquerda; olhos arregalados e boca ligeiramente aberta; cabelo mediano, sem barba; escudo circular com espada curta na base; ferimentos no flanco direito e na coxa esquerda, jorrando sangue.

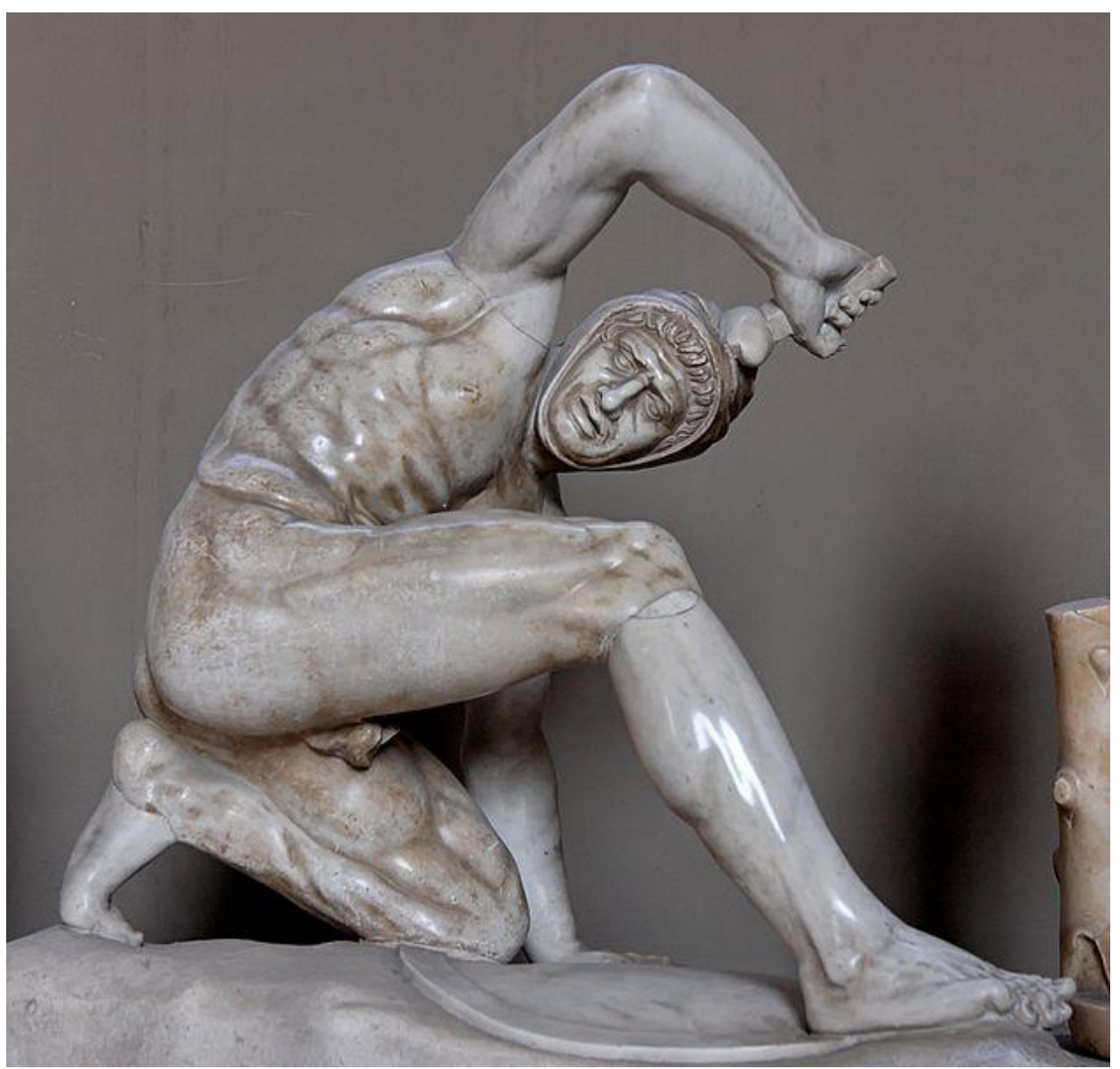

Figura 49. Fotografia da estátua plena do "persa" no Museu do Vaticano, tirada por Jastow em 2006 (Wikipedia Commons ${ }^{110}$ ).

${ }^{110}$ Disponível em: http://commons.wikimedia.org/wiki/File:Persian_soldier_Vatican_Inv2794.jpg. 


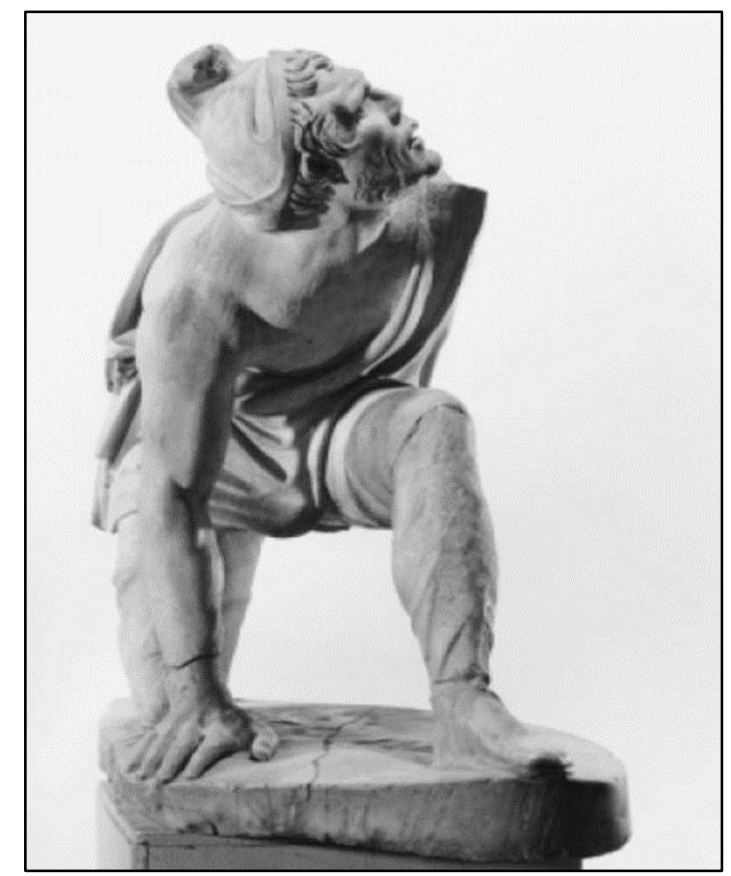

Figura 50. Fotografia da estátua plena do "gaulês" do Museu Granet (Stewart, 2004, p. 3, fig. 4).

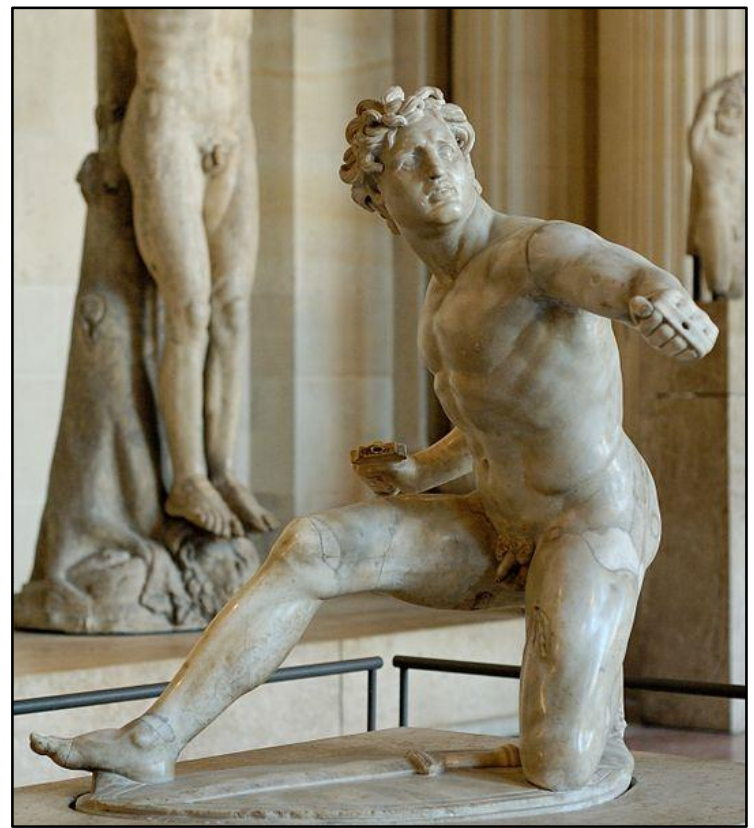

Figura 51. Fotografia da estátua plena do "gaulês" do Museu do Louvre, tirada por $M$. Nguyen em 2007 (Wikipedia Commons ${ }^{111}$ ).

Apesar da grande variação nas posturas e traços individuais, as estátuas apresentam algumas características recorrentes. Todas representam guerreiros derrotados, variando apenas o momento da derrota: da arma empunhada ao corpo sem vida. Praticamente todas apresentam marcas iconográficas para a rápida identificação: gigante associado a pele de animal, amazona com um seio de fora, persas com barrete frígio e/ou roupas compridas; quanto aos gauleses, possivelmente a marca definidora era a ausência de atributos exclusivos. As estátuas apresentam claras noções de equilíbrio, por meio da articulação entre diferentes posições dos membros (estendidos ou flexionados). O pathos das representações, para além da própria situação da derrota e iminência da morte, é reforçado com as incisões profundas sobre a superfície, intensificando os volumes e aumentando a expressividade dos personagens. Finalmente, em todas as estátuas a tridimensionalidade é reforçada - novas informações aparecem na medida em que se circunda a estátua - de modo que sua apreciação pressupõe a movimentação do espectador. Tais elementos são coerentes com as características da escultura helenística, e em particular dos experimentos praticados em Pérgamo,

\footnotetext{
${ }^{111}$ Disponível em:

http://commons.wikimedia.org/wiki/File:Kneeling_youthful_Gaul_Louvre_Ma324_n2.jpg
} 
descontados os elementos relacionados ao momento da cópia (Ridgway, 2001, pp. 275312; Stewart, 2006).

Um problema particularmente espinhoso é o da datação das estátuas, em virtude, especialmente, de sua condição de cópias. Se até a década de 1980 as cópias romanas em mármore eram analisadas somente em função de seus supostos originais gregos, posição reiterada pelo estigma de pouca criatividade da arte imperial, a renovação dos estudos de história da arte helenística e romana tem enfatizado os espaços de interpretação e desvio presente nas cópias, articuladas aos seus períodos de composição (Ridgway, 1984). A partir de paralelos no modo como cabelos, olhos e roupas foram esculpidos, A. Stweart defende que as cópias romanas sejam datadas do início do século II d.C., e sua realização atribuída a escultores de Afrodísias residentes em Roma, utilizando mármores microasiáticos. O local de proveniência, a região do Campo de Marte, sugeriria que os dez pequenos bárbaros estariam expostos em alguns dos edifícios restaurados por Adriano, como as termas (Stewart, 2004, pp. 136-180).

O estilo das estátuas, de qualquer maneira, aponta para originais helenísticos, em função principalmente de suas semelhanças com o friso do Altar de Pérgamo. Um problema que se coloca desde o princípio é a inexistência dos vencedores, o que seria dificilmente explicado pelo acaso: sobreviveram 10 estátuas de derrotados e nenhuma de vencedores. Uma explicação plausível é a de que, justamente, a representação somente dos derrotados, sem a presença dos vencedores, é uma prática romana do período imperial: no processo de inspiração pelos originais gregos, os escultores da época imperial teriam excluído deliberadamente os vencedores. Assim, o grupo original conteria também os vencedores, mais de acordo com as práticas clássicas e helenísticas de representação de batalhas.

A Dedicação Atálida inseriu a escultura tardo-helenística na acrópole ateniense, santuário/museu multissecular. A caracterização como museu não reduz aquela como santuário: num caso excepcional de documentação relativa ao uso posterior, sabe-se que no período augustano a Dedicação Atálida seria mencionada como algo "para a

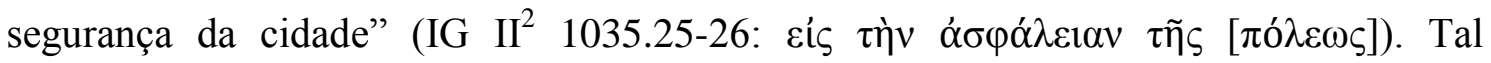
caracterização, se por um lado deve derivar de alguma inscrição na própria dedicação (tendo em vista o equivalente em Pérgamo: AvP 8.1.20-21,29), por outro ainda foi considerada relevante em um decreto voltado para a restauração de santuários áticos. $\mathrm{O}$ sentido religioso, portanto, é claro: a narrativa escultórica dos conflitos antibárbaros não se limitam à fruição estética, mas carregam também um sentido mágico, apotropaico. 
Desse modo, a dedicação figuraria ao lado de outros artefatos apotropaicos na acrópole ateniense, tais como a estátua de Nike sem asas, para que ela nunca abandonasse a cidade (Pausânias, 3.15.7) ou a Gorgoneion na muralha sul acima do teatro de Dioniso, dedicado por um certo Antíoco (Pausânias, 1.21.3, 5.12.4) ${ }^{112}$. Museu, mas também santuário para a segurança da cidade.

Pausânias diz que a Dedicação Atálida ficava junto ao muro sul. Fundamental para a identificação da localização mais precisa deste grupo foi a descoberta de uma alteração no padrão do terraço sul da acrópole, construída na época de Péricles: a partir da metade da colunata sul do Pártenon, a plataforma junto à muralha se torna abruptamente mais larga (cerca de 5 metros) e segue a muralha até o bastião medieval, com um comprimento total de 143 metros até o bastião medieval (figs. 52-53). Esta extensão não se explica somente em função da contenção da terra de preenchimento do terraço sul da acrópole, necessária para a estabilização do Pártenon ou da muralha, na medida em que em sua porção oeste a muralha não é mais larga que um metro. Neste sentido, é de se suspeitar de que já na época de Péricles havia um plano para a instalação de edifícios ou monumentos junto à porção sudeste da muralha, o que justificaria a largura maior da plataforma; assim, a Dedicação Atálida completaria um plano anterior (Korres, 2004), algo paralelo ao observado no caso da Stoa de Eumenes (cf. discussão abaixo).

M. Korres (2004) analisou uma série de blocos composta por oito plintos, quatro ortostatos e treze cornijas, todos eles parte de longas bases de estátuas. A localização dos achados, as características dos blocos e as marcas de encaixe de estátuas de bronze em sua superfície superior foram suficientes para que M. Korres sugerisse que se tratavam das bases da Dedicação Atálida. Com base no comprimento da plataforma, a largura das bases e a altura das cópias romanas, A. Stewart sugeriu que os quatro grupos da Dedicação Atálida eram compostos, no total, por cerca de 120 estátuas, se estendendo por 140 metros de comprimento (figs. 53-55; Stewart, 2004, p. 196); tais dimensões fariam com que o conjunto se constituísse com o maior monumento escultórico da acrópole, funcionando como uma espécie de pêndulo terrestre para as métopas do Pártenon, cujos relevos tinham dimensões equivalentes às estátuas plenas da Dedicação Atálida - paralelo que é reforçado pela coerência temática dos conflitos contra monstrons e bárbaros.

${ }^{112} \mathrm{Cf}$. a lista completa, com as respectivas referências documentais e bibliográficas, em Stewart (2004, p. 227). 

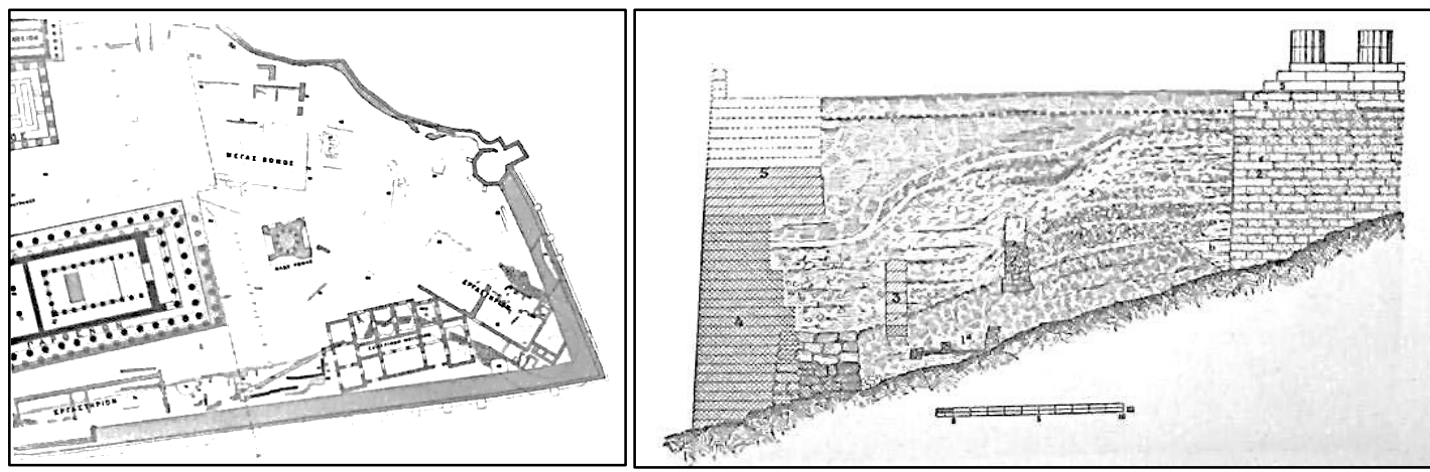

Figura 52. Proposta de planta baixa e seção da acrópole na (altura da fachada leste do Pártenon) após as escavações de 1885-90, por P. Kavvadias e G. Kawerau (Stewart, 2004, p. 183, figs. 2123).

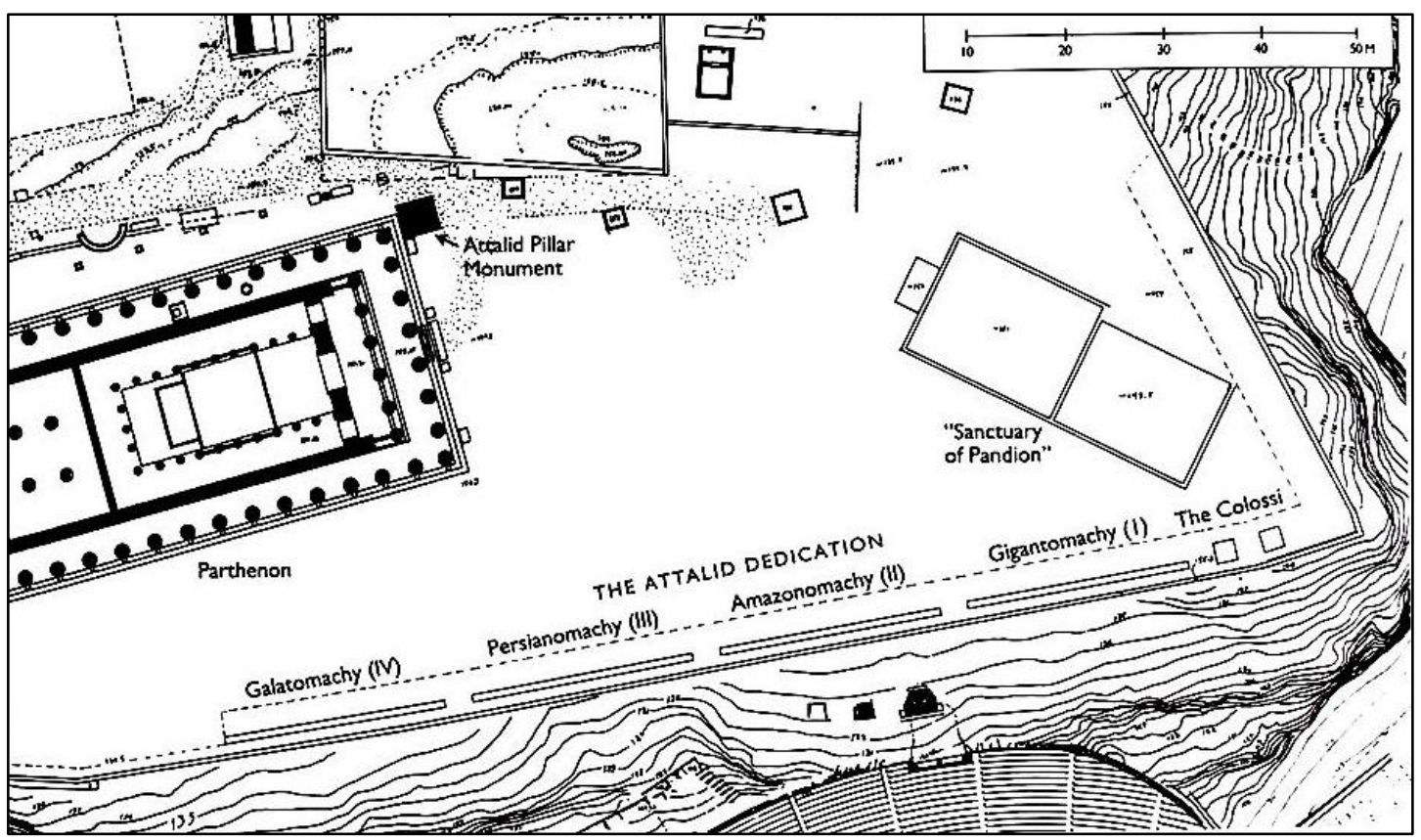

Figura 53. Proposta de reconstituição da planta da área sudeste acrópole de Atenas, por Erin Dirinto, com base na planta de M. Korres e nas hipóteses de A. Stewart e M. Korres (Stewart, 2004, p. 196, fig. 228). 


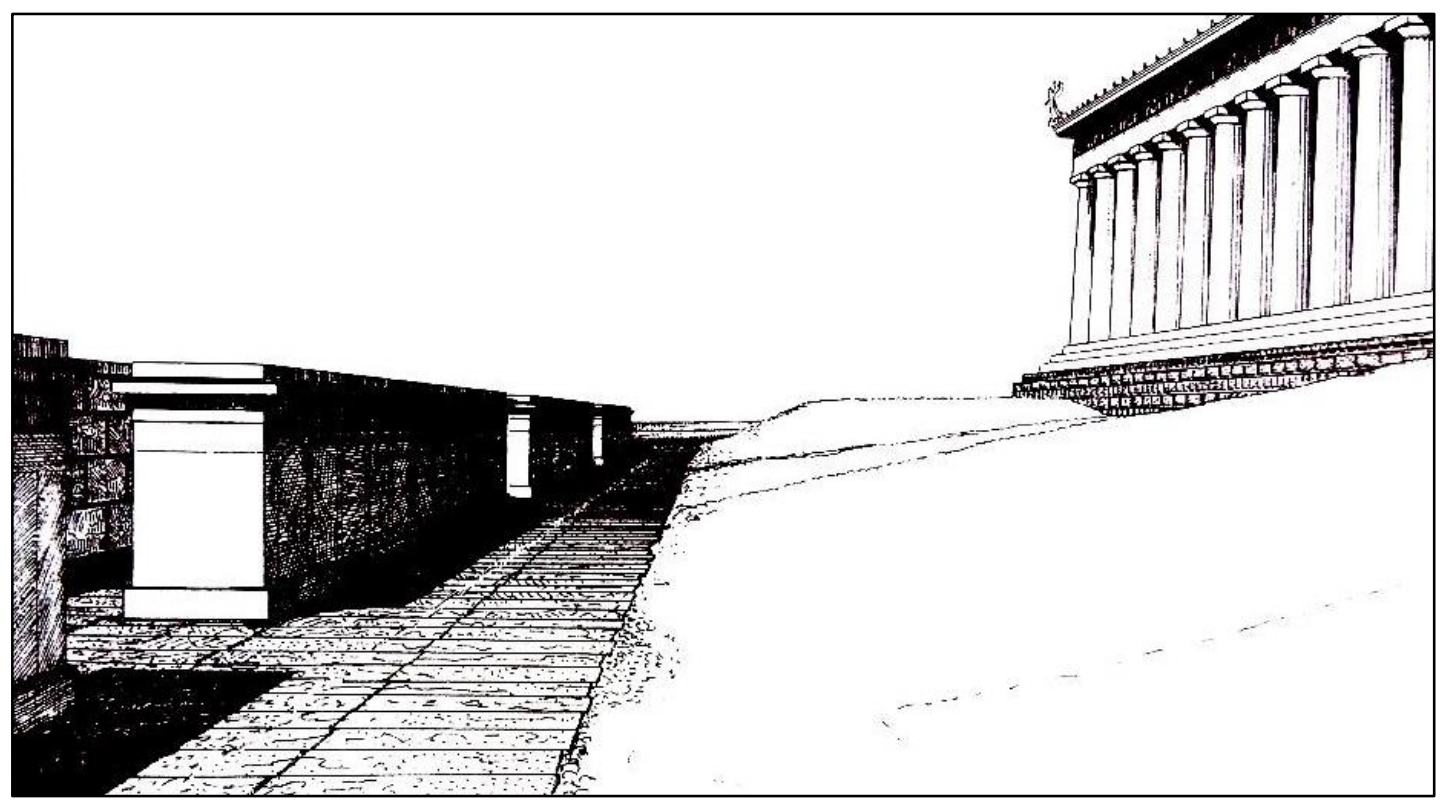

Figura 54. Proposta de reconstituição da perspectiva das bases da Dedicação Atálida vista do leste, por M. Korres (Stewart, 2004, p. 187, fig. 218).

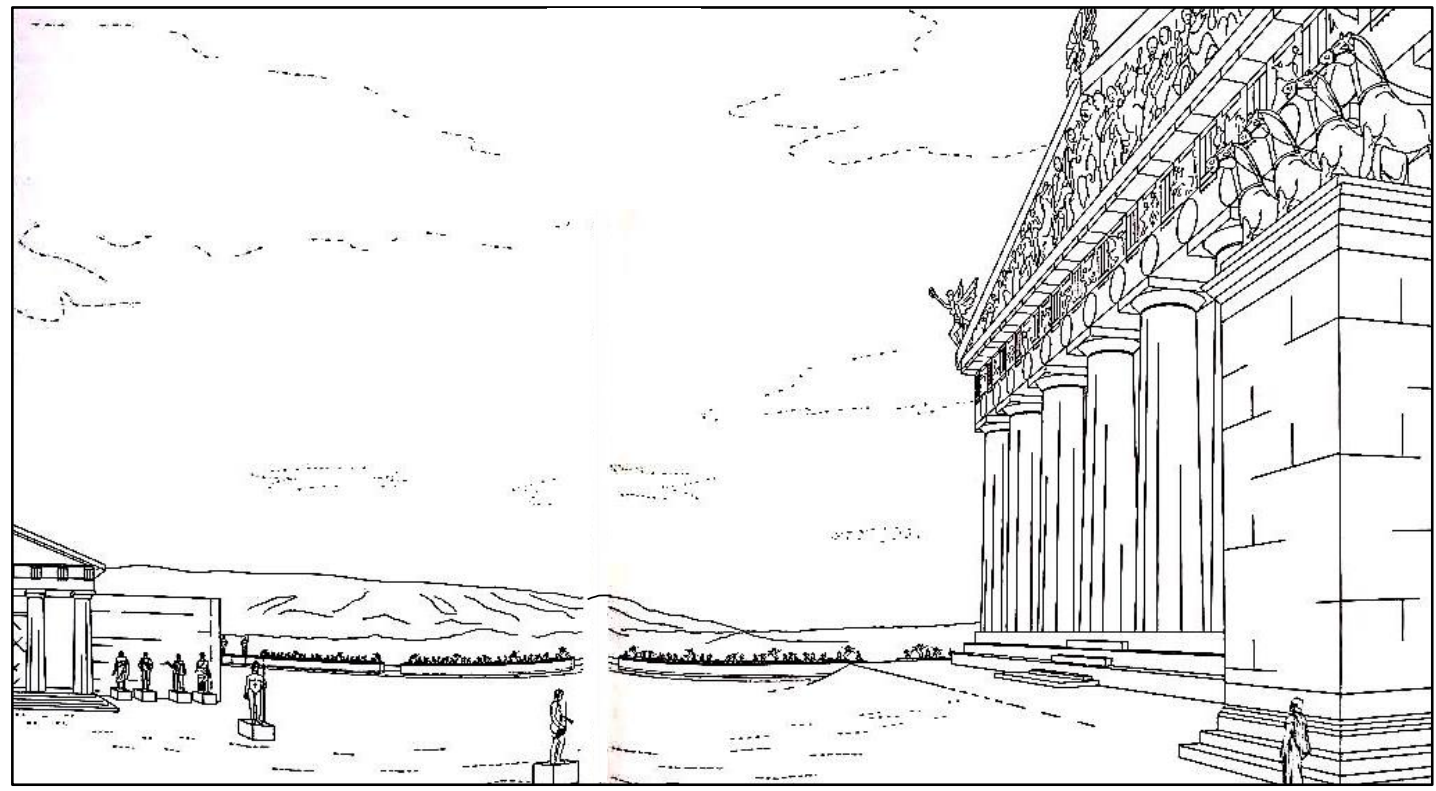

Figura 55. Proposta de reconstituição da elevação da área sudeste da acrópole no período helenístico vista do norte, por Erin Dintino, segundo hipóteses de A. Stewart e M. Korres (Stewart, 2004, pp. 194-5, fig. 227).

A monumentalidade da Dedicação Atálida reforçaria seus diálogos com outros monumentos e edifícios da acrópole ateniense. O primeiro, mais óbvio, é o diálogo com o Pártenon, cujas métopas tinham relevos referentes à gigantomaquia, à centauromaquia, à amazonomaquia e ao saque de Tróia, e cujas figuras mediam praticamente o mesmo das estátuas da dedicação (cerca de um metro de altura). Não por 
acaso, eram as métopas da centauromaquia que estavam na face sul do Pártenon, completando assim a grande narrativa da Dedicação Atálida (que não representava o conflito com os centauros). Mais do que incorporar o friso do Pártenon à narrativa, a dedicação incorporava a própria lógica de materialização narrativa, inserindo os feitos atenienses (e pergamenos) dentro da grande narrativa mítico-histórica da luta contra os bárbaros.

Outro diálogo importante era feito com o friso jônico do templo de Atena Nike, ao sul do propileu, que representava cenas da batalha de Maratona em sua face sul (fig. 56; além da gigantomaquia e da amazonomaquia em cada um de seus frontões): desse modo, as figuras dos persas estariam no início e no final do percurso da procissão panatenaica na acrópole, fazendo com que a Dedicação Atálida, de certo modo, fechasse o percurso figurativo persa que se iniciava com o templo de Atena Nike, e que tinha nos espólios persas dedicados no Erechtheion (Pausanias, 1.27.1) e nas arquitraves do Pártenon (Arriano, Anabasis, 1.16) objetos indiciários, que atestavam a autenticidade a figuração das batalhas.

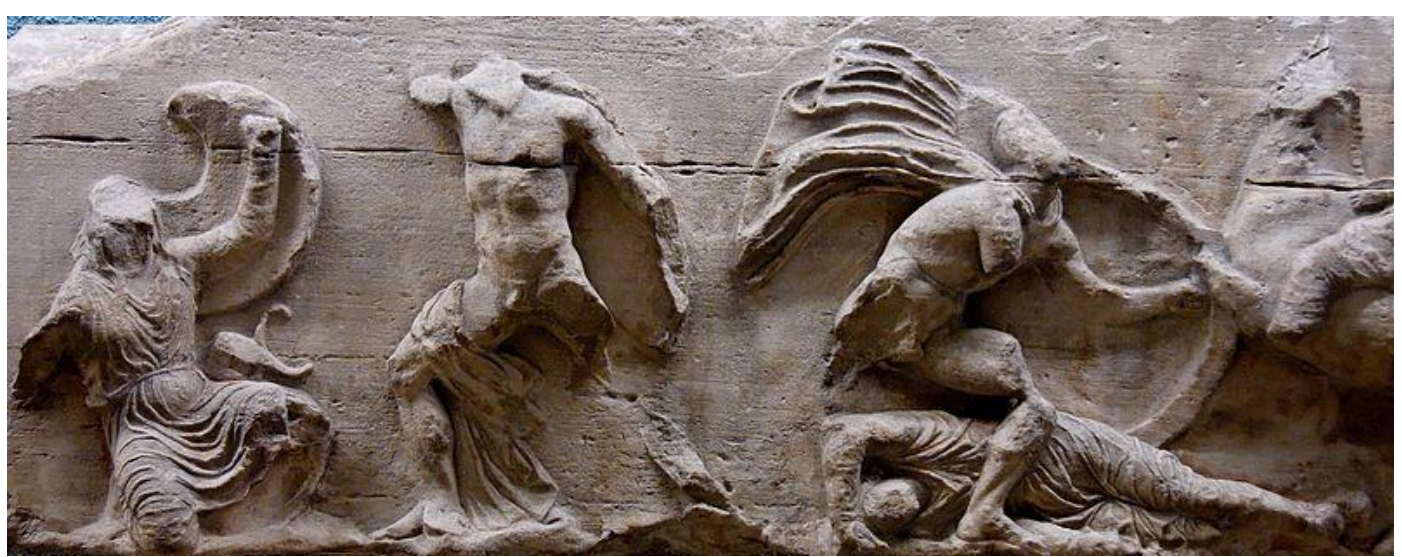

Figura 56. Fotografia do bloco do friso meridional do templo de Atena Nike exposto do British Museum, tirada por M. Nguyen em 2006 (Wikipedia Commons ${ }^{113}$ ).

Para além da acrópole ateniense, a Dedicação Atálida faz referências à acrópole de Pérgamo, em particular ao santuário de Athena Nikephoros (“Que Traz a Vitória”), construído por volta de 270 pelo fundador da dinastia, Filetairos (Hansen, 1971, p. 237). No final da década de 220 foram adicionados ao templo dois monumentos comemorativos de suas vitórias sobre os gálatas e sobre os selêucidas. Nada foi preservado além de duas bases, uma circular e outra retangular, o que limita grandemente as possibilidades de reconstituição segura da aparência dos monumentos

\footnotetext{
${ }^{113}$ Disponível em: http://commons.wikimedia.org/wiki/File:Acropólis_Athens_BM_424.jpg.
} 
(Stewart, 2004, pp. 191, 197). Particularmente importante, aqui, é a disposição das bases em relação ao templo e ao muro: a longa base retangular (c. de 19 metros) formava um ângulo com o templo de Atena ligeiramente mais aberto que o ângulo formado entre a Dedicação Atálida e o Pártenon, ambos formando um "conjunto teatral" (Stewart, 2004, p. 197) no santuário da divindade políade das duas cidades. Desse modo, o culto à Atena políade era o fundamento do paralelismo que era criado por meio tanto da disposição dos monumentos quanto pela presença temática dos gauleses nos dois locais.

Finalmente, pode-se sugerir um diálogo de Atenas com Pérgamo por meio de Egina. A escultura tardo-arcaica egineta exerceu forte influência sobre a escultura pergamena: a partir de 210, quando a ilha foi comprada por Átalo I, obras de arte eginetas foram dispostas na acrópole de Pérgamo formando o que S. Howard chamou de "a primeira grande coleção de arte do mundo clássico" (Howard, 1983, p. 483), o que provavelmente foi fundamental no desenvolvimento da nascente escola escultórica pergamena. Esta influência é notável na representação dos derrotados, tal como pode ser observado nos paralelos entre os guerreiros caídos dos frontões do templo de Afaia em Egina e alguns dos "pequenos bárbaros" (figs. 57-60).
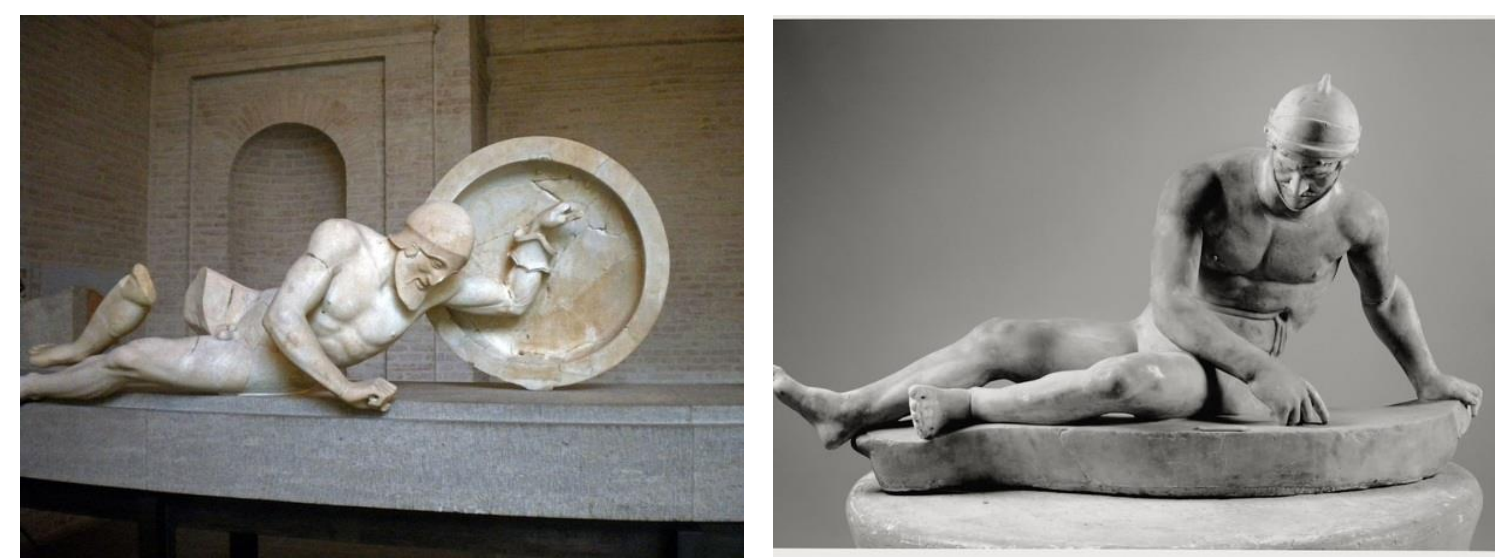

Figura 57. Fotografia da estátua plena do guerreiro moribundo do frontão oriental do templo de Afaia em Egina, tirada por Figura 58. Fotografia de estátua plena de "gaulês" (Museu Arqueológico Nacional de Nápoles ${ }^{115}$ ).

\footnotetext{
${ }_{114}^{114}$ Disponível em: http://commons.wikimedia.org/wiki/File:Aphaia_warrior_adjusted.jpg.

115 Disponível em: http://cir.campania.beniculturali.it/museoarcheologiconazionale/percorso/nelmuseo/P_RA8/RIT_RA325.
} 


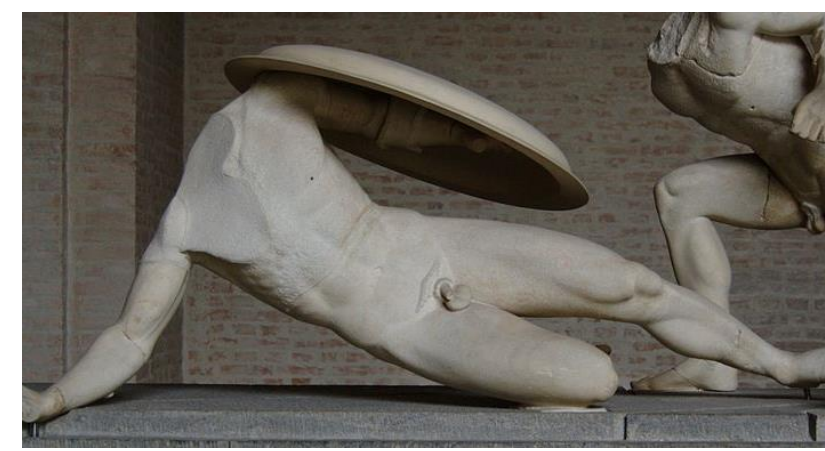

Figura 59. Fotografia de "guerreiro caído" do templo de Afaia em Egina, tirada em 2007 (Wikipedia Commons ${ }^{118}$ ).

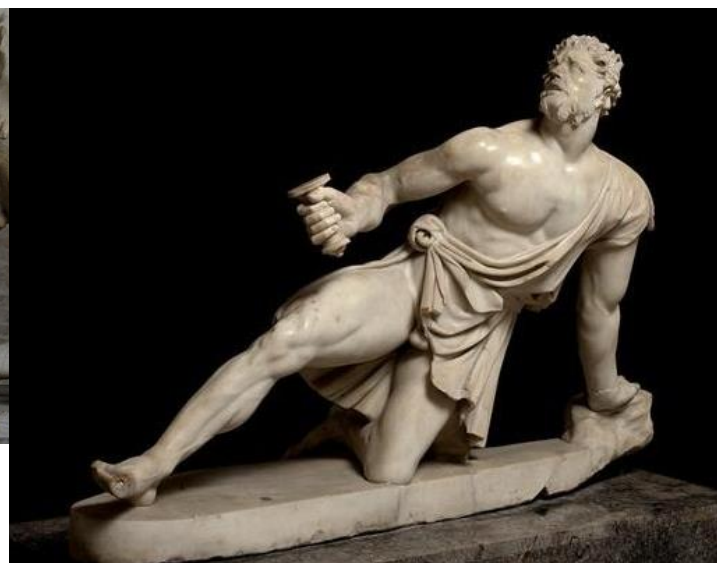

Figura 60. Fotografia da estátua plena de "gaulês" (Museu Arqueológico Nacional de Veneza ${ }^{119}$ ).

Os paralelos entre as cópias romanas da Dedicação Atálida e as estátuas tardoarcaicas e clássicas dos frontões do templo de Afaia em Egina podem ser interpretados como citações, dado o atestado conhecimento da escutura egineta pelos escultores de Pérgamo. Caso esta hipótese esteja correta, a Dedicação Atálida significou a introdução da escultura egineta na acrópole ateniense: uma irônica referência à enorme competitividade, tanto militar quanto artística, entre as duas cidades no início do século $\mathrm{V}$, considerando a convincente reconstituição da história do santuário de Afaia proposta em Watson (2011). Para o autor, a monumentalização dos santuários de Atena Políade em Atenas e de Afaia em Egina era paralela à competição militar e comercial das duas cidades, e um dos vetores desta competição seria o engajamento da guerra de Tróia na decoração arquitetural das respectivas acrópoles, especialmente após a batalha de Salamina em 480. Enquanto Egina celebrava a participação dos Eácidas nas duas guerras de Tróia (Télamon com Héracles na primeira, Aquiles e Ajáx na segunda) em cada um dos frontões do templo de Afaia, Atenas incorporava a (segunda) guerra de Tróia na grande narrativa que iniciava na gigantomaquia dos deuses olímpicos e terminava na amazonomaquia de Teseu, herói ateniense. A Dedicação Atálida, à sua maneira, promovia uma fusão entre as referências escultóricas eginetas com os padrões espaciais atenienses.

Assim, voltamos a Egina como ponto de ligação entre Atenas e Pérgamo. Tal mediação será retomada, a seguir, na discussão da Praça Sul. Antes, é preciso tratar do primeiro grande edifício atálida em Atenas: a Stoa de Eumenes.

\footnotetext{
118 Disponível em: http://commons.wikimedia.org/wiki/File:Aphaia_pediment_warrior_WXIII_Glyptothek_Munich_75.jpg.

${ }^{119}$ Disponível em: http://museoarcheologicovenezia.files.wordpress.com/2013/04/galata.jpg.
} 


\section{A Stoa de Eumenes}

O edifício identificado como o porticus Eumenicae mencionado por Vitrúvio (5.9.1) foi escavado em 1876-1877. Inicialmente, a longa stoa foi datada da época imperial, em função de sua ligação orgânica com o Odeion de Herodes Ático (fig. 61), do século II d.C.; entretanto, ainda no século XIX W. Dorpfeld sugere que o edifício se tratava do "pórtico de Eumenes" mencionado por Vitrúvio. Ao longo do século XX a questão continuou sendo debatida (Polacco, 1954), até que, em 1980, M. Korres fecha a questão comprovando que o mármore utilizado na stoa, assim como as técnicas empregadas, provinha de Pérgamo (Korres, 1984, 1988). A falta de um estudo exaustivo e mesmo de novas escavações impede uma datação mais precisa do que os limites do reinado de Eumenes II de Pégamo, entre 197 e 157.

A Stoa de Eumenes ${ }^{120}$ era um edifício retangular construído na encosta meridional da acrópole, o que foi possível graças a um corte de cerca de dez metros de profundidade na encosta, contra a qual foi construída um espesso muro de contenção de conglomerado, reforçado por contrafortes ligados por arcos semi-circulares construídos em calcário, semelhantes aos utilizados em Pérgamo. Diante da fachada da stoa, um amplo terraço se estendia cerca de 32 metros para o sul, limitado por um muro de contenção. O edifício tinha dois andares e media 163 metros de comprimento por 17,65 metros de largura (fig. 62).

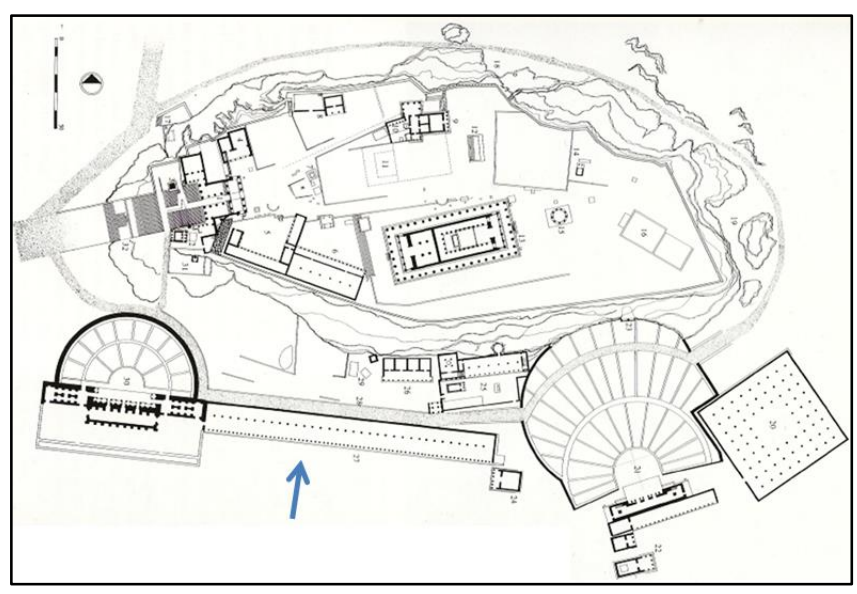

Figura 61. Proposta de reconstituição da planta da acrópole no período imperial (Hurwitt, 1999, p. 7), com indicação da Stoa de Eumenes.

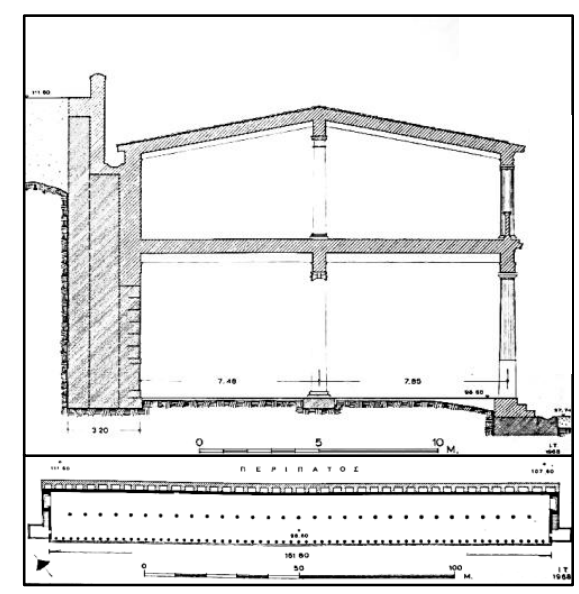

Figura 62. Propostas de elevação e de planta baixa da Stoa de Eumenes, elaboradas por J. Travlos em 1968 (Travlos, 1971, p. 525).

${ }^{120}$ A descrição do edifício baseia-se em Polacco (1954) e Mercuri (2004). 
Nas extremidades leste e oeste, escadarias comunicavam os dois andares; a escadaria oriental dava também acesso ao peripatos que circundava a acrópole. Internamente, apresentava um amplo saguão, dividido em dois corredores por uma colunata interna de 31 colunas; as fachadas contavam com 65 colunas. A disposição das ordens arquitetônicas seguia estritamente as stoas que bordeavam o santuário de Atena Nikephoros na acrópole de Pérgamo, e que será replicada na Stoa de Átalo II na ágora ateniense: o primeiro andar apresentava uma fachada dórica com a colunata interior jônica, enquanto o segundo andar tinha uma fachada com meias-colunas de base oval jônicas com a colunata interior com capitéis em palmetas. Não haviam salas divididas por paredes de pedra, o que não impede que os ambientes internos fossem divididos por estruturas provisórias. Quanto ao segundo andar, ainda que os vestígios sejam extremamente exíguos, é possível postular um parapeito entre as meias-colunas em função da semelhança da Stoa de Eumenes com a Stoa de Átalo II na ágora. Os materiais utilizados, além do conglomerado e do calcário para as fundações, arcadas e muros de sustentação, foram os mármores atenienses (azul do Himeto e branco do Pentélico), para determinados elementos arquitetônicos, e o mármore de Pérgamo, para a maior parte do edifício.

A Stoa de Eumenes, no século II, se articulava claramente a duas estruturas: o monumento corégico de Nícias e o teatro de Dioniso, ambos próximos à sua extremidade oriental. A partir do último, o caminhante poderia acessar os ambientes internos tanto por meio do peripatos ao norte, que se comunicava com a escadaria oriental, quanto pelo parodos do teatro, que levava à fachada da stoa: este duplo acesso é coerente com a função de abrigo para espectadores mencionada por Vitrúvio.

Já a articulação do monumento corégico com a stoa é relevadora de um importante aspecto da história do local. Construído em comemoração à vitória corégica de um certo Nícias em 320/19 (IG II2 3055), era um edifício em forma de templo dórico, construído sobre fundações de conglomerado, piso, muros e triglifos de calcário, e demais elementos de mármore pentélico. $\mathrm{O}$ monumento apresentava uma orientação diagonal em relação ao eixo leste-oeste, exatamente aquela que será usada na orientação da Stoa de Eumenes; além disso, se voltava para o oeste, para a área que seria no início do século II o terraço diante da fachada da stoa. Esta articulação, associada à lacuna de cerca de um século e meio (entre a dedicação do monumento e a construção da stoa), traz à tona o problema da possível inserção da Stoa de Eumenes dentro de um plano iniciado anteriormente, ainda no século IV. Mercuri (2004, pp. 67-72) desenvolve esta 
hipótese, argumentando que toda a região ao sul da acrópole teria sido objeto de um processo de publicização e sacralização, iniciado na época de Licurgo no século IV e continuado por Eumenes no século II. De fato, fundações de casas e poços foram encontradas abaixo do nível do terraço da stoa; a cerâmica associada leva a uma datação de uso entre os séculos IV e III; o padrão se repete nas áreas mais ao sul, o que indica que o fim da ocupação da área por habitações privadas antecedeu em quase um século a construção da stoa.

Diversos santuários receberam um grande investimento arquitetural no século IV: o teatro de Dioniso teve sua cavea coberta por placas de mármore pentélico, além de serem regularizadas por um novo muro de contenção; o Asklepieion é acrescido da stoa dórica, do templo e do altar, e possivelmente de todo o Períbolos ${ }^{121}$; um novo terraço é construído no nível do santuário das Ninfas, sobre o qual será construído o Odeion de Herodes Ático; e o pequeno santuário de Afrodite Pandemos, já próximo ao propileu, recebeu uma edícula. Deste modo, argumenta Mercuri, a intervenção helenística encontraria uma área já aplainada e liberada do espaço privado, mas que não tinha uma construção que ligasse os dois núcleos sagrados (teatro de Dioniso/Asklepieion a leste, e santuário de Afrodite/das Ninfas a oeste); a construção da Stoa de Eumenes, portanto, longe de significar uma intervenção externa violenta contra os moradores da região sul da acrópole, foi de fato a continuidade de um projeto estabelecido no final do século IV (Mercuri, 2004, p. 72).

Isto não significa, no entanto, uma continuidade simples: a topografia e arquitetura da stoa apontam também para a incorporação da região e do edifício dentro de projetos específicos da monarquia pergamena (Mercuri, 2004, pp. 74-76). A articulação da Stoa de Eumenes com o teatro de Dioniso em Atenas pode ser interpretada à luz do chamado "dionisismo atálida" (Musti, 1986), que se apropriava do culto a Dioniso associando-o ao culto dinástico: Dioniso Kathegemon, já associado à dinastia na época de Átalo I, passa a ser cultuado pela prestigiosa associação de atores dionisíacos da Jônia - responsável pelos festivais no teatro de Pérgamo; o culto terá o próprio Eumenes II como sacerdote logo após a vitória de Apaméia, em 188, prática

121 Não há consenso quanto à datação e mesmo identificação de todos os edifícios associados ao Asklepieion. Sabe-se que a stoa jônica e o templo de Têmis foram construídos no século V, e somente entre o século IV e III foi construído o santuário dominado pela stoa dórica de dois andares, o templo e o altar, mais ao leste. A fundação do santuário por Telêmaco em 420/19 pode ser associada à construção da stoa jônica, sendo transferido para o terraço leste por volta de 300. No entanto, nada garante que o santuário já era localizado no terraço leste, e que a stoa jônica não fizesse parte de outro santuário, como o de Têmis, de Afrodite, das Ninfas ou de Hipólito, localizados na encosta sul da acrópole. Ver a discussão em Aleshire (1989, pp. 21-36). 
reiterada nas décadas seguintes com outros membros família real ${ }^{122}$. Uma das manifestações materiais mais claras desta ligação é a reforma completa do teatro de Pérgamo, financiada pelo próprio Eumenes II (Hansen, 1971, pp. 276-277). Por outro lado, a proximidade da stoa com o Asklepieion ateniense também pode ser associada à monumentalização do Asklepieion extra-urbano pergameno, que receberá três stoas durante o reinado de Eumenes II (Coulton, 1976, p. 275; Mercuri, 2004, p. 75, . 91); o deus se tornaria objeto de dedicações como Asclépio Soter sob o reinado de Átalo III (Allen, 1983, p. 156-7). A Stoa de Eumenes, portanto, realiza um espelhamento das intervenções atálidas em Atenas e em Pérgamo, com um forte conteúdo de culto dinástico.

$\mathrm{Na}$ mesma direção, é preciso destacar o paralelismo entre a arquitetura da stoa e aquela empregada largamente em Pérgamo na época de Eumenes II (Korres, 1988). Não apenas do ponto de vista do sistema de contenção dos terraços - por meio de contrafortes e arcadas - com também da reprodução da arquitetura do santuário de Atena Nikephoros em Pérgamo, sem paralelos atenienses até então, na base do próprio santuário de Atena Polias em Atenas, o que será reproduzido na ágora, décadas depois, com a construção da Stoa de Átalo II. Esta articulação Atenas/Pérgamo via o culto de Atena também está presente na relação entre a stoa e a Dedicação Atálida junto ao muro sul do topo da acrópole: a partir do sul, o espectador veria a Dedicação Atálida (justamente a galatomaquia) e o Pártenon (na quina entre as métopas da amazonomaquia e da centauromaquia) em uma imagem que teria a stoa como seu limite inferior; a horizontalidade da Stoa de Eumenes dialogava com a horizontalidade do topo do muro da acrópole, intensificando a regularidade na sucessão de terraços que tornava a encosta sul da acrópole de Atenas paralela à articulação dos terraços da acrópole de Pérgamo. Dessa forma, seria a realização em Atenas do do "urbanismo cenográfico" (Hellmann, 2010, p. 211), que teria em Pérgamo sua maior expressão.

Quanto aos usos da stoa, um primeiro é indicado por Vitrúvio (5.9.1), que diz que stoas, tais como a de Eumenes em Atenas e de Pompeu em Roma, devem ser construídas atrás dos edifícios de cena (post scaenam), para que as pessoas tenham onde

\footnotetext{
${ }^{122} \mathrm{O}$ culto de Dioniso Kathegemon em Pérgamo provavelmente era realizado junto ao pequeno templo jônico no terraço acima do plano da orchestra do teatro de Pérgamo, ainda que não haja inscrições que comprovem a atribuição. Sobre o culto de Dioníso Kathegemon e sua relação com a dinastia, Michels (2011). Contra a identificação do templo como de Dioniso, cf. Romano (1982), que argumenta que o terraço do teatro era o dromos de um estádio (de fato, a skene, de madeira, poderia ser removida, como indicam as cavidades ao longo do terraço), e atribui o templo jônico ao culto de Atena Nikephoros, instituído após a vitória sobre Prusias da Bitínia em 182.
} 
se abrigar quando "tempestadades repentinamente interroperem os espetáculos" (cum imbres repentini ludos interpellaverint, habeat populus, quo se recipiat ex theatro). A Stoa de Eumenes não está posicionada atrás do edifício de cena, o que gerou uma série de dificuldades topográficas antes dos trabalhos de Korres. A esta questão, pode-se argumentar, como faz L. Mercuri (2004), que Vitrúvio se refere às intervenções helenísticas no teatro de Dioniso como um todo, aí incluídas as pequenas alterações no edifício de skene, a stoa atrás do edifício de skene e a Stoa de Eumenes; com a ampliação da cavea, a Stoa de Eumenes serviria para abrigar o número de espectadores que excederia a capacidade da stoa post scaenan.

A escassez de fontes relativas à stoa limita as hipóteses para outros usos. Um meio de superar esta escassez é o estabelecimento de correlatos da Stoa de Eumenes com outros edifícios semelhantes, e particularmente com a Stoa de Átalo II na ágora. Assim, considerando as similitudes arquiteturais entre as duas stoas, pode-se sugerir a existência de um pilar no centro de sua fachada, que serviria de base para um monumento equestre do doador; além disso, a existência de uma inscrição com o nome do doador na arquitrave da Stoa de Átalo II poderia indicar o mesmo na Stoa de Eumenes. Caso estas sugestões estejam corretas, pode-se postular o uso da Stoa de Eumenes como suporte da propaganda dinástica atálida, o que seria coerente com o nome do edifício preservado no relato de Vitrúvio. Demais usos, como, por exemplo, espaço de exposição de obras de arte e inscrições honoríficas, atestados para a Stoa de Átalo II, apesar de plausíveis, não possuem qualquer fundamento documental para a Stoa de Eumenes.

Em síntese: se por um lado a Stoa de Eumenes completava um projeto de monumentalização anterior, iniciado no século IV no contexto da restauração democrática licurgueana, por outro ela impunha sobre Atenas uma lógica arquitetônica profundamente ligada aos projetos atálidas de identificação e paralelismo entre Pérgamo e Atenas, reforçando e ampliando a presença atálida na acrópole ateniense, agora na direção da encosta sul. A mediação religiosa, presente na Dedicação Atálida (narrativas antibárbaras), também aparece no caso da Stoa de Eumenes por suas ligações com o culto a Dioniso em Pérgamo e em Atenas. A relação entre a Stoa de Eumenes e a Dedicação Atálida vai além dos semelhantes procedimentos de implantação: a stoa, colocada no sopé da muralha sul, de certo modo enquadra os edifícios da encosta sul, completando a moldura superior feita pelos perfis da Dedicação Atálida visíveis de baixo. Desse modo, surge mais uma semelhança com a acrópole de Pérgamo: nesta, a 
fachada ocidental, onde está situado o teatro, também era emoldurada por uma stoa associada ao teatro e pelo santuário de Atena no topo, onde estavam os grupos escultóricos dedicados por Eumenes II (figs. 63-64).

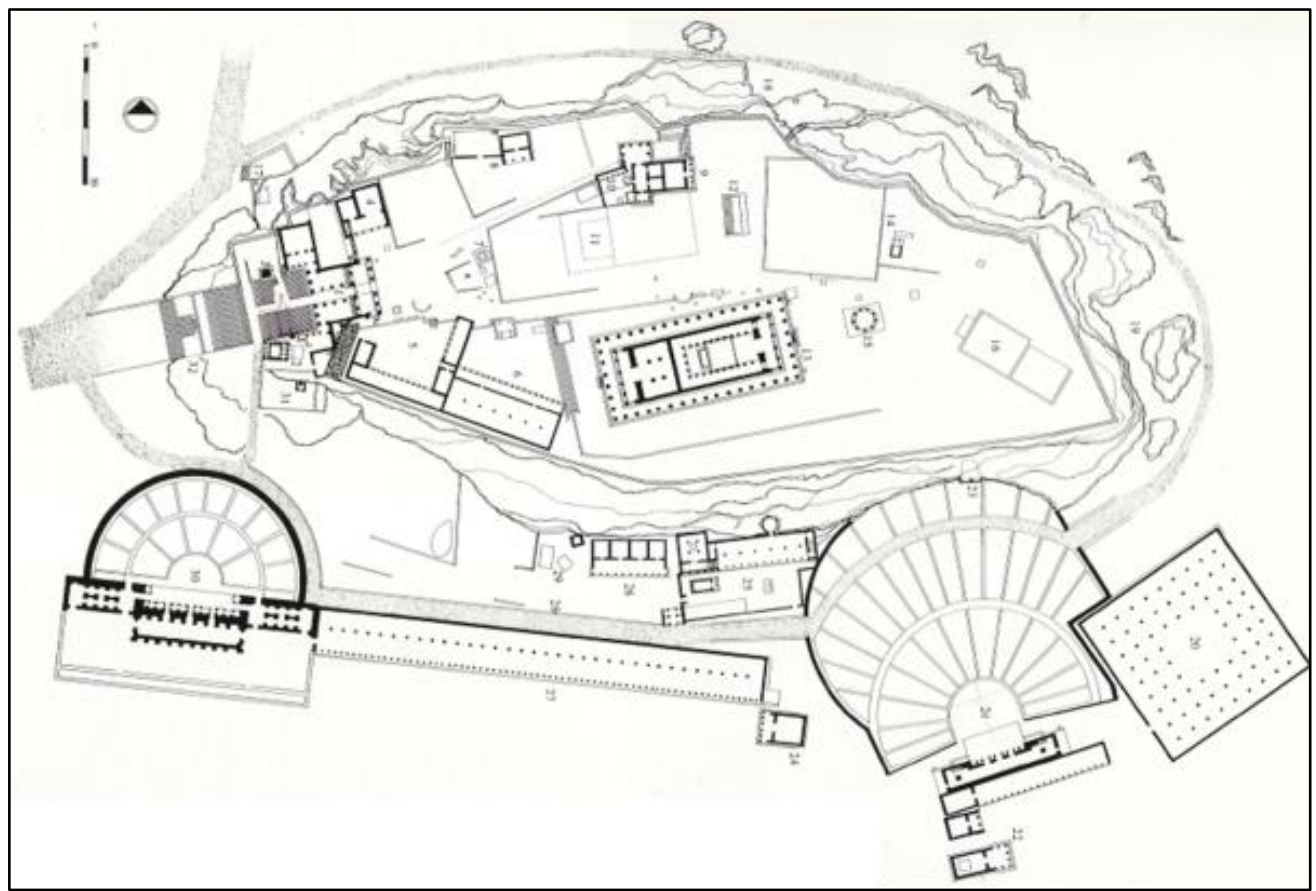

Figura 63. Proposta de reconstituição da planta da acrópole no período imperial (Hurwitt, 1999, p. 7).

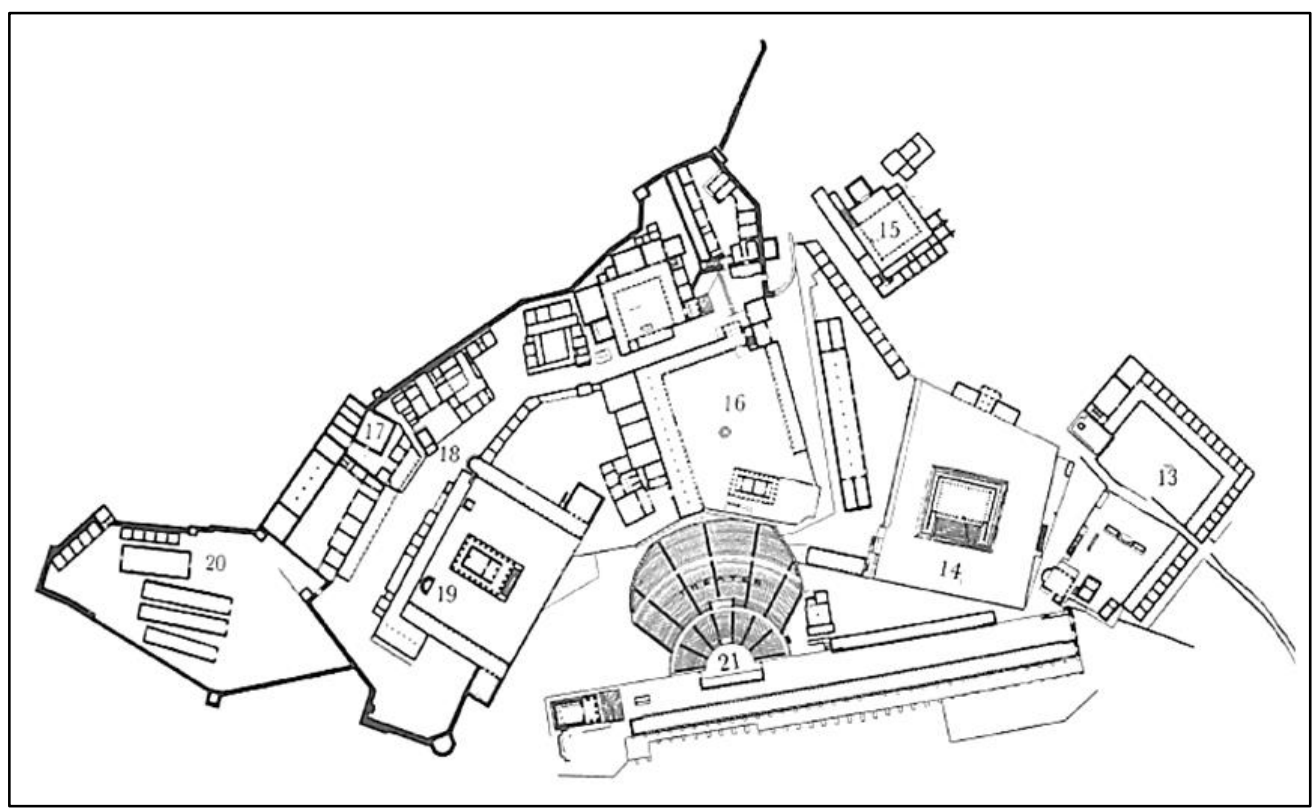

Figura 64. Detalhe de proposta de reconstituição da planta da acrópole de Pérgamo, de acordo com E. Hansen (1971, p. 248). O número 16 corresponde ao santuário de Atena. 


\section{Os pilares "atálidas"}

A encosta sul não seria o único local da acrópole com intervenções associadas a Eumenes: o topo receberia ainda novas intervenções escultóricas no século II. Tratam-se de dois pilares que sustentavam quadrigas de bronze, e mais dois colossos que figuravam Eumenes II e seu irmão e sucessor, Átalo II.
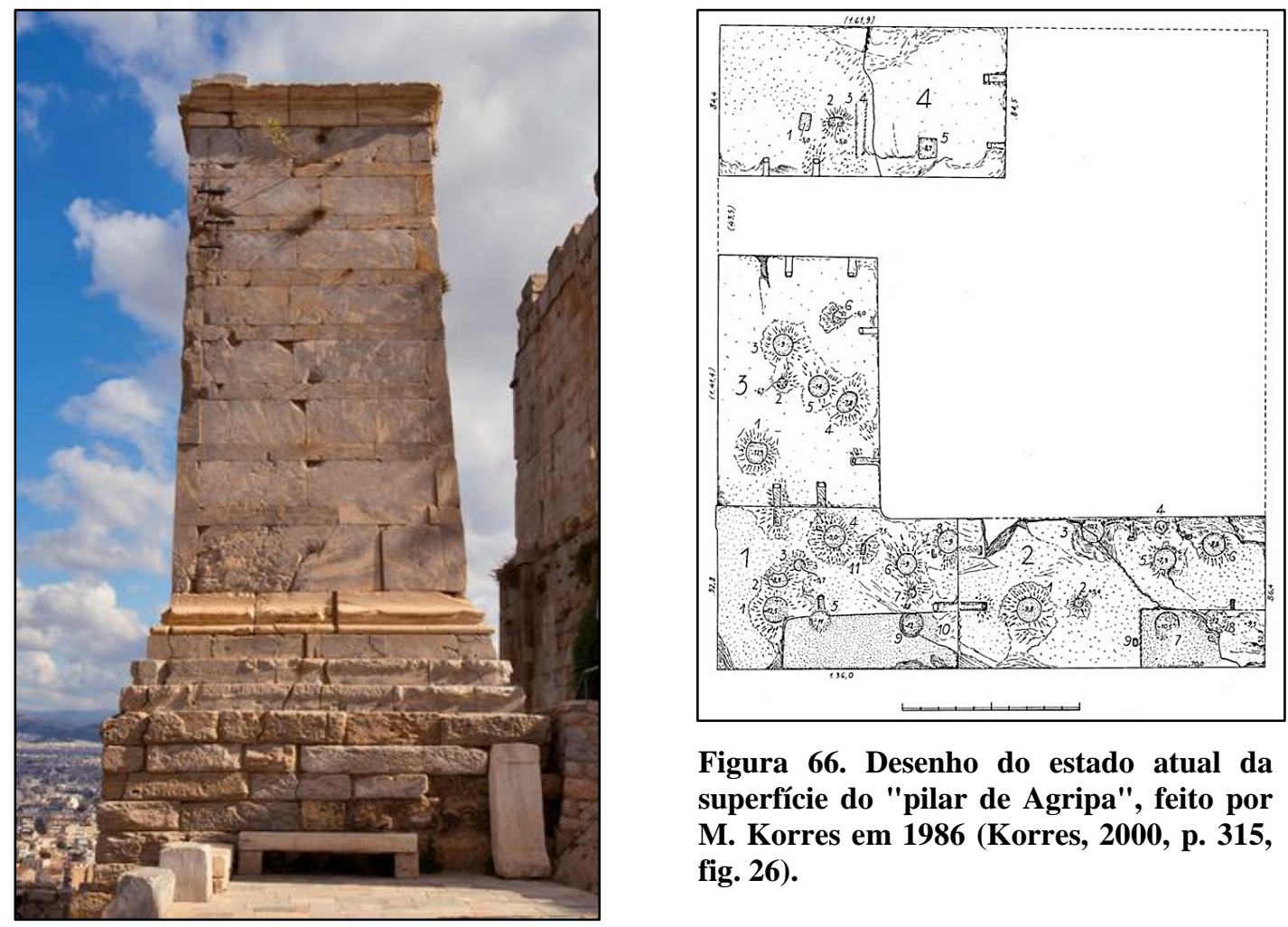

Figura 66. Desenho do estado atual da superfície do "pilar de Agripa", feito por M. Korres em 1986 (Korres, 2000, p. 315, fig. 26).

Figura 65. Fotografia do pilar de Agripa, tirada por Curtis Perry em 2013 (Flickr ${ }^{123}$ ).

Das quatro intervenções, apenas um dos pilares, situado sobre o terraço ao norte da via de acesso à acrópole (diante da "pinacoteca" do propileu), é conhecido com detalhe: trata-se de um pilar composto por blocos de mármore azul do Himeto (corpo principal) e branco do Pentélico (moldura inferior e superior), com fundações em poros, e atingindo uma altura de cerca de 9 metros (fig. 65). Marcas na superfície superior dos blocos preservados (fig. 66) são coerentes com a reconstrução de um monumento equestre de bronze composto por uma quadriga e seus condutores. Este pilar é conhecido como "pilar de Agripa" ou "quadriga de Agripa", em função da inscrição

\footnotetext{
${ }^{123}$ Disponível em: https://www.flickr.com/photos/curtisperry/13991458055/.
} 
dedicatória encontrada em uma de suas faces que apontava M. Agripa, genro de Augusto, como o destinatário da homenagem (IG $\mathrm{II}^{2}$ 4122). No entanto, como demonstrado por W. Dinsmoor (1920), a dedicação a Agripa estava inscrita sobre uma dedicação mais antiga que foi apagada. $O$ fato das técnicas construtivas e da ornamentação dos perfis serem datáveis da época tardo-helenística fez com que Dinsmoor sugerisse que a inscrição originária dedicava o monumento aos reis atálidas, e a Eumenes II em particular.

Tal hipótese se baseia principalmente na atestação de vitórias de Eumenes II e seus irmãos Átalo (II), Filetairos e Ateneu nas competições equestres da Grande Panatenéia de 178/7 (Shear, 2001, p. 1223), mas Eumenes I e Átalo (II) também são vitoriosos na Grande Panatenéia de 170/69. De qualquer modo, o fato de os quatro irmãos terem vencido competições no mesmo ano aponta para a dedicação da quadriga em 178/7, incorporando figuras dos quatro no mesmo monumento.

Outro pilar, não tão bem conservado, é aquele situado junto à quina nordeste do Pártenon (figs. 67-68), estudado em detalhe por Manolis Korres (2000, pp. 320-325). Suas similaridades com o pilar diante do propileu (técnica, ornamentação e rededicação na época imperial) apontam para uma datação semelhante; uma hipótese plausível seria sua dedicação em comemoração à vitória dos reis atálidas na Grande Panatenéia de 170/69.

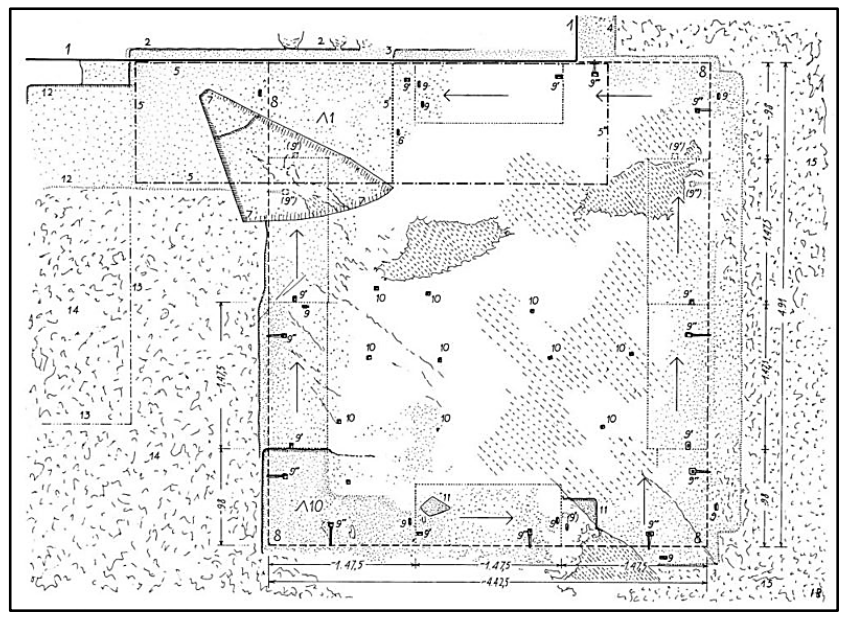

Figura 67. Desenho do estado atual do pilar ao nordeste do Pártenon, feito por M. Korres em 2000 (Korres, 2000, p. 321, fig. 30).

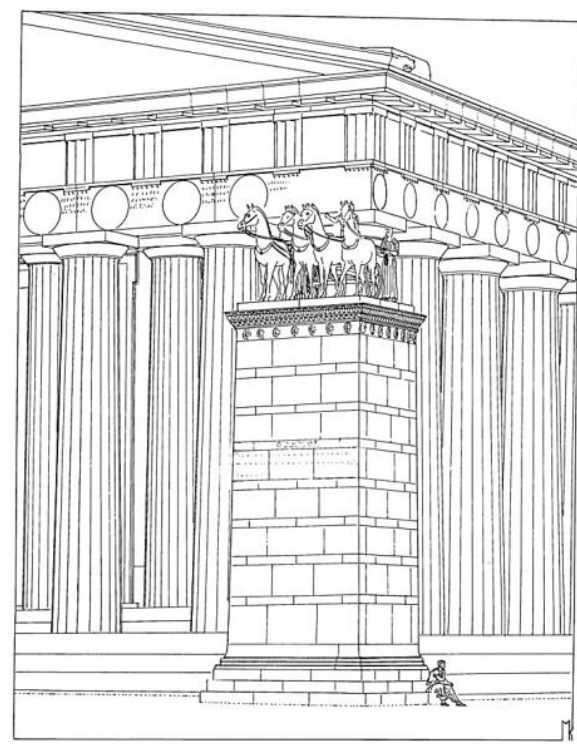

Figura 68. Proposta de reconstituição do "pilar atálida" junto ao nordeste do Pártenon, feito por M. Korres em 2000 (Korres, 2000, p. 323, fig. 31). 
Não há indícios claros para a iniciativa da dedicação dos dois monumentos, mas é plausível que tenha sido feita pelo demos, mesmo que contando com apoio financeiro dos próprios homenageados. A dedicação de quadrigas era prática já atestada em centros panhelênicos, em particular em Delfos (Korres, 2000). Um pilar semelhante aos da acrópole ateniense foi encontrado em Delfos, diante da Stoa de Átalo II I (Stewart, 2004, p. 211), datando do início do século II; tal intervenção, paralela aos monumentos atenienses, denotam a percepção da acrópole de Atenas como equivalente ao santuário de Delfos, utilizado como espaço de exposição para a monarquia atálida. No caso ateniense, a ligação do motivo figurativo do monumento - a quadriga - com uma das mais prestigiosas competições do principal festival da cidade é coerente com o efeito propagandístico: as competições equestres abertas a estrangeiros foram, entre as décadas de 180 e 140, espaços para a competição entre reis helenísticos, em particular de Pérgamo, do Egito e da Síria (Shear, 2001, p. 1223). Posicionados na entrada da acrópole e junto à quina nordeste do Pártenon, os dois pilares abriam e fechavam o percurso da procissão panatenaica sobre a acrópole, reforçando, pelo diálogo com o templo de Atena Nike (Nike/Atenas, Nikephoros/Pérgamo) num caso, e com a Dedicação Atálida e o Pártenon noutro, o paralelismo entre a acrópole de Pérgamo e a acrópole ateniense.

\section{A reforma do Erechtheion}

Antes de deixarmos a acrópole, é preciso apresentar, ainda que brevemente, a questão da reforma do Erechtheion, tradicionalmente datado do início do período augustano, mas que apresenta fortes indícios para uma datação mais alta.

Construído no final do século $\mathrm{V}$, o edifício apresentava uma estrutura bastante peculiar: um corpo central semelhante a um templo hexastilo, internamente dividido em três ambientes que se adaptam à irregularidade do terreno (mais profundo no lado oeste), com um pequeno pórtico com “cariátides" junto ao limite sudoeste, no nível mais alto do terreno, e um grande pórtico jônico junto ao limite noroeste, no nível mais baixo; diante da fachada ocidente, no mesmo nível do pórtico noroeste, se estendia um recinto murado a céu aberto. Sua planta peculiar é comumente interpretada como uma solução para a diversidade de cultos ali abrigados, todos eles intimamente ligados aos 
mitos de fundação da cidade: Atena Polias, Zeus, Poseidon-Erechtheus, Butes e Hefesto estavam entre os personagens cultuados (Lesk, 2004, pp. 129-164).

As ruínas do Erechtheion revelam, ao menos, duas reformas: a primeira é indicada por suportes nos blocos superiores das paredes para hastes de madeira, que sugerem a existência de um telhado temporário na parte ocidental; a segunda é indicada pela incoerência técnica e estilística entre alguns elementos arquitetônicos e o edifício como um todo, que foram interpretadas como evidências de um amplo projeto de restauração realizado em um período relativamente longo após a construção do edifício no século V. Estes elementos foram associados a dois eventos do século I: o saque de Atenas por Sula e a eventual destruição de edifícios na acrópole, durante a última fase do cerco a Aristion e seus seguidores, em 86, e a construção do monóptero de Roma e Augusto, em cujas fundações foi utilizada uma cornija da construção original do Erechtheion. A proposta então situava a necessidade de um telhado provisório logo após 86, que daria lugar a uma reforma completa somente na época de Augusto, quando construtores romanos trabalhariam tanto no Erechtheion quanto no monóptero de Roma e Augusto (Burden, 1999, pp. 32-62; cf. abaixo).

Esta tese foi amplamente aceita nos estudos que se dedicaram ao monóptero, mas um exame mais detido apresenta ao menos duas dificuldades, como bem apontou A. Lesk em estudo recente (2004, pp. 202-207). A primeira delas é de ordem estilística: a decoração floral (anthemion) da porta da fachada noroeste do Erechtheion (fig. 69), apesar de ter sido copiada em linhas gerais nas colunas do monóptero de época augustana, não tem semelhança com qualquer decoração datada do século I fora de Atenas; pelo contrário, A. Lesk demonstrou que a decoração somente encontra paralelos no século II, e particularmente na arquitetura pergamena (Lesk, 2004, p. 206). A segunda, de ordem narrativa, que busca um "evento histórico" como referência para a destruição: as fontes textuais sobre o cerco de Sula, como será discutido no capítulo seguinte, não fazem menção direta a batalhas no topo da acrópole ou a destruições de seus edifícios e monumentos. 


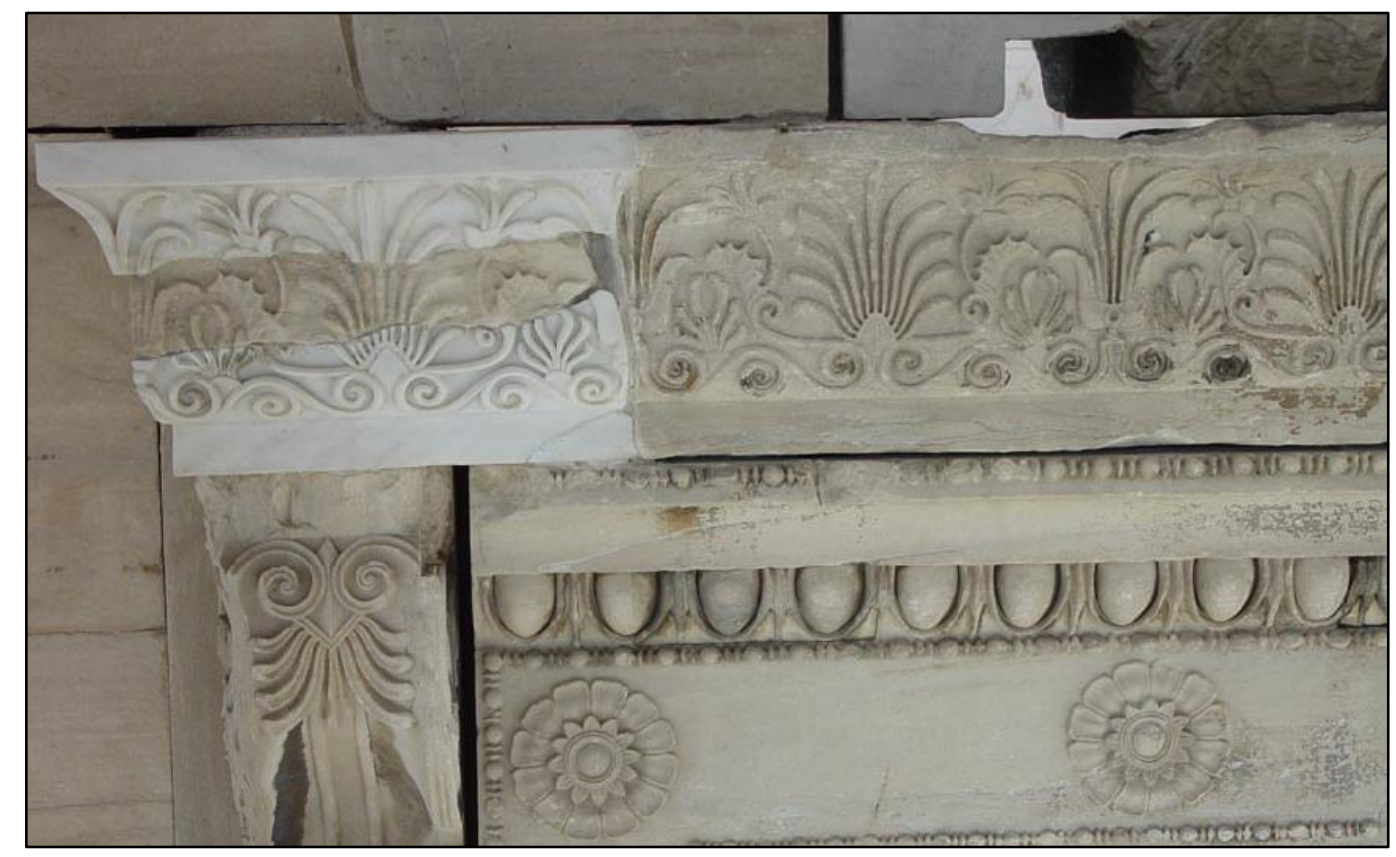

Figura 69. Fotografia do lintel da porta norte do Erechteion, com bloco de reforma helenística ou romana à direita e restauração moderna à esquerda (Lesk, 2004, p. 1208, fig. 353).

Contra a datação pós-86, Lesk sugere que a destruição ocorreu na turbulenta primeira metade do século III, quando em diversos momentos Atenas esteve em conflito aberto contra a Macedônia, após o que teria sido colocado o telhado provisório na área mais danificada; a restauração só teria lugar em meados do século II, quando (1) a atividade construtiva associada aos atálidas é intensa em toda a cidade, (2) inscrições mencionam reparos ao "templo de Atena", e (3) há um renovado interesse nos cultos ligados ao Erechtheion, vinculado ao crescente prestígio do clã dos Eteobutadai. Ao argumento de que a técnica de fixação dos blocos com grampos em “pi” (П) era de matriz romana, Lesk demonstra que tal técnica já era utilizada em Atenas desde o século IV, como é documentado na ampliação do Monumento dos Heróis Epônimos, e também nas intervenções associadas a Pérgamo no século II ${ }^{124}$.

A proposta de Lesk é atraente, mas não está isenta de problemas: considere-se, por exemplo, que não há qualquer referência para destruições na acrópole no século III ou II; em contrapartida, ainda que não haja referência direta para destruições na acrópole em 86, o cerco final a Aristion torna plausível a utilização de máquinas de guerra que causariam eventuais incêndios no topo, para além da bem documentada

${ }^{124}$ Como na stoa de Átalo II, na Stoa de Eumenes, no pilar do monumento em frente à stoa de Átalo, na Stoa Média (Lesk, 2004, pp. 174, n. 35 e 209), além da própria Dedicação Atálida (Korres, 2004, p. 243, fig. 265). Em Roma, a utilização de grampos em pi mais antiga é documentada a partir, somente, do final do século II (Lancaster e Ulrich, 2013, pp. 164-165). 
destruição do Odeion e do Asklepieion. Mas, de todo modo, as semelhanças estilísticas entre o lintel da porta noroeste do Erechtheion e a decoração arquitetural pergamena, associada à menção epigráfica a trabalhos de restauro no Erechtheion, ambos datados de meados do século II, apontam fortemente para uma datação helenística da restauração do Erechtheion, e, como é sugerido pelas semelhanças estilísticas, para a participação de Pérgamo no projeto. A ausência de indícios mais claros desta restauração, no entanto, impedem a sugestão de hipóteses mais sólidas.

\section{A ágora tardo-helenística}

As intervenções tardo-helenísticas na ágora concentraram a atenção dos estudiosos que se debruçaram sobre a produção do espaço urbano ateniense no período. Não à toa: construções de novos e imponentes edifícios, acompanhadas por um complexo sistemas de terraceamento do declive natural da ágora, alterarão a lógica estabelecida ainda nos primeiros tempos da ocupação do local por edifícios públicos, entre o século VI e V. As intervenções se estendem da década de 180 (com a construção da Stoa Média e o desmantelamento do Peristilo Quadrado) à década de 140 (com a reestruturação do Metroon), quando a atividade construtiva entrará em um longo período de estagnação, para ser retomada, de modo sistemático, somente após 31. Comecemos, pois, com a maior e mais enigmática intervenção: a construção da chamada Praça Sul e as demolições associadas.

\section{A praça Sul, as demolições e o Ptolemaion}

As escavações da área foram iniciadas em 1935, mas apenas em 1953 todo o conjunto foi escavado e seu traçado estabelecido, com pequenas correções derivadas das escavações na década de 1960 (Travlos, 1971, pp. 233-234). Alguns vestígios, tais como tambores de colunas e outros elementos arquiteturais de calcário, mármore e terracota, permitiram aos arqueólogos a proposição da restauração de boa parte da superestrutura do conjunto (figs; 70-71). 


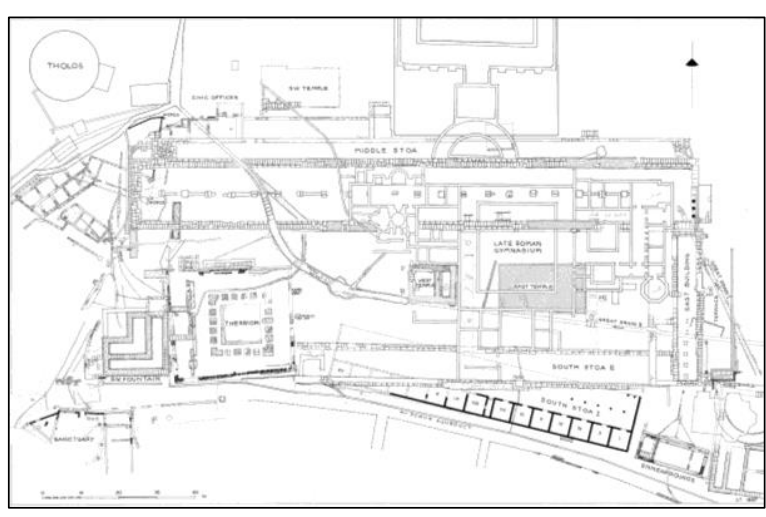

Figura 70. Planta do estado atual da "Praça Sul”, por J. Travlos em 1967 (ASCSA $\left.{ }^{127}\right)$.

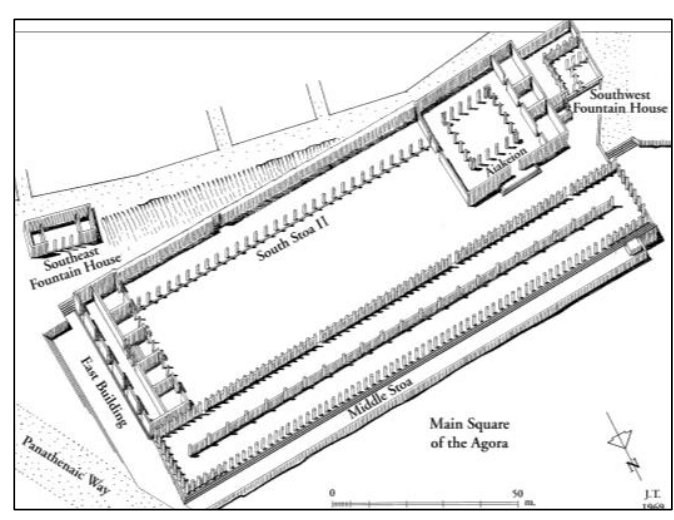

Figura 71. Proposta de reconstituição da elevação parcial da "Praça Sul", por J. Travlos em 1969 (ASCSA $\left.{ }^{128}\right)$.

A Praça Sul foi construída na primeira metade do século II a.C., incorporando edifícios anteriores em um novo conjunto. O edifício mais antigo é o chamado Períbolo Retangular, hoje identificado como santuário de Éaco ${ }^{129}$, mítico rei de Egina, construído em fins do século VI a.C.: tratava-se de uma área de 26,50 por 31 metros, rodeada por um muro de calcário importado de Egina, com duas entradas, a principal no meio do muro norte, acima de uma pequena escadaria de cinco degraus, e uma menor no muro leste. No século IV a.C., três salas foram adicionadas junto ao muro oeste; na área aberta restante no início do século II a.C. foi criado um pátio peristilo quadrado de 13 metros de lado, rodeado por quatro corredores cobertos com cerca de 5 metros de largura.

Contígua ao muro oeste do Períbolo Retangular estava a Fonte Sudoeste, construída no final do século IV a.C., consistindo em uma estrutura em formato de "L", dentro de um quadrado de cerca de 16 metros de lado, murado inteiramente nos lados sul e leste e apenas em um quarto nos lados norte e oeste. Uma fileira de colunas internas dividia o edifício em duas partes: uma bacia interna, abastecida por um canal subterrâneo vindo do leste, e um pórtico, que se abria para o noroeste. No início do século II, a fonte sofreu uma modificação no lado noroeste, que consistiu na adição de um muro no canto noroeste (fechando assim a área quadrangular) e de um anexo ao norte do canto nordeste, de onde se poderia buscar coletar a água de um duto independente da bacia central (Camp, 2010, p. 174).

\footnotetext{
${ }^{127}$ Disponível em: http://agora.ascsa.net/id/agora/image/2002.01.1522.

${ }^{128}$ Disponível em: http://agora.ascsa.net/id/agora/image/2008.20.0049.

129 Análise dos vestígios realizada por Camp (1996), e proposta de identificação em Stroud (1998, pp. 85108).
} 
A primeira construção do que seria, a partir do início do século II, a Praça Sul ${ }^{130}$, é também o maior edifício da ágora: a chamada Stoa Média. Estendia-se de oeste a leste com 147 metros de comprimento e 17 metros de largura, sendo rodeada nos quatro lados por 160 colunas (9 nos lados menores, 142 nos lados maiores), e dividida internamente em dois corredores por uma fileira longitudinal de 23 colunas. Tanto nas colunas internas quanto nas externas existem indícios da existência de parapeitos, separando os corredores internos e fechando total ou parcialmente o edifício. A partir da evidência de alças estampadas de ânforas da Ásia Menor e algumas moedas, V. Grace (1985) estabeleceu a data do fim do preenchimento do terraço da stoa no ano de 184/3. O material utilizado na construção foi o calcário de Egina, exceto para as métopas e gotas (mármore) e a calha (terracota); fragmentos preservados desta última revelam uma decoração com motivos florais alternados com bicas em forma de cabeça de leão, além de antefixos em forma de palmeta no topo e pinturas com motivos geométricos na base. A Stoa Média estava assentada sobre um terraço artificial de 5 metros de altura; o acesso a partir da ágora se dava, possivelmente, por uma escadaria em seu limite noroeste, mas é mais provável que o acesso estivesse limitado à entrada pelo segundo edifício construído do novo conjunto: o chamado Edifício Leste.

Este curioso edifício se estendia de norte a sul com 40 metros de comprimento e 12 metros de largura, dividido por um muro (com uma pequena abertura colunada no centro) em dois ambientes: um a leste, com aberturas para a escadaria que vinha da Via Panatenaica, e dentro do qual foram encontradas quatro bases de pedra de uma série de presumivelmente doze; e outro a oeste, este dividido em cinco compartimentos (duas salas na extremidade e uma escadaria no centro) que se abriam para a área central aberta da Praça Sul.

O último edifício a ser construído no complexo é a chamada Stoa Sul II, construída algum tempo após o início da construção do Edifício Leste. Paralela à Stoa Média, tinha 93 metros de comprimento e 10 metros de largura, com muros nos lados leste, sul e oeste e uma fachada com 30 colunas dóricas abrindo-se ao norte para a área central; entre as colunas, há indícios de que havia uma parapeito semelhante ao da Stoa Média. A Stoa Sul II seguia o eixo leste-oeste ligando o compartimento mais ao sul do Edifício Leste ao muro leste do Períbolo Retangular. Para sua construção, foi realizada a demolição de uma stoa anterior, datada do fim do século V a.C.: a Stoa Sul I, que

\footnotetext{
${ }^{130}$ A descrição que segue se baseia na síntese dos relatórios em Thompson e Wycherley (1972, pp. 65-
} $71)$. 
apresentava uma orientação sudeste-noroeste, menos comprida e mais larga que sua sucessora; ligado a essa substituição, foi realizado um corte na rocha em sua extremidade oeste e uma redução do terraço em cerca de 2 metros. Na parte oriental do muro sul da nova stoa foi feito um nicho para abrigar uma fonte, possivelmente associada a um lençol revelado pelo corte na rocha. Entre os materiais utilizados na construção do Edifício Leste e da Stoa Sul II figuravam elementos arquitetônicos do edifício conhecido como Peristilo Quadrado, localizado na ponta nordeste da ágora, construído por volta de 300, e dedicado provavelmente a atividades judiciais.

No centro da área aberta da Praça Sul foram encontradas fundações de dois edifícios, contemporâneos à contrução do conjunto, mas cujo estado de conservação mal permite a determinação de seu traçado; um deles foi identificado como um templo, mas não há evidências seguras para tanto (Thompson, 1968, 41-43).

Finalmente, também na primeira metade do século II ocorrem duas intervenções no lado sudoeste da ágora, certamente derivadas da construção da Praça Sul: um muro é construído entre a Fonte Sudoeste e a Stoa Média, fechando assim o único lado da Praça Sul não inteiramente ocupado por edifícios; e uma estrutura quadrada, com $6,6 \mathrm{~m}^{2}$, é construída junto à quina noroeste da stoa Media, sendo interpretada por H. Thompson como base de um pilar (Thompson, 1952, p. 88).

Tendo a datação da construção do conjunto entre as décadas de 180 e 140 obtido o consenso da maioria dos especialistas, permanece ainda a questão da atribuição da iniciativa, da identificação e do uso da Praça Sul. Desde a descoberta do primeiro edifício do conjunto, a Stoa Média (então denominada "stoa Sul”), em 1935, a questão da identificação e da atribuição da Praça Sul converteu-se num dos mais interessantes enigmas da topografia ateniense. Com o progresso das escavações e a maior consciência das dimensões e da localização do conjunto, considerou-se improvável que a "Praça Sul" não fosse mencionada nas fontes textuais. Pausânias seria o principal candidato para uma menção ao conjunto: assim nasce a hipótese do Ptolemaion.

Pausânias, após realizar digressões a partir das pinturas na Stoa Pintada, passa a descrever uma "ágora" (1.17.1) onde havia altares de abstrações personificados (a Misericórdia, o Rumor); em seguida (1.17.2), escreve:

“no ginásio não distante da ágora, chamado [ginásio] de Ptolomeu a partir do doador, existem hermas de pedra dignas de serem vistas e uma estátua de bronze de Ptolomeu; aqui há também [imagens] do líbio Juba e de Crísipo de 
Soli. Próximo do ginásio está o santuário de Teseu, onde estão pinturas dos atenienses combatendo as amazonas [...]".

Esta "ágora" mencionada por Pausânias foi primeiramente equacionada com a “ágora clássica”, por oposição à Ágora Romana, localizada mais ao leste. A partir disso, o célebre arqueólogo alemão W. Dorpfeld, incorporando os resultados das primeiras esvações americanas, sugeriu que a grande construção retangular encontrada no centro da ágora era o santuário de Teseu, a "Stoa Média" seria a Stoa Pintada, enquanto que a Praça Sul era simplesmente o ginásio de Ptolomeu mencionado por Pausânias. Esta tese foi publicada por Dorpfeld em livro de 1937, mas seria derrubada por H. Thompson (1950) - que se consolidaria, junto de J. Travlos, como o principal estudioso da topografia ateniense -, que identificou a grande construção retangular como o Odeion mencionado por Pausânias ou Agrippeion mencionado por Filóstrato. Sem o Theseion na ágora, dificilmente a Praça Sul poderia ser o ginásio de Ptolomeu.

Com a escavação do conjunto quase completa em 1951, H. Thompson (1952) elabora uma nova hipótese: a praça Sul era uma nova ágora de Atenas, formada por um "passeio corberto" (a Stoa Média) e um centro comercial (a Stoa Sul II). Dadas as dimensões do conjunto, Thompson sugeriu que se tratava de uma doação de um rei helenístico, mas descartou que se tratasse de um atálidas, em função do fato de que a Stoa de Eumenes ao sul da acrópole e a de Átalo na ágora, construídas respectivamente no início e na metade do século II a.C., apresentavam um refinamento técnico e uma suntuosidade nos materiais sem paralelo na praça Sul. Sobravam como candidatos: Antíoco IV da Síria e Ariarathes V da Capadócia. Considerando a proximidade deste último com Átalo II de Pérgamo, Thompson sugeriu que a construção da Praça Sul e da Stoa de Átalo II se tratava de uma “amigável rivalidade" entre os monarcas pergameno e capadócio.

Com a escavação detalhada no Peristilo Retangular, Thompson (1954) adiciona uma nova identificação para a "ágora comercial": a sede do tribunal da Heliaia, mencionado pela tradição textual como uma das principais instituições da democracia (Hansen, 1981-1982; Boegehold, 1996). Essa identificação, como se verá, formará o núcleo de uma hipótese que Thompson proporá quase trinta anos mais tarde. Antes, porém, Thompson defende uma segunda hipótese, para além da "ágora comercial": supreendentemente, em 1966 o autor adaptaria a hipótese de Dorpfeld e defenderia que a Praça Sul era, na verdade, o ginásio de Ptolomeu. 
A base desta hipótese repousa em uma nova identificação do Períbolo Retangular como sendo o santuário de Teseu (o Theseion) mencionado por Pausânias (1.17.2). De fato, a inexistência de material judiciário (tal como na região nordeste da ágora) no recinto enfraquecia a identificação como um tribunal; por outro lado, diversos indícios, tais como o pátio central rodeado por stoas, as salas do Edifício Leste, o formato de "palestra" do Períbolo Retangular, e as facilidades para obtenção de água na Stoa Sul II e na Fonte Sudoeste (reformada para abrigar uma piscina, segundo Thompson) apontavam a Praça Sul como um ginásio. Tal identificação seria coerente com a identificação do Períbolo Retangular como o santuário de Teseu, em função de sua associação com as atividades efébicas; consequentemente, este ginásio seria o Ptolemaion mencionado por Pausânias.

Esta identificação convenceu, entre outros, um dos principais colaboradores gregos das escavações norte-americanas na ágora: o arquiteto J. Travlos. No excelente Pictorial Dictionary of Ancient Athens publicado em 1971, Travlos não hesitaria em inserir a Praça Sul no tópico "Ginásio de Ptolomeu", acrescentando alguns indícios de que o conjunto era um ginásio: diversas inscrições encontradas em locais próximos indicando atividades ginasiais e efébicas; as quatro bases do Edifício Leste, de uma série de 12, ligadas às doze tribos atenienses; a construção, em épocas posteriores, de edifícios associados a ginásios - o Odeion de Agrippa no final do século I a.C., a biblioteca de Pantainos no final do I d.C., e finalmente a construção do Ginásio dos Gigantes no século V d.C. No entanto, no parágrafo final, Travlos menciona os achados encontrados na (hoje demolida) igreja de St. Dimitrios Katiforis, localizada cerca de 500 metros ao leste da Praça Sul, junto à antiga muralha pós-herúlea (na região da atual Catedral Metropolitana; fig. 72); entre os eles, estavam estatuetas de Teseu e o Minotauro e inscrições que faziam referência ao Ptolemaion e ao Theseion, indicando então que, enquanto toda esta área não for escavada, "a questão do local do Ginásio de Ptolomeu e do Theseion não estará fechada" (1971, p. 234). 


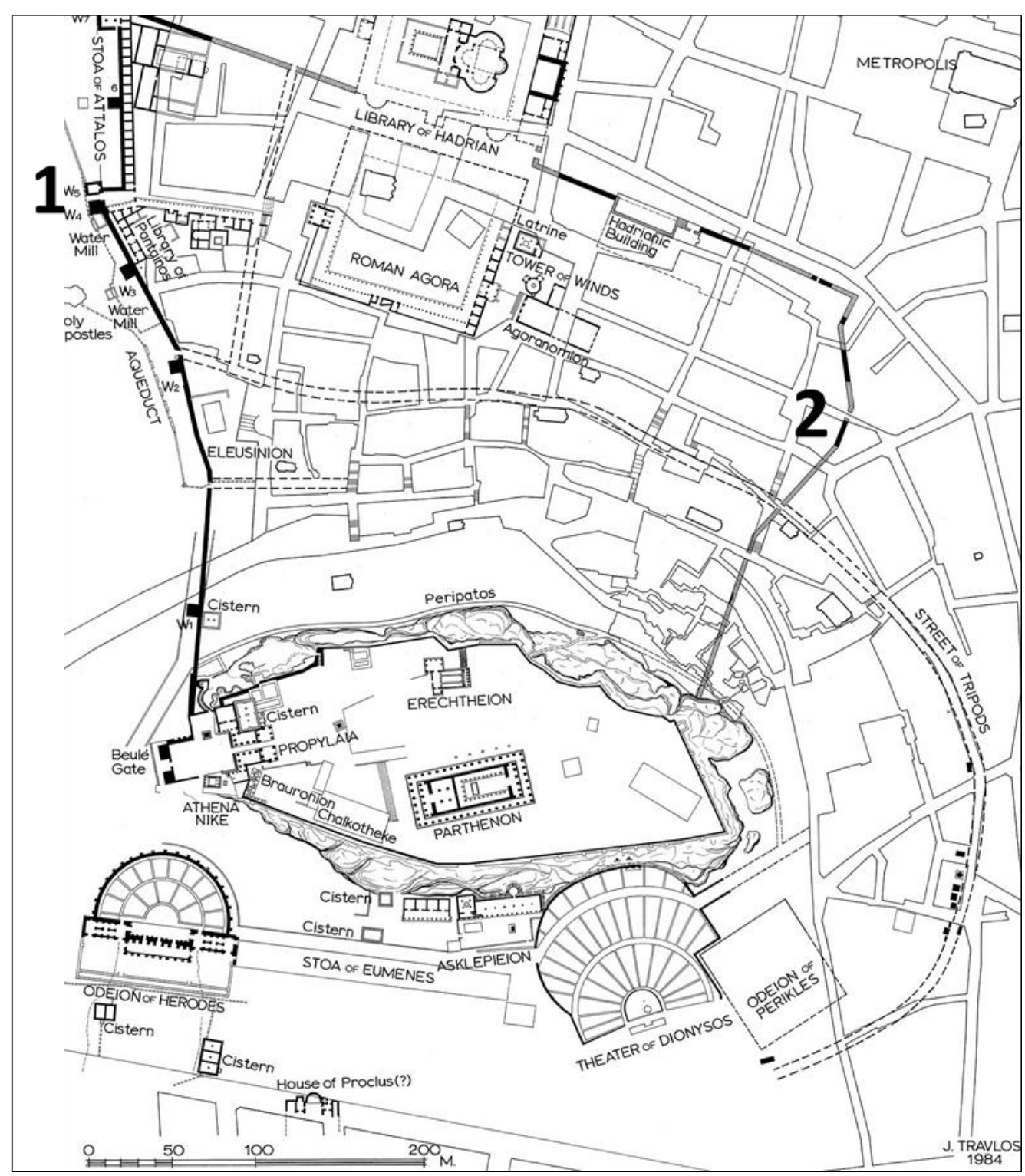

Figura 72. Proposta de reconstituição da planta da região ao norte da acrópole após a invasão dos hérulos em 267 d.C., de acordo com J. Travlos em 1984 (ASCSA $\left.{ }^{131}\right)$. 1. Localização da Praça Sul. 2. Localização da Igreja de São Demétrio Katifori.

E não estava. Um ano depois, com a publicação do volume 14 do projeto The Athenian Agora, Thompson elabora uma terceira hipótese. O autor abandona a identificação do Períbolo Retangular como sendo o santuário de Teseu e, por eliminação, retoma a identificação deste como sendo a sede do tribunal de Heliaia, baseado no fato de que ele se adequa às indicações na tradição textual de um recinto grande o suficiente para 1500 jurados e construído já no século V a.C. Partindo daí, Thompson expande a interpretação para toda a Praça Sul, que seria, a partir de sua construção no século II, um grande complexo judiciário: o Edifício Leste seria uma

${ }^{131}$ Disponível em: http://agora.ascsa.net/id/agora/image/2002.01.2574. 
espécie de ante-sala para controle do acesso aos tribunais, e as fontes se explicariam pela necessidade dos relógios d'água para as sessões, assim como as necessidades fisiológicas dos frequentadores (Thompson e Wycherley, 1972, p. 66-70). O autor não sugere um doador estrangeiro para o conjunto.

Treze anos depois, em 1985, V. Grace trouxe um novo dado para a questão: a datação do início da construção da Stoa Média, a partir principalmente das alças de ânforas de Rodes, Sínope e Cnido encontradas nas escavações do terraço de fundação do edifício. Com base na prática da estampagem dos nomes de magistrados das cidades de origem nas alças, V. Grace (1985) pôde estabelecer a data da alça mais recente presente nas fundações: o ano de 184/3 a.C. A partir desta data, a autora propõe uma nova identificação e atribuição para a Stoa Média. Uma inscrição ateniense em Delos, datada de 160/59, honrava Farnaces, rei do Ponto, por doações anteriores e futuras; considerando que Farnaces se assenhoreou de Sínope, importante porto do comércio de trigo do mar Negro, em 183 a.C., além da localização (próxima à rua do Pireu), dimensão e ventilação (com parapeitos baixos) da Stoa Média, a autora propõe a hipótese de que a Praça Sul seria um "mercado de grãos", construído inicialmente com ajuda de Farnaces, mas depois com o dinheiro público, o que explicaria o reuso de peças do recém-desmantelado Peristilo Quadrado no nordeste da ágora. Essa proposta, no entanto, não teve grande impacto entre os estudiosos, ao contrário da data de 184/3 como início da construção da Stoa Média.

A hipótese do "ginásio de Ptolomeu" já era amplamente questionada quando, em 1980, o arqueólogo G. Dontas encontrou, em uma caverna na encosta leste da acrópole, a inscrição com um decreto honorífico a Timocrite, filha de Polinikos de Afidna, sacerdotisa de Aglauros, com a indicação de que a estela deveria ser colocada "no Aglaureion" - descoberta que permitiu, finalmente, a identificação do Aglaureion, que era buscado na encosta norte da acrópole (Dontas, 1983). As implicações desta descoberta foram profundas para a topografia ateniense, especialmente em função do texto de Pausânias. O periegeta escreve (1.17) que o ginásio de Ptolomeu está "não

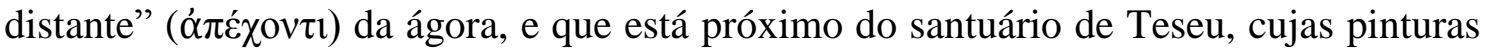
são descritas; na sequência (1.18), Pausânias escreve que o santuário dos Dioskouroi ficava abaixo do santuário de Aglauro. A identificação do Aglaureion na encosta leste da acrópole sugeriria que os locais mencionados nos capítulos 17 e 18 deveriam ser buscados em sua proximidade. A ágora mencionada no capítulo 17, até então considerada a mesma descrita nos capítulos anteriores - a ágora do Cerâmico - foi então 
associada a breves menções literárias a uma "ágora arcaica", na região noroeste da cidade; resolvia-se, assim, o problema do aparecimento tardio de edifícios públicos na ágora ateniense, no final do séc. VI, compreendida então como uma nova ágora erigida pela democracia, por oposição a uma ágora arcaica associada à oligarquia (Robertson, 1998; Schmalz, 2006; Osborne, 2007). O ginásio de Ptolomeu deveria, portanto, ser buscado nas proximidades da ágora arcaica e do Aglaurion, entre o local da futura da ágora romana e o local hipotético da ágora arcaica, que conta com uma série de vestígios de edifícios apenas parcialmente escavados, e ainda hoje pouco conhecidos.

Com as hipóteses do "ginásio de Ptolomeu" e do "mercado de grãos" deixadas em segundo plano, abre-se a possibilidade para o retorno de hipóteses antigas e a elaboração de novas. M. Torelli, por exemplo, em texto publicado em 1995 (a partir de comunicação realizada em 1993), mantem a identificação da Praça Sul como um ginásio (retomando os argumentos de Thompson e Travlos, e acrescentando a ideia de que a Stoa Média fosse um xystos, ou pista coberta de corrida), mas, dada a impossibilidade de se tratar do ginásio de Ptolomeu (que deveria estar ao nordeste da acrópole), seria um ginásio público, construído com o (pouco) dinheiro ateniense, o que explicaria o baixo custo dos materiais utilizados (calcário de Egina, blocos de reuso); o Períbolo Retangular seria uma palestra, com salas para os ginasiarcas (Torelli, 1995, p. 10). A. Boegehold, por sua vez, retoma a hipótese do complexo judiciário, defendendo que o Períbolo Retangular possa ser a sede de um dos tribunais do sistema jurídico ateniense mencionado nas fontes, como o Metiocheion; além disso, a Praça Sul teria substituído o Peristilo Quadrado, desmantelado no início do século II a.C., e que era, com grande probabilidade, utilizado como sede de tribunais (Boegehold,1995, p. 14 e 96).

Um novo passo foi dado, entretanto, com a proposta de identificação do Períbolo Retangular como o Aiakeion, ou santuário de Éaco, filho de Zeus e rei mítico de Egina, publicada por R. Stroud (1994, 1998). À menção em Heródoto (5.89), segundo o qual o santuário de Éaco foi construído ainda no século VI, no contexto das guerras entre Atenas e Egina, Stroud adiciona diversos outros indícios: a inscrição Agora I 7557, que menciona que os atenienses deveriam armazenar grandes quantidades de trigo no Aiakeion; Pausânias (2.29.6), que diz que o Aiakeion de Egina consistia em um períbolo de mármore branco; um papiro de Oxyrhynchos (POxy 2087) que menciona o Aiakeion ateniense em conjunção ao Tholos; e a localização, próximo ao local onde a via do Pireu encontra a ágora (Stroud, 1998, pp. 85-108). 
A proposta de R. Stroud tem sido amplamente aceita, e nos materiais de divulgação mais recentes produzidos pela Escola Americana a legenda "Aiakeion" já é constantemente associada ao Períbolo Retangular (Camp, 2010, p. 23; 170-171). No entanto, não foram desenvolvidas ainda as consequências desta identificação. J. Camp, por exemplo, tem retomado a hipótese de uma "ágora comercial", consonante à prática helenística de fechamento e especialização de funções nas ágoras - a despeito da ausência de paredes dividindo lojas, como na Stoa de Átalo II (Camp, 2010, p. 164).

O estudo mais recente que trata da Praça Sul, publicado em 2012, retoma, com novos argumentos, a hipótese do "ginásio de Ptolomeu". P. Marchetti (2012) propõe uma releitura de Pausânias afirmando que nada garante que os capítulos 17 (ágora, ginásio de Ptolomeu e Theseion) e 18 (Dioskoureion e Aglaureion) falam da mesma região, pelo contrário: o início abrupto do capítulo 18, sem preposições de lugar e movimento, indicaria que se trata de uma região diferente. Portanto, não haveria relação entre o ginásio e o Aglaureion, o que faz com que sua localização não necessariamente deva ser buscada na região ao noroeste da acrópole. Em relação à indicação de Pausânias de que o Ptolemaion estaria "não longe", ou seja, fora da ágora, Marchetti argumenta que a ágora havia sido diminuída com a construção do ginásio, como provam a posição dos horoi e das latrinas próximas da praça sul; neste sentido, a Praça Sul não seria parte da ágora clássica, ou seja, estaria fora e "não longe" dela. E por fim, adiciona ao debate uma análise das estátuas descritas por Pausânias no Agrippeion, edifício do século I a.C. que será uma espécie de extensão da Stoa Média: o periegeta menciona estátuas de reis helenísticos (cf. abaixo, cap. 3), todas elas relacionadas à dinastia lágida, e que poderiam estar originalmente no ginásio, sendo realocadas no teatro coberto - ele próprio uma extensão do complexo. Com isso, Marchetti defende fortemente que a Praça Sul deve ser identificada ao ginásio de Ptolomeu, construído por Ptolomeu VI Filadelfo, rei do Egito entre 186-145 - o que estaria de acordo com a datação de V. Grace. O Ptolemaion seria, para o autor, a referência para a construção da stoa de Attalos algumas décadas depois (construído em ângulo com a Praça Sul; v. abaixo), indicando a "amigável concorrência" entre os monarcas atálidas e lágidas.

Algumas ressalvas podem ser feitas à proposta de Marchetti, mas acredito que, no geral, sua identificação permanece como a melhor solução para o impasse. À ideia de que a ágora terminava na face norte da Stoa Média pode ser oposto o fato de que este edifício era colunado em todos os lados, indicando assim uma possível abertura para a ágora; no entanto, a inexistência de vestígios de uma escadaria entre o terraço da Stoa 
Média e o nível da região sul da ágora, díspares cerca de 5 metros, associada à estrutura do Edifício Leste e as escadarias em sua face leste, indicam que a entrada principal da Praça Sul era, certamente, realizada pelo Edifício Leste. Pode-se argumentar também que as estátuas de personagens ligados à dinastia lágida do Agrippeion tenham sido levadas a partir de outro local, e por motivos outros do que a eventual ligação do edifício ao Ptolemaion; no entanto, a integração do Agrippeion à Stoa Média torna bastante plausível uma coerência entre o novo edifício e a praça Sul, marcada pelo compartilhamento de estátuas de personagens que não eram, de todo modo, associados às figuras de Augusto ou Agripa, pelo contrário ${ }^{132}$. A isto deve ser acrescentada a crítica ao argumento de que o ginásio de Ptolomeu estivesse associado à criação da tribo Ptolemais em 224/3, defendido por Habicht (1982, pp. 112-117): as destruições dos ginásios extramuros atenienses por Filipe V, em 200, torna mais plausível a construção de um novo ginásioalguns anos depois, na década de 180.

A identificação da Praça Sul como "ginásio de Ptolomeu", mesmo se correta - o que somente poderá ser estabelecido com a escavação extensiva da região ao leste da Ágora Romana (Miller, 1995; Lippolis, 1995) - não põe um ponto final nas discussões: diversos elementos pouco analisados, até hoje, pela bibliografia trazem, pelo contrário, novas questões para a história de sua construção e, mais ainda, para a história da reorganização da ágora no século II. Vejamos.

A Praça Sul foi construída na primeira metade do século II a.C.; o primeiro edifício foi a Stoa Média, iniciado pouco depois de 183 a.C.; seguem-na o Edifício Leste e a Stoa Sul II. Ao longo deste processo, ocorrem as reformas do Períbolo Retangular, que ganha um pátio peristilado, e da Fonte Sudoeste, que recebe um muro no canto noroeste. Os materiais utilizados indicam escassez de recursos, por comparação às stoas doadas pelos reis pergamenos (Stoa de Eumenes e Stoa de Átalo II): são, em sua maior parte, ou calcário de Egina, ou blocos reutilizados de construções recentemente desmanteladas. Quanto à sua função, a ausência de instrumentos judiciários (fichas de bronze, clepsidras e kleroteria) torna improvável a identificação como conjunto judiciário; a ausência de paredes internas nas stoas, instrumentos de medição, decretos de agoranomoi e mesmo a criação da Stoa de Átalo II, fazem o mesmo para a hipótese de uma área especializada para o comércio. Por outro lado, sua disposição arquitetônica (pátio central, provável pista coberta de corrida, fontes), assim

132 Considere-se, por exemplo, a forte campanha anti-egípcia em torno do conflito entre Augusto e Antônio. 
como diversas inscrições encontradas nas proximidades que indicam atividades educativas e esportivas (Marchetti, 2012), apontam para um ginásio, ainda que não seja o ginásio de Ptolomeu.

Não obstante, a área construída é apenas uma parte da história; a área demolida é fundamental. Como já foi dito acima, na construção da Stoa Sul II, foram reutilizados peças do chamado Peristilo Quadrado, localizado no canto nordeste da ágora, e que daria lugar em meados do século II a.C. para a extensão norte da Stoa de Átalo II (Townsend, 1995). O curioso é que o desmantelamento do edifício é algumas décadas anterior ao início da construção da Stoa de Átalo II. Os vestígios mais tardios presentes no terraço imediatamente acima do nível do Peristilo Quadrado são uma alça estampada de uma ânfora de Rodes produzida em 193 a.C.; uma alça estampada de ânfora de Cnido produzida pouco depois de 188 a.C.; e uma moeda datada entre 196 e 190 a.C. Acima deste terraço, foi feito um outro, para servir de base para uma outra construção que antecedeu a Stoa de Átalo II: a alça de ânfora de Rodes mais tardia data de 193, e a de Cnido de um período entre 188 e 167 a.C. Isto indica uma data provável para o desmantelamento do Peristilo Quadrado ainda na década de 180 a.C., quase trinta anos antes do início da construção da Stoa de Átalo II, que governou Pérgamo entre 157 e 138 a.C.

Porque demolir o Peristilo Quadrado tanto tempo antes da construção da Stoa de Átalo II? O reuso de suas peças na Praça Sul, além do respeito da Stoa de Átalo II à orientação cardeal da Stoa Média, parecem indicar que se tratava, desde o início, de um mesmo programa de reordenação da ágora, no qual o novo uso do espaço do Peristilo Quadrado já estava determinado na época de sua demolição (Townsend, 1995, p. 104), na década de 180 .

Se estiver correta a sugestão de um programa unificado, um personagem central neste projeto é o rei Eumenes de Pérgamo. Seu nome foi normalmente desprezado pelos estudiosos como o financiador da construção da Praça Sul, como foi dito acima, em função das diferenças de custo entre esta e as outras doações pergamenas em Atenas. No entanto, esta abordagem pressupõe uma atuação totalizante do doador, tanto no financiamento, quanto na escolha do programa decorativo. Como é fartamente documentado nas fontes epigráficas, as doações dos monarcas helenísticos assumiam as mais diversas formas, desde a doação de dinheiro, até a doação de materiais e de mãode-obra (Bringmann, 2001). Isso significa que os reis de Pérgamo poderiam ter atuado em diferentes momentos da construção da Praça Sul, e mais importante, em colaboração 
com membros da comunidade local ${ }^{133}$. Há um respeito ao traçado original da ágora na concepção da Praça Sul, que mantem livre o trajeto da via que vem da região da futura ágora romana, assim como são feitas demolições de edifícios a oeste da Stoa Média, de modo a não afunilar a entrada que vem da porta do Pireu (Korres, 2002).

Coerentes com a participação atálida na concepção da Praça Sul são as ligações militares e religiosas entre Pérgamo e Egina, estabelecidas ainda no reinado de Átalo I. Considerando que Egina era uma possessão atálida, não causa surpresa que a Praça Sul, construída com matéria-prima egineta, siga a mesma orientação do Aiakeion ateniense, ele também construído com calcário egineta, tornado então um primeiro elemento de mediação das intervenções atálidas na ágora de Atenas, e que seria a matriz da orientação cardeal da ágora em seus lados sul e leste. A prática da mediação religiosa nas intervenções atálidas é bem atestada na construção da Stoa de Eumenes II (Dioniso Kathegemon) e nos pilares atálidas da acrópole (Atena Nike e Atena Pártenos), como visto acima.

Para além dos laços religiosos, a Praça Sul compartilha algumas premissas urbanísticas com outras intervenções seguramente atálidas em Atenas. Em primeiro lugar, a preocupação com a monumentalização das vias, presente tanto na Stoa de Eumenes em relação à via dos trípodes, quanto na Stoa de Átalo II na Via Panatenaica; a Stoa Média, além de servir como uma proteção aos espectadores da procissão panatenaica, emoldura a paisagem de quem olha para a acrópole (assim como a Stoa de Eumenes, do outro lado) e monumentaliza a via para quem vem da ágora romana. Em segundo lugar, próximo ao canto noroeste da Stoa Média está uma base que, segundo Thompson, seria o suporte para uma estátua equestre. A dedicação de estátuas equestres é uma prática tipicamente atálida em Atenas, sendo duas conhecidas na acrópole (de Eumenes junto ao Propileu, e de Átalo II a nordeste do Párthenon) e uma na ágora (no centro da Stoa de Átalo II, de frente ao Metroon) - seria de se esperar uma dedicação a Eumenes II na ágora, de acordo com a lógica de duplicação acrópole/ágora.

Finalmente, a doação de ginásios é bem atestada como prática evergética atálida, seja na forma de financiamento e manutenção, como em Rodes, seja na construção de ginásios novos, como em Mileto e na própria Pérgamo (Hansen, 1971). Nesta ultima, o famoso ginásio, um dos maiores do mundo grego, era construído em um sistema de três grandes terraços suplantados por sequências de stoas e templos; no ginásio médio, havia

\footnotetext{
${ }^{133}$ Um exemplo eloquente é a construção da Stoa Média, com materiais e arquitetura pergamena, dentro de um projeto de monumentalização iniciado mais de dois séculos antes (Mercuri, 2004).
} 
um xystos, ou seja, uma pista coberta de corrida, o que corresponderia a identificação da Stoa Média, também, como um xystos (Torelli, 1995).. Caso um dos edifícios cujas fundações foram encontradas na área central da Praça Sul seja, de fato, um templo, o paralelo com o Ginásio de Pérgamo seria ainda mais claro (Thompson, 1968, 41-43).

A construção da Praça Sul gerou uma radical transformação em toda a área sul

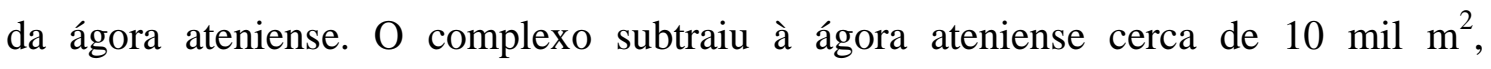
formando com isso, com seu pátio central de cerca de $3 \mathrm{mil} \mathrm{m}^{2}$, o que já foi sugerido como uma "nova ágora", mas que é, de qualquer forma, um espaço distinto, como é indicado pelo muro no lado oeste. A articulação de seus edifícios operou uma radical reorientação da borda sul da ágora: enquanto a demolida Stoa Sul I se orientava segundo um eixo sudeste-noroeste, alongando assim o limite da ágora na direção sudeste, a Praça Sul reforçaria a orientação ligeiramente cardeal do Períbolo Retangular e da Fonte Sudoeste, completada na borda leste pela construção da Stoa de Átalo II. Finalmente, a construção dos novos edifícios se conjuga com a reforma dos edifícios anteriores, indicando assim um programa único de intervenções que devem ser associadas, como se argumenta aqui, com a iniciativa atálida, que tem na Stoa de Átalo II sua mais clara manifestação.

\section{A Stoa de Átalo II}

Bem menos polêmica quanto à identificação é a Stoa de Átalo II, que fecharia o lado oriental da ágora. Algumas partes da stoa, especialmente em sua extremidade norte, sobreviveram em sua altura total, o que fez com que recebesse a atenção de viajantes já no século XVIII. O trabalho arqueológico de identificação de elementos pertencentes à stoa em outros locais (como a muralha pós-heruliana) e de escavação teve início na segunda metade do século XIX, fazendo com que a stoa, ao lado do Hephaisteion e ginásio (tardo-antigo) do Gigantes, se tornasse um dos monumentos mais conhecidos da ágora. Escavações intensivas foram realizadas a partir da década de 30 pela Escola Americana de Atenas, que decidiu reconstruir a stoa em seu formato original (exceto por uma fonte na extremidade sul) para abrigar o acervo e a exposição do Museu da Ágora Ateniense; a reconstrução, sob a supervisão de Ioannis Travlos, teve início em 1950 e foi finalizada seis anos depois. A complexa história dos edifícios 
anteriores à stoa, entretanto, só foi publicada em 1995, no volume 27 da coleção The Athenian Agora, a cargo de R. Townsend (1995).

Tratava-se ${ }^{134}$ de um edifício de planta retangular orientado de acordo com um eixo norte-sul, definindo o limite oriental da ágora (fig. 73-74). O corpo principal do edifício era composto por dois andares com 111 por 20 metros de área, chegando ao máximo de 13 metros de altura do ângulo do telhado até o primeiro degrau; duas escadarias nas extremidades norte e sul comunicavam os dois andares, medindo cada uma 2,7 por 14 metros; à frente do edifício, um terraço avançava para oeste em 12 metros, chegando a um comprimento de 120 metros e sua extremidade ocidental (o polígono formado tinha ângulo reto na extremidade sul e ângulo de 60 graus na extremidade noroeste). Adotando-se como referência o nível da Via Panatenaica na extremidade sudoeste do terraço, duas medidas foram realizadas para que o edifício se mantivesse plano em toda sua extensão: na área sul, o escudo rochoso do solo foi cortado, eliminando assim qualquer vestígio de edifícios anteriores; na área norte, o terraço acompanhava o declive do terreno chegando a uma altura de 8 metros em sua extremidade norte. Como apontou $\mathrm{H}$. Thompson, a diferença nítida de nível do terraço do edifício em relação ao terreno, também presente na relação da Stoa Média com o terreno ao norte, era uma marca da arquitetura pergamena (Thompson e Wycherley, 1972, p. 104, n. 115).

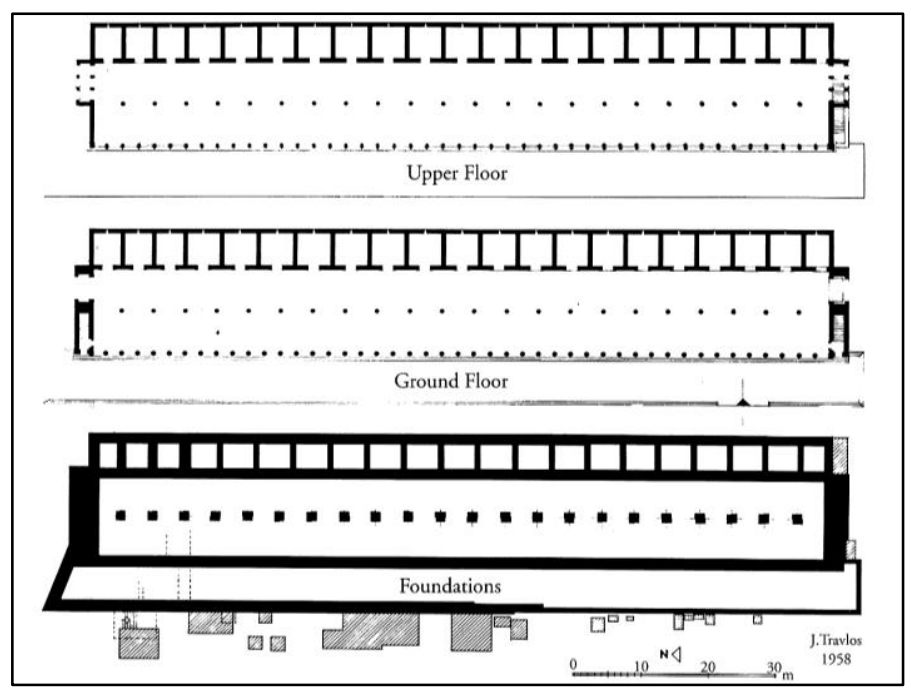

Figura 73. Proposta de reconstituição da planta dos três níveis da Stoa de Átalo II, feita por J. Travlos em $1958\left(\right.$ ASCSA $\left.^{135}\right)$.

\footnotetext{
${ }^{134}$ A descrição segue os dados fornecidos em Kohl (2001).

${ }^{135}$ Disponível em: http://agora.ascsa.net/id/Agora/Image/2008.20.0061.
} 


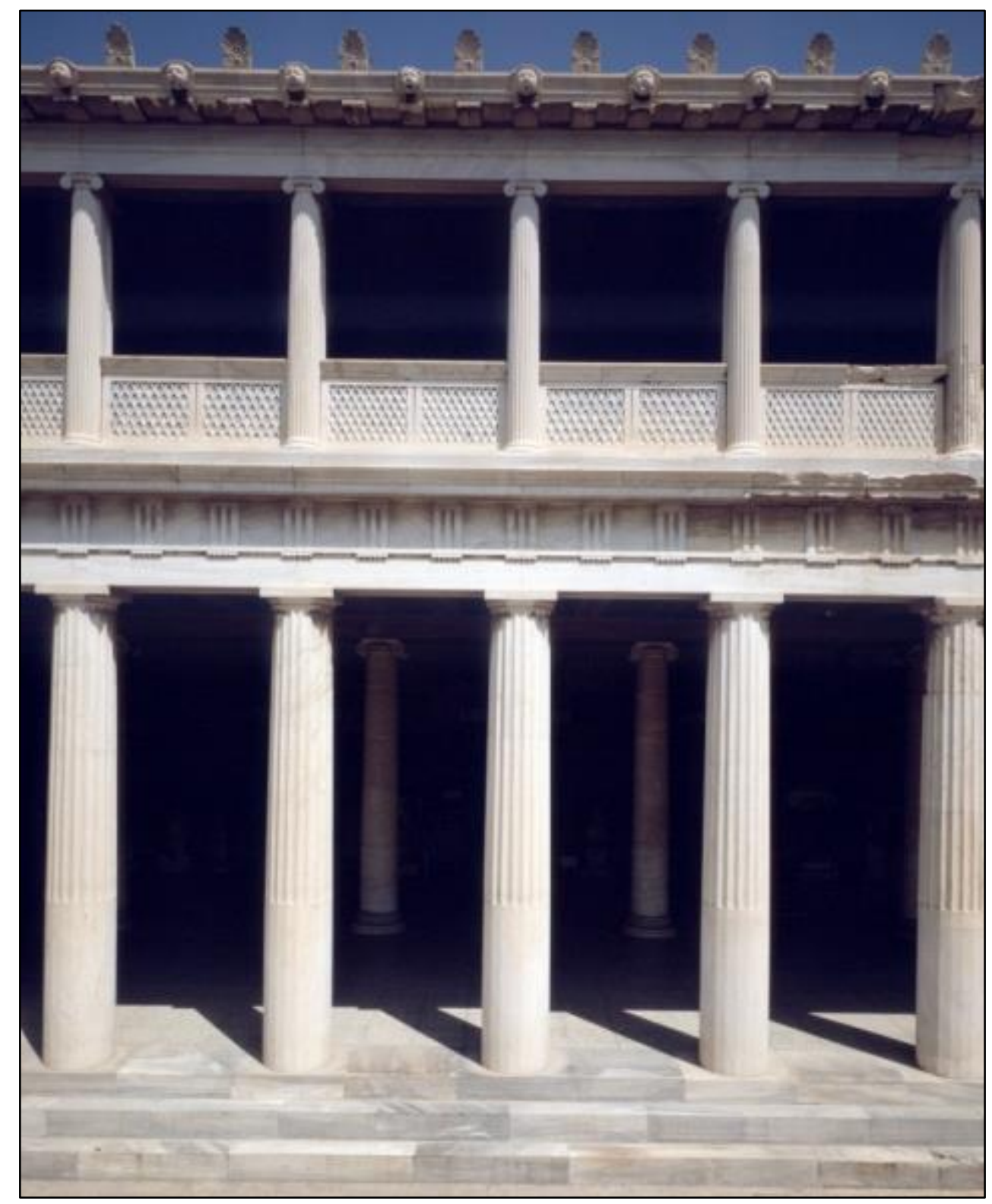

Figura 74. Fachada reconstruída da Stoa de Átalo II, fotografia tirada por C. Mauzy em 1985 $\left(\operatorname{ASCSA}^{136}\right)$.

O primeiro andar do edifício era composto por uma fachada dórica com 45 colunas, um amplo saguão dividido em corredores separado por 22 colunas jônicas sustentando as vigas de madeira, e, junto ao muro posterior do edifício, uma série de 21 salas com 4,91 de largura e comprimento variável entre 4,91 e 3,42, todas elas comunicando-se apenas com o saguão central. O fato de que as salas menores estão localizadas nas extremidades do edifício parecem indicar que elas são adições posteriores, assim como a escadaria, o que levou J. Travlos a propor um plano original de uma stoa de apenas um andar, muito mais modesta, posteriormente acrescida tanto

\footnotetext{
${ }^{136}$ Disponível em: http://agora.ascsa.net/id/agora/image/2004.02.0120.
} 
em comprimento quanto em altura - hipótese que recebou pouca aceitação. O segundo andar repetia o padrão do primeiro (45 colunas na fachada, 22 colunas interiores, 21 salas), exceto pela escolha das ordens: a fachada estava organizada de acordo com a ordem jônica, enquanto que as colunas interiores apresentavam capitel em palmetas. Duas diferenças adicionais se explicam por aspectos práticos: em função do formato de telhado em duas águas, as colunas jônicas exteriores tem a metade da altura das colunas dóricas do nível inferior, o que é compensado por um aumento da espessura por meio da inclusão, entre as duas metades, de uma seção retilínea; e por conta da altura da fachada, um parapeito foi adicionado entre as colunas exteriores, diminuindo os riscos de uma queda de quase 7 metros de altura. Este arranjo (superposição horizontal e vertical de ordens dórica, jônica e em palmeta, parapeito no segundo andar) se equiparava estreitamente ao arranjo das stoas do santuário de Atena Nikeforos na acrópole de Pérgamo (Kohl, 2001), sendo uma completa inovação, junto da Stoa de Eumenes, no âmbito das tradições arquitetônicas locais.

Os materiais utilizados foram conglomerado para as fundações, calcário do Pireu nos muros exteriores e paredes interiores, mármore azul do Himeto para os degraus, batentes, ortostatos e lintéis das portas, e mármore branco do Pentélico para as colunas exteriores e interiores, arquitraves, frisos, molduras, calha e telhas de beirais da fachada, e cerâmica para a maior parte das telhas da cobertura. A articulação entre estes materiais, em particular do mármore azul e branco da Ática, já havia sido usada na arquitetura ateniense (p. ex., no propileu de Mnésicles), mas deve-se notar tanto sua utilização do pilar de Eumenes diante da entrada da acrópole, quanto a diferença visual da fachada da Stoa de Átalo II em relação à Stoa Média, construída majoritariamente com calcário egineta. As relações entre as duas stoas serão retomadas mais adiante.

A Stoa de Átalo II apresenta uma diferença nítida entre frente e fundo: a fachada em mármore dialoga diretamente com o centro da praça, enquanto o muro oriental, construído com grandes blocos de calcário e sem qualquer abertura ou elementos decorativos, deixa claro o fechamento do lado oriental da ágora. Isto levanta a questão dos limites da ágora anteriores à construção da stoa: o novo edifício apenas regularizava um limite já existente, ou cortava a praça em duas?

As plantas produzidas pelos arqueólogos americanos normalmente projetam a área da ágora pós-Stoa de Átalo II para períodos anteriores, sem incluir as áreas mais a leste nas representações. Isto se deve, essencialmente, ao desconhecimento da história desta região da cidade (fig. 75): afora as escavações em porções da Ágora Romana, da 
Biblioteca de Adriano e de algumas fundações de edifícios, a área ao norte da acrópole é densamente ocupada por edifícios modernos. De fato, são atestadas apenas intervenções tardias: em meados do século II é construída a "stoa helenística", próxima ao Horologium de Andronikos, ele mesmo construído entre o século II e I; em época augustana é construída a Ágora Romana; já no século I d.C. surge uma nova construção a leste da Ágora Romana, conhecido (ainda que seja um aidentificação disputável) como Agoranomion, além da monumentalização da via entre a Ágora Romana e a Stoa de Átalo II com a construção de colunatas em ambos os lados. Considerando os fortes indícios que apontam para a utilização da Ágora Romana como espaço comercial a partir da época romana, além do que a possível vinculação do Horologium a atividades comerciais na área anteriormente à construção da Ágora Romana, a questão que se coloca é: desde quando a área é utilizada como centro comercial? E mais do que isso: se ela tinha uma função comercial já no período clássico, seria ela parte de uma "grande ágora" (que se estenderia do Hephaisteion até o Horologium), cortada ao meio pela Stoa de Átalo II por volta de 150 ?

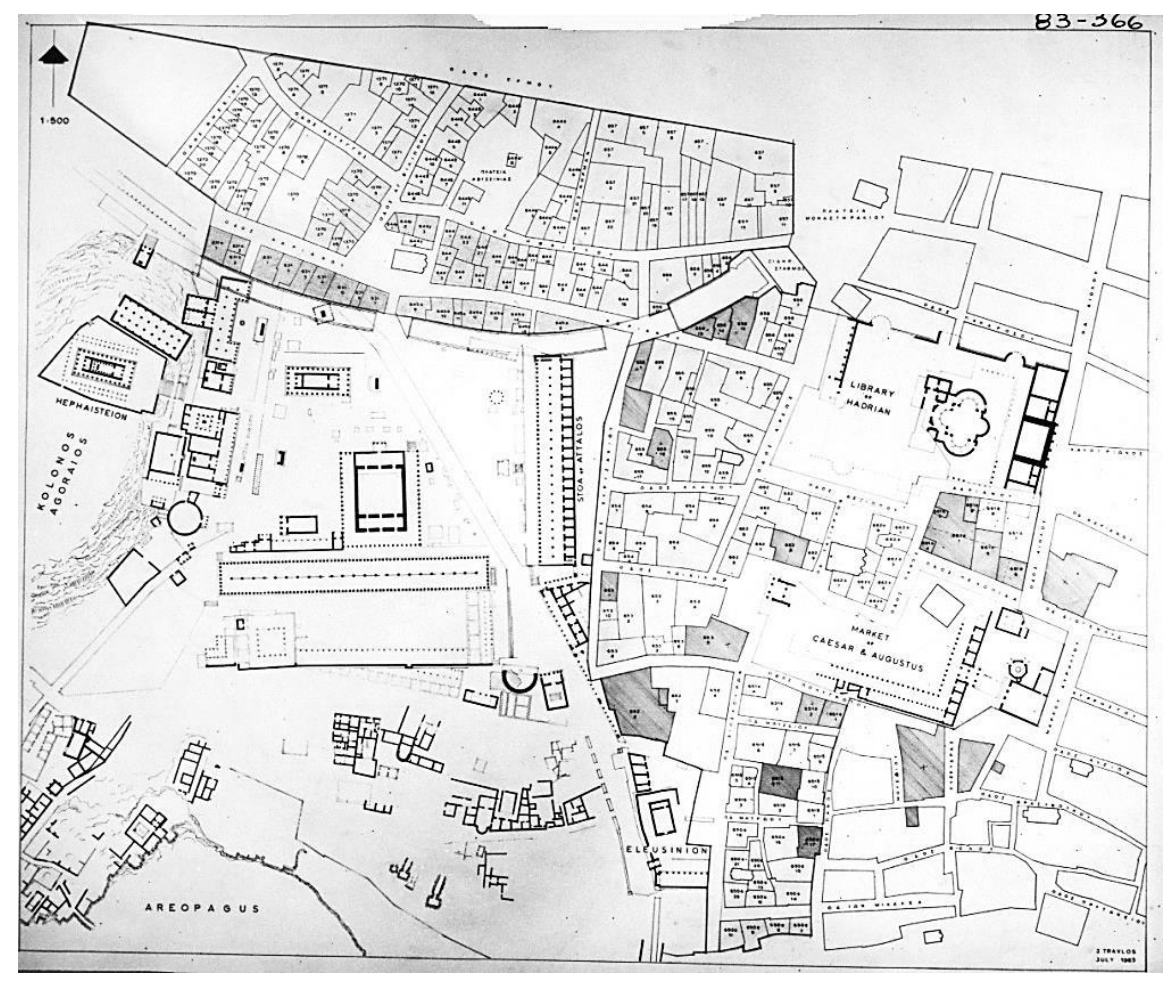

Figura 75. Planta com proposta de reconstituição da ágora e arredores e indicação dos lotes ocupados por edifícios modernos, feita por J. Travlos em 1963 (ASCSA $\left.{ }^{137}\right)$.

${ }^{137}$ Disponível em: http://agora.ascsa.net/id/agora/image/1997.02.0230. 
Se a hipótese da "grande ágora" (Dickenson, 2012, pp. 156-182) estiver correta, a construção da Stoa de Átalo II significaria a divisão e mesmo uma hierarquização das duas partes da ágora: a ocidental, de maior prestígio, ligada às tradições cívicas, religiosas e agonísticas da cidade, e para onde se voltaria a fachada da stoa; e a oriental, dominada pelas atividades comerciais, para onde se voltaria o fundo da stoa e que seria monumentalizada apenas em época augustana. A multiplicação de ágoras e sua diferenciação funcional seriam coerentes com as práticas urbanísticas do período helenístico, especialmente das cidades da Ásia Menor, e Pérgamo em primeiro lugar.

No entanto, as bases para a hipótese da "grande ágora" não são isentas de problemas: na falta de indícios claros de ocupação comercial da área a leste da Stoa de Átalo II em período anterior à sua construção, é pouco seguro postular a extensão da ágora. Além disso, a atividade comercial na área poderia ser uma consequência da construção da Stoa de Átalo II, gerando apenas em meados do século I a demanda pela construção de um espaço edificado (a Ágora Romana). A desarticulação da Ágora Romana com a ágora clássica e com seu entorno imediato - o propileu ocidental da Ágora Romana estava a mais de 100 metros de distância da Stoa de Átalo II - seria um indício do desenvolvimento desigual da área, dando lugar a espaços não comerciais ou "não monumentalizáveis" na área imediatamente a leste do fundo da Stoa de Átalo II. O fato é a separação que a Stoa de Átalo II promoveu entre as áreas ocidentais e orientais; se esta separação foi criada ou apenas reforçada pela stoa, é uma questão que esperará por novas escavações e análises.

A atribuição da construção da stoa à iniciativa pergamena, para além das características arquiteturais, é garantida pela inscrição monumental na arquitrave dórica da fachada ocidental (IG II 23171 + Agora I 6135), onde se lê:

O rei Átalo, filho do rei Átalo e da rainha Apolonis, [construiu] a stoa [e a fonte?] para o demos dos atenienses.

Pérgamo foi governada por três reis chamados Átalo, dois deles filhos de Átalo, mas apenas Átalo II, que governou Pérgamo entre 159 e 138, era filho de uma rainha chamada Apolonis. Com isso, costuma-se datar a construção da stoa em meados no século II, ainda que ela possa ter sido iniciada no final do reinado de Átalo, ou mesmo apenas financiada, e construída posteriormente. De qualquer maneira, a inscrição dedicatória e suas dimensões monumentais, erguida a mais de 6 metros de altura a partir 
dos degraus da stoa, já indica um de seus usos: a de suporte da comunicação entre Pérgamo e os atenienses, tanto como objeto do evergetismo, como indicado no conteúdo do texto, quanto, por meio da forma e contexto, como mecanismo de exposição do nome do evergeta na ágora ateniense, em uma posição intimamente relacionada com a Via Panatenaica e sua prestigiosa procissão. Neste sentido, é difícil concordar com M. Kohl (2001, p. 261), em artigo seminal sobre a stoa, quando o autor a interpreta simplesmente como um gesto de civismo do rei pergameno, antes de tudo um cidadão ateniense, demonstrando a grandeza da cidade; pelo contrário, a disposição monumental do nome de um monarca estrangeiro como tal - pois não é mencionado o demos ao qual Átalo II fazia parte, mas sim sua ascendência real - não tinha, até onde se sabe, paralelo na arquitetura pública ateniense.

Outros vestígios indicam um segundo uso da stoa (Wycherley, 1957, pp. 46-47). Uma estela encontra na igreja de Demétrio Kathephores (IG II ${ }^{2}$ 1043), contém um decreto efébico datado de 38/7, pelo qual se determina que um certo Sosis deveria receber um retrato a ser exposto na Stoa de Átalo II (linhas 68-69). Outra estela (Agora I 5990), encontrada acima dos "Civic offices" junto à ponta noroeste da Stoa Média, contém a inscrição um decreto cívico votado entre 74/3 e 63/2 que determinava a dedicação de um retrato em um escudo dourado de um cidadão na Stoa de Átalo II (linhas 6-10). Na área da stoa, foi encontrada uma base de estátua cuja inscrição (IG II ${ }^{2}$ 3781) indica que se tratava de uma estátua dedicada ao filósofo Carneades de Cirene por dois cidadãos do demos de Sypalletos, chamados Átalo e Ariarathes ${ }^{138}$. Ainda na área da stoa foi encontrada outra base de estátua (Agora I 3527+3601) dedicada por Átalo II a seu irmão Teófilo. Finalmente, a inscrição dedicatória do monumento localizado diante do centro do eixo longitudinal da stoa revela a dedicação ao imperador Tibério pelo Areópago, o Demos e o Conselho, provavelmente uma rededicação ao imperador romano de um monumento dedicado ao doador da stoa quando de sua construção (IG II ${ }^{2}$ 4209). Fica claro, portanto, que a stoa funcionava também como local de exposição de retratos e estátuas honoríficas, escolhidos tanto pela pólis, quanto pelo monarca.

Um terceiro uso, como centro comercial, é sugerido pela própria estrutura do edifício: a disposição das 21 salas ao fundo da stoa, nos dois andares, poderia indicar que se tratavam de lojas, com base seja na ausência de comunicação entre as salas, seja

\footnotetext{
${ }^{138}$ Tradicionalmente identificados a Átalo II de Pérgamo e Ariarathes da Capadócia. Cf, no entanto, Chr. Habicht (1992), que questiona a identidade deste Átalo com o rei pergameno com base no demótico do dedicante, que não pertencia à tribo Attalis, à qual pertencia certamente Átalo II.
} 
na atestada associação entre stoas e atividades mercantis (Coulton, 1976). J. Camp (1996) chegou a propor que a Stoa de Átalo II era um "shopping de luxo" na ágora ateniense - interpretação se tornaria amplamente difundida.

Um quarto uso, como santuário ou centro religioso, pode ser sugerido quando se compara a planta baixa da Stoa de Átalo II com a Stoa Sul I, cujo desmantelamento deve ter precedido em pouco tempo o início da construção da Stoa de Átalo II: a semelhança na disposição das salas ao fundo das duas stoas é evidente. Na medida em que o uso das salas da Stoa Sul I como locais para os banquetes rituais é bem atestado, pode-se sugerir a mesma utilização na Stoa de Átalo II, que se converteria de um "shopping antigo" em uma espécie de santuário, o que seria, ademais, adequado às necessidades religiosas da tribo Attalis, criada meio século antes da construção da stoa.

Um quinto uso da stoa, como espaço para abrigar espectadores dos festivais e rituais cívicos, é indicada pela articulação da stoa com a Via Panatenaica (tanto na planta quanto na elevação do terraço, cuja altura diminuía do norte para o sul da via), aliada aos parapeitos na fachada do segundo andar (Shear, 2001, pp. 881-883). Dessa maneira, a Stoa de Átalo II dialogaria diretamente com a Stoa Média, cujo terraço oferecia uma visão plena, e também diagonal, da Via Panatenaica. Inversamente, o caminhante que andasse pela Via Panatenaica também veria a Stoa de Átalo II diagonalmente, ampliando assim o efeito de profundidade criado pela colunata - efeito este já claramente utilizado no século $\mathrm{V}$, por exemplo, na apreensão visual inicial do Pártenon condicionada pela posição diagonal do Propileu da acrópole.

Finalmente, é preciso considerar as relações da stoa com outros edifícios contemporâneos a ela. A Stoa de Átalo II, como já foi dito, fecha o lado oriental da ágora, mas o faz de um modo específico: na planta, forma um ângulo de exatos 90 graus com a Stoa Média, que por sua vez fecha o lado sul. Este conjunto segue em sua orientação grosso modo os eixos dos pontos cardeais, apresentando em relação a eles apenas 2 graus de diferença na rotação no sentido anti-horário. Em relação aos outros lados da ágora, tanto a axialização quanto a orientação cardeal são inovações. Tomando como base o eixo leste-oeste, a maioria dos edifícios do lado ocidental da ágora apresenta um ângulo 79 graus, com exceção da Stoa Real, que apresenta 68 graus; no lado norte, o único edifício de massa considerável, a Stoa Pintada, apresenta um ângulo de 18 graus. Quanto aos edifícios demolidos, é notável o alinhamento da Stoa Sul I com os edifícios do lado ocidental, formando entre si um ângulo de 89,5 graus, enquanto a fachada do Peristilo Quadrado é praticamente paralela à fachada da Stoa Real, com 
apenas 1 grau de diferença. Dos edifícios construídos anteriormente às intervenções do século II, apenas um apresentava uma orientação próxima daquela dos novos edifícios, ou seja, cardeal: o Aiakeion, que também sofreu uma reformulação de sua estrutura interna no século II, tendo apenas 3 graus de rotação no sentido anti-horário em relação aos eixos cardeais, ou seja, apenas 1 grau a mais no sentido anti-horário em relação ao conjunto Praça Sul-Stoa de Átalo II.

Isto posto, mais do que uma regularização do espaço (Onians, 1979, p. 166), o que ocorre é a introdução de uma terceira estrutura de alinhamento dos edifícios, cardeal, acrescentada às estruturas não-cardeais (fig. 76) formadas pelo conjunto Stoa Real/Peristilo Quadrado (rotação de 22 graus no sentido horário) e pelo conjunto “edifícios do lado ocidental” / Stoa Sul I (rotação de 11 graus, também no sentido horário). Resta saber, pois, quando esta implantação foi planejada, por quem, e a partir de quais referências urbanísticas ela foi realizada.

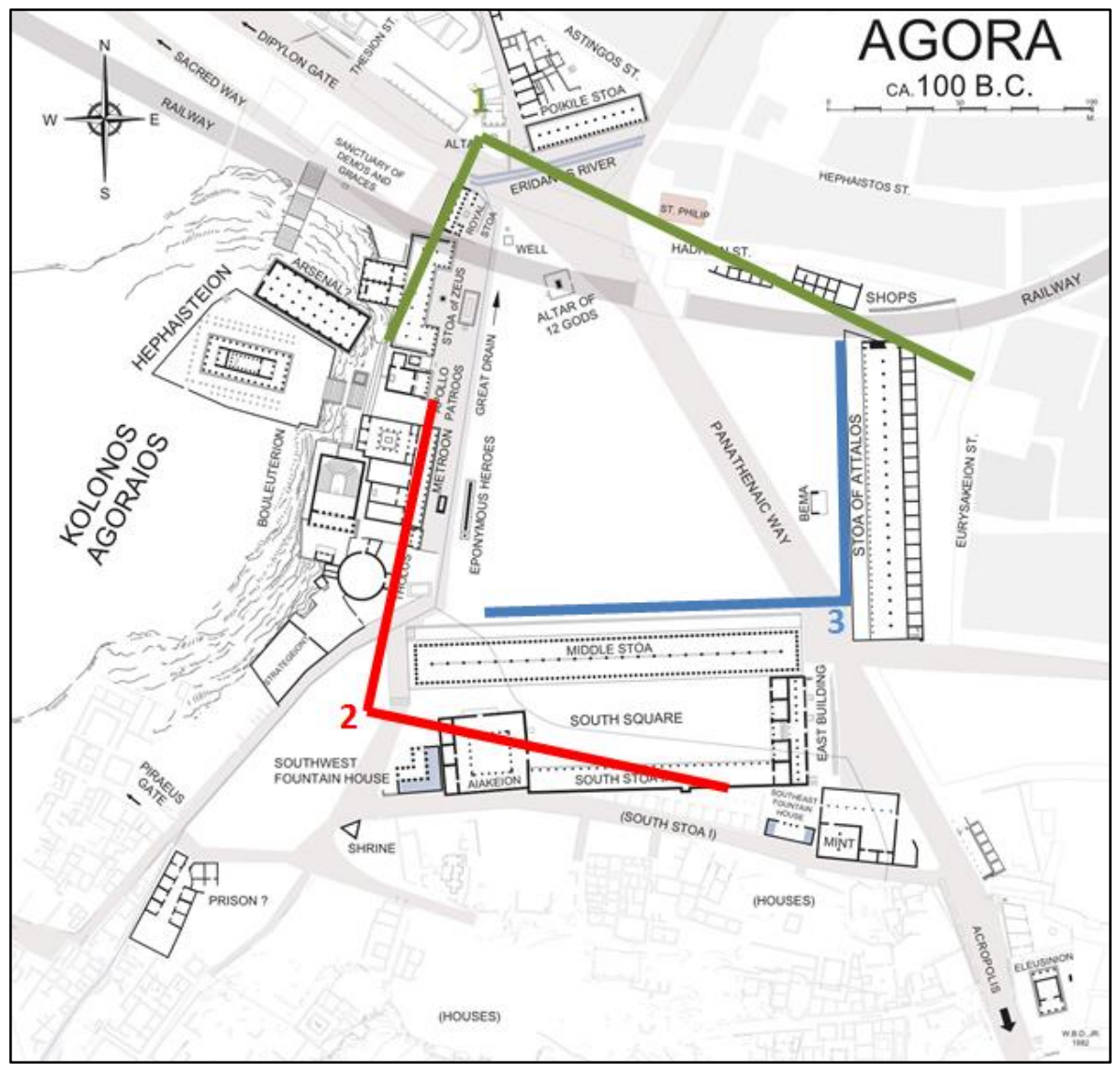

Figura 76. proposta de reconstituição da planta da ágora em c. 100, feita por Dinsmoor em 1982 $\left(\operatorname{ASCSA}^{139}\right)$. Indicação das diferentes orientações dos edifícios na ágora: 1. Stoa Real/Peristilo Quadrado. 2. Edifícios ocidentais/Stoa Sul I. 3. Praça Sul/Sta de Átalo.

${ }^{139}$ Disponível em: http://agora.ascsa.net/id/agora/image/2011.04.0041. 
A história das demolições, construções e reusos de elementos arquitetônicos aponta fortemente para um planejamento unitário desde o princípio da intervenção, ainda na década de 180. De fato, como já foi afirmado, o espaço de tempo entre o desmantelamento do Peristilo Quadrado, contemporâneo ao início da construção da Stoa Média, a reutilização de seus blocos na Stoa Sul I, cerca de 20 anos depois, e a ocupação de sua área pela Stoa de Átalo II, quarenta anos depois, seriam estranhos caso não houvesse já no desmantelamento do Peristilo Quadrado planos para a ocupação posterior de sua área; a reutilização de apenas alguns poucos elementos arquitetônicos na Stoa Sul II, torna implausível a hipótese de uma redução de gastos que justificasse a demolição do Peristilo Quadrado.

Quanto aos sujeitos envolvidos neste reordenamento, pode-se avançar a hipótese de uma colaboração entre elites locais e monarcas estrangeiros, e, acima de todos, dos monarcas atálidas. De fato, a arquitetura pergamena da Stoa de Átalo II, os paralelos entre a Biblioteca de Pérgamo e o Metroon (cf. abaixo), também reformado e claramente dialogando com as outras colunatas, e os indícios de participação pergamena na construção da Praça Sul, apontam claramente para um protagonismo atálida. Caso se concorde com proposição de que a Praça Sul era, de fato, o local do Ptolemaion, podese sustentar a colaboração entre as monarquias atálida e ptolomaica, aliadas tanto na proteção a Atenas quanto na oposição a selêucidas e antigônidas.

\section{O Metroon}

Escavado pela primeira vez em 1907-1908 pela Sociedade Arqueológica Grega, as fundações do chamado "novo Metroon" ou "Metroon helenístico" só foram exaustivamente analisadas no início da década de 1930 com escavações americanas na ágora (Thompson, 1937, pp. 115-140, 172-217; Travlos, 1971, p. 352). Trata-se de um edifício de planta bastante peculiar: a fachada colunada de 39 metros de comprimento, com 14 colunas provavelmente dóricas, dava acesso a um corredor retangular, para o qual se abriam quatro ambientes de área descrescento do norte para o sul. O primeiro a partir do sul ("sala 1"), menor, media $82 \mathrm{~m}^{2}$ e tinha uma abertura simples na parede oriental. O segundo ("sala 2") estava dividido em duas partes, uma sala junto ao muro de fundo que media $65 \mathrm{~m}^{2}$, que era precedido por um vestíbulo de $20 \mathrm{~m}^{2}$, que se comunicava com o corredor da colunata por meio de uma abertura formada por duas 
colunas in antis - estrutura semelhante a um templo prostilo distilo in antis. $\mathrm{O}$ terceiro (“sala 3") tinha área de $124 \mathrm{~m}^{2}$, e se comunicava com o corredor por uma abertura semelhante ao do primeiro ambiente. O quarto ambiente ("peristilo") era composto por um pátio central peristilo com $45 \mathrm{~m}^{2}$ área, possivelmente aberto, rodeado por uma área coberta que, junto do pátio, ocupavam uma área de $234 \mathrm{~m} 2$, além de um vestíbulo de 16 $\mathrm{m}^{2}$ que também apresentava por meio de duas colunas in antis, ladeado por duas escadarias de $11 \mathrm{~m}^{2}$ cada, que davam acesso a um andar superior que deveria encimar a área coberta ao redor do pátio central; finalmente, três salas de área variável no limite ocidental faziam com que o muro de fundo avançasse ainda mais 6 metros na direção oeste.

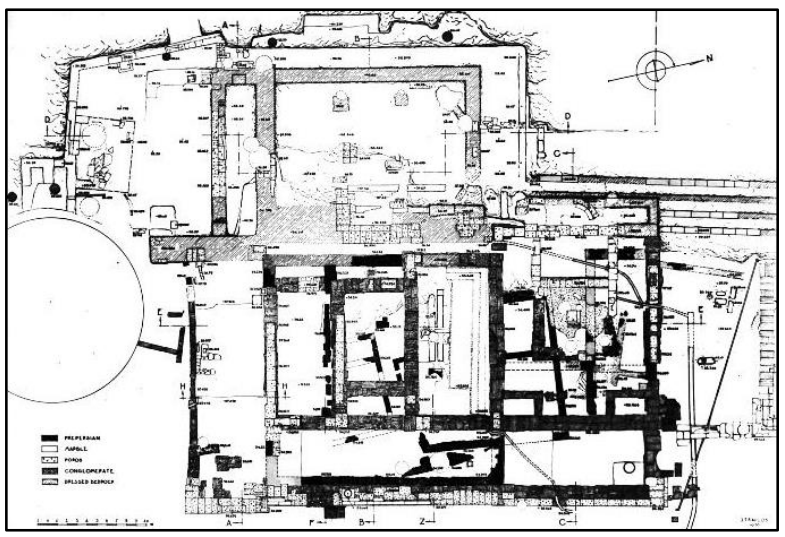

Figura 77. Planta do estado atual do Metroon e do Novo Bouleuterion, feita por J. Travlos em 1936 $\left(\operatorname{ASCSA}^{140}\right)$.

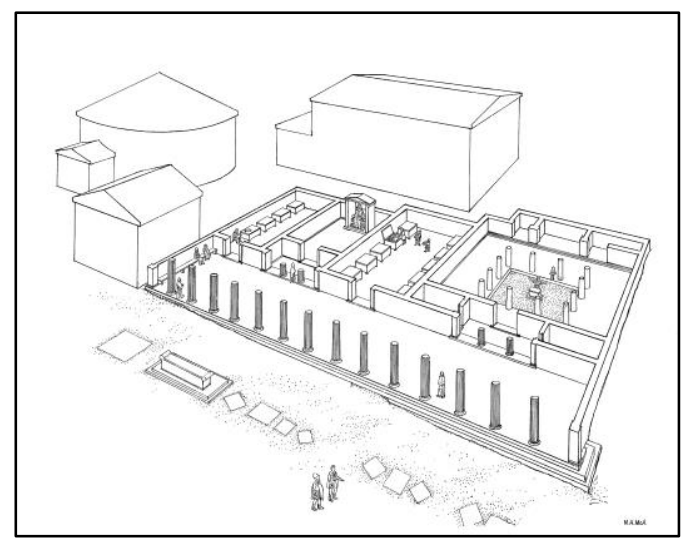

Figura 78. Proposta de elevação parcial do Metroon no século II, feita por $M$. McAllister em 1967 (ASCSA ${ }^{141}$ ).

Duas ordens de argumentos levam à datação do edifício em meados do século II. A primeira parte dos materiais associados às fundações, tais como moedas e cerâmica (Thompson, 1937, pp. 193-194). A segunda parte de suas similaridades arquiteturais com a Stoa de Átalo II, tais como o arranjo dos materiais (conglomerado, calcário, mármore azul e mármore branco) e os tipos de grampos e pinos (Thompson, 1937, pp. 192-193). Esta última também indica a provável participação atálida na construção do edifício: para além do diálogo técnico e espacial com a Stoa de Átalo II, a planta do novo Metroon remete claramente à biblioteca do santuário de Atena Nikephoros de Pérgamo, construída ainda sob o reinado de Eumenes II (Brehme, 2011).

\footnotetext{
${ }^{140} \mathrm{http} / / /$ agora.ascsa.net/id/agora/image/1997.04.0165

${ }^{141} \mathrm{http}: / /$ agora.ascsa.net/id/agora/image/2002.01.1908
} 
O novo edifício se aproveita de parte das fundações de construções anteriores, o que permitiu que as escavações revelassem ainda mais sobre a história do local (Thompson, 1937). As primeiras intervenções ocorrem no início do século V, com a construção do edifício-sede do Conselho dos 500, o chamado "velho Bouleuterion", e o templo identificado como o primeiro Metroon. Fontes tardias associariam os dois edifícios de formas diferentes, ora dizendo que fazem parte do mesmo santuário, ora inserindo o Bouleuterion no santuário da deusa Mãe. Se o primeiro está intimamente ligado às reformas clistenianas, com a instituição da composição do conselho por meio da escolha de 50 cidadãos de cada uma das 10 tribos, o segundo diz respeito à introdução do culto da deusa mãe em Atenas, seja ela associada à Cibele ou Deméter (Thompson, 1937, pp. 206-208; Robertson, 1996; Bogh, 2012). A ligação entre os dois edifícios e seus correspondentes usos (institucionais e religiosos) não está clara, mas é fato que o Metroon será transformado em edifício do arquivo público ateniense, onde serão colocados os documentos (em pedra, madeira, papiro) referentes a leis e decretos (Thompson e Wycherley, 1972, pp. 29-38). Isso só ocorrerá depois de duas grandes transformações: a primeira ocorre com o saque persa em 480, quando os dois edifícios são danificados - o Metroon não será mais reconstruído, enquanto que o Bouleuterion será reparado; a segunda, com a construção do "novo Bouleuterion" no final do século $\mathrm{V}$, a oeste do antigo, com a mesma orientação e planta baixa, mas com área um pouco menor. Com isso, o edifício do "velho Bouleuterion" passou a concentrar as atividades de arquivo público e de culto à deusa Mãe, hospedando a estátua de culto feita por Fídias ou Agorácritos.

A construção do novo Metroon, se por um lado incorpora algumas das fundações dos edifícios anteriores, por outro representa a introdução de uma planta completamente nova na ágora. Não apenas a estrutura e articulação interna dos ambientes são radicalmente diferentes do velho Bouleuterion, como também a área construída e a fachada propõem novos diálogos com os edifícios próximos. O velho Bouleuterion deixava livre a área ocupada pelo antigo templo, permitindo uma ampla visualização do Hephaisteion para quem estivesse no centro da ágora; o novo Metroon, com o pátio cobrindo a área do antigo templo, estreitava o espaço visual limitando a apreensão do Hephaisteion a seu aspecto frontal. Esta limitação à frontalidade, contrária aos padrões clássicos e helenísticos de reforço da tridimensionalidade dos edifícios peristilos por meio da apreensão diagonal, se explica ao menos por dois motivos: o primeiro, ao que tudo indica, havia a intenção de incorporar no novo santuário a área do antigo templo da 
deusa Mãe, destruído pelos persas; o segundo, havia a intenção de criar um eixo visual entre o Hephaisteion e o pilar atálida do outro lado da ágora, no centro da fachada colunada da Stoa de Átalo II (Onians, 1976; Schalles, 1982). É preciso destacar o papel da fachada colunada do novo Metroon, a qual, à diferença no muro contínuo do velho Bouleuterion, promovia um balanço e uma continuação das colunatas dos edifícios mais ao norte, a saber, os templos de Apolo, de Zeus e Atena Frátrios, a Stoa de Zeus e a Stoa Real. Ainda que descontínua - as colunatas não estavam alinhadas, assim como apresentavam articulações internas bastante diferentes - a reforçada sequência de colunas fazia o balanço com as recentemente construídas longas fachadas das bordas sul (Stoa Média) e leste (Stoa de Átalo II) da ágora, além da mais antiga, ainda que menor, colunata da borda norte (Stoa Pintada).

Vejamos com mais detalhe o papel do curso da deusa Mãe tanto na intervenção em si, quanto na articulação dos antigos e novos edifícios. Por um lado, o culto à deusa Mãe era já tradicional em Atenas (Bogh, 2012), e o novo Metroon ocuparia o local do já multissecular santuário da deusa. Em particular, a sala 2 se candidata como o espaço especificamente dedicado ao culto: além da planta de templo prostilo distilo in antis, a presença de um altar diante da fachada do Metroon e alinhado à sala 2 parece indicar sua natureza de santuário, como um templo integrado a um conjunto maior (Travlos, 1971, p. 352). Por outro lado, é preciso destacar a importância do culto da deusa Mãe em Pérgamo: tendo como principal santuário aquele localizado em Pessino (cidade em território gaulês autônomo graças a proteção de Pérgamo), foi utilizado como importante veículo diplomático quando uma missão romana buscou, em 205, a imagem da Magna Mater de Pessino, apontada pelas sibilas como trunfo para a vitória sobre os cartagineses (Tito Lívio, 29.11.4-8; Hansen, 1971, pp. 50-52). A ligação continuava efetiva em meados do século II, quando um sacerdote da deusa Mãe contou com a colaboração de Átalo II em seus conflitos com os chefes gauleses (OGIS 315.6).

Uma intervenção atálida de reconstrução do Metroon ateniense, desse modo, estaria de acordo com a já estabelecida tradição de mediação religiosa nas intervenções urbanas, fazendo dialogarem cultos locais e os cultos preferidos do evergeta. Esta mediação entre a deusa Mãe ateniense e a pergamena é evidente a partir do eixo visual estabelecido entre o pilar atálida e o novo Metroon, mediando assim o contato entre os deuses fundadores da população ática (Atena e Hefesto, pais de Erechtheus/Erichthonius, cultuados no Hephaisteion) e o rei pergameno (Stoa de Átalo 
II), elevando este último, ao menos no nível desta articulação axial, a "refundador" de Atenas (Schalles, 1982).

Esta mediação religiosa aparece, ainda, pelo culto dos Dióscuros no novo Metroon, como foi sugerido por M. Torelli (1995) a partir de um objeto encontrado nas escavações do complexo. Trata-se de um artefato de pedra de forma oval, com a base plana, decorado com diversas incisões regulares por toda a superfície, e com um buraco para inserção de outro artefato que não foi preservado. Interpretado inicialmente como um omphalos, ou umbigo, artefato associado ao culto de Apolo - e por isso considerado uma dedicação colocada inicialmente no templo de Apolo Patroos, poucos metros ao norte do local de achado (Thompson, 1937, pp. 110-112) - o objeto é melhor interpretado como uma representação do capacete de um dos dióscuros, também de formato oval e com uma estrela de metal sustentada por uma barra ligada ao capacete. Esta representação metonímica dos dióscuros por meio de um capacete já era comum na iconografia grega, e também aparece em Pérgamo (Torelli, 1995). A referência aos dióscuros aponta fortemente na direção de um culto aos reis pergamenos Eumenes II e Átalo II, renomados pelo amor filial mesmo nas situações mais embaraçosas ${ }^{142}$.

Em síntese: se o Metroon, por um lado, se relaciona com as necessidades administrativas e cultuais ligadas ao funcionamento da pólis ${ }^{143}$, por outro, ele se refere à identidade e à autorepresentação atálida (Biblioteca, deusa Mãe em Pessino, dióscuros). Novamente, observa-se a indissociação entre vida cívica políade e evergetismo monárquico, integrado ao grande projeto de reestruturação da ágora ateniense em função do urbanismo microasiático.

\section{O Olympieion}

O santuário de Zeus Olímpico em Atenas foi escavado em diversos momentos ao longo do século XIX e $\mathrm{XX}^{144}$. Mesmo que quase integralmente demolido, as poucas colunas e fragmentos de arquitrave que permaneceram em pé colocam o templo coríntio do Olympieion entre os mais notáveis monumentos de Atenas. Os vestígios do templo

\footnotetext{
${ }^{142}$ Como quando Átalo II casou-se com a esposa de seu irmão quando, erroneamente, pensava que este estava morto; o impasse foi resolvido amigavelmente (Plutarco, Sobre o amor fraternal, 489). Cf. também a recusa de Átalo à proposta de conspiração contra seu irmão: SEG 35.823.

${ }^{143}$ Sobre a relação entre o culto à deusa Mãe enquanto "protetora da cidade", cf. Bogh (2012).

${ }^{144}$ Para a história das escavações e levantamento da bibliografia produzida, cf. Wycherley (1964) e TölleKastenbein (1994).
} 
fazem parte de sua última fase construtiva, a saber, a finalização do templo na época do imperador Adriano, no início do século II d.C.; não obstante, as escavações revelaram parte considerável da longuíssima história do sítio, e em particular os pormenores da história construtiva do templo.

O sítio do Olympieion parece ter sido um foco de ocupação desde o período neolítico, mas somente no século VI há vestígios de uma primeira construção (Wycherley, 1964): trata-se de um templo dórico prostilo octastilo, com 30,5 metros de largura e o dobro de comprimento, construído com calcário da acrópole, e seguindo uma rígida orientação leste-oeste; a tradição atribuía a construção deste templo a Deucalião (Pausânias, 1.18.7-8). No final do século VI, o templo passa por uma profunda reformulação: as dimensões da planta são ampliadas $(44 \times 113 \mathrm{~m})$, e o templo se torna díptero, com 104 colunas de cerca de 10 metros rodeado a cela (três fileiras de 8 colunas em ambas as fachadas e duas de 20 colunas nas duas laterais), além de 16 colunas seguindo as paredes da cela por dentro; a ordem continuava dórica e, ao calcário da acrópole, foi acrescentado o calcário de Kara. Seguindo a tradição literária, a construção do templo foi atribuída à casa psistrátida, tendo sido iniciada por Psístrato ou um de seus filhos. O fato de que o templo permaneceu inacabado sugere que sua construção teve início pouco antes da abolição do regime, na década de 510.

Ainda que inacabado, o templo era considerado um dos mais notáveis exemplos da arquitetura grega, conforme se observa no relato de Heráclides, no final do século III (cf. discussão acima). Possivelmente a explicação do abandono da obra, para além de limites orçamentários, se explica pelo caráter ambíguo do templo, ao mesmo tempo obra monumental e edifício associado à tirania. Tal ambiguidade, porém, não foi um obstáculo para a retomada da construção com os recursos do rei sírio Antíoco IV Epiphanes (175-165), a partir do novo projeto estabelecido por um arquiteto romano chamado Cossutius (Estrabão, 9.1.17; Vitrúvio, 7.15). Ainda que o novo projeto mantivesse em linhas gerais a planta do edifício psistrátida de mais de trezentos anos antes, duas importantes alterações foram realizadas: em primeiro lugar, o calcário deu lugar ao mármore branco pentélico como material da superestrutura; em segundo lugar, a ordem dórica (figs. 79-80) foi substituída pela ordem coríntia (figs. 81-82), o que, além da introdução de novas possibilidades decorativas, significou o aumento da altura da coluna para cerca de 16 metros. De qualquer maneira, esta retomada teria o mesmo destino do início da construção: permaneceria inacabada, sofrendo ainda uma depredação com a retirada de algumas de suas colunas por Sula para o reuso em 
construções do monte Capitolino em Roma (Abranson, 1974). Apesar de termos a notícia de um projeto de retomada da construção na época de Augusto, somente sob o reinado de Adriano a obra seria concluída, mantendo a ordem coríntia.

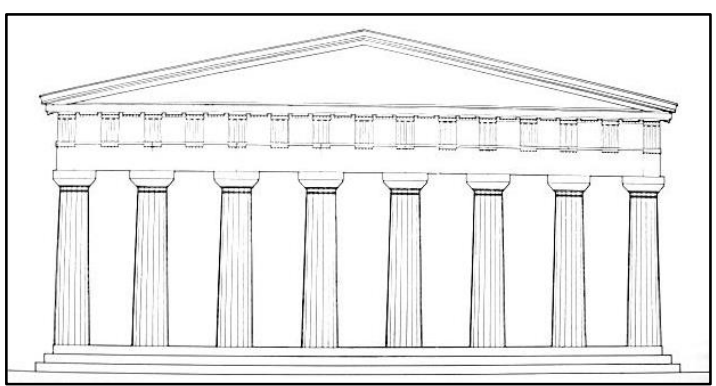

Figura 79. Proposta de reconstituição da elevação da fachada do Olympieion no século VI (Tölle-Kastenbein, 1994, plan 6).

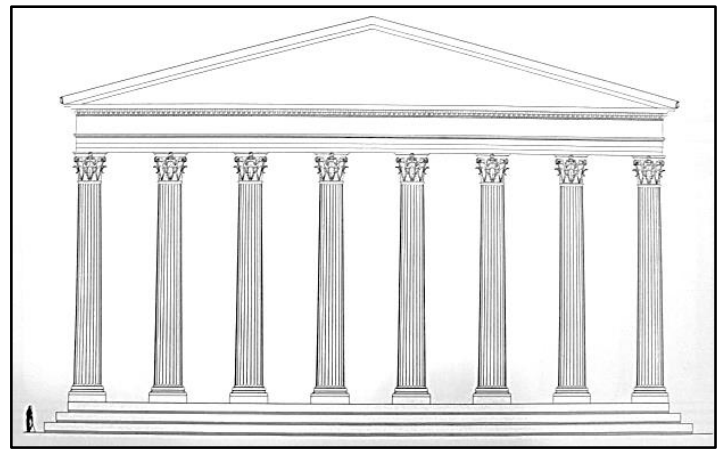

Figura 81. Proposta de reconstituição da elevação da fachada do Olympieion no século II (Tölle-Kastenbein, 1994, plan 14).

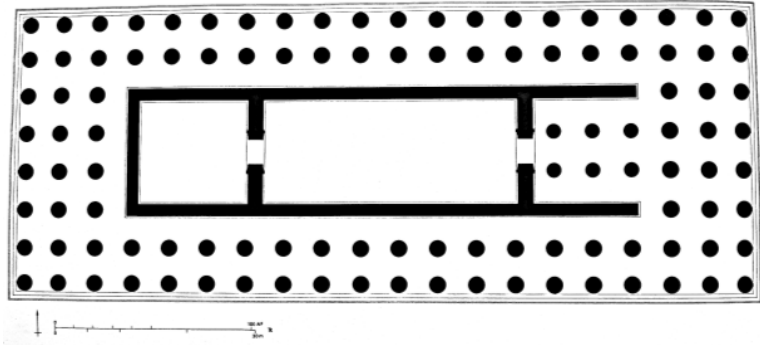

Figura 80. Proposta de reconstituição da planta do Olympieion no século VI (Tölle-Kastenbein, 1994, plan 5).

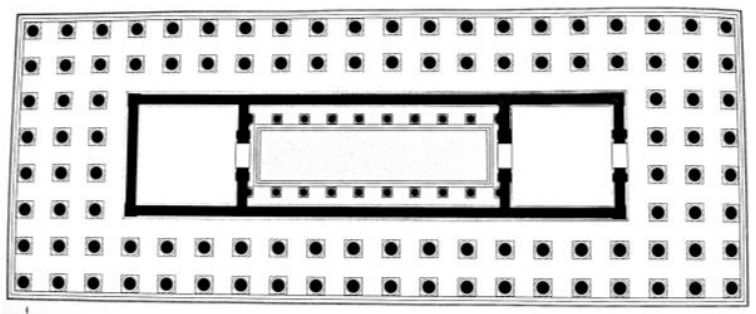

Figura 82. Proposta de reconstituição da planta baixa do Olympieion no século II (TölleKastenbein, 1994, plan 14).

Uma inscrição encontrada em local próximo ao Olympieion faz parte de uma dedicação do demos a um cidadão romano chamado Cossutius (IG II $^{2} 4099$ ), que foi naturalmente associado ao arquiteto do Olympieion. Entretanto, uma nova análise demonstrou que a inscrição deveria ser datada no século II d.C. (Byrne, 2003, p. 4, n. 7). Não obstante, diversos Cossuti são documentados como arquitetos no oriente grego, o que deve indicar que a família criou uma espécie de dinastia, possivelmente iniciada com o Cossutius do Olympieion (Rawson, 1975; Hoff, 2013, pp. 565-566). A escolha de um arquiteto romano para a reestruturação do templo de Zeus em Atenas tem intrigado os especialistas, que normalmente procuram na própria biografia de Antíoco IV a explicação. Antes de ser entronado rei da Síria em 175 (com intensa colaboração 
atálida), Antíoco viveu cerca de dez anos como refém em Roma, por conta da derrota de seu pai, Antíoco III Magno, na guerra contra Roma (192-188). A presença de Antíoco é atestada em Atenas no ano de 178 (Habicht, 2006, p. 161), três anos antes de usurpar o trono do irmão, Selêuco IV - certamente nesta estadia o futuro rei criaria laços com a cidade que se tornaria, algum tempo depois, objeto do evergetismo real. Não obstante, os anos em Roma foram marcantes: Antíoco IV é retratado nas fontes antigas, em especial em Políbio (26.1), como um monarca exageradamente romanizado. Segundo o historiador megalopolitano, Antíoco tentou introduzir jogos gladiatoriais no oriente grego, andava pelas ruas de Antioquia caçando votos para sua eleição como "edil" e, ao ser eleito, dispensava a justiça à moda romana, em um trono na ágora (Dickenson, 2012, pp. 389-390). A escolha de um arquiteto romano, pois, é coerente com a política de "romanização" de Antíoco. O impacto dessa escolha seria extraordinário: o Olympieion de Cossutius e Antíoco IV é um dos primeiros templos a utilizar a ordem coríntia no exterior, o que influenciará grandemente o desenvolvimento da arquitetura monumental romana (Hoff, 2013, p. 565).

O projeto helenístico do templo é extremamente significativo para a história urbana ateniense em diversos aspectos. Em primeiro lugar, o aumento da altura total do edifício reforçava seu aspecto monumental, funcionando como um contraponto, na cidade baixa, para o Pártenon: tanto visualmente, pela monumentalidade ou pelo mesmo material (mármore pentélico), quanto religiosamente, a partir dos paralelos entre Atena e Zeus já tradicionais na arquitetura ateniense ${ }^{145}$. Em segundo lugar, o projeto de utilização em larga escala do mármore pentélico fez com que a área do Olympieion se equiparasse à acrópole pericleana e à ágora atálida, inserindo-a na competição evergética - que parece ter tido neste mármore um de seus vetores. Em terceiro lugar, o uso da ordem coríntia fez com que o novo templo dialogasse com a arquitetura helenística de modo mais efetivo, com seus desenvolvimentos da ordem coríntia de maneiras cada vez mais monumentais. Em quarto lugar, o novo projeto dialogava de um modo bastante peculiar com o antigo: se por um lado respeitava de um modo geral o traçado, por outro a adoção de uma nova ordem é uma ruptura radical com as tradições arquiteturais locais ${ }^{146}$.

Finalmente, é preciso destacar a mediação religiosa também presente nesta intervenção: Antíoco IV Epiphanes, como é observável pela iconografia de algumas de

\footnotetext{
${ }^{145}$ Por exemplo, na acrópole (Zeus Polieus / Atena Polias) e na ágora (Zeus e Atena Frátrios).

${ }^{146}$ Contra, cf. Wycherley (1964, p. 170), por exemplo, vê pouca inovação no projeto de Cossutius.
} 
suas cunhagens, associava-se frequentemente a Zeus (Morkholm, 1963, 1966; fig. 83). Não mais a divindade da tirania, Zeus Olímpico tornava-se uma divindade selêucida, engajada na propaganda dinástica e na competição evergética do século II. Ainda que não existam sinais de culto direto a Antíoco ou a qualquer monarca selêucida em Atenas - como havia para Átalo I e Ptolomeu III -, a cidade tinha relações estreitas com Antíoco, sendo o primeiro local de estadia após seu retorno de Roma (Habicht, 2006, pp. 166-167). Dessa maneira, se por um lado o presente de Antíoco pode ter significado uma homenagem arquitetural à grandeza da cidade, por outro ele também funcionava como propaganda monárquica e como vetor de estreitamento dos laços entre selêucidas, atenienses e romanos - o que aparentemente deu certo, a partir ao menos do roubo de colunas por Sula, das referências em Vitrúvio e do projeto augustano, que demonstram o prestígio, entre os romanos, do templo selêucida.
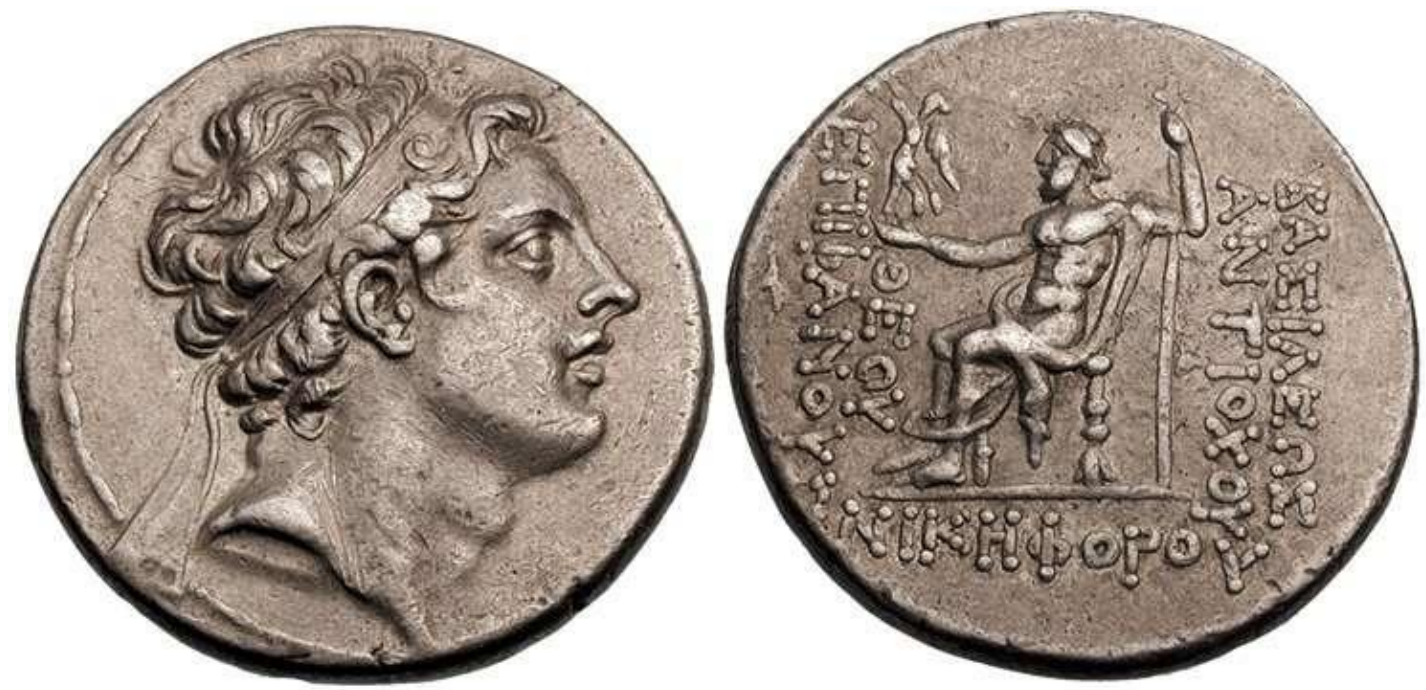

Figura 83. Antioquia, c. 169/8-164, prata. Anverso: Efígie de Antíoco IV com diadema, voltada

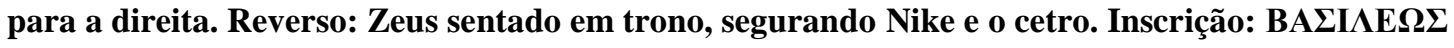
ANTIOXOY / NIKHФOPOY / ఆEOY EПIФANOY. Referência: Morkholm 16 (WildWinds ${ }^{147}$ ).

\section{O Banho Sudoeste e o Horologium}

O grande movimento construtivo do século II se extende de 200 a 140, quando as crises nas monarquias pergamena, síria e egípcia diminuem consideravelmente as

\footnotetext{
${ }^{147}$ Disponível em: http://www.wildwinds.com/coins/greece/seleucia/antiochos_IV/Morkholm_16.jpg.
} 
possibilidades do evergetismo monárquico em Atenas. Não obstante, duas novas intervenções são datadas do final do século II: a construção de um banho público na região a sudoeste da ágora, e de um relógio público - conhecido como "Torre dos Ventos" - na região a leste da ágora, próximo ao local onde será construída, na época de Augusto, a "ágora romana".

Localizado na esquina das ruas do Pireu e do Areópago, o chamado "Banho Público Sudoeste" era um edifício de estrutura circular, com 7,20 metros de diâmetro, cujas fundações de conglomerado aparecem associadas a cerâmica do século II. A linha circular da fileira de blocos é quebrada na parte ao sul, que se torna mais retilínea, indicando que o acesso ao ambiente interno se dava por aquele espaço. É provável que o edifício circular estivesse inserido dentro de um recinto mais amplo, do qual apenas os muros norte e sul sobreviveram; próximo ao limite noroeste do edifício circular, as fundações do muro apresentam uma abertura de tamanho suficiente para uma entrada dupla, a partir da rua do Pireu. A identificação do edifício como um banho público é assegurada pela existência de edifícios semelhantes com esta função datados do mesmo período, em outras cidades da Grécia (Ginouvès, 1962, pp. 191-6): seu espaço interno, segundo Shear Jr., seria suficiente para cerca de 20 banheiras de mármore tais como uma encontrada próximo ao edifício (figs. 84-85).

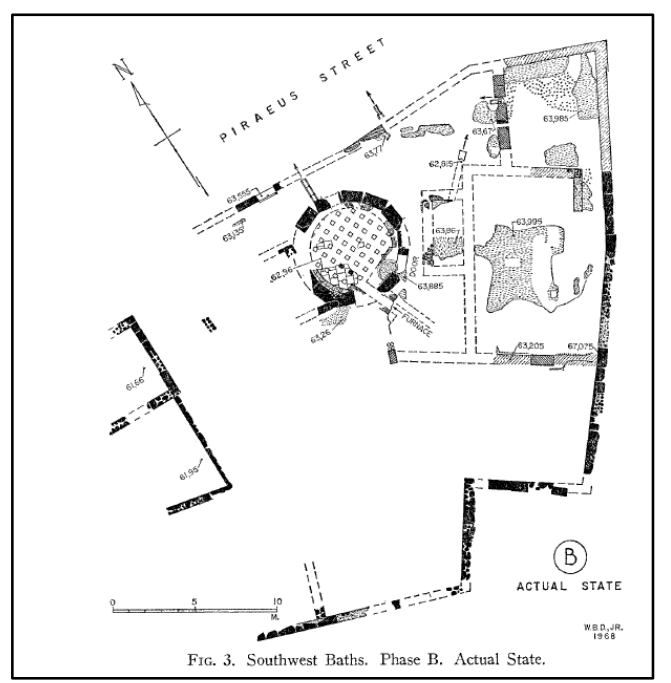

Figura 84. Planta do estado atual do "banho helenístico" (Shear Jr., 1968, p. 396, fig. 3).

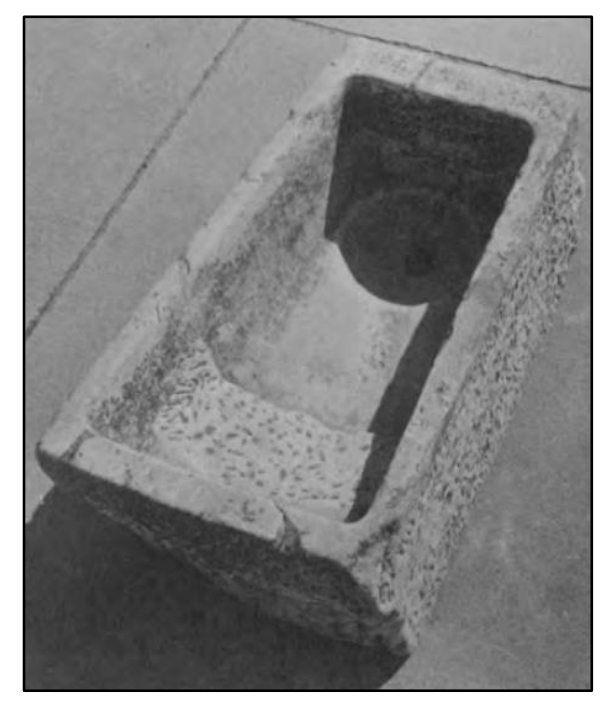

Figura 85. Fotografia debanheira de mármore encontrada próximo ao "banho helenístico" (Shear Jr., 1968, pl. 108e). 
O edifício circular está associado a muros externos ao norte e ao sul, construídos pouco tempo depois (final do século II e início do I; não há vestígios de muro ao oeste, mas é provável que seus limites fossem contíguos ao anexo nordeste do "edifício em poros" 148 (figs. 84-85). Trata-se de uma estrutura trapezoidal formada por três ambientes: um amplo pátio sem marcas de cobertura ao sul, um corredor ao norte ladeado por 8 salas ( 5 ao oeste e 3 ao leste do corredor), que se liga a um anexo na extremidade nordeste do edifício dividido em 4 salas. Foi construído em meados do século $\mathrm{V}$, passando por pequenas alterações no século IV. O edifício foi destruído no início do século I; no final do mesmo século (período augustano), uma casa é construída sobre a área do corredor norte-sul (casa Q), e entre o século I e II outra casa é construída ao leste (casa P). A identificação do edifício é controversa. Há vestígios de cisternas e poços, além de materiais associados ao trabalho com mármore e metais a alguns ambientes (o anexo e algumas salas) até o final do período clássico, o que indicaria a identificação como um complexo de oficinas de artesãos; no entanto, a disposição dos ambientes parece indicar um uso público ou semi-privado. M. Crosby (Young, 1951, pp. 168-187) sugeriu três hipóteses: um complexo de apartamentos, um complexo de tribunais ou um complexo de gabinetes cívicos. A arqueóloga descartou a primeira hipótese por conta da ausência de provimentos de água para usos domésticos e pela localização junto a uma via particularmente movimentada, e a segunda hipótese por conta do tamanho reduzido das salas, onde caberiam não mais que 200 pessoas (pouco para os julgamentos públicos que precisavam de no mínimo 500 jurados). A terceira hipótese lhe pareceu mais plausível, trazendo como argumento a comparação com o edifício identificado como "Strategeion", ao sul do Tholos na ágora. Mais recentemente, J. Camp propôs a identificação do edifício como uma "Prisão Estatal", em função do local apartado da ágora e da própria estrutura do edifício: o anexo seria uma torre, o edifício mais longilíneo abrigaria as celas e o corredor, enquanto a área ao sul seria um pátio a céu aberto (Camp, 1986, p. 13-16).

${ }^{148}$ A descrição e discussão completa, escrita por M. Crosby, foi incluída em Young (1951, pp. 168-187). 


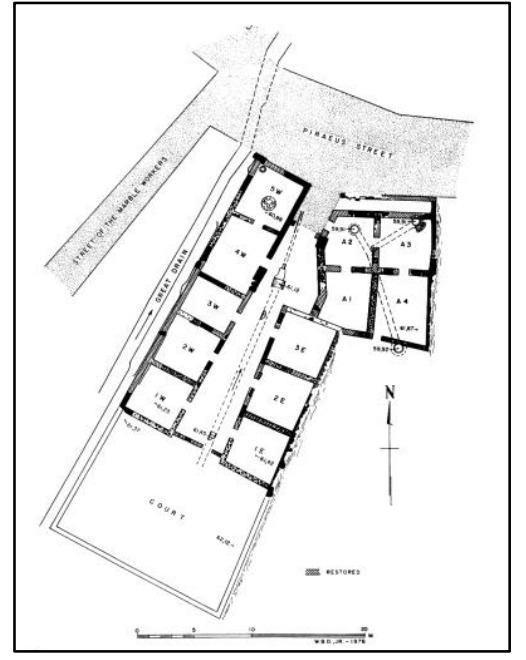

Figura 86. Proposta de reconstituição da planta do "edifício em poros", feita por W. Dinsmoor em 1978 (ASCSA) ${ }^{149}$.

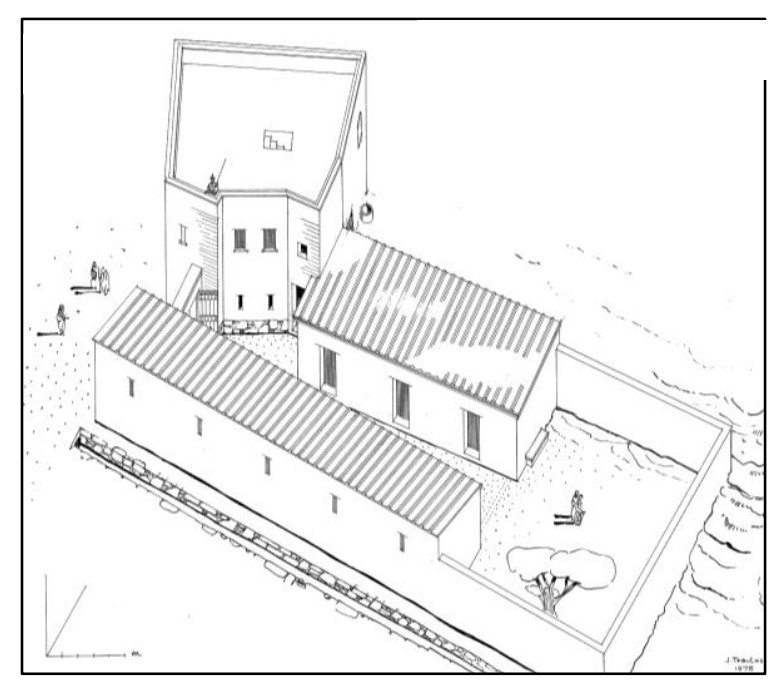

Figura 87. Proposta de reconstituição da elevação do "edifício em poros", feita por J. Travlos em $1975\left(\operatorname{ASCSA}^{150}\right)$.

A proximidade, ou mesmo contiguidade do "Banho Helenístico" com o "Edifício em poros" é difícil de ser interpretada. A princípio, a localização junto a uma via de fácil acesso - a via do Pireu - parece ter sido imperativa, e talvez, no século II, aquele seria um dos poucos espaços disponíveis para a construção. Uma hipótese plausível seria a de que, caso o "Edifício em poros" seja um complexo de gabinetes cívicos, o "Banho Helenístico" seria utilizado principalmente pelos magistrados. No entanto, na ausência de evidências mais concretas tanto da identificação do "Edifício em poros" quanto do uso do "Banho Helenístico", é impossível assegurar qualquer hipótese. Todo o conjunto será destruído no início do século I, provavelmente em função do saque de Sula em 86 (Shear Jr., 1969, p. 399); no período augustano, o edifício será inteiramente reformulado, dando lugar a um banho público maior e com técnicas marcadamente italianas.

O relógio público a leste da ágora, por sua vez, é um dos monumentos mais conhecidos de Atenas, em função do ótimo estado de preservação da superestrutura e de seu formato peculiar (fig. 88). Trata-se de uma torre octogonal com três anexos: dois pequenos propileus coríntios de base retangular, que davam acesso ao interior da torre, e um circular, que continha a cisterna necessária para o funcionamento do relógio hidráulico. A disposição dos três anexos conferem ao edifício uma clara orientação sulnorte (dois propileus no sudoeste e sudeste, cisterna ao norte). Os muros se elevavam

\footnotetext{
${ }^{149}$ Disponível em: http://agora.ascsa.net/id/agora/image/1997.18.0336.

${ }^{150}$ Disponível em: http://agora.ascsa.net/id/agora/image/2002.01.2300.
} 
até um largo friso que continha figuras em relevo dos oito ventos - daí ser conhecida como "Torre dos Ventos"; o teclado cônico terminava em uma base de mármore para uma escultura móvel em bronze - segundo Vitrúvio, um tritão - que indicava, ao girar, qual era o vento que soprava. Abaixo do friso e até a altura dos capitéis dos propileus, ainda são observáveis linhas incisas formando ângulos variados, que funcionavam como um relógio solar. Considerando isso, pode-se tomar o Horologium como uma espécie de vitrine da ciência helenística, com uma clara preocupação de dar visibilidade às informações derivadas da concepção arquitetônica do edifício.

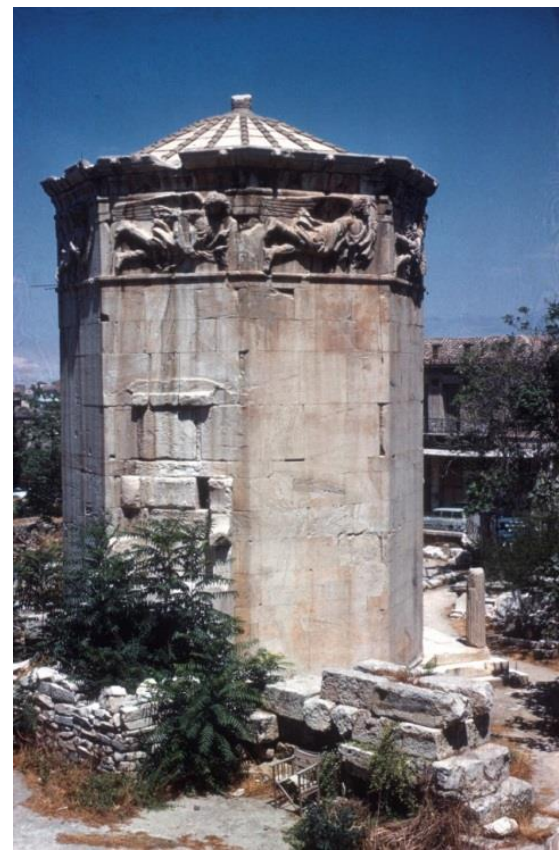

Figura 88. Fotografia da "Torre dos Ventos" a partir do noroeste, tirada em 1962 $\left(\mathrm{ASCSA}^{151}\right)$.

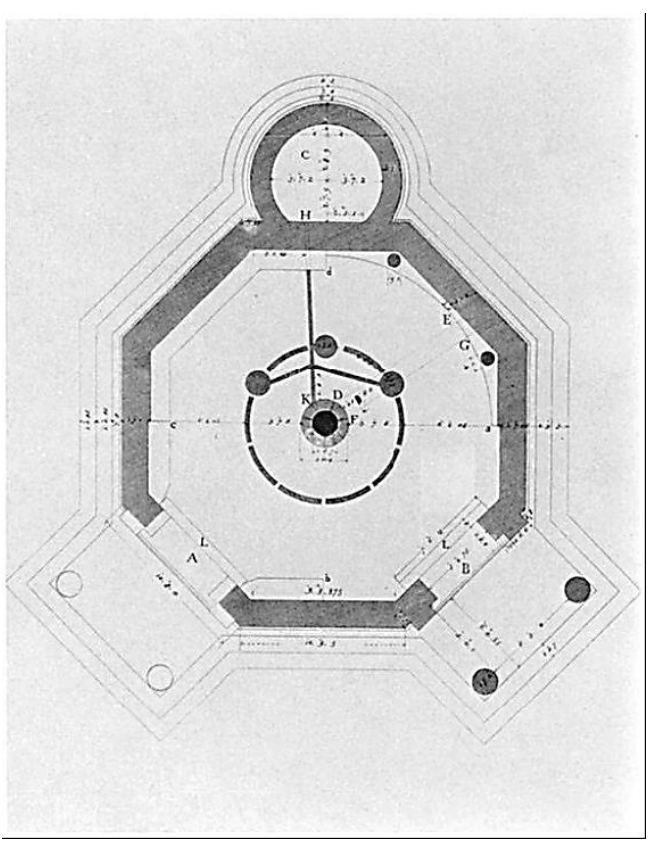

Figura 89. Planta da Torre dos Ventos, segundo Stuart e Revett em 1767 (Wikipedia Commons ${ }^{152}$ ).

A datação do edifício, sua atribuição a um doador ou à pólis e seu significado espacial são objeto de grande controvérsia ${ }^{153}$. O edifício já é mencionado por Varrão (de re rust. 3.5.17) e Vitrúvio (1.6.4), o que significa que já existia em meados do século I. Os interesses científicos de César, além da proximidade da torre à "ágora romana" (que foi financiada inicialmente por César), fizeram com que ele fosse considerado o doador

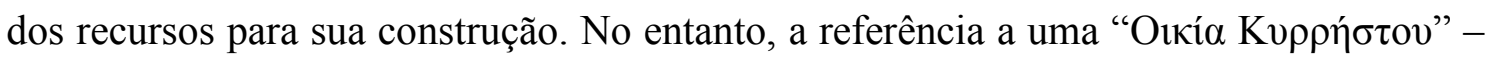
identificada ao Horologium - entre as restaurações do decreto IG II2 1035, datado do

\footnotetext{
${ }^{151}$ Disponível em: http://agora.ascsa.net/id/agora/image/2004.01.0388

${ }^{152}$ Disponível em: http://en.wikipedia.org/wiki/File:StuartRevettTowerLayout.jpg.

${ }^{153}$ Cf. Kienast, 1997, com bibliografia anterior. Também Tiveriou-Stefanidou, 2008.
} 
período augustano, indicaria que o edifício tenha sido construído em um tempo consideravelmente anterior a meados do século I, a ponto de já necessitar de restauração (Kienast, 1997, pp. 60-61). Neste sentido, uma data pré-Sula - entre o final do século II e início do I - parece razoável. Os poucos vestígios dos três anexos, que poderiam conter inscrições, além do caráter único do edifício na história da arquitetura grega, não permitem que se avance nenhuma hipótese quanto à identidade do doador.

A interpretação do significado espacial do Horologium não é mais simples, em virtude dos já mencionados dilemas topográficos derivados das raras escavações na área. A construção da "ágora romana", no final do século I, pode indicar que a área já era dedicada a atividades comerciais, o que justificaria a existência de um relógio público no local. Outra possibilidade é a existência de um ginásio nas proximidades, seja ele o Diogeneion (caso seja mais do que um santuário) ou mesmo o Ptolemaion: o relógio público serviria para a organização das atividades efébicas. Como já foi dito acima, somente a continuidade das escavações ao leste da Ágora Romana assegurar as hipóteses.

A intensa atividade construtiva em Atenas ao longo do século II promoveu uma radical rearticulação dos espaços públicos e monumentais, em particular na ágora, remodelada de acordo com uma estrutura ortogonal. Outras regiões, como a acrópole e a área do Olympieion, receberam novos investimentos construtivos com forte presençada propaganda monárquica helenística. A produção do espaço urbano ateniense se tornava, deste modo, intimamente relacionado às relações internacionais que se desenvolviam em um Mediterrâneo cada vez mais submetido a Roma. O evergetismo construtivo em Atenas no século II, entretanto, preservou pouquíssimos indícios da participação romana. Não obstante, o estabelecimento do evergetismo construtivo helenístico em Atenas, no contexto de construção da autoridade romana no Mediterrâneo, afetou profundamente o modo como os romanos se relacionaram com o espaço urbano ateniense, no complexo jogo entre as representações espaciais e as representações do espaço da cidade cultural e da cidade imperial, muito antes do novo período de intensa atividade construtiva no período augustano. Interpretar este período formativo das práticas espaciais romanas em Atenas, no quadro da crise do evergetismo helenístico, é o objetivo do próximo capítulo. 


\section{Capítulo 2. A formação da "Atenas}

\section{romana"}


A participação romana na produção do espaço urbano ateniense - se compreendida, prioritariamente, como atividade construtiva - apresenta uma grande ruptura na época de Augusto: esparsas intervenções construtivas e alguns projetos abandonados - que deixaram pouquíssimos vestígios - dão lugar a um amplo programa construtivo, fundado na construção de novos e reforma de antigos edifícios e monumentos, que alterariam profundamente a paisagem urbana ateniense e produziriam uma grande profusão de vestígios epigráficos e arqueológicos. Consequentemente, a bibliografia que teve objeto a "Atenas romana" concentrou sua atenção no período augustano, limitando a análise das intervenções associadas a Roma do período anterior - ou seja, pré-31 - a breves menções (cf. Introdução). Este desequilíbrio gerou um importante desvio nas interpretações: se o início do principado é a grande ruptura da história urbana ateniense, a chave de sua interpretação deveria ser buscada em Roma, e em particular nas expectativas e práticas da propaganda imperial e eventuais releituras da elite local (dentro do debate da "romanização"). Assim, independentes da "préhistória" das intervenções associadas a Roma em Atenas, as intervenções augustanas são apresentadas como inovações radicais dentro da nova conjuntura.

No entanto, se a produção do espaço urbano é compreendida em um sentido mais amplo, incluindo, ao lado da atividade construtiva, também a atividade destrutiva momento dramático de rearticulação de programas urbanos, eliminando lógicas e objetos do antigo e, simultaneamente, abrindo possibilidades para o novo - um outro marco rivaliza com a época augustana: o saque de Atenas pelo exército romano comandado por Sula em 86. Para além da eliminação das alternativas ao poder romano presentes no horizonte geopolítico ateniense até então, as destruições de 86 foram, conforme se argumentará, o fundamento de um relação espacial que se manifestaria de modo esparso e assistemático entre as décadas de 80 e 30, mas que formaria uma das bases do programa augustano: o urbanismo antiquário, marcado por uma preocupação mais ou menos acadêmica com as tradições arquiteturais e espaciais locais, e que terá na ideia de "restauração" um de seus eixos. As destruições de 86 fundaram a nova percepção da historicidade do espaço - replicando assim a invasão persa no século V ao mesmo tempo em que (literal e metaforicamente) abriram espaço para novas intervenções. É impossível, pois, compreender o grande programa construtivo augustano sem a formação deste potencial construtivo em 86, ou mesmo sem a formação de uma atitude antiquária nas décadas posteriores ao saque. Isto não significa, entretanto, que tenha ocorrido uma ruptura total com o programa urbano anterior, tardo- 
helenístico: pelo contrário, é na articulação deste novo programa em formação com o consolidado - mas transtornado - programa anterior que se encontra a chave para a produção de uma "Atenas romana".

Não se trata, entretanto, de simplesmente substituir um marco por outro e derivar a história urbana ateniense das vicissitudes da política romana de 86, e não 31 . O saque de Sula não foi a primeira manifestação de Roma no espaço urbano ateniense: algumas intervenções anteriores são atestadas, ainda que o caráter fragmentário e indireto da documentação seja um obstáculo considerável para sua análise. É o caso, por exemplo, para a possível existência de um santuário a Roma em Atenas (o Rhomaion), da inclusão - de datação incerta - da deusa Roma entre as divindades cultuadas no santuário do Demos e das Graças na ágora, e da construção de uma plataforma pelos/para os generais romanos na ágora em algum momento antes de 88/7. Estas três intervenções se relacionavam com o programa urbano anterior de modo complexo, pois se por um lado se associavam ao culto aos soberanos helenísticos, por outro implicavam tanto o culto a uma instituição (a cidade de Roma divinizada ${ }^{154}$ ), quanto a alteração da prática político-institucional da cidade (o pronunciamento dos generais para o povo na ágora, diretamente). As intervenções pré-86, além disso, se articulavam à própria construção da hegemonia romana sobre o Mediterrâneo oriental ${ }^{155}$, que teve em Atenas um ponto de referência importante, em particular a partir de 200, quando o exército romano, associado ao exército pergameno e ateniense, promoveu a defesa da cidade contra a invasão de Filipe $\mathrm{V}$ da Macedônia. A eleição de Atenas como ponto de referência da expansão romana se reforça em 168, quando Paulo Emílio derrota Perseu, último monarca da dinastia antigônida, e presenteia Atenas com a posse de Delos e outras ilhas do Egeu; o desenvolvimento de Delos como principal entreposto do Egeu será o fundamento para um grande ciclo de crescimento econômico em Atenas no final do século $\mathrm{II}^{156}$, representado tanto pelo sucesso da cunhagem de moedas de prata do chamado "novo estilo" (Thompson, 1961; Morkholm, 1984), quanto pela celebração de dispendiosas peregrinações para Delfos - as Pythais (Mikalson, 1998, p. 269-274). Entretanto, ao menos para a prática burocrática, outro marco foi mais decisivo: a lista

${ }^{154}$ Sobre o culto a Roma divinizada ou às instituições romanas, como o senado e o "povo", no Oriente grego, cf. Mellor (1975; 1981), Fayer (1976), Price (1984), Beard, North e Price (1998), Rochette (1998), Whittaker (2002).

${ }^{155}$ Para uma visão de conjunto do debate acerca da expansão romana no Oriente, cf. Eckstein (2006a), com bibliografia anterior; sobre a dominação romana em Atenas na primeira metade do século II, cf. Habicht (1997, 194-219)

${ }^{156}$ Sobre o impacto econômico de Delos para Atenas, cf. a discussão exaustiva de J. Day (1942, pp. 50109), atualizada em C. Habicht (1997, pp. 246-163). 
dos arcontes atenienses é reiniciada em 146/5, ano em que o exército romano, liderado por L. Mummius, derrota a Liga Aquéia, promove a destruição de Corinto e provincializa a Macedônia; apesar de não existirem vestígios de consequências mais diretas para Atenas, o impacto traumático da destruição de uma cidade vizinha parece estar na base do reinício da lista dos arcontes, símbolo da percepção de uma nova era ${ }^{157}$.

A construção de uma percepção da expansão romana como "necessidade histórica" - que tem em Políbio uma de suas mais exemplares formulações (Momigliano, 1991, pp. 27-50; Walbank, 2002, 2007; Sebastiani, 2006) - acabou por reforçar a estratégia geopolítica ateniense de investir em seu prestígio cultural como base para a aliança com Roma, em virtude de sua crescente insignificância militar; a eleição de Atenas como uma das referências para a expansão romana no Oriente é paralela à eleição da cidade como referência da cultura grega, que tem no decreto da Anfictionia de Delfos de 117/6, que louva os atenienses por terem levado o homem da "vida bestial" para a vida políade (IG II $^{2}$ 1134.16-20), sua manifestação extrema (Habicht, 1997, p. 278-279). Por um lado, a apropriação de aspectos da cultura grega por segmentos das sociedades italianas ao longo do século II (Veyne 1979; Ferrary, 1988, 517-526; Roman e Roman, 2005; Wallace-Hadrill, 2008, pp. 73-143), ao lado da prosperidade econômica da colônia italiana em Delos (Hasenohr, 2007), é um dos fundamentos para a crescente população de origem italiana - genericamente chamados em Atenas de "romanos" - na cidade (Charade, 2009); por outro lado, a abertura da efebia em 123/2, que paulatinamente começa a receber mais e mais efebos "romanos" (os quais, após receberem a educação física e cultural ateniense, seriam incorporados ao corpo cívico), é um dos fundamentos da consolidação de Atenas no lugar de "berço da civilização" na imagem ítalo-romana da Grécia a partir do final do século II (Pélekidis, 1962, pp. 186-196; Habicht, 1997, pp. 289-290; Perrin-Saminadayar, 2005, pp. 80-82).

A consolidação do poder romano sobre o Mediterrâneo oriental e a abertura de Atenas ao evergetismo e à presença romana no século II formaram o contexto fundamental para a construção de relações espaciais entre as duas cidades, que teriam, no ano de 86, um divisor de águas para suas modalidades e implicações materiais e simbólicas. Para melhor discutir este processo, o capítulo está organizado em três partes: a primeira trata das intervenções associadas a Roma antes de 86; a segunda trata

\footnotetext{
157 As listas de arcontes epônimos já havia sido reiniciada em 230/29, ano da libertação em relação à Macedônia, e seria novamente reiniciada em 87/6, na libertação contra o "tirano" Aristion; cf. Habicht (1997, pp. 270).
} 
do próprio saque de 86 e suas consequências materiais, a partir de uma discussão detalhada das fontes; a terceira trata das intervenções associadas a Roma após as destruições, mas antes do estabelecimento do principado.

\section{Antes do saque: as primeiras intervenções "romanas"}

Como dito acima, as primeiras intervenções espaciais de Roma em Atenas são terrivelmente mal documentadas: as pouquíssimas referências literárias, epigráficas e/ou arqueológicas muitas vezes não apresentam qualquer pista para sua datação, frustrando qualquer tentativa de determinação precisa de sua cronologia. Não obstante a escassez de vestígios e a abundância de dúvidas, a discussão destas intervenções é fundamental: elas se inserem no programa tardo-helenístico de modo peculiar, ora importando lógicas que lhes precederam, ora apontando para novas direções. Vejamos.

\section{O Rhomaion}

A hipótese de um santuário de Roma em Atenas ainda no século II foi sugerida apenas recentemente, e, no atual estado das escavações na região ao norte da acrópole, conta ainda com uma frágil base documental. A hipótese se baseia em uma nova interpretação da inscrição IG II $^{2}$ 958, encontrada no século XIX na igreja de Demétrio Kateforis (hoje demolida), então localizada na esquina entre as ruas Erechtheos e Kyrristou. Trata-se de um decreto honorífico pelo qual o Conselho e o Povo instituem uma série de honras para Miltíades de Maratona, pelo exercício do cargo de agonoteta da Theseia de 151/0: Miltíades receberá uma coroa de ouro e aclamações durante as Dionísias urbanas, a Panatenéia, a Eleusínia e a Ptoleméia. Além disso, o decreto determinava que Miltíades deveria receber um espaço para uma dedicação votiva em

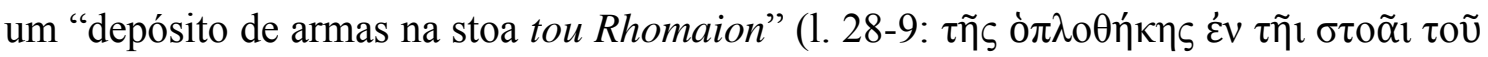

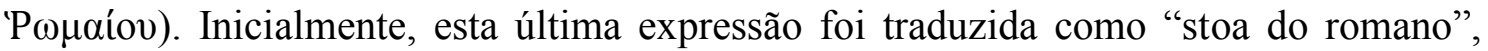

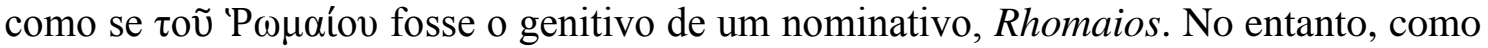
sugere fortemente C. Lasagni, este genitivo é melhor compreendido como derivado de 
um nominativo neutro, Rhomaion, assim indicando um santuário de Roma (Lasagni, 2008, com bibliografia precedente).

Se correta, esta hipótese dataria a construção de um santuário a Roma em meados do século II, cerca de cinquenta anos antes da primeira atestação de um sacerdócio de Roma em Atenas, datada de $103 / 2^{158}$. C. Lasagni propõe que a criação deste santuário estaria ligada aos ganhos territoriais de Atenas após a batalha de Pidna em 168, quando o general romano Paulo Emílio derrotou rei Perseu, rei da Macedônia (Habicht, 1997, pp. 213-219). Por seu apoio a Roma, Atenas recebeu a posse de Haliarto (Beócia) e das ilhas Lemnos, Imbros e Sciros no Egeu setentrional, e, mais importante de todas, a cíclade Delos, que haviam sido possessões atenienses antes do período de dominação macedônica. Esta anexação pode ter sido interpretada pelos contemporâneos, como sugere Lasagni, como um "novo sinecismo", no qual o evergetismo de Roma se equipararia aos atos de Teseu; tal hipótese é reforçada por uma das ilhas doadas ser, justamente, Sciros, onde teria morrido Teseu e de onde seu corpo teria sido retirado no século $\mathrm{V}$ e levado para um santuário próprio em Atenas, o Theseion (Plutarco, Cimon, 8.5-6). Isto, por um lado, explicaria a associação entre o Rhomaion e a organização da Theseia (a agonothesia de Miltíades mencionada no decreto); por outro, indicaria que o santuário estava localizado próximo ao santuário de Teseu, que Pausânias (1.17.2) menciona quando caminhava na região ao norte da acrópole. Mas é neste ponto que surgem mais uma série de problemas.

A região ao norte da acrópole, o atual bairro de Plaka, é um dos buracos negros da topografia ateniense, na medida em que a extensão das escavações é inversamente proporcional à importância que (se acredita) a região tinha na antiguidade. Por um lado, a esta área os topógrafos atribuem a localização do ginásio de Ptolomeu, do Pantheon de Adriano, de um santuário imperial, do ginásio ou santuário de Diógenes e do santuário de Teseu - ou seja, a região seria um polo de atividades ginasiais e religiosas fundamentais no calendário agonístico e nas relações da cidade com o poder romano e com sua própria história. Por outro lado, apenas pequenos trechos de fundações e poucos fragmentos arquitetônicos de edifícios aparentemente monumentais foram encontrados na região, em particular ao longo da rua Adrianou. Destes vestígios, destacam-se os fragmentos arquitetônicos do que J. Travlos identificou como sendo uma stoa, localizada próxima à área ao leste da Torre dos Ventos. Nas escavações dos

\footnotetext{
158 Sacerdócio de Pithilaos de Súnio, no arcontado de Theokleos, mencionado na lista dos contribuintes para a procissão para Delfos (Pyhtaidos) da passagem do século: SEG.32.218.41. Cf. Tracy, 1982, p. 213.
} 
anos 1950 e 1960 (Lippolis, 1995, p. 47, n. 12), foram encontrados fragmentos de colunas jônicas alongadas, além de poucos fragmentos de entablatura e colunas dóricas - que Travlos acredita terem sido reutilizadas na colunata interna da cela do Pártenon, após algum incêndio (Travlos, 1973). Baseado no formato dos fragmentos das colunas jônicas, extremamente próximas às colunas do segundo andar da fachada das stoas pergamenas em Atenas (de Eumenes e de Átalo), Travlos sugeriu uma datação de meados do século II, e a identificou à "stoa de Rhomaios" (ainda entendido como um certo "Romano") mencionada na inscrição de Miltíades.

Lasagni reforça a proposta de Travlos a partir da associação entre o santuário de Roma e o ginásio de Ptolomeu. Sua localização ao leste da Torre dos Ventos seria coerente com as propostas de localização do santuário de Teseu (as concessões romanas como o "novo sinecismo") e do ginásio de Ptolomeu, na medida em que uma inscrição (IG II ${ }^{2}$ 1938), datada de cerca de 150, lista em sequência os magistrados sacrificantes

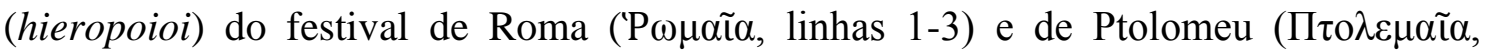
linhas 4-65). Uma questão não levantada pela autora é, justamente, a semelhança da coluna da stoa do suposto Rhomaion com as colunas da fachada superior da Stoa de Átalo II, o que poderia indicar a participação pergamena na construção de um santuário a Roma - que seria coerente com a íntima associação entre Pérgamo e Roma entre o fim do século III e início do II.

Finalmente, a autora adiciona dois argumentos de continuidade à hipótese: o primeiro, de que a associação entre o santuário de Roma e a figura de Teseu teria tido ecos na associação entre Sula e Teseu em 84, quando o festival do herói ateniense teria sido rebatizado como Sylleia por ocasião da passagem de Sula por Atenas, em retorno de sua vitoriosa campanha contra Mitrídates na Ásia (Raubitschek, 1951); o segundo, de que a região abrigaria, a partir de fins do século I a.C., um pólo do culto imperial romano com a construção da Ágora Romana e de um santuário dos imperadores (Sebasteion), que teria sede no edifício conhecido como Agoranomion ${ }^{159}$.

A hipótese é atraente, mas, como a própria autora reconhece, ainda apresenta uma série de problemas. O primeiro é que a inscrição de Miltíades seria a única referência conhecida, na tradição epigráfica e literária, a este santuário, o que seria improvável (ainda que não impossível). O segundo seria a datação da construção do santuário muito antes da evidência mais antiga do culto oficial a Roma, como

${ }^{159}$ Para a identificação do “Agoranomion” como Sebasteion, cf. Hoff (1994, 1996). 
mencionado acima - o que não impede que ele tenha existido antes de 103/2, mas pouco pode ser argumentado ex silentio. O terceiro é que, mesmo se a identificação dos fragmentos encontrados próximo à Torre dos Ventos como partes de uma stoa tardohelenística estiver correta, não necessariamente ela deva ser associada à stoa tou Rhomaiou mencionada na inscrição: o argumento de que a Rhomaia era celebrada junto da Ptolemaia se baseia no uso da mesma inscrição para listas magistrados de ambos os festivais, o que poderia significar, alternativamente, que eles foram realizados na mesma época ${ }^{160}$; e mesmo a localização do ginásio de Ptolomeu na região é questionável, como se viu na discussão da Praça Sul acima. A questão só poderá ser resolvida, de fato, com um projeto amplo de escavações no bairro de Plaka, ou com a descoberta de mais referências a um Rhomaion.

\section{O santuário do Demos, das Graças e de Roma}

Para além de um hipotético Rhomaion, outra possibilidade de sede espacial de um culto a Roma vem da adição da deusa Roma ao santuário do Demos e das Graças, localizado no limite noroeste da ágora ${ }^{161}$. Esta adição é claramente documentada apenas no período augustano, com base na inscrição em um assento do teatro de Dioniso que dava o direito de proedria ao "sacerdote do Demos, das Graças e de Roma" (IG II 5047) - contemporâneo ao assento reservado ao "sacerdote da deusa Roma e de Augusto César" (IG II ${ }^{2}$ 5114) - além de uma base de estátua dedicada, em Elêusis, ao "sacerdote do senado de Roma, do Demos e das Graças", datada do século I d.C. (IG II ${ }^{2}$ 3547). A questão central é, justamente, quando o culto a Roma foi adicionado. A hipótese mais óbvia, de fato, seria uma datação augustana, contemporânea à proedria concedida ao seu sacerdote. No entanto, os estudiosos tenderam a situar esta adição no século II $^{162}$, em associação à bem documentada existência de um festival dedicado a Roma (a Rhomaia: IG II ${ }^{2}$ 1938) e de sacrifícios “ao demos dos romanos” (Agora I 7188), mencionados em

\footnotetext{
${ }^{160}$ Mikalson defende que a Rhomaia e a Ptolemaia mencionadas em IG II2 1938 se referem aos festivais celebrados em Delos, e não em Atenas (Miklason, 1998, 274-5). Contra, Erskine (2000, pp. 125-6) e Lasagni (2008, p. 59 e n. 17).

${ }^{161}$ Cf. discussão no cap. 1; Monaco (2001).

${ }^{162}$ Cf. Ferguson (1911, p. 366), Mellor (1975, p. 23), Habicht (1997, p. 181), Monaco (2001, pp. 13-132) e, mais recentemente, Stephanidou-Tiveriou (2008).
} 
inscrições datadas de meados do século, assim como do sacerdócio de Roma mencionado na lista de contribuintes para a Pythais entre 103/2 e 98/7 (IG II 2336).

O santuário do Demos e das Graças, desde a sua criação no final do século III, estava diretamente associado à prática do evergetismo: era local de agradecimento, na forma de estátuas, decretos honoríficos e, possivelmente, rituais, a evergetas que haviam realizado facilitado, de algum modo, o contato de Atenas com as potências mediterrânicas (Monaco, 2001, pp. 120-129). À impressão de que o culto a Roma seria rebaixado ao nível dos intermediários do evergetismo, deve ser contraposto o fato de o culto a Roma era associado ao próprio Demos e às Graças, ou seja, estava no nível das divindades titulares do santuário. Neste sentido, Roma era colocada como um dos fundamentos da prática evergética, e não apenas como receptor do agradecimento poderia se tratar, portanto, de uma interpretação ritual local da realidade geopolítica mediterrânica, que tinha, de modo cada vez mais claro ao longo do século II, na dominação romana seu fator estruturante. Desse modo, pela adição ao santuário do Demos e das Graças, os atenienses teriam resolvido o problema de como cultuar uma comunidade - Roma, o povo romano - que era, de fato, muito mais poderosa e decisiva para a segurança de Atenas que as monarquias cujos soberanos eram cultuados como Heróis Epônimos, como a história das guerras no século II iria demonstrar.

A localização do santuário na entrada noroeste da ágora pode oferecer a chave para outros possíveis significados desta adição. Nesta área estavam localizados edifícios fundamentais tanto para a identidade e religiosidade políade quanto para o funcionamento da democracia ateniense ${ }^{163}$. O altar dos Doze Deuses era o ponto focal da Ática, a partir do qual todas as distâncias eram medidas; Píndaro o definiria como o "umbigo da cidade", apto a receber os deuses (Píndaro, frag 75.3). A Stoa Real era a sede do arconte-rei, magistrado responsável pela organização dos principais festivais religiosos da cidade e pelo julgamento de todos os casos de homicídio; na stoa estavam localizadas as leis de Sólon e ali eram realizados o juramento dos magistrados e eventuais reuniões do Conselho do Areópago (Thompson e Wycherley, 1972, p. 87). O arconte-rei era fortemente associado a Teseu, como é evidenciado pelo ritual da entrega

\footnotetext{
${ }^{163}$ Não tratarei aqui do recinto pentagonal localizado atrás da parte setentrional do muro posterior da stoa de Zeus: datado de cerca de 300, que não deixou qualquer vestígio arqueológico além de parte de seu muro setentrional e do corte na rocha natural da colina da Ágora, além de vestígios de atividades artesanais em estratos mais antigos. É possível que sua construção teria substituído um edifício destruído pela invasão persa em 480, provavelmente dedicado às refeições comuns dos magistrados atenienses (Monaco, 2001, p. 112). Se ele funcionava como um anexo à stoa de Zeus, como um recinto ligado ao santuário do Demos e das Graças, ou se era um santuário diferente, por exemplo, da Demokratia, a escassez de vestígios impede qualquer conclusão.
} 
de sua esposa para Dioniso durante o festival da Anthesteria, em referência à entrega de Ariadne ao deus por Teseu, quando retornava de Creta pouco antes de tornar-se rei de Atenas (Parker, 2005, pp. 303-305); ainda que este ritual não fosse realizado na própria Stoa Real - mas sim em um edifício localizado, provavelmente, ao leste da acrópole, na região da "ágora arcaica", o Boukoleion - as ligações da Stoa Real com o ciclo mítico de Teseu são evidentes a partir da descrição de Pausânias, que menciona a existência de imagens de cerâmica representando alguns dos feitos de Teseu em seu caminho de Trezena para a Ática (Pausânias, 1.3.1). Teseu também está presente na Stoa de Zeus Libertador, construída em cerca de 430, e em cuja parede de fundo havia, segundo Pausânias, uma pintura de Teseu, da Demokratia e do Demos, pelo qual, segundo Pausânias (1.3.3), os cidadãos saberiam que Teseu lhes havia dado "a igualdade cívica" ("َ̋ov $\pi 0 \lambda \imath \tau \varepsilon v ́ \varepsilon \sigma \theta \alpha \imath$ ). A inclusão do culto a Roma, deste modo, estaria associada profundamente tanto à organização cívica ateniense, quanto ao ciclo mítico de Teseu, o que corroboraria a hipótese de M. Monaco (2001, p. 132) de que a entrega de ilhas do Egeu a Atenas em 168 seria o motivo da homenagem a Roma no santuário do Demos e das Graças.

Uma série de indícios aponta, ainda que com pouca segurança, para uma associação entre o culto a Roma e o culto a Afrodite na região noroeste da ágora. $\mathrm{O}$ primeiro deles é o próprio altar de Afrodite Líder do Demos e das Graças, dedicado em 197/6 (IG II 2 2798). Outro é o corte retangular na rocha natural do limite setentrional da colina da Ágora que é atribuído, seja à existência de uma escadaria (fig. 90) que daria acesso, pelo norte, ao Arsenal helenístico (Pounder, 1983. P. 240), seja a um eventual templo (fig. 91), identificado, por I. Travlos (1949; 1980, p. 79), ao templo de Afrodite Urânia mencionado por Pausânias (1.14.7). Ainda que a proposta de Pounder seja plausível (caso o grande edifício retangular construído ao norte do Hehaisteion no século III seja, de fato, um Arsenal, seria de se esperar um acesso amplo ao Dípilo) a proposta de Travlos parece melhor fundamentada, em virtude não apenas da referência de Pausânias, como também da menção a elementos arquiteturais atribuíveis a um templo encontrados no local pelo escavador Th. Homolle em 1891, durante a construção da linha férrea (Travlos, 1949, p. 392). As fundações do "templo" datariam do início do período romano (Travlos, 1971, p. 79), mas teriam sido colocadas sobre um santuário anterior, do século III, como indica a existência de uma estatueta de Afrodite em forma de herma datada deste século e encontrada próximo às fundações (fig. 92), além da 
referência em Pausânias de uma estátua de culto feita por Fídias, no século V (Pausânias, 1.14.7).

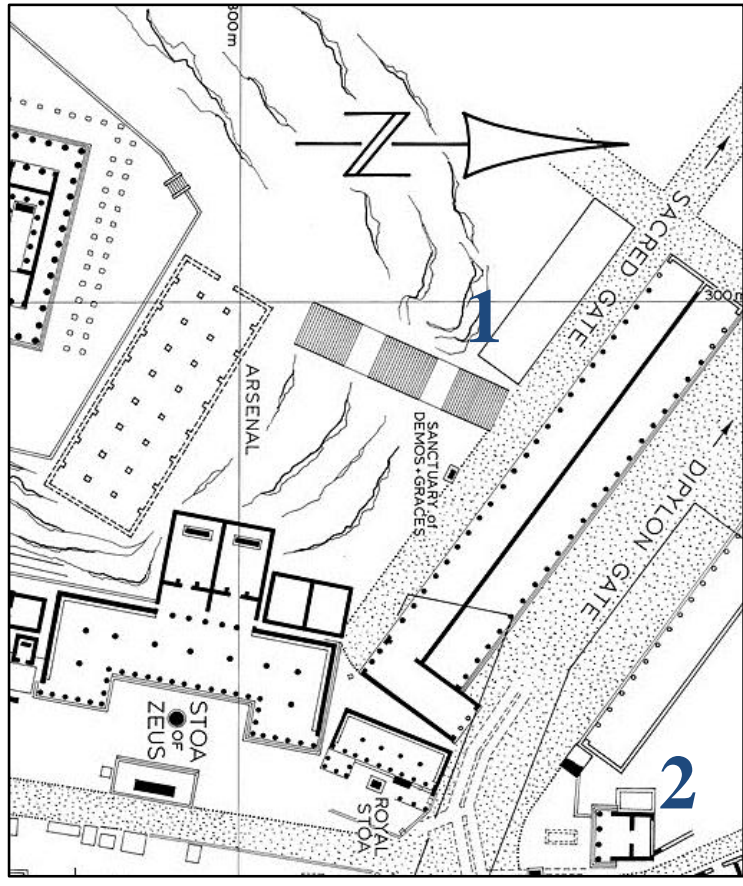

Figura 90. Detalhe da proposta de reconstituição da ágora ateniense no século II a.C., elaborada em janeiro de 1992 por R. C. Anderson (ASCSA ${ }^{164}$ ). 1. Escadaria de acesso ao "Arsenal Helenístico" (segundo R. Pounder). 2. Templo em pódio de Afrodite Urânia (segundo T. L. Shear Jr.).

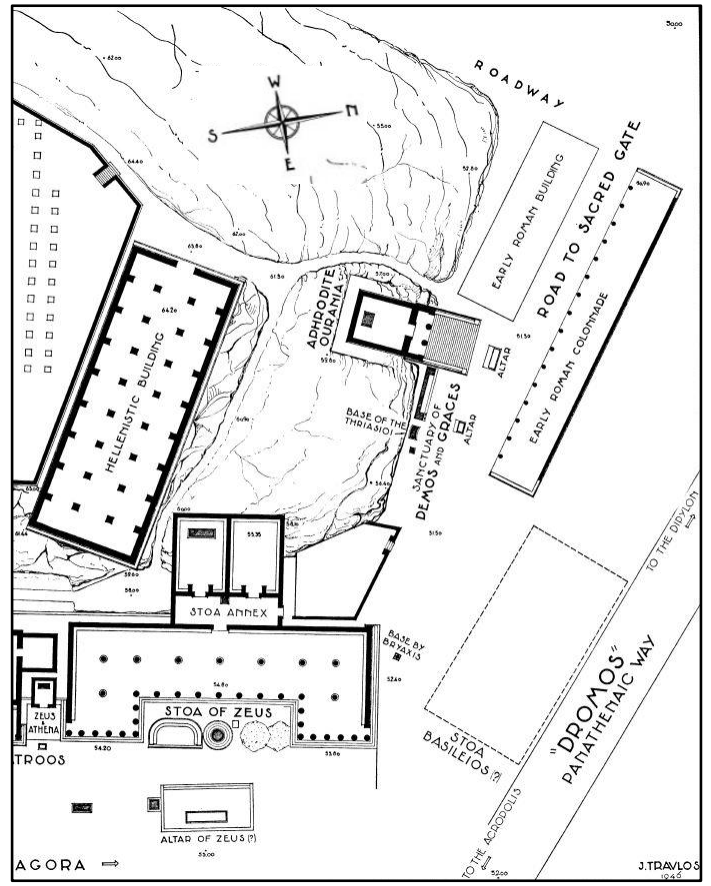

Figura 91. Detalhe da proposta de reconstituição da região noroeste da ágora elaborada em 1946 por I. Travlos (Travlos, 1949, fig. 2).

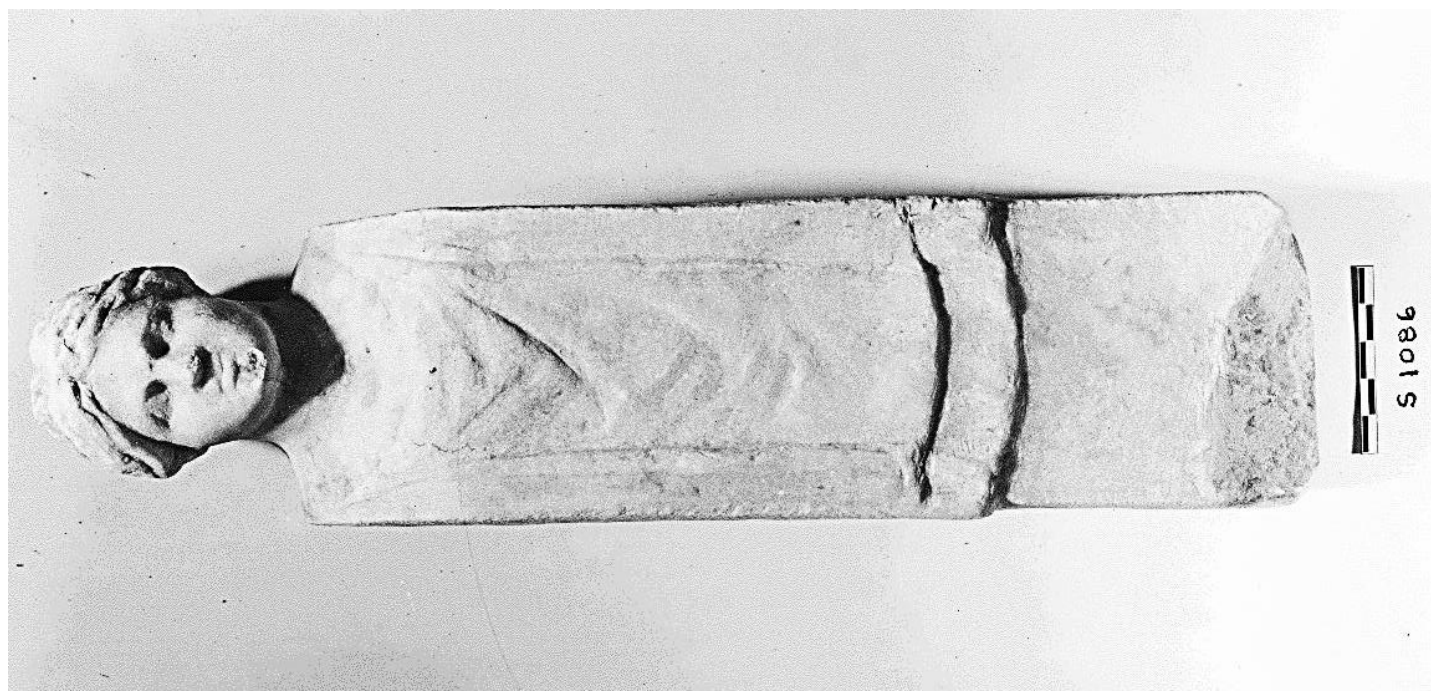

Figura 92. Estatueta identificada como "Afrodite Urânia" encontrada no noroeste da ágora (Shear, 1939, p. 239, fig. 37; $\operatorname{ASCSA}^{165}$ ).

${ }^{164}$ Disponível em http://agora.ascsa.net/id/agora/image/2002.01.2671.

${ }^{165}$ Disponível em http://agora.ascsa.net/id/agora/image/2002.03.0902. 
Na década de 1980, a ampliação das escavações para a região ao norte da moderna rua Adrianou revelaram um templo em pódio, de época augustana, construído alguns metros ao norte da fundação em questão e associado a um altar do século VI, e que foi identificado como o templo de Afrodite Urânia (Shear Jr., 1984; Camp, 1986, p. 57). Consequentemente, o corte retangular na Colina da Ágora passou a ser representado, nas plantas da ASCSA, como uma escadaria de acesso ao "Arsenal Helenístico". Entretanto, uma análise mais profunda conduzida por M. Osanna concluiu que o altar não poderia ser associado a Afrodite, por conta dos vestígios de sacrifícios animais incompatíveis com o culto à deusa, preferindo ver no altar - e no templo de época augustana - um santuário de Hermes Agoraios (Osanna, 1988). Tal identificação corresponderia tanto às referências a Hermes na tradição textual, quanto na própria posição de encruzilhada e limite da ágora. Alternativamente, um poço encontrado próximo às fundações (identificadas por Travlos) ao templo de Afrodite Urânia continha material funerário e votivo coerente com o culto de Afrodite Urânia, particularmente em suas variantes orientais (Osanna, 1988) ${ }^{166}$.

Caso esteja correta a proposta de Travlos de que existia um templo no corte da rocha natural da Colina da Ágora, e, mais do que isso, que este templo, construído em época augustana, é uma nova intervenção sobre o local de um templo anterior (do século $\mathrm{V}$ a julgar pela referência à estátua de culto feita por Fídias, ou do século III a julgar pela herma de Afrodite encontrada nas proximidades), não seria de se estranhar que a inclusão do culto de Roma ao santuário do Demos e das Graças estivesse intimamente ligada à proximidade deste santuário - cujo altar também foi dedicado a Afrodite Hegemone - com o santuário de Afrodite Urânia, fazendo assim referência aos mitos de fundação de Roma a partir da linhagem de Enéias, filho de Vênus. O fato de que a forma mais completa deste mito data da época augustana - a Eneida de Virgílio pode indicar a datação augustana tanto da inclusão de Roma ao santuário quanto da própria reforma do templo de Afrodite Urânia, mas isto não invalida que, antes mesmo, o culto de Afrodite Urânia tenha sido um dos principais vetores para a escolha daquele local como uma das primeiras aparições de Roma no horizonte religioso e espacial ateniense.

${ }^{166}$ A difusão da crítica de M. Osanna acabou por gerar uma curiosa combinação nas plantas mais recentes da Escola Americana: se por um lado se mantém a identificação de L. Shear Jr. do templo a oeste da stoa Pintada como templo de Afrodite Urânia, por outro a "escadaria" de acesso ao "arsenal helenístico" deu lugar às fundações de um templo, tal como na proposta de I. Travlos elaborada em 1946 e publicada em 1949, mas que não é numerada na planta ou mencionada nos textos (Camp, 2010, encarte). 
A partir das associações Teseu-Roma, por meio do novo sinecismo promovido por Roma com a doação de Delos e outras ilhas para Atenas assim como da defesa da liberdade e da democracia ateniense, e Afrodite-Roma, por meio do mito de fundação de Roma, é oportuno lembrar que a associação entre Teseu-Afrodite é parte fundamental dos mitos de fundação de Atenas: Egeu, pai de Teseu, fez votos a Afrodite para que fosse capaz de gerar um herdeiro para o trono, o que conseguiria em sua passagem por Trezena após a consulta do oráculo de Delfos (Pausânias, 1.14.7); Afrodite é a deusa que será tomada como guia (hegemone) de Teseu em sua expedição contra o minotauro, para cujo sucesso foi fundamental a paixão de Ariadne, filha de Minos (Plutarco, Teseu, 18.3; Apolodoro, Epítome, 1.8); a trágica morte de Hipólito, filho de Teseu e a amazona, teria suas raízes quando o jovem negara culto a Afrodite, por ter-se prometido apenas a Ártemis (Eurípides, Hipólito); e finalmente, foi o culto de Afrodite Pandemos ("todos os deme") que Teseu institui como base religiosa do sinecismo efetuado entre as aldeias áticas (Pausânias, 1.22.3), localizado na "ágora arcaica" de acordo com a Suda bizantina (s.v. Pandemos Afrodite), no que seria a leitura mítica do estabelecimento de Atenas como centro da Ática unificada. Deste modo, Roma, como novo Teseu, era incorporada no panteão ateniense por meio do diálogo com suas próprias tradições, com destaque para o papel de Vênus/Afrodite como ponte entre a cultura grega e a cidade latina.

A localização do novo culto de Roma justamente no final da principal via de entrada na cidade e pouco antes da ágora, para além das associações religiosas discutidas acima, se por um lado é uma estratégia fundamental de comunicação com os visitantes - ou seja, demonstrando a importância de Roma na reprodução da cidade por outro é uma metáfora espacial para outra entrada, de ordem etária, para a comunidade cívica: a efebia. Já foi ressaltado o papel do sacerdote do Demos e das Graças nas atividades dos efebos, e em particular na mais importante: o juramento efébico, tomando como testemunhas as Graças, e o recebimento das armas diante do Pritaneu. A inclusão de Roma, tendo ela ocorrido no século II - como parece provável ou depois, seria paralela à sua inclusão entre os evergetas aos quais os efebos (futuros membros da elite ateniense e, após 124/3, de elites de todo o Mediterrâneo) prestavam homenagens rituais. Roma, neste sentido, estava na entrada da ágora enquanto espaço físico e cívico - um exemplo eloquente do processo de interpretação religiosa e espacial dos limites e possibilidades para Atenas da dominação romana sobre o Mediterrâneo. 


\section{A plataforma "romana"}

A presença de uma plataforma para oradores no espaço aberto da ágora ateniense se baseia em duas evidências, uma literária e outra arqueológica. A primeira vem do Banquete dos Sofistas de Ateneu. O trecho em questão é parte de uma citação do historiador Posidônio de Apamea, que narra a instalação da "tirania" do filósofo ateniense peripatético e pró-mitridático Athenion sobre Atenas em $88^{167}$. Segundo o historiador, Athenion, após ter sido enviado como embaixador junto ao rei Mitridates VI do Ponto ${ }^{168}$, retorna a Atenas para ganhar o apoio da cidade à causa anti-romana do rei pôntico. Sendo recebido com grandes homenagens (cf. discussão abaixo), ele se dirige à ágora para discursar a uma multidão composta por atenienses e estrangeiros. Escreve Posidônio:

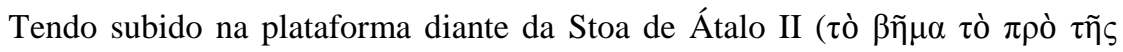

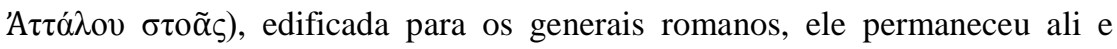
olhou para a multidão ao redor, e, encarando-a, disse: "Atenienses [...]" (Ateneu, Banquete dos sofistas, 5.50).

O texto segue com o discurso de Athenion e a narrativa de sua eleição como general dos hoplitas, efetivada quando a multidão deixa a ágora e se dirige ao teatro de Dioniso - transferência que será abordada mais a frente.

As duas referências espaciais fornecidas pelo texto - de que a plataforma estava diante da Stoa de Átalo II e de que uma multidão poderia se colocar ao redor para ouvir o orador - são compatíveis com o local onde foram encontradas, nas escavações de 1937, fundações de uma estrutura retangular medindo cerca de $50 \mathrm{~m}^{2}(8,5$ por $5,95 \mathrm{~m})$, com o lado mais longo paralelo ao eixo da stoa, com duas escadas nos dois lados menores, encontrada a poucos metros a oeste da base do "monumento do doador" da Stoa de Átalo II - o que fez com que de imediato o escavador a associasse ao bema mencionada por Posidônio (Shear, 1938, p. 324). A posição do bema, assim, permitiria que o orador se dirigisse a todo o espaço aberto da ágora. Tinha cerca de um 1, 5 metro de altura ${ }^{169}$; em função do declive do sudeste para o noroeste da ágora (fig. 93), havia

${ }^{167}$ Os diversos problemas envolvidos na análise de Posidônio serão abordados mais adiante.

${ }^{168}$ Sobre o uso do termo "Ponto" para a caracterização do reino de Mitridates, cf. Santangelo (2007).

${ }^{169}$ Os vestígios de escadas em ambos os lados da plataforma não esclarece quanto ao número, e portanto a altura da plataforma só pode ser hipotética. Com cinco degraus de cerca de 30 centimetros de altura e profundidade em cada um dos lados menores, o nível superior teria um metro e meio de altura. 
uma diferença de cerca de 5 metros na altura do solo do sul para o norte da fachada da stoa, o que fazia com que o orador estivesse na mesma altura ou um pouco abaixo dos ouvintes à sua esquerda, acima daqueles que estavam na faixa à frente, e bastante acima daqueles que estavam à sua direita.

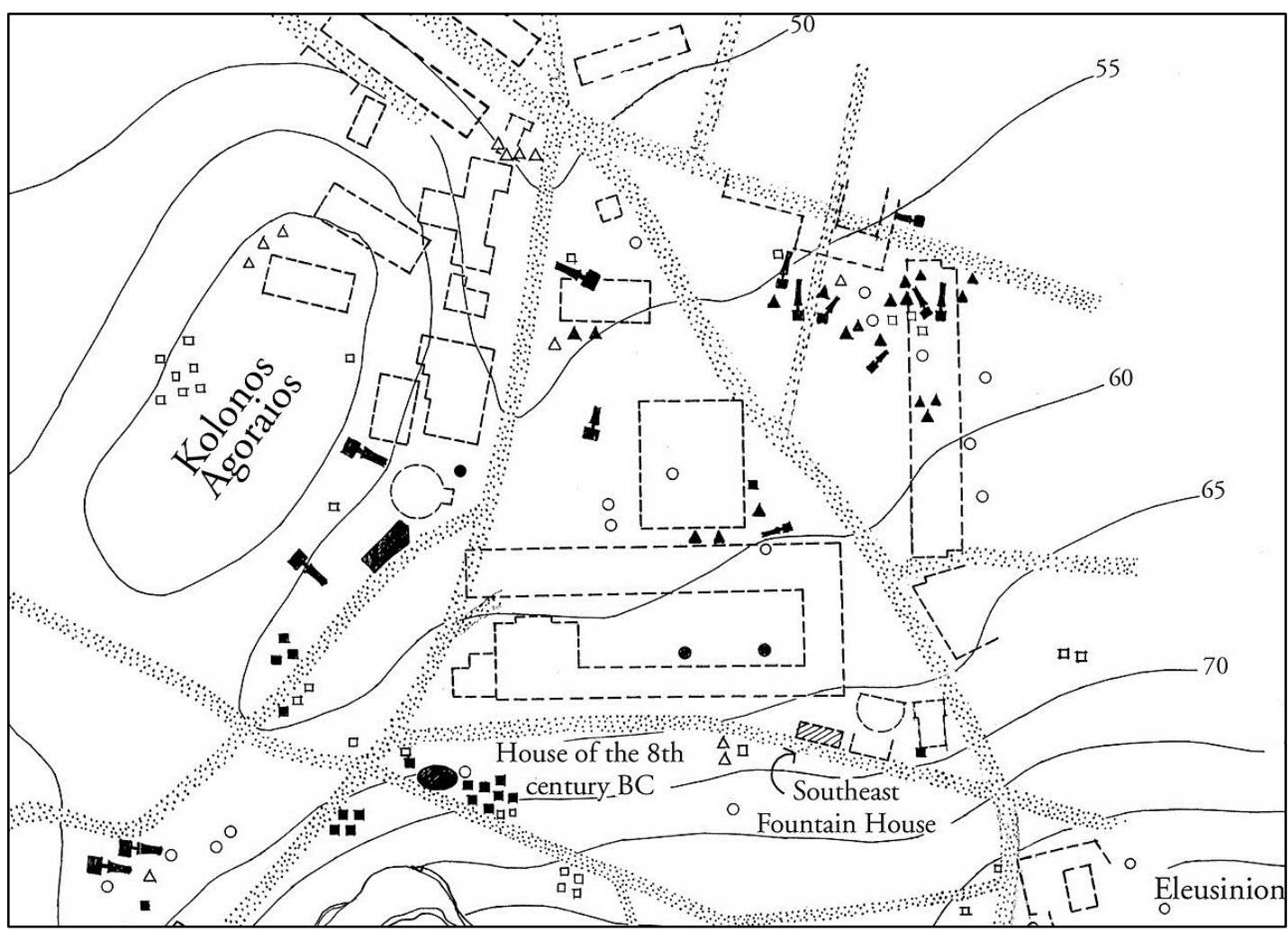

Figura 93. Detalhe de planta com curvas de nível da ágora e arredores, indicando enterramentos pré-arcaicos, elaborado por I. Travlos em $1975\left(\right.$ ASCSA $\left.^{170}\right)$.

Não tão clara, por outro lado, é a questão da iniciativa da edificação da plataforma: Posidônio usa o dativo sem preposição para marcar os generais romanos, interpretado normalmente como dativo de interesse ("edificada para os generais romanos"), o que pressuporia que não foram os generais romanos, mas sim os atenienses que edificaram a plataforma no interesse dos generais (Habicht, 1997, p. 294); alternativamente, foi proposto que se trata de um dativo instrumental de causa, indicando que a plataforma foi edificada pelos generais romanos (Dickenson, 2012, p. 391, n. 1670). Na medida em que são documentadas edificações de plataformas tanto por generais romanos quanto por membros das elites locais (Dickenson, 2012, pp. 38992), e também em função da escassez de vestígios e mesmo da ausência de um relato

${ }^{170}$ Disponível em: http://agora.ascsa.net/id/agora/image/2002.01.1196. 
exaustivo dos $\operatorname{achados}^{171}$, não é possível determinar com precisão a iniciativa da plataforma.

A pobreza dos vestígios e dos relatos é inversamente proporcional à importância explicativa que o "bema romano" conquistou em algumas interpretações de seu significado político e urbanístico - o que não é por acaso, pois, desconsiderando-se as hipóteses do Rhomaion e da inclusão de Roma no santuário do Demos e das Graças, discutidas acima, o bema seria a primeira intervenção urbana ligada diretamente a Roma em Atenas. Explorarei aqui duas interpretações diametralmente opostas: uma que vê no bema romano uma reminiscência da democracia clássica (Shear, 1981), e outro que vê no bema um indício da romanização e oligarquização da política ateniense (Dickenson, 2012).

Em texto sobre as intervenções urbanas associadas a Roma em Atenas, o então diretor das escavações da ágora ateniense T. Leslie Shear Jr. situa o bema em um momento de ruptura radical:

$[\ldots]$ by its capacity to accommodate great crowds of citizens, the open square itself palpably symbolized that democratic process which Athenians always considered their most distinguishing characteristic. The builders of the great Hellenistic stoas of the 2 nd century not only respected the ancient tradition of the open square but in fact sought to define it more tangibly by placing the Stoa of Attalos and the Middle Stoa precisely at right angles along its borders, and with their approaches at exactly the point where the Panathenaic Way bisected the southeastern angle of the square. Even as late as the 1st century B.C., there was a place of assembly in the Agora, and orators harangued the crowds from a speaker's platform erected for the Roman generals in front of the Stoa of Attalos. But to the Agora of the Roman period all this is foreign, for beginning in the reign of Augustus the entire public square came to be occupied by buildings and monuments.24 It is as clear a statement of the new order in the world as can be made through the medium of architecture. [...] The frenzied assemblies of 88 B.C. had pitched Athens into the turmoil of the Mithradatic Wars on the losing side, and it is almost as if in rejoinder that the builders of the new era seem determined to obliterate that symbol of Athenian democracy, the market square itself, in order to reflect the vanished reality. [...] (Shear Jr, 1981, pp. 360-1).

${ }^{171}$ Como bem observado por Dickenson (2012, p. 409), as fundações são mencionadas em um parágrafo do relatório de escavação (Shear, 1938, p. 324) e em uma nota na síntese de Thompson e Wycherley (1972, p. 51, n. 157). 
Para Shear Jr., o bema romano é uma reminiscência da democracia clássica, ainda que erigida para os generais romanos; o discurso de Athenion, interpretado como discurso de uma "assembleia", marcou justamente o fim das condições reais da democracia em Atenas - ao tomar partido do lado perdedor - e o anúncio do preenchimento da área central da ágora, ao mesmo tempo impedimento material das assembleias e metáfora do fim da democracia. O bema e o ano de 88 seriam assim marcos que dividem quatro séculos de democracia do resto do período imperial em Atenas, reduzida de "city-state" a "provincial town".

A interpretação de Shear Jr. tornou-se amplamente aceita, ainda que com ressalvas $^{172}$. Uma crítica radical só apareceria em 2012, com a tese de C. Dickenson, que derruba a interpretação de Shear com dois argumentos centrais: em primeiro lugar, o bema não pode ser interpretado como "reminiscência", na medida em que não há base documental para provar que ocorriam assembleias na ágora; em segundo lugar, as intervenções do período augustano não preencheram todo o espaço da praça pública, pois, mesmo com o Odeion, ainda havia um espaço ao redor do bema comparável à fase 2 (sécs. V e IV) da Pnix (Dickenson, 2012, pp. 397, 402-410). Alternativamente, Dickenson interpreta a instalação do bema e o discurso de Athenion como um movimento "na direção de um modo mais romano de conduzir a política local” (2012, p. 397).

A interpretação é baseada em dois argumentos principais: (1) o bema era um monumento claramente romano, e era compreendida como tal, e (2) o bema cria um espaço de reunião mais adaptado a um modo oligárquico de prática política. Para defender o primeiro ponto, o autor retoma as evidências de plataformas no mundo romano e grego. Uma matriz seria os rostra do fórum romano, onde, somente a partir do século II, tais plataformas passaram a ser usadas com o orador voltando-se para a área central do Fórum, e não somente para o Comitium $^{174}$. Mais do que isso, a instalação de plataformas nas praças públicas de cidades conquistadas por (ou para) generais romanos é atestada nas fontes literárias: além de Atenas, há notícia do mesmo ocorrendo na cidade de Auxinium (atual Osimo, próximo de Ancona, na costa oriental da Itália) por

${ }^{172}$ Cf., por exemplo, as análises de T. Stefanidou-Tiveriou (2008) e S. Alcock (2002). Um exemplo recente de aceitação integral é o capítulo de M. Hoff (2013) sobre Atenas e Corinto para o Companion to the Archaeology of the Roman Republic.

${ }^{174}$ Sobre o debate se a plataforma usada para as assembleias no fórum eram os rostra ou o pódium do templo de Castor e Polux, cf. Patterson (1992, pp. 190-2) e Dickenson (2012, pp. 388-389). 
iniciativa de Pompeu (Plutarco, Pompeu, 6.3), e em uma (indeterminada) cidade no Mediterrâneo oriental por iniciativa de Antônio (Plutarco, Antônio, 58.6). Na Síria, o rei Antíoco IV Epifanes construiu em meados do século II umo bema em Antioquia, conforme relatado por Políbio: segundo o historiador, Antíoco por vezes andava pela ágora "apertando mãos de alguns e abraçando outros, insistindo para que votassem nele como edil ou como tribuno", e quando ele assumia o cargo e "se sentava no trono de marfim de acordo com o costume romano, ele ouvia os casos que tinham lugar na ágora e dava seu veredito com grande seriedade e atenção" (Políbio, 26.1) - comportamento que justificaria o epiteto de Epimanes, marcando a loucura de um rei que viveu como refém por cerca de 10 anos em Roma. Por fim, o único caso registrado epigraficamente é o do bema de Argos, erigida por um certo Soikrates filho de Menandro, que acumulava os cargos de agoranomos, tameas e grammateus ${ }^{175}$, entre o final do século II e início do I; a influência romana sobre esta medida de Soikrates é usualmente sugerida, mas não há qualquer evidência direta.

Quanto ao segundo argumento, Dickenson lança mão de uma "psicologia espacial" quando argumenta que, falando a partir do bema, o fato de o orador literalmente ver o povo de cima para baixo reforçava seu aspecto aristocrático, por oposição à disposição teatral, na qual o orador falava para um auditório que se erguia acima do nível do proscênio. Além disso, o caráter honorífico e aristocrático do bema em Atenas, como os rostra do fórum romano, era reforçado pela sua associação aos monumentos ao redor: atrás do orador estava o "monumento do doador" da Stoa de Átalo II, um pilar que provavelmente sustentava uma quadriga de Átalo desde meados do século II até que, no século I d.C., fosse substituída com uma estátua representando o imperador Tibério; próximo ao bema estariam as colunas honoríficas do século II e I dedicadas a generais romanos, fazendo com que o orador se colocasse no nível visual dos homenageados, do ponto de vista do ouvinte (Dickenson, 2012, pp. 394-5, 399401).

A romanização/oligarquização da política ateniense, (re)produzida material e simbolicamente pelo bema romano, teria também manifestações na articulação constitucional - com a proeminência do Areópago - e na composição das elites, cada vez mais acumulando cargos cívicos e religiosos à moda romana (Dickenson, 2012, p.

\footnotetext{
175 Agoranomos: magistrado encarregado da ágora, especialmente em relação às transações comerciais; tameas, magistrado encarregado das finanças públicas; grammateos, espécie de secretário público, encarrego especialmente da legislação.
} 
400). Desse modo, o autor interpreta o bema também como um marco, mas no sentido oposto ao sugerido por Shear Jr:

The city had indeed been transformed into a provincial town and in what follows I will argue that one of the main functions of the agora of a Greek provincial town under the Empire was to serve as the venue for public gatherings, and in particular legal hearings. Rome, far from banishing such meetings from the agora, continued to provide a model for them to be used in this way, both in the way public space was used in Rome itself and in the way the fora were used in the Roman colonies in Greece. The meetings that were held on agoras may not have been Classical assembly meetings but they were occasions through which power was mediated and negotiated between the elite and the masses and gave subject citizens more of a voice in the determination of their destinies than has been recognized for the period (Dickenson, 2012, p. 410).

As reflexões de Dickenson sobre o bema - assim como sobre as ágoras em geral - são fundamentais para uma consideração mais complexa do fenômeno. No entanto, alguns limites devem ser apontados. Em primeiro lugar, à diferença da atitude em relação às bemata helenísticas e romanas em outras cidades, o autor não considera aquelas existentes e utilizadas na própria cidade de Atenas, o que limita a percepção da peculiaridade do bema romano. Curiosamente, ainda que o autor compare com profundidade a área da Pnix e dos arredores do bema romano na ágora, ele toma o teatro de Dioniso como protótipo da "assembleia democrática" em detrimento da Pnix, que apresenta, como se verá, diversas semelhanças com o "oligárquico" bema romano. Em segundo lugar, o autor fetichiza o bema e reifica a prática política, derivando do suporte material as relações sociais e políticas, que são oligárquicas ou democráticas, dependendo da altura do auditório! Esta abordagem, além de fazer com que alguns eventos centrais na história política ateniense sejam incompreensíveis, limita a consideração sobre as estratégias e as táticas envolvidas nas diferentes possibilidades de uso e de representação dos suportes materiais.

Basta considerar, em primeiro lugar, a semelhança do terreno da Pnix e do entorno do bema romano. Na fase 2 da Pnix (sécs. V e IV), os ouvintes posicionados num raio de cerca 16 metros estariam abaixo do nível do orador; aquele posicionado junto ao muro de contenção, a 58 metros de distância do orador, estaria pouco menos de 4 metros acima. No caso do bema romano, o ouvinte posicionado na área meridional da 
ágora ficaria cerca de 1,5 metro acima do orador, enquanto que aquele posicionado na área setentrional ficaria cerca de 2 metros abaixo. A altura do orador em relação aos ouvintes na Pnix era ampliada pelo uso de assentos, o que dificilmente ocorreria na ágora. Além disso, deve ser lembrado que a disposição do bema romano para o leste indica que o orador deveria se voltar para o lado mais amplo da ágora, e não o mais baixo (norte). Desse modo, não há diferenças radicais da altura do auditório em relação à altura dos bemata entre a Pnix e a ágora, como existe entre as duas e o teatro de Dioniso, e nem por isso as assembléias do século $\mathrm{V}$ deixariam de ser consideradas democráticas.

Em segundo lugar, a comparação entre o bema romano e o teatro de Dioniso não é definitiva: o teatro poderia ser utilizado como espaço de manifestação de eventos absolutamente contrários à democracia. Um caso célebre em Atenas é a tomada de Atenas por Demétrio Poliorcetes em 295: de acordo com Plutarco (Demétrio, 34), após o cerco imposto por Demétrio à cidade, os atenienses enviam embaixadores para negociar a rendição; Demétrio ordena que todos os cidadãos deveriam ir ao teatro, cerca o teatro com seus soldados, e, a partir do palco ("como os atores trágicos", diz Plutarco), pronuncia seu perdão aos atenienses e procede a uma distribuição de trigo. Em troca, a cidade oferece o porto do Pireu, que terá uma guarnição macedônica até $229^{177}$. Em terceiro lugar, ainda que se aceite que a política ateniense se tornou mais oligárquica ao longo do século I, isto não impedia que as assembleias continuassem a ser realizadas no teatro de Dioniso.

Em síntese: Dickenson critica corretamente a associação entre democracia e ágora como espaço de reunião na interpretação de Shear $\mathrm{Jr}$, mas incorre em um equívoco semelhante ao associar de modo reificado a democracia ao teatro e a oligarquia ao bema. Muito mais que isso, o significado do bema se relaciona aos poderes implícitos e explícitos de quem tem o direito de fala. Os constrangimentos materiais de um bema na ágora se aplicam mais à organização do discurso do que a seu conteúdo político; o uso do bema por generais romanos significava, por um lado, que a cidade estava submetida ao domínio romano, e por outro, que este domínio se

177 Outro testemunho eloquente, ainda que não tenha ocorrido em Atenas, é o verdadeiro espetáculo político realizado por Mitridates VI em Pérgamo, no qual o rei, sentado em um trono no palco, seria coroado por uma estátua da Vitória que descia, por meio de um mecanismo, em sua direção - seria, pois a estátua se quebrou em vários pedaços, anunciando a derrota do rei para Sulla (Plutarco, Sula, 11); para o uso monárquico dos teatros no período helenístico, cf. Strootman (2007, pp. 251-347). Dickenson (2012, p. 396) discute o uso do teatro como espaço de apresentação monárquica, mas o faz no contexto da discussão sobre a ágora como local de reunião, e não retoma o ponto em sua defesa do teatro como espaço "mais democrático" em si. 
manifestava na ágora em eventos não regulares, diferentes das assembleias realizadas no teatro. A oligarquização da política ateniense não deve ser vista na utilização da ágora como espaço de reunião política por meio do bema, mas, pelo contrário, na alteração da relação entre as diferentes instituições, e em particular no fortalecimento do Areópago, cujo enfraquecimento no século $\mathrm{V}$ foi uma das principais condições para a democracia radical do período clássico.

Dito isto, vale a pena comparar com mais detalhe o bema romano com as outras bemata conhecidas em Atenas, de modo a compreender de modo mais substancial seu significado espacial e urbanístico. O "bema romano" era - a partir da documentação epigráfica, arqueológica e literária disponível - a quarta estrutura utilizada como plataforma para oradores. Outras três plataformas conhecidas são as plataformas do Bouleuterion na ágora, a da colina da Pnix, e o proscênio do teatro no santuário de Dioniso.

A região dos edifícios que sediaram, em diferentes momentos, a reunião do Conselho ateniense, foi intensamente escavada desde o início do século XX; apesar disso, nenhum traço de bema foi encontrado - ou identificado - na área dos edifícios que sediaram o conselho em Atenas. Apenas uma pequena referência na tradição textual nos informa sobre sua existência: o orador ateniense Antifonte, no discurso em defesa de um membro do conselho e coreuta pronunciado provavelmente em $419^{178}$, menciona uma plataforma no Bouleuterion sobre o qual o acusador e um de seus acusadores conversaram à vista de todos os conselheiros (6.40). A datação do discurso não deixa claro a qual Bouleuterion o autor se referia: o "antigo Bouleuterion", construído no início do século VI sobre as fundações de edifícios identificados como sedes das magistraturas pré-democráticas ${ }^{179}$, deixou de ser a sede do "Conselho dos 500" no final do século V, quando um "novo Bouleuterion", pouco menor, foi construído poucos metros a oeste do antigo, que se tornaria, até sua reformulação no século II, no espaço do arquivo cívico e do santuário da Deusa Mãe (Metroon). Apesar disso, é de se esperar que, na medida em que apresentavam estruturas semelhantes, ambos apresentassem plataformas de oradores. Se esse for o caso, a plataforma estaria localizada na entrada

\footnotetext{
${ }^{178}$ Cf. a discussão em Maidment (1941, pp. 234-7) e Meritt (1961, p. 210-2).

${ }^{179}$ Um edifício construído no início do século VI (o edifício C) e outro no terceiro quartel do mesmo século ("edifício D), com um pátio entre eles fechado por um muro que levava até o famoso "edifício F", que já foi sugerido como o "palácio de Psístrato" (Camp, 1986, p. 44-45; para a história da região, cf. Thompson e Wycherley, 1972, pp. 25-38). O fato do "antigo Bouleuterion" manter a ligação com o "edifício F" e ter a mesma orientação do templo arcaico (Metroon?), ambos com fortes indícios de terem sido destruídos em 480, leva sua datação para o período pré-invasão persa.
} 
no saguão principal após o vestíbulo, no centro de uma estrutura em formato de cavea teatral - no caso do "antigo Bouleuterion", formada por arquibancadas de madeira, e no caso do "novo", por estruturas de bancos associadas à criação de um declive artificial na direção leste produzido na preparação do solo original (Thompson e Wycherley, 1972, p. 32). O acesso à área, desde a época dos edifícios do século VI, era restrito à abertura de um muro; cerca de um século depois da construção do "novo Bouleuterion", foi construído um propileu jônico que monumentalizava a passagem. Esta separação entre a área do conselho (Bouleuterion e, a partir do século V, Tholos onde se reuniam os prítanes) e a ágora fazia sentido pela própria estrutura de funcionamento das instituições, restritas aos conselheiros sorteados para determinado ano. Dessa forma, a única plataforma na ágora do período clássico estava em um contexto fechado e restrito a algumas centenas de cidadãos.

Diferente era o caso da plataforma da Pnix, colina onde se realizavam as reuniões da assembléia - que poderiam chegar aos milhares de participantes - a partir do século VI até o período helenístico, quando as reuniões são feitas majoritariamente no teatro do santuário de Dioniso. As intervenções construtivas na encosta nordeste da Pnix tem três fases de construção (Thompson, 1932; Thompson e Wycherley, 1972, pp. 48-52; Travlos, 1971, pp. 466-76). A primeira, datada do final do século VI e associada às reformas de Clístenes, é marcada pelo aproveitamento do declive natural da colina, no sentido sul-norte, formando um semicírculo semelhante a um auditório teatral, para a qual se voltava o orador, cuja plataforma estava posicionada em um terraço artificial; o auditório ocupava cerca de $2400 \mathrm{~m}^{2}$. A segunda fase, datada do final do século $\mathrm{V}$, foi marcada pela inversão da posição da plataforma: um novo e maior (c. $2600 \mathrm{~m}^{2}$ ) terraço de planta semicircular foi construído, suportado por um espesso muro de contenção, com um leve declive na direção norte-sul (ou seja, o oposto da fase anterior); a plataforma foi colocada no centro do limite sul. Mantendo a mesma disposição, a terceira fase, efetivada entre 330 e 326, se caracterizou pela ampliação do terraço em área (c. $5500 \mathrm{~m}^{2}$ ), o que ampliou a altura do muro de contenção, e pelo corte na inclinação natural da colina, criando uma grande parede rochosa ao longo de uma linha reta que fechava, no limite sul, o terraço semicircular; ao centro desta parede foi posicionada a novo bema (conservada em bom estado até a atualidade); além disso, na área acima da parede rochosa foram construídas duas novas stoas, e entre elas um altar de Zeus Agoraios. A alteração de disposição do final século V é normalmente associada ao regime dos "Trinta", que instituiu a oligarquia em Atenas entre 405/4 e 404/3; a 
motivação teria sido fazer com que o orador falasse voltado para o interior da Ática, e não para o mar, como ocorria na disposição anterior (Plutarco, Temístocles, 4). O fato é que, após a restauração da democracia, a disposição não foi alterada; pelo contrário, no século IV, provavelmente como parte do programa licurgueano, ela foi monumentalizada com um novo muro de contenção e com stoas no terraço superior. A distância da Pnix para a ágora - de onde os cidadãos normalmente partiam para a assembléia ${ }^{180}$ - era de cerca de 500 metros, por uma via que partia do canto sudoeste da ágora e passava a oeste do Areópago. Ainda que diferente quanto à ausência de cobertura e área total em relação ao Bouleuterion, a Pnix também apresentava a necessidade de controle de acesso. Hansen (1996) sugere que isto era feito a partir de cercas de vime - os gerra mencionados por Demóstenes (59.89) - colocados diante da escadaria de acesso ao auditório e/ou em uma determinada área do terraço do auditório, e retirados quando não eram mais necessários.

A Pnix deixou de ser utilizada como espaço da assembléia entre os séculos III e II, quando o teatro de Dioniso assumiu esta função ${ }^{181}$. Com isso, a cena ou mais provavelmente o proscênio do teatro era utilizado como bema. Uma questão frequentemente levantada pelos arqueólogos é, justamente, porque a assembleia desde o princípio não tinha lugar no teatro de Dioniso, dadas as facilidades acústicas e visuais da encosta sul da acrópole ${ }^{182}$. O santuário de Dioniso apresenta diversas fases de construção: na fase 1, datada de meados do século VI, foram construídos o templo de Dioniso e um muro semicircular que aproveitava a encosta da acrópole como auditório; no entanto, na medida em que as competições teatrais e musicais tinham lugar na ágora, este espaço provavelmente era dedicado aos rituais específicos do culto dionisíaco. $\mathrm{Na}$ fase 2, de meados do século V, a área semicircular é ampliada e é construído o Odeion de Péricles junto à extremidade leste do muro. Nas fases 3 e 4 os assentos do auditório (bastante ampliado) são revestidos de mármore, e também surgem um edifício de cena de pedra, um novo templo e uma stoa dórica na área meridional do santuário. A fase 5 é marcada por pequenas alterações no edifício de cena no período helenístico (possivelmente no século II, contemporaneamente à construção da Stoa de Eumenes). O século I é marcado pelas destruições no contexto do cerco de Sula em 86 e pela

\footnotetext{
${ }^{180}$ Cf., por exemplo, Aristófanes, Acarnânios, 21.

181 Assembleias no teatro de Dioniso, ainda que em número reduzido, são atestadas no período clássico (p.ex., Ésquines, 2.61).

${ }^{182}$ Thompson, por exemplo, descreve a transferência da Pnix para o teatro como vitória do bom senso (Thompson e Wycherley, 1972, p. 50).
} 
reconstrução do Odeion de Péricles em meados do século; novas construções (fase 6) aparecerão somente no período neroniano. É justamente na fase 4 (período helenístico, em particular o século II) que aumentam consideravelmente as inscrições que mencionam as reuniões da assembleia no teatro, o que faz com que McDonald date deste século o abandono da Pnix (1943. P. 60). Na mesma direção, Dickenson (2012, p. 396, n. 1687) lembra que Athenion, em seu discurso a partir do bema romano (Ateneu,

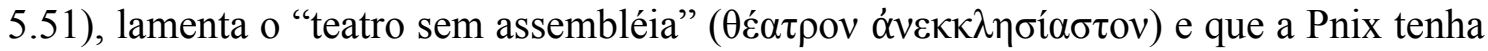

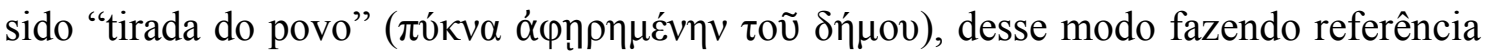
possivelmente à cessação (permanente) do uso da Pnix e (temporária) do teatro de Dioniso como espaço de assembléia. Não por acaso, após ouvir o discurso de Athenion,

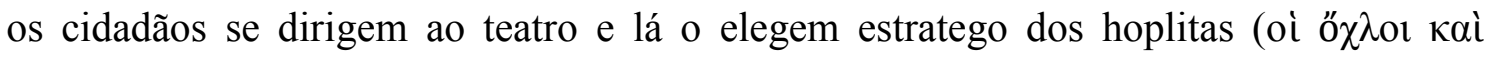

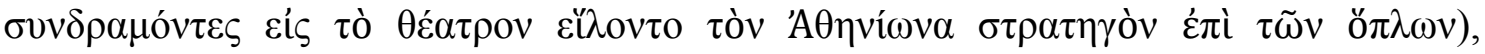
indicando que o teatro seria o espaço ainda adequado para a realização de assembleias. $\mathrm{O}$ acesso ao teatro era restrito: na fase 1, possivelmente em função do caráter de santuário do terraço semicircular, e a partir da fase 2 por um muro que continuava a parede de contenção das extremidades do auditório e permitia a entrada somente pelo parodos na parte mais baixa.

Estas quatro plataformas apresentam, cada uma, diferentes relações com o ambiente construído e com o espaço circundante. O bema do Bouleuterion estava dentro de um edifício coberto, limitado em todos os lados por paredes de pedra; era ponto focal da comunicação no saguão principal do prédio (reforçado por arquibancadas ou por assentos dispostos de acordo com os declives artificais), saguão este que se comunicava com o exterior através de uma porta que dava para o vestíbulo do edifício, que estava inserido, por sua vez, em um complexo de edifícios estatais e religiosos separado da área aberta da ágora por um muro. O bema da Pnix era também o ponto focal da comunicação, na fase 1 posicionada sobre um terraço artificial que aproveitava, como auditório, o declive natural da coluna, e nas fases 2 e 3 de frente a um declive artificial gerado por cada vez maiores trabalhos de terraceamento; estava a céu aberto, o que, além dos problemas vinculados à acústica e ao clima, também diminuíam a privacidade da reunião ${ }^{183}$. Outro bema ao ar livre era o do teatro de Dioniso, já inserido dentro de um contexto arquitetônico otimizado tanto para a recepção de milhares de pessoas

\footnotetext{
${ }^{183}$ É atestada a presença de não cidadãos como espectadores da assembleia ateniense (Demóstenes, 59.89; Ésquines, 3.224; Aristófanes, Assembleia das Mulheres, 243); Hansen conjectura que os não-cidadãos ficariam no terraço superior da Pnix, acima do nível da bema, ao sul.
} 
quanto para a melhor escuta e visualização do orador, em função da elevação do auditório, muito mais intensa que aquela da Pnix; o teatro mantinha seu isolamento como santuário, o que não impedia de modo radical a visualização do que ocorria no interior por aqueles que estivessem fora tanto no nível da cena quanto acima do auditório, no peripatos da acrópole.

As peculiaridades do bema romano são evidentes. A ágora, que apresenta um declive sutil e irregular do sul para o norte, não era utilizada para apresentações teatrais e musicais há muitos séculos; além disso, não são atestadas reuniões de debate e deliberação da assembleia na ágora - apesar do senso comum ter sido construído na direção contrária ${ }^{184}$. A céu aberto como a Pnix e o santuário de Dioniso, o bema romano, diferentemente, não apresentava fronteiras ao acesso de quem quer que estivesse na área central da ágora - ou pelo menos tais fronteiras não são visíveis arqueologicamente nem foram mencionadas na tradição literária. Desse modo, a conversão do espaço em frente ao bema romano em auditório estava vinculada à apropriação cotidiana do espaço: era preciso que outras atividades cessassem e que um determinado arranjo espacial das pessoas se produzisse para que o bema funcionasse, em um momento específico. O conteúdo destes momentos seriam limitados por uma acústica de pouca qualidade, tanto em função da pouca e irregular inclinação do "auditório", quanto da abertura do espaço da ágora em si e em relação à cidade - seria preciso um silêncio sepulcral não apenas na ágora como também em seus arredores para que grandes multidões compreendessem discursos longos com argumentação rebuscada. Neste sentido, é indicativo que os únicos usos atestados do bema romano fossem de comunicados com forte conteúdo militar: aqueles realizados por generais romanos, que se podem inferir da afirmação de Athenaion de que o bema teria sido erigida por eles, e o próprio comunicado de Athenion em 88, que usa a plataforma para brevemente informar sobre os avanços de Mitrídates e traçar um panorama dos prejuízos causados por Roma a Atenas. O bema romano, portanto, se insere em um contexto de comunicação pública irregular, não regrada por um calendário de reuniões como no conselho ou na assembleia, mas por circunstâncias que podem ser desde a passagem de um general romano, ao qual não é dado o direito de se pronunciar na assembleia, ao discurso de um embaixador que catalisaria uma mudança geopolítica.

${ }^{184}$ Cf. a discussão em Hansen e Fischer-Hansen (1994). Um evento intimamente ligado à assembleia e que ocorria na ágora era o ritual do ostracismo; no entanto, o debate e a decisão de realiza-lo se faziam nos espaços tradicionais da assembleia, seja na Pnix ou no teatro de Dioniso. 
Dickenson, com base em uma leitura muito particular de uma passagem de Posidônio, sugere que o bema, pelo contrário, fazia com que a ágora se tornasse o local para a realização de assembleias regulares, "em emulação à situação do fórum romano" (Dickenson, 2012, p. 396). A passagem em questão é a seguinte:

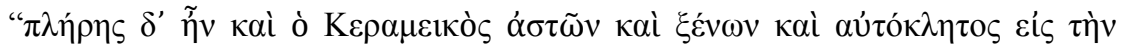

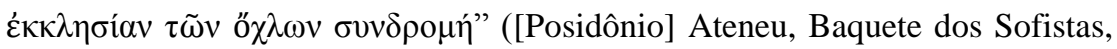
5.49)

que Dickenson traduz como:

The Kerameikos was full of citizens and foreigners, and the crowds converged spontaneously upon the place of assembly (ekklesia) (Dickenson, 2012, p. 396).

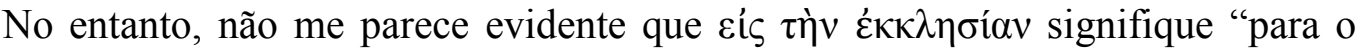
local da assembleia", e não simplesmente "para a assembleia", sem indicar com isso a institucionalização da ágora como local da assembleia ${ }^{185}$. Prova disso é o destaque que Posidônio coloca no fato de que cidadãos e estrangeiros estavam na ágora e que ambos se dirigem para a assembleia, sem qualquer referência à separação entre eles para que a assembleia cumprisse seu requisito básico, ou seja, de ser composta apenas por cidadãos. Dickenson interpreta a ida dos atenienses da ágora para o teatro como um "retorno simbólico ao passado", o que não é necessariamente o caso: a caracterização do teatro de Dioniso como "sem assembleia" por Athenion, para além dos problemas retóricos, não deixa claro a qual período ele se refere - se aos anos do arcontado em sequência de Medeios do Pireu (91-88) ou às décadas anteriores. Em outro momento, Dickenson claramente defende o uso do bema e da ágora como espaço para reuniões públicas como audiências judiciais (2012, p. 410), e não assembleias, a partir de evidências provenientes de outras cidades e de períodos posteriores. Isto posto, a afirmação de H. Thompson de que "não há nada que indique que [o bema] tenha sido usada mais do que ocasionalmente" continua válida (Thompson e Wycherley, 1972, pp. $51-52)$.

${ }^{185}$ Não há um marcador espacial claro, como ocorria, com frequência, quando se fazia referência a

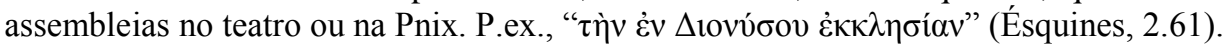


Em suma: parece-me que deve ser mantida a interpretação dos eventos que tiveram e que poderiam ter tido lugar no bema como essencialmente diferentes das assembleias, prescindindo da separação entre cidadãos e não cidadãos, como era possível na Pnix e no teatro. É preciso, mais do que isso, atentar-se aos dois eventos referidos no relato de Posidônio: um genérico, qual seja, o uso do bema pelos generais romanos, e outro específico, o discurso de Athenion contra Roma. Em ambos os casos, Roma é o referencial, seja legitimando o orador (generais), seja estruturando a oposição de seu discurso (Athenion). Neste sentido, pode-se desenvolver o problema da "romanização" da ágora por meio do bema em direção diversa daquela apresentada até aqui. Diferente de tomar a emulação do fórum como causa da construção (Dickenson, 2012, p. 396), é preferível observar tal construção à luz dos processos paralelos que ocorrem em Roma e Atenas entre o final do século II e o início do I: não uma simples passagem da democracia para a oligarquia mas, pelo contrário, o rearranjo e eventuais crises das oligarquias em Atenas e em Roma, geradas seja pela contestações populares, seja pelo aparecimento de indivíduos particularmente poderosos. Não por acaso, o uso dos rostra em Roma voltado para o fórum, e não para o Comitium, está associado às reformas populares propostas pelos Gracos; até o período de Augusto, os rostra serão espaços fundamentais na comunicação política dos grandes generais e ditadores com a plebe romana.

Talvez essa seja a chave para a compreensão da política ateniense do período imediatamente anterior ao discurso de Athenion (Ballesteros Pastor, 2005; AntelaBernardez, 2009a, 2009b, 2009c). Por um lado, temos notícia de uma grande rebelião de escravos em 100 (Tracy, 1979), possivelmente associada à anarquia - ou seja, a ausência de um arconte epônimo, sinônimo de crise política - deste mesmo ano (IG II ${ }^{2}$ 1713.12). Por outro, a eleição por três anos consecutivos do mesmo arconte epônimo algo sem precedentes na história ateniense - nos anos 92//92, 91/89 e 89/88 são indicativas não apenas de uma crise política, mas de um poder extraordinário conquistado por um indivíduo, Medeios do Pireu (Antela-Bernardez, 2009b). O "modo romano de se conduzir a política local" seria, pois, aquele que concentra em poucos indivíduos um poder sem precedentes, de modo que o bema seja vista e utilizada como forma mais adequada de comunicação entre estes indivíduos e a massa. Esta pode ser a chave, também, para o apoio ateniense a Mitridates: a massa age politicamente homenageando e legitimando o poder de Athenion que se torna uma espécie de tirano anti-romano, em comparação aos pequenos tiranos pró-romanos do período anterior. 
Trata-se, em todo caso, de uma crise da oligarquia estabelecida entre o final do século III e II, fundada na aliança entre as elites locais e as monarquias estrangeiras e reproduzida por meio do evergetismo - em particular, do evergetismo construtivo - e que teve, entre seus principais articuladores, a família de Euricleides e Mícion; a crise se dá, justamente, no processo de afirmação da nova articulação evergética de determinadas famílias na direção de Roma.

\section{O saque de 86: destruições e recomposições}

A primeira grande intervenção urbana atribuída com segurança à iniciativa romana é, ironicamente, a destruição de diversos edifícios e monumentos atenienses realizada durante a invasão da cidade pelo exército romano, liderado por Lúcio Cornélio Sula, em 86 a.C., no contexto da chamada "Primeira Guerra Mitridática" (88-86). O significado destas destruições não se limita à história dos edifícios afetados, mas tem um alcance maior na posição de Atenas na rearticulação do Mediterrâneo oriental sob o domínio de Roma. A conversão da diplomacia ateniense para a causa mitridática em 88 , os governos pró-mitridáticos de Athenion e Aristion ${ }^{186}$, e a invasão de Sula são momentos centrais para a reflexão do modo pelo qual a história urbana ateniense é engajada e entrelaçada nas transformações ligadas à rearticulação do Mediterrâneo oriental sob dominação romana, assim como às transformações da própria república romana.

Este momento decisivo é conhecido por uma documentação particularmente rica. Da tradição textual, temos: uma narrativa da tirania de Athenion em um fragmento das Histórias de Posidônio, escrito em meados do século I a.C., citada no quinto livro do Banquete dos Sofistas (211d-215b) de Ateneu, escrita entre o final do II e início do III d.C.; duas breves passagens na Geografia de Estrabão $(9.1 .15,20)$, escrita entre o final do século I a.C. e o início do século I d.C.; uma narrativa do cerco de Atenas por

\footnotetext{
${ }^{186}$ Uma das questões mais debatidas pela bibliografia específica do saque foi se Athenion e Aristion eram dois nomes atribuídos à mesma pessoa, ou se se tratava de duas pessoas diferentes. A confusão nasce pois Athenion aparece em apenas um relato (Posidônio), onde Aristion não é mencionado, enquanto Aristion aparece em todos os outros (Estrabão, Plutarco, Apiano, Pausânias). Mantenho aqui a proposta de Bugh (1992), segundo o qual tratavam-se de duas pessoas diferentes que governaram Atenas subsequentemente (primeiro Athenion, depois Aristion), reforçada por diversos argumentos entre os quais a identificação do "arconte Athenion" na inscrição IG II2 1334, se correta, parece ser o mais eloquente (Verdejo Manchado e Antela-Bernardez, 2011).
} 
Sula presente da Vida de Sula (13-14) de Plutarco, além de breves menções à tirania de Aristion ou ao saque de Sula em quatro outras obras: as vidas de Lúculo (19.6) e Numa (9.4-5), Sobre o atraso da punição divina (558c) e Preceitos políticos (809e), escritos entre o fim do século I e o início do II d.C.; uma breve menção à resistência ateniense nos Anais (2.55.1) de Tácito, escritos no início do século II d. C; uma narrativa do cerco de Atenas presente no livro sobre as Guerras Mitridáticas (28.40) da História Romana de Apiano, de meados do século II d.C.; uma breve narrativa do cerco na Descrição da Grécia (1.20.4) de Pausânias, escrita na segunda metade do século II d.C.; uma breve passagem na Epítome de História Romana (I.40.10) de L. A. Floro, escrita em meados do século II d.C.; uma breve passagem no sumário da obra de Tito Lívio (Periochae, 81), cuja datação varia do século II ao IV d.C.; uma breve passagem sobre o cerco no Breviário de História Romana (5.6.1) de Eutrópio, escrita na segunda metade do século IV d.C.; uma breve passagem sobre o cerco na História contra os pagãos (6.2.4-5), de Orósio, escrita no início do século V d.C.; uma breve passagem no Livro sobre os homens ilustres da cidade de Roma (75.7), de Pseudo-Aurélio Vitor, escrito no século IV d.C. Destas referências, apenas quatro contam com uma extensão considerável e tratam mais detidamente do aspecto espacial do saque, e por isso serão analisadas com mais detalhe: Posidônio/Ateneu, Plutarco, Apiano e Pausânias. Todos os outros autores mencionam apenas de passagem o episódio, em função seja da narrativa das guerras mitridáticas, seja da caracterização de Sula ${ }^{187}$.

Em relação às fontes materiais, as escavações na ágora forneceram um grande número de indícios de destruição associada à invasão em 86 (Hoff, 1997), além de ter acrescentado uma grande quantidade de evidência para a série da chamada "tetradracma de prata do novo estilo", cujas inscrições e relevos no reverso, a cada ano, são documentos imprescindíveis para a reconstrução das tensões dos anos imediatamente anteriores e posteriores à invasão (Thompson, 1960). Finalmente, diversas inscrições revelam detalhes sobre a composição dos grupos governantes do período. Tanto as fontes materiais quanto as fontes literárias serão discutidas na medida em que trazem elementos para a discussão da produção do espaço urbano ateniense.

${ }^{187}$ Com duas exceções importantes: Estrabão faz duas pequenas menções ao episódio discutindo ora a muralha, destruída por Sula (9.1.15), ora as tiranias em Atenas, mencionando Aristion (9.1.20); Tácito, por sua vez, reproduz o discurso de Piso em Atenas em 18 d.C., quando este recriminara os atenienses por terem se aliado a Mitridates contra Sula, e a Antônio contra o divino Augusto (2.55.1). 


\section{Filosofia e tirania em Posidônio/Ateneu}

A passagem em questão de Posidônio está citada no quinto livro da obra Banquete dos Sofistas, de Ateneu de Náucratis, escrita entre o fim do século II e início do III d.C. (Braund e Wilkins, 2000; Wilkins, 2008). A obra, composta por 15 livros, é um relato feito por Ateneu a Timócrates de um banquete realizado, em Roma, na casa de Larensis, funcionário imperial e bibliófilo, ao qual compareceram dezenove intelectuais de diversas áreas, da poesia à medicina, do direito à história. Ao longo do relato, Ateneu reproduz um grande número de citações feitas pelos convivas, retiradas principalmente de autores gregos, sobre os mais diversos assuntos relacionados ao banquete. Tais citações foram durante um longo período o elemento que mais atraiu a atenção dos estudiosos, que encontraram na obra de Ateneu, com bastante sucesso, uma das principais ferramentas para sugestão e verificação de atribuições de autoria para diversos textos gregos preservados em outros suportes, assim como a coleta de fragmentos de autores cujas obras não sobreviveram de modo independente; a consideração da obra como um conjunto coerente e original, e não apenas uma coletânea de citações, é recente (Braund e Wilkins, 2000; Wilkins, 2008).

Muito se discutiu sobre a caracterização e contextualização da obra. Sua forma peculiar - relato de um banquete repleto de citações oriundas de diversos autores e épocas - revela as influências tanto do Banquete de Platão quanto da literatura de viagens (da qual a Periegesis de Pausânias é o principal exemplo preservado), na medida em que o autor viaja pela história e pela cultura grega através das indicações topográficas das citações e de vários mecanismos de "navegação" literária (Wilkins, 2008). O caráter livresco da obra, apresentando uma organização bibliotecária, se articula com a ênfase na tradição literária característica da Segunda Sofística (Bowersock, 1969; Bowie; 1970; Anderson, 1993; Borg, 2004; Eshleman, 2008). O enquadramento da narrativa, porém, aponta para uma direção bastante específica. $O$ banquete ocorre em Roma, na casa de Larensis, caracterizado por Ateneu como um alto funcionário do reinado de Marco Aurélio, especialista em assuntos religiosos e ávido colecionador de livros, que reunia constantemente estudiosos de todos os assuntos; ainda que centrado na tradição grega, os temas tratados na obra dão conta de um amplo espectro espacial, fazendo com que a casa de Larensis se torne o duplo literário da 
síntese produzida por Roma como metrópole imperial (Wilkins, 2008, p. 149), respondendo assim às críticas feitas à rusticidade romana frente à cultura grega ${ }^{189}$.

A relação entre Ateneu e seus fontes não é, por sua vez, isenta de problemas ${ }^{190}$. $\mathrm{O}$ autor certamente tinha acesso a uma grande quantidade de originais e cópias, nas bibliotecas seja de Roma, seja, principalmente, de Alexandria. No entanto, quando outras versões dos textos originais sobreviveram de modo independente (p.ex., Heródoto), é perceptível que Ateneu muitas vezes intercala citações sem as devidas indicações de autoria e pertinência (Pelling, 2000, 175-6). Uma hipótese avançada por C. Pelling é que Ateneu seguia o princípio da paráfrase, comum na historiografia grega, tendo como horizonte a reprodução das intenções do autor, e não necessariamente suas palavras exatas (Pelling, 2000, p. 175; Gorman e Gorman, 2007). No caso da citação de Posidônio, um obstáculo intransponível é dado pelo fato de que não há outra versão da mesma passagem; desse modo, concordamos com G. Bugh quando este afirma que "the extract as it is preserved in Athenaios cannot really represent what Poseidonios originally wrote" (1992, p. 110). Neste sentido, é imprescindível considerar o contexto específico no qual a citação se insere, ou seja, a lógica geral do livro V de Ateneu ${ }^{191}$.

Este livro é composto por uma longa fala de um certo Masurius, poeta e jurista de conhecimento enciclopédico (1C), sobre vários aspectos do banquete, que vão da caracterização dos banquetes em Homero (185A-193C) à discussão da opulência dos monarcas helenísticos que, entre outras coisas, ofereciam banquetes (193D-210C). Neste contexto, Marusius se volta para a questão da participação de filósofos nos banquetes monárquicos (210D-211D); de modo algo abrupto, traz a história de Atenion, filósofo peripatético que se tornou tirano em Atenas (211E-214B). A fonte básica para esta digressão é Posidônio, que já havia sido citado acerca dos banquetes reais sírios; Masurius afirma que fará a citação para que "cuidadosamente examinemos todos aqueles que afirmam ser filósofos e não acreditemos apenas em seus casacos

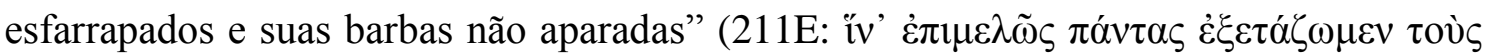

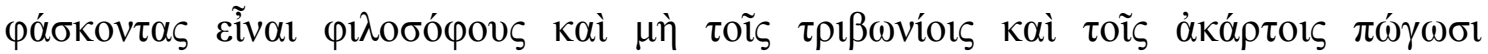
$\pi \imath \sigma \tau \varepsilon v ́ \omega \mu \varepsilon v)$. Após a citação, Masurius dá o exemplo de mais um filósofo que havia se

\footnotetext{
${ }^{189}$ Da parte de escritores latinos como Horácio, Juvenal e Petrônio, entre outros (Wilkins, 2008, 150 e n.79).

${ }^{190}$ Sobre Ateneu e os historiadores, cf. Braund e Wilkins (2000). Uma discussão bastante interessante sobre a historicidade de vários elementos do relato de Posidônio se encontra em Ballesteros Pastor (2005).

${ }^{191}$ Exemplo disso é a recorrente citação de Posidônio com base apenas nos fragmentos recolhidos por F. Jacoby (1926) e L. Edelstein e I. G Kidd (1989), deslocado de seus contextos específicos.
} 
tornado tirano - Lísias de Tarso, epicurista - para então iniciar uma longa discussão sobre a participação militar de Sócrates e a falta de rigor historiográfico de Platão e Xenofonte (215A-221A). Após algumas breves considerações - repletas de diletantismo - de outros convivas e do anfitrião, os convivas começam a deixar o ambiente e o festim acaba (221B-222F).

Antes de analisarmos com detalhe a citação de Posidônio, é preciso considerar os dados disponíveis sobre sua vida e obra (Strasburguer, 1965). Estima-se que Posidônio viveu entre a segunda metade do século II e a primeira do século I; nascido em Apamea, na Síria, morou em Rodes tempo suficiente para tornar-se chefe da escola estóica da ilha, cidadão e embaixador, cargo pelo qual partiu para Roma em missão diplomática no ano de 88/7. Escreveu livros sobre diversos assuntos, entre os quais uma continuação das Histórias de Políbio, tratando da história universal de 146 a $88^{193}$, dividida em 52 livros, da qual só sobraram fragmentos citados em autores como Estrabão e Ateneu.

É provável que tenha vivido em Atenas por volta de 110, onde teria tido lições com o estóico Panécio de Rodes. Em Roma, teve contato com figuras proeminentes como Mário, Pompeu e Cícero, além da família dos Marcelli. Tais contatos, aliado ao fato de ter escrito uma continuação da obra de Políbio, são indícios importantes para a hipótese segundo a qual uma de suas preocupações principais era, justamente, discutir o sentido da dominação romana na Grécia e no mundo civilizado. A. Momigliano, por exemplo, sugere que o espaço de tempo entre Políbio e Posidônio fez com que "a identificação de interesses das classes ricas e instruídas gregas com a sobrevivência do império romano se tornara evidente por si mesma" (Momigliano, 1991, p. 38). Desse modo, uma discussão sobre o apoio ateniense a Mitridates se explicaria não somente em função da imbricação de seus desdobramentos para a guerra mitridática e a própria carreira de Sula, como também como momento decisivo da afirmação da ordem romana na Grécia. É possível, neste sentido, que o relato da "tirania" de Athenion em Atenas, mais do que vinculado a uma preocupação em discernir o bom do mau filósofo - o que pode ser uma intrusão de Ateneu no texto - está voltado para uma audiência que foi contemporânea dos acontecimentos, e pode buscar em sua história elementos para a interpretação do que ocorreu e de como se comportar diante da dominação romana, então já sem rivais no Oriente próximo.

${ }^{193}$ De acordo com a proposta de Bringmann (1997. pp. 151-154). 
O texto de Posidônio citado por Ateneu começa com a caracterização de Athenion (211G-212A): filho de uma escrava egípcia com um filósofo ateniense (ou de qualquer outro), Athenion "herdou" a cidadania do pai e tornou-se filósofo, o que lhe permitiria conquistar uma considerável fortuna enquanto dava aulas na Messênia e na Tessália. Já rico, retornou a Atenas. Dois topoi recorrentes na tradição retórica grega estão presentes: a origem escrava e o uso da filosofia como forma de enriquecimento. Se por um lado não é claro que a inclusão de Athenion como cidadão ateniense tenha sido ilegal, dado o provável relaxamento das restrições criadas no período clássico ${ }^{194}$, por outro pode-se sugerir que a passagem se trata de um eco da crítica polibiana, justamente, à abertura excessiva do corpo cívico ateniense (Políbio, 30.20.5-6). A crítica à filosofia como forma de enriquecimento, por sua vez, se articula não apenas à tradicional represália aos sofistas, como também aos princípios filosóficos de Posidônio, para quem a educação moral serve para enfraquecer as faculdades irracionais da alma em sua busca por riqueza e poder, para satisfazer o desejo de prazer e força (Bringmann, 1997, p. 155-6); a carreira como sofista de Athenion, associada ao casamento como uma "garota de belas formas", é o registro invertido da proposta filosófica de Posidônio, anunciando a tragédia de quando Athenion se tornasse o líder da cidade.

$\mathrm{O}$ autor segue dizendo que Athenion foi indicado como embaixador ateniense junto a Mitrídates, de quem se tornou um dos amigos e foi honrado de maneira grandiosa. Da corte de Mitrídates, enviava cartas aos atenienses onde prometia que

\footnotetext{
não somente seriam libertados das dívidas adquiridas e viveriam em

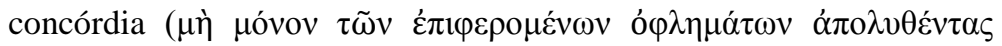

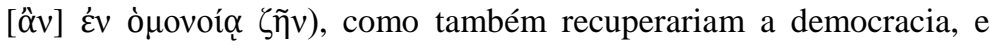

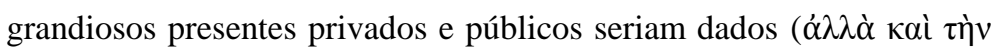

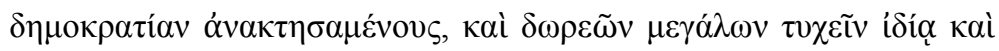
$\delta \eta \mu о \sigma i ́ \alpha$.$) . Os atenienses vangloriavam-se com isto, acreditando que a$ hegemonia romana havia acabado (212A).
}

Várias questões podem ser levantadas a partir destas promessas. A primeira é o problema da libertação das dívidas. Recentemente, Antela-Bernardez (2009, pp. 54-60) sugeriu que Athenion se referia à necessidade de endividamento de parte da população

${ }^{194}$ Cf. Osborne (1981-1984, pp. 140-5 e 167-8), Rubenstein et al. (1991, p. 139-51) e Ogden (1996, p. 317). Críticas e ressalvas à tese da "facilitação" de Osborne foram feitas por Perrin-Saminadayar (2005) e Byrne (2003a e 2003b), e de um modo mais radical em Oliver (2010). 
ateniense com credores romanos, em virtude da crise econômica causada pela revolta escrava em 100/99, mencionada em uma citação de Posidônio em outra passagem de Ateneu (272E-F; Tracy, 1979). Entretanto, não há evidência suficiente para sustentar a hipótese de que doze anos depois a revolta ainda tivesse efeitos como o endividamento $^{195}$. Alternativamente, pode-se pensar que a promessa de libertação das dívidas dialoga muito mais com a propaganda mitridática já consolidada na Ásia Menor (Glew, 1977, p. 255), em particular na preparação das "vésperas asiáticas": a ordens secretas emitidas pelo rei às cidades gregas incluíam a promessa do perdão de metade da dívida daqueles devedores que matassem um credor (Apiano, Guerras Mitridáticas, 22).

A segunda questão diz respeito à suposta ausência de concórdia em Atenas. Não está claro se esta concórdia se refere à política externa ou interna de Atenas, mas é possível que as duas dimensões estivessem conectadas. O principal indício é a magistratura de Medeios do Pireu três vezes como arconte epônimo, entre os anos 91/90, 90/89 e 89/88, algo inédito na história ateniense. A pertinência de Medeios ao grupo pró-romano é bastante segura (Antela-Bernardez, 2007), e a sincronia entre sua permanência como arconte epônimo e a eclosão da Guerra dos Aliados na Itália pode indicar que os dois eventos estão conectados: a ausência de concórdia poderia se referir a uma crescente oposição à oligarquia pró-romana em virtude da crise da dominação romana na própria Itália, e que teria na permanência de Medeios no cargo uma tentativa radical, mas ainda pacífica, de manutenção da aliança com Roma.

A terceira se refere à restauração da democracia, que pode ter tanto um significado mais amplo - o governo do povo - como mais restrito - o reestabelecimento da ordem democrática após o arcontado trienal de Medeios, questão que está relacionada ao problema dos espaços da assembléia (cf. discussão acima).

A quarta, finalmente, diz respeito da promessa de "grandiosos presentes públicos e privados". Os dons não são especificados para além dos qualificativos "públicos e privados", que funcionam, certamente, como recurso retórico de amplificação: não apenas o tesouro público será beneficiado, mas também cada cidadão individualmente. Mais do que uma oferta de ocasião, a oferta se insere dentro de uma tradição multissecular pela qual a cidade se relaciona com os monarcas estrangeiros: o

\footnotetext{
195 Antela-Bernardez sustenta a afirmação citando Tracy (1979), mas faz referência a uma página inexistente no artigo. Ademais, Tracy sugere que o impacto da revolta é mais perceptível na redução do número de peregrinos na Pythais de 98/7, mas o faz com uma série de ressalvas; nada é sugerido quanto aos seus efeitos uma década depois.
} 
evergetismo. O interesse ateniense nas grandes reservas cereais do mar Negro data do início do período clássico, e esta relação assumiu um formato evergético a partir pelo menos do século IV (Engen, 2010; Deene, 2012); já no início do século II a monarquia pôntica assume um papel coadjuvante no evergetismo dominado por atálidas, lágidas e selêucidas (Mattingly, 1997, 135-7). Neste sentido, o que está em questão é a rearticulação da estrutura evergética que manteve a segurança e a prosperidade ateniense, em um momento de aparente crise da dominação romana tanto na Itália quanto na Ásia Menor; a promessa dos grandiosos presentes, portanto, é um importante elemento na construção de uma nova configuração geopolítica.

Até aqui, a cidade no relato de Posidônio tem apenas uma existência discursiva, na medida em que é mencionada nas palavras de Athenion; mesmo Athenion só existe como discurso, por meio da leitura de suas cartas, em um contexto sobre o qual não há documentação disponível. A espacialização da ruptura da aliança com Roma, no relato, acontece quando Athenion chega a Atenas (212C-E). Diz o autor que após alguns contratempos na travessia, Athenion é trazido por navios de guerra enviados pelos próprios atenienses; uma multidão o recebe na entrada e o conduz à cidade em uma

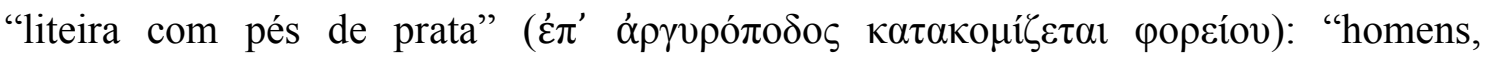
mulheres, velhos e crianças esperam por grandiosos honras da parte de Mitrídates"

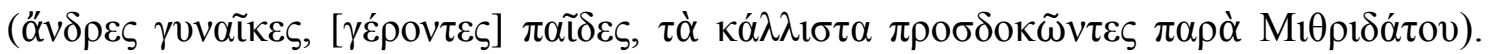
Athenion foi recebido com especial pompa pelos artistas dionisíacos (oì $\pi \varepsilon \rho \grave{~} \tau$ òv

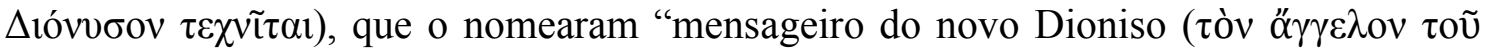

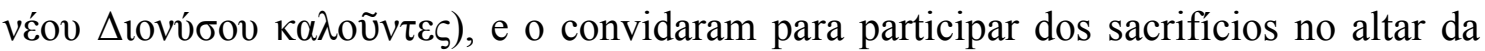
companhia. Após esta recepção, Athenion foi conduzido à casa de um certo Dies, homem enriquecido pelas atividades em Delos; desta casa Athenion partia para a ágora em verdadeiras procissões, exibindo seus mantos e seu anel dourado gravado com um

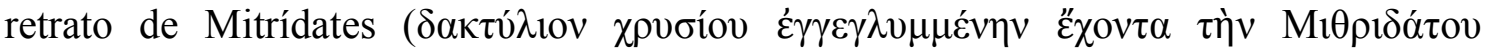

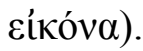

O relato é dominado pelo tema da inversão, que é aparece três vezes: o cidadão irregular que é conduzido à cidade em uma liteira com pés de prata; o antes pobre (ò $\pi \varepsilon ́ v \eta \varsigma)$, que dava aulas por somas insignificantes de dinheiro, agora era levado em procissão pelo campo e pela cidade; aquele que habitava uma casa alugada, seria hospedado por um homem rico. A multidão exercia dois papéis na recepção: por um lado observadora do "paradoxo da fortuna" provocado pela inversão, e por outro participante do evento que, ele próprio, realizava o paradoxo. 
O relato da recepção de Athenion na cidade apresenta uma série de marcas espaciais, com seus respectivos sujeitos e ações rituais: os espaços abertos percorridos pela multidão em procissão (o porto, a $\chi \omega ́ \rho \alpha$, as ruas da cidade), a casa de Dies caracterizada pelo luxo, e o santuário da companhia dos artistas dionisíacos que fariam suas preces e sacrifícios. Deste modo, Athenion é introduzido tanto à comunidade como um todo, quanto a um personagem do segmento mais rico da sociedade, e a uma das associações ao mesmo tempo religiosas e agonísticas mais importantes da cidade. $\mathrm{O}$ modo pelo qual Athenion percorre estes espaços reforça o aspecto discursivo do ritual: carregado sobre uma liteira prateada - o que nem mesmo os romanos tiveram a ousadia da fazer em Atenas - Athenion exibia sua túnica púrpura e anel dourado com um retrato de Mitrídates, manifestação material da legitimação de todo o ritual, e que funciona, no discurso, como reforço do topos da luxuria asiatica ${ }^{196}$, junto ao mobiliário da casa de Dies.

A recepção de Athenion, portanto, se insere dentro dos rituais de "entradas reais", já tradicionais em diversas cidades e inclusive em Atenas: basta lembrar das homenagens prestadas três vezes a Demétrio Poliorcetes em 306, 304 e 291/0, ou a Átalo I em 200/199 ${ }^{197}$. Como nos casos anteriores, a entrada de Athenion era um momento decisivo no processo de alteração das alianças atenienses. No entanto, a entrada de Athenion apresentava uma peculiaridade: não era o próprio rei, mas um mensageiro dele - como é lembrado pelos artistas dionisíacos, que o chamam de "mensageiro do novo Dioniso" - que recebia as honras, fazendo com que este ritual tivesse uma dupla função: ao mesmo tempo em que marcava, pela apropriação do espaço da cidade, a nova aliança ateniense com o rei pôntico, por outro apontava para o fortalecimento de seu mensageiro, tornado um duplo do próprio rei. Desde modo, Posidônio já antecipava a tirania de Athenion, que só se consolidaria em momento posterior.

Ao lado da ênfase retórica na inversão e o tom satírico, outro elemento aponta para a exigência de precaução na leitura de Posidônio: o paralelo com a descrição da

\footnotetext{
${ }^{196}$ Vale lembrar a condenação de Timágoras no início do século IV, acusado no tribunal ateniense de ter sido corrompido pelos presentes do rei Artaxerxes da Pérsia, entre os quais estava uma liteira (Plutarco, Pelópidas, 30.6; Mitchell, 1997, pp. 128-9; Ballesteros Pastor, 2005, p. 389). Sobre o topos da luxuria asiatica na literatura grega e latina, cf. Spawforth (2012, pp. 10-14). Sobre a tryphe como sinal de decadência na obra de Posidônio, cf. Hahm (1989, pp. 1325-1363).

${ }^{197}$ As entradas de Demétrio Poliorcetes são descritas por Plutarco (Demétrio, 10.1-4, 12.1-4 e 13.1-2); a entrada de Átalo I é descrita por Políbio (16.25). Sobre as entradas reais em geral, v. Bérenger e PerrinSaminadayar (2009); sobre as entradas reais helenísticas, v. Strootman (2007, pp. 289-305), com bibliografia anterior.
} 
entrada de Átalo I em Atenas por Políbio (16.25), cuja obra Posidônio pretende continuar. De fato, dois elementos centrais são recorrentes: a multidão de homens, mulheres e crianças acompanhando a procissão e o engajamento de sacerdotes e de santuários no evento aparece em ambos os relatos; as diferenças de tom talvez se expliquem pelo fato de Políbio estar descrevendo a aliança de Atenas com Roma, e Posidônio justamente o contrário.

A questão da participação dos artistas dionisíacos na recepção a Athenion atraiu a atenção dos estudiosos em função, principalmente, do prestígio da companhia em Roma, como é observado pelo senatus consultum favorável à companhia ateniense em sua longa disputa contra sua equivalente no Istmo, no final do século II, registrada em uma inscrição encontrada em Delfos (FD 3.2.70). Tamura (1988) via na atitude da companhia uma decisão pragmática: obtendo já uma série de privilégios concedidos pela Anfictionia de Delfos - como isenção de impostos e serviço militar, segurança e inviolabilidade - a companhia avaliou os benefícios que poderiam vir com o apoio a Mithridates, e, no contexto ateniense de crença no colapso iminente da hegemonia romana, fez sua decisão (Tamura, 1988, pp. 174-5). Le Guen (2007), em uma visão que nos parece mais completa, acrescenta aos critérios pragmáticos uma possível iniciativa do estado ateniense no convite à companhia, assim como a influência da bem atestada associação de Mitridates com o deus Dioniso ${ }^{198}$.

A hospedagem de Athenion na casa de Dies, por sua vez, também é significativa. Três "Dies" são mencionados na documentação epigráfica do período, e normalmente associados à mesma família: o mais velho, Dies (I) da cidade fenícia de Tiro, se estabeleceu em Delos na segunda metade do século II e tornou-se rico o suficiente para inscrever seus dois filhos, Heliodoros e Dies (II), na efebia deliana no ano de 105/4 (ID 2599); ambos os irmãos são atestados em outra inscrição de Delos, onde são identificados como cidadãos atenienses (ID 2595). Finalmente, um certo Dies (III), filho de Basilides, do demos de Melite, é mencionado em uma lista de pompostoloi (“condutores de procissão”) do início do século I (ID 2607); Dies é o nono da lista, encabeçada por Medeios, filho de Medeios, do Pireu, possivelmente filho do Medeios

\footnotetext{
${ }^{198}$ McGing propôs que a adoção do nome "Mitridates VI Eupator Dioniso" pelo rei pôntico poderia estar associada ao seu parente materno Antíoco VI Dioniso, rei da Síria (McGing, 1986, p. 90, n. 5), o que poderia ser uma das raízes do dionisismo de Mitridates. Sobre a evidência da associação do rei ao deus Dioniso, cf. Hojte (2009) para escultura, Smelakova (2009) para numismática e Saprykin (2009) para arqueologia e epigrafia do Ponto. Uma inscrição particularmente interessante é aquela do epistilo do santuário de Mitridates em Delos, construído em 102/1; a inscrição indica que o santuário foi dedicado pelo ateniense Helianax, sacerdote de Poseidon e dos Dióscuros-Cabeiri, para "o povo ateniense, o povo romano, os Cabeiri e Mitridates VI Eupator Dioniso" (SEG 45.1053); cf. Kreuz (2009).
} 
três vezes arconte nos anos anteriores à chegada de Athenion. Esta ligação, além do fato de que um outro Dies filho de Basilides de Melite é mencionado como prítane ateniense em 30/29 - ou seja, a família teria sobrevivido ao saque de Sula -, fez com que S. Dow excluísse o terceiro Dies entre os prováveis anfitriões de Athenion. Restariam, então, o pai e o filho mencionados nas inscrições efébicas de Delos, dentre os quais não é possível ter certeza sobre qual se tratava o anfitrião: o mais novo, já cidadão ateniense, teria 35 anos na época, enquanto que seu pai teria entre 50 e 60 anos. Dow sugere que o anfitrião de Athenion seria o mais novo (II), pois é mais provável que o mais velho resistisse a se mudar de Delos, onde havia uma considerável colônia fenícia, para Atenas, onde originários de Tiro mal são conhecidos; a juventude e a residência atenienense de Dies (II), prossegue Dow, seria mais coerente com o apoio dado a Athenion, ignorando assim a convivência entre italianos e fenícios na ilha (Dow, 1942, pp. 313-4). De todo modo, qualquer que seja o Dies em questão, a presença e a posição proeminente da família em Delos correspondem à menção de Posidônio, o que atesta que o anfitrião de Athenion fazia parte de uma elite econômica com profundas raízes em Delos - o que também era o caso para a elite pró-romana, como atesta a atividade de Medeios em Delos (Antela-Bernardez, 2009).

O segundo dia de Athenion na cidade é marcado pelo discurso na ágora e a reorganização do governo. Posidônio diz que a multidão aguardava Athenion em sua casa, enquanto que uma multidão de "cidadãos e estrangeiros" o aguardava no "Cerâmico". Athenion se dirigiu para a ágora rodeado por uma guarda pessoal, subiu na "plataforma construída para os generais romanos", e pronunciou um discurso de duas partes. Na primeira, Athenion fazia um balanço das conquistas de Mitridates na Ásia Menor, as humilhações sofridas pelos romanos, e o apoio recebido por cidades de todas as partes, em particular da Itália e de Cartago. Na segunda - após um curto intervalo para que a multidão conversasse sobre tais informações - Athenion diz:

A que então eu vos aconselho? Não perpetuem a anarquia, a qual o senado romano fez contínua, enquanto examina qual constituição nos é adequada. Não fiquemos indiferentes aos santuários fechados, aos ginásios sujos, ao teatro sem assembléias, aos tribunais sem voz, e à Pnix, consagrada pelo oráculo dos deuses, ser tirada do povo. (213C-D). 
E a lista continua com o santuário de Elêusis e as escolas filosóficas fechadas e silenciadas. O povo então se dirige ao teatro onde, em assembléia, elege Athenion general dos hoplitas, e assiste ao novo magistrado compor seu novo governo (213F).

O relato do segundo dia é estruturado pela relação entre Athenion, a multidão e os espaços públicos atenienses, que serão tanto suporte quanto o conteúdo do discurso. Como suporte, dois espaços são mencionados: a ágora, onde ocorre o discurso, e o teatro de Dioniso, onde ocorre a nomeação de Athenion para o cargo de general dos hoplitas e a nomeação de novos membros do governo sob indicação de Athenion. Ambos os locais e sua relação com a prática política ateniense foram discutidos na seção anterior; aqui, vale ressaltar um elemento importante da narrativa: a presença de estrangeiros na ágora. Esta é a terceira vez que Posidônio usa o tema do estrangeiro: a primeira vez na caracterização da mãe de Athenion, uma escrava egípcia - que ecoa na referência a Athenion como "este escravo" (213E) -, e na menção a Dies, com toda a probabilidade membro de uma família fenícia originária de Tiro. A ênfase dada por Posidônio reforça o topos da inclusão ilegal de estrangeiros na história política ateniense, servindo para a deslegitimação das ações de Athenion.

Em seu discurso, Athenion faz uma ampla caracterização da situação crítica de Atenas. O primeiro ponto é a "anarquia" causada pelo Senado romano. A existência desta "anarquia" é confirmada pela lista dos arcontes epônimos que, logo após a tripla aparição do nome de Medeios, insere o termo "anarquia" no espaço do arconte epônimo do ano de 88/7 (IG II ${ }^{2}$ 1713.12). Muito se especulou sobre tal inserção. Habicht (1976) sugeriu que o arconte em questão seria o próprio Mitridates, tese reforçada por Tracy (1991), que sugeriu que se tratava de uma damnatio memoriae; mas a ausência de marcas de raspagem e mesmo o espaço reduzido tornam esta hipótese implausível. Mattingly (1971) propôs como causa da anarquia a incapacidade de um membro da elite de financiar os custos do cargo, relevando uma crise econômica; Antela-Bernardez (2009b) acrescenta à tese da crise econômica a hipótese de que Medeios havia sido indicado pelo Senado para ocupar o cargo e, com seu eventual falecimento falecendo 89/88, não houve tempo para que o Senado, envolvido com os conflitos na Itália, indicasse outro arconte epônimo - entretanto, não há evidência para sustentar a ideia de que o Senado romano intervisse na política ateniense neste ponto ${ }^{199}$. Na ausência de

199 Além disso, a sugestão de que Medeios fosse mais próximo ao grupo mariano em Roma (AntelaBernardez, 2009b, pp. 55-57), que seria atacado tanto por Mitridates (contra os negotiatores) quanto por 
mais evidências, é impossível ter certeza quanto às razões da "anarquia" de 88/7, ainda que a tese de um conflito interno à oligarquia, sendo influenciado - mas não determinado - pelos acontecimentos na Itália e na Ásia Menor, seja uma hipótese mais plausível.

O segundo ponto é a caracterização de diversos espaços da cidade como fora de seu funcionamento normal: santuários fechados, ginásios sujos, teatro sem assembléia, tribunais silenciosos, Pnix retirada do povo, santuário de Dioniso silencioso, santuário de Elêusis fechado, escolas filosóficas silenciosas. O panorama de Athenion tem um padrão claro: o abandono atinge os espaços da prática religiosa, da prática educativa, da prática agonística e da prática política, e se manifesta tanto na falta de manutenção quanto na falta de uso. A importância destes espaços para a reprodução social ateniense, tanto no nível local quanto no internacional, dificilmente poderia ser superestimado. Os ginásios eram pontos focais da efebia, instituição fundamental na reprodução da elite ateniense assim como a criação de laços com membros de elites estrangeiras. As escolas filosóficas, os festivais de teatro e os Mistérios de Elêusis eram fundamentais na comunicação da cidade com o Mediterrâneo, tornando-se um polo de atração para filósofos, artistas, peregrinos e turistas em geral: as multidões que afluíam para Elêusis durante a celebração dos mistérios, o prestígio internacional da companhia dos artistas dionisíacos e a peregrinação de estudiosos em busca das aulas dos filósofos em Atenas, particularmente de romanos (Habicht, 1997, pp. 342-350), atestam sua importância. Os tribunais, a Pnix e o teatro de Dioniso como ekklesiaterion, por sua vez, estavam relacionados não somente ao próprio funcionamento do governo, mas também à prestigiosa tradição literária ateniense, em particular no campo da retórica, construída em função dos discursos pronunciados nos tribunais e na assembleia.

Em suma: mais do que procurar no discurso de Athenion uma análise objetiva, deve-se observar que todos os espaços mencionados no discurso são ao mesmo tempo fundamentais para a reprodução social local e para o prestígio internacional da cidade, fundado em seus festivais e sua cultura literária. Neste sentido, pode-se sugerir a estruturação do discurso a partir de uma posição externa de observação, que pode ser explicada seja pelas experiências profissionais e diplomáticas de Athenion (sofista no Peloponeso, embaixador na Ásia Menor), seja por interpolações de Posidônio (que

Sulla, é enfraquecida pela presença de um exilado ateniense chamado Medeios junto a Sula durante o cerco a Atenas, com toda a probabilidade ou o Medeios três vezes arconte, ou um membro de sua família. 
estudou filosofia em Atenas e se estabeleceu em um centro rival, Rodes) ou mesmo de Ateneu, dois séculos depois.

De qualquer modo, o discurso de Athenion revela dois pressupostos importantes: primeiro, o significado dos lugares é construído em função das práticas espaciais; segundo, a reorientação da diplomacia ateniense envolve novas práticas espaciais. A Atenas do relato de Posidônio, no primeiro dia transformada em palco do ritual da entrada "monárquica" de Athenion, no segundo dia se tornava ao mesmo tempo suporte e objeto da ação política, seja no discurso sobre a plataforma romana, seja nas atividades posteriores realizadas no teatro, as quais efetivavam o discurso pronunciado na ágora.

A descrição da assembleia no teatro de Dioniso contém um elemento precioso, ignorado nas análises anteriores. Posidônio afirma que Athenion, após ser eleito general dos hoplitas e ter, consequentemente, poder sobre o exército, foi para a orchestra "como Pítocles". A passagem é uma citação por Posidônio de um discurso de Demóstenes, o Sobre a falsa embaixada, pronunciado em 343/2, no qual Demóstenes acusa Ésquines e outros embaixadores de corrupção e desrespeito às decisões atenienses no contexto da negociação de paz de Atenas com Filipe II da Macedônia; Pítocles, filho de Pitodoro, é um dos acusados. Na seção 314 do discurso, Demóstenes descreve o comportamento de Ésquines, que andava na ágora "como Pythocles", afirmando com sua arrogância e o luxo de suas roupas que era um "amigo de Filipe". Ora, o paralelo Athenion/Mitridates com Ésquines/Filipe é evidente. Tal paralelo com os reis macedônicos é reforçado mais uma vez na descrição de Posidônio: como já mencionado, Demétrio Poliorcetes toma a cidade em 295 e reúne os cidadãos no teatro de Dioniso, onde, após perdoar os atenienses e promover a distribuição de trigo, Demétrio escolhe novos magistrados (Plutarco, Demétrio, 34) - assim como Athenion. Na sequência, Plutarco diz que o orador Domoclides propôs a entrega do Pireu para Demétrio; sabemos a partir de Apiano que o Pireu será o centro das operações militares mitridáticas na Grécia. Um paralelo final entre Demétrio Poliorcetes e Athenion/Mitrídates é dado pelo dionisismo: Demétrio escolheu Dioniso como patrono (Plutarco, Demétrio, 2.3), e em Atenas seu culto era fortemente associado ao culto de Dioniso (idem, 12.1-3). O destaque dado por Posidônio à companhia dos artistas dionisíacos na descrição da entrada de Athenion, 
portanto, contribui para a "macedonização" discursiva de Athenion/Mitrídates, coerente com a construção de uma cultura antimacedônica tanto em Atenas quanto em Roma ${ }^{200}$.

O texto de Posidônio segue com a descrição da perseguição aos inimigos do regime, qualificados como "atenienses sóbrios", por um Athenion nomeado por si mesmo como "tirano". Acusações de traição eram acompanhadas por execuções sem julgamento, que ocorriam também contra aqueles que eram capturados em fuga ou no exílio; todas as portas da cidade eram vigiadas por guardas, que impediam a livre movimentação; uma carestia foi criada pelo próprio tirano, que racionava quantidades insuficientes de trigo aos atenienses. A perseguição é reiterada ao longo do relato, até que Posidônio acrescenta que Athenion também enviou hoplitas para o campo para

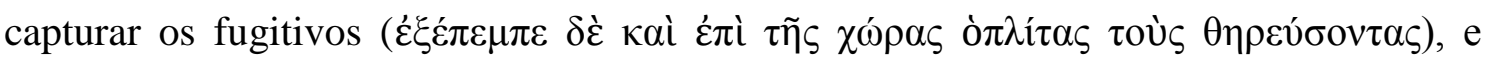
mesmo instituiu um toque de recolher na cidade (214C).

Este trecho apresenta um terceiro momento da espacialização do apoio a Mitridates, embora com uma temporalidade indefinida: se no primeiro dia Athenion ocupou as vias, alguns santuários e um espaço doméstico, e no segundo dia ocupou a ágora e o teatro, no período que tem início "alguns dias depois" é marcado pela conversão da Ática inteira como objeto da ação de Athenion. A cidade é isolada de seu entorno com o estabelecimento da guarda nas portas da cidade; o campo é inserido como espaço de atuação da tirania como teatro das missões de hoplitas em busca de fugitivos. Dentro da cidade, Athenion institui também o controle sobre o tempo da produção do espaço: o pôr do sol era definido como o limite da apropriação do espaço público da cidade, indicando desta forma que não apenas a saída da cidade, mas também a circulação interna dos habitantes, estava sob a vigilância do regime.

O poder sobre o espaço e o tempo da cidade era acompanhado pela suspensão do direito de propriedade que afetava cidadãos e estrangeiros, indicando um paralelo da tirania de Athenion não apenas com o regime dos Trinta em Atenas no final do século $\mathrm{V}$, mas também ao topos do confisco da propriedade dos exilados e opositores na tirania grega $^{201}$. Neste ponto, um segundo espaço externo à cidade se junto ao campo: a ilha de Delos, em virtude dos recursos em posse do santuário de Apolo. O confisco da propriedade sagrada é um expediente pouco atestado, mas um dos testemunhos é

\footnotetext{
${ }^{200}$ Basta lembrar, por exemplo, a Dedicação Atálida na acrópole ateniense ou o investimento de Políbio e, posteriormente, de Tito Lívio, na crítica da dominação macedônica na Grécia, encerrada com as vitórias romanas no século II.

${ }^{201}$ Por exemplo, em Aristóteles (Política, 1311a). Cf. Berger (1992, p. 103) e Stein-Hölkeskamp (2009, p. 101).
} 
particularmente rico: quando Plutarco descreve os preparativos do cerco de Atenas por Sula, afirma que este solicitou o envio de recursos dos santuários de Olímpia, Epidauro e Delfos; os santuários obedeceram com alguma resistência, e ainda na expectativa de uma compensação vantajosa - no entanto, afirma Plutarco, os generais da época de Sula se aproximavam mais dos demagogos do que dos generais corretos e respeitosos do período anterior (Plutarco, Sula, 12.8). A decisão de Athenion de adquirir os recursos de Delos encontraria, pois, paralelo na própria expedição de Sula contra Atenas - paralelo que Posidônio, ao menos a partir do fragmento em questão, evitou.

O fragmento de Posidônio termina com a descrição da missão de conquista de Delos por Apélico de Teos, filósofo peripatético e bibliófilo ${ }^{202}$ naturalizado ateniense e, portanto, mais um cidadão de origem estrangeira ao lado de Athenion - que é facilmente derrotado pela guarnição romana na ilha.

Feito este percurso, é possível apontar alguns elementos mais gerais. Sobre o projeto do autor, fica claro que a caracterização de Athenion se articula claramente com uma postura pró-romana: Athenion é desqualificado por sua origem servil e estrangeira, por seu amor à riqueza e ao luxo e por seus excessos; seu governo passa da demagogia, com o apoio de uma multidão facilmente manipulável formada por cidadãos e estrangeiros, à tirania, marcada pela perseguição política e confissco de propriedade. As críticas podem ser ampliadas a todos os atenienses, que são representados como facilmente manipuláveis, demasiado abertos em relação à inclusão de estrangeiros nas atividades políticas e no corpo cívico, e prontos para a bajulação a monarcas estrangeiros ou seus mensageiros, envolvendo, para isso, as associações religiosas mais prestigiosas da cidade. Tais críticas se aproximam, como foi demonstrado, da imagem geral dos atenienses na obra de Políbio, o que seria coerente com a atribuição da autoria a Posidônio, ele mesmo continuador da obra polibiana. Paralela a esta influência, é provável que a identidade cívica de Posidônio seja determinante: Rodes manteve-se fiel a Roma nas guerras mitridáticas, o que lhe rendeu importantes frutos após a vitória romana (Ballesteros Pastor, 2005, pp. 389-90). Outro fator, que não é excludente em relação aos anteriores, é o de que o próprio Ateneu reproduzia esta imagem: o escritor de Náucratis caracteriza os atenienses como "aduladores de aduladores" em relação à recepção de Demétrio Poliorcetes séculos antes (253B-F; Ballesteros Pastor, 2005, p. 390 e n. 24). A abordagem moral na compreensão da ação individual e coletiva

202 Conhecido na antiguidade por haver possuído a biblioteca de Aristóteles, como é mencionado por Posidônio (214d) e Estrabão (13.1.54), entre outros (Schubert, 2002). 
empregada por Posidônio, não preocupado com causas sociais mais profundas, tais como eventuais conflitos no seio da oligarquia ou críticas à dominação romana, que são perceptíveis nas referências do próprio autor ao apoio dado a Athenion e às promessas da aliança com Mitrídates, é indicativa da postura naturalizante do autor em relação à dominação romana.

Quanto à espacialidade do episódio, é possível observar um movimento do exterior para o interior, e do interior para o exterior, em quatro etapas. Na primeira, de duração indefinida, Athenion está fora de Atenas e manipula os atenienses a partir de cartas enviadas da corte mitridática. Na segunda, com duração de um dia, Athenion é recebido com o ritual das "entradas reais", e se comunica com a multidão por meio de artefatos (liteira prateada, túnica púrpura, anel) ou ações (presença no santuário de Dioniso, hospedagem na casa de Dies). Na terceira, que dura mais um dia, Athenion ocupa os dois espaços principais da reunião cívica (política ou não), a saber, a ágora e o teatro, e se comunica com a multidão a partir de suas formas institucionalizadas: a primeira, vinculada à passagem dos generais romanos, e a segunda, vinculada à realização da assembléia democrática. Na terceira etapa, que tem duração indefinida, Athenion amplia seu poder de ação para, simultaneamente, os espaços públicos intramuros, a área rural da Ática, e a ilha de Delos, utilizando a violência como forma de comunicação não apenas com a multidão, mas também com os cidadãos não engajados nas reuniões ou aqueles que se opõem ao regime. No centro deste movimento pendular está o período entre a eleição de Athenion como general dos hoplitas, dentro da legalidade, e a sua ilegal auto-nomeação como tirano, a qual, se não era evidente para a multidão, já estava indicada na caracterização de Athenion por Posidônio desde o princípio. De todo modo, é perceptível tanto na narrativa de Posidônio quanto no discurso de Athenion a importância da cidade em sua materialidade na construção e compreensão da realidade política e diplomática ateniense.

\section{Plutarco, entre Atenas e Roma}

Plutarco de Queronéia ${ }^{203}$ escreveu a vida de Sula dentro do grande projeto das comparações entre gregos e romanos ilustres; no caso de Sula, o paralelo era feito com o

\footnotetext{
${ }^{203}$ Sobre o uso de Plutarco como fonte histórica, cf. Stadter (1992) e Silva (2007, pp. 15-70), com bibliografia anterior.
} 
rei espartano Lisandro. A razão desde paralelo foi discutida por Ph. Stadter, que defende que o traço de união entre os personagens seria o caráter paradoxal da personalidade ambos (Stadter, 1992); ao que deve ser acrescentado, evidentemente, o fato de ambos terem submetido Atenas.

O relato do cerco e da invasão de Atenas em 86 se insere, na narrativa plutarquiana, no contexto da oposição entre Mário e Sula criada há cerca de 20 anos antes. De acordo com o autor, os sucessos de Sula na Guerra de Jugurta e na Guerra dos Aliados havia cimentado a inveja de Mário pela glória de seu antigo general; a oposição se tornou um conflito aberto com a disputa pelo comando da guerra contra Mitridates VI Eupator, rei do Ponto, que conquistara boa parte da Ásia Menor e declarara guerra a Roma em 88, contando com o apoio de diversas cidades, entre as quais Atenas. Inicialmente, o Senado romano havia concedido o comando a Sula; no entanto, após a pressão exercida pelo tribuno da plebe Sulpicius, aliado de Mário que contava com mais de 3 mil soldados a seu serviço em Roma, o Senado transferiu o comando para Mário. Sula consegue fugir da perseguição realizada pelo grupo mariano, e se encontra com as seis legiões romanas que o acompanhariam na primeira invasão de Roma por um general romano. Após forçar a entrada pela muralha, Sula realiza incêndios e assassinatos; segundo Plutarco:

\footnotetext{
Não o fez por cálculo, mas estando pela paixão, e tendo entregado o comando do que fazia à raiva, via apenas seus inimigos; sem considerar nem ter pena de amigos, parentes ou conhecidos, fez sua entrada por meio do fogo, para o qual não há distinção de quem era e quem não era culpado (Plutarco, Sula, 9.7).
}

Já dentro de Roma, persegue Mário e seus aliados e faz com que o Senado lhe conceda novamente o comando da guerra contra Mitridates. Com isso, parte para a Ática e inicia o cerco de Atenas, utilizando como fonte de matéria-prima para as máquinas de guerra as árvores dos jardins da Academia, do Liceu, e provavelmente do jardim de Epicuro entre a Academia e o Dipilon (Plutarco, Sula, 12.3). Após uma digressão sobre a diferença entre os generais que anteriormente estiveram na Grécia e aqueles da época de Sula, Plutarco afirma:

Um desejo inexorável e terrível de conquistar Atenas o possuía, seja pela ânsia de lutar contra a sombra antiga da cidade, seja porque o tirano Aristion, que de 
cima da muralha dançava e zombava, com piadas e obscenidades ditas a respeito dele e de [sua esposa] Metela (Plutarco, Sula, 13.1).

Atenas aparece para Sula de duas maneiras: como representação da grandeza do passado e como experiência da insolência do presente. No primeiro caso, Sula reconhece a fama da cidade, ainda que isso o incentive ainda mais a tomar a cidade. No segundo caso, as ofensas de Aristion relevam o grau de conhecimento que um membro da elite ateniense tem dos detalhes da política romana.

Após uma breve caracterização de Aristion, Plutarco descreve a situação da cidade após o longo cerco, dominada pela fome e pela inobservância dos rituais (Sula, 13.2-3). Diante desta situação, escreve Plutarco:

\footnotetext{
[Aristion] enviou dois ou três de seus companheiros para fazer a paz, que sem considerar a salvação, falaram empoladamente sobre Teseu, Eumolpo e as guerras médicas. Sula então disse: "Saiam daqui, educados senhores, levando estes discursos; eu não fui enviado pelos romanos para ter aulas, mas para submeter desertores (Plutarco, Sula, 13.4).
}

Os elementos a partir dos quais os embaixadores procuram negociar com Sula são claros: o passado da cidade é a defesa que lhes resta. As referências são eloquentes. Teseu é ao mesmo tempo herói local e pan-helênico, quando se consideram o sinecismo da Ática ou a expedição cretense contra o Minotauro; Eumolpo se relaciona ao mito da divulgação da agricultura aos homens a partir de Elêusis; as guerras médicas se referem certamente à participação de Atenas na defesa da Grécia. A aposta dos embaixadores é inequívoca: mais do que o reconhecimento da fama da cidade, Sula deveria reconhecer os serviços prestados pelos atenienses (míticos ou históricos) à civilização como um todo, da qual Sula eventualmente se beneficiaria no presente. A resposta de Sula, por sua vez, demonstra uma das possíveis interpretações romanas acerca da tradição ateniense: pura matéria de erudição, mas sem maiores consequências práticas. $\mathrm{O}$ fracasso da embaixada demonstra o limite do discurso da civilização greco-romana, ainda em fabricação.

O cerco continuou até que os soldados de Sula ouvissem dois atenienses, do lado de dentro da muralha, criticando Aristion por não proteger um determinado segmento da muralha. Com esta informação, Sula invadiu a cidade e o massacre teve início, cobrindo de sangue o bairro do Cerâmico. A destruição apenas tem fim quando Sula, 
por causa de Meidios e Califon que lhe suplicaram e se ajoelharam diante dele, ou por causa dos senadores, os quais o acompanhavam, que intercediam pela cidade, estando ele satisfeito com a vingança, fazendo um elogio aos antigos atenienses disse que perdoava poucos pelo bem de muitos, os vivos pelos mortos. [...] (Plutarco, Sula, 14.5).

No perdão de Sula, as tradições de Atenas, repudiadas diante dos embaixadores de Aristion, voltam a ter validade para dar fim às destruições: os mortos (muitos) garantiriam a salvação dos vivos (poucos) - tal argumento será utilizado novamente no perdão aos atenienses em algumas décadas por César. Vale reter, aqui, a importância das representações do passado na consolidação da atitude romana diante da cidade: a valorização das tradições atenienses devem partir dos romanos, já iniciados no conhecimento erudito, mas que estabelecem quando e como o discurso sobre o passado deve ser feito; são os romanos, e não os atenienses, que tem primazia sobre este discurso.

A descrição segue com a tomada da acrópole, para onde Aristion e alguns seguidores fugiram (tal o aspirante a tirano Cílon, em 632), para então prosseguir na narrativa das batalhas de Sula no oriente.

Vários elementos da narrativa equiparam os acontecimentos em Atenas e em Roma: ambas foram invadidas por Sula, e sofreram grandes destruições e assassinatos indiscriminados; em ambas Sula foi ofendido em função de seu casamento com Metela (6.10); ambas foram consideradas traidoras, seja em relação a Roma (Atenas) ou a Sula (Roma). Atenas, neste sentido, é para Plutarco uma segunda Roma, palco para mais uma etapa do fortalecimento político e militar de Sula em busca da glória pessoal, que se sobrepõe à glória cívica de Atenas (13.1).

Quando se considera o significado das duas cidades para Sula, no entanto, uma importante diferença se torna evidente. O cerco de Roma começa com o assassinato, pelos soldados leais a Sula, dos tribunos militares leais a Sulpicius; nenhuma consideração quanto à antiguidade ou glória da cidade é feita por Plutarco, mas, pelo contrário, Roma é representada por suas instituições, com as quais Sula dialoga na reorganização dos grupos antes de sua partida para a Grécia. No caso de Atenas, a antiguidade da cidade aparece em três momentos: no desejo de construir sua glória pessoal contra a antiga glória da cidade; na fala dos embaixadores atenienses, que mencionam Teseu, o herói fundador, Eumolpo, herói ligado aos mitos eleusinos - e 
consequentemente ao nascimento e difusão da agricultura - e as guerras médicas, antes de serem rechaçados por Sula; e na ordem para o fim do massacre, na salvação dos poucos pelo bem dos muitos, os antigos atenienses. Observa-se, desse modo, como o "argumento antiquário" ateniense está presente tanto nas considerações do invasor quanto nas estratégias do invadido. A contradição entre as atitudes de Sula, que ora aceita e ora repele o argumento, é apenas aparente: o fracasso da estratégia dos embaixadores muito provavelmente se deve ao seu próprio conteúdo retórico. De fato, quando eles trazem as figuras de Teseu, Eumolpo e as guerras médicas, a estratégia é justamente enfatizar o papel de Atenas na defesa e beneficio da civilização - Teseu contra os monstros, Eumolpo difusor da agricultura, as guerras contra os persas - da qual Roma é herdeira. Em outras palavras, Sula deveria considerar a salvação de Atenas pelo débito que tinha em relação a seus heróis e feitos, o que dificilmente convenceria um general ávido por se tornar maior que os heróis atenienses. Ademais, como dito acima, o fundamental é que são os romanos que devem determinar os momentos nos quais o discurso sobre o passado ateniense é enunciado, e não o contrário.

\section{Apiano, entre Atenas e Alexandria}

Outra fonte literária que trata com detalhe do cerco e do saque de Atenas é a História Romana de Apiano de Alexandria, membro da ordem equestre e procurador do Egito indicado pelo imperador Antonino Pio, escrita em meados do século II d. C (Bucher, 2000; Wolf, 2004, pp. 1-14). A posição do relato no conjunto é estratégica, tendo em vista a lógica geral da obra. A História Romana de Apiano é composta por diversos livros, muitos dos quais inteiramente perdidos ou conhecidos apenas por fragmentos. O primeiro livro, Basilike, trata da história de Roma no período monárquico; os próximos onze livros fazem parte dos chamados "livros étnicos", que tratam das guerras travadas entre os romanos e os povos estrangeiros, organizados em função da cronologia destas guerras; os cinco livros seguintes tratam das guerras civis romanas do século I até 35; os livros seguintes, que não foram preservados, tratam da história do Egito e das guerras travadas já sob o regime imperial - que Apiano não se exime de qualificar como monárquico. A obra, portanto, está estruturada por uma combinação de espaço e cronologia bastante peculiar - e que, não por acaso, perdura até hoje nas narrativas gerais da história romana: trata-se da história da afirmação da 
dominação romana sobre o Mediterrâneo e Oriente Próximo, que atinge sua culminância espacial no Egito e política na afirmação da monarquia sob Augusto, a qual, segundo Apiano, seria a responsável pela paz e prosperidade do período posterior. A defesa da monarquia augustana em Apiano, que a opõe às guerras civis da república, é paralela à defesa do imperialismo romano, explicado em função das virtudes da prudência e da coragem dos romanos em seus diversos conflitos. O pró-romanismo de Apiano só é contrabalançado pelo elogio do Egito, onde se situam o fim das guerras civis e início da monarquia romana: o fato do último livro sobre as guerras civis acabar em 35 e ser sucedido diretamente pelos livros da História Egípcia é indicativo do "nacionalismo" de Apiano (Bucher, 2000).

O livro sobre as guerras mitridáticas, último dos livros étnicos, está na transição dos livros sobre as guerras externas e as guerras internas: se as primeiras reafirmam os valores romanos que fundamentam o império, as últimas são sintomas dos problemas estruturais da dispersão de poderes do regime republicano. Nesta confluência, Sula é o protagonista. Assim, após traçar um panorama histórico da região ao norte da Ásia Menor e do Mar Negro nos séculos anteriores, Apiano descreve a expansão territorial de Mitrídates e seus crescentes conflitos com Roma, até a declaração de guerra em 88 e os consequentes massacres na Ásia Menor nos meses seguintes. Atenas entra no relato (Apiano, Guerras Mitridáticas, 28-39) a partir da chegada de Aristion, filósofo ateniense apoiado pelo general mitridático Archelaus, a Atenas, onde se torna tirano. Sula, após o fracasso na tentativa de tomar o porto do Pireu (ocupado pelo destacamento mitridático comandado por Archelaus), se volta para a tomada de Atenas; após alguma resistência, as tropas romanas conseguem ultrapassar as muralhas e o massacre tem lugar. Na medida em que os soldados invadiam as casas, descobriam que os atenienses, pressionados pela fome, praticavam o canibalismo. Apiano acrescenta à narrativa de Plutarco do cerco a Aristion na acrópole o incêncio do Odeion de Péricles, atribuído aos próprios sitiados. Após o massacre indiscriminado e o saque realizado pelos soldados, Sula concede restaura a constituição "instituída anteriormente pelos romanos" (Apiano, Guerras Mitridáticas, 39), e continua sua missão no Oriente.

A Atenas de Apiano é uma cidade marcada pela oposição entre civilização e barbárie: o apoio ao monarca bárbaro leva ao cerco de Sula, que por sua vez leva os atenienses ao canibalismo (em função da impossibilidade de obter suprimentos pelo Pireu, também cercado); a vitória de Sula significa o massacre inicial e a reestruturação da vida cívica, com a concessão de uma nova - ou restauração de uma antiga - 
constituição $^{204}$. O tema da inversão, aqui, ressalta o papel regenerador da dominação romana: o rompimento da aliança com Roma significou, para Atenas, o afastamento dos valores civilizatórios que tinham no passado ateniense suas raízes; a tomada da cidade por Sula, então, promoveu o retorno dos atenienses à vida políade, materializada pela constituição instituída por Sula. Tal interpretação pró-romana da história ateniense, certamente, estava relaciona às tensões oriundas da dominação romana na própria Alexandria de Apiano (Clímaco, 2007 e 2013), que poderia tomar o caso ateniense como exemplo do colapso inevitável a um rompimento político.

\section{Pausânias e a indignidade de Sula}

Pausanias ${ }^{205}$ menciona o episódio no contexto de seu percurso na região ao leste da acrópole. Após iniciar o trajeto próximo à encosta leste do rochedo da acrópole (1.18.1), Pausânias faz um desvio na direção do Olympieion, dos ginásios do Cinosarges e Liceu e do estádio (1.18.4-19.6), e então retorna à via dos Trípodes (1.20.1), onde observa os monumentos da via e o santuário de Dioniso. Neste ponto, afirma Pausânias:

Próximo do santuário e do teatro de Dioniso está uma estrutura, que é dita como sendo uma cópia da tenda de Xerxes. Ela foi feita uma segunda vez, pois o antigo edifício foi incendiado pelo general romano Sula quando da tomada de Atenas (Pausânias, 1.20.4).

A descrição não fornece o nome do edifício, os usos ou os materiais utilizados na construção - como é habitual na Periegesis, em particular dos edifícios não religiosos. No caso do Odeion de Péricles, Pausânias seleciona três elementos para a descrição: a localização (junto ao teatro); um discurso a respeito de sua forma (cópia da tenda de Xerxes); e um discurso sobre sua história construtiva (destruição por Sula e reconstrução), para então iniciar a digressão sobre o cerco de Atenas. É significativo que esta seja a única passagem na descrição da Ática em que Sula é mencionado; sinal, possivelmente, de que a memória do cerco não estivesse presente nos espaços da cidade por onde Pausânias passou, seja pela decisão dos atenienses de não monumentalizarem o episódio, seja pela reconstrução dos edifícios destruídos operada em períodos posteriores. Neste caso, porque mencionar a história diante do Odeion? Pausânias

${ }^{204}$ Cf. o debate sobre a "constituição sulana de Atenas" em Geagan (1967).

${ }^{205}$ Sobre as questões específicas do uso de Pausânias como fonte histórica, cf. cap. 1. 
certamente conhecia a história da invasão de Sula; a reconstrução do Odeion era indicada em inscrições em bases de estátuas dispostas junto ao edifício, que mencionavam o nome dos arquitetos, os romanos Caio e Mario Stallius e o grego Menalippos, e o do financiador, o rei Ariobarzanes II Filopator ${ }^{206}$, rei da Capadócia entre 63 e 52, e filho do rei Ariobarzanes I, retirado do trono por Mitrídates em 88 e reentronado por Sula em 95 e novamente em 86/5 - estes elementos, associados ao uso de informantes locais, são suficientes para justificar a referência ao cerco nesta passagem. É importante destacar, ainda, que na descrição de Pausânias o edifício é relacionado claramente às invasões de Xerxes e Sula, sem qualquer referência aos responsáveis pelo iniciativa da construção - Péricles, após a invasão de Xerxes, e Ariobarzanes, após a invasão de Sula.

A digressão de Pausânias segue com uma breve narrativa do início da guerra mitridática, da captura da cidade e da tirania de Aristion. Escreve Pausânias:

Quando Sula retornou à Ática aprisionou no Cerâmico os atenienses que se opuseram a ele, e um em cada dez, escolhido ao acaso, ordenou que fosse executado (Pausânias, 1.20.6).

A ágora se torna local para a punição exemplar: mais do que o massacre desordenado das narrativas anteriores, Pausânias ressalta a lógica disciplinar - a dizimação, assassinando um a cada dez rebeldes. Casos concretos de dizimação militar no período republicano anterior a 86 são muito pouco atestados, mas a menção de Políbio, na descrição da constituição romana, à prática da execução por sorteio (utilizando como base da proporção o número de insubordinados), para indicar o caráter regular da prática (Políbio, 6.38.1-4). Ao longo do século I a.C. e do século I d.C. a prática é melhor atestada, ainda que seja objeto de um intenso debate sobre sua efetividade e/ou crueldade (Phang, 2008, pp. 125-9). No que diz respeito ao tratamento de civis rebeldes por Sula, são documentados casos de punição em massa, chegando ao limite da execução de toda a população masculina, como ocorreu no caso de Preneste (Santangelo, 2007, p. 84); mas nenhuma dizimação. A partir disto, não me parece seguro tomar a dizimação dos atenienses como fato ${ }^{207}$. Pode-se argumentar que a passagem reitera a crueldade de Sula, de acordo com a representação de Pausânias; no

\footnotetext{
${ }^{206}$ IG II $^{2} 3426$, base de estátua dedicada ao rei pelos arquitetos; IG II2 3427, base de estátua dedicada ao rei pelo demos. Informação adicional é dada por Vitrúvio (5.9). Cf. discussão abaixo, cap. 3.

${ }^{207}$ Como o faz, por exemplo, Antela-Bernárdez (2013, p. 87), entre outros.
} 
entanto, não me parece que a dizimação, com tão forte conotação disciplinar, realce mais a crueldade do que o massacre indiscriminado.

O espaço urbano volta à narrativa com o cerco à acrópole, onde se refugiaram Aristion e seus apoiadores. Neste ponto, Pausânias também se desvia das versões anteriores, ao afirmar que a captura de Aristion se deu pela invasão, e não pelo cerco prolongado. Possivelmente, esta explicação tenha sido utilizada para justificar a doença sofrida por Sula como punição ao sacrilégio - o desrespeito ao asilo de Aristion no santuário de Atena -, reforçando assim a caracterização negativa de Sula, mas que pressuporia a fraqueza da acrópole como fortaleza.

O final da narrativa deixa clara a opinião de Pausânias quanto ao episódio e a história posterior de Atenas: à selvageria de Sula se oporia o filatenismo de Adriano, encerrando um longo período de estagnação. A referência ao "florescimento" de Atenas sobre Adriano também é significativo em relação à ausência, em toda a descrição da Ática, do nome de Augusto - o que significa ignorar, por exemplo, o monóptero de Roma e Augusto na acrópole -, o que se liga ao projeto de Pausânias de amplificar o elogio da política cultural de Adriano para a Grécia ${ }^{208}$.

O espaço aparece na descrição de Pausânias em dois níveis diferentes. No nível da descrição da realidade empírica, o Odeion de Péricles é o suporte para uma narrativa histórica de sua história construtiva. No nível da própria narrativa, o espaço ateniense aparece como (1) a cidade toda, convertida em sede do demagogo e da multidão dos pobres turbulentos, (2) a ágora, transformada em palco para a punição exemplar, a dizimação, transpondo a disciplina militar romana para a população civil rebelde, e (3) a acrópole, que é insuficiente tanto como fortaleza e quanto como espaço sagrado diante do exército romano. Em síntese: a rebelião dos atenienses suspendeu, do ponto de vista de Sula e o exército romano, os significados históricos ou religiosos imbricados nos espaços públicos da cidade, que é justamente o oposto do projeto de Pausânias em sua descrição, a todo momento resgatando as tradições míticas e históricas dos locais visitados. Pausânias, neste sentido, faz pela escrita o oposto do que Sula fez com Atenas pelas armas.

\footnotetext{
208 Pausânias menciona Augusto poucas vezes em todo o relato, e mesmo seus elogios são comedidos em relação aos elogios a Adriano: tome-se como exemplo o elogio a Augusto feito na descrição de Corinto, na qual Pausânias afirma que Augusto conseguiu manejar o império melhor e ter mais fama e poder que César, associado ao fato de que nenhum edifício, em toda a obra, é atribuído por Pausânias a Augusto; a descrição do Olympieion e suas múltiplas referências a Adriano marcam bem a diferença. Sobre Pausânias e Augusto, cf. Arafat, 1996, 126-38; sobre Pausânias e os governantes romanos como um todo, cf. Arafat (1996, pp. 80-201) e Pereira (2011, p. 181).
} 


\section{Arqueologia}

O saque de Sula é utilizado como referência para a datação de diversos vestígios de destruição revelados pelas escavações. Estes vestígios são compostos, principalmente, por ruínas de edifícios associadas a fragmentos de cerâmica datados do início do século I; em poucos casos existem marcas de incêndio. A evidência foi reunida por M. Hoff (1997), que servirá como base a discussão a seguir a respeito da disposição espacial dos vestígios.

$\mathrm{Na}$ ágora e em seus arredores, diversos edifícios foram total ou parcialmente destruídos. Na região ao sudoeste da ágora, entre a rua do Pireu e a rua dos "Marmoreiros" - onde se localizavam diversas casas com vestígios de trabalho com mármore e metais -, três edifícios apresentam marcas de destruição datadas da época da invasão de Sula: o "Edifício em Poros", a “casa F” (Young, 1951, pp. 229-33), e o Banho Helenístico. Na ágora, as evidências das destruições são mais abundantes que em qualquer outro lugar, o que se explica tanto em função da intensidade das escavações, quanto da centralidade da ágora para todo o processo de invasão e massacre em 86 . As destruições de edifícios e monumentos se concentraram nas áreas sudoeste, sul e noroeste. No sudoeste, foram danificados o edifício identificado como "escritórios públicos"209 ao oeste da Stoa Média, o edifício chamado de Strategeion, o Tholos, o Monumento dos Heróis Epônimos e diversas estátuas localizadas próximo ao Novo Bouleuterion. No noroeste, o edifício conhecido como Arsenal Helenístico foi completamente destruído, e a Stoa Real teve algumas de suas paredes danificadas. Na área sul, alguns edifícios que compunham a Praça Sul foram danificados parcialmente (Stoa Média, Fonte Sudoeste, Aiakeion), enquanto outros foram completamente destruídos e não foram reconstruídos até o século II d.C. (o Edifício Leste e a Stoa Sul II). Até a reconstrução, a área foi utilizada como sede de oficinas de artesãos, o que indica que a "Praça", seja um ginásio, espaço comercial ou complexo judiciário, deixou de ser usada como tal; o pilar que possivelmente sustentava uma quadriga foi também destruído. Não há indício de destruições nos edifícios do centro da área oeste (Novo Bouleuterion, Metroon, Hephaisteion, templos de Apolo Patroos e de Zeus e Atena Frátrios, e Stoa de Zeus); o mesmo vale para as áreas leste (Stoa de Átalo II) e norte (Stoa Pintada). Fora da ágora, mas próximo dela, diversos edifícios identificados como

\footnotetext{
${ }^{209}$ Não confundir com os "Civic offices” de época romana.
} 
lojas ao leste da Stoa de Átalo II foram destruídos; a área se manteve em ruínas até o período augustano, quando toda a via foi nivelada para a regularização da ligação da ágora com a "Ágora Romana” que estava em construção.

$\mathrm{Na}$ acrópole, há indícios de danos produzidos no teatro de Dioniso e no Asklepieion. Quanto ao Odeion, a destruição é assegurada pela documentação epigráfica e literária, mas não há vestígios arqueológicos. Na encosta noroeste da acrópole, houve dano à Klepsidra, dentro da qual foi encontrada uma inscrição de contas do Erechtheion. No topo da acrópole, há evidência de danos provocados ao Erechtheion, na forma tanto de blocos com marcas de incêndio, quanto de blocos com técnicas romanas de grampeamento, que devem ser associadas à reconstrução de época augustana.

M. Hoff (1997) sugere que as destruições na ágora e arredores não foram aleatórias, mas foram determinadas por dois fatores principais: a localização do edifício nas vias utilizadas pelos soldados invasores, em particular nas áreas mais estreitas, e a função militar de alguns edifícios (Strategeion, Arsenal Helenístico). Os edifícios poupados da destruição foram aqueles ligados à administração pública (como o Bouleuterion) que não estavam na intersecção de vias, o que demonstra uma preocupação com o governo da cidade após o saque, e os edifícios religiosos. Hoff ressalta que monumentos históricos e culturais, como o monumento dos Heróis Epônimos e as estátuas próximas do Bouleuterion, também sofreram destruição, mas não desenvolve nenhuma explicação para além da constatação; pode-se pensar, por exemplo, na destruição consciente de marcos da memória ateniense, a partir da consideração das estátuas como objetos que incorporavam tanto a identidade cívica e quanto as práticas evergéticas.

A hipótese da "passagem das tropas" de Hoff, no entanto, não dá conta da intensa destruição na Praça Sul, na medida em que os edifícios mais destruídos (Edifício Leste, Stoa Sul II) eram aqueles que não estavam diretamente ligados à passagem de soldados da muralha até a ágora. Uma razão plausível seria a de que a monumentalidade da Praça Sul atrairia a atenção dos soldados; no entanto, a ausência de vestígios de danos na Stoa de Átalo II, e mesmo a quantidade reduzida de danos na Stoa Média, enfraqueceriam esta hipótese. A possibilidade de que muitas pessoas estivessem reunidas na área, o que também atrairia os soldados, é enfraquecida pelo horário no qual a invasão começou: segundo Plutarco, meia-noite. Talvez a chave esteja na topografia da Praça Sul: o edifício Leste e a Stoa Sul II estavam posicionados um nível abaixo da 
via imediatamente ao sul, o que facilitaria a ação destrutiva de soldados posicionados ali. De qualquer maneira, a ausência de mais evidências torna qualquer hipótese bastante frágil.

As destruições ao redor da acrópole certamente estão ligadas ao cerco a Aristion e seus apoiadores, quando a cidade já havia sido invadida e ocupada pelo exército romano. Não é evidente, entretanto, quem foi o responsável pelas destruições. Como vimos, a tradição literária as atribui tanto a Aristion (Apiano) quanto a Sula (Pausânias); o mesmo poderia ser dito a respeito dos outros edifícios. Parece mais plausível que os sitiados no topo da acrópole tenham sido os responsáveis pelas destruições na encosta do rochedo, a partir do lançamento de artefatos contra os sitiantes na tentativa de afastalos; o inverso pode ser proposto para as destruições no Erechtheion, causadas pelo lançamento de artefatos incendiários da encosta para o topo. Obviamente, outras hipóteses são possíveis, tais como a destruição acidental de determinados edifícios no esforço de ataque ou defesa das partes oponentes.

A partir destes elementos, é possível propor uma periodização da destruição, dividida em três momentos: a entrada tumultuosa do exército, marcada pela destruição de edifícios no caminho; a destruição punitiva, mais ou menos planejada, de edifícios de uso militar (Arsenal, Strategeion), de caráter monumental (Praça Sul) ou de grande valor simbólico (Heróis Epônimos, estátuas); a destruição vinculada ao sítio da acrópole. A preservação de edifícios religiosos e cívicos é indicativa tanto da preocupação com o governo da cidade após o saque, como afirma Hoff, quanto a eventuais considerações religiosas dos soldados e/ou seus comandantes. Interagiam, desta maneira, diferentes fatores destrutivos, definindo o que destruir e o que poupar. Em ambos, além das considerações práticas, é importante destacar aquelas religiosas (para a preservação) e aquelas históricas (para a destruição).

\section{Depois do saque: as duas vias}

O saque de Sula representou, sem dúvida alguma, um grande marco na história urbana ateniense: os danos em edifícios públicos na ágora e na acrópole são a parte arqueologicamente visível da grande destruição gerada tanto dos edifícios quanto das próprias vidas de atenienses. No entanto, é preciso situar o saque de 86 dentro de um contexto mais amplo, e que se iniciou algumas décadas antes: a crise do evergetismo 
construtivo monárquico. De fato, após 130 - com o fim da monarquia atálida e a crescente crise das dinastias selêucida e ptolomaica -, não há notícia de doações para construção de edifícios; as próximas doações documentadas serão a de Pompeu, em 62, que dá 50 talentos para a reforma do porto do Pireu, e a reconstrução do Odeion de Péricles financiada por Ariobarzanes II da Capadócia, 63 e 52 - mantido no poder sob os auspícios, justamente, de Pompeu. O saque de 86 , portanto, se situa no meio de um grande período de escassez de doações para a construção de edifícios, a qual parece ter se limitado justamente às práticas evergéticas. A grande destruição de edifícios, por outro lado, abria diversos campos para o reestabelecimento desta prática, o que dependia, fundamentalmente, da disponibilidade financeira dos potenciais evergetas (Habicht, 1997, p. 331-2). Entre o saque e o restabelecimento do evergetismo construtivo na década de 60 , foi configurada uma nova forma de relação com o espaço urbano, que marca um contraste radical com o período anterior. Dois personagens foram de fundamental importância para esta reconfiguração: Tito Pompônio Ático e Marco Túlio Cícero.

\section{Ático, Cícero e o antiquarianismo romano em Atenas}

Tito Pompônio Ático residiu em Atenas por cerca de 20 anos, a partir de meados da década de 80; seu amigo de vida inteira Cícero visitou Atenas ao menos três vezes, permanecendo na cidade seis meses em 79, cerca de suas semanas em 51, e provavelmente pouco tempo mais em 50 (Habicht, 1997, p. 329-30, 334). Nenhuma atividade construtiva é atribuída a eles; entretanto, as práticas espaciais na cidade que são mencionadas, de passagem, em diversos textos escritos por Cícero e na biografia de Ático escrita por Cornélio Nepos, são reveladoras das atitudes de romanos com o espaço ateniense e da recepção destas atitudes pelos atenienses.

As Cartas a Ático (Ad Atticum) são parte da abundante epistolografia de Cícero, que reúne, além delas, as Cartas aos Amigos (Ad Familiares), Cartas ao irmão Quinto (Ad Quintum fratrem) e Cartas a Bruto (Ad Brutum). Algumas cartas foram divulgadas pelo próprio Cícero - como é o caso da carta endereçada a César (Cartas a Ático, 8.9.1) - mas a maior parte foi publicada postumamente, como é o caso do conjunto de cartas a Ático (Nepos, Vida de Ático, 16.3; Wilkinson, 1982, p. 249). Infelizmente, não foram publicadas as cartas enviadas por Ático, o que faz com que diversas referências no texto 
de Cícero sejam incompreensíveis, e, mais importante para o nosso caso, não tenham sobrevividos relatos de Ático sobre o final de sua estadia em Atenas. As cartas enviadas por Cícero a Ático se estendem de 68 a 43 (Winstedt, 1961); sendo assim, apenas as cartas dos três primeiros anos foram enviadas a Ático enquanto este esteve em Atenas. Pouquíssimo é dito sobre o que ocorria em Atenas, e as referências às respostas de Ático são sintéticas demais para qualquer conclusão. No entanto, um tema recorrente nestas primeiras cartas é bastante revelador: as encomendas de estátuas e de livros que Cícero faz a Ático. Vejamos.

A primeira menção à biblioteca de Ático em Atenas aparece em carta do início de 68, quando Cícero, após atualizar rapidamente Ático sobre assuntos privados em Roma, pede que Ático o atualize a respeito das obras compradas para ele, assim como reitera o desejo de ter a possa de sua biblioteca, que seria a fonte de "deleite" para quando chegasse ao "ócio" (Cartas a Ático, 7). As "obras” compradas provavelmente são as estátuas referidas em cartas posteriores, como uma Hermerácles (Cartas a Ático, 10) e uma Hermatena (Cartas a Ático, 1, 4), que Cícero planeja colocar em seu ginásio - às vezes chamado de "minha Academia" (Cartas a Ático, 4, 9) - na vila de Túsculo, comparada com inferioridade ao Cerâmico onde estaria Ático, em carta de 67 (Cartas a Ático, 10). A biblioteca aparece novamente em duas cartas de 67, caracterizada ora como um suporte para a velhice (subsidium senectuti; Cartas a Ático, 10), ora como objeto de um "desejo que aumenta com o desgosto pelas outras coisas" (summum me eorum studium tenet sicut odium iam ceterarum rerum; Cartas a Ático, 11); e em outra de 66, cuja posse faria com que Cícero superasse a riqueza de Crasso e desprezasse casarios e prados (quod si adsequor, supero Crassum divitiis atque omnium vicos et prata contemno; Cartas a Ático, 4).

A partir destas passagens, é possível fazer ao menos duas observações. A primeira, de que Atenas era vista por Cícero como fonte de artefatos associados ao mundo ginasial - estátuas e livros -, aos quais teria acesso por meio de Ático. Por um lado, isto pressupõe a capacidade de Ático de converter-se em eventual comprador de estátuas e organizador de uma biblioteca privada. O impacto econômico das demandas romanas por estátuas atenienses - um dos principais combustíveis para a chamada escultura neoática - foi longamente discutida por Day (1942, p. 129). A aquisição de livros por Ático indica que a organização de bibliotecas privadas de tamanho considerável - ou seja, que apesar dos exageros, seria importante para os planos de Cícero na velhice - era mais um circuito de produção e consumo de livros, paralelo à 
imposição estatal da doação de livros pelos efebos aos ginásios, como é atestado para o Ptolemaion, que recebia cem livros anualmente de cada efebo, prática atestada em 97 (IG II ${ }^{2}$ 1029, 1. 25-26) e em 37 (IG II ${ }^{2}$ 1043.50). O envio de estátuas e livros de Atenas para Roma não seria uma novidade, como vimos acima: o saque de Sula significou, além das destruições, o envio de obras de arte e elementos arquitetônicos atenienses para Roma, assim como a biblioteca de Aristóteles, até então em posse de Apélico, aliado de Athenion. Para além do saque, é possível supor um comércio regular ao menos de estátuas, vinculado à retomada de elementos escultóricos clássicos e arcaicos na chamada escultura neoática (Day, 1942, p. 129). A importância das cópias de época romana de esculturas gregas anteriores para a conformação de uma estética helenizante das elites italianas já foi destacado com detalhe nos estudos de Zanker (1988) e Wallace-Hadrill (2008), muitas vezes vinculadas à criação de um espaço de negação da vida cívica, dominado pelo ócio e pelo prazer.

Disto decorre a segunda observação: Atenas, inclusive sua ágora (o “Cerâmico”), referência da vila de Cícero em Túsculo, é vista como oposto do fórum romano, tanto pela geografia quanto pelo modo de vida. $\mathrm{O}$ afastamento dos assuntos públicos romanos se apresenta de modo diferente para os dois correspondentes: Ático abandona uma eventual carreira política ainda na juventude ao partir para Atenas, consolidando uma atitude de neutralidade que o marcará por toda a vida, conforme Nepos (cf. abaixo); Cícero projeta este afastamento para a velhice, quando se deslocará definitivamente para sua "Academia" em Túsculo. Cristaliza-se, assim, a imagem de Atenas como cidade universitária, cujo modo de vida é visto como o oposto da política $^{210}$. Este topos terá uma longa trajetória na literatura posterior, sendo o Discurso Panatenaico de Aélio Aristides uma de suas principais expressões (Oliver, 1968). É importante destacar, além disso, a interpretação etária implícita e Cícero: Atenas é onde se vive o que um cidadão romano viverá quando estiver velho, após sua carreira política; por outro lado, é para Atenas que Cícero manda seu filho para sua formação cultural (De Officis, 1.1.1). Assim, Atenas está no início e no fim da trajetória de um cidadão romano culto, o que se adequa à imagem, também ciceroniana, de Atenas como berço da civilização: lá as bases da cultura foram criadas, e à cultura letrada ateniense deverá voltar o homem em sua velhice. É possível que esta imagem cíclica da historicidade de Atenas esteja vinculada à experiência de Cícero na iniciação aos

\footnotetext{
${ }^{210}$ Mais uma ironia, especialmente quando se lembra da lei soloniana que punia a apatia política em momentos de stasis.
} 
mistérios de Elêusis, os quais, apesar das incertezas, estavam diretamente relacionados à ideia de Atenas como berço da civilização (especialmente da agricultura) e ao fim da vida (Cícero, De Legibus, 2.35-36; Clinton, 1989 e 1997; Barnard, 2011).

Mais outras duas referências à cidade de Atenas nas cartas de Cícero são importantes para a discussão da espacialidade ateniense pós-Sula. A primeira delas é conhecida a partir de duas cartas: uma enviada a C. Mêmio, enteado de Sula, (Cartas Familiares, 13.1) e outra enviada a Ático (Cartas a Ático, 5.11), ambas em 51, referentes ao projeto de Mêmio, residente em Atenas desde seu exílio da Itália em 53, de construir uma casa sobre as ruínas da antiga casa de Epicuro, para a qual havia

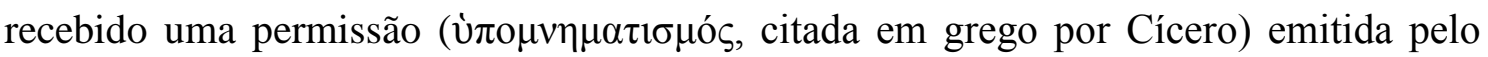
Areópago. Cícero diz que foi procurado por Ático e por Patrão e Fedro, filósofos epicuristas, que solicitaram que ele intervisse diretamente junto a Mêmio; Cícero o faz por meio de carta enviada a Mêmio quando este estava em Mitilene, e provavelmente também quando ambos se encontraram em Atenas: o pedido consiste em que Mêmio solicite o cancelamento da permissão do Areópago.

A carta a Mêmio é fortemente retórica: Patrão é caracterizado como um homem honesto, mas que eventualmente poderia criar mais problemas do que o razoável, coisa que não seria esperada de Mêmio; o fiel da balança é Ático, caracterizado como particularmente altruísta e próximo tanto de Patrão e seu amigo Fedro quanto do próprio Cícero, que aparentemente aquiesce aos pedidos em função da intervenção de Ático. Os sentimentos de Mêmio são tema recorrente: Cícero insiste que, caso Mêmio desista do projeto, ele deve fazê-lo por vontade e disposição própria, contra a qual Cícero não deseja se colocar. A lógica do argumento é a amizade: Mêmio deve desistir do projeto por conta do pedido de Cícero, que o fez a pedido de Ático, que o fez a pedido de Patron. Somente em um momento aparecem os argumentos de Patrão (que Cícero diz acreditar que Mêmio já os conheça): "honra, dever, o direito de testamento, a autoridade de Epicuro, as súplicas de Fedro, a sede, o domicílio, e os vestígios de homens superiores" (honorem, officium, testamentorum ius, Epicuri auctoritatem, Phaedri obtestationem, sedem, domicilium, vestigia summorum hominum [...]; Cartas Familiares, 13.4).

Os argumentos de Patrão, sintetizados por Cícero, têm matrizes variadas - os encargos de sua posição, o direito cívico, a amizade, o espaço e o valor histórico ligado a ele - e revelam tanto o investimento retórico de Patrão quanto sua fraqueza inerente diante do poder de Mêmio. Vale notar que a condenação e o exílio de Mêmio em Roma 
não resultou em perda de poder nem em relação aos atenienses, nem em relação a outros cidadãos romanos em Atenas, como Ático e Cícero. Mas, dos vários argumentos de Patron, nos interessam particularmente aqueles de ordem espacial. Vejamos com mais detalhe.

Epicuro, nascido na colônia ateniense na ilha de Samos em 341, residiu e lecionou em Atenas entre o final do século IV e início do III. Entre suas posses, estavam um jardim fora das muralhas, junto à via que levava à Academia, e uma casa e um jardim dentro das muralhas, no demos de Melite. É muito provável que o objeto da disputa entre Patrão e Mêmio seja esta última casa: a ausência de argumentos de ordem religiosa, que certamente seriam engajados para a defesa do jardim extraurbano - onde eram realizados diversos cultos mensais e anuais ligados a Epicuro, sua família e alguns de seus seguidores, ainda que contrário a doutrina epicurista ${ }^{211}$ - não aparecem entre os argumentos de Patron, segundo Cícero ${ }^{212}$. Por oposição à série de cultos no jardim extraurbano mencionados no testamento de Epicuro (Diógenes Laércio, Vidas $e$ Doutrinas dos filósofos eminentes, 10.16-21), pouco é dito a respeito da casa em Melite. Não há indícios para sua localização exata; a referência a Melite indica apenas que a casa estava na região oeste de Atenas ${ }^{213}$. No entanto, o testamento de Epicuro fornece duas informações importantes: a casa seria transmitida por herança para Hermarchos (Diógenes Laércio, Vidas, 10.17), o mesmo que receberia seus livros (10.21). A referência à casa de Epicuro como "sede" e "residência" (sedem, domicilium) na argumentação de Patron, garantidos pelo testamento de Epicuro (testamentorum ius) guardado do Metroon, parece indicar que a casa ainda tinha esta função, abrigando a biblioteca da escola epicurista - algo impossível para o jardim extramuros, onde ocorriam os rituais e eventualmente as aulas e reuniões dos seguidores (Cícero, De Finibus, 1.4).

Para além das funções práticas da casa, outro argumento de ordem espacial entra em cena: aquele baseado na "autoridade de Epicuro" (Epicuri auctoritatem) e no fato de

\footnotetext{
${ }^{211}$ Mencionados no testamento de Epicuro, conforme transcrito por Diógenes Laércio no início do séc. III d.C. Tais cultos foram tomados como uma contradição entre os epicuristas e sua doutrina; cf. Clay (2009, pp. 22-6).

${ }^{212}$ Sobre o jardim extraurbano, v. Clay (2009). Para o debate sobre a localização da casa de Epicuro no demos de Melite, cf. Judeich (1931, pp. 364 e 391), Wycherley (1959), Dontas (1971), Clarke (1973).

${ }^{213}$ Sobre a localização e extensão do demos de Melite, cf. Lalonde (2006), que propõe que Melite tinha uma forma trapezoidal, com os lados divergentes partindo um do sudoeste da ágora até a colina das Ninfas, e outro do noroeste da ágora até o Dipilon, o lado paralelo menor acompanharia a face ocidental da kolonos Agoraios, e o lado maior acompanharia a linha ocidental muralha entre a colina das Nifas e o Dípilo, ainda que não haja certeza quanto à continuidade do demos para além da muralha.
} 
a casa de alguma maneira se ligar aos "vestígios de homens superiores" (vestigia summorum hominum). A imbricação entre narrativa e espaço, aqui, funciona para a criação de um espaço carregado de significação histórica pelo contato com figuras importantes para a memória social. O que está em questão no episódio é, justamente, a descaracterização daquele espaço como "espaço histórico", como a "casa de Epicuro", ao mesmo tempo patrimônio de epicuristas e de atenienses, que pode desaparecer diante do poder aparentemente incontestável de Mêmio. A rede criada para a defesa da casa de Epicuro é reveladora tanto da fraqueza institucional ateniense quanto das novas vias pelas quais esta defesa pode ser realizada: o Areópago, instituição que ao longo do século I se consolidaria como a maior importante na cidade, ou não se opôs ao projeto de Mêmio, ou, o que é mais provável, não se atreveu opor; a saída para os responsáveis pela escola epicurista foi justamente utilizar os canais da amicitia entre os membros da elite romana, estratégia que teve em Ático um apoio fundamental - considerando o desprezo de Cícero pelo epicurismo e a afeição por Ático. A adesão de Ático ao epicurismo, sua longa residência em Atenas, assim como o facínio de Cícero pelo patrimônio histórico da cidade, foram ingredientes indispensáveis na fixação desta estratégia.

Em carta enviada para Ático (Cartas a Ático, 5.2) pouco depois do pedido a Mêmio revela outros detalhes da história, assim como sua conclusão. Cícero diz que o plano inicial de Patrão era que Cícero, quando chegasse a Atenas, solicitasse ele mesmo o cancelamento da permissão dada pelo Areópago para Mêmio, do que foi demovido por Cícero. A estratégia de Patron, talvez corretamente, que Cícero teria um poder equivalente ao de Mêmio diante do Areópago; no entanto, isto faria com que tanto o Areópago quanto o próprio Cícero entrassem em conflito com Mêmio. A alternativa de Cícero, de pedir a Mêmio que ele mesmo solicitasse o cancelamento ao Areópago, manteve as relações de amicitia seguras, mas ao mesmo tempo torna mais evidente ainda a submissão do Areópago a Mêmio. Esta última estratégia deu certo: como escreve Cícero, Mêmio abandou seu projeto de construir uma casa, ainda que guardasse consigo a ira contra Patron.

Em resumo: três formas de produção do espaço urbano entram em disputa neste momento, a saber, o frágil poder das instituições cívicas (o Areópago) e as associações filosóficas (a escola epicurista), o incontestável poder de um membro da aristocracia senatorial romana (Mêmio), ainda que formalmente excluído das instituições romanas, e as relações de amicitia desta aristocracia, que seriam capazes de realizar o que as 
instituições cívicas não conseguiram. É preciso destacar, enfim, que a defesa da casa de Epicuro com argumentos "históricos" sintetiza tanto a tradição filosófica ateniense quanto sua apropriação a partir de um modo antiquário, elementos centrais na produção da concepção de segmentos espaço físico da cidade como patrimônio cultural a ser preservado - concepção que teve nas destruições de Sula, padrasto de Mêmio, talvez o seu principal mote.

Além da participação na defesa da casa de Epicuro, Cícero chegou a formular um projeto de intervenção construtiva em Atenas. O projeto aparece em duas cartas endereçadas a Ático e datadas de 50, quando Cícero era procônsul na Cilícia. Na primeira (Cartas a Ático, 6.1), escrita na cidade de Laodicéia, o projeto é introduzido já no final da carta, após mencionar diversos assuntos - como os atritos com Ápio Cláudio Pulcher, governador da Cilícia nos dois anos anteriores, ou os atritos entre César e Pompeu, por conta da doação de César ao ateniense Herodes ${ }^{214}$. Cícero pergunta a Ático sua opinião a respeito de um plano de doar à Academia um novo propileu, justamente quando Pulcher planejada o propileu de Elêusis; Cícero visava criar um memorial (monumentum) para si mesmo (Cartas a Ático, , 6.1.26). Em outra carta, escrita alguns meses depois em Rodes (Cartas a Ático, 6.6), Cícero, logo após mencionar um possível atrito com Appius - se tornara sogro de seu acusador - reitera o desejo de contruir o propileu, diante do abandono do projeto por Pulcher do propileu em Elêusis.

Em ambas as cartas, Cícero ressalta a competição, implícita em seu projeto, com Ápio Cláudio Pulcher: se por um lado a competição gera a sensação de ridículo na primeira carta, por outro é justamente a ausência da competição que desanima Cícero de seu projeto, apesar do apoio inicial de Ático. A escolha do elemento arquitetônico e do local da dedicação ao mesmo tempo demonstrava a igualdade e a diferença dos projetos: ambos visavam a dedicação de um propileu a um santuário extraurbano, cujo local diferia em função das preferências religiosas ou filosóficas dos evergetas - a religiosidade de Pulcher versus o platonismo de Cícero. Ao problema da competição implícita se uniria a questão da percepção dos atenienses: Cícero representa a doação quase como seu inverso, o agradecimento, seja o propileu em função de seu amor por Atenas, que doou a civilização à humanidade, seja a distribuição de trigo em função da hospitalidade ofertada pelos atenienses.

\footnotetext{
${ }^{214}$ Relacionada por Hoff ao financiamento da ágora romana, que seria completada apenas no período augustano; cf. abaixo, cap. 3.
} 
No entanto, a inversão não é completa: Cícero afirma claramente o desejo de ter um "monumento seu" em Atenas. A escolha do propileu é adequada a este fim: enquanto elemento funcional, o propileu delimita o espaço interior e exterior de um determinado recinto, qualificando a comunicação entre eles; é impossível não perceber sua presença. A provável inscrição na arquitrave do propileu - marca apropriada pelo evergetismo romano em Atenas (propileu de Elêusis dedicado pelos descendentes de Pulcher, propileu oeste da Ágora romana) - reforçaria o personalismo da doação, fazendo com que todos os que entrassem na Academia lembrassem do evergeta, ele próprio um platonista.

Infelizmente (para nós), Cícero abandonaria o projeto do propileu para a Academia, o que é indicado pela ausência de vestígios nas escavações. De todo modo, o projeto é coerente com a celebração da tradição filosófica ateniense, encarnada em seus espaços e circuitos, como é evidente na narrativa de abertura do livro 5 do Sobre os fins de Cícero, escrito pouco depois.

No diálogo filosófico De finibus bonorum et malorum, escrito em 45, Cícero situa no início do quinto livro um diálogo travado entre ele, seu irmão Quinto Cícero, seu primo Lúcio Cícero, Ático, e Marco Piso, no caminho entre a cidade (intramuros) e a Academia. No trajeto, cada um dos interlocutores faz referência a personagens importantes da história ateniense: Piso, na Academia, lembra de Platão e seus seguidores; Quinto Cícero, quando passa pelo demos de Colono, lembra de Sófocles e seu Édipo em Colono; Ático faz referência a Epicuro, ao passar por seu antigo jardim; e assim por diante. Cícero, antes de mencionar o filósofo platônico Carneades, faz uma breve reflexão sobre a memória e o espaço: "por toda Atenas, existem muitos indícios de homens eminentes (indicia summorum virorum) no local mesmo onde eles viveram" (Cícero, Sobre os fins, 5.4).

A ideia de que Atenas é repleta de lugares de memória é reforçada por Lúcio Cícero, o qual, quando perguntado se visitava frequentemente os locais onde os oradores discursavam, diz: "para onde quer que vamos, pisamos em chão histórico" (in aliqua historia vestigium ponimus; Sobre os fins, 5.5).

A relação que os personagens do diálogo têm com a cidade não é, certamente, imediata: entre os olhos, os corações e a imaginação de cada um e o espaço ateniense está o tempo dedicado ao conhecimento que informa sobre a historicidade de cada lugar. A cidade é história, mas somente na medida em que a tradição a produziu assim. Dois meios de produção da tradição são mencionados: a tradição literária (os discursos, a 
tragédia, os diálogos) e as aulas nas escolas filosóficas. No caso da tradição clássica, sua efetividade na produção do "espaço histórico ateniense" depende de circuitos que ultrapassam a cidade: a circulação dos textos e sua disponibilidade respondem aos mais diversos imperativos. Já as escolas filosóficas reproduzem a historicidade do espaço em sua própria existência: as escolas criam circuitos inter e extraurbanos (especialmente entre o Ptolemaion e a Academia), pelo qual se deslocam os interessados em ouvir as aulas de filósofos que reforçariam, ainda que indiretamente, o valor histórico dos locais onde os "antigos filósofos" lecionaram ou viveram cotidianamente.

É importante destacar que as lembranças não dizem respeito apenas aos grandes eventos - os embates entre Demóstenes e Ésquines na Pnix, ou mesmo míticos, como a morte de Édipo em Colono - mas também a ações cotidianas, como as aulas de Platão e Carneades e o treinamento oratório de Demóstenes na baía do Falero. Esta maleabilidade permite uma multiplicação dos suportes espaciais da memória, que está, justamente, na base da consideração da "cidade inteira" ("in omini parte Athenarum", "aliqua historia vestigium ponimus") como histórica.

Acerca da presença de Ático em Atenas, a principal fonte é a biografia escrita por Cornélio Nepos, o primeiro ou um dos primeiros biógrafos latinos (Titchener, 2003; Kraus, 2005), escreveu a obra De viris illustribus (Sobre homens ilustres), composta por cerca de 300 biografias; destas, sobreviveram apenas o livro sobre os generais estrangeiros e duas vidas sobre os historiadores latinos (Catão e Ático). A vida de Ático foi escrita em ao menos dois momentos: a maior parte na década de 30, ainda no período triunviral, e uma extensão após a morte de Ático, no início do principado. A consideração deste período, como se verá, é fundamental para a discussão da caracterização de Ático segundo Nepos.

A vida de Ático é dividida em partes bem definidas: começa com as origens, a infância e a educação do personagem; segue com a narrativa cronológica de sua vida em Atenas e em Roma; passa para uma discussão das virtudes de Ático tanto na vida pública quanto privada; e termina com uma extensão sobre a relação de Ático com Augusto e sua morte. A biografia é estruturada a partir de uma oposição entre envolvimento e neutralidade de Ático nas guerras civis romanas do século I: geralmente com relações de amizade em ambos os lados, Ático não toma partido nunca; sua participação se limita ao socorro financeiro àqueles que são perseguidos, sem, com isso, entrar em conflito aberto contra os perseguidores. Dessa forma, Nepos consegue tratar dos temas "historiográficos" do final da república - as guerras civis - sob a ótica da 
vida de um personagem secundário, ao mesmo tempo relacionando e diferenciando a historiografia e a biografia como gêneros literários (Kraus, 2005).

De um ponto de vista historiográfico, o texto é repleto de anticlímaces: em vários momentos Ático está no centro dos acontecimentos, e em todos eles prefere se ausentar a tomar partido no conflito. O primeiro destes exílios voluntários se dá entre 86 e 84, quando L. Cornélio Cinna assume o comando em Roma e passa a perseguir os apoiadores de Sula, então em guerra contra Mitrídates; tendo amigos em ambos os lados, Ático viaja para Atenas para "devotar-se aos seus estudos", levando consigo "uma grande porção de sua fortuna" (Nepos, Vida de Ático, 2.2-3). Em Atenas, Ático praticaria ao menos três formas de evergetismo: o empréstimo de dinheiro sem juros à cidade, a distribuição de trigo para os cidadãos e o conselho nos assuntos públicos. Em troca, a cidade ofereceu a cidadania ateniense, negada pelo evergeta temeroso de que a aceitação implicaria na perda de sua cidadania romana, e estátuas, também negadas enquanto Ático esteve na cidade, mas dedicadas em abundância "nos lugares mais sagrados" após ter deixado a cidade, diante das lágrimas dos atenienses, em 65.

Os estudos aos quais Ático se devotou em Atenas eram, sem dúvida, os filosóficos, o que reforça a imagem de Atenas como uma espécie de cidade universitária, em função das escolas filosóficas disponíveis, mesmo após o saque de Sula $^{217}$. Mas além deste, dois outros usos da cidade são mencionados no texto, e receberam pouca atenção dos estudiosos: a cidade como base do evergetismo e a cidade como exílio político.

Em Atenas, Ático viverá sua única experiência de evergeta de uma cidade inteira, na medida em que suas doações posteriores mencionadas por Nepos serão sempre voltadas para particulares. As formas do evergetismo praticado por Ático em Atenas são reveladores: a distribuição de trigo demonstra ao mesmo tempo a manutenção da fraqueza agrícola ateniense e a força da tradição deste presente; o empréstimo de dinheiro é um exemplo claro do endividamento público em relação aos romanos, prática que pode estar na base da promessa de Mitrídates, via Athenion, de cancelar as dívidas; finalmente, a posição como "conselheiro informal" e sua presença provavelmente ativa - nas assembleias demonstra a importância política de Ático na cidade, rompendo assim com as tradições cívicas de interdição da participação de nãocidadãos na condução da política local. O uso de Atenas como base do exílio político

\footnotetext{
${ }^{217}$ Vale lembrar que muitos filósofos deixaram a cidade ainda em 88. Sobre Atenas como base de estudos filosóficos na Vida de Ático, conferir também 12.3.
} 
funciona no texto para resumir a conduta que Ático seguirá pelo resto de sua vida: a neutralidade. Em Atenas, Ático estaria longe o suficiente de suas obrigações de apoiar um ou outro lado do conflito, mas não longe o bastante para impedi-lo de ajudar financeiramente amigos que estivessem em perigo.

A estadia de Ático em Atenas sintetiza duas características do personagem: a neutralidade política e o amor à antiguidade. A despolitização do antiquarianismo, como bem notado por F. Millar (2002, pp. 192-7), é apenas aparente, na medida em que o antiquarianismo se tornaria uma peça fundamental na propaganda do regime augustano, e que contaria, inclusive, com a assistência do próprio Ático. Mas é possível ir além, seguindo a pista de Millar, para quem "a tranquilidade filosófica e a neutralidade, observada por Ático e louvada por Nepos, somente serviu para suavizar o caminho da monarquia" (2002, p. 199).

\section{Pompeu e Ariobarzanes em Atenas: novos e antigos bárbaros}

As duas décadas posteriores ao saque foram marcadas pela baixíssima atividade construtiva, o que certamente estava relacionado às dificuldades econômicas da cidade. Ao final deste período, as transformações da política em Roma, rumo a uma nova guerra civil, e na Ásia, com o retorno de Mitrídates, terão importantes efeitos para a história urbana ateniense. Os personagens principais da produção do espaço ateniense nas décadas de 60 e 50 serão o general romano Cneu Pompeu e o rei capadócio Ariobarzanes II, eles próprios profundamente relacionados.

Pompeu faria duas visitas a Atenas, em 67 e em 63. Apesar de curtas - como Plutarco dá a entender, elas são extremamente significativas do ponto de vista da produção do espaço. A primeira visita ocorreu logo no início da operação contra a pirataria no Mediterrâneo: Plutarco relata como Pompeu, após estabelecer condições favoráveis à expedição em Roma, desvia seu curso para Atenas, "subiu para a cidade, sacrificou aos deuses, e se dirigiu ao povo", e ao sair da cidade, lê uma inscrição comparando-lhe a um deus (Plutarco, Vida de Pompeu, 27.3). A brevidade da referência de Plutarco impede uma leitura mais detalhada da visita; nenhum dos locais pode ser identificado com segurança. É de se esperar que a "subida" e o "sacrifício aos deuses" 
se refiram a rituais realizados na acrópole, em função da importância do visitante, mas é impossível determinar com precisão. É tentadora a hipótese de que Pompeu, como os "generais romanos" mencionados no discurso de Athenion, tenha discursado no bema na ágora - mas a reverência ao general, cujo poder excedia aquele dos generais anteriores, pode indicar que o discurso tenha sido realizado no teatro. O portão onde estariam as inscrições, por sua vez, seria provavelmente aquele do Pireu, o que explicaria o fato de Plutarco não mencionar o Dypilon ou o Portão Sagrado, mas, novamente, não há garantias. Certo é que Pompeu perfaz duas ações, uma de caráter religioso - os sacrifícios - e outra de caráter político - o discurso. Se a primeira se explica pelo prestígio das tradições religiosas atenienses, a segunda é mais complexa. Pode-se sugerir o papel de Atenas como centro difusor de informações para a comunidade helênica, para quem Pompeu comunicaria o sentido de sua expedição; mas não se pode descartar mesmo o sentido histórico do ato de discursar aos atenienses, onde duas décadas antes Sula, patrono de Pompeu, havia imposto sua autoridade, e menos de três séculos antes Alexandre, também Magno, havia se arrependido do massacre de Tebas (Plutarco, Alexandre, 13.1). Finalmente, a menção da visita apressada de Pompeu a Atenas está articulada à narrativa subsequente: Pompeu, após vencer as várias frotas piratas, ao invés de executar os culpados, estabelece-os em cidades (Plutarco, Pompeu, 28.3).

Pompeu, portanto, civiliza os piratas, e o faz após sua visita a Atenas considerada por Cícero, Plutarco e outros como o berço da civilização. O tema da civilização versus barbárie retorna na narrativa de Plutarco na referência à participação das amazonas nas batalhas entre albaneses e romanos próximo ao Cáucaso. Plutarco não confirma esta participação - "que se diz" ter ocorrido, sem ser verificado pelos romanos - mas não se exime de fazer uma digressão sobre o país e o modo de vida das amazonas, reforçando desse modo o paralelo entre Pompeu e Alexandre (Plutarco, Alexandre, 46). Tal combate teve lugar já no final da terceira guerra mitridática, que acaba com o suicídio de Mitrídates em 63; após assentar a vitória em Amisos (leste do mar Negro), Pompeu retorna para a Itália passando por Mitilene, onde assiste a competições poéticas e se maravilha com o edifício do teatro, por Rodes, onde ouve os sofistas (incluindo Posidônio) e por Atenas, onde, após tratar os filósofos com munificência, “dá 50 talentos para a restauração da cidade" (Plutarco, Pompeu, 42.5-6).

O contraste com a primeira visita é evidente: se antes Pompeu realizou atividades religiosas e cívicas, o que ocorre no retorno à Itália é uma espécie de turismo 
cultural, relacionado à poesia em Mitilene, à retórica em Rodes e à filosofia em Atenas, cada uma das cidades tendo um grande renome em cada um dos gêneros. Neste percurso, Pompeu por duas vezes se interessa pelo aspecto espacial: em Mitilene, obtém plantas e desenhos do teatro com o objetivo de construir um semelhante em Roma; em Atenas, financia a restauração da cidade. Não há, infelizmente, indicações claras para intervenções realizadas a partir do financiamento de Pompeu na cidade; as poucas referências se limitam a restaurações realizadas no Pireu, particularmente do complexo comercial conhecido como Deigma, de época pericleana, e certamente danificados durante o cerco do porto por Sula ${ }^{219}$.

Enquanto Militene e Rodes não serão, até onde se sabe, objeto de intervenções espaciais, Atenas e Roma serão centrais no evergetismo construtivo de Pompeu. O paralelo ressalta as diferenças: em Atenas, a referência do evergetismo são as destruições de Sula, e as intervenções, financiadas mas não projetadas por Pompeu, visam o passado pré-86; em Roma, a construção do primeiro edifício em pedra marca uma enorme inovação em sua história urbana, marcando indelevelmente o espaço urbano romano com a presença arquitetural de Pompeu, que participou diretamente do projeto. Certamente, questões práticas foram determinantes para esta diferença, pois Atenas entra apenas marginalmente na ação evergética pompeiana, apenas um sítio de passagem. No entanto, o critério utilizado por Pompeu - a restauração - é um indício para o modo como a cidade era percebida pelos evergetas estrangeiros que, mais do que construir grandes monumentos para si, buscavam intervir na reconstrução dos edifícios danificados. O financiamento do Pompeu certamente está no início de uma nova atitude em relação ao espaço ateniense: mais do que a preservação ciceroniana, trata-se da restauração, que contará com evergetas locais e estrangeiros.

Após 86, Atenas não estará mais no centro dos acontecimentos centrais da história política e militar do Mediterrâneo - nada comparável ao que ocorreu em Roma, Farsalo, Ácio ou Alexandria ocorrerá na cidade. Não obstante, ela continuará sendo objeto de presentes dos protagonistas desta história, o que revela a sobrevivência de seu prestígio mesmo quando sua importância militar e mesmo diplomática é uma lembrança cada vez mais evanescente. A única construção, de fato, datada deste período na cidade de Atenas (excetuando-se, portanto, Elêusis e o Pireu) é a reconstrução do Odeion de

\footnotetext{
${ }^{219}$ A identificação parte da menção, no decreto de restauração dos santuários ao "deigma dedicado pelo

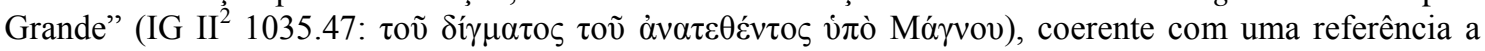
Pompeu pelo cognome latino magnus.
} 
Péricles com o financiamento de Ariobarzanes II Filopator da Capadócia; no entanto, a grande quantidade de referências textuais e epigráficas associadas ao evergetismo de membros da elite romana justificam sua análise de um ponto de vista espacial. Nesta seção, discutiremos a formação de dois padrões de intervenção no espaço, que ora se mesclam, ora se distanciam: o urbanismo antiquário e o (reprimido) culto aos evergetas romanos.

O edifício conhecido como "Odeion de Péricles" era um teatro coberto situado na encosta sudeste da acrópole, junto ao teatro de Dioniso. Este odeion - um dos três existentes na cidade ${ }^{220}$ - é conhecido a partir de escassas referências literárias ${ }^{221}$ e epigráficas $^{222}$, às quais se somaram as conclusões derivadas de escavações parciais realizadas em diferentes momentos do século XX d.C. ${ }^{223}$. Trata-se de um edifício hipostilo de planta aproximadamente quadrangular (c. $62 \times 68 \mathrm{~m}$ ), com 90 colunas (9 fileiras no sentido leste-oeste e 10 no sentido norte-sul) espaçadas regularmente em toda a área interna edifício; a partir das escavações realizadas, não é possível localizar com clareza a entrada do edifício. A cobertura, mencionada na tradição literária como semelhante à tenda de Xerxes (Plutarco, Péricles, 13.9; Pausânias, 1.20.4), deveria ser de formato piramidal. As colunas eram de pedra (não está claro se mármore ou calcário) e a cobertura de madeira; Vitrúvio, que atribui a construção a Temístocles, afirma que foram utilizados espólios dos navios persas destruídos após a batalha de Salamina (Vitrúvio, 5.9.1). A grande quantidade e disposição das colunas foi certamente um problema para a visibilidade das atividades realizadas no espaço interno; a ampliação dos espaços cobertos sem colunas internas, no entanto, somente seria alcançada no século II, com o desenvolvimento de estruturas tais como o Bouleuterion de Mileto ou o Odeion de Pompéia (Winter, 2006: 96-111, 135-149). Sobre os usos do edifício, para além de "odeion" - espaço para performances musicais - são atestados os usos como

\footnotetext{
${ }^{220}$ Junto do odeion de Herodes Ático, na encosta sudoeste da acrópole, e o odeion de Agrippa, no centrosul da ágora ateniense.

221 Aristófanes (Vespas, 1109), Andócides (Sobre os mistérios, 1.38), Hiperides (fr. 118), Xenofonte (Helênicas, 2.4.9), Demóstenes (Contra Neaera, 50.52; Contra Fórmio, 34.37), Cratino (fr. 73), Eupolis (fr. 325), Teofrasto (Caráteres 3.3), Heráclides Crítico (GGM 1.98), Diodoro Sículo (Biblioteca, 1.48.56), Vitrúvio (5.9.1), Apiano (Guerras Mitridáticas, 38), Plutarco (2.605a; 605a; Péricles, 13.9-11), Pausânias (1.20.4), Diógenes Laércio (7.184), Suida (s.v. Odeion), e os escólios de Ésquines (3.66-67) e Aristófanes (Vespas, 1109a).

${ }^{222}$ IG II $^{2}$ 968.47; 1688.3; 3426; 3427.

${ }^{223}$ Conduzidas pela Sociedade Arqueológica Grega entre 1914-1929, conduzidas por P. Kastriotis, entre 1931-1932, conduzidas por A. Orlandos, além de demolições de residências acompanhadas por pequenas escavações nos anos 1960 e 1980 (Tofi, 2010:161-163).
} 
tribunal, espaço para disputas filosóficas, abrigo para cavalaria, sede de magistrados agonísticos e local para distribuição de trigo (Tofi, 2010: 162).

A datação da construção é polêmica: enquanto a maior parte das fontes atribui a iniciativa da construção a Péricles, Vitrúvio menciona expressamente Temístocles como o idealizador. A maior parte da bibliografia tende a considerar que tal menção se deva a um erro de Vitrúvio, ainda que não se possa descartar uma primeira e inacabada fase construtiva anterior à finalização do edifício na época de Péricles (Mosconi, 2000; Tofi, 2010: 162). É conhecida uma reforma do edifício na época de Licurgo, no terceiro quartel do século IV, certamente associada ao projeto de monumentalização da encosta sul da acrópole, em particular do complexo teatral (Mercuri, 2004). O edifício aparentemente não sofreu alterações significativas por mais de dois séculos, até que fosse inteira ou parcialmente destruído no contexto do saque de Sula em 86. A destruição do Odeion de Péricles, como visto acima, é apresentada de duas formas na tradição literária: enquanto Apiano (Guerras Mitridáticas, 38) afirma que o edifício foi incendiado por Aristion e seus aliados que se refugiaram na acrópole, de modo que o exército de Sula não teria materiais para a construção de máquinas de guerra, Pausânias (1.20.4) atribui a destruição ao próprio Sula; tal divergência pode ser derivada tanto de tradições conflitantes produzidas a partir de diferentes pontos de vista - a Alexandria de Apiano ou a Atenas visitada por Pausânias - quanto em função dos diferentes projetos político-literários dos autores.

A próxima referência ao Odeion de Péricles é sua restauração, conhecida a partir de Vitrúvio e de duas inscrições encontradas na região do teatro de Dioniso. Vitrúvio afirma que "o rei Ariobarzanes reconstruiu" o edifício destruído na guerra mitridática (5.9.1: ideo autem etiam incensum Mithridatico bello rex Ariobarzanes restituit), o que é corroborado pela inscrição IG II $^{2} 3426$, onde se lê:

\footnotetext{
Ao rei Ariobarzanes Filopator, filho do rei / Ariobarzanes Filorromano e da rainha / Atenides Filostorgos, tendo sido designados / por ele para a preparação do odeion, / Caio e Marcos Stalli filhos de Caio e / Melanipo, [dedicam] ao seu evergeta.
}

Além da dedicação dos arquitetos, outra inscrição (IG II2 3427) encontrada no mesmo local indica uma dedicação da própria cidade: 
O povo [dedica] / ao rei Ariobarzanes / Filopator, filho do / rei Ariobarzanes / Filorromano e a rainha / Atenides Filostorgo / seu evergeta.

O homenageado com duas estátuas, colocadas junto ao santuário de Dioniso e ao Odeion de Péricles, é certamente Ariobarzanes II, rei da Capadócia entre 63/2 e 51 a.C., cujo reinado é a única indicação de datação para os trabalhos de restauração. A Capadócia, antiga satrapia persa, tornou-se reino independente em meados do século III a.C. com Ariarates III, fundador da dinastia ariarátida - de origem iraniana - que governaria a Capadócia até a morte de Ariarates IX em 96/5 a.C. ${ }^{224}$. As relações do reino capadócio com Atenas são bem conhecidas no século II: Estratonice, filha de Ariarathes IV e esposa primeiro de Eumenes II e depois de Átalo II de Pérgamo, recebeu uma estátua em Delos dedicada pelo demos ateniense (ID 1575); seu irmão Ariarathes V da Capadócia, que reinou entre 163 e 130, foi agonoteta de uma Grande Panatenéia e foi objeto, junto da rainha Nysa (filha do rei Farnaces do Ponto), de um decreto honorífico da companhia dos artistas dionisíacos de Atenas (IG II $^{2} 1330$ ) que determinava proclamações nos festivais e um dia de festa dedicado ao rei, associado a Dioniso (Habicht, 1997: 282). A última referência a um rei da dinastia ariarátida no âmbito do domínio ateniense é a dedicação de um busto a Ariarathes VII no santuário dos Cabeiri em Delos, ele próprio dedicado aos deuses, a Mitrídates VI e a Roma (ID 1562; Habicht, 1997: 263). A ausência de referências está ligada, certamente, ao turbulento final de século na Capadócia, objeto da disputa entre os reinos do Ponto e da Bitínia, com a mediação diplomática de Roma.

Um momento crucial - não apenas para a Capadócia, mas para toda a Ásia Menor - foi o fim da dinastia ariarátida em 96/5 a.C., com a deposição de Ariarathes IX, filho de Mitrídates VI, pelo Senado romano e por setores da elite capadócia. Nesta ocasião, após a rejeição das formas republicanas sugeridas pelo Senado aos capadócios (Justino, 38.2.8), um membro desta elite foi escolhido para assumir o trono, assumindo o nome de Ariobarzanes I Filoromano. O reinado de Ariobarzanes I seria marcado por uma série de deposições, ora orquestradas por Mitrídates, ora por Tigranes, rei da Armênia - cada vez mais autônoma em relação ao domínio parta -, ora pela oposição de facções locais. A primeira deposição ocorreu em 95, realizada por Górdio, um aliado de Mitrídates VI; pouco tempo depois, Ariobarzanes foi reconduzido ao trono por Sula, em

\footnotetext{
${ }^{224}$ Para a história da Capadócia após as conquistas de Alexandre, cf. Will (2003) e Sullivan (1980).
} 
sua primeira expedição no Oriente e então como governador da Cilícia, onde ficaria por cerca de três anos (Santangelo, 2007: 29-31). As fontes relatam um encontro de Sula, Ariobarzanes e Orobazos, um embaixador do rei Mitrídates II da Pártia - e que teria sido o primeiro encontro entre romanos e partas (Plutarco, Sula, 5.4; Santangelo, 2007: 28, n. 39). Uma segunda deposição de Ariobarzanes I ocorreu por volta de 92/1, quando Tigranes I da Armênia - até então um protetorado da Partia - o tira do poder e reestabelece no trono Ariarathes IX, filho de Mitrídates VI que alegava legitimidade por um suposto parentesco com a dinastia ariarátida. O Senado de Roma intervém desta vez, em 90, com uma embaixada liderada por Manius Aquilius, que não apenas restaura o trono de Ariobarzanes, como também incita este último e o rei Nicomedes da Bitínia a atacarem o reino do Ponto, impedido de se defender por ordem do Senado - o que será o catalisador para a primeira guerra mitridática (Madsen, 2009). Ariobarzanes será deposto uma quarta vez pelo próprio Mitridates VI, por volta de 88/7, e será restabelecido pela segunda vez por Sula, em 85, após suas vitórias sobre o exército pôntico. Finalmente, Ariobarzanes será deposto por Mitrídates VI em 67, na passagem do comando romano da terceira guerra mitridática de Lucullus para Pompeu; em 63, seu trono será restaurado por Pompeu, onde permanecerá até que em 63/2 abdique do trono em favor de seu filho, Ariobarzanes II Filopator, na presença do próprio Pompeu (Valério Máximo, Fatos e Ditos memoráveis, 7.7; Sullivan, 1980; Kallet-Marx, 1996, pp. 291-334).

O conturbado reinado de Ariobarzanes I Filoromano da Capadócia esteve intimamente vinculado à rearticulação das forças geopolíticas na Ásia Menor, que tem início no fim da dinastia atálida e consequente criação da província romana da Ásia, na década de 130 a.C., seu marco inicial (Habicht, 1989). Por um lado, o fim do reino de Pérgamo abre espaço para a ascensão do Ponto e da Bitínia, que intensificam a disputa por territórios na Anatólia; por outro, a formação do reino da Armênia, em aliança com o Ponto e em estado de latente conflito com a Pártia, adiciona mais um ator no conflito. Aos reinos mais fracos - como era o caso da Paflagônia e, evidentemente, da Capadócia - restava a aliança com a potência mais forte e ao mesmo tempo mais distante, o que explica tanto as deposições quanto as restaurações. Um elemento complicador da situação geopolítica da Capadócia era sua localização: estava entre a Síria e o Ponto, e a Anatólia e a Mesopotâmia, o que significava que era uma das principais rotas para o contato - nem sempre pacífico entre o império romano, os reinos do norte da Anatólia, e as novas potências médio-orientais, a Armênia e a Partia (Will, 2003). Às turbulências 
internacionais se juntaram, certamente, as divisões no seio da sociedade capadócia, dividida entre as várias opções geopolíticas e as diferentes lealdades dinásticas. Ariobarzanes I procurava conciliar as diferentes facções a partir de recursos híbridos de legitimação: se por um lado mantinha as tradições ariarátidas (cuja iconografia numismática é o testemunho mais claro, especialmente com a manutenção, no reverso, da figura de Atena com escudo e lança apoiados à sua esquerda e segurando Nike com a mão direita, entre as inscrições com o nome e epíteto real; Simonetta, 1961) e em diversas ocasiões selou tratados com Mitrídates (inclusive casando a princesa do rei pôntico com seu filho e futuro sucessor, Ariobarzanes II), por outro reforçava sua aliança com Roma, única potência que realmente lhe garantiria a permanência no trono, ainda que esta aliança gerasse mais oposição das facções pró-pônticas (Apiano, Guerras Mitridáticas, 61; Dio Cássio, 36.9.2; Sullivan, 1980, p. 1130-2). Neste sentido, é de se esperar que Ariobarzanes tenha construído, seja em seus exílios em Roma, seja nos tratados de paz, uma relação política sólida com Sula, duas vezes responsável pelo seu retorno ao trono e o grande diretor da rearticulação dos poderes microasiáticos até a vitória de Pompeu e a nova organização provincial (Santangelo, 2007, pp. 50-66).

A ligação com Sula e Pompeu, associada à oposição à Mitrídates VI até 63 e, no final da década de 50, aos partas, pode ser a chave para a explicação da restauração do Odeion de Péricles pelo segundo rei da nova dinastia capadócia. Ariobarzanes II Filopator, já desde o início de seu reino, apresentava diversos elementos fundamentais para a conciliação das facções pró-romanas e pró-pônticas da Capadócia, especialmente após a vitória final de Pompeu: sua coroação ocorreu sob os auspícios de Pompeu em pessoa; sua rainha era, muito provavelmente, a filha de Mitridates VI prometida a ele cerca de vinte anos antes ${ }^{225}$; e seu epíteto "Filopator" indicava a continuidade em relação ao reinado de seu pai (Sullivan, 1980, pp; 1137-8). No entanto, uma nova fonte de divisão se apresentaria: em carta ao Senado datada de 51, Cícero menciona os rumores de uma invasão parta da Cilícia por meio da Capadócia, que estaria, segundo Cícero, aberta aos invasores (Cartas familiares, 15.2). Caso Cícero estivesse certo, seria plausível que a construção de uma posição pró-pártica e anti-romana na Capadócia houvesse sido construída no final do reino de Ariobarzanes II; basta lembrar a famosa

\footnotetext{
225 A esposa de Ariobarzanes II chamava-se Atenais Filotorgos, que era o mesmo nome e epíteto da esposa de Ariobarzanes I. Caso se trata-se da filha de Mitrídates, a adoção do nome da sogra e fundadora da nova dinastia é revelador da preocupação com a legitimidade dinástica (Sullivan, 1980, p. 1137).
} 
derrota de Crasso diante dos partas em 53, o que provavelmente teve como efeito o aumento da incerteza em relação à prontidão romana na defesa da Capadócia.

A isto tudo deve ser acrescentada uma evidência normalmente negligenciada pelos estudiosos da restauração do Odeion de Péricles: o decreto efébico de 79/8 (IG II ${ }^{2}$ 1039) lista entre os efebos Ariobarzanes e Ariarathes, filhos do rei Ariobarzanes Filoromano, registrados no demos de Sypaletos, ano no qual os efebos ofereceram sacrifícios durante o festival dedicado a Sula (Sylleia), celebrado anualmente em outubro (Raubitschek, 1951). O Ariobarzanes mencionado como efebo é certamente Ariobarzanes II; sua participação no festival dedicado ao personagem que por duas vezes restaurou o trono de seu pai, certamente, é significativo, como veremos.

Como isto se relaciona com a restauração do Odeion? Em primeiro lugar, o Odeion foi destruído durante o saque de Sula em Atenas. Como foi dito acima, Vitrúvio, o autor mais próximo do episódio, afirma laconicamente que o edifício foi incendiado na guerra mitridática; Apiano, mais de um século depois, afirma que o Odeion foi incendiado por Aristion para dificultar o cerco da acrópole por Sula; e Pausânias, dois séculos depois, afirmaria que o responsável pela destruição teria sido o próprio Sula. É impossível responsabilizar categoricamente um ou outro; no entanto, a indeterminação nas fontes pode ser indício da indeterminação da história relativa à destruição do edifício. A restauração por Ariobarzanes II seria adequada à versão de Aristion como o responsável pelo incêndio: desse modo, o rei capadócio estaria reconstruindo um edifício destruído pelo "tirano" ateniense Aristion, representante do asiático Mitrídates, deposto por Sula; assim como o general romano havia restabelecido a politeiai dos atenienses (Geagan, 1967), Ariobarzanes reconstruiria um edifício particularmente célebre e importante para os rituais agonísticos da cidade. A dedicação de estátuas a Ariobarzanes pelo povo e pelos arquitetos romanos (IG II $^{2} 3426$ e 3427 , respectivamente), além da dedicação de outra estátua (IG II $^{2}$ 3428) a seu filho e sucessor, Ariobarzanes III Eusébio Filoromano, provavelmente no mesmo local, indica a constituição do Odeion como uma espécie de memorial romano-capadócio, celebrando a um tempo as tradições agonísticas atenienses e o retorno da cidade à aliança com Roma - o epiteto "Filoromano" de seu pai, presente em todas as inscrições, e a participação de arquitetos romanos na reconstrução do edifício, apontam fortemente para esta direção.

Em segundo lugar, o Odeion era fortemente associado às guerras médicas do século V a.C.: segundo Vitrúvio (9.5.1), espólios navais persas eram exibidos ali, 
certamente se referindo à vitória de Salamina; segundo Plutarco (Vida de Péricles, 13.56) e Pausânias (1.20.4), o edifício era uma réplica da tenda (ou "palácio itinerante") de Xerxes (Heródoto, 9. 80). De fato, as escavações do século XX revelaram um edifício extremamente semelhante à "sala de cem colunas" em Persépolis (fig. 94), que apresenta uma planta quadrangular com 68,5 de lado e 100 colunas, e cuja construção começou na primeira metade do século $\mathrm{V}$, ainda sob o reinado de Xerxes ${ }^{226}$. A forte associação persa - pela planta e pela decoração -, que deveria superar as dificuldades inerentes à estrutura do edifício para a realização das competições musicais (em particular os obstáculos visuais das colunas), também pode ser interpretada como significativa para a restauração de Ariobarzanes II: tanto o rei Mitrídates VI Eupator, quanto os monarcas da Pártia, são fortemente associados à herança persa, tanto por eles mesmos quanto na visão negativa construída na tradição literária pró-romana ${ }^{227}$. Desse modo, Ariobarzanes II, rei de uma Capadócia tornada independente por uma dinastia que alegava suas raízes persas, sintetiza sua identidade cívica ateniense (adquirida via efebia) com a oposição aos novos persas: Mitrídates (até 62) e Orodes II da Pártia (a partir de 57). A localização do Odeion, na encosta sudeste da acrópole, dialoga com duas outras intervenções do topo do rochedo marcadamente anti-bárbaros: o Pártenon e a Dedicação Atálida, que ao menos parcialmente poderia ser vista da região em frente ao Odeion. Ariobarzanes, deste modo, não apenas se inseria na tradição pericleana, mas também na tradição atálida de comemoração anti-bárbara; ainda que seu nome, marcadamente de origem persa ${ }^{228}$, acrescentasse alguma ironia na dedicação.

Em terceiro lugar, a reconstrução do Odeion de Péricles inscrevia o nome de Ariobarzanes firmemente no contexto teatral e agonístico ateniense, tanto pela proximidade ao teatro de Dioniso - e talvez seja relevante lembrar das honras, acima citadas, concedidas pela companhia dos artistas dionisíacos atenienses a Ariarathes V da Capadócia, que garantiu aos artistas, no século II, segurança e imunidade no território capadócio - quanto pela própria utilização do edifício como sede de competições musicais na Grande Panatenéia. Dessa forma, Ariobarzanes II retomava também a tradição evergética helenística das construções associadas topográfica e utilitariamente à

\footnotetext{
${ }^{226}$ Sobre a sala das cem colunas de Persépolis, cf. Herzfeld (1941: 228-9). Sobre a tradição arquitetônica das salas hipostilas - especialmente o Telesterion de Elêusis, contemporâneo do Odeion de Péricles, cf. a discussão em Gopnik (2010).

227 Sobre a "persianização" de Mitrídates, cf. Olbrycht (2009) com bibliografia anterior; sobre a persianização dos partas, cf. Curtis e Stewart (2007: 7-25), e, especialmente no período augustano, cf. Rose (2005), com bibliografia.

${ }^{228}$ Considere-se, por exemplo, o general persa Ariobarzanes derrotado por Alexandre em 330 a.C., mencionado em Arriano (Anabasis, 3.18.2) e Diodoro Sículo (17.68.1).
} 
tradição agonística local, o que garantia ao mesmo tempo a visibilidade local e internacional do evergeta.

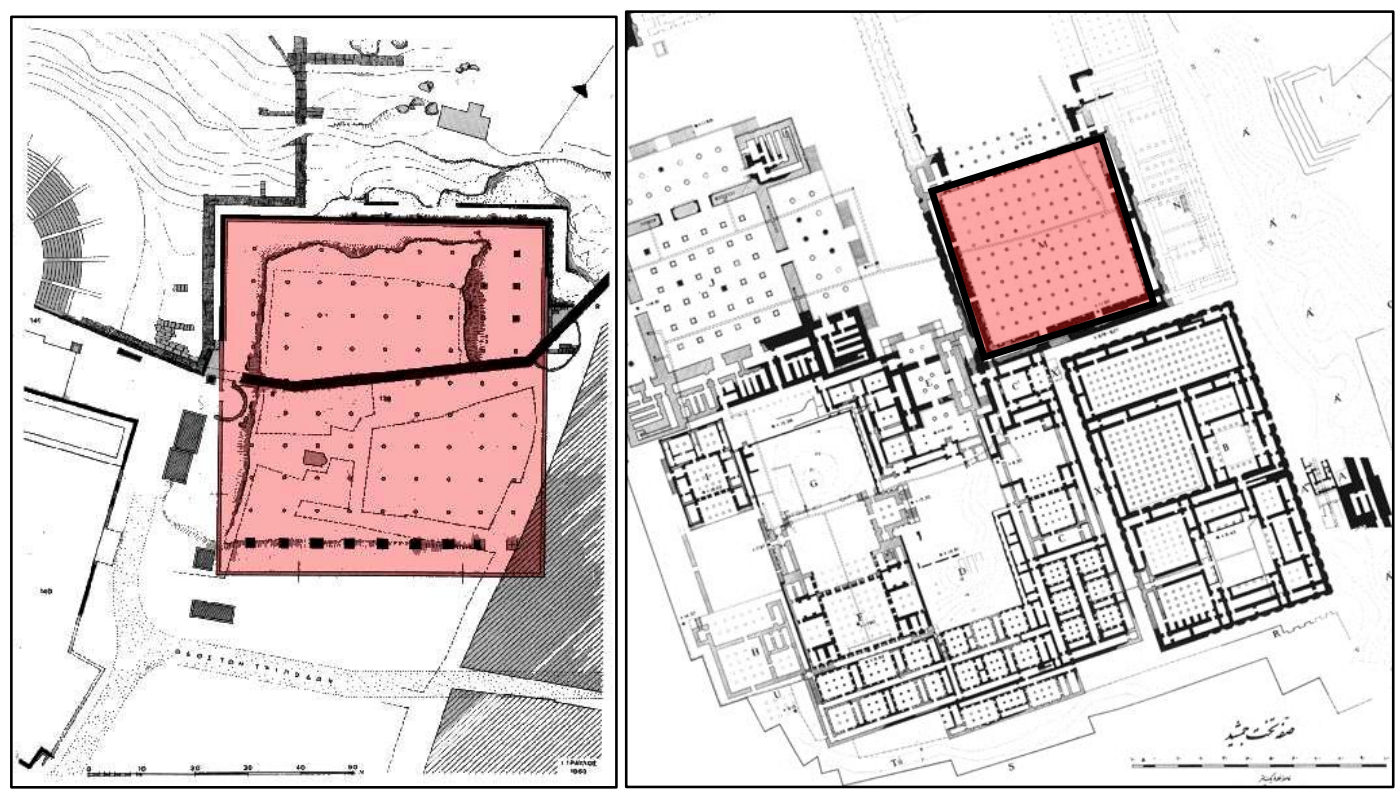

Figura 94. Comparação das propostas de planta do Odeion de Péricles (esquerda), segundo I. Travlos em 1929 (THEATRON $^{229}$ ), e da Sala do Trono de Persépolis (direita; Encyclopaedia Iranica $\left.^{230}\right)$.

No entanto, é preciso marcar a especificidade desta intervenção em relação ao evergetismo do século II: o rei capadócio não constrói um novo edifício, fazendo dialogar a arquitetura capadócia e ateniense e ao mesmo tempo impondo sua presença massivamente na cidade ${ }^{231}$; pelo contrário, trata-se de uma reconstrução. Não é possível determinar em que medida esta reconstrução implicou na adição de inovações arquitetônicas, ou se, ao contrário, respeitou uma lógica de restauração acadêmica: Vitrúvio utiliza o verbo restituto, que pode apontar para ambas as direções. As escavações, no entanto, estabeleceram que, mesmo que inovações fossem incluídas, o principal obstáculo funcional - as colunas interiores - não foi modificado, mesmo tendo em vista, por exemplo, o desenvolvimento grego e italiano de estruturas com amplos saguões cobertos, sem necessidade de suportes internos. De qualquer modo, a decisão de reconstruir um edifício fortemente associado à memória do período clássico revela,

\footnotetext{
${ }^{229}$ Disponível em:

http://www.kvl.cch.kcl.ac.uk/THEATRON/theatres/pericles/assets/images/perimg33.jpg.

${ }^{230}$ Disponível em: http://www.iranicaonline.org/uploads/files/Persepolis/persepolis_fig_2.jpg.

${ }^{231}$ Por exemplo, o conjunto das intervenções associadas a Pérgamo, englobando a duas stoas (de Eumenes II na encosta da acrópole e de Átalo II na ágora) e a famosa Dedicação Atálida junto ao muro sul da acrópole.
} 
num sentido mais amplo, uma atitude antiquária em relação ao espaço urbano, fundada na valorização de um passado conhecido por meio da tradição literária e imbricado no espaço construído. Este "urbanismo antiquário", ainda que fragmentário, é a chave da ruptura do evergetismo do século I em relação ao do século anterior, e o Odeion de Péricles, oportunamente, aponta para a importância das destruições associadas ao saque de Sula para o nascimento desta atitude em Atenas. Que este passo tenha sido dado, pela primeira vez, por um rei de origem persa que governa um território que fazia fronteira com os "novos persas" - o Império Parta -, demonstra de modo eloqüente o modo como é absolutamente impossível compreender a história ateniense isolada dos processos de integração com os "bárbaros"232, os quais, eventualmente, se apropriam da comemoração antibárbara ateniense como estratégias de sobrevivência, como parece ter sido o caso de Ariobarzanes II.

Uma última intervenção construtiva realizado em meados do século I é a reforma do santuário de Asclépio, dedicado em 419/8 por Telêmaco, e monumentalizado, com a construção de edifícios em pedra, apenas no século IV. A ausência de um estudo detalhado das escavações impede uma reconstituição precisa da história do sítio $^{238}$, mas é consenso que entre sua dedicação e o final do século IV o santuário era composto por um Períbolo que abrigava um templo e um altar, dedicados a Asclépio e Higéia, e uma stoa dórica, que funcionava como espaço de incubação para os pacientes (abaton), com poço ritual e fonte, e, fora do Períbolo, uma stoa jônica dedicada ou aà recepção de visitantes, ou aos escritórios dos magistrados do santuário.

As intervenções do século I são conhecidas apenas por meio da epigrafia. A primeira é mencionada em uma dedicação (IG II ${ }^{2}$ 4464) de Sócrates, filho de Sarapion

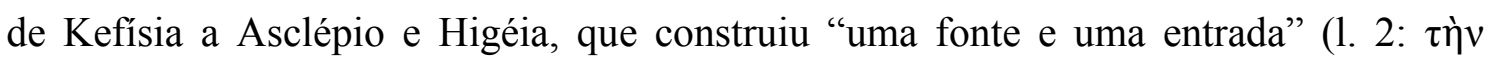

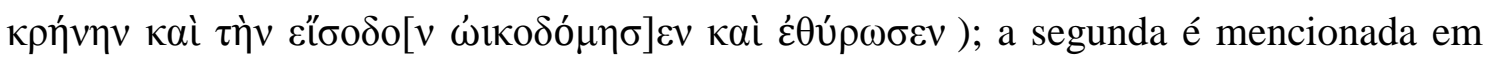
um decreto (IG II ${ }^{2}$ 1046) que permite ao sacerdote Diocles, filho de Diocles de Kefísia,

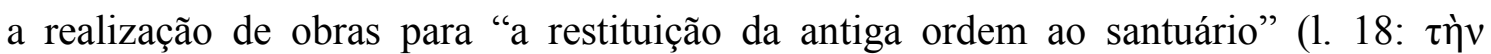

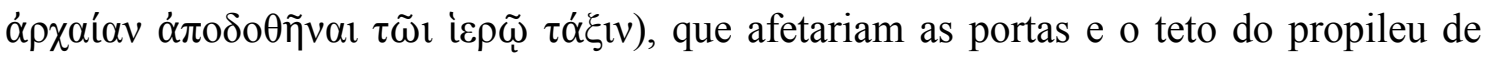

\footnotetext{
${ }^{232}$ Sobre o problema da integração e conectividade no Mediterrâneo, cf. Horden e Purcell (2000), com as críticas de Morris (2003) e Guarinello (2003, 2010), entre outros. Para uma interessante proposta de abordagem histórica e arqueológica dos processos de integração entre "gregos e bárbaros", cf. Vlassopoulos (2012).

${ }^{238}$ Cf. o tratamento das questões topográficas e arqueológicas em Travlos, 1971 (pp. 138-139), Aleshire (1989, pp. 7-36) e Baldassarri (1998, pp. 64-66).
} 
entrada e o templo ${ }^{239}$. A datação das inscrições é bastante segura: Sócrates de Kefísia foi sacerdote do Asklepieion em 63/2, enquanto Diocles de Kefísia foi sacerdote em 51/0. Não está claro a qual "entrada" a inscrição de 63/2 se refere, mas o fato de se

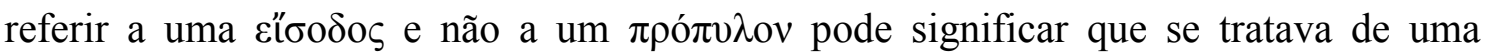
entrada menor, possivelmente da stoa dórica ou mesmo da área da fonte; o mesmo é indicado pela restauração do propileu em 51/0, que seria improvável - ainda que não implausível - caso ele tivesse sido construído pouco mais de dez anos antes. As intervenções no templo não são especificadas no decreto, mas a inexistência de vestígios arqueológicos de reestruturação da planta indicam que deveria se tratar de reformas localizadas.

A necessidade destas reformas e intervenções está ligada, muito provavelmente, ao cerco à acrópole que resultou, além da derrota final de Aristion, na destruição do Odeion de Péricles. A posição do Asklepieion, acima e um pouco ao oeste do Odeion, é coerente com eventuais dados provocados tanto pelos sitiados quanto pelos sitiantes. É possível que as reformas estivessem em relação à memória da guerra do Peloponeso na medida em que a fundação do santuário estava intimamente associada à peste que ocorreu em Atenas no início da guerra - dialogando desse modo com a comemoração das guerras médicas implícita na restauração do Odeion. Mas não há qualquer indicação clara neste sentido, e mesmo a grande circulação do santuário, o único da cidade - ainda que existissem outros santuários na Ática, como no Pireu, em Acharnes, Prospalta e Elêusis (Aleshire, 1989, pp. 35-36) - é uma razão suficiente para a realização das reformas.

É sintomático que as intervenções foram realizadas não pela cidade, mas por indivíduos no exercício de seus cargos - o evergetismo ob honorem de P. Veyne - o que, ao lado da contemporaneidade da restauração do Odeion por Ariobarzanes II, indica que o final da década de 60 foi marcado pela retomada da atividade construtiva na cidade, limitada aos edifícios mais frequentados entre os danificados por Sula, e a partir da iniciativa de evergetas locais ou estrangeiros. O longo tempo entre o saque e as restaurações e reformas (cerca de 25 anos), associado às referências ao evergetismo financeiro de Ático à cidade, são evidências eloquentes da situação de crise em que se encontrava a cidade, assim como para a inexistência de iniciativas evergéticas por parte

239 Alguns fragmentos de blocos com partes da inscrição dedicatória de Diocles foram encontrados no santuário (IG II ${ }^{2}$ 3174), e provavelmente se referem a inscrições na arquitrave ou do propileu, ou do templo; o estado fragmentário dos blocos, no entanto, impede uma reconstituição precisa (Baldassarri, 1998, p. 66, n. 13). 
dos cidadãos, que só o farão enquanto ocupantes de cargos especifícos. A timidez das intervenções de Sócrates - trabalhos na fonte e em uma entrada - talvez significaram o primeiro passo para as intervenções de maior escala na encosta sul da acrópole, com a restauração do Odeion e o novo propileu de Diocles. A participação de membros da elite ateniense como financiadores da atividade construtiva, no entanto, pararia por aí, ou ao menos não deixaria mais registros; já a participação de estrangeiros se consolidaria como a força dominante na produção do espaço urbano ateniense, deixando uma grande quantidade de vestígios. A retomada da guerra civil romana, no entanto, afetará diretamente o modo como os evergetas estrangeiros - romanos, acima de tudo se relacionarão com o espaço ateniense, até que um novo padrão ganhe corpo já sob o principado.

\section{Atenas na guerra civil: César, os cesaricidas e Antônio}

O final da década de 50 abre uma nova fase na história urbana ateniense: a demanda inicial por novas construções, após o ciclo das restaurações, é radicalmente afetada pelas reviravoltas da política romana, que em diversos momentos terá em Atenas um de seus palcos principais. Não obstante exista pouquíssima referência à atividade construtiva por quase trinta anos, o espaço urbano será engajado nos dilemas políticos e militares que a cidade viverá.

A participação de Atenas no contexto da guerra civil está relacionada diretamente às ligações da cidade com Pompeu. Que a cidade se posicionaria ao lado de Pompeu no iminente conflito com César, não era surpresa. No entanto, há indícios de que ao menos parte da elite ateniense, na figura de Herodes de Maratona - arconte epônimo em 60/59 (IG II2 716) -, começava a construir laços com o outro lado mesmo antes do início do conflito, em março de 49. Em carta datada de fevereiro de 50, Cícero (Cartas a Ático, 6.1), ainda em Laodicéia, como governador da Cilicia, reporta diversos assuntos, públicos e privados, a seu amigo Ático, então a caminho de Atenas. Ao final da carta, e pouco antes de perguntar a opinião de Ático quanto ao propileu da Academia, Cícero relata que um íntimo de Pompeu, encontrando-o em uma estrada, contou que o general ficara irado ao ouvir que um certo Herodes havia tentado obter de 
César, então governador da Gália, a quantia de 50 talentos (6.1.24). Cícero subentende que Ático conhece este Herodes, que se trata, certamente, do mesmo Herodes de Maratona mencionado na arquitrave da Ágora Romana como aquele que obteve, junto a César, o financiamento inicial para a construção do complexo terminado somente na época augustana, com novos recursos obtidos por seu filho Eucles junto ao princeps. A proximidade com Ático é coerente com a alta posição social de Herodes, o que pressupõe uma proeminência ainda no período em que Ático residia em Atenas.

O fato do valor obtido junto a César ser idêntico ao valor doado por Pompeu para a restauração da cidade - 50 talentos - é significativo: assim como Cícero, na mesma carta, colocava em questão a competição com Pulcher tanto na gestão provincial quanto no evergetismo construtivo em Atenas (propileu de Elêusis vs. propileu da Academia), a quantia idêntica certamente se articula à competição cada vez mais intensa entre César e Pompeu. As duas doações, separadas por mais de uma década, se assemelham e se diferenciam: por um lado, enquanto a doação de Pompeu visava a restauração da cidade, a de César visava a construção de um complexo novo; por outro lado, considerando a referência ao deigma do Pireu, ambas se voltavam para as atividades comerciais. Não há documentação para a participação da elite local na doação de Pompeu, mas é provável que a iniciativa tenha partido dos atenienses, mesmo que não tão abertamente quanto no caso da missão de Herodes.

O segundo contato de César com o espaço urbano ateniense se deu pela ausência, mas uma ausência importante. Na guerra civil, Atenas tomou o lado de Pompeu, inclusive militarmente (Lucano, Farsalia, 3.181-183; Apiano, Guerras civis, 2.315; Habicht, 1997, p. 350-351). Em contrapartida, entre o final de 49 e início de 48 Q. Fúlvio Caleno, legado de César, devastou a Ática e sitiou Atenas, sem sucesso - o que indica que a muralha havia sido reconstruída, possivelmente com parte da doação de Pompeu ou César. Com a vitória de César na batalha de Farsalos, em agosto de 48, Atenas imediatamente se rendou ao vitorioso, a partir de uma embaixada que esperava o desfecho da guerra. César, coerente com sua alardeada clementia, concede o perdão aos atenienses. Segundo Apiano (Guerras civis, 2.88), César teria dito aos suplicantes embaixadores: "quantas vezes, da destruição por vós mesmos causada, o renome dos

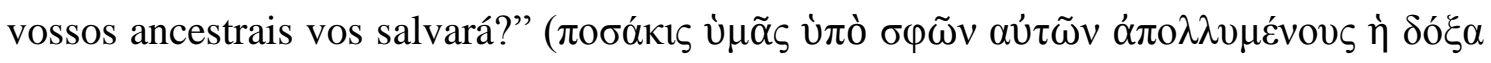
$\left.\tau \tilde{\omega} v \pi \rho \gamma^{\prime} v \omega v \pi \varepsilon \rho ı \sigma ́ \sigma \varepsilon \imath\right)$. Dio Cássio (42.14.2) relata que “César, sem lembrar dos males passados, liberou [os embaixadores atenienses] sem punição, dizendo simplesmente que, tendo cometido muitos erros, seriam salvos por seus mortos" (ò 


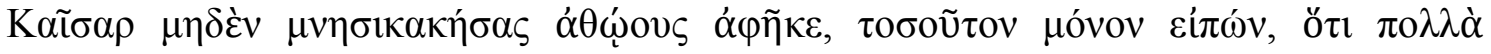

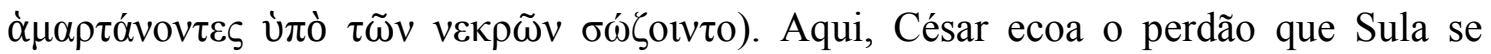
orgulhava por ter dado aos atenienses, retomando o prestígio dos ancestrais como argumento para a preservação da cidade - do mesmo modo, é o passado que estrutura a relação entre César e Atenas naquilo que poderia se constituir como uma nova destruição. O contraste com a Ágora Romana, edifício novo, é claro, o que pode ser explicado, ao menos neste primeiro momento, pela diferença da iniciativa: na Ágora Romana a iniciativa é dos próprios atenienses, após cerca de dez anos às voltas com (de Pompeu, de Ariobarzanes, de Sócrates e Diocles); o perdão aos atenienses parte de César, que teria contato com Atenas, até então, apenas por meio da linguagem e, consequentemente, com o prestígio de seus ancestrais. A única referência a uma visita de César a Atenas está em uma carta de Cícero a Ático, datada de agosto de 47, onde Cícero afirma que César não chegaria a Atenas em setembro, por conta de assuntos a resolver na Ásia (Cícero, Cartas a Ático, 11.21).

A documentação epigráfica relativa a César é exígua, porém eloquente. Duas bases de estátuas (fig. 95) encontradas em muros tardios na ágora ateniense contem inscrições dedicatórias a César:

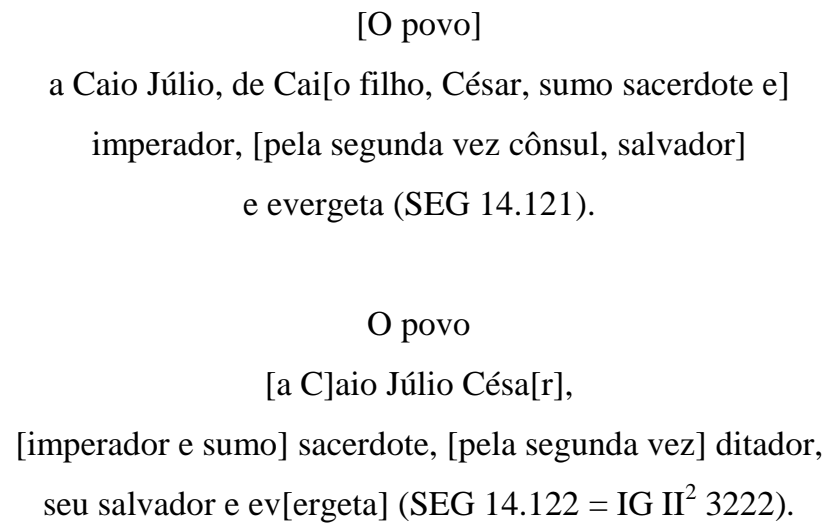



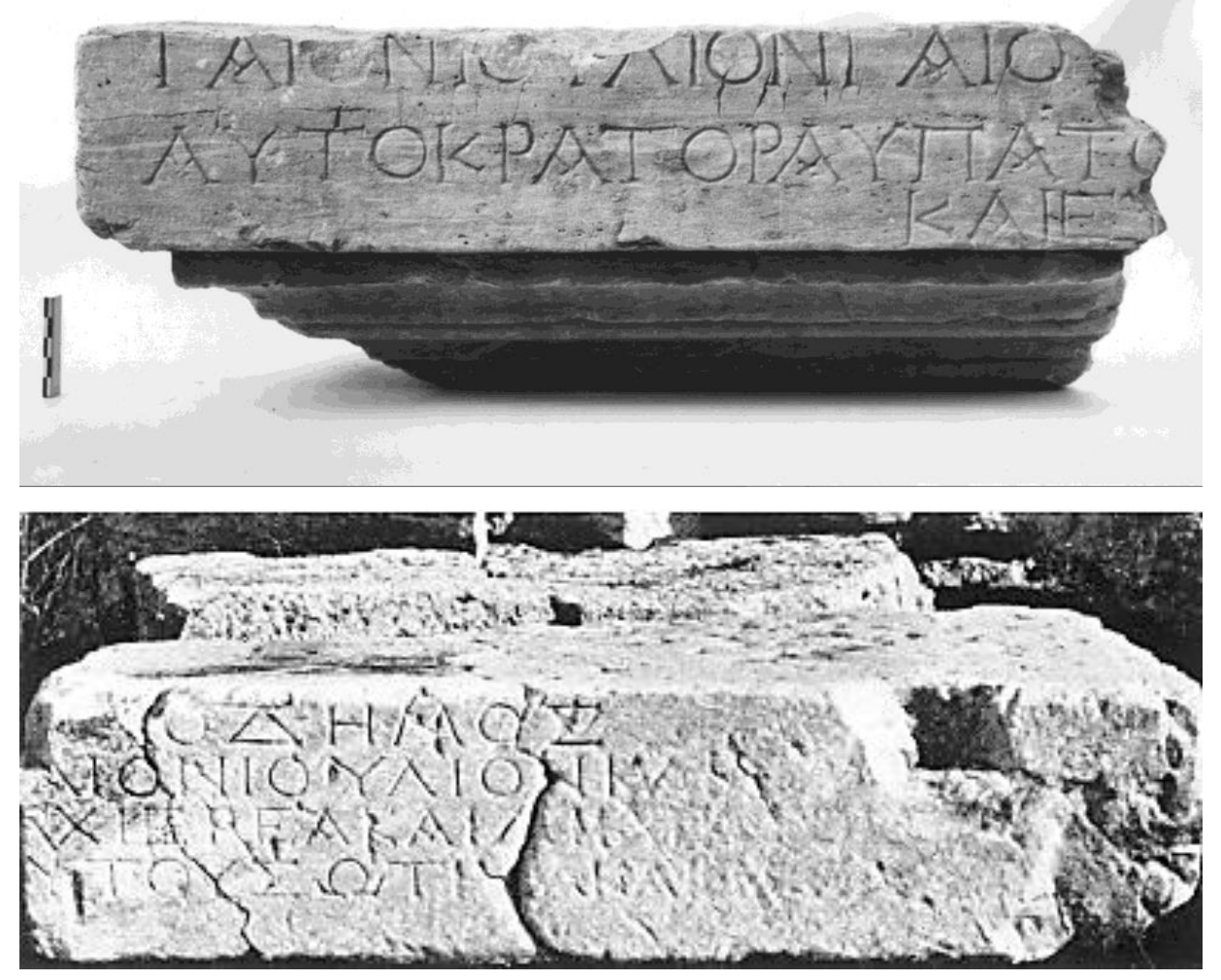

Figura 95. Fotografias de bases de estátua dedicadas a Júlio César encontrada na ágora ateniense, s/d. (ASCSA ${ }^{244}$ e Raubitschek, 1954, pl. 3).

A primeira inscrição, de 48, é interpretada como uma manifestação de apoio e agradecimento da cidade pela clementia de César. A segunda inscrição é normalmente associada a uma eventual visita de César a Atenas em 47 mencionada por Cícero, quando também a doação dos 50 talentos requerida por Herodes 3 anos antes teria se efetivado, e César teria participado também do projeto da nova ágora (Raubitscek, 1954, p. 69, n. 7). O local de achado das bases não é claro: ambas foram reutilizadas em muros tardios, a primeira no limite oriental do Agrippeion, a segunda em um muro próximo ao Eleusinion, ambos na região sudeste da ágora. É plausível que as estátuas fossem colocadas na ágora, mas não sua localização precisa - e consequentemente sua relação com outros edifícios e monumentos - não pode ser determinada.

A datação da dedicação é dada pela indicação das magistraturas: a primeira é de 48, logo após a batalha de Farsalos, e a segunda de 47, quando César já assumira pela segunda vez a ditadura. O modo como as magistraturas são mencionadas é importante: archiereus, não sendo atestado nem o termo nem a prática em Atenas, é compreensível

${ }^{244}$ Disponível em: http://agora.ascsa.net/id/agora/image/2008.16.0771 
como tradução para pontifex maximus; o mesmo para o termo dictatora, sem equivalente na administração ateniense. A partir da romanidade das expressões, Raubitschek sugere que as dedicações atenienses - semelhantes a de outras cidades (Payne, 1984, pp. 308-313) - foram inspiradas por agentes de César, que determinaram como César deveria ser mencionado (Raubitschek, 1954, p. 73; Edwards, 1997, p. 131$133)$.

A denominação de César como "salvador" e "evergeta" também são semelhantes às dedicações a César nas outras cidades. Não obstante, dizem respeito a formas helenísticas de agradecimento e honra a seus benfeitores já comuns no período helenístico. A celebração de evergetas romanos como soteres, apesar de antiga, era bastante $\operatorname{rara}^{245}$; apenas concedida em situações particularmente importantes (Payne, 1984, p. 101). Com esta fusão entre magistraturas romanas e práticas evergéticas gregas, César e seus agentes, mais do que se contrapor às tradições gregas (Edwards, 1997, p. 133), promovia uma interpretação de seu poder que passava tanto pela determinação específica sua posição institucional romana (sobre a qual era cada vez mais crucial que os gregos tivessem conhecimento preciso) quanto pelo reconhecimento dos modos de integração já tradicionais no mundo helenístico, e de forte matriz monárquica (soter).

Em síntese: César se relaciona com o espaço ateniense de três maneiras. A primeira, como financiador de um edifício novo - terminado apenas na época augustana -, a partir de uma demanda local, possivelmente ligada aos interesses comerciais da cidade. A segunda, como ausência, decidindo não punir Atenas, por meio de uma clara referência ao perdão (pós-destruição) de Sula em 86; mantendo assim, digamos, uma “tradição" romana de perdão da cidade, criada por Sula em 86 e reiterada por Otávio em 31. A terceira, como comemoração evergética, apresentado tanto como magistrado romano quanto como monarca helenístico (provavelmente na ágora ateniense).

O apoio ateniense a César provou não ter sido absolutamente sincero quando, pouco tempo depois de seu assassinato em março de 44, dois dos cesaricidas receberão grandes honras em Atenas. Bruto e Cássio chegam a Atenas em outubro de 44; segundo Plutarco (Bruto, 24.1), Bruto foi recebido prontamente pelo povo, com louvações e

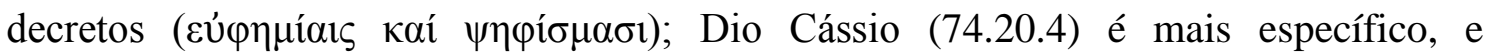
menciona que, enquanto toda a Grécia comemorava seu feito, os atenienses deram a Bruto e Càssio uma "recepção esplêndida", dedicando "estátuas de bronze ao lado

\footnotetext{
245 Payne (1984, pp. 127, 137, 144, 160, 202) lista poucos casos no século II (Tito Flamínio em 195,
} Cecílio Metelo em 148 e Múcio Scaevola em 98), nunca em Atenas. 
daquelas de Harmódio e Aristogíton, de modo que eles se tornaram deles emuladores"

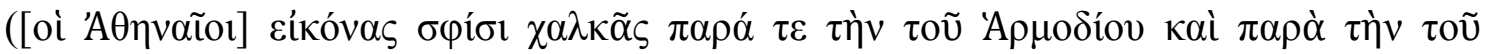

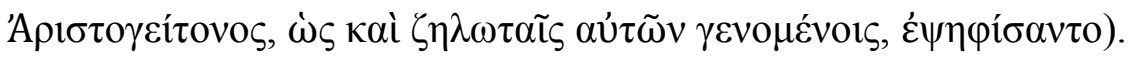

As estátuas dedicadas a Bruto deixaram ao menos um vestígio arqueológico na ágora ateniense: um fragmento de uma base de estátua (Agora I 3366; fig. 96) foi encontrada na Via Panatenaica já fora da ágora, em contexto moderno, com uma inscrição reconstituída por Raubitschek (como base em paralelos em Oropos e em Delos) da seguinte maneira:

\section{[O povo]}

[a Quinto Servíli]o, de Quinto

[filho, Caépio] Bruto ${ }^{246}$.

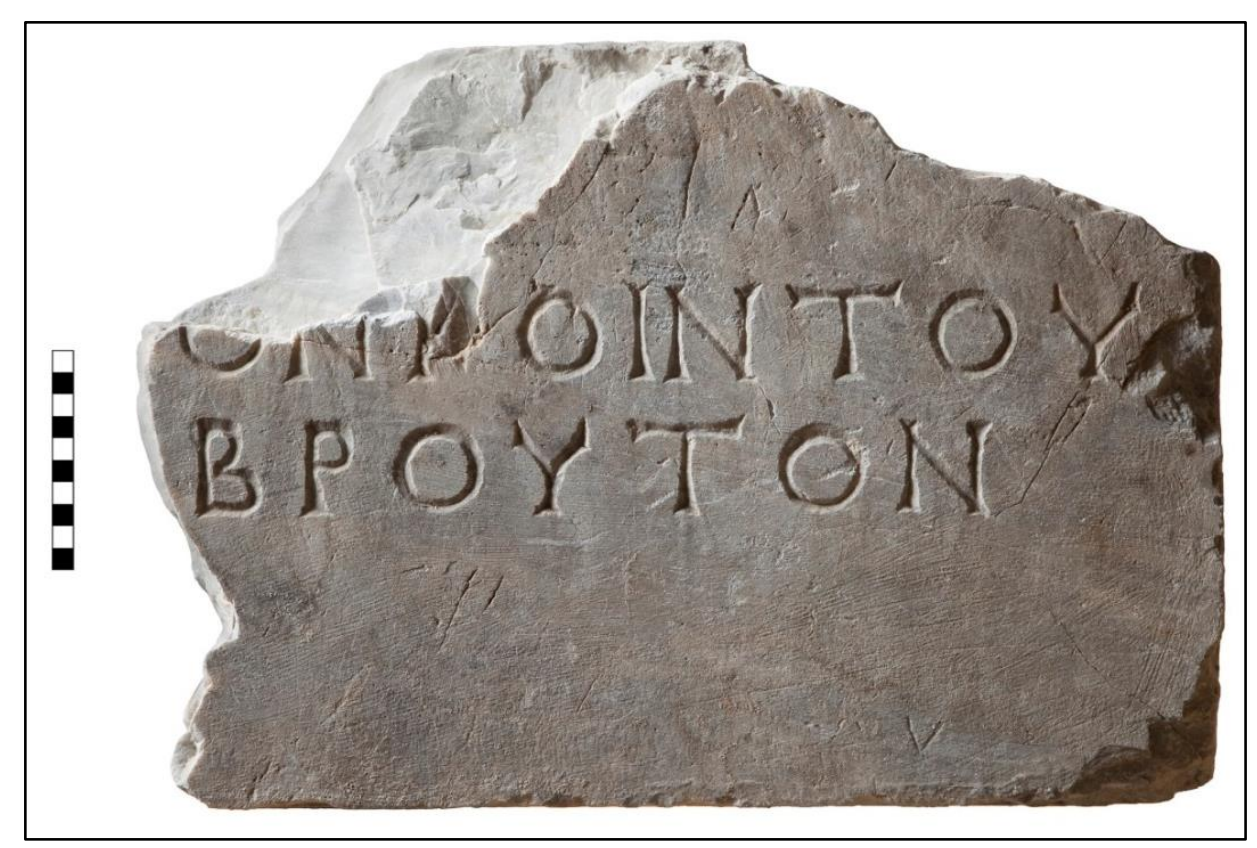

Figura 96. Fotografia de fragmento de base de estátua de Bruto encontrada na ágora ateniense, tirada por C. Mauzy em $2010\left(\operatorname{ASCSA}^{247}\right)$.

É tentador sugerir que esta era justamente a base mencionada por Dio Cássio, colocada ao lado das estátuas dos tiranicidas, mas não há indícios suficientes: o reuso a sudeste da ágora pode indicar tanto que a base foi transportada quanto que ela estava localizada nas proximidades. O local do célebre conjunto dos tiranicidas estava localizado provavelmente entre o templo de Ares e o Agrippeion na época de Pausânias

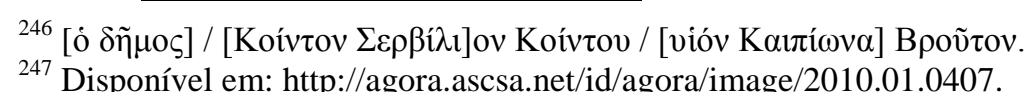


(1.8.4-5), o que é relativamente próximo do local do achado, mas a existência de mais de uma estátua dedicada a Bruto também é plausível, dada a referência a evergesias feitas por ele a Atenas em uma inscrição encontrada em Delos (ID 1622).

A colocação de estátuas de Bruto e Cássio ao lado daquelas de Harmódio e Aristogíton é extremamente significativa do modo como atenienses e romanos se apropriavam daquele espaço. As estátuas dos tiranicidas já tinham uma longa história: a primeira, encomendada por Clístenes e realizada por Antenor, havia sido roubada por Xerxes em 480, e levada para Susa; após a vitória em Platéia, os atenienses encomendaram um novo grupo aos escultores Kritios e Nesiotes - conhecido a partir de uma cópia encontrada na vila de Adriano em Tivoli (fig. 97); no local das estátuas eram realizados rituais do culto aos tiranicidas, associados intimamente à procissão panatenaica (Shear, 2001, 208-222, com bibliografia precedente). As estátuas e o culto aos tiranicidas já havia sido engajado na diplomacia ateniense ao menos duas vezes: Alexandre teria encontrado as estátuas originais de Antenor em Susa em 331/0, e as enviado para Atenas (Arriano, 3.16.7 ${ }^{248}$ ), numa clara referência à vitória sobre Dario como tirano persa; algumas décadas depois, em 307/6, os atenienses incluíram entre as honras concedidas a Antígono e Demétrio Poliorcetes a dedicação de estátuas ao lado dos tiranicidas, em uma alusão a queda do regime de Demétrio de Falero. Do final do século IV à época de Bruto, não há referências claras à história das esculturas; no entanto, considerando que até a época de Augusto a área onde estavam as estátuas permaneceu livre de construções, o culto aos tiranicidas (isolados com a retirada das estátuas macedônicas em 200) manteve seu prestígio.

A localização das estátuas de Bruto e Cássio ao lado do grupo dos tiranicidas, deste modo, pode ser tomada como uma interpretação ateniense da história política romana, pensada nos termos da história política ateniense. No entanto, os tiranicidas não eram apenas patrimônio ateniense, por assim dizer: o prestígio da história da democracia ateniense, que no período helenístico ganhou uma proporção mediterrânica, havia chegado também em Roma. Um fragmento de uma estátua de Aristogiton (fig. 98) foi encontrado no Capitólio em 1937. F. Coarelli (1969) argumentou para uma datação no século I, associando a estátua tanto às oficinas neoáticas quanto à dedicação de Metelo Cipião a seu ancestral Cipião Nasica, assassino de Tibério Graco, em 52 (Coarelli, 1969, p. 156). Apesar dos indícios coletados por Coarelli, a associação da

${ }^{248}$ E também Plínio, o Velho (34.70). Contra, cf. Valério Máximo (2.10), que atribui o retorno a Selêuco I da Síria. 
estátua ao episódio de Tibério, ou mesmo a proposta de datação da dedicação na década de 50, se sustenta em bases frágeis; no entanto, como Coarelli $(1969$, p. 143) aponta, uma datação pré-44 é provável, dado que dificilmente Otávio teria mantido o grupo exposto após o assassinato de César e as associações com os tiranicidas promovidas pelos cesaricidas. Um levantamento exaustivo do tema do tiranicídio, assim como do conhecido acerca da história ateniense em Roma ainda está por se fazer, mas se nos apresenta aqui uma hipótese promissora: dada a associação entre Sula e os tiranicidas na cunhagem ateniense de 84, o tema pode ter sido levado a Roma pelo próprio Sula, junto das colunas do Olympieion que seriam colocadas, justamente, no Capitólio.

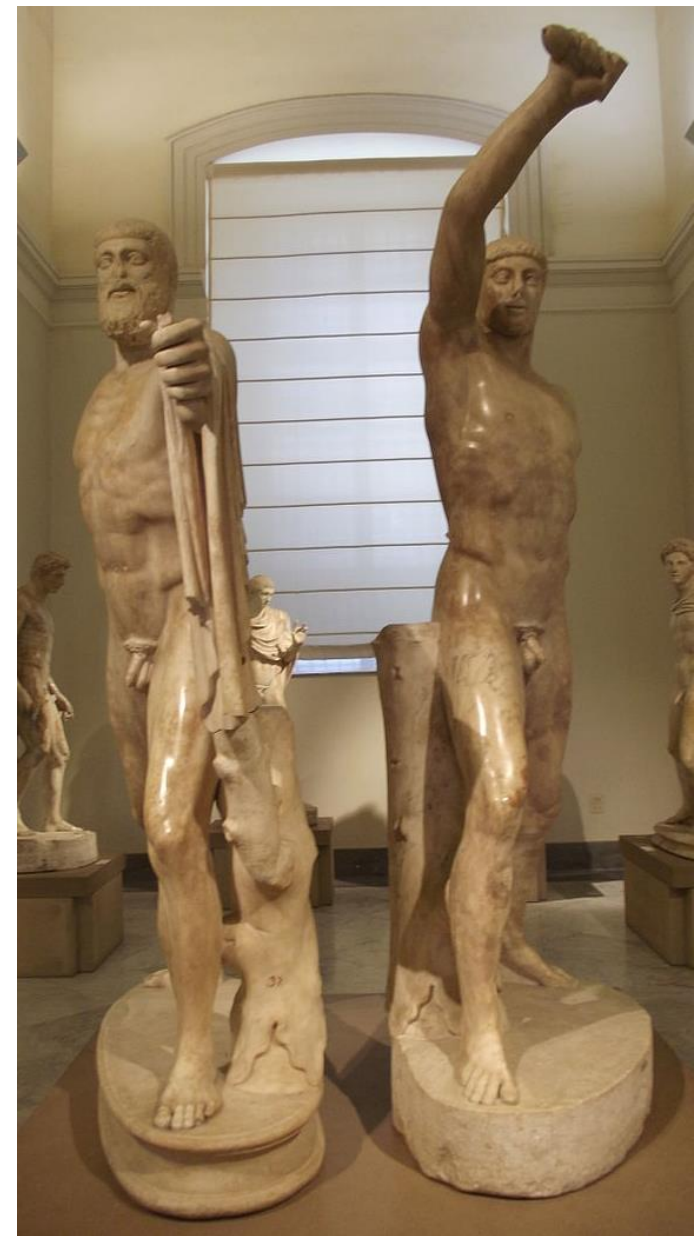

Figura 97. Fotografia da cópia romana do grupo de Harmódio e Aristogiton, tirada por E. Brown em 2012 no Museu Arqueológico de Nápólis (Wikicommons ${ }^{249}$ ).

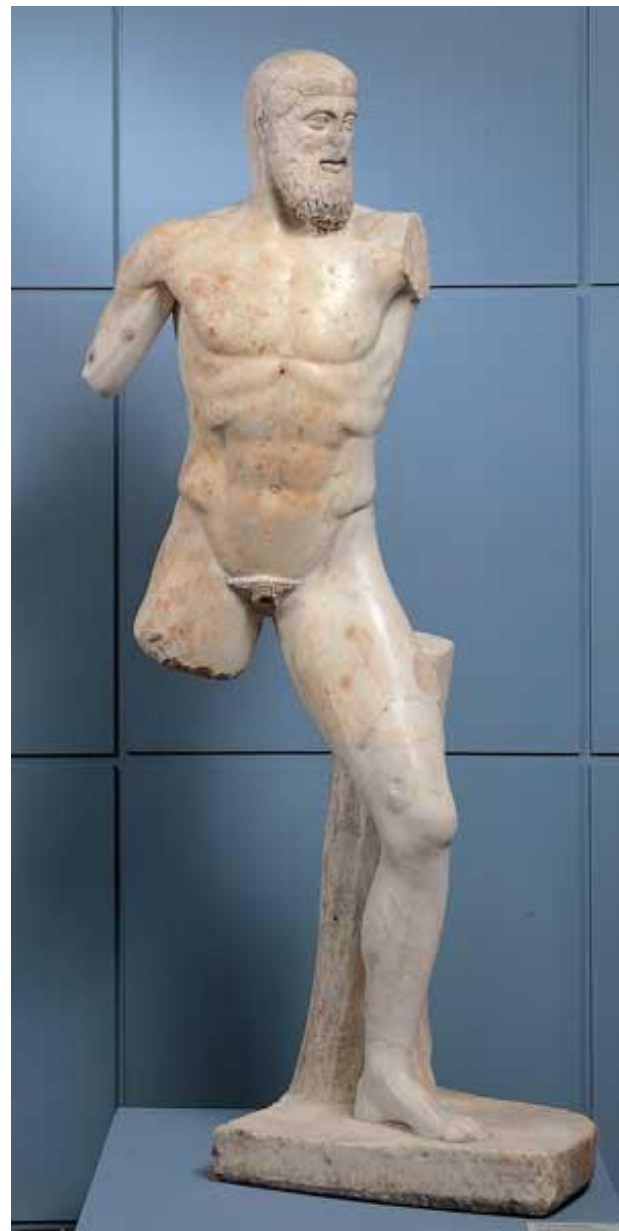

Figura 98. Fotografia da cópia romana em mármore da estátua de Aristogiton encontrada no Capitólio, atualmente na Centrale Montemartini (Museus Capitolinos ${ }^{250}$ ).

\section{${ }^{249}$ Disponível em:}

http://commons.wikimedia.org/wiki/File:National_Archaeological_Museum_of_Naples_Tyrannicide_group_-_Harmodius_and_Aristogeiton.jpg

${ }^{250}$ Disponível em:

http://www.centralemontemartini.org/collezioni/percorsi_per_sale/sala_macchine/campidoglio/statua_di_ aristogitone 
Datando da década de 50 ou pouco antes, o "Aristogiton do Capitólio" sugere a utilização do repertório tiranicida ateniense para a interpretação da política romana pelos próprios romanos. Tendo isso em mente, a escolha da localização do grupo de Bruto e Cássio faz sentido também do ponto de vista dos cesaricidas: M. Junio Bruto era descendente de L. Bruto, primeiro cônsul da república romana e personagem importante na derrubada da monarquia, contemporânea à queda da tirania ateniense, no final do século VI (Forsythe, 2005, pp. 153-155). A associação cesaricidas/tiranicidas, desse modo, significava a confluência de diversas tradições, tais como a celebração clássica da democracia ateniense na ágora, a associação helenística entre dinastas estrangeiros e os tiranicidas, a tradição tardo-republicana de leitura atenizante de sua própria história, e a tradição local recente ligada à memória de Sula. Há aqui, portanto, simultaneamente a preocupação antiquária, que considera a densidade histórica de cada monumento, quanto a atitude de adaptação das demandas externas às tradições espaciais locais. A potência desta associação, ainda que extremamente fugaz - pois durou o tempo da passagem dos cesaricidas por Atenas em 44 até sua derrota, dois anos depois, em Filipes, na Macedônia -, se revela no quase solene desprezo à tradição tiranicida expresso pelas intervenções associadas a Antônio ou a Otávio/Augusto em Atenas, como se verá adiante.

Marco Antônio é certamente, dentro os generais romanos, o que mais passou tempo em Atenas ${ }^{253}$ : alguns meses entre 42 e 41, uma passagem em 40 a caminho de Roma, cerca de dois anos entre 39 e 37, e alguns meses em 32. Mesmo após 37, Atenas permanece como sua segunda principal base, perdendo cada vez mais espaço para Alexandria. Três esposas de Antônio estiveram em Atenas: Fúlvia em 40, Otávia entre 39 e 37, e Cleópatra em 32; as duas últimas foram cultuadas, cada uma a seu momento, como "divindades benevolentes", a primeira associada a Atena, a segunda a Ísis. Cleópatra ainda teria concedido muitos presentes a Atenas, motivada pelo ciúme diante da adoração da cidade a Otávia (Raubitschek, 1946; Lesk, 2004, pp. 295-296). Antônio, por sua vez, tornou-se o "Novo Dioniso", e muito se discute em relação à adaptação do festival das Grandes Panatenéias à sua personalidade.

O impacto da presença de Antônio, Otávia e Cleópatra na religiosidade ateniense, entretanto, não parece ter tido equivalente na produção do espaço. Apenas três referências aparecem na tradição literária, todas em Plutarco. Na primeira, Plutarco

${ }^{253}$ Cf. discussão em Habicht (1997, pp. 360-364) e Baldassarri (1998, pp. 14-15). 
diz que, em sua primeira estadia, Antônio, como ginasiarca, deixava as insígnias militares romanas em casa e frequentava o ginásio vestido à moda grega (Plutarco, Antônio, 33.4), o que indica uma concepção do espaço público como lugar de exposição da helenidade, reforçada pelo prazer que Antônio sentia de ser chamado de “filateniense", segundo o mesmo Plutarco (Antônio, 23.2). Na segunda, Plutarco diz que, ao deixar Atenas para sua primeira missão na Ásia, Antônio leva, respeitando um oráculo, um ramo da oliveira de Atena na acrópole e um recipiente com água da Klepsidra, o que é coerente com o respeito às tradições locais, mas nada é mencionado quanto a intervenções construtivas relacionadas a este gesto (Plutarco, Antônio, 34.1).

A terceira, mais importante, é o relato dos prodígios anunciadores da derrota no Ácio, em 31. Plutarco, após narrar os sinais $(\sigma \eta \mu \varepsilon \tau \tilde{\alpha})$ ocorridos em outras cidades, diz que em Atenas:

\footnotetext{
“o Dioniso da gigantomaquia de Atenas foi derrubado pelo vento e caiu sobre o teatro. Antônio associava a si a Héracles por linhagem e a Dioniso por emulação do modo de vida, [...] e era cumprimentado como Novo Dioniso. A mesma tempestade também derrubou os colossos de Eumenes e Átalo, reinscritos com o nome de Antônio, e únicas que caíram, entre muitas" (Plutarco, Antônio, 60.2-3).
}

A estátua de Dioniso certamente diz respeito à Dedicação Atálida, colocada junto ao muro sul, o que tornaria coerente a imagem dela caindo sobre o teatro (ainda que apenas uma estátua de bronze se descolar da base de mármore não fosse uma reconstituição plausível). As estátuas colossais de Eumenes e Átalo rededicadas a Antônio, no entanto, não podem ser localizadas com precisão: Plutarco poderia estar se referindo tanto a estátuas colossais individuais, dispostas, por exemplo, nas proximidades da Dedicação Atálida (como sugere A. Stewart, 2004), ou a um dos grupos equestres colocados na acrópole (diante do propileu ou na quina noroeste do Pártenon). A associação entre Antônio e Dioniso não são exclusivas a Atenas, mas aparecem em outras cidades. Plutarco certamente aproveitou tal associação como eixo em sua escolha de comparar Antônio e Demétrio Poliorcetes, ambos dinastas dionisíacos com fortes ligações com Atenas. Não houvesse referência externa a esta associação, seria de se suspeitar que fizesse parte da propaganda augustana, pois, tomando Atenas como referência, o último monarca a se associar diretamente a Dioniso havia sido, justamente, Mitrídates. Apropriar-se de uma lógica que o associaria a um rei 
com raízes persas, ainda mais no momento de preparação de suas expedições contra a Pártia, seria incoerente da parte de Antônio, o que resulta em duas possibilidades: ou a memória de Mitrídates-Dioniso não era tão forte em Atenas na década de 30, ou, o que é mais plausível, a ligação do próprio Antônio com o deus estava acima de qualquer reminiscência anti-romana local. A postura "monárquica" de Antônio, "novo Dioniso" para além de qualquer resquício mitridático, era reforçada pela rededicação das estátuas colossais de Eumenes e Átalo na acrópole. Antônio, desse modo, se apropriava do padrão espacial de matriz marcadamente atálida: a comemoração dinástica na estátua dos dois irmãos, o dionisismo atálida ligado ao teatro (Stoa de Eumenes) e à célebre dedicação, além da participação ativa na vida ginasial e agonística local. Antônio não transformou radicalmente o espaço ateniense, como fizeram (destrutivamente) Sula e (construtivamente) Augusto: bastava, ao que parece, inserir-se nas tradições locais, não como magistrado romano, mas como monarca helenístico. Será necessário o fim das guerras civis para que, do ponto de vista da produção do espaço urbano, as ambiguidades república/monarquia, tradição/ruptura, local/estrangeiro, simultaneamente se intensifiquem e se resolvam no que ficou conhecido como a "Atenas augustana".

Quanto às doações de Antônio, de Otávia e de Cleópatra, nenhum detalhe é revelado: não se sabe se foram presentes na forma de dinheiro, grãos ou edifícios. O mais provável é que tenham assumido as duas primeiras formas, pois não há na epigrafia, na tradição literária ou na arqueologia, nenhum vestígio de intervenções construtivas datável com certeza à década de 30. Isto levanta a questão das razões para essa inatividade. Pode-se pensar, por exemplo, que a cidade já havia realizado as restaurações necessárias nas décadas anteriores, e não havia mais urgências - exceto pelos edifícios ao sul da Stoa Média, destruídos por Sula e algum tempo depois substituídos por oficinas, para serem reconstruídos somente na época de Adriano. Além disso, a atividade construtiva não parecia ser prioridade no evergetismo antoniano, como é sugerido, por exemplo, por seu plano aparentemente não realizado de reconstruir o templo de Apolo e o conselho em Mégara (Plutarco, Antônio, 23.3), ou pela ausência de menções na biografia de Plutarco. O contraste com o período augustano, como será demonstrado no capítulo 3, é gigantesco. 


\section{Capítulo 3. A cidade augustana}


A década de 20 marca um ponto de ruptura radical na história romana: as décadas de guerra civil e de instabilidade dão lugar à hegemonia, cada vez mais inconteste, de Otávio - chamado de Caio César desde 44, e César Augusto desde 27. Determinar a natureza desta ruptura, e mesmo se foi de fato uma ruptura tão radical, anima ainda intensos debates da historiografia especializada ${ }^{255}$. Entre as questões centrais, está justamente o problema da natureza do regime de Augusto: monarquia ou república? Que não era um regime republicano como no período anterior, ou uma monarquia como nos reinos helenísticos, não está em questão: o regime augustano apresentava traços de diversas referências, ao mesmo tempo apresentando um complexo novo e que se mostraria particularmente durável (Millar e Segal, 1984; Meier, 1990; Millar, 1998; Winterling, 2009). No entanto, se por um lado os "arranjos constitucionais" do regime augustano apontavam para um amalgama entre formas republicanas e imperiais de poder (de fato e de direito), por outro lado diversas dimensões da vida social apontavam para a afirmação de uma monarquia e de uma comunicação propriamente dinástica - é o caso, por exemplo, do espaço urbano romano. Assim, a multiplicação de intervenções espaciais com caráter propagandístico, do Mausoleu ao Fórum de Augusto, de sua casa no Palatino ao Panteão no Campo de Marte, foi normalmente interpretada como discurso espacial de caráter monárquico, fundado na comemoração do autocrata e de sua dinastia (Leach, 1988; Zanker, 1988; Kellum, 1990; Favro, 1998; Walker, 2000). Tais intervenções, certamente, não seriam absolutamente inovações na tradição urbana romana: grandes complexos construtivos anteriores, como o teatro de Pompeu e o Fórum de César, por exemplo, já apontavam para esta direção. As intervenções augustanas diferenciavam-se, essencialmente, pelo seu contraponto institucional e militar, que garantiu a permanência de Augusto no centro da vida política romana ao longo de muito mais tempo do que seus possíveis antecessores (Winterling, 2009).

A posição de Atenas no contexto destas transformações pareceria, de um primeiro ponto de vista, óbvio: a cidade terá de se adaptar à nova realidade política, apagando assim a memória de sua adesão a Antônio e procurando, de variadas formas, conquistar a simpatia do novo governante. No entanto, quando observada mais atentamente, a questão se mostra mais complexa: Atenas será uma peça estratégica da propaganda anti-antoniana do regime augustano, e o fará, justamente, em função de sua

${ }^{255}$ Cf. os balanços do debate em Galsterer (1990), Galinsky (2007) e Winterling (2009). Para a crítica da ideia de ruptura radical, a partir dos modos de articulação entre Estado e sociedade, cf. Faversani (2013). 
tradição. Nesta lógica, Atenas não poderia se tornar simplesmente em uma "vitrine do regime augustano", ou num "santuário da família imperial" (Gros, 1989): Atenas deveria representar o que foi - o berço da cultura, o bastião da civilização - de modo a justificar a autorepresentação de Roma sob Augusto. Como, então, conciliar as estratégias já consolidadas do evergetismo - a comemoração do autocrata por meio de intervenções monumentais no espaço urbano, normalmente envolvendo cultos diretos ou indiretos ao soberano - com um imperativo de tornar-se representação de um passado autônomo e triunfante, inclusive, contra potências estrangeiras? Até que ponto cada uma destas estratégias, desdobradas, inclinar-se-iam mais ou menos para uma "resistência" ou uma "acomodação" aos imperativos da dominação romana ou da propaganda dinástica?

Este debate dominou os estudos sobre as intervenções urbanas de época augustana em Atenas: as virtudes e vícios desta abordagem, ligada ao debate sobre a romanização das provinciais, foram discutidas na Introdução. Boa parte dos vícios, de fato, parte de um problema de ordem documental: os vestígios das intervenções, no mais das vezes, são avessos a tentativas de datação absoluta ou relativa, assim como impedem a elaboração de uma caracterização segura quanto às várias etapas da implantação e uso das intervenções. A consequência disto, do ponto de vista da apresentação da discussão que se seguirá, é a necessidade de se ter em mente que a ordenação temporal é posterior, e não anterior, à interpretação - o risco de circularidade nos argumentos, portanto, é constante. Semelhante circularidade pode aparecer também quando se analisa o conjunto das intervenções: parte-se da categoria de "propaganda augustana" para se explicar a coerência das intervenções que são, por sua vez, utilizadas como base da caracterização mesma da "propaganda augustana" em Atenas ${ }^{256}$.

Uma saída recorrente para este problema é buscar, na história de Roma, uma espécie de fiador das interpretações: a "propaganda augustana" se produz em Roma e vai a Atenas como que por meio de um "moinho de vento", que sopra do Ocidente para o Oriente (Spawforth, 2012, p. 130). O problema desta estratégia é, justamente, tudo derivar de Roma, como se a Atenas não tivesse seus próprios "moinhos de vento" soprem eles a partir das necessidades de elites locais em reafirmar sua posição sob novas condições, ou a partir de tradições espaciais incorporadas nas práticas, de modo que novas intervenções teriam que dialogar não somente com intervenções anteriores,

\footnotetext{
${ }^{256}$ Como por vezes ocorre, por exemplo, no excelente livro de A. Spawforth (2012); cf. Morales (2013b).
} 
mas também, e principalmente, com os padrões espaciais já estabelecidos. O modo como este diálogo ocorre não se reduz a uma antinomia "resistência ou propaganda", na medida em que a própria resistência poderia ter sido apropriada como propaganda - não há, simplesmente, evidências para sustentar uma hipótese definitiva. Antes, serão explorados neste capítulo as modalidades e conteúdos deste diálogo, ao lado das possibilidades e limites que cada intervenção e o programa como um todo apresentavam para as formas de produção social do espaço ateniense.

\section{Augusto e a acrópole de Atenas}

A presença de Augusto na acrópole de Atenas é, aparentemente, tímida: uma inscrição em um pequeno edifício e uma estátua no topo, uma inscrição na arquitrave de uma stoa na encosta sul, e talvez uma associação a um santuário na encosta norte. No entanto, quando se considera a densidade material e simbólica da paisagem construída na acrópole, os diálogos e relações estabelecidos por estas pequenas intervenções são extremamente significativas. As intervenções augustanas na acrópole inserem o nome de Augusto no principal santuário da cidade e ao mesmo tempo reiteram padrões tradicionais de produção do espaço: romanização ou resistência? Vejamos com detalhe.

\section{O monóptero de Roma e Augusto na acrópole}

Provavelmente a primeira intervenção construtiva de época augustana em Atenas, o monóptero da acrópole é um dos edifícios mais discutidos nos estudos sobre a "Atenas romana" ${ }^{257}$. Seus vestígios foram escavados e reunidos no século XIX por Kawerau (1888), e já na obra de P. Graindor (1927) ocupavam um lugar de destaque na interpretação do sentido das intervenções augustanas em Atenas. Os vestígios são compostos por uma série de blocos de mármore pentélico da superestrutura (fig. 99), que sustentam com alguma segurança a reconstrução (figs. 100-101) de um monóptero de 7,35 metros de diâmetro, rodeado por nove colunas jônicas que sustentam um entablamento circular composto por arquitrave em três faixas e friso contínuo, coroadas pela cornija e por uma cobertura cônica ou em cúpula, que não deixou vestígios - e que

${ }^{257}$ Entre os estudos específicos recentes, vale destacar Schmalz (1996); Baldassarri (1995); Spawforth (1997); Schäfer (1998); Kajava (2001); Kantiréa (2007); Thakur (2008). 
faz com que alguns sugiram que se trata-se de uma cobertura com telhas de cerâmica. Entre estes vestígios, de enorme importância é o fragmento da arquitrave com a inscrição dedicatória (IG III 3173; fig. 102), onde se lê:

O povo [dedica à] deusa Roma e Augusto César, sendo general dos hoplitas Pamenes, filho de Zenon de Maratona, sacerdote da deusa Roma e de Augusto Salvador na acrópole, sendo sacerdotisa de Atena Políade Megiste, filha de Asclepídes de Halai. No arcontado de Areios, filho de Dorion de Peânia.

Os fragmentos da superestrutura foram associados, ainda no século XIX, a uma fundação retangular de 10,4 x 13,2 metros, formada por blocos de calcário encaixados com relativamente pouco cuidado (entre os quais estava um fragmento de cornija do Erechtheion), localizada 21 metros ao leste do Pártenon, exatamente em seu eixo longitudinal. Esta proposta de localização se baseava em dois elementos: em primeiro lugar, boa parte dos fragmentos foi encontrada no (ou próximo do) local; em segundo lugar, não havia outros bons candidatos para ocupar aquela fundação. Assim, o monóptero, cada vez mais conhecido como “o templo de Roma e Augusto", primeiro templo do culto imperial na cidade, e passou a ser uma das principais manifestações da "romanização" de Atenas, tendo sido construído entre 27, quando Otávio recebe o título de Augusto, e 19/8, quando reiniciava a lacunar lista dos arcontes sem o nome de Areios.

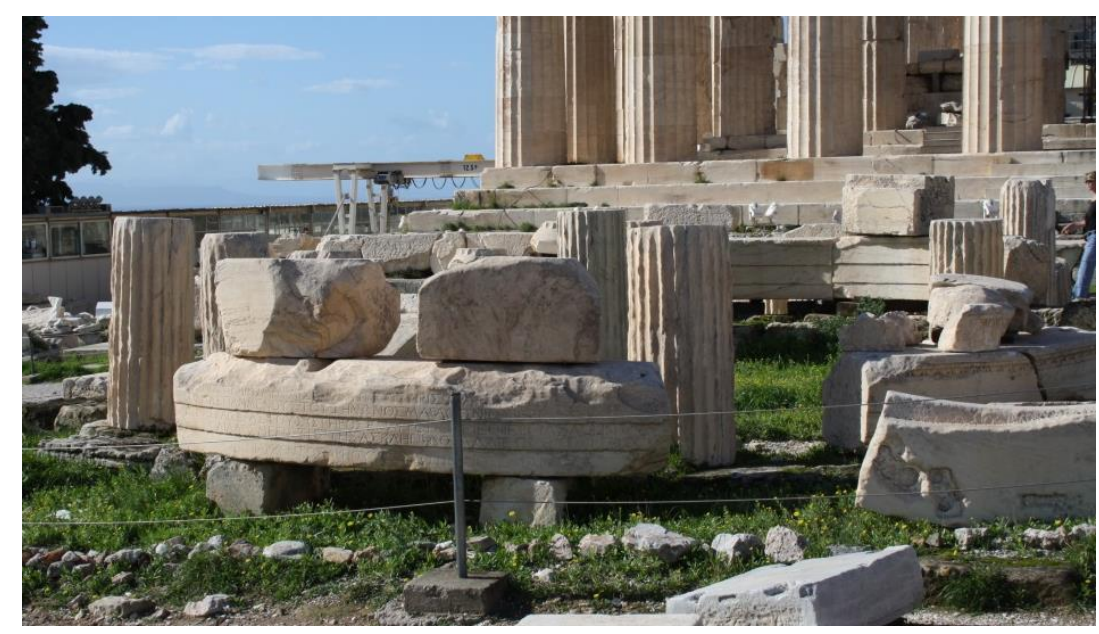

Figura 99. Fotografia dos vestígios do monóptero expostos atualmente na acrópole de Atenas, tirada em 2013 (WikiCommons ${ }^{259}$ ).

\footnotetext{
259 Disponível em: http://commons.wikimedia.org/wiki/File:2747_-_Athens_-_Acropolis_-
} _Temple_of_Rome_and_Augustus_-_Photo_by_Giovanni_Dall'Orto,_Nov_09_2009.jpg. 


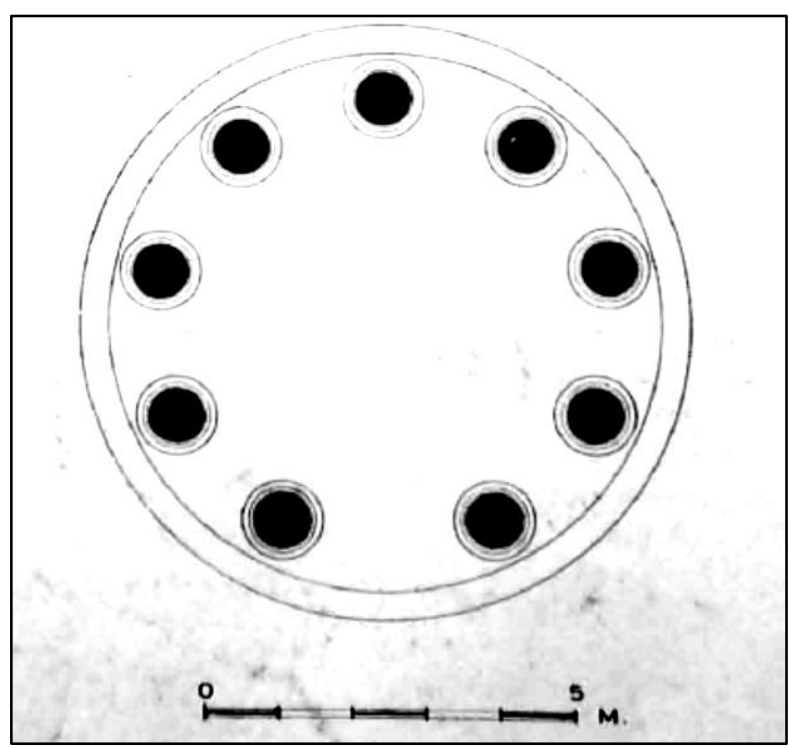

Figura 100. Reconstituição da planta do monóptero de Roma e Augusto, segundo J. Travos (1980, p. 494, fig. 623).

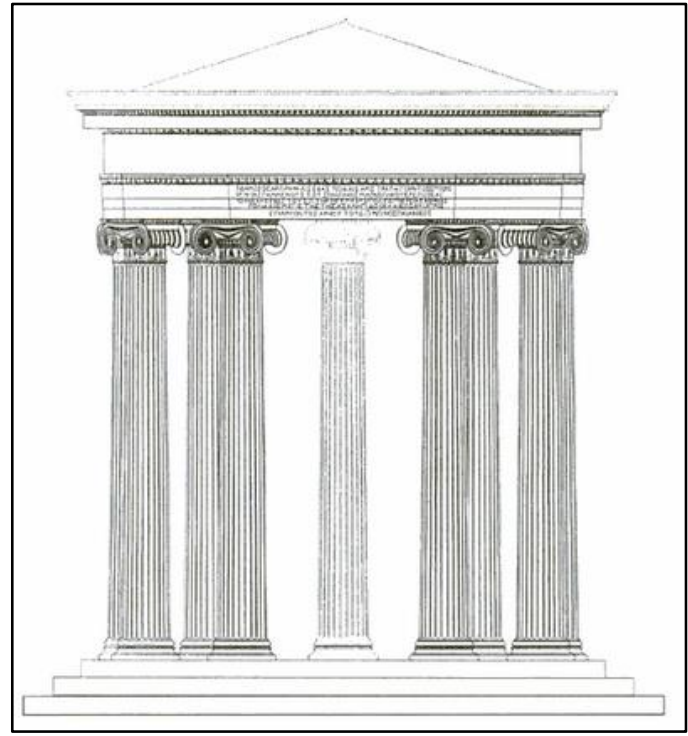

Figura 101. Proposta de reconstituição da elevação do monóptero, segundo Kawerau (1888).

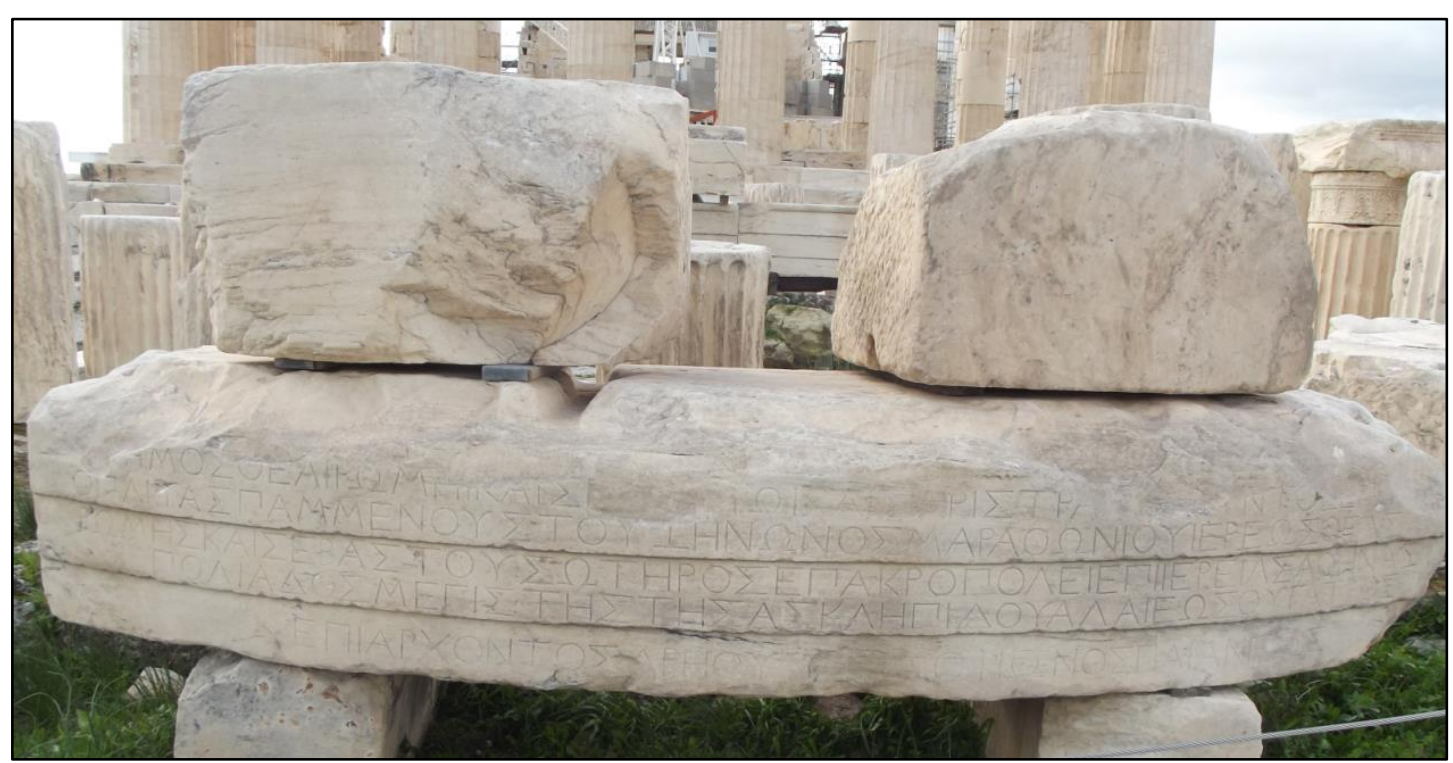

Figura 102. Fotografia da arquitrave inscrita do monóptero de Roma e Augusto tal como exposta na acrópole de Atenas atualmente, tirada em 2012 (Acervo pessoal).

Entretanto, diversas questões permanecem abertas. A primeira delas diz respeito à localização do templo. W. Binder, em dos mais exaustivos estudos sobre o monóptero (1969), levantava uma série de questões acerca da associação entre o monóptero e a fundação retangular ao leste do Pártenon: eram inconsistentes para sustentar um edifício de quase 8 metros, além do que um edifício circular seria mais adequado a uma fundação circular. Assim, W. Binder sugeriu que o monóptero estivesse localizado mais 
ao norte, em algum ponto mais próximo do Erechtheion, como indicariam as citações arquiteturais das colunas jônicas do Erechtheion nas do monóptero (ambas apresentam na gola uma estreita faixa em "conta e pérola", seguida por um anthemion com lótus e palma, um faixa em "conta e pérola" igual à inferior, uma faixa mais larga em "ovo e dardo", e uma faixa convexa com pequenas incisões logo abaixo do equino côncavo em listras que foram as volutas nas extremidades, encimado por um ábaco em "ovo e dardo"; fig. 103). Esta tese foi retomada por A. Lesk (2005, pp. 296-297), que enfatizou a referência à sacerdotisa de Atena Políade na arquitrave do monóptero, cujo culto teria como ponto de referência o Erechtheion, e adicionou ao argumento uma interpretação da iconografia do reverso de algumas moedas de bronze atenienses do século III d.C. (fig. 104), que figuram um pequeno edifício com cobertura cônica logo à esquerda do Erechtehion, e que poderiam ser interpretadas como indício da posição do monóptero próximo ao Erechtheion, e não ao Pártenon (Lesk, 2004, p. 293, n. 170-171). A fundação ao leste do Pártenon, por sua vez, na medida em que para Lesk (2005, o desmantelamento do Erechtheion ocorreu no século III - muito antes da construção do monóptero - ela poderia ter sido designada para sustentar outro monumento, por exemplo, uma estátua colossal de Apolo, que seria mencionada por Pausânias em sua visita à acrópole (1.24.8).
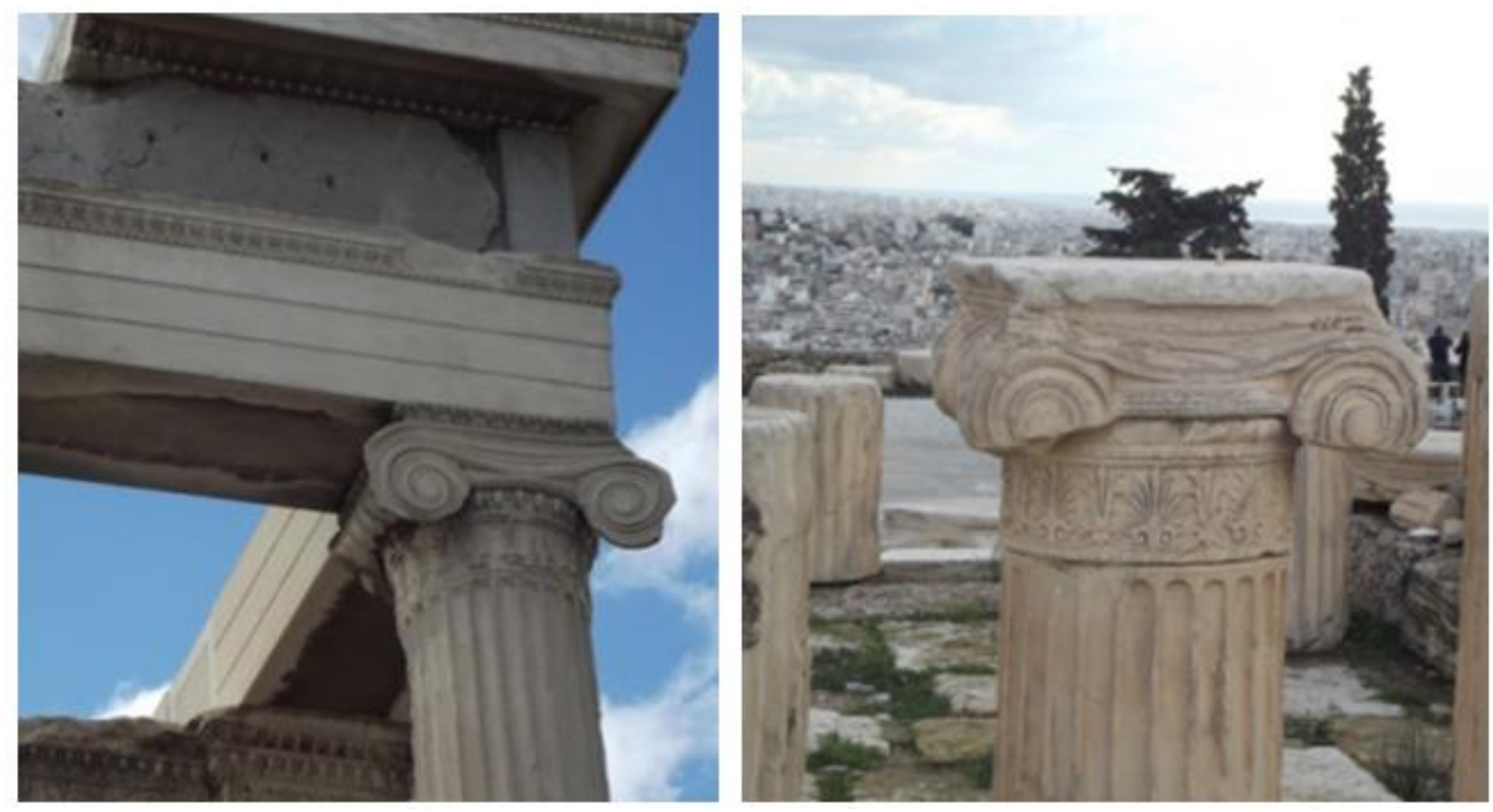

Figura 103. Fotografia de detalhe da fachada oriental do Erechtheion e detalhe de coluna jônica do Erechtheion, tirada em 2011 (Acervo pessoal). 


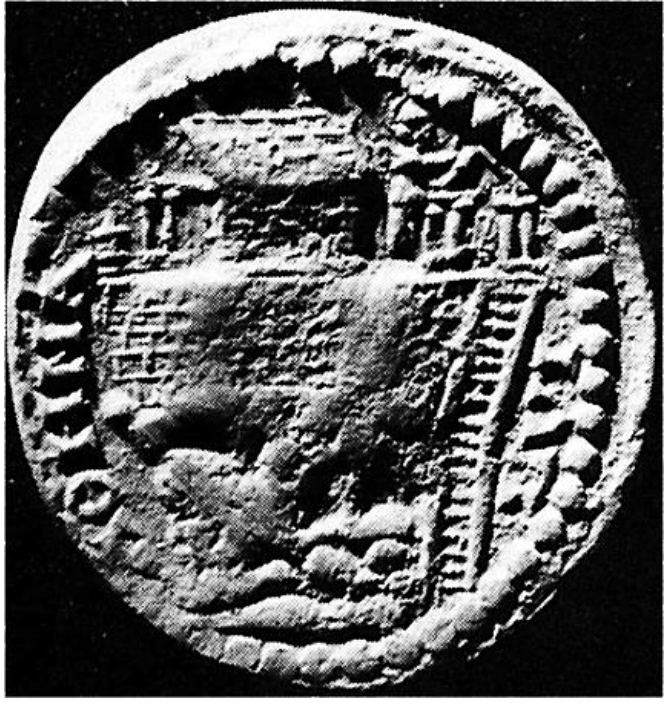

Figura 104. Atenas, c. 264-267 d.C., bronze. Anverso: Busto de Atena, com elmo, voltado para direita Reverso: acrópole ateniense vista do norte, figurando, da direita para a esquerda, a escadaria de acesso, o Propileu, a estátua de Atena Promakhos, o Erechtheion (?) e o monóptero de Roma e Augusto; figuração da muralha norte na encosta

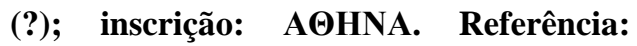
British Museum Coins and Medals, 1922.3-17.82. Cf. Kroll (1993, p. 145 [cat. 280], pl. 19, e p. 159 [cat. 375], pl. 21) e Lesk (2005, p. 293, n. 170-171). Fonte: Quizlet $^{261}$.

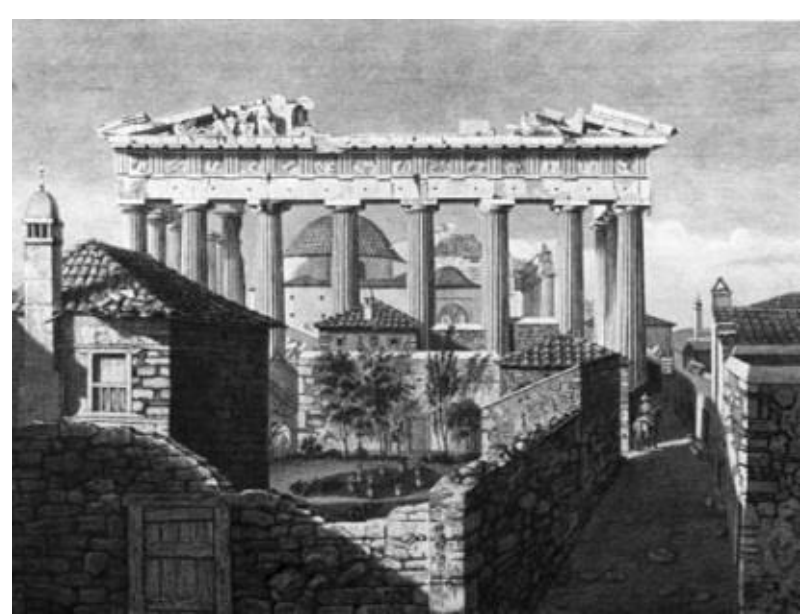

Figura 105. Gravura da região diante da fachada leste do Pártenon, segundo E. Stuart e N. Revett, a partir de viagem realizada entre 1751 e 1753 (1762, cap. 1, pl. 1).

As críticas de W. Binder e A. Lesk à proposta "tradicional" de localização do monóptero são atraentes, mas não definitivas. Em primeiro lugar, a base retangular, apesar de incomum, não é incoerente com edifícios circulares, como demonstra o monumento de Babbius em Corinto, construído pouco depois do monóptero. Em segundo lugar, a sugestão de que a fundação ao leste do Pártenon fosse dedicada a uma estátua colossal apenas mencionada por Pausânias não é plausível: a área desta fundação é maior do que a base da estátua colossal de Atena Promachos, ricamente citada na tradição literária e iconográfica, o que torna muito difícil que uma estátua de

${ }^{261}$ Disponível em: http://quizlet.com/28668409/ahis-321-final-flash-cards/ 
maiores proporções, e em um espaço de tamanha evidência, não fosse mencionada em outras fontes. Em terceiro lugar, a leitura do reverso das moedas de bronze imperiais não pode ser feita com base em um suposto "realismo": a imagem não procura representar a acrópole tal e qual ela aparece aos olhos, mas sim seleciona e distorce as proporções para realçar determinados objetos, aumentando com isso sua inteligibilidade. Assim, por exemplo, seria impossível ver, ao mesmo tempo, a escadaria de acesso, a fachada ocidental do Propileu, o perfil da Atena Promakhos, o lado norte do Erechtheion e qualquer parte do monóptero do mesmo ponto de vista. A seleção dos objetos a serem figurados responde muito mais a imperativos de inteligibilidade do que da empiria: a inclusão do monóptero entre edifícios e monumentos célebres poderia estar ligada a sua associação ao culto imperial, mas do que por seu eventual destaque arquitetural na paisagem da acrópole ${ }^{262}$. Finalmente, como oportunamente lembrou P. Baldassarri (1995, p. 73), uma gravura publicada por E. Stuart e N. Revett em 1762 portanto, muito antes do início das escavações - retratando a fachada leste do Pártenon, destaca uma estrutura circular em uma região que, aparentemente, era a mesma da fundação designada pelos arqueólogos ao monóptero (fig. 105). Diante disso, será mantida aqui a proposta de localização do monóptero na fundação ao leste do Pártenon, aguardando novas pesquisas tanto na própria fundação - que ainda não foi objeto de um estudo detalhado - quanto da área ao leste do Erechtheion, junto ao santuário de Zeus Polieus.

A segunda questão em aberto se refere à própria natureza do monóptero: trata-se de um templo ou de um monumento honorífico? O formato circular não é contraditório à utilização como templo ou edifício de culto, como é indicado, por exemplo, pelo templo de Afrodite Euploia em Cnido, o Philippeion em Olímpia, o templo de Hercules Victor em Roma, ou os templos de Vesta em Roma e em Tivoli. Um elemento fundamental, no entanto, seria a existência de uma estátua de culto de Roma e de Augusto, os dedicados do monóptero, assim como uma cela que protegesse a estátua. Não há vestígio nem de estátuas de culto ${ }^{263}$, nem de um muro circular para a cela. $\mathrm{O}$ espaço maior entre duas colunas do monóptero - colocado nas reconstituições sempre

\footnotetext{
${ }^{262} \mathrm{E}$ mesmo que somente neste ponto o artesão procurasse representar a experiência visual, o tamanho extremamente reduzido do monóptero poderia ser entendido como um efeito de perspectiva, demonstrando que o monóptero se localizada ao sul do Erechtheion.

${ }^{263}$ A única estátua de Augusto atestada na acrópole (IG II ${ }^{2} 3253$ ) foi erigida em conjunto das estátuas de Tibério (IG II ${ }^{2} 3254$ ), Germânico (IG II ${ }^{2} 3255$ ) e Druso (IG II ${ }^{2} 3256$ ), o que aponta para uma data após a morte de Caio César, em 4 d.C., quando os projetos de sucessão se voltam para os filhos de Lívia (Cook, 1996, pp. 104-105).
} 
ao leste - foi interpretado como indicativo de uma entrada, pressupondo que o espaço entre as outras colunas fosse fechado por algum tipo de vedação (Graindor, 1927, p. 182); no entanto, não há marcas nas colunas que permitam tal suposição, fazendo com que um eventual maior espaçamento seja interpretado apenas como a entrada preferencial, mas não única. Além disso, entre os 20 altares dedicados a Augusto provenientes de Atenas, nenhum deles foi encontrado na acrópole. Por outro lado, a semelhança do monóptero da acrópole com o monumento de Babbius em Corinto, construído no século I d.C., aponta na direção que o primeiro se tratava também de um monumento honorífico, em uma espécie de desenvolvimento de monumentos circulares já presentes em Atenas, como era o caso do monumento corégico de Lisícrates, na rua dos Trípodes ao leste da acrópole ${ }^{264}$. De maiores dimensões e em uma localização de muito maior prestígio, o monóptero se adaptaria assim ao diferente nível dos dedicados.

Mas, se o monóptero era um monumento honorífico e não um templo, onde situar o foco do culto "da deusa Roma e de Augusto Salvador na acrópole", mencionado na arquitrave? Como A. Lesk observou, a referência a Megiste de Halai, sacerdotisa de Atena Políade, na inscrição dedicatória do monóptero não era fortuita: demonstrava laços cultuais entre os o monóptero e o edifício citado em seus detalhes ornamentais, o Erechtheion; além disso, há menos de uma década a irmã de Augusto, Otávia, havia sido associada em Atenas, justamente, a Atena Políade (Raubitschek, 1946; Lesk, 2004, pp. 295-296). A partir disso, uma hipótese plausível é que o culto imperial na acrópole estivesse localizado, justamente, no Erechtheion, incorporado à série de cultos estabelecidos neste edifício e que remontavam ao passado mítico e fundacional ateniense.

Esta hipótese é corroborada por uma série de outras indicações, a partir, especialmente, da análise dos testemunhos epigráficos relacionados a Megiste de Halai (Schmalz, 2009, p. 282) e Areios de Peânia (Schmalz, 2009, p. 241). Atestada como sacerdotisa de Atena Políade em 19/8 - provável ano do arcontado de Areios - Megiste mantem o posto até cerca de 4, quando é sucedida por Hipostenis do Pireu. Megiste pertencia ao genos dos Eteobutadai, que alegava ascendência a partir de Butes, irmão de

\footnotetext{
${ }^{264}$ Um paralelo possível para sustentar a identificação do monóptero como um "templo" seria o monóptero de Afrodite Euploia em Cnido, onde estava exposta a famosa escultura de Praxíteles; Plínio o descreve como aedicula, e enfatiza a ausência de muros para a total exposição da estátua (36.21). No entanto, como se verá a seguir, o objeto mais provável que seria abrigado dentro do monóptero da acrópole ateniense seria algo referente às insígnias romanas resgatadas por Augusto em 21, o que faz com que o monóptero mantenha sua identidade como monumento honorífico, sem que seja equiparado a um templo de Roma e Augusto.
} 
Erechtheus e filho de Pandion, rei mítico de Atenas, que dividiu o poder entre os filhos: Erechtheus teria o reinado, enquanto Butes se tornaria sacerdote de Atena e de Poseidon Erichthonios (Apolodoro, 3.14.8-15.1). Outras genealogias existiam (Parker, 1997, p. 290; Sourvinou-Inwood, 2011, pp. 51-107), que identificavam este Erechtheus ao próprio Erichthonios, fruto da fecundação da terra pelo sémen de Hefesto, após a fracassada tentativa de estupro de Atena; C. Sourvinou-Inwood (2011, p. 88-89) sugere que a separação entre Erechtheus e Erichthonios nos mitos de fundação de Atenas é tardia, se tratando originalmente do mesmo personagem. Portanto, Megiste fazia parte do mais prestigioso genos ateniense, que contava entre seus membros o orador do quarto século Licurgo. Mas um parente mais próximo de Megiste é particularmente importante para esta discussão: seu avô, Demétrio de Halai. Demétrio é listado entre os contribuintes da grande procissão a Delfos (a Pythais) de 97/6, mencionado como “sacerdote de Roma” (IG II2 2336.265; Tracy, 1982, p. 196), o que demonstra a ligação entre o culto a Roma e o genos dos Eteobutadai desde pelo menos o final do século I; a hipótese de que o Erechtheion hospedava o culto de Roma - ou alguns de seus rituais é atraente, mas não há evidências para garanti-la. De qualquer modo, o fato de uma neta de um sacerdote de Roma ser mencionada como sacerdotisa de Atena em uma dedicação para a deusa Roma e Augusto não me parece ser uma simples coincidência.

Outra indicação é a publicação, em uma estela inscrita e exposta no Erechtheion (IG II 2338), de uma lista com os membros (gennetai) do genos de Amynandridai, no ano em que um de seus membros era arconte epônimo: Areios de Peânia, em c. 19/8. A este genos era atribuído o culto de Cécrops, rei mítico de Atenas, nascido da própria terra e parte serpente, que teria sido a testemunha da disputa pela cidade entre Atena e Poseidon; dois objetos fundamentais desta disputa, a saber, a oliveira dada por Atena aos atenienses - que resultou em sua vitória - e a bacia com a água marinha, prova do dilúvio causado por Poseidon após a derrota, estavam expostos dentro do recinto sagrado do Erechtheion; e acima de tudo, a própria tumba de Cécrops (Kekropeion) estava localizada sob o edifício, possivelmente como vestígio do templo arcaico de Atena (Lesk, 2004, pp. 154-164 e 763). De fato, o sacerdote de Cécrops, ao menos para aquele ano, era o próprio Areios de Peânia.

A lista dos membros dos Amynandridai é bastante rica para a discussão do impacto de Roma para a religiosidade ateniense. Mais do que vestígio de um passado longínquo, a publicação desta lista é melhor interpretada como parte de um movimento complexo de reorganização gentílica ateniense, iniciada ainda no século II, mas cujo 
ápice se dá entre as décadas de 30 e 20. A. Spawforth observou que diversos membros listados não são de origem ateniense, e mesmo alguns apresentam nomes ítalo-romanos (C. Rubrius, Plotius e Vargonius): indício de que o genos era uma forma importante de integração de estrangeiros nos quadros das elites ou sub-elites atenienses (Spawforth, 2012, p. 198). Mas as relações entre o genos e os romanos iam além: Cécrops era conhecido nos círculos intelectuais romanos como herói civilizador (Spawforth, 2012, p. 199), seja criando leis funerárias (Cícero, Leges, 2.63), seja criando algumas letras do alfabeto (Tácito, Anais, 11.14.2). A associação entre Augusto e Cécrops, por meio de Areios de Peânia - arconte epônimo e sacerdote de Cécrops -, como heróis civilizadores, é paralela ao evento que provavelmente motivou a dedicação do monóptero: a missão diplomática na Pártia.

Augusto realiza no ano de 21 uma viagem para a Pártia com o objetivo de discutir as fronteiras e as relações entre as duas maiores potências imperiais de então, e passa ao menos duas vezes por Atenas, uma na ida e outra no retorno a Roma. Augusto já havia estado em Atenas uma vez, pouco depois da vitória do Ácio em 31; na ocasião perdoou o apoio ateniense a Antônio e realizou distribuições de grãos, o que deve ser conectado com sua primeira iniciação nos mistérios de Elêusis. A segunda passagem ocorre no inverno de 21, quando Augusto, após permanecer parte do inverno em Esparta, faz uma rápida visita em Atenas onde, aparentemente, contou com a oposição de parte dos atenienses: Dio Cássio menciona o misterioso prodígio ocorrido na acrópole, onde uma estátua de Atena, voltada para o Ocidente, começou a cuspir sangue; por conta disso, segundo Dio Cássio, Augusto desapropriou Atenas de Egina e Eritréia, e proibiu os atenienses de venderem sua cidadania (54.7.2-3; Hoff, 1989, pp. 267-269). Após isso, partiu para a Síria e a Armênia onde efetuou negociações com Fraates IV, rei da Pártia desde 37, que havia vencido Antônio em 35 e que detinha prisioneiros e insígnias romanas desde a derrota de Crasso em 53. A negociação resultou no retorno dos prisioneiros e insígnias para Roma, a garantia de não intervenção romana nos conflitos dinástico partos, e a consolidação da Armênia como reino cliente de Roma (Gruen, 1996, pp. 158-160). Augusto retorna para Roma em 19, após passar o inverno de 20/19 em Samos; antes, faz uma terceira visita em Atenas, quando novamente participa das celebrações dos mistérios de Elêusis, e, muito provavelmente, é homenageado em Atenas com a dedicação do monóptero e com a instituição da comemoração de seu aniversário (do dia 12 do mês Boedromion) com o 
estatuto de jogos "isopíticos" (IG II2 1071; Schmalz, 2009, pp. 17-18), em referência ao festival anual do "aniversário" de Apolo cinco dias antes (7 Boedromion).

A ligação entre o monóptero e a missão pártica é reforçada pela representação do

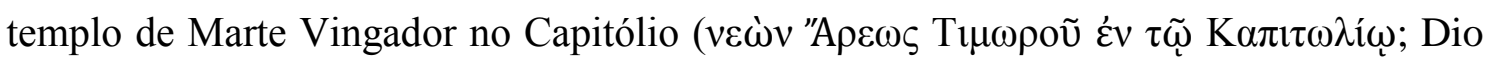
Cássio, 54.8.3), que o Senado romano havia decidido construir para abrigar as insígnias retornadas (projeto, entretanto, abandonado), em algumas emissões provinciais. É o caso, por exemplo, do cistóforo de prata de Pérgamo e do denário emitido na Espanha, ambos datados de 19/8 (figs. 106 e 107). A variação na iconografia diz respeito, nos dois casos, à direção do busto de Augusto, na inscrição e nos objetos abrigados pelo templo, ora uma estátua de Ares segurando um bastão encimado pela águia romana, ora um troféu com coroas e outros objetos. A natureza circular do templo é confirmada pela figuração ovalada da cobertura, contrastante com a figuração habitual de templos retangulares, que destacam o frontão triangular ${ }^{265}$. A semelhança com o monóptero é mais evidente quando se nota, no detalhe, a figuração de capitéis jônicos nas colunas dos dois exemplos. Uma hipótese interessante seria de que o monóptero funcionasse, em relação ao culto imperial, como uma espécie de tesouro de eventuais relíquias da "vitória diplomática", sendo deste modo um paralelo tanto ao Erechtheion quanto ao (projetado) templo de Marte no Capitólio, o qual, no projeto senatorial, seria um duplo augustano do templo de Jupiter Feretrius, dedicado pelo próprio Rômulo para abrigar os espólios da vitória sobre Acron, rei dos gênicos (Tito Lívio, 1.10.5-6). A ausência de qualquer vestígio de tal uso, entretanto, impede qualquer conclusão ${ }^{266}$.

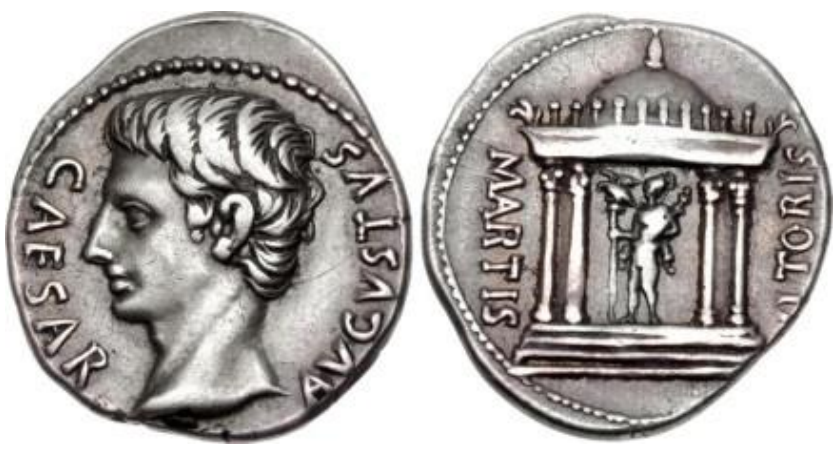

Figura 106. Espanha (Caesaraugusta?), c. 19/8, denário. Anverso: Busto de Augusto voltado para a esquerda, com a inscrição “CAESAR AVGVSTVS”. Reverso: Templo circular abrigando

\footnotetext{
${ }^{265}$ Por exemplo, algumas emissões de Caesaraugusta de 19/8 com a figuração do templo de Jupiter no reverso: RIC I 63a, 63b, 64, 65, 66 e 67.

${ }^{266}$ Uma hipótese a ser desenvolvida é aquela sugerida por P. Baldassarri (1995, p. 80, e 1998, p. 57, com maiores ressalvas), segundo a qual a função "expositiva" do monóptero encontraria no monóptero de Afrodite de Cnido um paralelo eloquente, na medida em que, caso o monóptero fosse uma citação daquele de Cnido, isto seria coerente com a associação entre Afrodite e Vênus, central na mitologia dinástia da gens Júlia.
} 
estátua de Marte segurando insígnias romanas e bastão com águia, com a inscrição "MARTIS VLTORIS”. Referência: Roman Imperial Coinage, I, 39b. Fonte da imagem: CNG ${ }^{267}$.
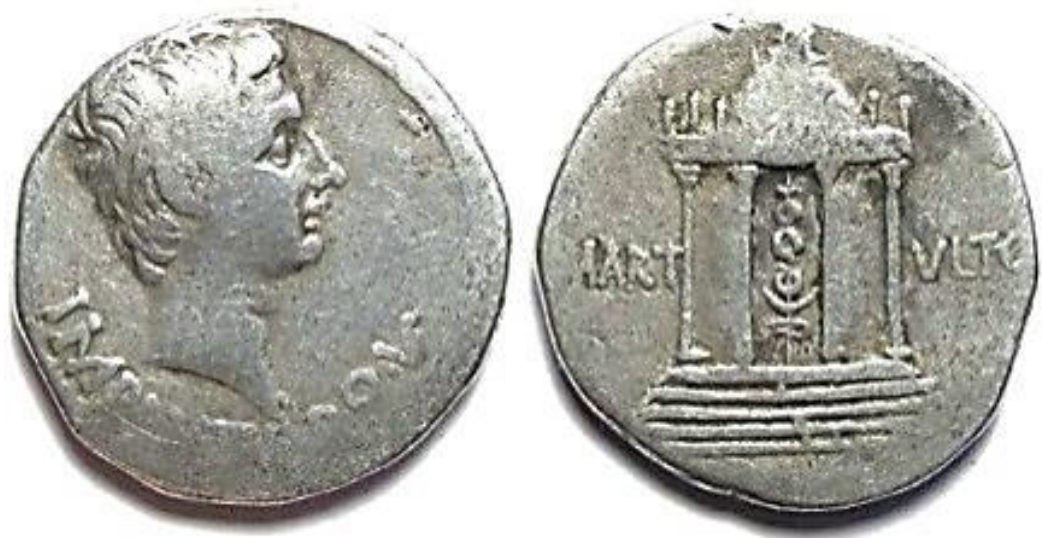

Figura 107. Pérgamo, c. 19/8, cistóforo de prata. Anverso: busto de Augusto voltado para a direita, com a inscrição "IMP[ERATOR] IX TR[IBUNICIA] PO[TESTATE] V". Reverso: templo circular de Marte Ultor abrigando insígnia, com a inscrição "MART VLTO". Referência: Roman Imperial Coinage, I, 507. Fonte da imagem: Calgary Coins ${ }^{270}$.

A miríade de referências arquiteturais no monóptero levanta o problema da iniciativa, do financiamento e da mão de obra do edifício. A arquitrave informa: o demos dedica à deusa Roma e a Augusto. Mas quem é o demos, neste caso? Era habitual a decisão de dedicar monumentos honoríficos a evergetas estrangeiros partir da Assembléia, mas não há qualquer vestígio ou notícia de um decreto formal. A referência aos três personagens locais na inscrição - Megiste de Halai, Areios de Peânia e Pamenes de Maratona - foge da formula tradicional de datação por meio do arconte epônimo, que só é mencionado no final. Isto pode indicar que a iniciativa tenha partido justamente destes três personagens, sendo a referência ao demos uma indicação mais da anuência do que da iniciativa. Já foram discutidas as relações dos dois primeiros, Megiste e Areios, com os cultos atenienses e com o culto a Roma; tratemos agora de Pamenes de Maratona.

Assim como os outros dois, Pamenes fazia parte de um dos mais importantes gene de Atenas: os Gephyraioi, que segundo Heródoto eram fenícios que vieram junto de Cadmos - o inventor do alfabeto - para a Beócia (5.57) e, segundo outra tradição, haviam sido guiados para a Ática pela própria Deméter (Etymologikon Mega, 180.34, s.v. `A $\chi \alpha 1 \alpha$ ), e que tinham entre seus membros mais ilustres os tiranicidas Harmodios e

\footnotetext{
${ }^{267}$ Disponível em: http://www.cngcoins.com/Coin.aspx?CoinID=216124
}

${ }^{270}$ Disponível em: http://www.calgarycoin.com/roman/4446Lg.jpg 
Aristogiton $^{271}$. Além dos Gephyrarioi, Pamenes faz parte de um clã délio, o dos Erysichthonidai, a cujo ancestral mítico, Erysichthon, filho de Cécrops e Aglauros, era atribuída a introdução do culto a Apolo em Delos (Mavrojannis, 1995, p. 90; Parker, 1996, pp. 289-90). A família de Pamenes aparece nos vestígios desde meados do século II, sempre com proeminência na vida política ateniense e délia: seu bisavô havia sido epimeleta de Delos no final do século II, seu avô, arconte epônimo em 83/2, e seu pai, sacerdote vitalício de Apolo Délio, epimeleta de Delos e arconte epônimo em 54/2 272 . Pamenes seguiria a tradição familiar tornando-se, entre o final da década de 30 e início da de 20, agoranomos (IG II $^{2}$ 3493), em meados da década de 20 arconte epônimo (SEG 47.196b), general hoplitas provavelmente entre 20 e 18 (IG II ${ }^{2} 3173$ ) e na mesma época ginasiarca de Delos (ID 1956), e em 16/14 se torna sacerdote vitalício de Apolo Délio (ID 1592-1594, 2515-1519). Nesta função, Pamenes será o responsável pelo culto à família imperial, incluindo Agripa e Júlia (Schmalz, 2009, pp. 297-298). A associação de Pamenes a Apolo, o que certamente facilitou seu contato com Augusto - vale lembrar que o princeps seria chamado de "novo Apolo" em Atenas (SEG 29.167), e seu aniversário seria comemorado em conjunção ao festival ao deus (IG II ${ }^{2} 1071$ ) - partia não apenas do fato de ser filho do sacerdote vitalício de Apolo Délio; como membro dos Gephyraioi, já havia sido enviado para uma consulta ao oráculo de Delfos (SEG 30.85). A participação na dedicação da primeira intervenção associada diretamente ao culto imperial em Atenas, portanto, pode ser interpretada como uma etapa fundamental na ocupação de uma posição de destaque no quadro do culto imperial em Atenas; a própria associação entre Augusto e Apolo em Atenas, replicando aquela já consolidada em Roma $^{273}$, pois, pode ser interpretada em conjunção com a ascensão de Pamenes em Atenas e Delos.

Quanto à mão-de-obra, a presença do fragmento de cornija do Erechtheion na fundação ao leste do Pártenon fez com que os estudiosos associassem a reforma do Erechtheion e a construção do monóptero; na medida em que o monóptero havia sido construído no final dos anos 20, o Erechtheion, que eventualmente fora danificado na invasão de Sula em 86, faria parte do mesmo projeto. As técnicas "romanas" da reforma do Erechtheion - em particular os grampos em "pi” para a fixação dos blocos entre si -

\footnotetext{
${ }^{271}$ A fama dos tiranicidas não apenas em Atenas, mas também em Roma, certamente não passaria desapercebida na época de Augusto (Spawforth, 2012, 155-156).

${ }^{272}$ Sobre a família de Pamenes, cf. Geagan (1992), Mavrojannis (1995, p. 89) e Schmalz (2009, pp. 297 8).

${ }^{273}$ Tendo no templo de Apolo Palatino sua mais clara evidência. Cf. Hoff (1992), Mavrojannis (1995), e Hekster e Rich (2006).
} 
e o acabamento incompleto ou pouco sofisticado da ornamentação do monóptero foram interpretadas como indício de que se tratava do mesmo grupos de artesãos e do mesmo arquiteto: Dorpfeld chegou a atribuir as duas obras a Diogenes de Atenas, escultor que seria contratado por Agripa para a ornamentação do Panteão no Campo de Marte em Roma (Dorpfeld, 1903, p. 466; Schmalz, 1995, pp. 16-17). No entanto, considerando os fortes argumentos de A. Lesk para a datação da reforma do Erechtheion no século II, quando já eram conhecidas e utilizadas as técnicas consideradas como "romanas" - em particular nas intervenções pergamenas - não faz sentido sustentar a existência de um arquiteto para ambos os projetos. O uso do mármore local e os problemas de acabamento tanto da fundação - onde os blocos apresentam algumas lacunas - quanto da superestrutura, além das dimensões reduzidas do edifício, podem indicar tanto a iniciativa quanto o financiamento local, no qual participariam ativamente os personagens mencionados na dedicação. Um contexto plausível seria a dedicação do monóptero durante a expectativa da passagem de Augusto em Atenas, e em particular no período em que, já no retorno a Roma, o imperador permaneceu em Samos; as sanções aos atenienses em sua primeira passagem, em 21, justificariam uma nova invectiva para reforçar os laços evergéticos da cidade (e sua elite) com Augusto.

Este reforço, é importante destacar, não se faz em uma página em branco: as citações arquiteturais e cultuais ao Erechtheion e aos cultos mais antigos da cidade, relacionando-os ao culto à deusa Roma e a Augusto - resolvendo assim as ambiguidades do culto ao soberano que não se voltava a uma pessoa, mas a uma instituição, Roma, no período republicano - se fazem no contexto bastante específico da nova etapa da propaganda civilizatória augustana. De fato, durante a guerra triunviral, (o então chamado) Otávio reforçou a oposição entre um Antônio orientalizado e feminilizado por oposição a Roma e suas tradições (Spawforth, 2012, pp. 16-24); após a "vitória diplomática" de 21, Augusto poderia inserir-se mais completamente na grande narrativa do conflito da civilização contra a barbárie, no qual os partos ocupavam o lugar, no imaginário greco-romano (para além das próprias invectivas partas sobre o legado Aquemênida; cf. Curtis, 2007), a posição que os persas ocuparam no imaginário grego no período clássico e helenístico, e que seria profusamente utilizado em Roma nos anos seguintes do principado de Augusto $^{274}$ (Rose, 2005; fig. 108, com a figuração

\footnotetext{
${ }^{274}$ Pausânias (1.18.8) faz referência a um monumento composto por estátuas de persas em mármore frígio que sustentam um trípode de bronze, que estaria localizado diante da estátua de Isócrates no recinto do Olympieion. Alguns estudiosos procuraram associar a dedicação deste monumento à passagem de
} 
de um parta entregando o estandarte romano a um personagem com couraça romana). A dedicação de um monóptero na acrópole ateniense que funcionasse, justamente, como marco para esta nova orientação anti-bárbara e pan-helênica, é mais relevante ainda quando se leva em consideração que há menos de 20 anos antes Antônio era celebrado na acrópole de Atenas com a rededicação de um dos pilares pergamenos; Augusto se torna então Soter, "Salvador", recuperando assim um epíteto utilizado por generais romanos e, antes deles, pelos reis helenísticos em seus conflitos contra inimigos classificados como bárbaros.

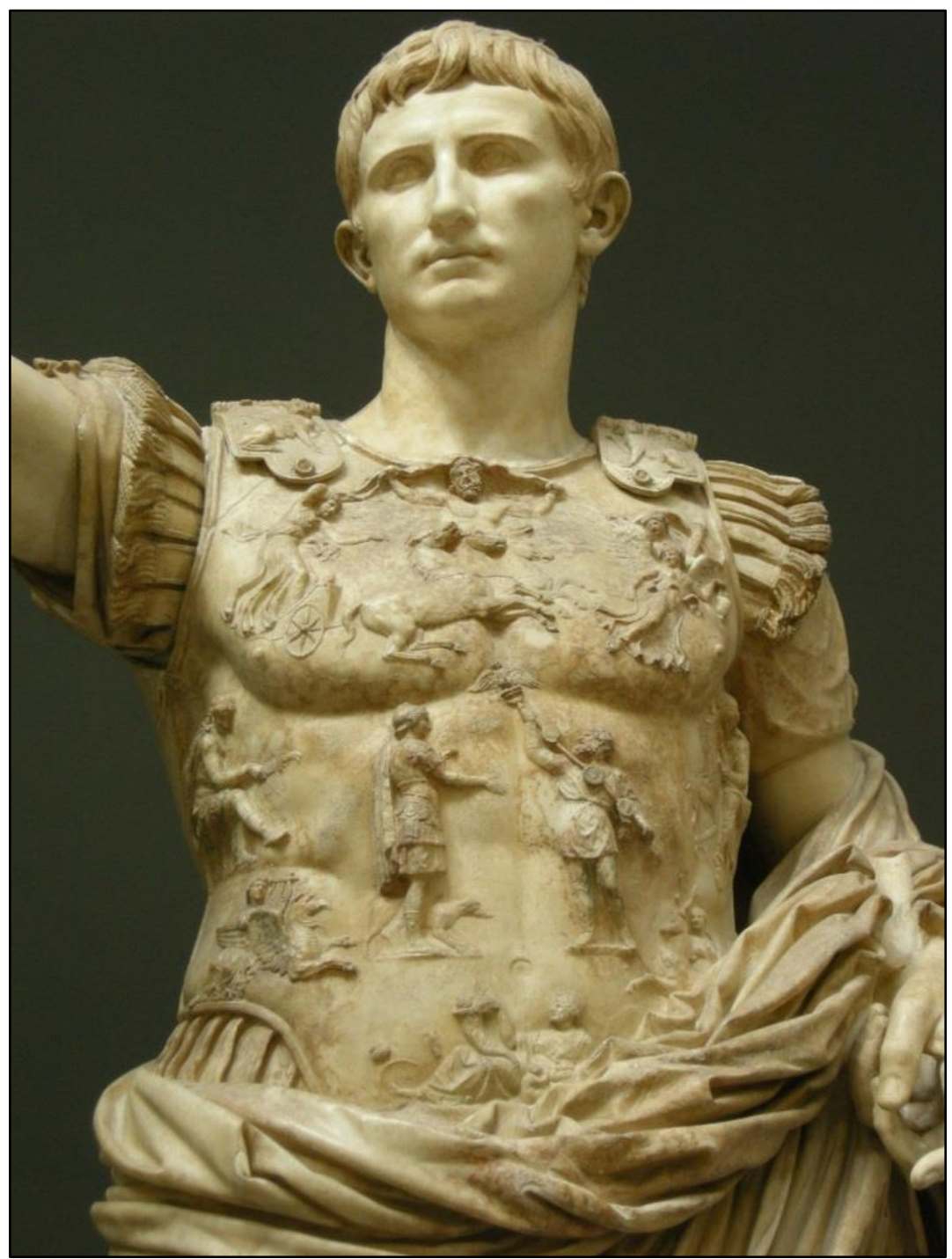

Figura 108. Fotografia da estátua em mármore de Augusto de Prima Porta, c. 20, hoje no Museu do Vaticano, tirada por Sailko em 2010 (Wikipedia Commons ${ }^{275}$ ).

Augusto por Atenas em 19, assim como à dedicação de um monumento paralelo no Palatino, do qual teriam sobrevivido os fragmentos de persas hoje expostos na Domus Augustana. A brevidade da descrição de Pausânias, no entanto, torna bastante insegura tal reconstrução. Cf. Baldassarri (1995, p. 79), com bibliografia anterior.

${ }^{275}$ Disponível em:

http://commons.wikimedia.org/wiki/File:Augusto_di_pirma_porta,_inv._2290,_02.JPG 
Neste sentido, é particularmente eloquente a posição do monóptero em relação ao Pártenon. Schmalz percebeu que não apenas o monóptero - caso a atribuição da fundação esteja correta - está posicionado no eixo longitudinal do Pártenon, como também dialoga com algumas das proporções deste último (fig. 109): a largura do Pártenon é igual à distância máxima entre ele e o monóptero (33,7 metros), a largura da cela é igual à distância mínima (21,7 metros), e a distância entre o centro do Pártenon e o centro do monóptero é igual ao comprimento da cela do Pártenon (59 metros).

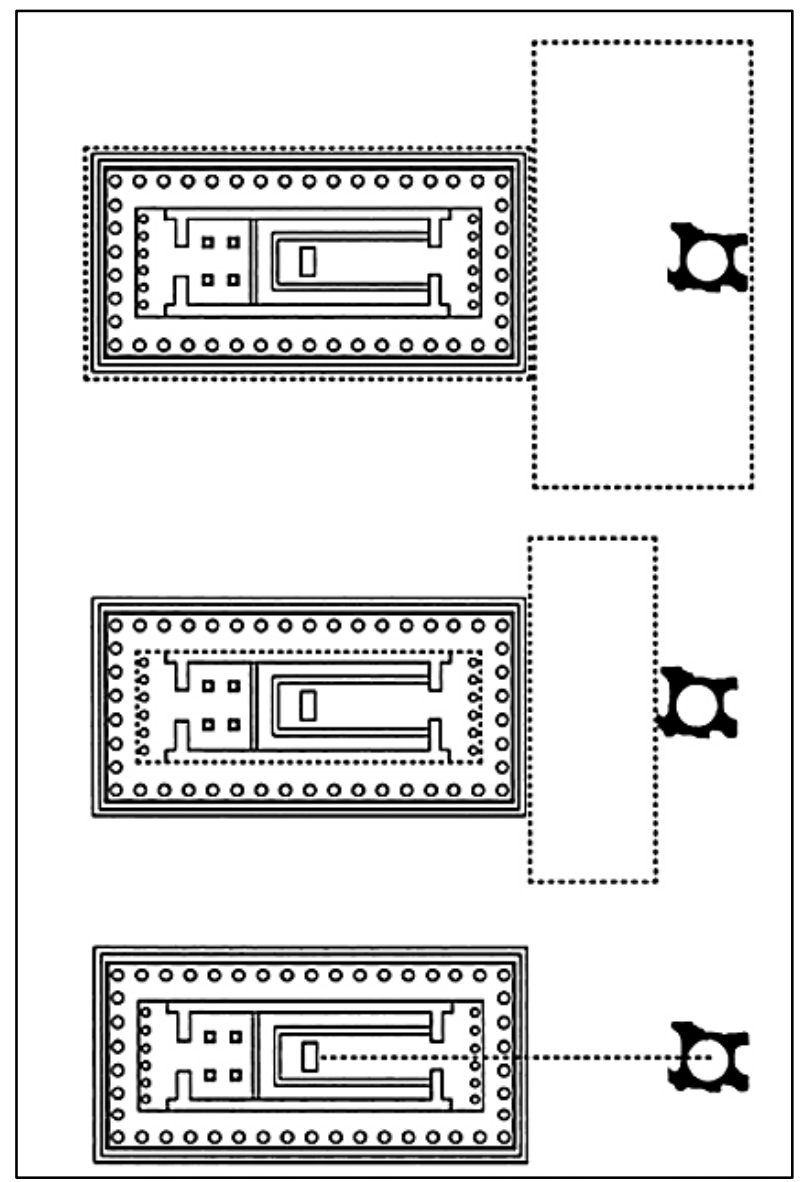

Figura 109. Representação das relações métricas entre o Pártenon e o monóptero, segundo G. Schmalz (1995, p. 256, fig. 2).

A ligação entre o monóptero e o Pártenon, caso esteja correta tanto sua situação pelos arqueólogos quanto a associação entre sua dedicação e a missão diplomática de Augusto na Pártia, tem nas relações métricas um paralelo espacial para a introdução de Augusto e de Roma na grande narrativa mítica da oposição entre a civilização e a bárbarie, que tem no templo clássico sua principal manifestação. Este empréstimo 
narrativo, por sua vez, se insere na já longa tradição de apropriação da narrativa por parte dos monarcas estrangeiros: Augusto ocupa um lugar antes ocupado por Alexandre - com os 300 escudos persas doados a Atenas - e, principalmente, Átalo I e sua dedicação junto ao muro sul da acrópole, cujo impacto na composição da paisagem visual deveria ser extremamente importante. A citação do Erechtheion no monóptero, caso ele tenha sido realmente reformado a partir da iniciativa pergamena, torna o paralelo ainda mais claro. Na mesma direção, vale lembrar que o espelhamento entre a área leste da acrópole de Atenas e o santuário de Atena Nikephoros em Pérgamo, já iniciado no século II com a colocação da Dedicação Atálida junto ao muro sul, é ainda mais reforçado pela construção do monóptero, paralelo ateniense do monumento circular pergameno (figs. 110-111); a existência de um templo de Roma e Augusto em Pérgamo, dedicado já em 29 e que será o foco do culto imperial da província romana da Ásia - em particular durante a celebração dos Romaia Sebasta (Mellor, 1975, p. 81) demonstra a importância que Pérgamo terá na mediação dos contatos entre Roma e Atenas, e que será discutida ao final do capítulo.

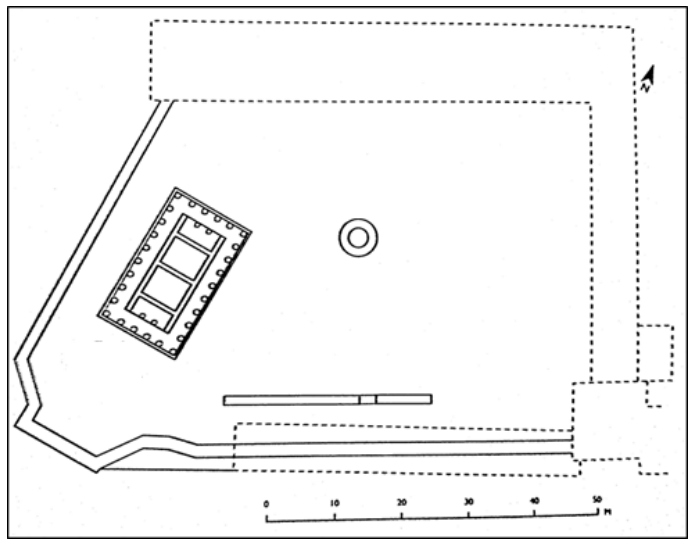

Figura 110. Proposta de reconstituição da disposição dos edifícios e monumentos do santuário de Atena Nikephoros em Pérgamo no início do século II, por Erin Dintino, com base na proposta de $\mathrm{A}$. Stewart (2004, p. 197, fig. 229).

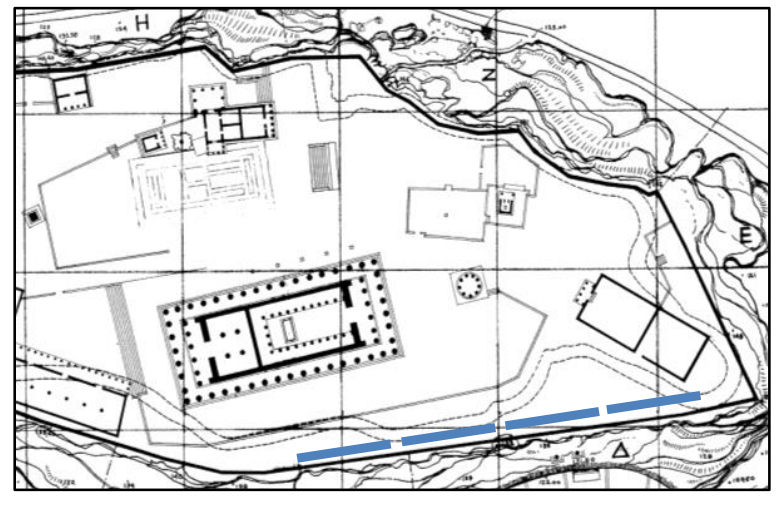

Figura 111. Detalhe da proposta de reconstituição da planta da acrópole ateniense, segundo J. Travlos em 1971 [com a adição das bases da Dedicação Atálida, de acordo com a proposta de Stewart e Korres]. (ASCSA ${ }^{276}$ ).

Uma questão complexa envolve a relação do monóptero com duas das mais importantes procissões que tomavam a acrópole, a saber, a última de cada ano - a

\footnotetext{
${ }^{276}$ Disponível em: http://agora.ascsa.net/id/agora/image/2002.01.2201
} 
Dipolieia, no dia 14 Skyphorion - e a que encerrava o principal festival da cidade, a procissão panatenaica. O trajeto da primeira revertia o caminho percorrido por um festival realizado dois dias antes, a Skyraphoria: liderada pelos sacerdotes de Atena Políade e de Poseidon-Erechtheus - ambos oriundos da família dos Eteobutadais, descendentes de Pandion, portanto - esta procissão partia do Erechtheion na acrópole e seguia até um local chamado de Skyra, no meio do caminho entre Atenas e Elêusis; dois dias depois, a procissão da Dipolieia, liderada por um sacerdote do genos dos Kerykes (uma das famílias encarregadas dos mistérios eleusinos), partia de Skyra para a acrópole, terminando com o sacrifício de um touro no santuário de Zeus Políade. A segunda, que encerrava a cada ano as Panatenéia e a cada cinco anos as Grandes Panatenéias, partia do Pompeion junto ao Dípilo para terminar na acrópole, tendo como referência o Erechtheion, onde provavelmente a estátua de Atena Políade receberia o novo peplos e o altar de Atena Políade, onde ocorreria o grande sacrifício (Shear, 2001, pp. 167-186; Lesk, 2004, pp. 138-142; Gerding, 2006, pp. 399-400). Em ambos os casos, o foco dos rituais realizados ao final das procissões era a área norte da acrópole, limitada pelo Erechtheion ao norte, o Parthenon ao sul, a estátua de Atena Promachos ao oeste e o santuário de Zeus Políade ao leste. Dificilmente as atividades relacionadas às procissões se estendessem à área sudeste da acrópole, ainda que já foi sugerido que o peplos seria dedicado no Pártenon, hipótese que não conquistou consenso (Burden, 1999, p. 218). Se este era o caso, a área sudeste da acrópole se opunha à área norte: enquanto a apropriação desta se articulava a atividades executadas por grandes multidões, a apropriação daquela se dava, provavelmente, por meio da articulação visual dos monumentos e santuários que "irradiavam" do monóptero (Thakur, 2007, p . 115).

Ao redor do monóptero estavam localizados o Pártenon, cujo eixo estruturava a posição do monóptero, mas também a longa Dedicação Atálida ao sul, o chamado "Edifício IV", ao leste, e o santuário de Zeus Polieus, ao norte. O "edifício IV", construído em meados do século $\mathrm{V}$, foi identificado por alguns como uma espécie de oficina, mas hoje há um consenso de que se tratava do santuário de Pandion, rei de Atenas, filho de Erichtonios e pai de Erechtheus e Butes (Hurwitt, 1999, p. 188-189; Barringer, 2005, p. 169 e p. 175, n. 46). O santuário de Zeus Políade, construído no início do século $\mathrm{V}$, santuário central no calendário religioso ateniense a partir do festival da Dipolieia, que unificava as tensões fundacionais entre Elêusis e Atenas. A posição do monóptero entre santuários tão intimamente ligados à identidade políade - culto aos reis ancestrais e aos deuses políades, Zeus e Atena, comemoração anti-bárbara - aponta para 
o modo como o culto imperial seria interpretado nos termos da religião tradicional: Augusto, se por um lado era incorporado aos generais conquistadores dos bárbaros como Miltíades, Alexandre e Átalo I, por outro era associado aos deuses protetores da cidade (Atena e Zeus ${ }^{277}$ ) e aos reis fundadores: o que era Augusto, se não um rei digno de culto (Thakur, 2007, p. 114)? Absorvido pela tradição local, o monóptero, no processo de interpretação local da nova realidade religiosa e política do Mediterrâneo, absorvia a topografia sagrada da acrópole, reforçando, por um lado, a presença imperial na cidade, e por outro, a hegemonia dos clãs associados tanto aos cultos ancestrais quanto ao culto imperial. As novas listas de membros de clãs (IG II $^{2}$ 2338) e a restauração dos santuários e suas propriedades fundiárias (IG II $\left.^{2} 1035\right)$ da época augustana são alguns dos pontos de amarração da rearticulação da sociedade ateniense neste novo contexto, que tem na produção do espaço uma de suas arenas mais movimentadas. Novas intervenções urbanas como o monóptero, que alterarão radicalmente a paisagem ateniense, são, pois, vestígios materiais das ofensivas - e eventuais vitórias - de determinados grupos sobre o espaço em um novo momento da luta de classes.

\section{Reforma do Asklepeion}

$\mathrm{Na}$ encosta meridional da acrópole ocorrerá, na época augustana, uma retomada da atividade construtiva no Asklepieion: um fragmento de uma arquitrave jônica, contem a inscrição dedicatória, onde se lê:

[A Asclépio], Higéia e Augusto César [...] / [...] sob o arcontado e sacerdócio do cônsul Druso de Polikharmo, filho de Policrito, de Azênia / sendo sacerdote vitalício Zenon, filho de Leukios, de Ramnonte (IG II2 3120).

J. Travlos (1980, p. 128), no que é seguido por P. Baldassarri (1994, p. 67, n. 16), identifica a arquitrave como parte de um propileu do santuário, possivelmente situado na entrada sudoeste. Já S. Walker (1979, p. 243) e G. Schmalz (1994, p. 55)

\footnotetext{
${ }^{277}$ A associação entre Augusto e Atena será reforçada na dedicação do propileu da chamada "Ágora Roma", enquanto que sua associação a Zeus aparece na stoa de Zeus na ágora o no Olympieion na área leste da cidade.
} 
identificam-na como parte da stoa localizada ao sul do templo de Asclépio e Higeia, ainda pouco escavada e sem indicações de datação. A hipótese de que a arquitrave pertença à stoa parece mais plausível, dada a restauração de um propileu realizada poucas décadas antes. No entanto, a falta de um estudo aprofundado dos vestígios escavados, assim como de uma escavação mais completa, torna impossível uma identificação precisa: P. Baldassarri sugere que a stoa ao sul do templo data de época tiberiana, mas não há ainda elementos suficientes para tanto ${ }^{279}$.

A localização da inscrição na arquitrave é paralela à do monóptero, discutido acima. A datação augustana da dedicação é fortemente sugerida tanto pelo uso de "Augusto" como prenome - diferenciando-se dos usos comuns a outros imperadores quanto pela referência ao sacerdócio de Druso, associado ao arcontado epônimo a partir da morte deste, o que permite afirmar que a dedicação foi realizada em algum momento entre 9 a.C. e 14 d.C. O arconte mencionado, Policarmo de Azênia (Schmalz, 2009, pp. 301-302), era membro do genos dos Eumólpidas, um dos clãs responsáveis pelos

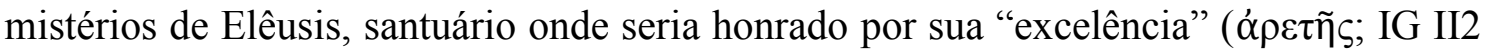
3904); seu pai é conhecido como um dos sacerdotes principais ao menos da Dodekais procissão ateniense a Delfos - de 26 (Schmalz, 2009, p. 303). A relação do arconte e de sua família tanto com os cultos eleusinos quanto com o Apolo pode ser um indicador da ligação com Augusto.

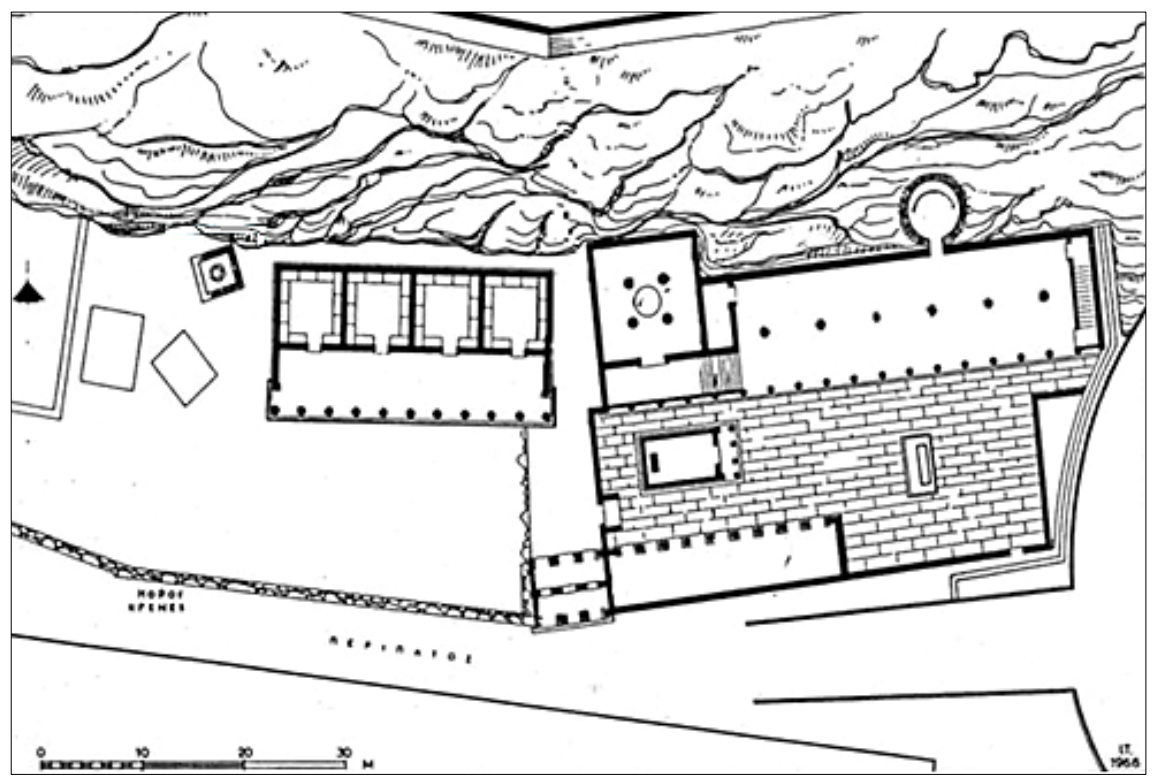

Figura 112. Proposta de reconstituição de planta do Asklepieion, segundo J. Travlos em 1966 (Travlos, 1971, p. 129, fig. 171).

\footnotetext{
${ }^{279}$ No caso da hipótese de Travlos e Baldassarri estiver correta, a reconstituição de um propileu tetrastilo jônico ou coríntio o faria paralelo ao novo propileu do Tholos, na ágora, na época augustana.
} 
A referência ao sacerdócio vitalício de Asclépio é uma das inovações do sistema religioso ateniense, que tem paralelo em outros sacerdócios, como o de Pamenes de Maratona, sacerdote vitalício de Apolo Délio. Zenon de Ramnonte só é conhecido por inscrições encontradas no Asklepieion, e não se sabe de qual genos fazia parte; seu pai, Leukios, possivelmente foi arconte em meados do século I, mas a datação das inscrições que mencionam um arconte Leukios não é segura (Schmalz, 2009, p. 318). O fato de ter assumido o sacerdócio vitalício de Asclépio implica que seja membro da elite ateniense, dados os gastos envolvidos na manutenção das atividades terapêuticas do santuário; a própria transformação do sacerdócio anual em vitalício pode estar associada à dificuldade, em virtude dos custos, do recrutamento de sacerdotes.

O fato de que ao lado de Asclépio e Higéia figura Augusto como homenageado poderia sugerir a proximidade do sacerdote com a família imperial ou da participação de Augusto no financiamento da intervenção (Baldassarri, 1998, p. 71), o que, se por um lado seria coerente com a recorrente associação de membros da família imperial às divindades terapêuticas, tanto em Atenas como em Roma, por outro não é garantia de que a dedicação não se tratasse apenas de uma manifestação pública da lealdade de um membro da elite ateniense ao principado. A inexistência de referências a outros cargos ocupados por Zenon pode sugerir que sua associação a Augusto, seja no nível das relações pessoais, seja no nível apenas da dedicação, era um importante meio para sua inserção nos círculos da elite ateniense mais próximos do imperador - e consequentemente do topo do poder político e social ateniense.

Esta associação é reiterada em um monumento dedicado no santuário de Asclépio pelo mesmo sacerdote, como indica outra inscrição encontrada do santuário, e bastante semelhante à dedicação na arquitrave ${ }^{280}$. A inscrição foi realizada sobre uma outra, apagada, com orientação diversa daquela augustana: enquanto o bloco na época augustana foi inscrito horizontamente, no monumento anterior foi inscrito verticalmente, como ortostatos, o que é indicado pela preservação, na inscrição parcialmente apagada, de apenas fragmentos de nomes, com ductus típico do período helenístico (Baldassarri, 1998, p. 70, n. 28). Outra inscrição (IG II ${ }^{2}$ 3447), proveniente do Asklepieion, menciona uma dedicação do demos ateniense ao "demos dos

${ }^{280}$ IG II 2 3176: "A Asclépio, Higéia e Augusto, sob o arcontado / e sacerdócio do cônsul Druso de Demokhares de Azênia / sendo sacerdote vitalício Zenon de Ramnonte". 
romanos"281; sua datação é obscura, mas provavelmente se refere ao período entre $182 \mathrm{e}$ o fim do século I, quando são atestadas dedicações ao "povo romano" como evergeta em diversos locais da Grécia (Erskine, 1994; Baldassarri, 1998, p. 71, n. 29). A presença de inscrições citando diretamente o imperador torna plausível que este monumento houvesse sido dedicado antes do principado. $\mathrm{O}$ estado fragmentário dos blocos onde estas inscrições foram feitas, assim como incertezas relativas a sua história posterior, impedem uma determinação precisa da forma original do bloco da dedicação a Augusto, do bloco com a dedicação ao povo romano, e mesmo sua datação no período helenístico conta com evidências frágeis. É possível afirmar, não obstante, que o sacerdote Zenon de Ramnonte transforma, em algum momento da virada do século, o santuário de Asclépio em um espaço de exposição de sua fidelidade à família imperial, atualizando, possivelmente, uma tradição anterior materializada na dedicação ao povo romano.

\section{O santuário de Apolo Hypoakraios}

$\mathrm{Na}$ encosta norte da acrópole, uma das cavernas foi identificada o santuário de Apolo Hypoakraios: os nichos nas paredes serviam como suporte para as placas votivas encontradas nas escavações no século XIX. A datação da criação do santuário foi tradicionalmente atribuída ao século VI, com base na associação entre este santuário e o santuário de Apolo Pítio, situado próximo ao Olympieion. Em um recente estudo, P. Nulton (2003) argumentou que os dois santuários eram independentes, e que o culto de Apolo Hypoakraios, mencionado apenas nas placas votivas (produzidas a partir do século I d.C.) e em Pausânias, era uma criação da época imperial ${ }^{282}$. Para o autor, Apolo Hypoakraios associava-se a Apolo Patroos com base nas referências às grandes rochas na peça Ion (v. 1400) de Eurípides e em algumas placas votivas de época imperial, representado como o pai dos ancestrais dos jônios; a criação de um santuário de Apolo na acrópole, pois, seria quase uma “cópia em carbono" (Nulton, 2003, p. 27) do santuário de Apolo Patroos na ágora.

Partindo da hipótese de que o santuário foi criado na época imperial, Nulton retoma a conhecida relação entre Augusto e Apolo (Hoff, 1992). Além de ter construído

\footnotetext{
${ }^{281}$ IG II2 3447: “do demos dos atenienses ao demos dos romanos por conta de benfeitorias".

${ }^{282}$ Sobre a longa controvérsia acerca de uma duplicação ou não dos santuários de Apolo Pítio e Zeus Olímpio na acrópole, cf. Nulton (2003, pp. 15-23), com bibliografia precedente.
} 
um templo de Apolo intimamente associado a sua própria casa no Palatino, circulava em Roma a história de que Otávio havia sido concebido em uma união de sua mãe com o deus (Suetônio, Augusto, 94.4; Dio Cássio, 45.2-3): Apolo seria pai de Augusto assim como era pai de Ion, na versão de Eurípides. Em Atenas, a associação é reforçada pela assimilação de Augusto como "Novo Apolo" em uma base de estátua (PepasDelmousou, 1979), além de um molde de bronze representando Apolo com a inscrição "kaisar" (Hoff, 1992, pl. 1); na retomada das procissões para Delfos - as Dodekais - na época de Augusto; e, finalmente, a comemoração do aniversário de Augusto, provavelmente associado ao festival do aniversário de Apolo seis dias antes $\left(\mathrm{IG} \mathrm{II}^{2}\right.$ 1071). Isto tudo apontaria para uma datação augustana da criação do santuário de Apolo na acrópole ${ }^{283}$.

Tal hipótese é atraente, mas deve ser considerada com ressalvas. Em primeiro lugar, sucessores de Augusto também foram associados, direta ou indiretamente, a Apolo: Tibério aparece associado a Apolo Patroos em uma dedicação de Elêusis (IG II ${ }^{2}$ 2906), assim como Calígula e Cláudio na ágora (respectivamente, SEG 34.182 e IG II ${ }^{2}$ 3274); Nero é chamado de "Novo Apolo" em um altar sem localização definida (IG II ${ }^{2}$ 3278). Em segundo lugar, a placa votiva mais antiga encontrada nas escavações do santuário na acrópole é datável, com base prosopográfica, do principado de Tibério, e não de Augusto (Nulton, 2003, cat. 2). De qualquer modo, associação entre Apolo e os sucessores de Augusto faria mais sentido se o discurso que ligada Apolo à família imperial tivesse tido início ainda sob influência de Augusto, considerando o investimento deste nesta associação desde o início da década de 30. Desse modo, Augusto estaria presente no topo (monóptero) e nas encostas de ambos os lados da acrópole: tanto aquele voltado para o teatro de Dioniso e para o sul da cidade (Asklepieion), quanto aquele voltado para a ágora (Hypakraieion), que será, justamente, um dos principais locais para o evergetismo de época augustana.

\section{A nova ágora}

A diversidade das intervenções, reforçada pela abundância de fontes derivadas das escavações americanas, fizeram com que a ágora se tornasse o foco dos estudos que

${ }^{283}$ Para as relações entre Augusto e Apolo Délio, cf. Mavrojannis (1995). 
buscaram desvendar o programa construtivo augustano em Atenas; de fato, a abundante presença de intervenções espaciais da época augustana permite afirmar que este local foi absolutamente estratégico para o estabelecimento do programa. Vejamos com detalhe cada uma das intervenções.

\section{O Agrippeion na ágora}

A presença inicial de Augusto em Atenas é impactante; a de Agripa não o será menos. O maior edifício construído no período augustano foi o Agrippeion: um enorme teatro coberto que dominaria boa parte da área sul da praça pública. $\mathrm{O}$ nome do edifício, suas referências arquiteturais e sua posição na ágora foram utilizados como elementos centrais da tese da "romanização da ágora ateniense"; o conjunto de suas características também pode levar à interpretação oposta, da "resistência". Aqui, o edifício será analisado a partir dos diferentes diálogos - arquiteturais, espaciais e funcionais estabelecidos com as tradições locais e mediterrânicas; mais do que apontar para uma ou outra interpretação, a complexidade está em, justamente, demonstrar a integração entre elementos aparentemente contraditórios de uma intervenção bastante duradoura, considerando os mais de trezentos anos em que manteve suas características originais.

O "Odeion" da ágora mencionado por Pausânias, equivalente ao "Agrippeion" mencionado por Filostrato, foi seguramente identificado aos abundantes vestígios de um grande edifício localizado na área sul da ágora, junto à face norte da Stoa Média. Medindo 51,38 por 43,20 metros, o Agrippeion ocupava mais de dois mil e duzentos metros quadrados, o que equivalia a cerca de 1/5 da área total livre da ágora, antes da construção do templo de Ares. Na primeira fase construtiva, datada do período augustano (Thompson, 1950, pp. 37-98), tratava-se de um edifício teatral coberto composto por um corpo central, onde se localizavam o auditório semi-circular voltado para o estreito palco ao norte, e limitado ao norte por um vestíbulo (associado ao propileu ao norte) e ao sul por uma galeria, ambos de dimensões iguais, e um corpo adjacente, formado por dois andares de corredores ao longo dos lados oeste, sul e leste. A partir deste segundo andar e sobre as fundações do corpo central, se erguia um alto bloco retangular em formato de templo, rodeado por pilastras coríntias, incorporadas à 
parede externa nos lados oeste, leste e norte, e colunas plenas coríntias no lado sul, em duas sequências (no limite sul do auditório e no limite sul da galeria), criando um lado vazado que permitia a entrada da luz solar e a consequente iluminação natural do interior. Na reconstrução de Thompson, o edifício alcançava quase 30 metros de altura, sendo deste modo o mais alto da ágora (figs. 113-118).

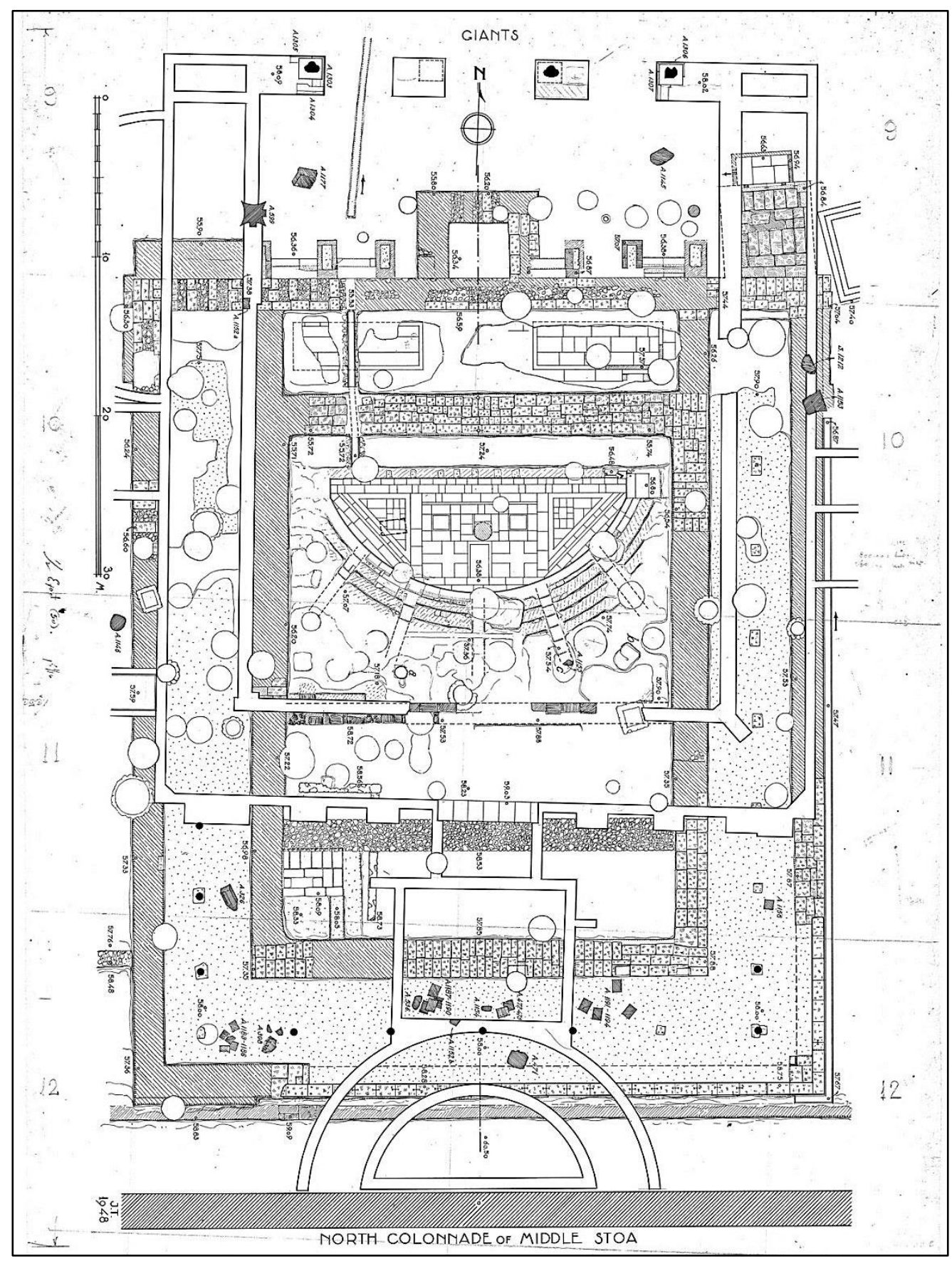

Figura 113. Planta baixa do estado atual do Agrippeion, segundo J. Travlos em 1948 (ASCSA $\left.{ }^{284}\right)$.

${ }^{284}$ Disponível em: http://agora.ascsa.net/id/agora/image/2002.01.0088. 

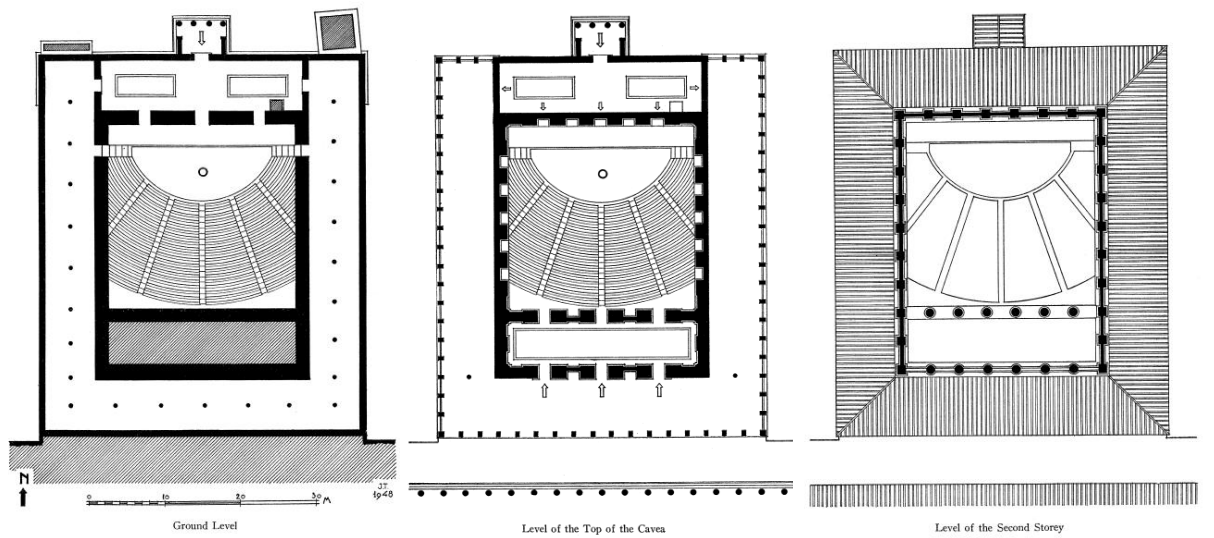

Figura 114. Reconstituição das plantas do Odeion em três níveis: da esquerda para a direita, térreo, topo da cavea e segundo andar (Thompson, 1950, pl. 17).

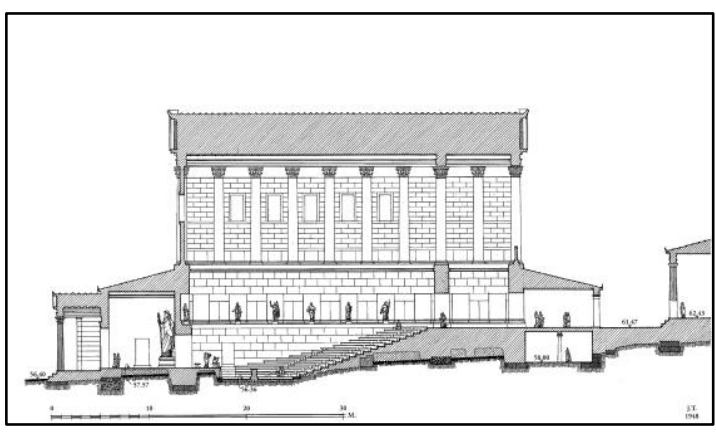

Figura 115. Reconstituição da seção norte-sul do Odeion, segundo J. Travlos em 1948 (Thompson, 1950, pl. 18).

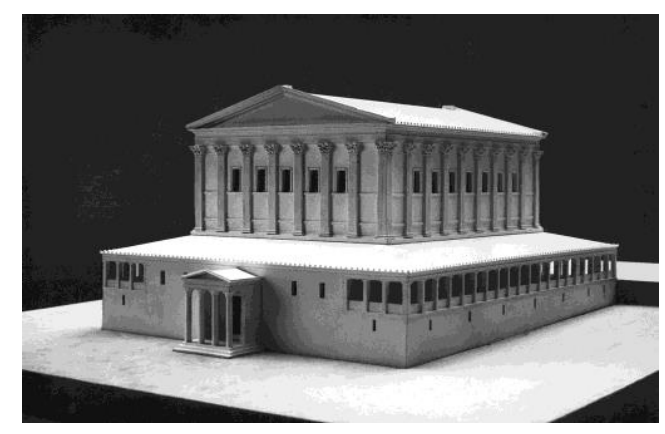

Figura 117. Maquete do Agrippeion, visto a partir do noroeste (ASCSA ) ${ }^{285}$.

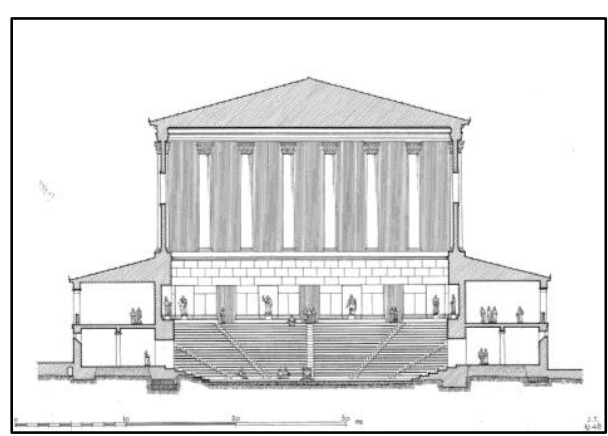

Figura 116. Reconstituição da seção lesteoeste do Agrippeion, segundo J. Travlos em 1948 (Thompson, 1950, pl. 19).

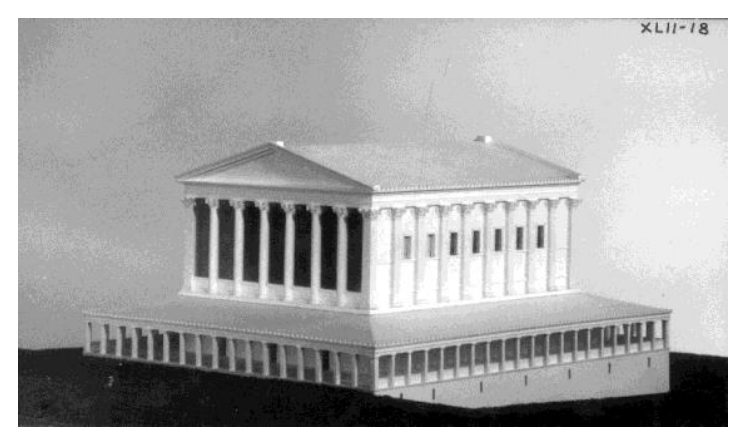

Figura 118. Maquete do Agrippeion, visto a partir do noroeste (ASCSA ${ }^{286}$ ). 
Mencionado em Pausânias apenas como “Odeion”, o edifício é referido em Filóstrato como "o Odeion chamado de Agrippeion". A partir desta referência - e de elementos ornamentais e cerâmica associada às fundações - data-se o início da construção do edifício para a época augustana, e mais especificamente durante a segunda missão para o Oriente de Agripa. O general esteve ao menos duas vezes no Mediterrâneo oriental, entre 23 e 21 como imperator proconsularis, e entre 17 e 13 com o mesmo título acrescido do maius imperium; se na primeira expedição passou a maior parte do tempo em Mitilene, com rápidas missões na Síria e em outros locais da Ásia, na segunda é provável - a partir da documentação epigráfica - que tenha permanecido algum tempo na Grécia Continental. Não há evidência direta para a cronologia exata da(s) passagem(ns) de Agripa por Atenas: apenas duas inscrições honoríficas se referem a Agripa (IG II ${ }^{2} 4122,4123$ ), e em apenas uma delas há referência ao seu terceiro consulado, em 27 (IG II ${ }^{2}$ 4122.3). A hipótese de que o Agrippeion foi construído a partir da segunda passagem de Agripa se baseia no muito maior prestígio que o general carregava consigo desta vez: se em 23 ele era o principal apoiador de Augusto e imperador do Oriente, em 17 ele já é membro da família imperial (após seu casamento com a filha de Augusto, Júlia, em 20) e pai dos sucessores de Augusto, após a adoção de seus filhos com Júlia, Caio e Lúcio César, por Augusto, em 17 (Baldassarri, 1998, p. 32). Esta hipótese é reforçada pela datação da dedicação do monóptero em c. 19: dificilmente um edifício construído por e para Agripa em Atenas antes que o próprio Augusto recebesse tal homenagem. Poder-se-ia argumentar que o Agrippeion foi dedicado a Agripa apenas em sua segunda passagem, e que se tratava de um edifício construído por iniciativa local - daí Pausânias mencioná-lo como "o teatro que chamam de Odeion" (1.8.6). No entanto, a existência de um Odeion recém reformado, o de Péricles, as variadas referências à arquitetura italiana e a bem documentada participação de Agripa em grandes projetos urbanísticos (Roddaz, 1984, pp. 231-306; Zanker, 1988, pp. 139-143) apontam fortemente para a participação do general desde o projeto do Agrippeion.

Atenas se insere em um contexto, portanto, já estabelecido na política do principado: a comemoração dos membros da família imperial incorporados como evergetas, tanto no plano da atividade construtiva, quanto no plano da disposição espacial da gratidão ao evergetismo. Agripa já estava habituado a estas relações, como é evidenciado em inscrições de diversas cidades orientais que o denominam "evergeta", 
"patrono", "fundador", "salvador" e mesmo "deus"289. Em Atenas, uma das duas inscrições referentes a Agripa é particularmente importante: trata-se da inscrição dedicatória do pilar do monumento equestre junto ao Propileu da acrópole (Baldassarri, 1998, pp. 247-249). Lê-se na inscrição:

[O de]mos [dedica] / a Marcos Agripa, / filho de Lúcio, / três vezes cônsul, / seu evergeta (IG II2 4122).

O texto da inscrição não apresenta grandes inovações: generais romanos já haviam sido homenageados como evergetas de Atenas. $\mathrm{O}$ aspecto importante desta inscrição é que ela substituiu uma inscrição mais antiga, promovendo uma nova dedicação de um monumento antigo, prática atestada em diversas cidades gregas no período imperial. A inscrição apagada dedicava o monumento equestre a Eumenes II, no início do século II, provavelmente em função de vitórias nas competições equestres em uma Grande Panatenaica (de 182 ou 178). Poderia tratar-se de um monumento já rededicado a Antônio, mas é mais provável que o monumento rededicados a Antônio se localizasse na área sudeste da acrópole - possivelmente o pilar na quina nordeste do Pártenon. A reutilização do monumento equestre atálida junto ao Propileu como monumento de agradecimento evergético a Agripa é mais significativa na medida em que não há qualquer referência à participação de Agripa em uma Grande Panatenéia, o que faz com que o monumento, originalmente ligado a uma vitória, fosse reincorporado pela sua associação ao evergetismo monárquico helenístico. Entretanto, a ambiguidade estruturante do regime augustano - monarquia/república - aparece também neste monumento: mais do que imperator/autokrator, Agripa é mencionado como "três vezes cônsul", ao mesmo tempo em que sua estátua ocuparia o lugar de uma estátua de um monarca helenístico. O "pilar de Agripa” seria, deste modo, uma manifestação material do modo como os atenienses interpretavam e se relacionavam com o caráter ambíguo de um personagem cujos poderes derivam tanto das instituições republicanas quanto dos laços dinásticos.

Voltando ao Agrippeion, é importante lembrar que ele não foi a primeira intervenção construtiva de Agripa no Oriente, ao menos se levarmos em conta o relato

${ }^{289}$ Agripa foi honrado como evergeta e patrono de cidades gregas em Tróia, Esparta, Delos, Oropos, Atenas, Corinto, Corcira e Lesbos, entre outras; é chamado de "fundador" e "salvador" em Cízico, Lesbos, Mitilene, Corcira e Mira; em Mitilene é cultuado como "deus", normalmente em associação aos outros membros da família imperial (Roddaz, 1984, pp. 442-449). 
bastante tardio de J. Malalas: o cronista relata que o general patrocinou a construção de

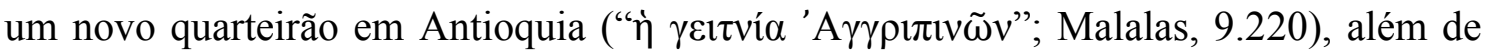
banhos públicos e o alargamento do teatro (Malalas, 9.15-22). A caracterização do Agrippeion como um teatro coberto e, como se verá, como extensão de uma estrutura ginasial, o torna coerente com o programa construtivo de Agripa tanto no oriente quanto no ocidente do império.

A caracterização do edifício é clara em função dos vestígios encontrados: o conjunto auditório-orquestra-palco, as numerosas telhas cerâmicas encontradas na escavação e as referências literárias não deixam dúvidas de que se tratava de um teatro coberto. O repertório de formas arquitetônicas com o qual o edifício dialoga é amplo e variado. Localmente, o Agrippeion, enquanto edifício retangular com um auditório em semicírculo, faz uma referência clara ao "novo Bouleuterion" (séc. IV), localizado na ágora a poucas dezenas de metros a oeste do novo edifício; as dimensões e o formato "truncado" do auditório do Agrippeion, assim como as facilidades relacionadas à atividade teatral - como o palco, o edifício de cena e os corredores - o diferenciam de seu vizinho. Enquanto amplo edifício coberto, o Agrippeion dialoga com dois edifícios pericleanos: o Telesterion de Elêusis e o Odeion de Péricles junto ao teatro de Dioniso. Em ambos os casos, a cobertura é garantida por uma multidão de colunas, criando problemas para a visibilidade dos espectadores que o Agrippeion resolveria com técnicas mais eficientes de sustentação, possibilitando uma extensão de 28 metros de cobertura sem colunas. O sistema de iluminação do Agrippeion, por sua vez, remete às amplas janelas da face oeste do Erechtheion, o que garantiria uma fonte abundante de luz natural para as apresentações. Finalmente, a escolha da ordem arquitetural coríntia para a ornamentação do segundo nível do Agrippeion, ainda que seja coerente com o contexto estético augustano, dialoga com o primeiro edifício a utilizar a ordem coríntia no exterior, a saber, o inacabado Olympieion. A semelhança entre os capitéis augustanos do Olympieion e a ornamentação dos capitéis coríntios do Agrippeion (Burden, 1999, pp. 93-94), se por um lado se relacionam com formas já conhecidas e utilizadas em Roma (cf. a seguir), por outro demonstram a ligação entre a construção do Agrippeion e a retomada da construção do Olympieion.

Dentro da tradição arquitetural grega, o Agrippeion dialoga com ao menos duas vertentes: os bouleuteria microasiáticos e os teatros cobertos da Sicília. A mais clara referência é ao Bouleuterion de Mileto (figs. 119-120), construído como uma dedicação de Antíoco IV (175-164) a Apolo, Héstia e o Demos milésio (Thompson, 1950, p. 90; 
Baldasarri, 1998, p. 130-131). Trata-se de um complexo formado por um propileu, decorado com quatro colunas coríntias, um amplo pátio peristilo dórico com um altar monumental ao centro, e um edifício retangular composto por um auditório semicircular, cuja cobertura é sustentada por quatro colunas jônicas, e cujo exterior é dominado por um muro contínuo no primeiro nível e um pseudoperíptero dórico com grandes janelas no segundo nível. A semelhança mais radical está na quase sobreposição de dois edifícios, um de muro contínuo e outro períptero, dórico no caso milésio, coríntio no caso ateniense. Quanto aos teatros cobertos da Sicília, encontrados na cidade grega de Akrai e na cidade púnica de Solunto, e datados do período helenístico, muito pouco foi publicado; aqui retemos apenas a visão de Lauter (1986, p. 161), para quem este é o local de origem da forma arquitetural do Odeion, que se apropriará das técnicas italianas para a ampliação da área coberta sem necessidade de colunas internas (cf. a discussão em Winter, 2006, pp. 135-149).

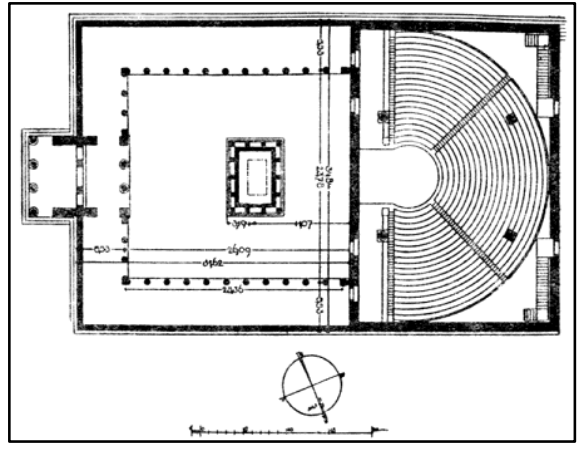

Figura 119. Proposta de reconstituição da planta do Bouleuterion de Mileto (Robertson, 1997, p. 207, fig. 79).

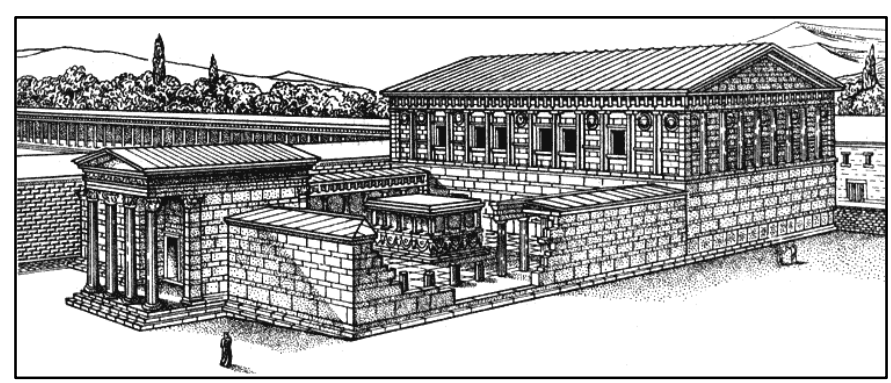

Figura 120. Proposta de reconstiuição da elevação do Bouleuterion de Mileto (StudyBlue ${ }^{291}$ ).

Ao lado do Bouleuterion de Mileto, outro edifício que parece ter influenciado mais diretamente o Agrippeion é o Odeion de Pompéia, construído na primeira metade do século I: são similares a articulação "truncada" do auditório com os muros laterais, a estreiteza do palco, a existência de uma galeria atrás do auditório, e os corredores colunados ao redor do corpo central do edifício (fig. 121). Outras referências italianas podem ser encontradas na forma da basílica, em particular naquelas do século I, com a ampliação do espaço interno com o mínimo de colunas internas para a sustentação da

\footnotetext{
${ }^{291}$ https://classconnection.s3.amazonaws.com/851/flashcards/2803851/gif/mil0011445A7888430E08C6FF.gif
} 
cobertura, encontradas Pompéia e Roma: basta lembrar que a basílica Emília em Roma apresentava uma área sem sustentação de cerca de 27 metros, próximo aos 28 metros do Agrippeion, e muito maiores do que os exemplos locais, como o Pártenon (c. 10 metros) e o Bouleuterion de Mileto (c. 15 metros; Thompson, 1950, p. 92). Estes dados, associados às representações de edifícios circundados por loggia presentes na pintura parietal pompeiana (Thompson, 1950, p. 93) e as citações na ornamentação dos capitéis coríntios em monumentos de Roma, como o arco de Augusto, o templo do Divino Júlio e o templo de Apolo in circo (Burden, 1999, p. 93), são as bases paraa visão amplamente aceita de que o arquiteto responsável pelo Agrippeion fosse profundamente familiarizado com a arquitetura italiana, e em particular a da Campânia (Thompson, 1950, p. 93). Mesmo que seja o caso, é importante lembrar que tanto o Odeion de Pompéia quanto o Agrippeion dialogam com tradições atenienses e pan-helênicas, apresentando inovações - especialmente no sistema de cobertura - dentro de quadros já estabelecidos.

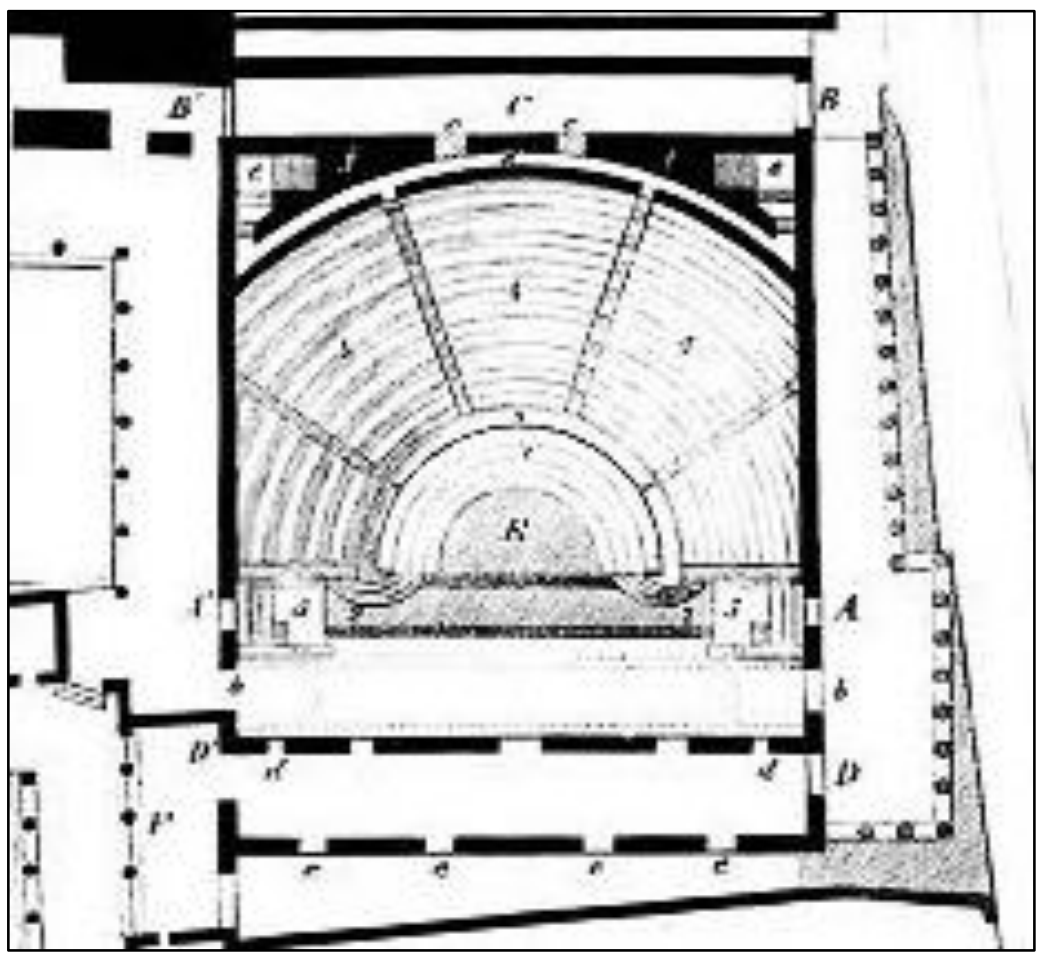

Figura 121. Proposta de reconstituição da planta do "pequeno teatro" de Pompéia (Wikicommons ${ }^{292}$ ).

${ }^{292}$ Disponível em: http://commons.wikimedia.org/wiki/File:Pompeii_Odeion_plan.jpg 
A localização do Agrippeion na ágora e sua articulação com os demais edifícios foi tradicionalmente tomada como mais um argumento para a tese da romanização da ágora. Rompendo com o secular padrão espacial da ágora, que mantinha sua área central livre de grandes edifícios, o novo teatro coberto impunha, pelo nome e pelas referências arquiteturais, a presença romana sobre o espaço público ateniense. Articulado às stoas ao sul e ao leste, o Agrippeion transformava a ágora ateniense em um duplo do fórum de Júlio César e do (possivelmente projetado) fórum de Augusto em Roma, com suas estruturas axiais e seus templos avançando sobre o pátio a partir do centro de um de seus limites, rodeado por pórticos colunados (Thompson, 1950, pp. 95-98). A disposição do Agrippeion, assim, seria mais um símbolo da dominação romana sobre a cidade-estado transformada em cidade provincial (Shear, 1981).

Por outro lado, a localização do Agrippeion pode ser interpretada de outra maneira. Em primeiro lugar, sua ligação estrutural com a Stoa Média, que servia de entrada principal para os espectadores em direção ao auditório, pode indicar que o novo edifício era um prolongamento da Praça Sul, cujos edifícios meridionais (a Stoa Sul II e os dois edifícios retangulares) foram destruídos em 86 e não foram reconstruídos até o século II; caso esteja correta a identificação da Praça Sul como um ginásio, a construção do Agrippeion pode ser vista como uma extensão da estrutura ginasial para o norte, após a redução de sua área sul, ocupada então por oficinas. Em segundo lugar, ainda que nas plantas o Agrippeion faça a ágora ateniense lembrar a axialidade dos fóruns imperiais, é preciso lembrar que a via principal de circulação na ágora era a Via Panatenaica, o que significa que a apropriação visual do Agrippeion era, na maior parte do tempo, diagonal, remetendo assim aos padrões espaciais típicos dos santuários gregos. Em terceiro lugar, o Agrippeion se localizava próximo de onde, no século VI, estava situado o primeiro "teatro" da cidade, construído com arquibancadas de madeira (ikria), onde ocorriam as competições teatrais antes da construção do teatro de Dioniso (Thompson e Wycherley, 1972, pp. 127-129); a construção de um teatro coberto no local onde teriam ocorrido as primeiras competições seria coerente com a preocupação antiquária corrente no período, e em particular nas intervenções associadas a Augusto (Baldassarri, 1998, p. 135; contra, Miller, 1995, pp. 218-219). Deste ponto de vista, a construção do Agrippeion continuaria o processo de redução da ágora iniciado, ainda no século II, pela construção da Stoa Média e da Stoa de Átalo II. A construção de uma nova ágora - a "Ágora Romana”, que será discutida mais adiante -, projetada ainda na década de 40, poderia 
ser uma das etapas de um processo de transferência de parte das atividades comerciais para o leste e consequente ampliação do espaço livre na ágora ateniense. $\mathrm{O}$ fato de Vitrúvio recomendar intervenções para se evitar que os fora se tornassem demasiadamente amplos (5.1.2) não precisa ser interpretado como uma iniciativa vitruviana, a qual, em si mesmo, é uma formalização de padrões espaciais de produção de praças (reduzidas e segmentadas) já presentes na arquitetura helenística - inclusive em Atenas. Sua articulação à Stoa Média, ademais, remete à relação entre o teatro de Dioniso e a Stoa de Eumenes, mencionada por Vitrúvio como uma facilidade para os espectadores contra eventuais mudanças climáticas; a cobertura do Agrippeion evitaria tal problema, mas de qualquer maneira sua associação a uma longa stoa dialoga claramente com os dois espaços teatrais do outro lado da acrópole.

O financiamento do Agrippeion é normalmente equacionado ao seu próprio nome: a honra concedida a Agripa de nomear o novo edifício deveria estar associada a uma grande doação do general romano. As dimensões, materiais utilizados e o acabamento de alta qualidade apontam para um alto custo: as fundações e os muros do Odeion foram feitos com blocos de calcário, enquanto as colunas, pilastras e entablamento da ordem principal foram feitos com mármore branco pentélico e azul do Himeto; o telhado do corpo central, por razões de leveza, era composto por telhas de cerâmica, diferente do telhado das galerias laterais, feitos em mármore. A técnica empregada para a fixação dos blocos indica a utilização tanto de grampos em "pi" quanto em "duplo T”, ambas já conhecidas na arquitetura ateniense, em particular na ágora (grampos em “pi”, normalmente associados à arquitetura romana, já aparecem no monumento dos Heróis Epônimos, do século IV; Lesk, 2005); a técnica para a cobertura do edifício, como já mencionado, encontra paralelos apenas na Itália (Odeion de Pompéia e basílica Emília em Roma). A articulação dos materiais e técnicas com as referências arquiteturais presentes no Agrippeion apontam para uma equipe de trabalho habituada tanto à arquitetura local quanto à arquitetura mediterrânica, com referências em particular à Ásia Menor e à Campânia, seja ela composta por técnicos apenas locais (Rodaz, 1984, p. 438) ou uma equipe mista (Thompson, 1950, p. 93; Bowersock, 1965, p. 94; Burden, 1999). A composição de tal equipe é plausível se associada à presença de Agripa em Atenas, tendo em vista o amplo leque de intervenções urbanas em Roma, especialmente a partir de 27, com a construção dos Saepta Iulia, do Pantheon e do conjunto termal no Campo de Marte (Rodaz, 1984, pp. 245-298); a escolha do escultor ateniense Diógenes para a realização das cariátides no Pantheon em Roma (Plínio, 
36.38), assim como a documentada experiência de arquitetos romanos trabalhando em Atenas nas décadas anteriores, apontam na mesma direção.

As referências textuais aos usos do Agrippeion só aparecem no século III d.C., com breves menções em Pausânias e Filóstrato. Comecemos pelo último: na vida de Alexandre de Selêucia, escrita no início do século III d.C. mas referente a pouco antes do ano 172, Filóstrato escreve que a primeira declamação do sofista em Atenas, e o encontro com o maior sofista ateniense de então, Herodes Ático, ocorreram no teatro do Cerâmico chamado Agrippeion, quando, após Alexandre ter feito o elogio de Atenas e ter declamado um discurso sobre o tema escolhido pela audiência - a saber, a necessidade do retorno dos citas à vida nômade - Herodes Ático, após elogiar Alexandre, e também a pedido da audiência, declamou um discurso sobre a derrota ateniense na Sicília durante a guerra do Peloponeso (Filóstrato, Vidas dos Sofistas, 2.5.4). O clima amistoso é invertido na vida de Filargos, referente ao mesmo período: o sofista da Cilicia, que eventualmente reutilizava seus discursos quando devia improvisar, é duramente criticado por Herodes Ático e companhia, justamente, no Agrippeion (Filóstrato, Vidas dos Sofistas, 2.8.4). A escrita de Filóstrato se insere no contexto da Segunda Sofística - assim denominada pelo próprio autor - que teria em Atenas uma de suas principais referências espaciais e temáticas; em virtude disso, a passagem dos sofistas por Atenas era fundamental, o que explica a necessidade sentida por Alexandre de Selêucia de desculpar-se por não tê-lo feito antes. A escolha do Agrippeion é plausível: sua capacidade para centenas de espectadores e suas facilidades acústicas e climáticas eram coerentes com a popularidade conquistada pelos sofistas que viajavam o Mediterrâneo declamando, entre outras coisas, os feitos e os dilemas dos atenienses (Bowie, 2004, pp. 70-72). Mas teria o Agrippeion sido construído, dois séculos antes de Filóstrato, visando este uso?

Recentemente, A. Spawforth retomou a hipótese de P. Graindor segundo a qual a construção do Agrippeion se relacionava ao sucesso das declamações em Roma (Graindor, 1927, p. 181; Spawforth, 2012, pp. 64-86). De fato, Atenas era um importante centro não apenas para os estudos filosóficos, mas também retóricos: Cícero, Bruto, Marco Antônio, Marcus Cícero e outros romanos proeminentes tomaram lições com sofistas sediados na cidade, alguns dos quais também lecionariam em Roma; Augusto e Agripa, ainda que não tenham estudado em Atenas, também se aventuravam na arte oratória (Spawforth, 2012, p. 71). O fundamental do argumento é que, não apenas havia uma ênfase augustana na retórica, como também havia um interesse 
polemizante: o Agrippeion seria um monumento ao aticismo, marcado por um estilo sóbrio e direto, privilegiado pelos críticos da época augustana (Dihle, 1994, p. 76; Connolly, 2007, p. 154-157), por oposição ao asianismo, caracterizado por Cícero como irrestrito e redundante (Sobre o orador, 51). O uso do Agrippeion como "monumento aticista" seria coerente com a propaganda anti-antoniana de Augusto: assim como o culto de Roma e Augusto na acrópole suplantaria a memória da presença de AntônioDioniso, o Agrippeion, como pólo do estilo aticista, combateria a retórica asianista que, segundo Plutarco, havia sido a escolha pessoal de Antônio (Plutarco, Antônio, 2.4). Dito isto, parece plausível a tese de que o Agrippeion tenha sido não apenas uma afirmação de uma preferência retórica - com todas as suas implicações políticas e mnemônicas mas também um importante marco para a afirmação do aticismo, que tinha, em Cícero e Dioniso de Halicarnasso, alguns de seus principais defensores.

A menção ao Agrippeion em Pausânias (1.8.6-14.1) aponta para uma direção diferente. O periegeta menciona o "Odeion” logo após o santuário de Ares e as estátuas dos tiranicidas, e imediatamente lista as estátuas posicionadas diante da entrada do "Odeion": reis lágidas (Ptolomeu I Soter, Ptolomeu II Filadelfo e sua irmã Arsinoe, Ptolomeu VI Filometor), Filipe, Alexandre, Lisímaco e Pirro; após a menção às estátuas dos lágidas, de Lisímaco e de Pirro, Pausânias faz breves digressões a respeito da história dos respectivos reinados (não o faz a respeito de Filipe e Alexandre, cujas vidas são "muito importantes" para se limitarem a digressões; 1.9.4). O que estariam fazendo lá as estátuas de reis helenísticos? Uma hipótese instigante foi sugerida por P. Marchetti, no contexto da defesa da identificação da Praça Sul como o Ptolemaion. Para Marchetti, a presença de estátuas de diversos lágidas ao lado de Pirro (genro de Ptolomeu I Soter) e Lisímaco, pai de Arsinoe I (esposa de Ptolomeu II), deve ser associada às estátuas de Juba (descendente dos lágidas) e do filósofo Crísipo de Soli que Pausânias menciona no ginásio de Ptolomeu, que por sua vez devem ser associadas à estátua de Crísipo que Cícero viu in Ceramico (De finibus, 1.11). Argumentando que a estátua de Crísipo que Cícero viu na ágora é a mesma que Pausânias viu no Ptolemaion, e que a estátua de Juba (no Ptolemaion) faria sentido ao lado dos lágidas e de Lisímaco (no Odeion), Marchetti defende que o Agrippeion havia incorporado as estátuas do Ptolemaion, que serviam como uma espécie de memorial dinástico lágida, legitimados pelas estátuas de Filipe e Alexandre como fundadores do poder macedônico (Marchetti, 2012, pp. 214-216). 
Apesar de atraente, a hipótese ainda tem alguns problemas. A identificação da Praça Sul ao Ptolemaion esbarra no fato de que Cícero frequentou o ginásio sem mencionar qualquer ruína (Sobre os fins, 5.1), o que não corresponde à destruição da Stoa Sul II, do edifício Leste e dos edifícios retangulares internos causada pelo saque de Sula em 86. Em segundo lugar, a presença de duas estátuas de Crísipo em locais diferentes não é absolutamente implausível: a dedicação de estátuas de um filósofo na ágora, onde eram dedicadas dezenas de estátuas honoríficas ${ }^{293}$, e em um ginásio, onde eram ministradas aulas de filosofia, dizem respeito a audiências diferentes.

Não é possível, entretanto, oferecer uma hipótese alternativa com menos dificuldades. Uma solução, mais modesta, pode ser sugerida a partir da própria leitura de Pausânias: as estátuas próximas ao “Odeion" levam o periegeta a refletir sobre histórias dinásticas. Segundo a hipótese amplamente aceita, a construção do Agrippeion teria iniciado em 16/5, quando Agripa estaria em Atenas; isto seria apenas um ano após a adoção dos filhos de Agripa, Caio e Lúcio César, por Augusto, avô materno dos rapazes, indicando claramente o critério - naquele momento - para sua sucessão: a consanguinidade. Neste sentido, mais do que imperator do Oriente, Agripa chegava em Atenas como pai dos herdeiros de todo o império - isto pode significar que a decoração escultórica do Agrippeion monumentalizava a monarquia e sua organização dinástica, envolvendo personagens relacionados ou aos benfeitores de Atenas (Ptolomeu II e Ptolomeu VI), ou à história romana (Pirro), mas que estavam na base do sistema monárquico que dominou o Mediterrâneo Oriental que tinha, na figura de Agripa, seu atual representante e futuro ancestral dinástico. Um elemento que segue esta mesma direção é a articulação entre o Agrippeion e o templo de Ares, o qual, como será discutido mais adiante, era profundamente relacionado a Caio César, filho de Agripa e herdeiro de Augusto.

Um outro uso do Agrippeion - para além de local de performances retóricas e de espaço de culto dinástico - foi sugerido: servir como espaço para a visualização dos rituais realizados na ágora, em particular as procissões panatenaicas (Thompson, 1950, pp. 75-76; Shear, 2001, pp. 899-900), o que explicaria os pórticos que circundavam o Agrippeion, exceto na face norte. J. Shear argumenta, inclusive, que o pórtico leste do edifício, junto da porção leste da Stoa Média não obliterada pelo novo edifício "proveria uma esplêndida visão da procissão e de outros eventos que teriam lugar [na Via

${ }^{293}$ Por exemplo, a estátua em homenagem ao filósofo Carneades (IG II2 3781; Habicht, 1990, pp. 571 572) 
Panatenaica]" (Shear, 2001, p. 899). Entretanto, quando se analisa a planta da ágora ateniense com o Agrippeion, percebe-se que a preocupação em criar um suporte para a visualização da procissão não foi determinante: a posição do Agrippeion em relação à Stoa Média, mais ao leste do que ao centro, reduz esta possibilidade ao limite sudeste da ágora, impedindo a visão de toda a ágora disponível para os espectadores posicionados na Stoa Média antes do Agrippeion. No mesmo sentido, a área maior a oeste do Agrippeion não beneficiaria espectadores interessados na procissão panatenaica, exceto uma pequena quantidade de pessoas posicionadas no limite do pórtico ocidental do Agrippeion. A ausência de um pórtico na face norte, o que de fato garantiria uma ampla visibilidade para a maior parte do trajeto da procissão na ágora, demonstra que esta não era uma prioridade. O inverso parece ser mais provável: o Agrippeion deveria ser visto pelos caminhantes na Via Panatenaica. Sua apropriação visual primeira, do ponto de vista daquele que entrasse na cidade pelo Dípilo, era diagonal: o caminhante veria tanto as colunas plenas, com ornamentação simples, do pórtico oeste, quanto o pseudoperíptero coríntio no corpo central do edifício. Assim, mais do que ser mais uma facilidade para os espectadores das procissões, o Agrippeion pode ser interpretado como parte do projeto de monumentalização da ágora a partir do ponto de vista do caminhante na Via Panatenaica (Burden, 1999).

Finalmente, é preciso considerar a função "simbólica" do Agrippeion, qual seja, a de representar, no plano arquitetural, a submissão ateniense ao império romano. T. L. Shear Jr. propõe esta função nos termos de um diálogo entre o Agrippeion e a ágora: se no período clássico os generais e oradores dominavam a cena política, no período imperial Atenas estaria nas mãos de filósofos e declamadores. A ocupação do espaço central da ágora pelos novos edifícios, e particularmente pelo Agrippeion, seria o símbolo do fím da política, com o que se abriaria o espaço para a musealização da ágora ateniense (Shear Jr., 1981).

Contra esta visão, Dickenson argumenta que mesmo o Agrippeion poderia ser utilizado como local de reuniões políticas - o que é atestado, por exemplo, no Odeion de Pompéia (Baldassarri, 1998) - e que, mesmo que se limitasse a apresentações artísticas, sua presença na ágora não eliminaria o espaço disponível para aglomerações, pelo contrário: o Agrippeion funcionaria como uma parede acústica de uma área do tamanho do auditório da colina da Pnyx, tendo como referência o bema romano (Dickenson, 2012). A alegação de um enfraquecimento da atividade construtiva relacionada a edifícios administrativos é contestada, em Atenas, pelos trabalhos de 
restauração e ampliação do complexo do Bouleuterion, além de em diversas outras cidades ser documentada uma intensa atividade de construção e reparação de edifícios públicos (Dickenson, 2012). Finalmente, a ocupação do centro da ágora não "simboliza" o fim das reuniões políticas, pois, como já mencionado acima, as reuniões democráticas ocorriam majoritariamente na Pnix ou no teatro, com raras exceções, como era o caso do ostracismo (Dickenson, 2012).

A percepção ateniense contemporânea da relação entre retórica e política, infelizmente, não foi documentada - não há para o período augustana nada parecido com a reflexão plutarquiana sobre a memória política e a retórica dos líderes nas cidades gregas. O fato é que, por um lado, com a construção de um luxuoso e novo teatro coberto, a cidade estava ainda melhor equipada para o desenvolvimento da tendência já consolidada no período helenístico, mas que se abria para novas possibilidades sob a pax romana: a tendência de se tornar o principal centro cultural pan-helênico, competindo com a própria cidade de Roma com a desvantagem da falta de poder político e consequentemente de recursos, e a vantagem de ter, em sua paisagem, boa parte dos referenciais materiais das narrativas que circulam por meio de textos e declamações Mediterrâneo a fora. Por outro lado, a cidade reforçava seus laços com o novo evergetismo do principado, centrado na comemoração dinástica e na adequação às tendências do projeto cultural augustano (Spawforth, 2012).

\section{O templo e o altar de Ares}

Em ângulo com o Agrippeion se localiza, nas plantas da ágora no período augustano, o templo de Ares (McAllister, 1959). Trata-se do mais célebre dos "templos flutuantes" da ágora no período augustano: fragmentos de edifícios ou edifícios inteiros que foram transpostos de áreas rurais ou costeiras da Ática para o centro da cidade. No caso do templo de Ares, é provável que se trata-se de um templo dedicado a Atena e localizado a cerca de $11 \mathrm{~km}$ de distância da ágora; a transposição para o centro da ágora e a rededicação a uma divindade tão central na religiosidade romana foi tomada, como seria de se esperar, como um dos maiores símbolos da romanização de Atenas. No entanto, diversos elementos apontam para direções diferentes, e possibilitam uma abordagem mais complexa. Vejamos com detalhe. 
Escavadas a partir da década de 30, as fundações e as centenas de elementos arquiteturais encontradas na área centro-ocidental da ágora foram sem grande dificuldade equacionadas à menção de Pausânias ao "santuário de Ares" ("A

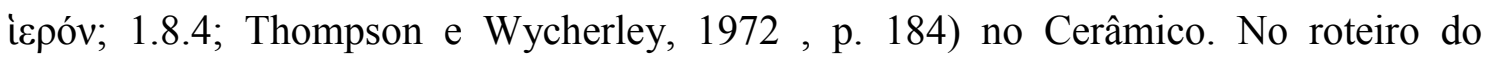

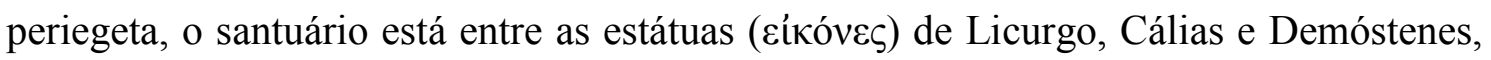
de um lado, e de Harmodios e Aristogiton, de outro. O santuário interessa Pausânias na medida em que contem estátuas: dentro do templo estão duas estatuas de culto ( $\alpha \gamma \alpha \dot{\alpha} \lambda \mu \alpha \tau \alpha)$ de Afrodite, de Ares (feita por Alcamenes), de Atena (feita por um pário chamado Locrus), de Ênio (pelos filhos de Praxíteles); ao redor do templo estavam estátuas de Héracles, Teseu, Apolo prendendo o cabelo com um laço, Calades (que teria dado leis aos atenienses) e Píndaro (em agradecimento a uma ode aos atenienses).

Voltaremos adiante para a discussão sobre a decoração escultórica do santuário. Aqui, é importante destacar que a localização das fundações correspondem à descrição de Pausânias, o que torna a identificação segura. Bastante controversa, entretanto, é a história do local e do edifício, em virtude de um fato sem paralelo na arquitetura grega: a transposição integral de um templo de um lugar a outro. As evidências para tal reconstituição são o estilo arquitetural do templo, do período clássico (bastante semelhante, no plano e na elevação, ao Hephaisteion), um vaso associado às fundações na ágora e datado do final do século I, e acima de tudo, as marcas dos construtores por meio de duas ou três letras do alfabeto grego em praticamente todos os fragmentos encontrados, cujo estilo epigráfico data do final do século I. As letras se referem à posição que o bloco deve ocupar no edifício, sendo que, segundo a hipótese de M. McAllister (1959, pp. 47-54), a primeira letra indica a posição horizontal, a segunda a posição vertical, e a terceira o lado do edifício, a partir da entrada; esta hipótese corresponde à grande variação nas duas primeiras letras e à limitação da última letra a

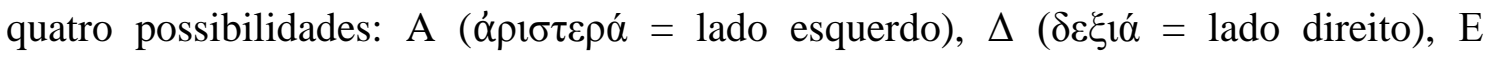

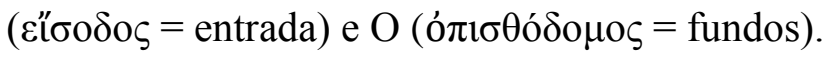

O templo de Ares é um períptero dórico hexastilo de 14 x 34 metros, com fundações em poros e toda a superestrutura em mármore pentélico, com um pronaos com duas colunas in antis, o que se repete no opistodomo; fragmentos das colunas e do entablamento permitem uma reconstituição aproximada (figs. 122-123). Uma série de fragmentos escultóricos foi associada por A. Delivorrias (1974, pp. 94-102), seguida por P. Baldassarri (1998, pp. 157-158) ao frontão do templo de Ares: tratam-se de figuras femininas e masculinas, que fariam parte, no frontão leste, de uma composição 
figurando o julgamento de Paris, com estátuas de Atena, Afrodite e Hera no centro, e, no frontão oeste, de uma composição figurando a amazonomaquia de Aquiles. No entanto, ainda que os dois temas sejam coerentes com a presença de estátuas de Afrodite, Ares, Ênio e Atena - divindades atuantes na Ilíada - no templo, os indícios nos quais se baseiam tal reconstrução são extremamente fragmentários e, no mais das vezes, sem ligação direta com o templo. De resto, semelhança na planta e na elevação com o Hephaisteion fez com que Dinsmoor (1940) o atribuísse ao mesmo arquiteto, datando assim sua construção original na década de 430 .

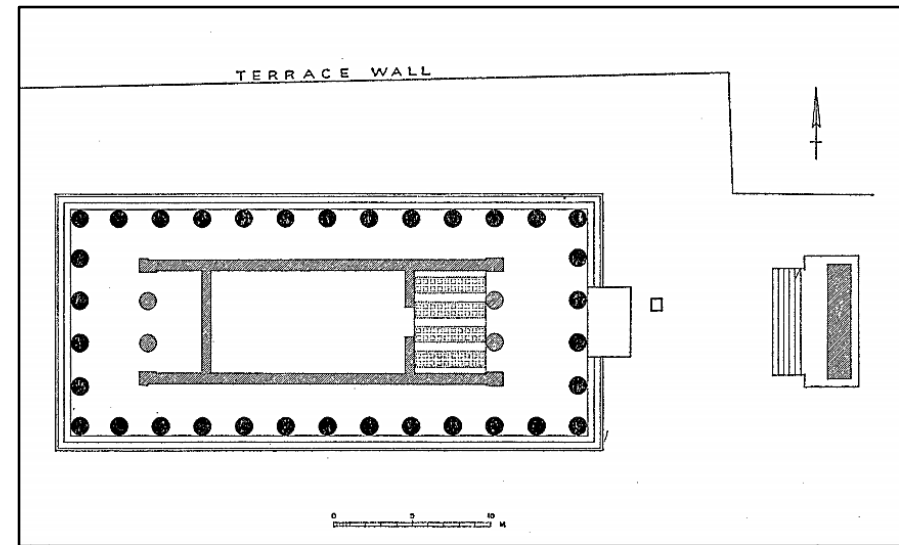

Figura 122. Proposta de reconstituição da planta do templo de Ares, segundo M. McAllister (1959, p. 61, fig. 24).

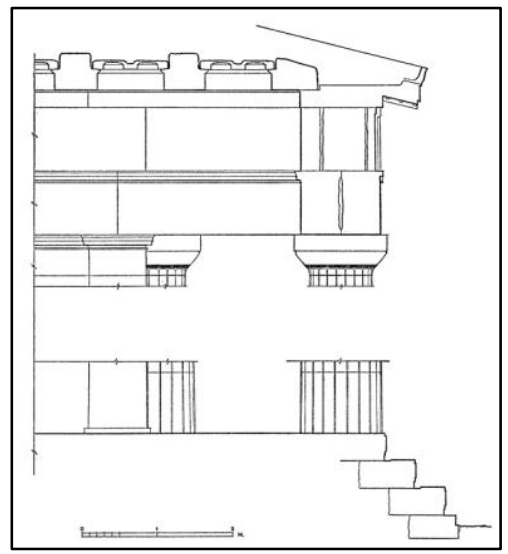

Figura 123. Proposta de restauração da seção longitudinal da elevação do templo de Ares, segundo $M$. McAllister (1959, p. 57, fig. 23).

A localização original do templo foi primeiramente associada ao Areópago (Dorpfeld, 1939, p. 140-150) e à Ágora Romana (Dinsmoor, 1940, p. 50), mas as revisões arqueológicas e a ampliação do confronte com as fontes epigráficas produziu uma hipótese melhor fundada: o templo se localizava originalmente no demos de Acharnai, a cerca de $12 \mathrm{~km}$ da ágora, onde é atestada a existência de um santuário de Ares e "Atena Areia” já no período clássico (SEG 21.519, 34.104, 39.324, 40.126; Kellogg, 2013, pp. 150-167), e cuja comunidade inscreveu uma dedicação a Ares e a Augusto (IG II2 2953). A associação entre Atena e Ares em Acharnai, inclusive figurativa - o decreto SEG 21.510 é encimado por um relevo representando Atena coroando Ares - seria coerente com a presenta de estátuas de Ares e Atena no templo descrito por Pausânias. Entretanto, até hoje não foram encontrados indícios de um templo de Ares em Acharnai, sendo mais provável que o santuário consistisse em um recinto e um altar (Kellogg, 2013, pp. 165-166, n. 67); por outro lado, os arqueólogos gregos encontraram recentemente fundações no demos de Pallene, a cerca de $11 \mathrm{~km}$ da 
ágora, que batem com bastante precisão com as dimensões no templo de Ares na ágora (Korres, 1992-8, pp. 83-104; figs. 124-126); há notícia para um templo de Atena administrado pela Liga de Atena Pallenis, que já no século V demandaria reparos (Schlaifer, 1943, p. 43). O achado, na área do templo de Ares na ágora, de alguns elementos arquiteturais não pertencentes ao templo original - a saber, um fragmento de calha que pertenceu, originalmente, ao templo de Poseidon no Súnio (Dinsmoor, 1974, pp. 211-238), e um fragmento de calha e fragmentos do forro em mármore pentélico menos desgastado e com marcas dos construtores diferentes do resto do edifício, todos datados da época da transposição - faz sentido com um templo que necessitaria de reparos já no século V.

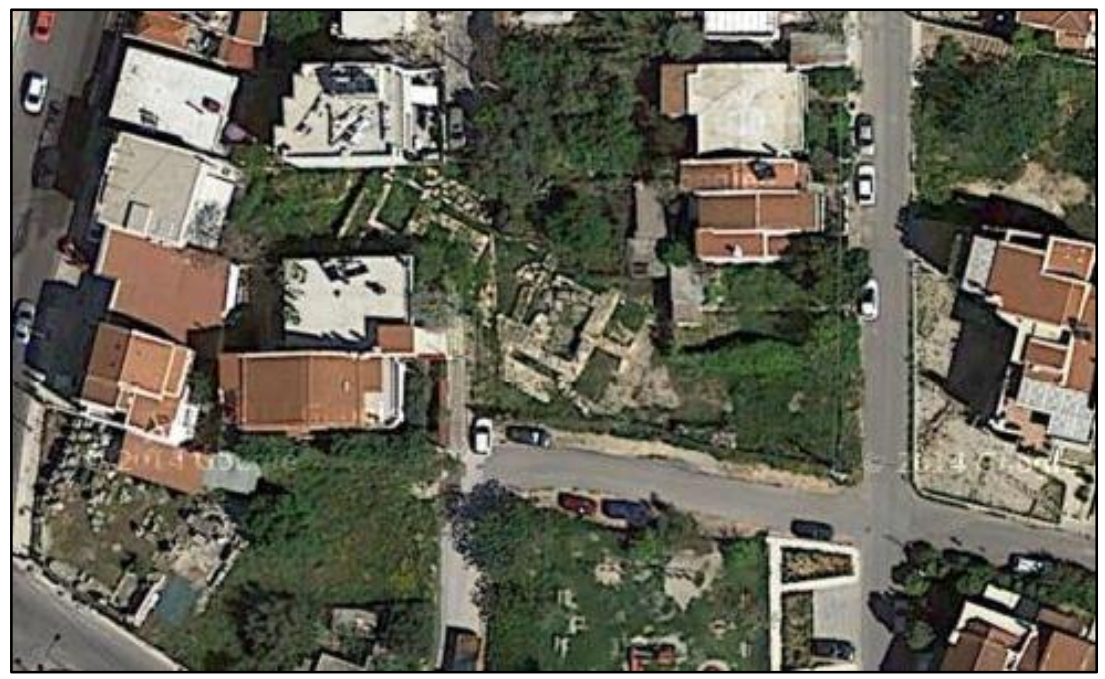

Figura 124. Imagem de satélite das fundações do templo de Athena Pallenis, esquina da atual rua Makrigianni com a rua Zalogou em Gerakas, Atenas (Google Maps $^{294}$ ).

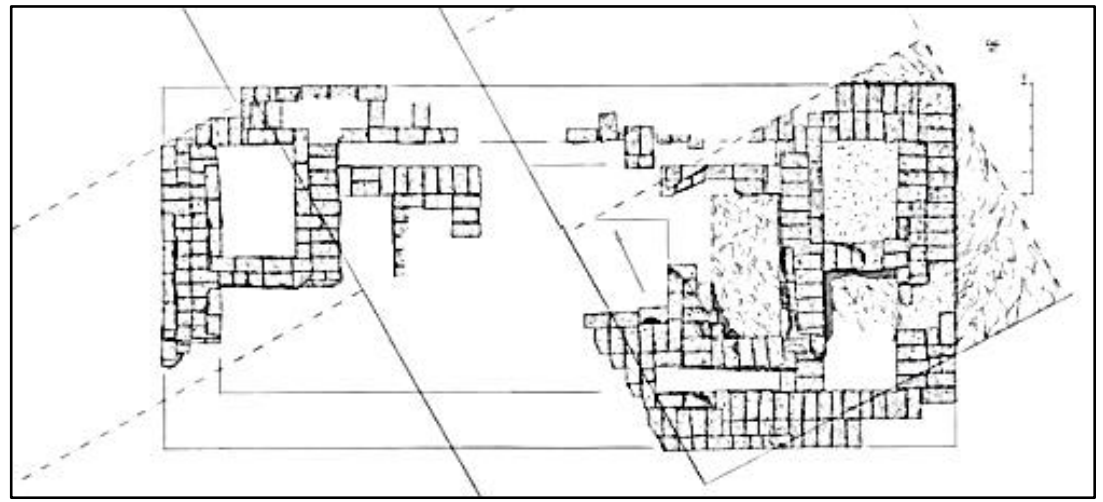

Figura 125. Estado atual das fundações do Santuário de Atena Pallenis (República da Grécia, 2014, p. 39).

${ }^{294}$ Coordenadas: 38.014044, 23.844371. Disponível em: https://www.google.com.br/maps/place/Zaloggou+7,+Gerakas+153+44,+Greece/@38.0139149,23.84448 $12,157 \mathrm{~m} / \mathrm{data}=! 3 \mathrm{~m} 1 ! 1 \mathrm{e} 3 ! 4 \mathrm{~m} 2 ! 3 \mathrm{~m} 1$ !1s0x14a19970b4284c89:0x509c7413df411b2a 


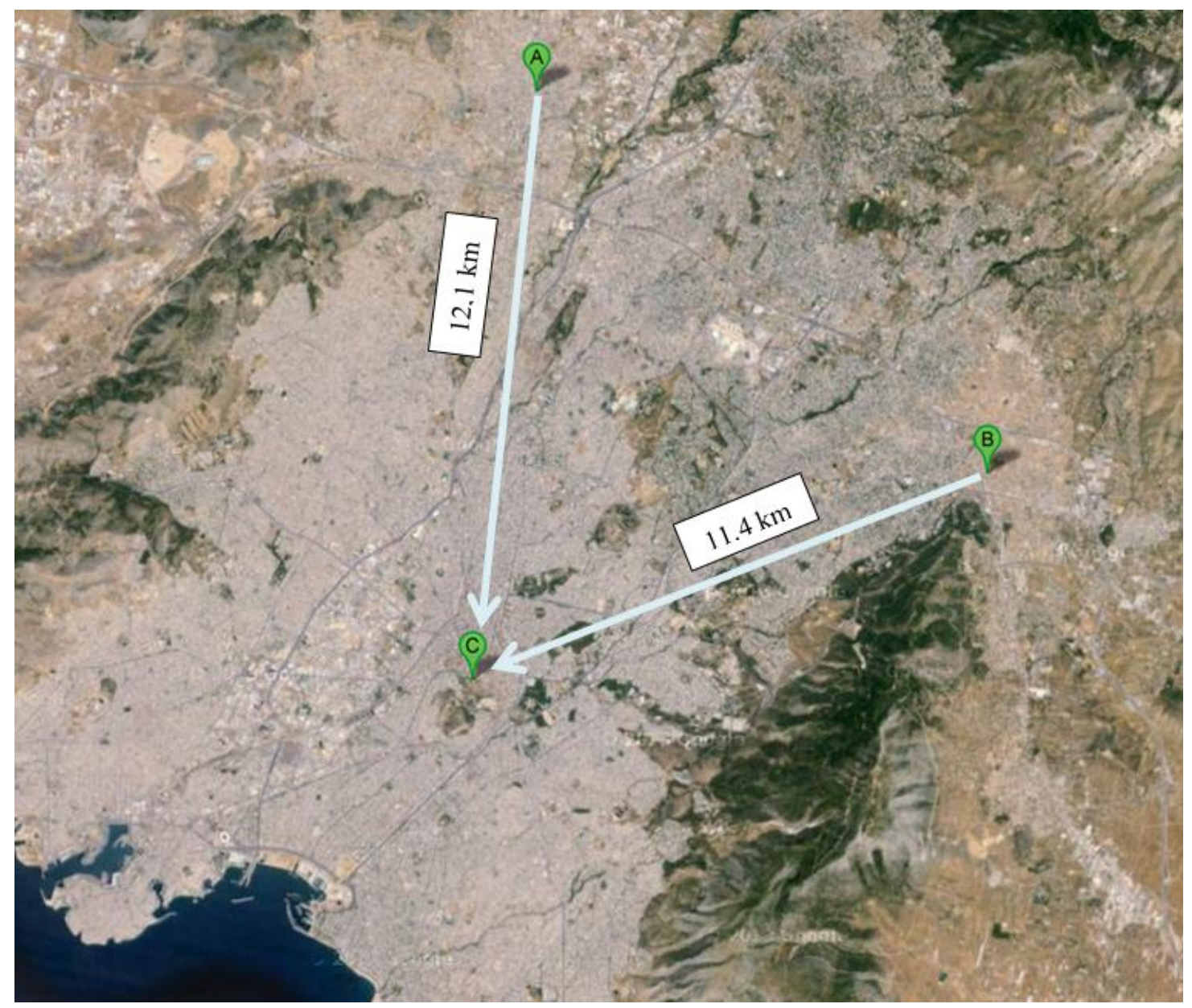

Figura 126. Mapa com as indicações do centro da atual Acharnes (a), do local do santuário de Atena Pallenis (b), das fundações do templo de Ares (c), e da distância em linha reta entre os dois primeiros locais e a ágora (Google Maps).

A relação de Acharnai e Pallene com a transposição do templo de Pallene ainda pode ser desenvolvida. Por um lado, deve-se considerar que a estela com a dedicação do demos de Acharnai a "Ares e Augusto" (IG II2 2953) não foi encontrada em Acharnai, mas, segundo K. Pittakis, próximo ao Areópago ${ }^{296}$. A ligação de Ares com o Areópago é evidente pela toponímia - Areópago como colina onde Ares foi julgado e absolvido pelo assassinato de Haliartus, filho de Poseidon -, enquanto que o crescente prestígio do conselho no século I é coerente com sua associação a Augusto (tema que será desenvolvido mais adiante). A dedicação a "Ares e Augusto" pode estar associada à transposição do templo, no sentido em que a comunidade decide marcar sua presença na

${ }^{296}$ Os registros de achado da estela são confusos: a primeira referência foi feita por L. Ross em 1838, que afirma que a estela foi encontrada em Egina; no ano seguinte, K. Pittakis a descreve como tendo sido encontrada "em Atenas, próximo do Areópago". Não é possível determinar com precisão a proveniência, e mesmo o transporte da estela de Atenas para Egina e novamente para Atenas não é implausível (Spawforth, 1997, p. 188). 
ágora em associação ao novo culto (Spawforth, 1997, p. 188). Por outro lado, um elemento pouco levado em conta bastante é relevante: há indícios de que o demos de Acharnai fazia parte da Liga de Atena Pallenis (Schlaifer, 1943, pp. 35-67; contra, Lewis, 1997, p. 91). De qualquer forma, se sugerir uma ação conjunta dos sacerdotes de Ares e Atena Areia de Acharnai com dos sacerdotes de Atena Pallenis na transposição do templo é exagerado, não parece prudente descartar absolutamente, após o achado das fundações em Pallene, a participação do demos de Acharnai na instalação do culto de Ares na ágora, tendo em mente, principalmente, o fato de Ares ser sunnaos com Atena.

A datação da transposição é bastante controversa. Apenas três elementos diretamente associados ao templo são utilizados para a datação: um vaso associado às fundações, datado do final do século I a.C., o tipo de letra - especialmente o alfa - das marcas dos construtores nos blocos reutilizados, que aparece em inscrições de meados do século I a.C. a meados do I d.C., e a reforma de um canal subterrâneo que partia do Agrippeion na direção do rio Eridanos, ao norte da ágora, que foi ligeiramente desviado para o oeste na altura do altar do templo (Burden, 1999, p. 120). Este último elemento fornece o principal terminus post quem, qual seja, a construção do Agrippeion, normalmente associada à passagem de Agripa por Atenas em 16/5.

O terminus ante quem, por seu turno, só pode ser inferido por evidências externas ao templo - mas com relações bastante prováveis. A principal fonte é a inscrição, em uma base de estátua atualmente no teatro de Dioniso (IG II $^{2} 3250$; Levensohn e Levensohn, 1947, pp. 68-69), que se refere a honras concedidas pelo

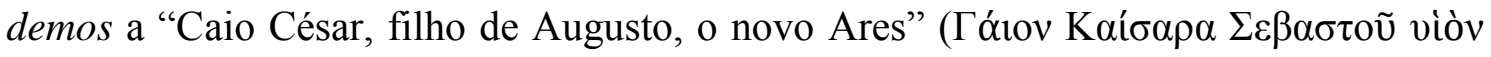

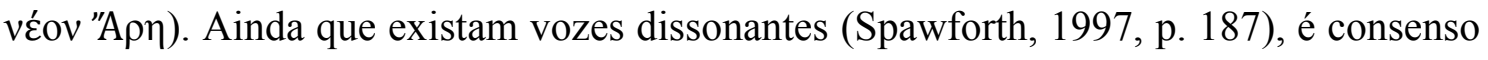
de que esta inscrição está associada à transposição do templo e rededicação do templo a Ares. Caio César parte de Roma no ano de 2 para assumir o comando militar do Oriente; o início de sua missão é comemorado por Augusto com a dedicação do templo de Marte Vingador e de todo o chamado Fórum de Augusto, além da realização de espetáculos que incluíam uma representação da naumaquia de Salamina de 480/79, na qual os atenienses venceram os persas. A incorporação da comemoração anti-bárbara ateniense na missão pártica de Caio César e a dedicação do templo de Marte em Roma, por um lado, a comemoração de Caio César como "novo Ares" em Atenas, por outro, são eventos muito coerentes para serem completamente desassociados da transposição de um templo do século $\mathrm{V}$, construído no contexto do programa pericleano, para a ágora, em ângulo - tendo o altar do templo como nó - com o Agrippeion (nomeado em 
função do pai biológico de Caio César), e rededicado a Ares. Desse modo, sugere-se a provável passagem de Caio César por Atenas como o momento ideal para a realização da transposição/rededicação ${ }^{297}$.

A associação entre Ares, Caio César, Augusto e Agripa, seguindo esta interpretação, seria um dos maiores símbolos da romanização de Atenas: divindade relativamente marginal no panteão ateniense, Ares seria introduzido no centro da ágora como tradução grega de Marte, pai dos fundadores de Roma, atualizado tanto como Augusto - "vingador" do assassinato do pai adotivo na batalha de Filipi, contanto com a ajuda de Marte, e "vingador" dos romanos derrotados pelos partas após o retorno das insígnias em 20/19 - quanto como Caio César, continuador da missão de imposição da autoridade romana sobre o Oriente. A presença no templo, de acordo com Pausânias, de divindades associadas à Guerra de Tróia, e particularmente de Afrodite, sugere que o templo buscava situar na ágora ateniense o mito fundador de Roma e da gens Iulia tendo como referência Enéias, tema particularmente importante na literatura da época augustana, em particular em Virgílio e Tito Lívio. A articulação com o Agrippeion, finalmente, fazia com que a área central da ágora - espelhando os fora imperiais com templos avançando sobre a área livre - se tornasse um santuário dinástico, com as referências culturais e religiosas ao pai biológico e ao pai adotivo do (então) futuro imperador.

Entretanto, uma interpretação oposto pode ser proposta com praticamente os mesmos elementos. Em primeiro lugar, a representação da batalha de Salamina em Roma indica claramente a referência ateniense para a estruturação do lugar de Roma na oposição aos bárbaros, ecoando o jogo de associações feito na dedicação do monóptero de Roma e Augusto na acrópole ateniense décadas antes; Caio César seria um continuador dos atenienses clássicos. Em segundo lugar, Ares já era cultuado em Atenas em associação a Atena (no demos de Acharnai), e Pausânias menciona que havia uma estátua de Atena dentro do templo, que pode ser interpretada ou como uma

\footnotetext{
${ }^{297}$ Burden, refletindo sobre o processo de demonstagem/remontagem, sugere que o novo templo da ágora teria sido construído em tempo curto, dado que, sem a necessidade do corte de novos blocos, o grosso do trabalho se concentrava na retirada dos grampos originais. Tempo curto que não significa, certamente, baixo custo: a alta qualidade das inscrições consideradas "marcas dos construtores" torna implausível que elas tenham sido inscritas no momento da retirada; Burden sugere que os construtores marcavam os blocos com tintas ou outros materiais durante a retirada, para depois serem inscritas por escribas profissionais (Burden, 1999, p. 123).
} 
reminiscência do culto de Atena Pallenis, ou como culto conjunto (sunnaos) de Ares e Atena Areia, não tão relevante para Pausânias, preocupado, então, com as estátuas enquanto exemplares da escultura grega. Em terceiro lugar, caso o templo fizesse de fato referências à Guerra de Tróia - considerando as estátuas de divindades mencionadas por Pausânias e a reconstrução moderna dos frontões -, se por um lado poderia fazer referência aos mitos de fundação de Roma, por outro remetia a uma já estabelecida tradição de temática iconográfica ateniense de representação da guerra de Tróia associada a edifícios, sendo o templo de Atena Nike e o próprio Pártenon os exemplos mais eloquentes; a presença de estátuas de Héracles e de Teseu no santuário, fora do templo, reitera a tradição de representação do herói da Ática em paralelo do herói pan-helênico, como exemplificado no friso Hephaisteion (figs. 127-128) a algumas dezenas de metros do templo de Ares. Em quarto lugar, se a posição do templo poderia remeter aos fora imperiais romanos, tratava-se de qualquer maneira de um templo ateniense do século $\mathrm{V}$, o que poderia significar a prestação de uma homenagem ao período clássico - paralela à naumaquia romana -, duplicando o templo de Hefesto (praticamente idêntico) na parte baixa da ágora. Em quinto lugar, a transposição do templo pode ter partido de uma iniciativa local, vinculada a eventuais enfraquecimentos dos cultos em seus locais originais (Pallene e/ou Acharnai), ou mesmo ligado ao fortalecimento do conselho do Areópago no século I a.C. Finalmente, o Agrippeion e o templo de Ares, em sua articulação, reiteram a ortogonalidade produzida no século II com a construção das stoas Média e de Átalo, ou seja, mantem padrões espaciais locais, produzidos mais de um século e meio antes.

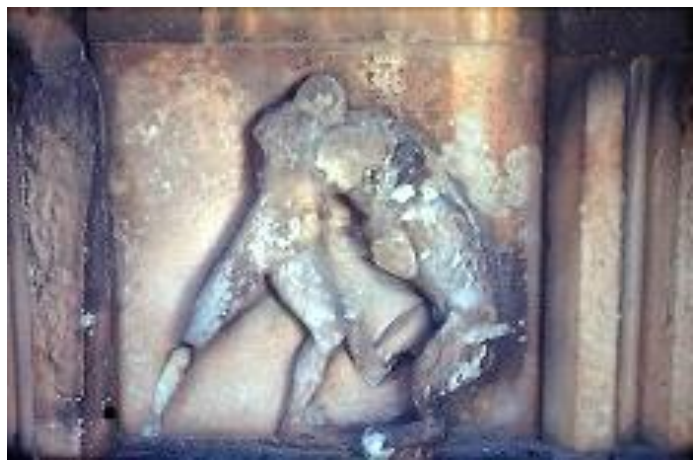

Figura 127. Métopa I do friso leste do templo de Hefestos na ágora ateniense, com cena de luta entre Héracles e o leão da Neméia $\left(\mathrm{ASCSA}^{298}\right)$.

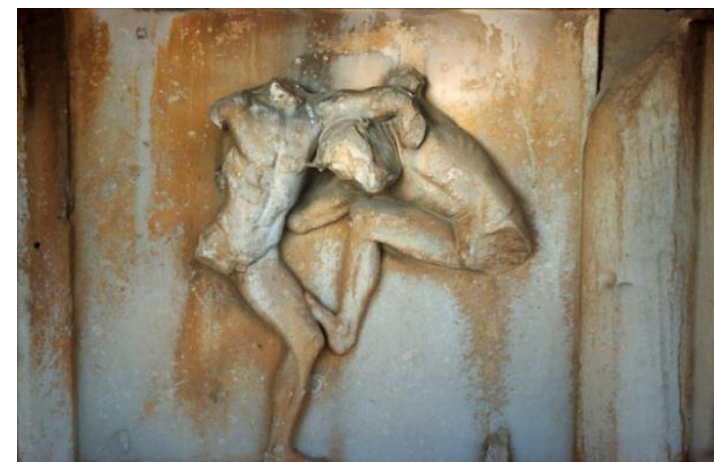

Figura 128. Métopa IV do friso sul do templo de Hefesto na ágora ateniense, com cena de luta entre Teseu e o Minotauro (ASCSA $\left.{ }^{299}\right)$.

\footnotetext{
${ }^{298}$ Disponível em: http://agora.ascsa.net/id/agora/image/2004.01.0910.

${ }^{299}$ Disponível em: http://agora.ascsa.net/id/agora/image/2004.01.1000.
} 
Diante disso, é evidente que propor uma leitura unívoca do templo "romanização da ágora" (Shear, 1982) ou orgulho local (Stefanidou-Tiveriou, 2008) - é no mínimo temerário. Diferentemente, é importante ressaltar as ambiguidades envolvidas na intervenção, que mescla elementos imperiais e locais tanto no nível arquitetural-espacial (arquitetura pericleana, disposição romana), quanto no nível narrativo (romanos/atenienses contra partos/persas) - ambiguidades que respondem, como se argumentará, aos dilemas produzidos tanto no processo de construção do principado quanto na construção do lugar de Atenas dentro do projeto imperial, sintetizados na ideia de "restauração". O antiquarianismo tardo-republicano, implícito na transposição quase "acadêmica" do templo, fundado ao mesmo tempo em uma reverência à arquitetura clássica e uma irreverência quanto aos locais sagrados, consolida-se no período augustano como padrão de produção do espaço, trazendo consigo as ambiguidades e contradições inerentes à nova modalidade do evergetismo construtivo - e da integração no Mediterrâneo.

Além do templo e do altar de Ares, duas outras intervenções na ágora tem marcas de transposição: o chamado "altar de Zeus Agoraios", o templo Sudeste e o templo sudoeste. Por vezes datadas do período augustano, as três intervenções, recentemente, tiveram suas datações alteradas.

O altar tem marcas de construtores com tipo de letra utilizado entre o século I a.C. e o século I d.C., próximas às marcas dos blocos do templo de Ares, mas com um acabamento muito inferior (Burden, 1999, p. 153). Sua identificação como um altar de Zeus Agoraios se assenta na hipótese de que este templo originalmente se localizava na Pnix, onde há um entalhe na rocha de dimensões próximas à base do altar; esta identificação apontaria não para o período augustano, mas sim para um período anterior, próximo ao abandono da Pnix como local para as assembleias atenienses, em algum momento do século II; a existência de material cerâmico do início do século I a.C. associado às fundações do altar na ágora, por sua vez, poderia indicar que o altar foi transposto com a utilização mais recorrente da ágora como local de reuniões políticas, o que ocorreu, como argumenta Dickenson (2012), em associação à instalação do bema romano, algum tempo antes de 88 . Mas não há garantias de que a localização original do altar tenha sido, de fato, a Pnix, o que derrubaria a identificação da divindade cultuado como sendo Zeus Agoraios. Stillwell (1933, p. 147, n. 1) e Torelli (1995, p. 9), no que são seguidos com cautela por Baldassarri (1998, p. 179), propuseram que o altar estava localizado originalmente na própria ágora, e que teria sido transposto por conta 
da construção seja do Agrippeion, seja do templo de Ares. Burden (1999, p. 154), por sua vez, sugere que o altar tenha sido transposto antes da construção do Agrippeion, dado sua "desprestigiosa" articulação com a lateral deste edifício, ou ainda pouco antes da dedicação do altar de Zeus Eleutherios em frente à stoa de mesmo nome, entre o

século II e I, que teria sido motivada por uma "competição" com o novo altar poucos metros ao sul. Não há, de qualquer maneira, a partir dos conhecimentos atuais, fundamentos seguras para a defesa da datação augustana da transposição deste altar e nem mesmo para sua identificação como sendo dedicado a Zeus Agoraios.

No caso dos templos sudeste e sudoeste, compostos ao menos parcialmente por material proveniente de outros templos - entre os quais o de Atena e o de Poseiodon no Sounion -, é consenso atualmente que suas (re)construções na ágora devem ser datadas entre meados e o fim do século I d.C. (Baldassarri, 1998, pp. 202-215).

\section{O "anexo" à Stoa de Zeus}

Uma intervenção particularmente intrigante é a construção de um anexo, em época augustana, à Stoa de Zeus Libertador, construída no final do século V. Tal stoa consiste em um edifício retangular com duas alas nas extremidades norte e sul que avançam para o leste (fig. 129), em cuja construção foi utilizado poros para as fundações, mármore azul do Himeto para o piso e degraus, mármore branco para a superestrutura (exceto o friso dórico, em poros e o muro externo, em calcário egineta), e cobertura com tijolos e antefixos de cerâmica; nas escavações, foram encontradas, associadas ao edifício, fragmentos de acrotérios figurando Vitórias aladas (fig. 130). Pausânias (1.3.3-4) menciona a existência de pinturas de Eufranor retratando a batalha de Mantinéia em 362 (na qual atenienses, espartanos e outros venceram a coalisão liderada por Tebas) na parede oeste, e, nas paredes norte e sul, representações dos doze deuses, de Teseu, da Demokratia e do Demos; a associação a Eufranor e a referência à batalha apontam a datação destas pinturas para meados do século IV. Pausânias não faz referência, no entanto, a uma estrutura construída a partir do centro do muro oeste que avança sobre uma área talhada na rocha da colina da ágora, composta por dois ambientes retangulares, alinhados com a stoa, cujas fundações estão separadas apenas por uma faixa de um metro. Dentro de uma das salas foi encontrada uma base de estátua com fragmentos da inscrição dedicatória; o tipo da letra, sendo bastante próximo às 
"marcas dos construtores" nos blocos do templo de Ares, junto de cerâmica associada, apontam fortemente para uma datação augustana da construção desta nova estrutura.

Não há indicações precisas sobre as formas de acesso à nova estrutura: as propostas de reconstituição oscilam entre uma porta no muro longo da stoa e uma entrada (em arco ou porta) para cada um dos ambientes (fig. 131) e uma grande abertura colunada nos fundos da stoa que dá acesso a uma espécie de pronaos in antis de cada uma das salas (fig. 132). Por vezes aparece nas propostas um acesso para o recinto ao norte do anexo, localizado junto ao limite noroeste da Stoa de Zeus: a história desta área, no entanto, é extremamente obscura ${ }^{300}$. Assim, ainda que a orientação dos novos ambientes aponte fortemente na direção de que se tratava, de fato, de um "anexo" à Stoa de Zeus, a determinação de sua possível comunicação com a área às costas da stoa, fortemente relacionada ao santuário do Demos e das Graças a partir do final do século III, pode trazer uma série de relações espaciais não consideradas pela bibliografia.

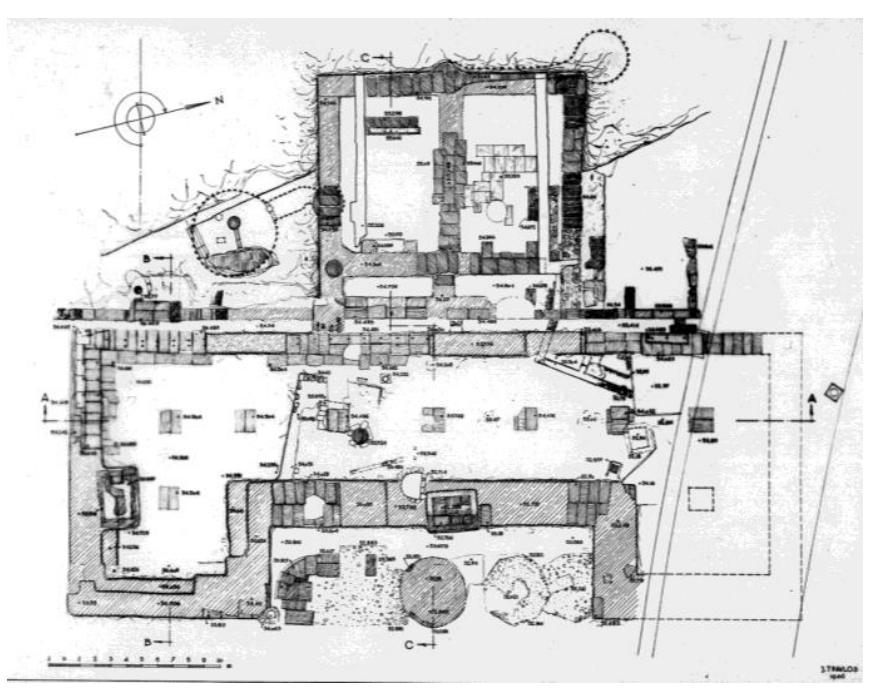

Figura 129. Planta do estado atual e reconstituição do limite setentrional da Stoa de Zeus Libertador, segundo Travlos em $1936\left(\right.$ ASCSA $\left.^{301}\right)$.

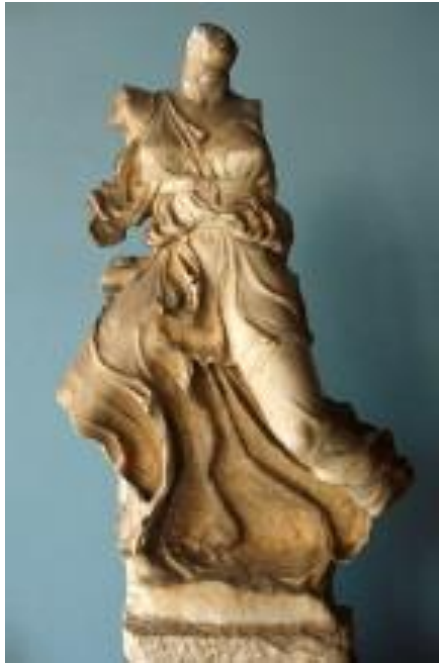

Figura 130. Fragmento de estátua de Vitória alada atribuído aos acrotérios da Stoa de Zeus Libertador (ASCSA ${ }^{302}$ ).

\footnotetext{
${ }^{300}$ Thompson (1966, pp. 178-180) faz referência a três estruturas: um edifício do século IV que só restou por meio de um muro, um edifício em dois ambientes, datado no século II, e um edifício semelhante ao anterior construído após a construção do anexo em questão; entretanto, em diversas plantas da ágora a partir de 300 até a época de Adriano, é representado um recinto pentagonal limitado pelo muro posterior da stoa de Zeus e por um entalhe na rocha natural da colina, que se abre para a via ao norte (Monaco, 2001, p. 112). Nenhum destes edifícios foi identificado, sua(s) função(ões) não foram assegurada(s) com precisão (apesar de indícios de atividade artesanal na área), e nem mesmo há uma apresentação sistemática nas plantas produzidas pelo Athenian Agora Project. Um novo estudo é essencial para a análise desta área, em particular para suas relações com a stoa de Zeus, o anexo e o santuário do Demos e das Graças, localizado poucos metros ao oeste.

${ }^{301}$ Disponível em: http://agora.ascsa.net/id/agora/image/1997.03.0192.

${ }^{302}$ Disponível em: http://agora.ascsa.net/id/agora/image/2000.02.0220.
} 


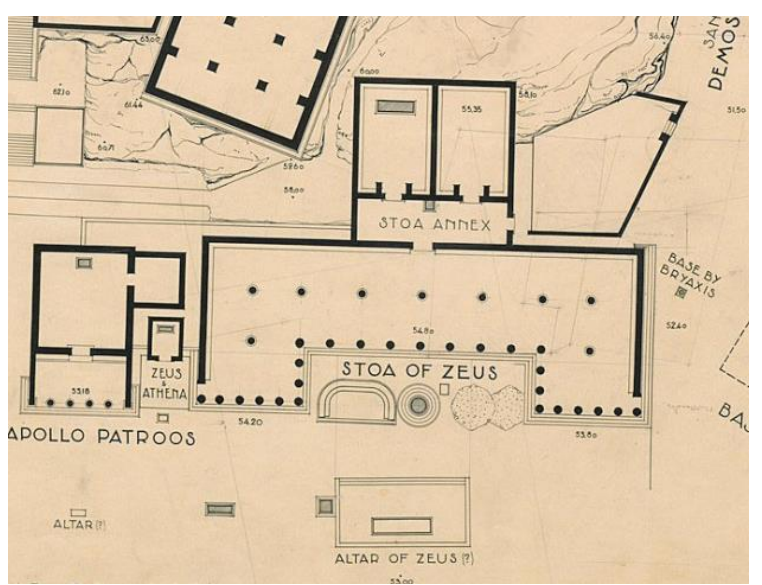

Figura 131. Detalhe da proposta de reconstituição dos edifícios do lado ocidental da ágora, segundo J. Travlos em 1946 $\left(\mathrm{ASCSA}^{303}\right)$.

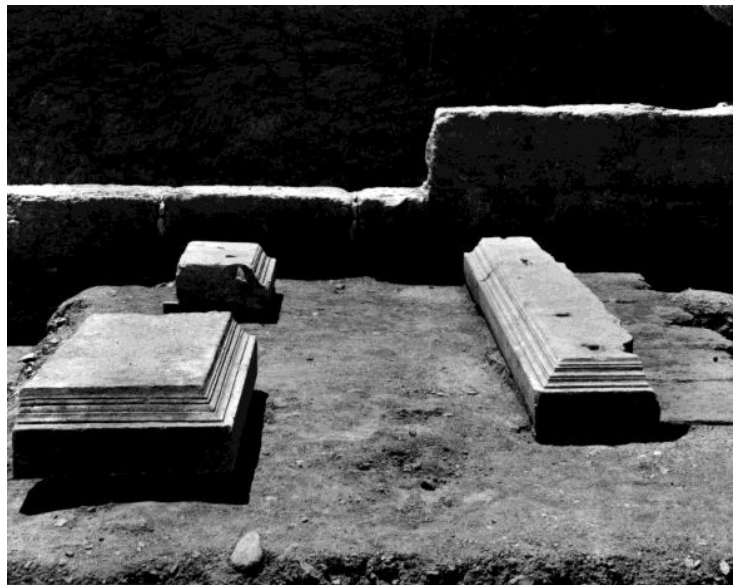

Figura 133. Fotografia dos fragmentos de base de monumento encontrados no ambiente meridional do anexo da Stoa de Zeus Libertador, tirada em 1932 (ASCSA $\left.{ }^{305}\right)$.

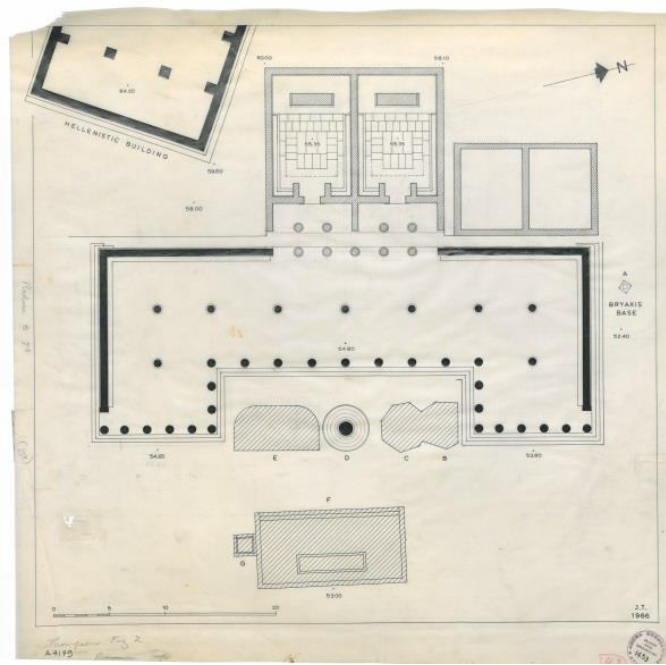

Figura 132. Proposta de reconstituição da planta da Stoa de Zeus Libertador em época romana, segundo J. Travlos em 1966 $\left(\mathrm{ASCSA}^{304}\right)$.

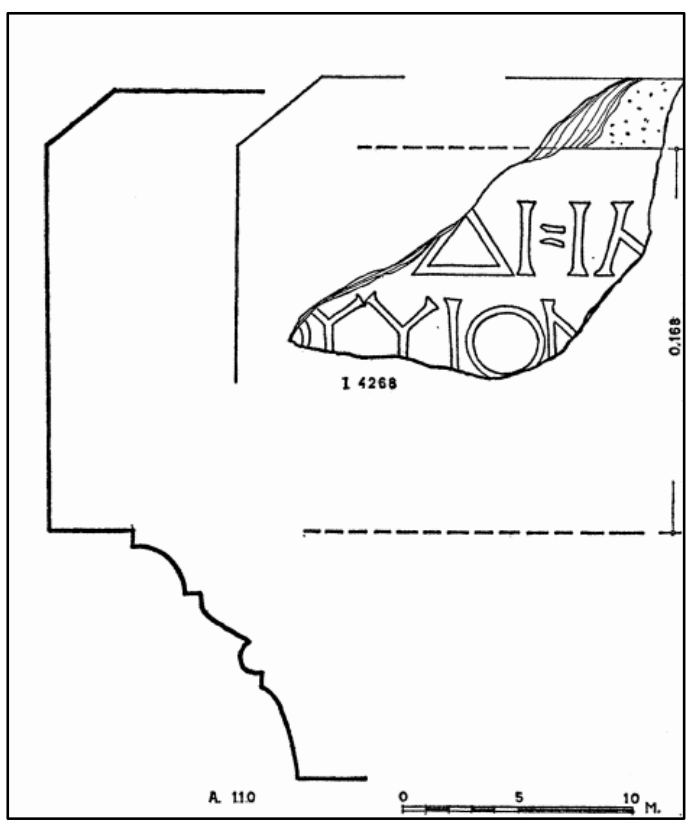

Figura 134. Fragmento inscrito da base do monumento localizado em ambiente medional do anexo da Stoa de Zeus Libertador, inserido no perfil do pilar, segundo Thompson (1966, p. 175, fig. 3).

${ }^{303}$ Disponível em: http://agora.ascsa.net/id/agora/drawing/da\%204135.

${ }^{304}$ Disponível em: http://agora.ascsa.net/id/agora/drawing/da\%204179.

${ }^{305}$ Disponível em: http://agora.ascsa.net/id/agora/image/1997.03.0179. 
Os fragmentos da base de um monumento escultórico, encontrado no ambiente meridional do anexo, são evidências centrais para a contextualização da intervenção como um todo. Tratam-se de peças de mármore pentélico, com marcas de uso de grampos em "pi" - diferente dos grampos em "duplo T" das fundações do anexo -, com marcas de encaixe de estátuas de bronze (fig. 133). Um dos fragmentos está inscrito com parte da inscrição dedicatória (Agora I 4268; fig. 134), onde se lê: “ $\Delta E M$ / $[\mathrm{O}] \mathrm{YYIO}[\mathrm{N}] ”$.

Apesar do péssimo estado de conservação, a segunda linha oferece uma pista para a identidade do(s) homenageado(s): a presença de "vió[v]" seguida das letras

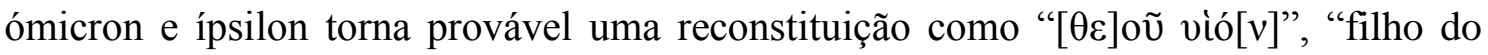
deus" epíteto utilizado largamente nas inscrições relacionadas a Augusto tanto em latim quanto em grego (Schmalz, 1995), o que é coerente com a datação augustana proposta para o anexo. Se a proposta de G. Schmalz, para quem a dedicação se lia como "o demos [dedica ao imperador César Augusto] filho do deus[, e aos [seus] filhos Caio César e Lúcio César] "306 tem uma dose talvez exagerada de especulação (assumida pelo autor), é provável que o monumento representasse não apenas Augusto, como também membros da família imperial. A existência de dois ambientes no anexo, por sua vez, pode significar que se tratava de um culto conjunto de Augusto e Roma, que seria paralelo aos santuários, de época augustana, de Roma e o divino Júlio em Éfeso e de Roma e Augusto em Léptis Magna (Baldassarri, 1998, p. 151, n. 55). Esta hipótese é corroborada pela menção ao culto a Roma e Augusto Salvador "na acrópole", presente na dedicação do monóptero, o que se explicaria melhor pela existência de um culto fora da acrópole; a lógica de duplicação entre a acrópole e a ágora faz com que o ambiente duplo do anexo seja o local ideal para tal culto. Além disso, o culto a Roma já estava associado ao culto de Zeus Eleutherios já no século II, como é documentado em várias cidades da macedônia após a derrota de Perseu em Pidna, em 168 (Monaco, 2001, p. 130, n. 217; Mellor, 1975, p. 107; Mellor, 1981, p. 983). Finalmente, a dedicação de uma estátua de Adriano encouraçado, no século II d.C., diante da Stoa de Zeus, pode ser tomado como mais um indício do envolvimento do anexo com o culto imperial.

A identificação do anexo como sede do culto imperial na ágora é a base para a interpretação da intervenção no sentido da romanização. Augusto (e possivelmente Roma e a família imperial) seria incorporado a um dos principais edifícios da ágora

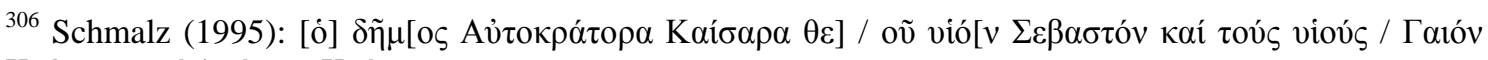

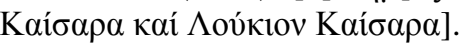


ateniense, que se converteria cada vez mais em um santuário dinástico pelo uso, e ao chalcidicum romano no tipo arquitetural (Torelli, 2005, pp. 26-27). A associação entre Augusto e Zeus, que tem paralelo no projeto de retomada da construção do Olympieion pelos "reis amigos" (Suetônio, Augusto, 60), significaria a cooptação da divindade para a reprodução da autoridade romana sobre a cidade.

No entanto, o modo como a intervenção se insere no edifício - e nas narrativas espaciais atenienses e panhelênicas - ocorre de um modo muito peculiar, diferente de uma simples imposição violenta do culto imperial. O anexo está posicionado atrás da Stoa de Zeus, o que não altera a fachada e não é imediatamente visível para o visitante o que talvez explique a ausência de menção na descrição de Pausânias, para além de decisões conscientes de pouco mencionar Augusto para elevar a memória de Adriano. Não poderia ser diferente: a Stoa de Zeus era um dos mais prestigiosos edifícios da ágora, ligado diretamente à manifestação arquitetural da comemoração antibárbara. $\mathrm{O}$ culto de Zeus Eleutherios foi instituído logo após a batalha de Platéia, em 479, tornando-se assim indissociável da memória da vitória grega sobre os persas ${ }^{307}$. A execução das pinturas com cenas da batalha de Mantinéia, no século IV, demonstra o modo como os atenienses reencenavam o discurso da liberdade da cidade contra ameaças de dominação, sejam elas persas ou tebanas; a pintura de figuras representando os deuses, Teseu, a Democracia e o Demos são indícios da interpretação ateniense do entrelaçamento das relações geopolíticas da cidade com a manutenção do próprio regime democrático. Deste ponto de vista, a instalação de uma sede do culto imperial na Stoa de Zeus seria uma manifestação do processo de integração da nova ordem romana às narrativas fundantes do regime político ateniense, associando o império à democracia, contra leituras que eventualmente denunciassem a abolição da democracia pela própria existência da dominação imperial - ecos do discurso de Athenion. Se esta hipótese estiver correta, o culto imperial na Stoa de Zeus, se por um lado reitera a tradição anti-bárbara ateniense inserindo nela a propaganda imperial (paralela ao monóptero e ao templo de Ares), por outro pode ser interpretada como uma medida das elites locais de fixação da dominação romana nas tradições cívicas e democráticas atenienses.

307 Plutarco, Aristides, 19-21; Diodoro Sículo, 11.29.1-2; Estrabão, 9.2.31. Sobre o protagonismo ateniense no culto, cf. Kelly, 2010, pp. 62-65. 


\section{O novo recinto do Tholos-Bouleuterion-Strategion e outras reformas}

A lista de intervenções augustanas no lado ocidental da ágora inclui, além do anexo à Stoa de Zeus, uma série de pequenas obras de reformas e adições ao complexo administrativo do limite sudoeste da ágora, formado pelo Tholos, o Novo Bouleuterion e o edifício identificado como o Strategion, todos eles datados do século V, sem terem sofrido alterações significativas até então. Tratam-se de edifícios centrais para a administração da cidade: no Tholos reuniam-se os conselheiros da tribo responsável pela condução diárias dos assuntos públicos em um mês determinado, reunião esta que incluía a refeição coletiva financiada pelo estado; o novo Bouleuterion sediava as reuniões do Conselho dos 600 (considerando as doze tribos remanescentes, as dez clistênicas mais aquelas em homenagem a Ptolomeu II e Átalo I); o Strategion, caso esteja correta a identificação, era a sede dos gabinetes de generais, um para cada tribo, e provavelmente submetidos à autoridade do general dos hoplitas, cargo de importância crescente a partir do século I - o que pode estar associado, como se argumentará, ao conjunto das reformas.

As intervenções de época augustana incluem a construção de um propileu no Tholos, junto à sua entrada oriental, de outro propileu, externo, sobre o muro que ligava o recinto do Tholos ao recinto do Strategion, uma pequena fonte ao sudoeste do Tholos, uma fonte de maiores dimensões diante do novo Bouleuterion, e uma exedra ao leste do Tholos $^{308}$. A articulação dos espaços é complexa (fig. 135): a sucessão e sobreposição de acessos é indicativa da possível necessidade de controle da mobilidade nos prédios administrativos. Assim, o recinto do Tholos, a partir da época augustana, poderia ser acesso a partir do novo propileu exterior, que dava acesso à entrada sul do recinto do Tholos e, por meio desta, ao novo propileu leste do Tholos; uma alternativa era utilizar o propileu helenístico, ao sul do Metroon, que dava acesso à entrada norte do recinto do Tholos, a partir da qual se alcançava a entrada tanto da cozinha a leste quanto da entrada norte do próprio edifício. O Strategion era acessado primordialmente pelo novo propileu exterior. O Novo Bouleuterion era acessado de duas maneiras: pelo sul,

\footnotetext{
${ }^{308}$ A ordem cronológica das adições é bastante complexa: com base na cerâmica associada às fundações e do fato de que o Tholos foi fortemente danificado durante o saque de 86 , P. Baldassarri sugere que o pórtico do Tholos tenha sido a primeira das intervenções, seguida pela ampliação do muro do recinto e pela construção do propileu externo - o que gerou a necessidade de uma rearticulação do sistema drenagem na área - e pela posterior construção da "exedra" e da fonte do Novo Bouleuterion (Baldassarri, 1998, p. 223). No entanto, não há indicações claras para tal sequência, e é possível que a exedra seja posterior ao período augustano, dadas as semelhanças na disposição dos blocos de fundação com edifícios posteriores, como o Templo Sudoeste (Burden, 1999, p. 161-162).
} 
utilizando-se o propileu exterior, por um caminho que passava pelo Tholos e pela nova fonte, ou diretamente pelo leste, através do propileu do século IV; a disposição da colunata de fachada do edifício, com sete colunas na sua face sul e duas na face leste, aponta para uma apreensão mais clara da monumentalidade para aqueles que utilizavam a entrada pelo novo propileu.

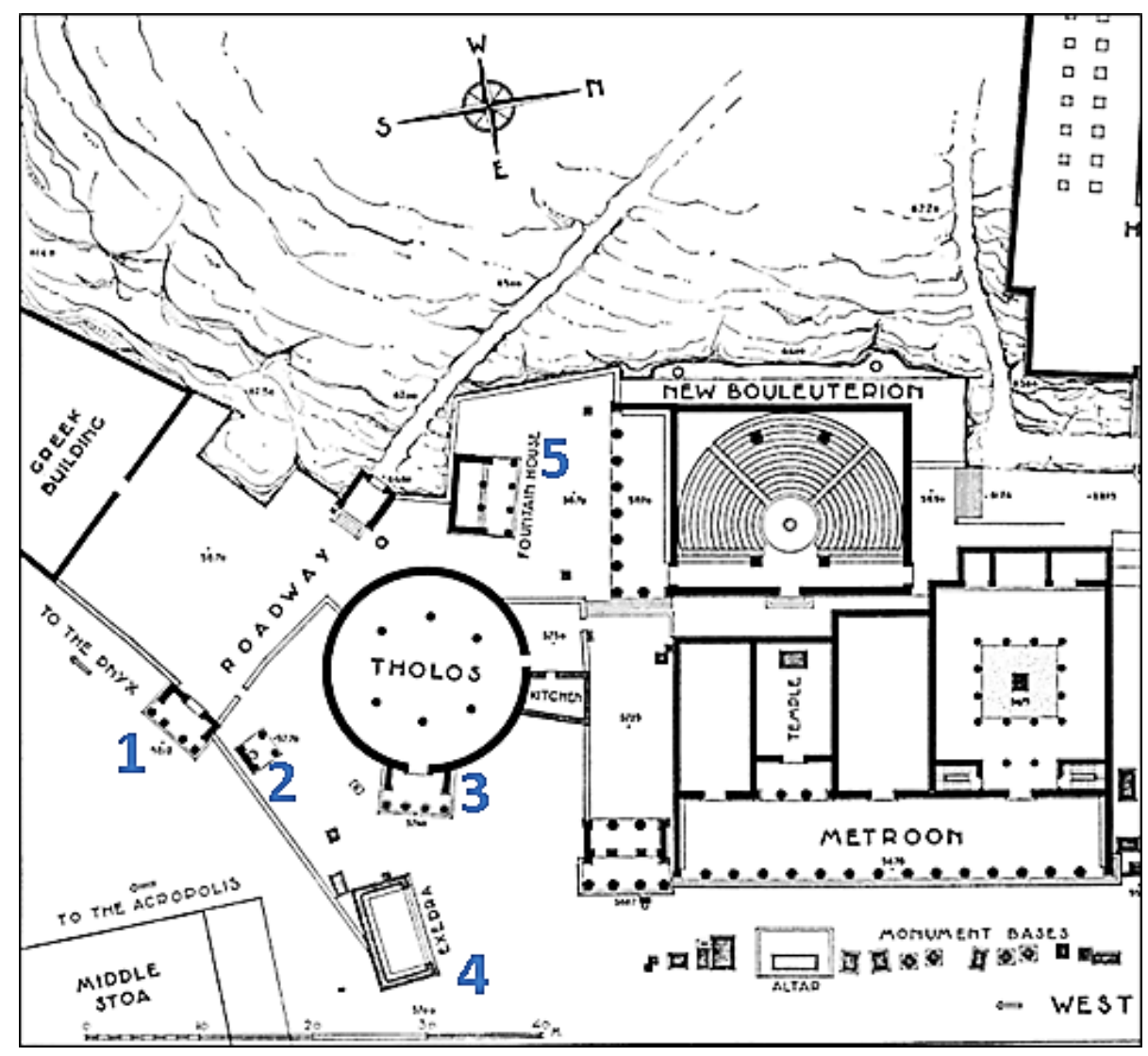

Figura 135. Detalhe da proposta de reconstituição do lado ocidental da ágora no período imperial, segundo J. Travlos em 1946 (Travlos e Thompson, 1949, p. 390, fig. 2). 1. Propileu exterior do Strategion. 2. Fonte do Tholos. 3. Propileu do Tholos. 4. Exedra. 5. Fonte do Bouleuterion.

Os vestígios do propileu externo se limitam às fundações de blocos em poros de reuso, blocos dos degraus em mármore do Himeto, e fragmentos de superestrutura (arquitrave e cornija) em calcário com marcas da utilização de estuque branco, siulando o mármore pentélico; a partir disso, foi sugerida uma elevação como um propileu tetrastilo dórico. O propileu do Tholos, por sua vez, é conhecido pelas fundações em conglomerado, poros e mármore de reuso, além de degraus em mármore do Himeto; as proporções do edifício e das fundações indicam um propileu tetrastilo jônico ou coríntio - neste último caso, paralelo ao propileu da "Torre dos Ventos". O reuso de materiais, 
ao lado da utilização de estuque, indica a preocupação em reduzir custos de construção, o que pode apontar para a ausência de participação de evergetas no financiamento da construção - o que seria coerente com o financiamento público por iniciativa dos magistrados que ocupavam o edifício, cuja entrada seria monumentalizada com o novo propileu.

A cerâmica associada às fundações do muro meridional e oriental do Tholos e as alterações no sistema de drenagem apontam para uma datação augustana (Baldassarri, 1998, p. 225), o que significa que a área do recinto - chamado Pritanikon - foi consideravelmente ampliada. Tal extensão pode ser explicada pela própria construção do novo propileu do Tholos, que reduziu a área livre utilizada, desde o período clássico, para dedicação de estelas com decretos honoríficos aos conselheiros. Tal espaço foi novamente reduzido com a construção de uma estrutura semelhante a uma exedra, cujos vestígios se limitam às fundações em conglomerado. Caso seja de fato uma exedra, surge a questão da identidade das estátuas dedicadas ali, das quais não há nem vestígios nem menções. A base de estátua com inscrição dedicatória a "Júlia Augusta [Héstia] Boulaia mãe de Tibério César Augusto, [dedicada pelo] demos e [pelo] conselho do Areópago" (SEG 22.152; Schmalz, 2009, p. 107), encontrada próxima ao Bouleuterion e datada da época de Tibério, poderia indicar que a exedra contivesse um grupo escultórico em honra à família imperial, reforçando a tradição, encontrada alhures, da dedicação de estátuas imperiais em edifícios da administração pública; no entanto, não é possível afirmar com certeza tal destinação.

Finalmente, duas fontes foram adicionadas, datadas com alguma segurança do período augustano, ao Tholos e ao Novo Bouleuterion, ambas com fundações com blocos de reuso de calcário, conglomerado e, no caso da segunda, mármore. Esta, consideravelmente maior, foi abandonada pouco depois de sua construção, como demonstra a presença de vestígios de um muro construído em meados do século I d.C. sobre as ruínas da fonte. A funcionalidade das fontes, tanto para a hidratação cotidiana quanto para os rituais associados aos sacrifícios propiciatórios às atividades administrativas, explica sua colocação, o que seria coerente com uma iniciativa dos próprios usuários do complexo. $\mathrm{O}$ abandono da fonte maior poderia estar ligado tanto a eventuais dificuldades no abastecimento hídrico, quanto a alterações no projeto do Bouleuterion no período posterior; a manutenção da fonte menor do Tholos pode indicar que a construção da fonte diante do Bouleuterion fosse percebida, algum tempo depois 
ao menos, como um projeto desnecessário - indício de uma prodigalidade demasiada dos conselheiros da época augustana?

Caso esta hipótese esteja correta, é possível interpretar o conjunto das intervenções como formas de monumentalizar o Strategion-Tholos-Bouleuterion, que não havia sido objeto de ação construtiva no século II - por oposição ao Metroon, profundamente remodelado com provável participação pergamena. $\mathrm{O}$ amplo processo de reestruturação e monumentalização da ágora, com a construção do Agrippeion e a transposição do altar de Zeus Agoraios (?) e do templo de Ares, pode ter sido percebida pelos magistrados do Strategion e os conselheiros como uma oportunidade de investir em seu próprio complexo. A crescente importância política das magistraturas associadas a este complexo, ao longo do século I e particularmente no período augustano - em função da maior oligarquização da política ateniense - talvez seja a chave destas reformas, que adequam o complexo ao restante da ágora ${ }^{309}$.

Por outro lado, a prática da reutilização de materiais, assim como da utilização de estuque, é sintomática da ocupação rotativa das magistraturas, que não seriam associadas, de modo definitivo, à personalidade de potenciais evergetas locais. Se a sugestão da existência de uma "competição arquitetural" entre a iniciativa estatal (reforma do complexo administrativo) e o evergetismo imperial (Agrippeion e, provavelmente, os templos e santuários transpostos) seja exagerada, é lícito observar o desnível entre a opulência das construções que ocupavam o centro da ágora em relação aos arranjos e adaptações de edifícios periféricos na ágora mas centrais na estruturas administrativas atenienses.

\section{Intervenções no norte da ágora}

A região ao norte da ágora ateniense também foi objeto de ação construtiva na época augustana: um novo templo aparece no limite noroeste e uma nova stoa no limite nordeste. Provavelmente relacionadas a elas, duas novas stoas são construídas ao longo de parte da Via Panatenaica, no final do trajeto entre o Dípilo e a Stoa Real. Vejamos.

${ }^{309}$ Uma associação entre a reforma no Banho helenístico, construído no século II e danificado em 86 (Shear Jr, 1969, pp. 394-415), e a reforma do complexo administrativo é atraente, na medida em que poderia indicar o investimento arquitetural em espaços ocupados por magistrados e membros da elite ateniense; estudos mais detalhados sobre os dois conjuntos, no entanto, são necessários para o desenvolvimento desta hipótese. 
O chamado "Templo Noroeste" foi escavado somente na década de 80, com a ampliação da área do Athenian Agora Project para além da rua Adrianou. Tal ampliação foi responsável, entre outras coisas, pela identificação e determinação da correta orientação da Stoa Pintada, a qual, diferentemente do que se pensava, a stoa se oriente em um eixo sudoeste-nordeste, e não noroeste-sudeste, o que ampliou consideravelmente a área norte da ágora (fig. 136). A poucos metros ao oeste do limite ocidental da Stoa Pintada, foi escavado um altar, dedicado entre o século VI e V, contendo uma série de restos de sacrifícios animais, em particular pássaros, com orientação norte sul. A poucos metros ao norte do altar foram encontrados blocos de poros relativos às fundações e a alguns degraus da fachada de um edifício em pódio, de planta muito próxima a um pronaos e o início da cela, o que levou o escavador a sugerir que se tratava de um templo, medindo 10 por 9,45 metros. A exiguidade dos vestígios da superestrutura impede uma reconstituição mais precisa, mas há fortes indícios de era um templo tetrastilo prostilo, possivelmente jônico, caso se aceite a associação de Shear Jr. do capital jônico encontrado nas proximidades ao edifício em questão (Burden, 1999, p. 165). O edifício apresenta uma orientação ligeiramente noroeste-sudeste, não completamente alinhado ao altar.
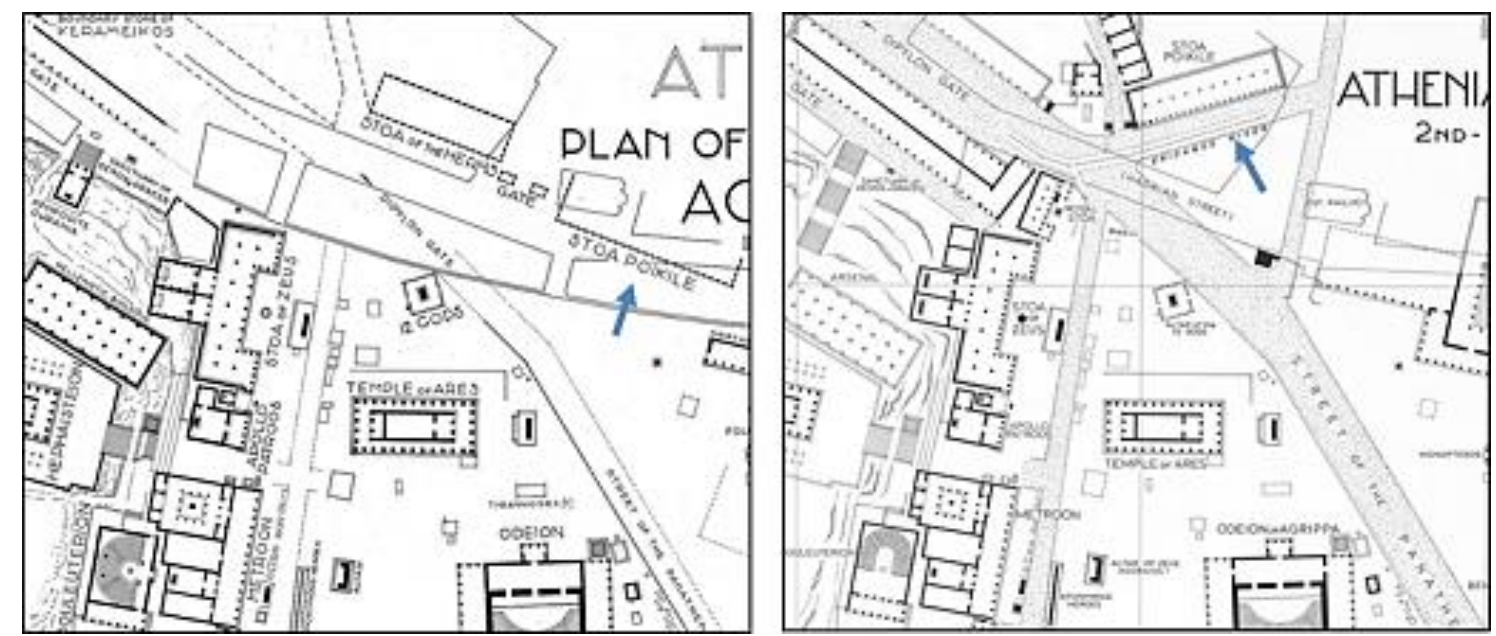

Figura 136. Comparação da localização da Stoa Pintada (indicada pela seta azul) no detalhe das propostas de reconstituição da planta da ágora, respectivamente, de J. Travlos em 1959 e de $R$. Anderson em 1992 (ASCSA $\left.{ }^{310}\right)$.

\footnotetext{
${ }^{310}$ Plantas integrais disponíveis em, respectivamente: http://agora.ascsa.net/id/agora/image/2002.01.0750 e http://agora.ascsa.net/id/agora/drawing/da\%203912.
} 
A identidade do altar é fundamental para a identificação do templo. Com base no relato de Pausânias e em uma primeira análise dos restos de animais sacrificados, o altar foi associado ao santuário de Afrodite Urânia. A partir disso, construiu-se uma interpretação que via no templo uma intervenção augustana inserindo, monumentalizando o santuário de uma deusa intimamente ligada às tradições romanas (Afrodite/Vênus) na principal entrada da ágora. Um paralelo eloquente seria o templo $\mathrm{F}$ do fórum de Corinto, atribuído provavelmente a Vênus, contemporâneo e similar na topografia e planta ao Templo Noroeste da ágora ateniense (Williams, 1989, p. 26-37; Burden, 1999, pp. 166-168).

No entanto, ainda que ainda apareça nos materiais de divulgação da Escola Americana, esta identificação foi profundamente criticada a partir de fortes argumentos formulados primeiramente por M. Osanna (1988-89), e desenvolvidos por M. Torelli (1995, p. 29-30) e P. Baldassarri (1998, pp. 182-197). Em primeiro lugar, a análise mais detalhada dos restos de animais sacrificados demonstrou reduziu a importância relativa da quantidade de pássaros, associados ao culto de Afrodite, além de apontar para a existência de restos de porcos, animal interdito no culto a Afrodite, ao menos no continente grego (Torelli, 1995). Em segundo lugar, Pausânias (1.14.7) menciona o santuário de Afrodite Urânia como próximo ( $\pi \lambda \eta \sigma i ́ o v)$ o Hephaisteion, enquanto que, na passagem seguinte, afirma que, no caminho para a Stoa Pintada, estão uma estátua de bronze de Hermes Agoraios e um portão - o que torna improvável que o santuário de Afrodite Urânia se localizasse muito mais próximo à Stoa Pintada do que ao Hephaisteion, como é o caso do "Templo Noroeste". Em terceiro lugar, um poço encontrado na encosta da Kolonos Agoraios (depósito G 5:3, "bone well"311) continha uma série de depósitos coerentes com o culto (ctônico e curotrófico ${ }^{312}$ ) de Afrodite: uma herma feminina (fig. 137), ossos associados de crianças e de cães (fig. 138) e fragmentos de cerâmica (como alças de ânfora), os dois últimos datados do terceiro quartel do século II. Em nenhuma planta geral da ágora há indicação da localização exata deste poço, mas, a partir do rascunho do "estado geral" da seção $\Lambda \Lambda$, onde o poço foi encontrado, é possível determinar com alguma exatidão sua localização (fig. 139). Que o santuário de Afrodite Urânia se localize na encosta nordeste da Kolonos

311 Explorado em 1938 (Shear, 1939, pp. 238-239). Fotografias dos cadernos de notas e materiais encontrados no poço disponíveis em: http://agora.ascsa.net/id/agora/deposit/g\%205\%3a3\&t=deposit\&v=list

${ }^{312}$ Ou seja, ligado à proteção das crianças e à comunicação entre os mundos. Cf. Osanna (1988-1989, pp. 91-94) sobre estes aspectos do culto de Afrodite Urânia em Chipre e na Grécia continental. 
Agoraios, pois, é extremamente provável. Duas estruturas poderiam estar associadas ao santuário, mas a exiguidade dos vestígios impede uma determinação mais precisa. São eles um entalhe retangular na rocha natural, de datação muito incerta entre o período helenístico e o romano, identificado por J. Travlos (1980, pp. 79-83) como base de um templo, por Thompson (e Wycherley, 1972, p. 142, n. 127), como base para um templo ou propileu, e por Pounder (1980, p. 240, n. 20) como base de uma escadaria que daria acesso ao "Arsenal" helenístico; e o misterioso recinto pentagonal construído junto ao muro posterior da Stoa de Zeus (1966, pp. 178-180). O poço com material associável ao culto de Afrodite se localiza mais próximo do último, mas a proximidade do primeiro ao santuário do Demos e das Graças, que continha um altar dedicado, inclusive, a Afrodite Hegemone, o torna um forte candidato.
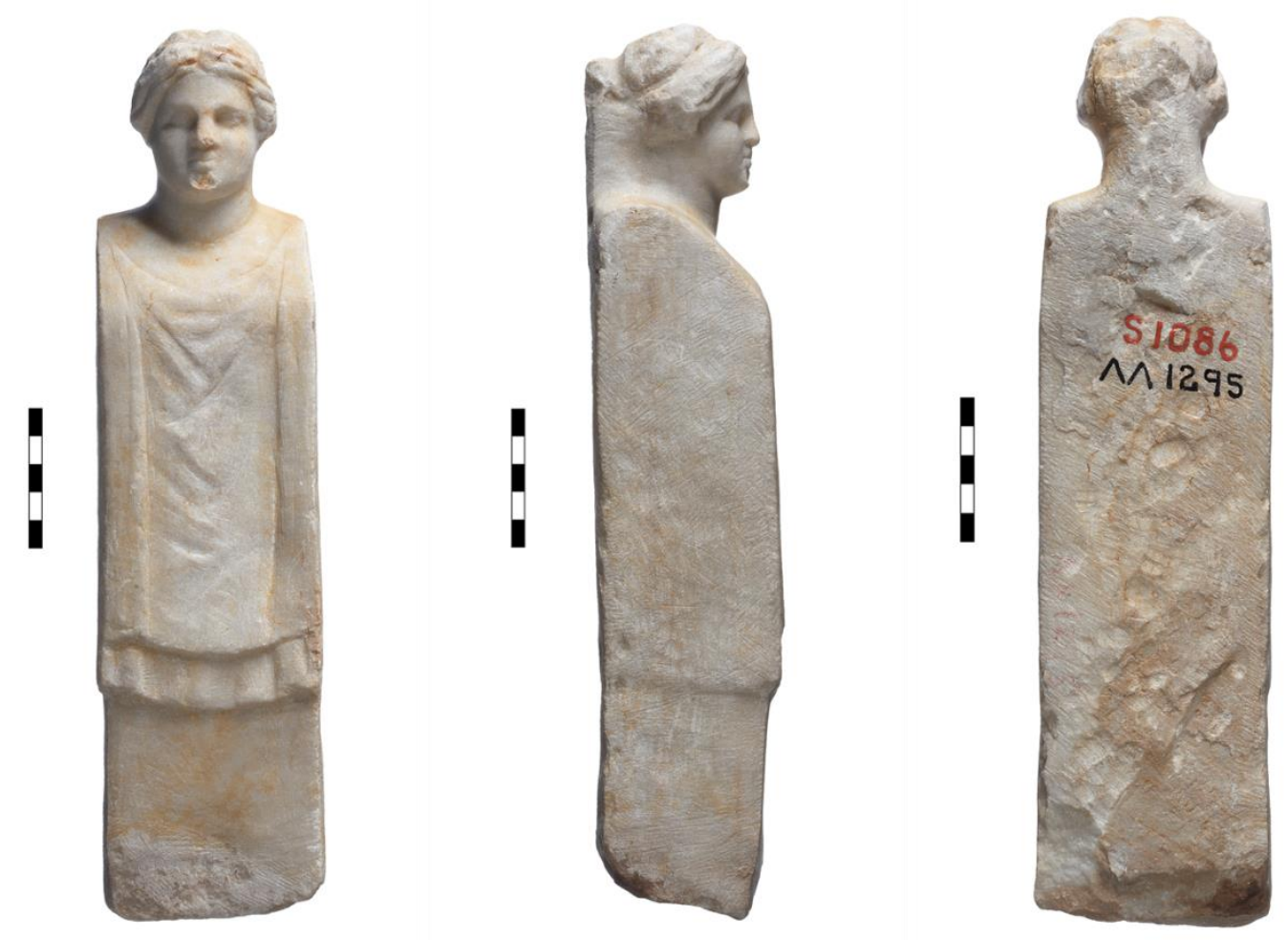

Figura 137. Fotografia da frente, perfil e costas da herma feminina encontrada em poço na encosta nordeste da Kolonos Agoraios, tirada em 2013 por C. Mauzy (ASCSA ${ }^{315}$ ).

${ }^{315}$ Disponível em: http://agora.ascsa.net/id/agora/object/s\%201086. 


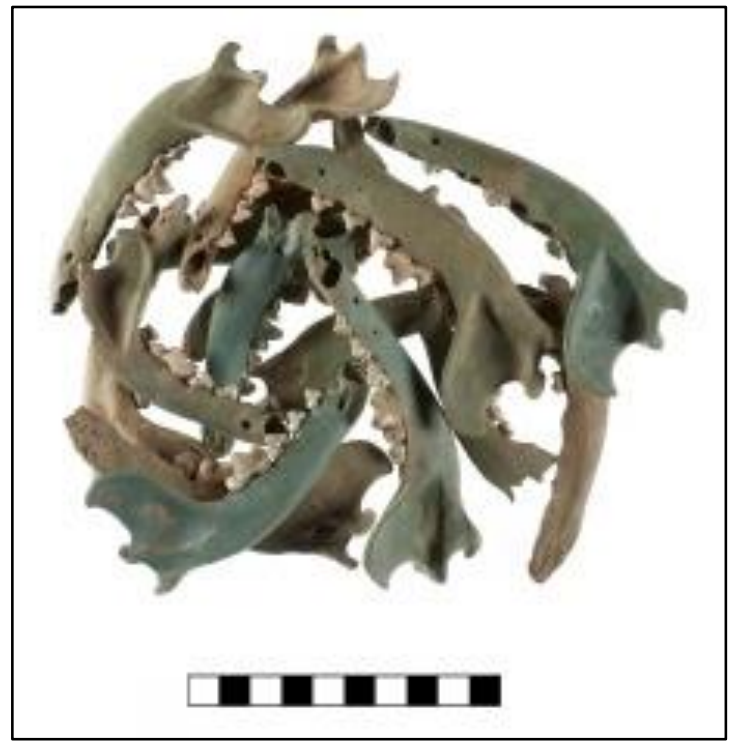

Figura 138. Fotografia dos fragmentos ósseos de cães encontrados no depósito $G$ 5:3, tirada por Angelique Sideris em 2011 (ASCSA $\left.{ }^{316}\right)$.

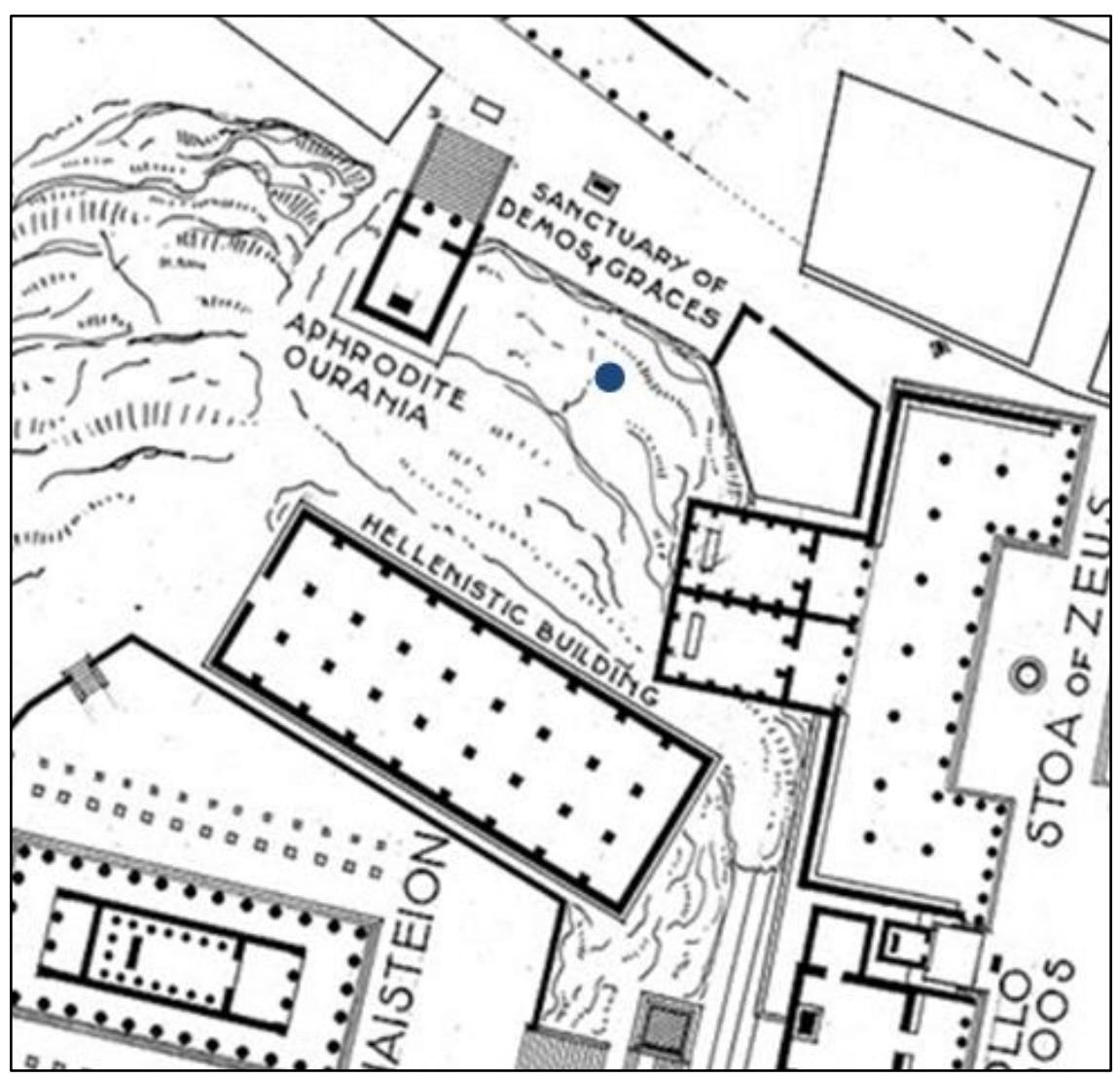

Figura 139. Detalhe da proposta de reconstituição da planta da ágora, segundo J. Travos em $1959\left(\operatorname{ASCSA}^{317}\right)$, com indicação (minha) da localização do poço "g 5:3" (ponto azul) de acordo com a planta do estado atual da seção $\Lambda \Lambda$ produzida em $1937\left(\operatorname{ASCSA}^{318}\right)$.

\footnotetext{
${ }^{316}$ Disponível em: http://agora.ascsa.net/id/agora/image/2013.01.0027

${ }^{317}$ Disponível em: http://agora.ascsa.net/id/agora/image/2002.01.0750.

${ }^{318}$ Disponível em: http://agora.ascsa.net/id/agora/drawing/da\%20106.
} 
Aceitando-se a proposta dos arqueólogos italianos de localizar o santuário na encosta da Kolonos Agoraios, abre-se novamente a questão da identidade do Templo Noroeste. Uma solução bastante plausível foi sugerida por M. Osanna (1988-1989), seguida pelos arqueólogos italianos (e solenemente ignorada pelos americanos), para quem o altar e o templo eram dedicados ao culto de Hermes. Esta identificação se baseia em três fatores. O primeiro é a reconstituição a partir de duas menções de Pausânias a Hermes na ágora: a primeira (1.2.5) é feita logo após descrever o Pompeion, ou seja, após atravessar o Dípilo mas antes de entrar na ágora, quando Pausânias menciona um

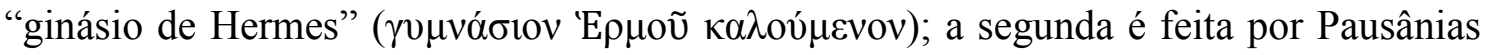
no contexto da descrição da Stoa Pintada, acima mencionada $(1.14 .7)^{319}$. A existência de um altar dedicado especificamente a Hermes Agoraios, mencionado por PseudoPlutarco (Vita X Orat., 844b), une o altar à estátua mencionada por Pausânias. O segundo fator é a localização do santuário, na imbricação de duas vias de acesso à ágora (pelo norte e a partir do Dípilo), coerente com as atribuições religiosas de Hermes como deus dos caminhos; as evidências de práticas comerciais realizadas em associação aos edifícios ao norte da Stoa Pintada vão na mesma direção. O terceiro fator é a importância de Hermes na propaganda augustana, o que seria coerente com a datação do edifício. De fato, Augusto é associado a Hermes mesmo antes do principado, o que é reforçado ao longo de seu governo como parte da representação de Augusto como propiciador da prosperidade e da concórdia, tanto na literatura (Horácio, Carm., 1.2.41), quanto na epigrafia e na numismática (fig. 140; Zanker, 1988, pp. 53-54, 132-134, 267269; Baldassarri, 1998, pp. 195-196, nn. 60-62).

A partir destes elementos, foi estabelecida a interpretação romanizante do Templo Noroeste: se santuário de Afrodite Urânia, seria a inclusão de uma deusa associada à gens Júlia na entrada da ágora; se santuário de Hermes Agoraios, seria a introdução de uma divindade fortemente associada a Augusto neste privilegiado local. $\mathrm{O}$ pódio sobre o qual se esguia o templo, por sua vez, reforçaria a leitura romanizante dos visitantes da ágora.

${ }^{319}$ Ao que se acrescente a referência a um altar de Hermes Agora 


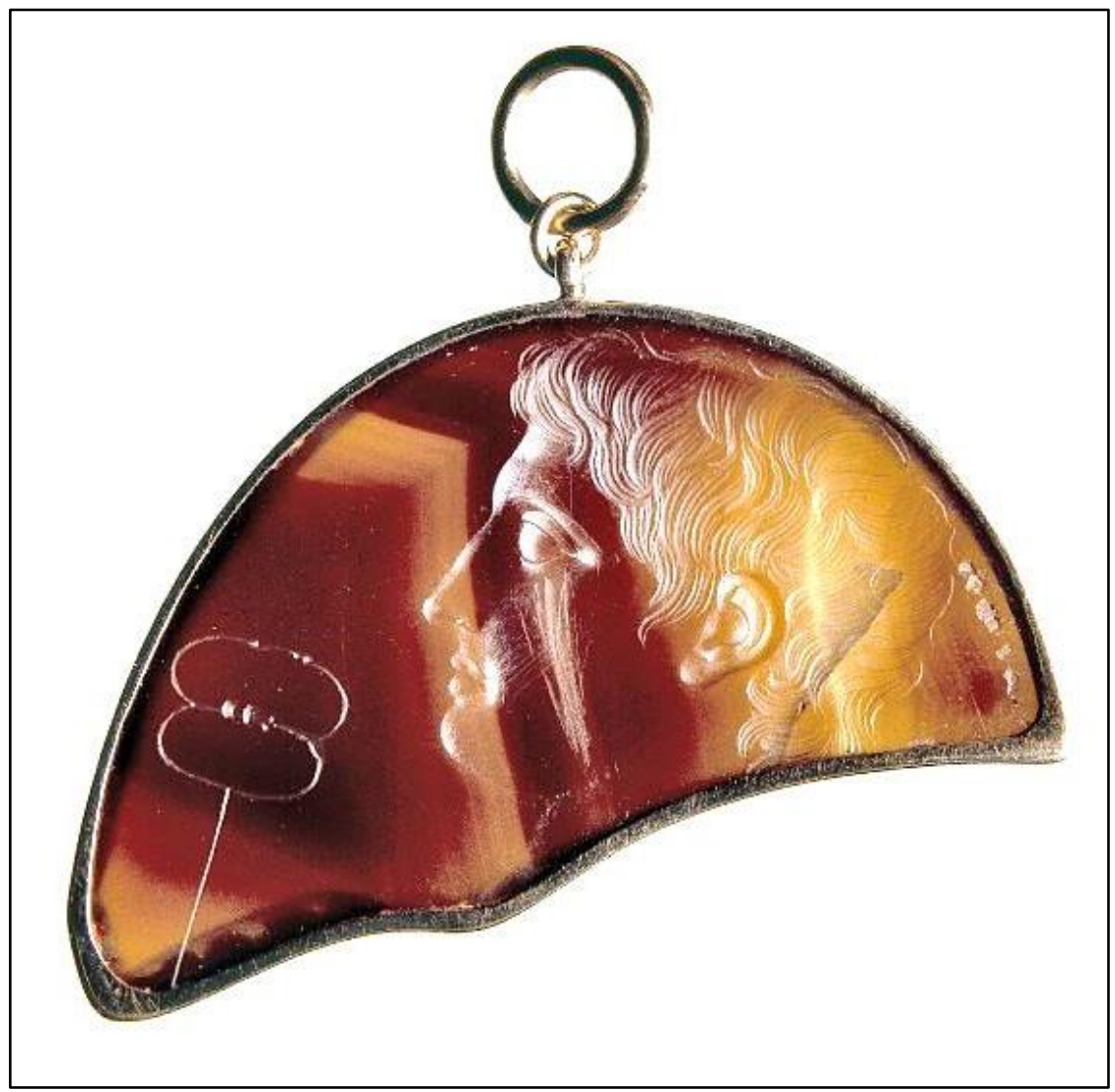

Figura 140. Fotografia de fragmento da parte superior de placa em ágata (quartzo) marrom com perfil de Otávio e caduceu em baixo relevo ("Otávio Ionides", aprox. 6 x 4 cm), atribuído ao gravador Sólon, datada de 35 e 27 a.C. Atualmente no Museu Britânico ${ }^{320}$.

No entanto, outros elementos apontam para a direção oposta. Em primeiro lugar, seja como santuário de Afrodite Urânia, seja como santuário de Hermes Agoraios, o templo se articulava a cultos já tradicionais na ágora. O papel de Afrodite nos mitos de fundação atenienses, em particular aqueles ligados a Egeu e a Teseu, já foram ressaltados antes; Hermes, por sua vez, para além de sua quase onipresença nas vias e cruzamentos, é uma divindade profundamente relacionada aos mistérios eleusinos: é ele que leva Perséfone de volta a sua mãe, Deméter, o que propicia o ciclo agrário. $\mathrm{O}$ prestígio dos mistérios eleusinos entre os romanos e, acima de tudo, em Augusto iniciado duas vezes no ritual - pode ser um indício da eleição de Hermes como divindade cujo santuário receberá um projeto de monumentalização; santuário este já antigo naquele ponto da ágora, caso se aceite a identificação do altar do século VI/V como sendo atribuído a este deus, como parece indicar as passagens de

\footnotetext{
${ }^{320}$ Disponível em:

http://www.britishmuseum.org/research/collection_online/collection_object_details.aspx?objectId=46744 $0 \&$ partId $=1$
} 
[Pseudo]Plutarco e de Pausânias acima mencionadas. Em segundo lugar, caso se confirme a sugestão de L. Shear Jr. (realizada em uma apresentação oral, não publicada; cf. Burden, 1999, p. 165) de atribuição ao templo de fragmentos de colunas jônicas encontradas na proximidade, um novo elemento seria introduzido: tais fragmentos revelam que a ornamentação da coluna segue estritamente o programa da colunata leste do Erechtheion, e consequentemente do monóptero de Roma e Augusto na acrópole. Se esta hipótese estiver correta, o novo templo presta homenagem à arquitetura clássica assim como o monóptero e/ou reitera as relações já estabelecidas na instalação do culto imperial na acrópole.

De um ponto de vista espacial, portanto, o Templo Noroeste tanto se articula com o programa augustano, em sua arquitetura e possíveis referências religiosas, quanto com as lógicas espaciais e rituais locais. Se por um lado a utilização do pódio apresenta uma clara referência romanizante, por outro sua localização no limite, e não no centro da ágora, rompe com a tendência de ocupação da área interna inaugurada pelo Agrippeion e pelo templo de Ares, construídos, com grande probabilidade, algumas décadas antes. De qualquer modo, a instalação neste ponto de um templo se articula a um projeto maior de monumentalização da área norte na ágora, realizado, além do novo templo, com a construção de três novas stoas. Vejamos.

Pelo noroeste, a ágora era alcançada pelas vias que partiam da Porta Sagrada e do Dípilo. Não está claro se se tratavam de uma ou mais vias, e a partir de que ponto a via principal passava a se chamar "Via Panatenaica"; a localização do Pompeion junto ao Dípilo, entretanto, parece indicar que esta via era assim denominada já desde um dos portões. A distância entre o Dípilo e a entrada da ágora, tomando como referência a Stoa Real, era de aprox. 400 metros. Nos últimos (cerca de) 70 metros a Via Panatenaica era emoldurada por duas stoas, ao norte e ao sul, construídas no final do século I (datação a partir da cerâmica associada às fundações; Shear Jr., 1971, pp. 260261). A stoa ao norte ainda não foi escavada integralmente, o que compromete de modo radical seu conhecimento; a stoa ao sul, por sua vez, foi profundamente estudada ao menos em seus primeiros 32 metros, do leste para o oeste, sendo portanto melhor conhecida que a primeira. Trata-se de uma stoa "dupla", ou seja, colunada tanto na face norte quanto na face sul, medindo cerca de 76 metros de extensão e cerca de 14 metros de largura, fechada por muros contínuos nos lados menores. Na extremidade oriental, um propileu avança para o norte, garantindo acesso tanto à área coberta norte quanto à sul, aparentemente separadas pelo muro contínuo que corre entre elas, exceto pela 
existência de aberturas (que não deixaram vestígio inequívoco). A disposição das colunatas e dos espaços cobertos indica que a stoa se comunicava com ambas as vias, mas controlava a circulação entre elas: indício de especialização de atividades? A diferenciação entre o norte e o sul é reforçada pelos materiais utilizados: a face sul utiliza muito mais blocos de reuso do que a face norte. Estes blocos são provenientes no Arsenal helenístico localizado na Kolonos Agoraios, destruído durante o saque de 86; sua reutilização na "Stoa Dupla" pode estar associada tanto à proximidade entre os locais de descarte e de reuso, quanto às fragilidades econômicas da cidade na atividade de construção civil - o que apontaria para o financiamento local, sem a participação de evergetas. O uso da stoa é dificilmente determinável: Schmalz (1995, p. 71) sugere um uso comercial, mas não se podem negligenciar as relações da stoa com os santuários do local. Considerando a posição do propileu leste da stoa, parece evidente a monumentalização do acesso, a partir da encruzilhada da ágora, ao conjunto dos santuários do Demos e das Graças e de Afrodite Urânia, assim como ao próprio Hephaisteion, e eventualmente para as câmaras do culto imperial no lado posterior da Stoa de Zeus, caso elas se comunicassem com a área. Além disso, a descrição de Pausânias acerca das stoas que bordejam a Via Panatenaica a partir do Dípilo apontam para a utilização desta stoa em parte como santuário (de Dioniso?), em parte como espaço de exposição de estátuas associadas ao passado mítico ateniense (Pausânias, 1.2.4-5). Em associação à stoa ao norte, a Stoa Dupla realiza na Via Panatenaica um processo já conhecido no período helenístico, mas difundido especialmente no período do Alto Império: a monumentalização das vias principais por meio da construção de stoas em ambos os lados (Schmalz, 1995, pp. 72-73).

No limite nordeste da ágora um projeto diferente parece ter tido lugar: trata-se da chamada Stoa Nordeste, cujas fundações e parte da superestrutura foram escavadas já em 1938, revelando uma face colunada da ordem jônica, medindo cerca de 26 metros de comprimento. Sua articulação em um edifício posterior, a chamada "Basílica Adriânica" (fig. 141), além da construção da linha férrea, impede a compreensão do restante do edifício. Os fragmentos arquiteturais que sobreviveram revelam um edifício bastante eclético quanto ao uso dos materiais: mármore azul do Himeto para os degraus e as paredes, colunas monolíticas em mármore esverdeado da Eubéia, e mármore branco pentélico para a entablatura; fragmentos de capitéis, bastante semelhantes na ornamentação aos capitéis do Erechtheion, indicam a ordem jônica da stoa - além de mais uma possível reiteração da relação entre os edifícios novos e o Erechtheion, como 
demonstrado no monóptero de Roma e Augusto e, possivelmente, no Templo Noroeste (fig. 142).

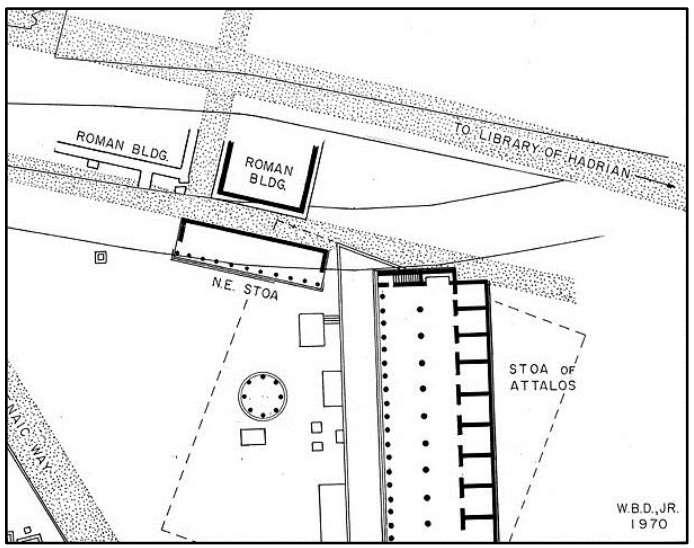

Figura 141. Detalhe da proposta de reconstituição da planta da região norte da ágora, segundo W. Dinsmoor em 1970, com destaque para a Stoa Nordeste $\left(\operatorname{ASCSA}^{321}\right)$.

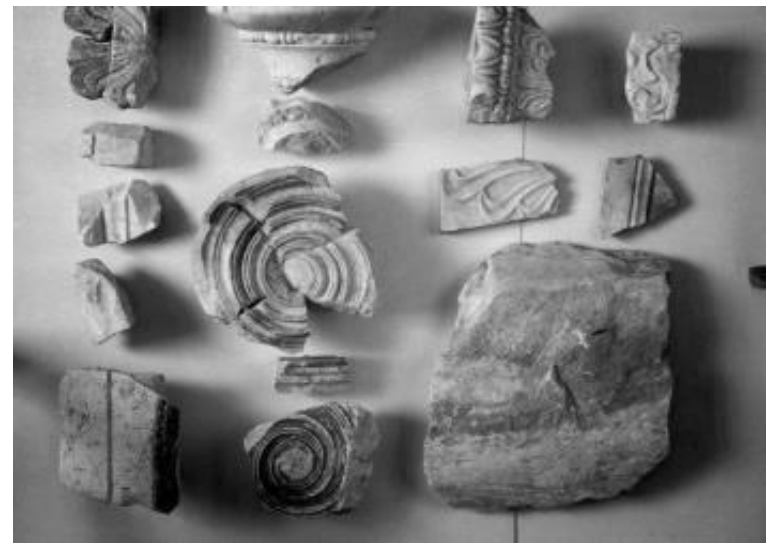

Figura 142. Fotografia dos fragmentos arquiteturais associados à Stoa Nordeste, tirada em $1950\left(\mathrm{ASCSA}^{322}\right)$.

Não há indicações do uso da stoa; a sugestão de Schmalz (1995, pp. 73) de que a stoa se destinava a abrigar sedes de magistraturas se funda somente na posição da stoa em relação à ágora, o que está longe de ser definitivo. Com argumentação mais consistente, Schmalz (1995, pp. 76-79) sugere a existência de um evergeta estrangeiro como financiador da construção: a utilização de mármore importado justamente em Atenas, rica em mármore e em tradições arquiteturais, e em particular do mármore da Eubéia, amplamente utilizado na atividade construtiva romanas, indica que o evergeta ou era romano - e possivelmente membro da família imperial - ou muito próximo de Roma; um candidato possível seria Herodes da Judéia, o qual teria dado presentes aos atenienses segundo F. Josefo (Guerra judaica, 1.425), mas a associação entre o edifício e qualquer doador é fatalmente limitada pela exiguidade dos vestígios.

Se as stoas noroeste monumentalizam a entrada da ágora pela Via Panatenaica, a Stoa Nordeste fecha o limite nordeste da ágora, de uma certa maneira completando o processo de compactação das ágoras gregas iniciado no período helenístico (Sielhost, 2011), e efetuado em Atenas por meio da construção da Stoa Média, da Stoa de Átalo II e da reforma do Metroon. A orientação noroeste-sudeste da Stoa Nordeste dialoga de modo muito peculiar com os edifícios circundantes: por um lado, ela retoma a articulação dominante até o século II, composto pela sequencia de edifícios do lado

${ }^{321}$ Disponível em: http://agora.ascsa.net/id/agora/image/2002.01.1969.
${ }^{322}$ Disponível em: http://agora.ascsa.net/id/agora/image/2004.01.0676. 
oeste da ágora, a Stoa Sul I e o Peristilo Quadrado; por outro, ela reduz ou isola o espaço imediatamente ao norte, e que eventualmente faria parte da ágora pelo efeito de inclusão criado pela fachada da Stoa Pintada. Sua orientação, pois, deveria estar ligada aos padrões de circulação já estabelecidos na região. De qualquer maneira, com a construção deste conjunto de stoas e do Templo Noroeste, a área norte da ágora finalmente recebe um investimento construtivo significativo após mais de quatro séculos de pouca atividade, desde a construção da Stoa Pintada - com a exceção do portão helenístico e do Peristilo Quadrado, este último que não chegou a ser finalizado.

\section{A “Ágora romana”}

Considerando a cidade como um todo, a maior intervenção da época augustana é sem dúvida o quadripórtico conhecido como "Ágora Romana” (fig. 143): mede 111 por 104 metros, equivalente a mais de 11 mil e quinhentos metros quadrados. Suas dimensões, suas referências arquiteturais e os artefatos e inscrições associados a tornam um dos edifícios mais ricos para a discussão sobre a romanização de Atenas na época de Augusto. As dificuldades na reconstituição da identidade, da natureza e da pré-história da área, no entanto, trazem uma série de dificuldades para uma interpretação unidirecional.

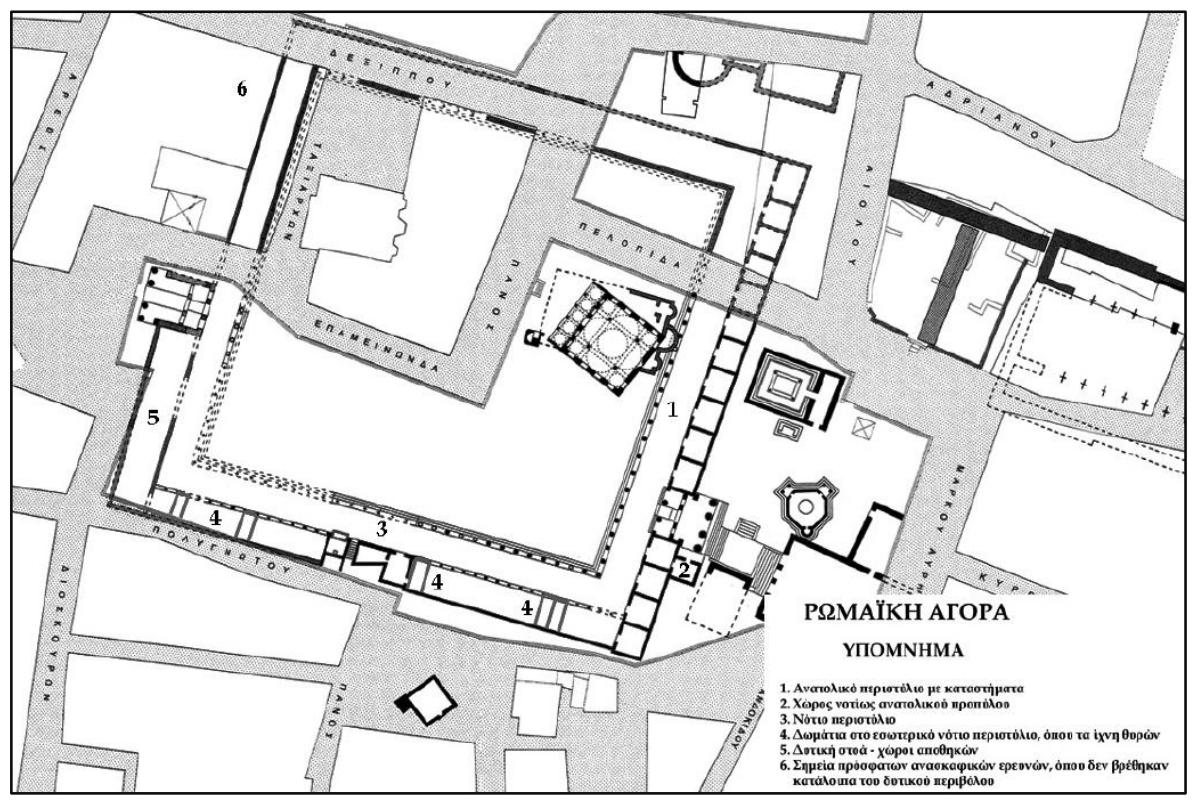

Figura 143. Proposta de reconstituição da planta da Ágora Romana, com indicação das vias e blocos ocupados atualmente (Sourlas, 2012, p. 120). 1. Peristilo leste com ambientes. 2. Ambiente ao sul do propileu leste. 3. Peristilo sul. 4. Ambientes do Peristilo interior sul, onde se encontram traços de portas. 5. Pórtico oeste. 6. Área das escavações atuais. 
A região da ágora romana era ocupada por habitações até o século XIX, quando tiveram início as escavações, em especial a partir de 1890. Antes disso, o propileu ocidental já era notado pelos viajantes, como Stuart e Revett (figs. 144-145), que identificavam no conjunto a fachada de um templo dórico dedicado a Roma e Augusto (Stuart e Revett

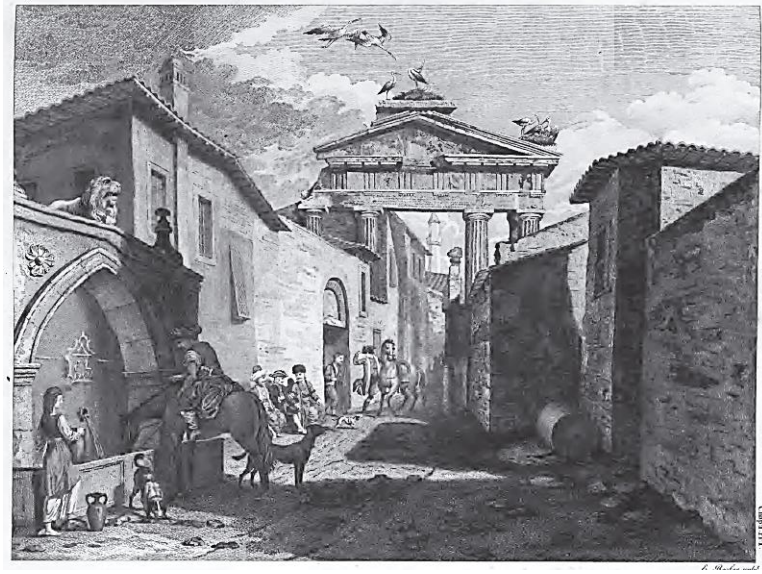

Figura 144. Desenho da vista do propileu ocidental da Ágora Romana a partir do oeste, segundo J. Stuart e N. Revett em 1767 (v. 1, cap. 1, pl. 1).

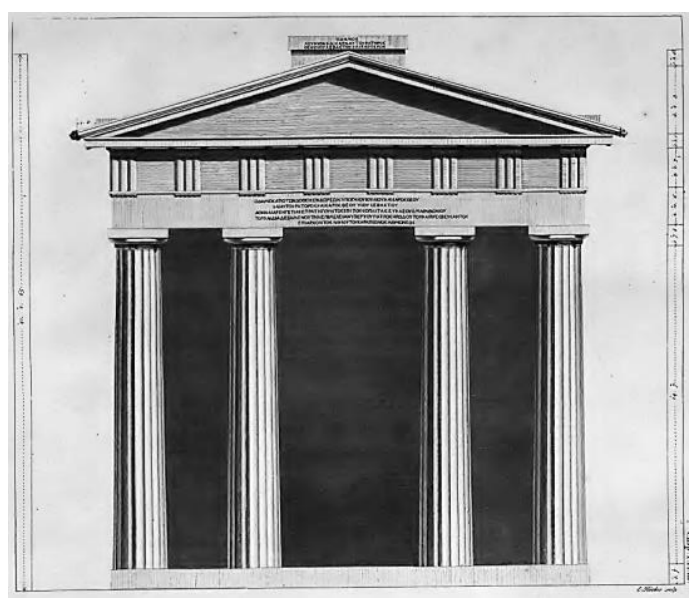

Figura 145. Proposta de reconstituição da fachada do propileu (interpretado como um templo), segundo J. Stuart e N. Revett em 1767 (v. 1, cap. 1, pl. 3).

A identificação de Stuart e Revett como um templo se baseava não apenas no formato do conjunto, mas também na inscrição na arquitrave, onde se lia:

O povo [dedica], a partir dos presentes dados pelo deus Caio Júlio César / e pelo Imperador César Augusto filho do deus, / a Atena Fundadora, sendo Eucles de Maratona general dos hoplitas / e tendo sucedido seu pai Herodes como supervisor, e tendo sido embaixador, / sob o arcontado de Nícias, filho de Sarapion, de Athmonia (IG II $\left.{ }^{2} 3175\right)$.

Esta dedicação é uma das raras fontes que mencionam diretamente as formas de financiamento da atividade construtiva: presentes dados por César e por Augusto. O primeiro financiamento é conhecido por meio de uma carta de Cícero a Ático (Cartas a Ático, 6.1.25), na qual o orador faz menção ao pedido de 50 talentos feito por um certo Herodes a César (então na Gália), o que teria causado animosidade da parte de Pompeu - que deu a mesma quantia aos atenienses cerca de 10 anos antes, para reformas no 
Pireu (Rawson, 1985, pp. 44-49). Este Herodes é certamente aquele de Maratona, ancestral do famoso orador Herodes Ático do século II d.C., e membro de uma família já proeminente no século II; sinal da posição de elite desta família é o serviço de Herodes como arconte epônimo em 60/59 (IG II ${ }^{2}$ 716). Seu filho, Eucles, tornou-se sacerdote de Apolo em 38/7 (Colin, 1906, nn. 55-56), sendo responsável, provavelmente a partir de 29 , da retomada das procissões atenienses na direção de Delfos (FD 3.2.59-64), além de ter servido como arconte epônimo em algum momento na primeira metade da década de 20 (IG II $\left.{ }^{2} 1719\right)$. Sua gestão como general dos hoplitas é conhecida por meio da arquitrave da Ágora Romana e de uma base de estátua dedicada a ele em Delos (IG 1627). Não é claro quando Eucles ocupou este último cargo, mas é provável que o tenha feito não muito tempo depois de ser arconte epônimo; da mesma época deve datar sua "embaixada", provavelmente para Augusto. Uma data plausível seria a terceira visita de Augusto em Atenas em 19, após a "vitória diplomática" na Pártia, e que teria sido o contexto da dedicação do monóptero na acrópole, que poderia, por sua vez, estar associado à construção da Ágora romana (seja como honra anterior, que teria motivado o presente, seja como agradecimento ao presente já dado). A datação da arquitrave, no entanto, deve ser buscada no arcontado de Nícias de Athmônia, que não é mencionado em nenhuma outra fonte. Algumas indicações, no entanto, são preciosas: Nícias não é listado entre os arcontes epônimos dos anos 18/17 a 11/10, e quando é mencionado na arquitrave da Ágora Romana, não há referência ao culto a Druso, que a partir de 9/8 tornou-se associado ao próprio cargo de arconte epônimo. Disso resulto duas possibilidades: ou Nícias foi arconte epônimo em 10/9, ou nas lacunas de períodos anteriores $(29-26,25-22,19-17)$. A primeira opção é geralmente aceita com base na probabilidade da embaixada de Eucles em 19, o que faria com que a construção da ágora terminasse no máximo dois anos após a retomada augustana (Hoff, 2002; Baldassarri, 1998, p. 109; Étienne, 2004, p. 177). No entanto, não há garantias de que a embaixada tenha ocorrido em 19; pelo contrário, o uso do termo embaixada seria estranho para indicar o contato com Augusto quando este estava em Atenas; G. Schmalz, por exemplo, propõe uma datação da dedicação em meados da década de 20 (Schmalz, 2009, p. 79).

A inscrição certamente não se refere apenas ao propileu: é implausível que os 50 talentos de César mais uma quantia não determinada dada por Augusto tenham sido dedicados apenas à sua construção. Deste ponto de vista, a inscrição se refere a toda a Ágora Romana. Mas, a partir da inscrição, o que é ela? A dedicação é clara em apontar 


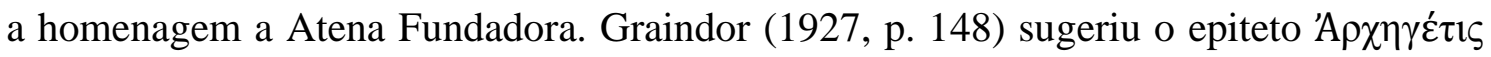
se referisse aos atributos da deusa mais ligados ao comércio, em particular ao do azeite; tal associação é plausível, na medida em que um dos mitos centrais da fundação de Atenas é a escolha da deusa como divindade políade após esta ofertar a Cécrops a oliveira, determinando assim a derrota de Poseidon. Caso esta sugestão estiver correta, esta poderia ser uma primeira ligação entre a Ágora Romana e a acrópole, tendo em mente que a oliveira sagrada se localizava no recinto do Erechtheion (Pausânias, 1.27.2; Lesk, 2005, pp. 136-138). De qualquer modo, o epíteto pode significar o sentido de refundação que a construção da nova ágora traria para a cidade (especialmente de um ponto de vista comercial) sem que referências tão diretas aos mitos fundadores fossem realizadas - o que não quer dizer que o edifício não fosse carregado de implicações religiosas, questão que será tratada mais adiante.

Antes de avançarmos na discussão do complexo como um todo, um elemento do propileu merece consideração: a base de estátua disposta atrás do frontão, mas visível a partir de fora, contento uma inscrição (hoje perdida) onde se lia: "O povo [dedica] a Lúcio César, filho do imperador Augusto César filho do deus" (IG II2 3151). A datação desta dedicação, provavelmente composta por uma estatua equestre, é complexa: não há indícios claros que tenha sido feita quanto Lúcio ainda estava vivo, ou seja, até o ano de 2 d.C. Hoff (2002) considera que o monumento foi construído como parte do propileu original: mantendo a datação do propileu em 10/9, isso faria com que Lúcio fosse representado com apenas 7 anos, o que é implausível; aceitando-se a datação de meados da década de 20, a única solução possível é de que o monumento foi uma adição posterior. Schmalz (2009, pp. 101-102) sugere o ano de 2 a.C., quando Lúcio atinge a maioridade, uma datação coerente com outros exemplos de monumentos equestres para o então herdeiro erigidos alhures, inclusive em Roma (Rose, 1997, p. 99), o que parece muito mais plausível. A dedicação de uma base de estátua para Lúcio César, associada a outros achados importantes e ao próprio formato do complexo, são indicações claras que apontam para o uso da Ágora Romana em associação ao culto dinástico imperial.

O desenvolvimento das escavações revelou a existência do quadripórtico jônico que circunda todo o pátio central. Nos lados oriental, meridional e ocidental, este pórtico era duplicado ${ }^{325}$. No lado oriental, 15 ambientes, de tamanho variável, eram

\footnotetext{
${ }^{325}$ Não é claro se o pórtico oeste era inteiramente duplicado ou se o era somente ao sul do propileu; em planta publicada em 2008, D. Sourlas reconstitui a planta da região ocidental com uma continuação do muro ao norte do propileu, ao passo que na planta publicada em 2012 o mesmo autor indica que não
} 
interrompidos pelo propileu ocidental após o quarto ambiente, do sul para o norte, e se comunicavam com o quadripórtico por meio de portas em paredes contínuas. No lado meridional, uma colunata interna, dórica, separava os dois corredores; o intercolúnio dórico interno não correspondia ao intercolúnio jônico externo, o que pode ser um indício de que foram construídos em momentos diferentes (Burden, 1999, pp. 105-196). A existência de marcas de portas entre as colunas dóricas internas indica a compartimentação de ambientes do corredor interno com materiais perecíveis, por oposição às paredes em pedra do pórtico oriental. Ao centro do pórtico meridional, uma pequena escadaria dava acesso à rua ao sul do complexo; nos dois lados da escadaria, ambientes isolados por paredes de pedra indicam usos mais permanentes, tais como sede do magistrado responsável, o agoranomos e/ou capela do culto imperial (Hoff, 1994, p. 112, n. 4, Sourlas, 2012, p. 131-132). No lado ocidental, um amplo ambiente se estendia do muro externo ao propileu ocidental, sem que haja indícios de que havia um ambiente semelhante ao norte. Os materiais utilizados são conglomerado e poros para as fundações e segmentos das paredes de separação entre os ambientes, mármore do Himeto e do Pentélico para a ordem do quadripórtico jônico e da colunata dórica ao sul, além de segmentos das paredes entre os ambientes; o pátio interno era coberto com placas de mármore pentélico. Os acessos principais ao complexo eram os propileus oriental e ocidental; um acesso mais modesto era dado pela escadaria ao sul, e é possível que houvesse outro acesso ao norte, ainda não escavado.

A identificação da Ágora Romana como um espaço comercial se baseia em uma série de indícios. Em primeiro lugar, as cavidades em um dos blocos do degrau localizado no sudeste do pátio foram interpretadas como um equipamento para medida de mercadorias (fig. 146), o que encontra paralelo ao menos em Delos. Em segundo lugar, inscrições relativas ao magistrado responsável pela gestão dos mercados, o agoranomos, foram encontradas no local (IG II2 3238, 3391, 3602). Em terceiro lugar, a existência de um equipamento para extração do azeite de oliva (fig. 147), associada à inscrição, no propileu ocidental, da regulação da produção e comércio de azeite ateniense da época de Adriano (IG II2 1100), são coerentes com o comércio de um dos principais produtos da cidade. Em quarto lugar, as pequenas e irregulares inscrições em paredes e em colunas do quadripórtico, especialmente a seção sul, são melhor

foram encontrados vestígios de tal muro nas escavações recentes. Sua inexistência, entretanto, é improvável, pois criaria tanto um desequilíbrio no pórtico sul quanto inviabilizaria a continuidade com o muro exterior da Biblioteca de Adriano, construída no século II d.C., que segue a linha de uma hipotética continuação do muro exterior ocidental da Ágora Romana (Sourlas, 2008, p. 100, e 2012, p. 120, fig. 1). 
interpretadas como marcações dos espaços específicos ocupados pelos mercadores, mais do que como "vandalismo" (Sourlas, 2012, pp. 122-126).

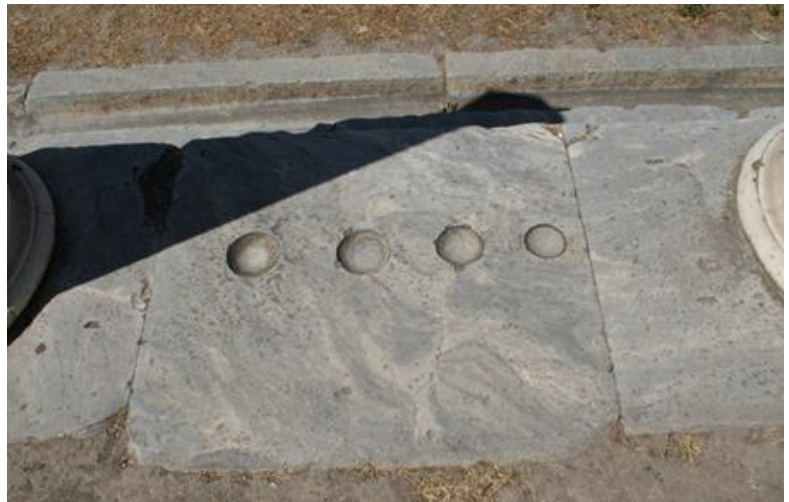

Figura 146. Fotografia das cavidades "de medida" no intercolúnio da colunata jônica exterior do pórtico sul, tirada pelo autor em 2011 (Acervo pessoal).

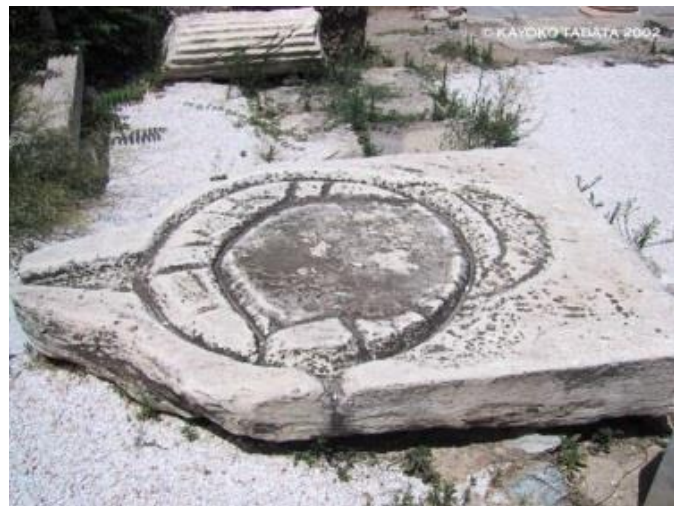

Figura 147. Fotografia de equipamento para extração de azeite encontrado na ágora romana (Gate to Greece).

A atividade comercial não resumia, entretanto, as funções da Ágora Romana. O achado de fragmentos de estátuas, inscrições honoríficas e a própria dedicação na arquitrave do propileu ocidental demonstram o uso do espaço como local de celebração de membros da elite local e da família imperial. Neste sentido, a Ágora Romana se aproxima, em planta e em função, da Ágora dos Italianos de Delos: mais do que uma área comercial, este quadripórtico se destinava a abrigar as atividades sociais da colônia dos italianos de Delos, e particularmente a celebração por meio de inscrições estátuas. É tentador sugerir uma associação mais concreta entre os italianos de Delos e a construção da Ágora Romana, em função seja da semelhança formal e funcional, seja do declínio da atividade comercial de Delos após as Guerras Mitridáticas, que acabou por resultar no abandono da ilha cerca de um século depois. A inscrição honorífica a Pamenes, filho de Zenon de Maratona, da parte dos comerciantes ( $\varepsilon \mu \pi \circ \rho \circ$ ), datada de 27, pode estar ligada a esta transferência: este Pamenes, o mesmo sacerdote de Roma e de Augusto Salvador na acrópole, havia sido ginasiarca em Delos e seria ainda sacerdote vitalício de Apolo em Delos, culto que seria associado à veneração da família imperial (Schmalz, 2009, p. 297-298). Uma ligação mais direta é indicada pela dedicação de uma base de estátua em Delos (ID 1627) em homenagem a "[Eucles filho de He]rodes de Maratona, general dos hoplitas", da parte do "demos dos atenienses" e, a partir de uma restauração provável, dos habitantes de Delos. Caso a restauração do dedicado como "Eucles" esteja correta, e considerando que na inscrição da arquitrave da Ágora Romana Eucles é 
mencionado pelo mesmo cargo, "general dos hoplitas”, parece plausível uma associação mais próxima entre os comerciantes de Delos e a construção da Ágora Romana.

A interpretação que busca na Ágora Romana uma sede do culto imperial se baseia em quatro evidências centrais. Em primeiro lugar, a estátua equestre de Lúcio César no propileu ocidental, cuja base inscrita foi vista por J. Stuart e N. Revett no século XVIII; o texto reiterava a paternidade divina de Augusto, já presente na dedicação da arquitrave, reforçando assim não a divindade latente do imperador, como também a lógica dinástica da sobreposição "Lúcio César que é filho de Augusto César que é filho do divino Júlio César"; seria de se esperar, ainda que não haja qualquer vestígio, de um monumento semelhante, dedicado a Caio César, no propileu oriental (Badassarri, 1998, p. 106). Em segundo lugar, o fragmento de estátua (cabeça) encontrada na Ágora Romana e identificada como um retrato de Augusto do tipo Prima Porta (Stavropoulos, 1930-1931, p. 7, fig. 8). Em terceiro lugar, a dedicação de uma estátua a Lívia durante o governo de Tibério, mas que pode ser tomada como indício de continuidade (IG II2 3238). Em quarto lugar, a disposição peculiar dos três ambientes emparedados no pórtico sul, junto da escadaria na zona central do pórtico, que poderia significar seu uso como sede do culto imperial (Hoff, 1994, p. 112). Em quinto lugar, o achado de diversos altares dedicados a Augusto nas proximidades do local (Benjamin e Raubitsch, 1959, pp. 76, 85). Em sexto lugar, pela utilização, atestada somente uma vez em uma inscrição hoje perdida, do epíteto "Archegetis" para se referir a Augusto (IG II2 3237). E por fim, a semelhança formal da Ágora Romana com edifícios claramente identificados como santuários dinásticos: os Kaisareia, conhecidos em Alexandria e em Cirene, ou mesmo os fóruns imperiais.

Como se vê, há normalmente uma confusão entre a celebração ou comemoração dinástica e o culto imperial. Não há evidência direta para o culto imperial na Ágora Romana: apesar dos altares terem sido encontrados nas proximidades, nenhum deles foi encontrado dentro da Ágora Romana; os ambientes fechados no pórtico oriental ou meridional poderiam ter sido usados como lojas de produtos específicos ou escritórios dos magistrados; a existência de estátuas e inscrições associadas à família imperial não transforma o espaço, automaticamente, em um santuário onde se realizariam sacrifícios e rituais a determinadas entidades divinas ou divinizadas. Que a Ágora Romana era espaço de comemoração dinástica é ratificado pelo propileu ocidental; daí para se tornar santuário, literalmente, do culto imperial, há uma distância considerável. 
E o que era, afinal, a Ágora Romana? O termo é moderno, e compete com "mercado de César e Augusto", sempre com base na inscrição dedicatória. Não há, entretanto, qualquer referência a este espaço na Antiguidade. Uma possibilidade é de que a região da Ágora romana correspondesse à "ágora arcaica", anterior ao estabelecimento de edifícios públicos no Cerâmico (a "ágora ateniense"), descrita por Pausânias e mencionada por outros autores; no entanto, a descoberta do santuário de Aglauros na encosta leste da acrópole, próxima do qual estaria a "ágora" mencionada por Pausânias, descartou a Ágora Romana como uma das candidatas (cf. discussão no cap. 1). Outra possibilidade é que a área correspondesse à "Eritréia de Atenas" ( $\tau \tilde{\eta} \varsigma$

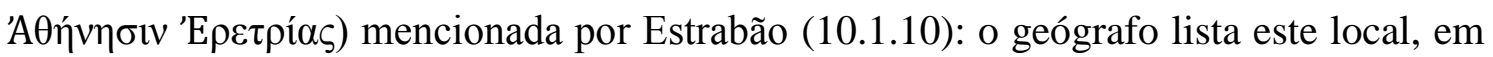

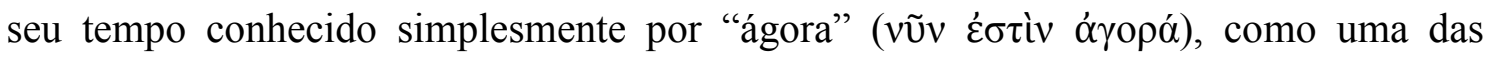
possíveis matrizes para a fundação da pólis de Eretria (Eubéia). E. Greco propõe que esta referência em Estrabão signifique que a área era ocupada por metecos mercadores da Eubéia, o que faz com que o espaço já fosse uma área comercial desde o período clássico, pelo menos (Greco, 2010, p. 29); os achados associados ao comércio na área localizada entre a ágora ateniense e a Ágora Romana seriam evidências da consideração de que a Ágora Romana era, de fato, uma ágora no sentido comercial. Ora, apesar de interessante, basear a identificação de uma área com base apenas na referência de Estrabão, que na passagem em questão sugere um movimento na direção oposta (atenienses indo fundar a pólis eubéia), nos parece demasiadamente arriscado. Além disso, é preciso considerar um elemento fundamental: o complexo conhecido como Ágora Romana era explicitamente dedicado a Atena Archegetis, o que o habilita a ser um santuário da deusa políade (Stefanidou-Tiveriou, 2008, pp. 26-27).

Com isso, podemos agora abordar mais diretamente a questão da romanização ou resistência representada pela construção da Ágora Romana. A tese da romanização parte da identificação - como dito acima, exagerada - da área como um santuário do culto imperial, além de promover paralelos com quadripórticos contemporâneos associados diretamente a César ou a Augusto, como o caso dos Kaisareia de Cirene, Antioquia e Alexandria e o tetragonos de Eféso, além do próprio Fórum de César e de Augusto em Roma. Ou ainda, o paralelo da Ágora Romana com os macella, edifícios porticados especializados para a comercialização de determinados produtos, em função da região (De Ruyt, 1983). Neste sentido, a Ágora Romana seria não apenas romanizante do ponto de vista dos usos (culto imperial), mas também da forma (arquitetura itálica e/ou cesariana). 
No entanto, é possível situar as experiências arquiteturais dos Kaisareia e dos macella como experimentações dentro de um repertório marcadamente helenístico, pelo qual os atenienses teriam também sido influenciados. Especialmente no século II, a tendência à compactação das ágoras desenvolve os pórticos semi ou inteiramente fechados, como no caso de Mileto e o conjunto em "ferradura", seja os quadripórticos das ágoras alta e baixa de Pérgamo. A Ágora dos Italianos em Delos, do século II, é um exemplo eloquente da construção de um quadripórtico utilizado, substancialmente, como espaço de expressão da identidade étnica e religiosa da colônia italiana em um importantíssimo entreposto comercial helenístico; não há referenciais claros para esta "ágora" na Itália, para além dos santuários porticados cuja existência na Grécia e Ásia Menor já era mais antiga. Neste sentido, a Ágora Romana pode ser interpretada como parte de um processo mais amplo de expansão de uma forma específica de intervenção, o quadripórtico helenístico, que tem na participação de César e Augusto um vetor, mas não uma origem.

Para além das referências formais à arquitetura helenística microasiática, a Ágora Romana também faz, ao menos, dois diálogos formais com a arquitetura local, ambos claramente observáveis no propileu ocidental - justamente aquele que se volta para a ágora clássica. Em primeiro lugar, o propileu apresenta um arranjo ao propileu da acrópole: se a quantidade de colunas é diferente, a decoração do capital dórico, o arranjo entre triglífos e métopas e a proporção entre o intercolúnio central e os laterais são idênticos (fig. 148); Graindor foi um dos primeiros a sugerir que o propileu da Ágora Romana citava, diretamente, o propileu da acrópole. Em segundo lugar, o que ainda não foi observado pela bibliografia, é o paralelo que este propileu fazia com outro, na ágora clássica, construído também na época augustana: o propileu do conjunto identificado como Strategion. A exiguidade dos vestígios não permite uma reconstituição detalhada da elevação, mas era certamente um propileu dórico. O paralelo é sugestivo quando se considera a proximidade do general dos hoplitas - sediado no Strategion - com os membros da família imperial, especialmente no caso de Pamenes de Maratona (general dos hoplitas e sacerdote de Roma e Augusto na acrópole) e do próprio Eucles de Maratona, general dos hoplitas e supervisor da construção da Ágora Romana como fundos doados por Augusto. A menção ao cargo na arquitrave da ágora romana e a construção contemporânea de um propileu dórico na entrada do Strategion, do outro lado da ágora clássica, pode ser uma indicação da aumento do poder desta magistratura e de sua conexão com a família imperial. 

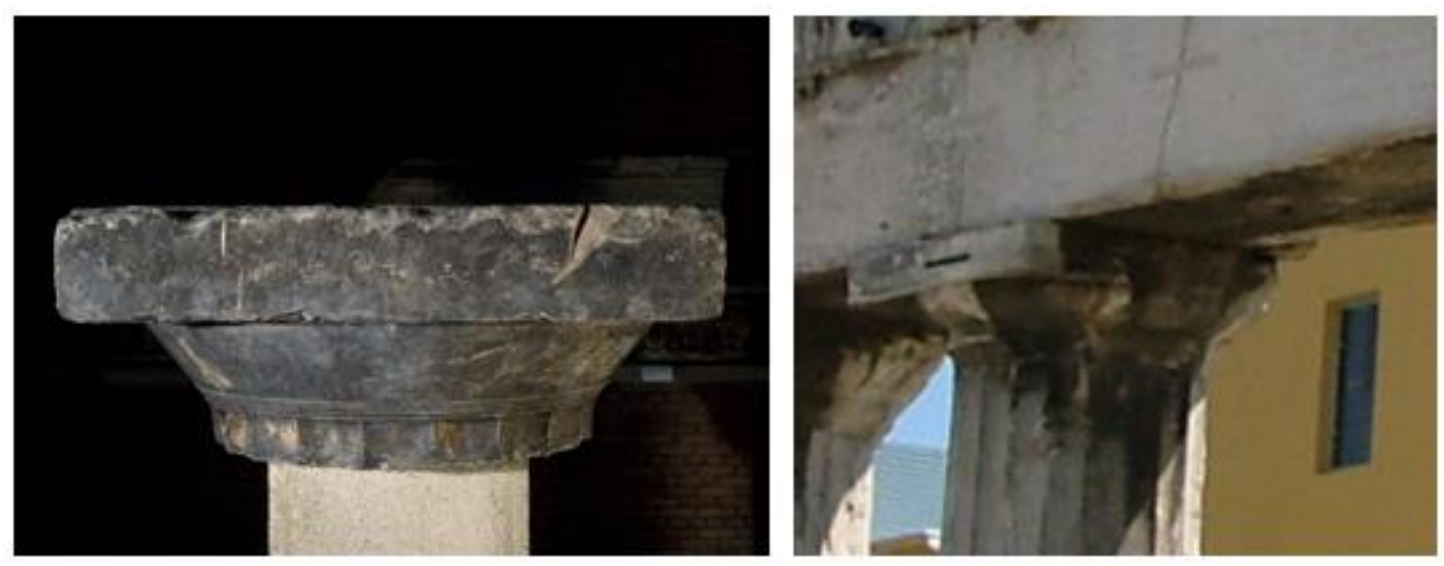

Figura 148. Fotografias do capitel dórico da fachada oriental do propileu da acrópole (esquerda; Museu Britânico ${ }^{326}$ ) e do capitel do propileu da Ágora Romana (direita; Wikicommons ${ }^{327}$ ).

Finalmente, a questão sobre os usos da área pré-construção do quadripórtico é fundamental para a discussão da romanização ou não operada na/pela Ágora Romana. As escavações mais recentes vêm apontando com cada vez mais força, ainda que não de modo conclusivo, que a área já era destinada ao uso comercial desde o período clássico (Sourlas, 2008 e 2012). Caso esta hipótese se confirme, seria plausível sugerir que a área começa a ser monumentalizada no final do século II com a construção do Horologium de Andrônico ${ }^{328}$, útil para a regulação do tempo das atividades comerciais assim como um atrativo especial para os visitantes, e com o início de intervenções que resultariam, no final do século I, na construção do quadripórtico. É provável que a monumentalização da ágora houvesse sido projetada na primeira metade do século I,no contexto da reconstrução da cidade após o saque de Sula, o que é indicado tanto pela embaixada de Herodes junto a César em 51 - que implica o projeto já existia, ainda que não seja claro há quanto tempo - quanto pelas "incoerências" arquiteturais no muro de contenção meridional e entre a colunata dórica interna e jônica externa no lado sul do quadripórtico, que Burden interpreta como sinal de diferentes fases construtivas ${ }^{329}$. Que a construção do Agrippeion e do templo de Ares tenha afetado as eventuais atividades

\footnotetext{
${ }^{326}$ Disponível em: http://www.britishmuseum.org/collectionimages/AN00441/AN00441168_001_1.jpg.

${ }^{327}$ Disponível em:

http://upload.wikimedia.org/wikipedia/commons/3/3a/Gate_of_Athena_Archegetis_(1)_-

Athens_Roman_Agora.jpg;

${ }^{328}$ Sobre a datação do Horologium no século II, cf. Baldassarri, (1998, p. 100-101, n. 6).

${ }^{329}$ Reconstruídas, por Burden, por um movimento inicial após a doação de César depois retomada na época de Augusto (Burden, 1999). Contra isso, Sourlas argumenta que a semelhança entre técnicas e soluções em diferentes locais do edifício indicam uma fase única (Sourlas, 2012) - o que não me parece conclusivo, dado que estas mesmas soluções poderiam ter sido adotadas em diferentes períodos.
} 
comerciais no centro da ágora ateniense, não parece questionável, e pode ser tomado como um marco importante para a intensificação dos trabalhos ao leste da Stoa de Átalo II. No entanto, argumentar que a construção da Ágora Romana, como espaço comercial, é paralela à musealização da ágora clássica - que seria esvaziada de seu sentido comercial - nos parece temerário, pois pressuporia que (1) a Stoa de Átalo II não fosse mais usada como espaço comercial, como se acredita seja sua função básica, e (2) a Ágora Romana não fosse também um espaço de celebração da memória ateniense e da presença imperial, o que também ocorria na ágora. Antes, é preferível uma interpretação que leve em consideração a continuidade entre as duas áreas, com uma diferença de ênfase, mas não de natureza: uma ágora mais comercial, mas com sede de magistratura e diversas referências religiosas - talvez, inclusive, ao culto imperial -, e uma ágora mais administrativa-cultural, mas com edifícios dedicados às práticas comerciais e religiosas.

\section{A restauração dos santuários da Ática (IG II2 1035)}

As intervenções augustanas discutidas até aqui são conhecidas por meio de vestígios arqueológicos e poucas referências literárias e epigráficas - os limites e possibilidades para sua interpretação derivam em grande parte do caráter esparso da documentação. Ironicamente, a inscrição que trata sistematicamente de um grande conjunto de intervenções construtivas não faz, para o desespero do pesquisador, qualquer menção clara àquelas discutidas acima. Trata-se do célebre decreto da restauração dos santuários (IG II2 1035), que lista cerca de 80 sítios, entre santuários

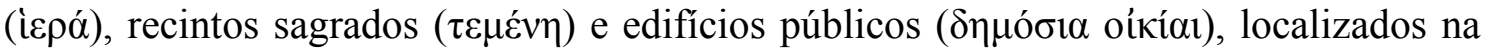
ilha de Salamina, no Pireu, no interior da Ática e em Atenas e arredores. O estado fragmentário da inscrição impede uma determinação precisa da datação e da listagem integral dos sítios relacionados, mas a expressiva bibliografia dedicada a este documento construiu bases importantes para sua interpretação ${ }^{330}$. Aqui, serão tratados apenas os sítios intramuros, quais sejam: os santuários das jacintides, do herói Strategos,

\footnotetext{
330 Tsoundas (1885), Culley (1975 e 1977), Shear Jr. (1981), von Freeden (1983), Habicht (1996), Baldassarri (1998, pp. 242-246), Schmalz (2007-2008) e Spawforth (2012).
} 
da Boa Fortuna, da Glória e Concórdia, de Serápis, de Zeus Olímpio e de Teseu, além da Dedicação Atálida, do antigo Bouleuterion e do Horologium.

A inscrição é composta por três textos relacionados. O primeiro é o decreto instituído pelo demos que decide pela restauração dos santuários e precintos dos deuses

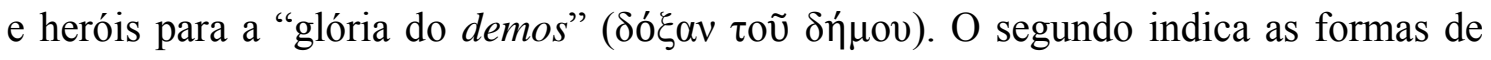
sua implementação, tendo como protagonistas o arconte-rei, o general dos hoplitas e um tesoureiro para os assuntos religiosos ( $\tau \alpha \dot{\mu} \mu 1 \alpha \varsigma \tau \tilde{\eta} \varsigma$ i $\varepsilon \rho \tilde{\alpha} \varsigma)$, que deverão promover a restituição das terras sagradas ocupadas por privados aos santuários, a realização de rituais purificatórios, e a restauração de edifícios, monumentos e objetos sagrados. $\mathrm{O}$ terceiro é um catálogo dos sítios que receberam a ação restauradora. O general dos hoplitas mencionado é um certo Metrodoros, filho de Xenon, do demos de File, que deveria executar o projeto ao lado do arconte-rei Mantias, filho de Dositheos, de Maratona. Estes dois personagens não são mencionados em outras fontes, o que tornou a datação do decreto particularmente complexa - as sugestões variavam do período pós86 ao século II d.C., ainda que a datação augustana tenha se tornado hegemônica, em função da lógica subjacente ao programa. Recentemente, G. Schmalz ofereceu uma solução com bases prosopográficas mais seguras, identificando Mantias como filho de Dositheos, membro do genos dos Kerykes, sacerdote eleusinos e arconte-rei do início do principado (Schmalz 2007-2008, p. 15, e 2009, pp. 282-282), e datando a magistratura de Metrodoros de pouco tempo depois de seu exercício enquanto arconteepônimo, que ocorreu pouco tempo depois de 10/9; assim, a proposta de datação no final do século I a.C. e início do I d.C. se torna a mais plausível.

O catálogo está incompleto, mas os trechos preservados permitem uma aproximação das lógicas envolvidas nas restaurações. Os sítios e monumentos a serem restaurados se referem, em quase sua totalidade, a importantes eventos míticos ou históricos do passado ateniense, em particular o conflito entre Mégara e Atenas pela posse de Salamina - no qual Ajáx e seu filho Eurisaces (que ofereceu a ilha em troca da cidadania ateniense) ocupam papel central -, as guerras médicas, a guerra do Peloponeso e a resistência à ocupação macedônica. A comemoração do passado local é coerente com as intervenções do período augustano, como visto acima, e a participação de Mantias é indicativa de uma proximidade maior ao próprio Augusto. O pai de Mantias, Dositheos, exerceu uma série de cargos sacerdotais eleusinos na época de Temístocles de Hagnous, sacerdote eleusino responsável pela segunda iniciação de Augusto em 19; como membro do genos dos Kerykes e filho de um importante 
sacerdote, é possível que Mantias tenha tido fortes relações com os mistérios de Elêusis e com personagens mais ou menos ligados ao princeps, o que explicaria sua ascensão a arconte-rei no momento da implementação deste grande projeto de restauração.

Os sítios instramuros listados no catálogo são ${ }^{331}$ :

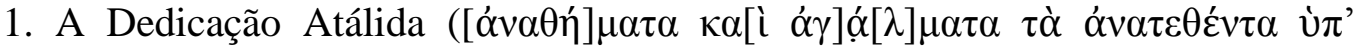

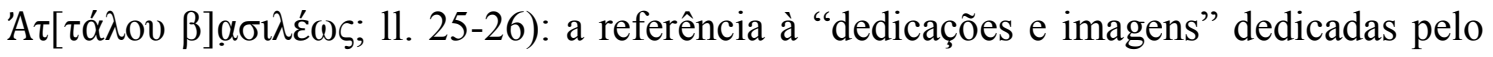
rei Átalo certamente se referem à Dedicação Atálida mencionada por Pausânias (1.25.2). Sua posição no decreto - no trecho dedicado a detalhar os procedimentos para a restauração, e não no catálogo de intervenções - é peculiar, mas pode ser entendido

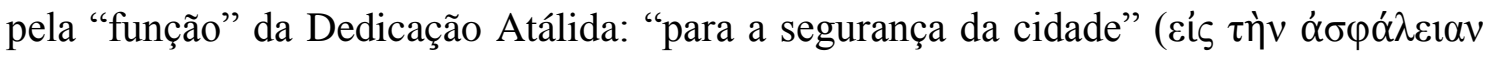
$\tau \tilde{\eta} \varsigma[\pi o ́ \lambda \varepsilon \omega \varsigma])$. Assim, não está claro se a Dedicação Atálida recebeu trabalhos de restauração, ou se servia de modelo para as restaurações a serem realizadas. De qualquer modo, está claro que a Dedicação Atálida tinha um sentido mágico na época do decreto, o que deve significar a permanência deste significado, original da dedicação, mais do que uma releitura religiosizante do final do século I.

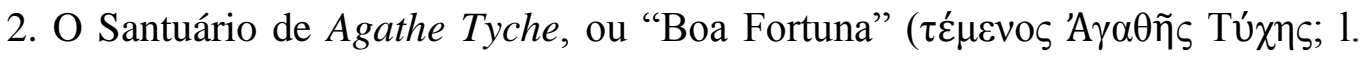
48): seguramente localizado na Colina das Musas, próximo às muralhas no limite sudeste da cidade; o santuário foi restaurado em 335/4, na época de Licurgo, e recebeu um grande sacrifício no final do século IV "para garantir a segurança do demos dos atenienses" (SEG 44.42.29-30), o que possivelmente estava associado à constante ameaça macedônica à democracia e à população ateniense, coerente com a menção de

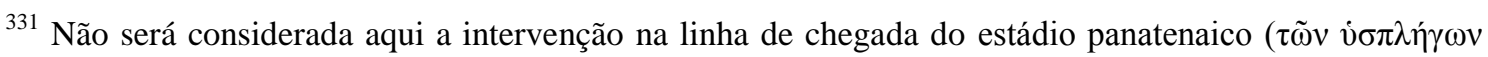

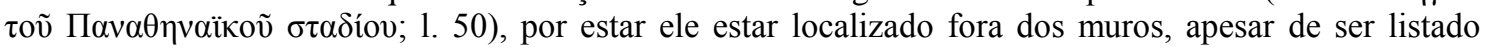
entre as intervenções intramuros. De qualquer modo, vale destacar um fator pouco observado pela bibliografia: é atestada a utilização do estádio Panatenaico como espaço para assembleias no ano de 188/7 (IG II2 893) e realização das reuniões do Conselho nos anos de 229/8 (Agora I 7181), 216/5 (IG II2 794), 192/1 (IG II2 916) e 38/7 (IG II2 1043), no mesmo período em que as assembleias tendem a ocorrer regularmente no teatro de Dioniso e não mais na Pnyx. Neste sentido, ainda que o estádio não seja enquadrado tão facilmente na categoria de "santuário", a restauração pode estar associada a seu uso como sede de reuniões políticas que subentendiam rituais e sacrifícios (para a assembléia: Ésquines, 1.23 e 2.158; para o Conselho, SEG 40.289; entre outros), para além da utilização do estádio nos festivais do calendário religioso da cidade. Cf. Romano (1985, p. 454, n. 58). O decreto também faz referência a um

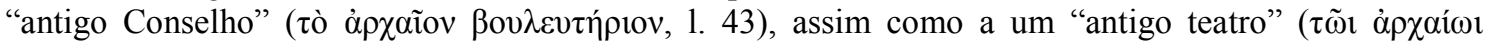
$\theta \varepsilon \alpha ́ \tau \rho \omega 1,1.44)$. Não é possível determinar se este Conselho e este teatro são o conjunto conhecido como Metroon a partir do século II e o teatro de Dioniso, ou se são edifícios de função semelhante localizados no Pireu, dado que estas linhas do catálogo estão no trecho dedicado às intervenções no porto. A ausência de vestígios de intervenções de época augustana no Metroon e no teatro de Dioniso corrobora a segunda hipótese, e por isso estas intervenções não serão discutidas na presente listagem.
} 
Pausânias às sepulturas públicas de 13 atenienses mortos na colina das Musas no conflito com as tropas macedônicas no século III (Pausânias, 1.29.13).

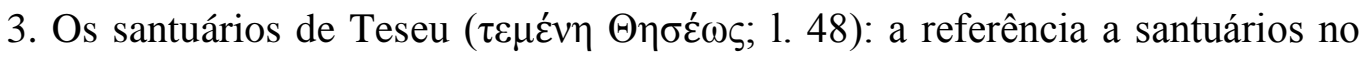
plural indica claramente que não se trata apenas do Theseion construído por Címon no século VI, mas dos diversos santuários de Teseu na Ática; no entanto, dificilmente não seria incluído o Theseion urbano. Sua localização ainda não foi determinada, mas provavelmente estava situado ao norte/nordeste da acrópole, próximo ao ginásio de Ptolomeu. Além de heroon com o túmulo de Teseu, rei responsável pelo sicenismo na Ática, o Theseion era decorado com pinturas representando uma centauromaquia, uma amazonomaquia, e um episodio da expedição de Teseu a Creta (Pausânias, 1.17.2). Assim, a comemoração anti-bárbara é fundamental neste santuário, e em particular a celebração da defesa contra a invasão bárbara, seja no caso da amazonomaquia, na qual Teseu foi protagonista, seja na maratonomaquia, à qual Teseu era diretamente associado em uma pintura na Stoa Pintada na ágora (Pausânias, 1.15.3).

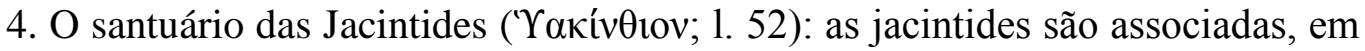
diferentes tradições, a jovens imoladas para a defesa da cidade; a principal versão, provavelmente, é aquela que aparece na peça Erechtheus de Eurípides (frag. 47.60.27, 65.67-87), na qual as jacintides são as filhas do rei Erechtheus, sacrificadas pelo pai como forma de vencer a guerra contra Elêusis. No período histórico, sacrifícios eram praticados pelo exército ateniense antes de ações militares (Burkert, 1983, p. 66, n.33, e 1985, p. 439, n.13). O santuário estava ligado não apenas à proteção da cidade, mas também à construção de sua composição territorial, cujas implicações religiosas, no caso de Elêusis, são claras: a imolação das jovens seria fundamental para a anexação do santuário de Deméter, base da percepção de Atenas como berço da agricultura; a presença de um membro do genos Kerykes como arconte-rei, responsável pelo projeto, pode estar associada à escolha deste santuário.

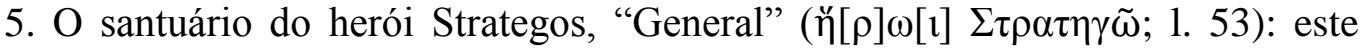
herói é conhecido apenas por meio de dedicações encontradas na ágora, e somente a partir de 200 (Rostroff, 1978, p. 205); é provável que seu altar estivesse localizado no Strategion, ao sul do Tholos (Wycherley, 1957, p. 176). É tentador sugerir que a construção do propileu dórico do Strategion da ágora esteja vinculada ao decreto de restauração, o que poderia ser associado, além dos valores militares inerentes ao santuário, ao prestígio da magistratura dos generais dos hoplitas, especialmente quando 
se considera que eles eram os responsáveis, junto do arconte-rei, pela execução do decreto.

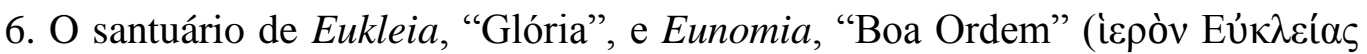
кaì Eúvopías; 1. 53): seja como sede do culto de Ártemis Eukleia (Schmalz, 2007-2008, p. 44), ou de abstrações divinizadas (Eunomia filha de Themis em Hesíodo, Teogonia, 902; cf. Wycherley, 1957, p. 58), este santuário era diretamente associado à vitória sobre os persas: seu culto foi instituído logo após a batalha de Platéia, remetendo ao culto de Ártemis realizado no local; sua localização não é conhecida, ainda que existam referências para seu culto na ágora, talvez na Kolonos Agoraios (Schmalz, 2007-2008, p. 44) ou mesmo no Tholos (Wycherley, 1957, pp. 58-59). O sacerdote do culto tinha assento inscrito para si no teatro de Dioniso, o que demonstra o prestígio do culto.

7. O "ginásio" ( $\pi \alpha \lambda \alpha i ́ \sigma \tau \rho \alpha v ; 1.54)$ : a referência a uma palestra no decreto, infelizmente, se faz no final de uma frase perdida; não possível, portanto, determinar a qual ginásio esta palestra correspondia, nem se a própria palestra ou algo relacionado a ela foi objeto de intervenção. A sugestão de que se tratava do complexo do Ptolemaion, que incluía, provavelmente, o santuário de Diógenes, faria sentido considerando o caráter anti-macedônico de determinadas restaurações; mas o caráter lacunar da inscrição impede qualquer avanço nesse sentido.

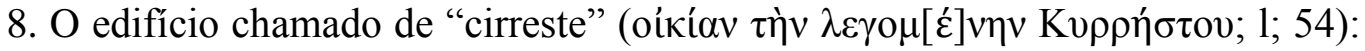
trata-se do Horologium construído por Andrônico de Cirro no século II ao leste do que seria a Ágora Romana. Sua inclusão no plano de restauração deve estar associada a necessidades práticas de restauração, dada a utilização do edifício como relógio solar e hidráulico; não há elementos claros para associar tal intervenção a santuários ou significados religiosos.

9. O Olympieion ( $\left.\Delta \mathrm{\imath}\left[{ }^{\prime} \mathrm{O} \lambda \nu \mu\right] \pi \mathrm{i}^{\prime} \omega 1,1.55\right)$ : localizado na região leste da cidade, foi objeto da ação construtiva augustana, e estava associado, para além das origens tirânicas, ao evergetismo sírio patrocinado por Antíoco IV. A densidade religiosa do santuário, repleto de cultos de caráter pan-helênico, associada à secular e então ainda incompleta construção, justificaria sua inclusão no projeto de restauração - relativa aos terrenos diante do santuário - possivelmente associado às intervenções augustanas projetadas - e eventualmente realizadas, ainda que parcialmente - pelos "reis amigos" (Suetônio, Augusto, 60).

10. O santuário de Sarapis ( $\Sigma \alpha \rho \alpha \pi[1 \varepsilon \tau ̃ o v] ; 1.56-57)$ : tradicionalmente localizado pelos estudiosos na área sob a atual catedral metropolitana, foi construído 
provavelmente por Ptolomeu III (Pausânias, 1.18.4), provavelmente em cerca de 220 (Mikalson, 1998, p. 276, n. 94); a instituição deste culto greco-egípcio certamente estava associada à proteção garantida pela monarquia lágida à liberdade ateniense contra a macedônia.

A comemoração do passado militar ateniense, em particular do ponto de vista da proteção e defesa da cidade, bastante claro nas restaurações em Salamina e no Pireu mencionadas no início do catálogo, estão presentes nas restaurações intramuros: as guerras do tempo mítico estão presentes na restauração do santuário das Jacintides (Elêusis) e de Teseu (amazonas, Creta); as guerras médicas estão presentes nos santuários de Teseu (Maratona) e da Glória e Boa Ordem (Platéia); as guerras macedônicas estão presentes nos santuários da Boa Fortuna (séc. III?), no santuário de Sarápis (pós-229?) e na Dedicação Atálida (200?), e talvez na "palestra", caso ela esteja relacionada ao Ptolemaion e/ou Diogeneion (pós-229); é plausível que o santuário do herói Strategos estivesse relacionado à cultura militar ateniense como um todo. As intervenções não diretamente relacionadas às guerras atenienses, tais como o santuário de Zeus Olímpio e o Horologium (e talvez a "palestra") podem ser interpretadas em termos de oportunidade construtiva: o Horologium poderia ser objeto das intervenções por problemas relacionados à sua funcionalidade, enquanto as intervenções no santuário de Zeus Olímpio estariam relacionadas ao interesse constituído entre os evergetas da época em função da já secular história construtiva do templo. A hipótese de que alguns santuários podem ter sido escolhidos em função de um eventual enfraquecimento de seus cultos é indicada pela transposição do templo de Ares e pela reutilização de elementos arquiteturais de outros templos, em particular os de Atena e Poseidon no Sounion; no entanto, a recorrência de santuários ligados à memória militar ateniense não deixa dúvidas de uma lógica dominante no programa.

O programa ateniense de restauração de santuários não é caso único: o paralelo evidente é a grande restauração de santuários em Roma levada a cabo por Augusto (Gros, 1976). Para além das semelhanças de quantidade e tipologia (cerca de 80 santuários), os dois projetos apresentam um grande paralelismo na preocupação antiquária: no caso ateniense, a mitografia e a atidografia é visível na escolha dos sítios, intimamente ligados à tradição mítica e histórica ateniense, e que terá ecos em autores como Plutarco e Pausânias; no caso romano, entre os eruditos convocados a participar do processo de seleção dos santuários a serem restaurados estava Tito Pompônio Ático, nos últimos anos de sua vida, responsável direto pela escolha do templo de Júpiter 
Feretrius como objeto da restauração augustana (Nepos, Ático, 20). No Oriente grego, há evidências para projetos semelhantes - em menos escala - na Messênia e em Argos na Grécia, Efeso e Cime na Ásia Menor (Schmalz, 2007-2008, pp. 26-27; Spawforth, 2012, pp. 211-232), todos eles associados direta ou indiretamente a Roma e aos membros da família imperial (seja como financiadores, seja como homenageados).

Sem negligenciar completamente as implicações materiais do decreto - em particular a questão das terras sagradas - G. Schmalz propõe uma interpretação geral para o programa restaurador: trata-se de um episódio da construção de um idioma comum às cidades gregas para a comunicação cultural entre elas e com as autoridades romanas no início do principado, no qual a memória cultural grega desempenharia um papel central (Schmalz, 2007-2008, p. 11). A. Spawforth (2012, pp. 107-112) desenvolveu esta interpretação a partir da ênfase nos processos de seleção do passado a ser lembrado: os atenienses selecionaram os sítios não em função simplesmente do "orgulho local", mas também em função das expectativas romanas em relação ao passado grego. Assim, a atenção dada aos equipamentos náuticos do Pireu era contraditória com a então irrelevante marinha ateniense; no mesmo sentido, a referência à guerra do Peloponeso, que resultou na traumática derrota, só faria sentido para uma audiência ávida pela história grega, e não somente os sucessos atenienses (Spawforth, 2012, p. 110) ${ }^{332}$.

A restauração dos santuários atenienses seria, dessa forma, um dos fatores mais importantes da romanização de Atenas. No entanto, é possível levantar uma série de ressalvas a esta interpretação. Em primeiro lugar, a celebração das guerras médicas como referência central da identidade grega - e ateniense - não pode, de maneira alguma, ser tomada como uma invenção augustana: a intensa construção na acrópole na época de Péricles e nos séculos seguintes, em particular no final do IV e início do II, demonstram com clareza o modo como as guerras médicas já eram um elemento estrutural da identidade local e da comunicação cultural de Atenas com as potências e centros culturais mediterrânicos. A valorização das guerras médicas por Roma é parte deste processo de consolidação de um discurso autoreferenciador grego, que tem no período helenístico sua formação em âmbito mediterrânico: é neste momento, em

${ }^{332} \mathrm{O}$ sucesso do programa cultural das restaurações, centrado especialmente na celebração das guerras médicas, seria evidente, por exemplo, no evergetismo praticado por C. Júlio Nicanor, um evergeta sírio que se tornaria general dos hoplitas em Atenas, e que teria recebido o título de "Novo Temístocles", provavelmente por ter restaurado a Atenas a posse de territórios em Salamina (Schmalz, 2007-2008, pp. 16-17). 
particular com Alexandre e com os reis atálidas, que a memória local anti-bárbara ateniense se torna um "idioma" para a diplomacia, tanto para a segurança de Atenas, quanto para a afirmação de novas potências. Em segundo lugar, a prática de restauração dos santuários é atestada em diversos momentos na história ateniense, em particular nas reformas de Licurgo (Étienne, 2005); provavelmente não por acaso, Temístocles de Hagnous, um dos personagens centrais da política e da religiosidade ateniense na época de Augusto, era descendente tanto do vencedor dos persas em Salamina, quanto, por meio da esposa, do legislador do século IV (Spawforth, 2012, p. 116, n. 48). Não há indícios claros para a participação de Temístocles no programa da restauração, mas o prestígio mantido pela família e do genos de Licurgo (os Eteobutadais) no período helenístico e romano vão na direção de uma retomada de sua política religiosa de restauração de santuários e práticas rituais (Mikalson, 1998, p. 11-45, p. 241, 307). Em síntese: as práticas e as idéias pressupostas na restauração dos santuários já existiam no período anterior, e faziam parte do repertório disponível para sua nova execução.

Um aspecto particularmente interessante do decreto é a sua ênfase nas questões fundiárias. O decreto é explícito: visa, além da restauração de edifícios, a restauração da propriedade das terras sagradas invadidas por agentes privados. Dois santuários são centrais para este processo: os santuários de Teseu e de Atena Polias, que detinha terras não somente nos arredores de Atenas, como também em outras regiões da Ática. As implicações desta restauração fundiária são enormes: trata-se de uma recomposição da estrutura da propriedade da terra - para cujas grandezas não temos, infelizmente, documentação - que passa a ter como agentes centrais os sacerdotes encarregados da manutenção de seus respectivos santuários. Não por acaso, o período augustano assiste a processos de recomposição dos gene tradicionais, em particular os Kerykes (de Temístocles de Hagnous) e o Eteobutadai (de Areios de Peânia). Diversos sacerdócios se tornam vitalícios, tais como o de Apolo Délio ou o de Asclépio, o que significa que o sacerdote será o administrador para toda a vida de propriedades de terra dos santuários ${ }^{333}$. A raridade de documentação relativa à propriedade fundiária ateniense na época augustana impede a construção de hipóteses mais seguras, mas é tentador pensar que a afirmação da aristocracia fundiária ateniense passa, neste período, por uma reconfiguração: os sacerdócios se tornam mecanismos fundamentais para a obtenção e

\footnotetext{
${ }^{333}$ Sobre a administração pública e clânica das terras sagradas, cf. Papazarkadas, 2011, especialmente pp. 170-190. Sobre as estelas com inscrições de limite das terras sagradas, cf. Lalonde, 1991, que cita dois horoi de época romana relativos ao temenos de Atena Polias, gerido pelo genos dos Etebutadais (H23$\mathrm{H} 24)$.
} 
acumulação de propriedade, que se não é privada - posto que pertencente ao santuário é vitalícia, e permanentemente ligada ao genos, daí a importância econômica da atualização das listas de membros, das quais sobreviveram de dois dos principais gene áticos.

Além da questão fundiária, a própria restauração arquitetural dos santuários, a ser capitaneada pelo arconte-rei e pelo general dos hoplitas, demonstra o fortalecimento destas magistraturas do ponto de vista da produção do espaço urbano. A participação do arconte-rei em intervenções urbanas atenienses no período augustano só é atestada no decreto IG II2 1035, o que se explica pela fundamental importância das corretas práticas rituais no reestabelecimento dos santuários e seus cultos; a participação do general dos hoplitas, por outro lado, é bem atestada em outras intervenções (monóptero, Ágora Romana), o que indica que esta magistratura se tornou a chave para a atividade construtiva ateniense - ecoando assim as épocas de Péricles e de Licurgo. O decreto de restauração dos santuários áticos, deste ponto de vista, é uma etapa fundamental dos conflitos relacionados ao controle da produção do espaço urbano ateniense; a ambiguidade local/imperial, renovação/restauração, presente em praticamente todas as intervenções analisadas, comparece aqui de maneira particularmente associada às magistraturas, pontos de ligação entre elites imperiais e locais. 


\section{Conclusão}




\section{As lógicas do programa urbano tardo-helenístico}

Os sessenta anos entre a Dedicação Atálida e a reforma do Metroon alteraram radicalmente a paisagem urbana ateniense: conjuntos escultóricos em longas bases baixas ou altos pilares se posicionavam em locais estratégicos da circulação urbana, grandes stoas emolduravam a ágora e a encosta sul da acrópole, o gigantesco templo de Zeus na região leste da cidade se aproximava da completude e um novo complexo (ginasial?) tomava espaço da antiga ágora. É possível falar em um programa nestas intervenções? Certamente não, caso se entenda "programa" como um conjunto de ações coordenadas por um projeto único. No entanto, se entendermos por programa o conjunto das lógicas, significados e das práticas associados aos edifícios e monumentos ao longo de sua história, ou seja, incorporando seus vários momentos de realização (projeto, manufatura, uso, descarte), este pode ser um conceito útil para a interpretação das intervenções helenísticas.

A coerência do programa tardo-helenístico em Atenas é dada por dois fatores: a atualização do urbanismo ateniense em relação às cidades helenísticas, particularmente da Ásia Menor, e o papel do evergetismo monárquico na estruturação da produção do espaço urbano. Vejamos com mais detalhe.

A instalação de grandes stoas em Atenas - na ágora, na encosta sul da acrópole e, possivelmente, na região ao leste da ágora - é uma inovação do ponto de vista do urbanismo local. De fato, grandes stoas já existiam, mas não tão compridas quanto as novas. Mais do que as dimensões, a ocupação do espaço também é diferente: cada uma das três stoas helenísticas domina inteiramente o lado do espaço que procura emoldurar, enquanto a Stoa de Zeus é apenas parte da descontínua colunata que apenas no século II emoldurará o lado oeste da ágora. As grandes stoas helenísticas em Atenas, limitando e emoldurando os espaços abertos, fazem referência clara ao urbanismo microasiático, que tem em Mileto, Priene e Assos seus exemplos mais eloquentes. Não se trata, certamente, da "ágora jônica", marcada por uma grande "stoa em ferradura", ou mesmo a ágora fechada pergamena, mas percebe-se claramente na ágora ateniense o esforço para a utilização de colunatas na regularização dos limites da área aberta, cardealmente nos lados sul e leste (Stoa Média e Stoa de Átalo II), descontinuamente no lado oeste (Tholos, propileu do Bouleuterion, Metroon, templos de Apolo e Zeus e Atena, Stoa de Zeus, Stoa Real), e incompletamente no lado norte (Stoa Pintada). 
Mais do que referências genéricas ao urbanismo microasiático, as intervenções helenísticas reforçaram em Atenas os diálogos espaciais com Pérgamo. A Dedicação Atálida faria da acrópole ateniense um espelho do santuário de Atena na acrópole de Pérgamo, tanto pela temática da figuração, quanto pela relação espacial das bases com os templos. Além disso, a Stoa de Eumenes na encosta sul da acrópole faz referência à stoa do teatro de Pérgamo, na medida em que ambas emolduram a encosta atribuindo maior destaque aos edifícios na própria encosta e em seu topo. Tomando como ponto de vista seja a região sul da cidade, seja a ágora, a acrópole ateniense aparece como o estágio superior de uma série de cenários, tornando-se um exemplo eloquente do "urbanismo cenográfico" sugerido por R. Martin. Finalmente, os indícios de participação pergamena na construção da Praça Sul, associados à possibilidade de que ela era, na verdade, um ginásio - fosse ou não fosse o Ptolemaion - apontam fortemente para um paralelo com o ginásio de Pérgamo, intimamente associado à “ágora inferior”, e que tinha estruturas semelhantes a templos ou tesouros dentro de seu pátio interno.

O evergetismo, por sua vez, se torna apenas no século II o elemento de estruturação da produção do espaço urbano em Atenas, até então dominada pela ação políade. De fato, os dois grandes programas construtivos em Atenas no período clássico, apesar de associados à iniciativa de Péricles e de Licurgo, foram financiados pelo tesouro público; se a lógica das intervenções se relacionava às preferências políticas de seus idealizadores, isso se deve a eles ocuparem cargos centrais da administração pública por aqueles. A partir do século II, e em particular com a construção da Stoa de Eumenes, a cidade entra em um novo período de sua história construtiva no qual o evergetismo fornecerá tanto a gramática quanto as palavras.

É preciso dissociar, em primeiro lugar, dois aspectos do evergetismo construtivo. O primeiro é o evergetismo que realiza a doação no próprio edifício, ou seja, no qual o edifício é o presente. Este foi o caso claramente da Dedicação Atálida, da Stoa de Átalo II, da Stoa de Eumenes II e do Olympieion, e também, conforme discutido acima, foi o caso da reforma do Metroon e da construção da "Praça Sul". O segundo é a resposta da comunidade local ao evergetismo, que também assume uma dimensão espacial: foi o caso dos pilares atálidas, das estátuas no monumento dos Heróis Epônimos, da inscrição na arquitrave da Stoa de Átalo II e das estátuas e decretos honoríficos no santuário do Demos e das Graças.

Em segundo lugar, é preciso dissociar também os momentos do programa construtivo no qual o evergetismo se realiza. Assim, a Stoa de Átalo II revela a 
interferência do evergetismo atálida ainda em seu projeto e também na manufatura, com a utilização de técnicas construtivas e repertórios ornamentais pergamenos (que espelham a stoa do santuário de Atena em Pérgamo), mas não na proveniência dos materiais, onde, diferentemente da Stoa de Eumenes (que usa mármore da Ásia Menor), foram utilizados mármores áticos. A Stoa de Eumenes aparentemente foi uma intervenção puramente pergamena - forma, materiais, técnicas - mas, quando se considera a história da área, percebe-se que ela se integrou a um projeto urbanístico anterior, datado ainda do século IV e ligado às reformas licurgueanas. Os usos dos edifícios podem estar ligados ao evergetismo, mas não se limitam a ele: assim, é de se supor que a Stoa de Átalo II tenha servido como local para as atividades da tribo Attalis, criada em homenagem a Átalo I; no entanto, os indícios de utilização para práticas comerciais ou mesmo como terraço para espectadores de festivais que ocorreriam na ágora apontam para outros usos possíveis; o mesmo vale para a Stoa de Eumenes como abrigo para os espectadores do teatro de Dioniso. A Dedicação Atálida revela a interferência pergamena na escolha do tema e no estilo escultórico (projeto e manufatura), mas esta interferência se articulava a práticas artísticas e espaciais já presentes na acrópole, e mesmo a disposição da dedicação ao longo a área sul, se paralela àquela do monumento equivalente pergameno, possivelmente já estava prevista no programa pericleano na acrópole, o que é indicado pela extensão da muralha que só teria sentido como fundação para intervenções construtivas. Se considerarmos o Olympieion, o evergetismo é evidente no financiamento, na escolha da ordem e no fornecimento da mão-de-obra especializada - o arquiteto Cossutius - mas não na escolha da localização do templo ou mesmo da divindade à qual ele será dedicado, dois aspectos que já haviam sido definidos séculos antes da iniciativa de Antíoco IV.

Tomando as intervenções como um todo, vemos que o evergetismo pode se realizar em qualquer momento do programa, mas não se realiza em todos. Isto evidencia o fato de que, apesar do evergetismo ter se tornado o elemento de estruturação da produção do espaço, ele não é total, ou seja, as intervenções de natureza evergética devem dialogar com as tradições locais na formação de um programa coerente, levando em consideração, em determinada intervenção, o espaço disponível (alocado ou não para tal intervenção anteriormente), os materiais e técnicas locais e, principalmente, os usos da intervenção que são criados na medida de sua articulação com o amalgama de programas construtivos anteriores que formaram o espaço urbano. 
A interação do programa construtivo helenístico com os programas anteriores é complexa. Por um lado, as intervenções helenísticas continuam aspectos destes programas: são exemplos disso a localização do Olympieion, da Dedicação Atálida e da Stoa de Eumenes, que se aproveitam de espaços preparados em períodos anteriores para tal. Por outro lado, algumas intervenções claramente rompem com tradições anteriores, como é o caso da Stoa de Átalo II e da Stoa Média na ágora: a divisão da área aberta na parte sul da ágora claramente contradiz a lógica espacial de uma grande ágora evidente na construção da Stoa Sul I no período clássico; o mesmo pode ser sugerido em relação à área leste da ágora com a construção da Stoa de Átalo II, ainda que as poucas escavações e ausência de fontes epigráficas enfraqueçam a hipótese de uma "grande ágora" também para o leste, até o Horologium. Dentro desta dualidade de continuidade e ruptura, duas intervenções são particularmente interessantes: o Olympieion e a "Praça Sul”. O primeiro é tanto continuidade de localização e divindade quanto ruptura de ordem e (consequentemente) dimensões. A ruptura da ordem coríntia do Olympieion não é apenas em relação ao dórico psistrátida, mas também em relação à arquitetura grega como um todo: trata-se do primeiro templo a usar a ordem coríntia na face externa, tornando-se desse modo em um manifesto da arquitetura romano-selêucida que influenciará profundamente a arquitetura posterior. Não houve, então, qualquer preocupação "antiquária”, em se preservar as escolhas estéticas anteriores; talvez em função mesmo da ambiguidade do Olympieion - por sua associação à tirania - não houve qualquer reverência a um passado materializado na ordem dórica. A "Praça Sul", por sua vez, implicou diretamente na demolição de dois edifícios (a Stoa Sul I e os edifícios no canto sudoeste da ágora) e indiretamente no reuso de elementos arquiteturais de outro (o Peristilo Quadrado). O programa construtivo tardo-helenístico na hesita na demolição ou remodelagem de edifícios de programas anteriores, quando se está em jogo um novo padrão de ocupação do espaço - padrão este que se aproxima do modelo microasiático das ágoras menores, fechadas e especializadas.

A execução de uma reestruturação urbana, que visava ao mesmo tempo a atualização do espaço urbano ateniense frente aos modelos helenísticos e estabelecimento do evergetismo como elemento estruturante da produção do espaço, não poderia ser feita sem mediações que permitissem o diálogo entre ideias e práticas espaciais locais e estrangeiras. Duas mediações são particularmente visíveis na documentação: a mediação religiosa e a mediação agonística. A primeira tem como pressuposto a ideia de que cultos semelhantes nas duas cidades envolvidas - Atenas e a 
capital do monarca evergeta - são facilitadores das intervenções espaciais. Assim, o culto a Atena como vencedora dos bárbaros foi o fundamento do paralelismo entre Atenas e Pérgamo na acrópole: a Dedicação Atálida duplicava o monumento anti-gálata da acrópole pergamena, assim como o pilar de Eumenes ao lado do propileu se equilibrava com o templo de Atena Nike. O culto de Éaco na ágora pode ser considerado, conforme se argumentou, como o fundamento da construção da Praça Sul, na medida em que seu santuário era a única construção próxima a uma orientação cardeal ortogonal - que estruturará tanto a Praça Sul quanto a Stoa de Átalo II, superando a possibilidade de uma estruturação baseada nos edifícios do lado oeste ou na Stoa Poikile - assim como as referências ornamentais (como a sima de cerâmica) e mesmo o material de construção (calcário egineta) indicam o papel do culto de Éaco em Egina, associado ao culto ao próprio Átalo na ilha, na instalação da primeira intervenção helenística na ágora. O Metroon é mais um exemplo da importância desta mediação, seja pela importância do culto da deusa Mãe em Pérgamo, seja pela presença de um culto aos dióscuros (associados aos irmãos Eumenes II e Átalo II) indicado pelo capacete esculpido em pedra encontrado em um dos recintos. Finalmente, deve-se destacar o papel do culto a Zeus/Júpiter na ideologia e na propaganda de Antíoco IV na escolha do Olympieion como o templo cuja construção seria financiada pelo rei sírio.

Os festivais da cidade, por seu turno, também foram mediações fundamentais para as intervenções. Esta "mediação agonística" é visível na íntima relação entre algumas das intervenções e os espaços das competições ligadas à realização dos festivais atenienses, em particular das Dionisías urbanas e das Grandes Panatenéias. A Stoa de Eumenes se associava tanto de um ponto de vista funcional (relatado por Vitrúvio) quanto espacial com o teatro de Dioniso: monumentalizava uma via que dava acesso à orchestra do teatro; a ligação da monarquia atálida ao culto a Dioniso, em particular por meio da companhia dos artistas dionisíacos da Jônia, é bem documentada. Apesar da importância do teatro na vida políade ateniense, nenhum festival é comparável às Grandes Panatenéias, e nenhum ritual à grande procissão que fechava o festival quadrienal. A influência da procissão panatenaica na disposição dos edifícios e monumentos helenísticos já foi discutida por J. Shear (2001), que sugere que a procissão panatenaica tenha um papel espacial estruturante. De fato, as stoas na ágora serviam não apenas como emolduração da ágora, mas também como plataformas para os espectadores da procissão; os grandes pilares helenísticos estão posicionados em pontos de destaque no percurso da procissão, da entrada da ágora ao final diante do 
Pártenon. Pode-se dizer, correndo algum risco de exagero, que houve uma lógica panatenaica nas intervenções atálidas, ausente nas preocupações, por exemplo, de Antíoco IV. Esta atenção atálida com os festivais panatenaicos tem como evidência definitiva a presença da família real pergamena nas listas de vencedores da primeira metade do século II, assim como a criação de uma Panathenaia em Pérgamo. No caso da dinastia ptolomaica, sabe-se que Ptolomeu VI venceu uma competição disputada em plena ágora, e reservada aos cidadãos; caso a Praça Sul seja, de fato, o Ptolemaion, sua localização na ágora se torna eloquente diante de sua valorização pelo rei egípcio.

Além dos pressupostos para as intervenções, que permitissem o diálogo entre tradições locais e estrangeiras, era necessária a mediação dos agentes do evergetismo, sejam eles locais ou estrangeiros. Neste ponto, a documentação é tragicamente pobre. Não há referência a epimeletas responsáveis pelas obras das intervenções helenísticas em Atenas, tal como para a Ágora Romana na época de Augusto; as intervenções helenísticas são associadas ou diretamente ao monarca, ou à iniciativa estatal na dedicação de um monumento de agradecimento - neste ponto, a documentação ateniense não se compara às fontes do evergetismo na Ásia Menor helenística e romana. Das poucas inscrições indicando a ação de embaixadores atenienses ou estrangeiros que mereceram honras na forma de decretos honoríficos ou estátuas em Atenas, nenhuma pode ser associada diretamente a qualquer intervenção construtiva. As listas de vencedores nas competições atléticas atenienses, e em particular nas competições de custo maior, como as corridas equestres, podem ser tomadas como indícios da proximidade entre membros da elite local e membros das monarquias helenísticas; no entanto, nenhuma informação pode ser extraída de modo direto.

No entanto, as intervenções se relacionam diretamente com a elite ateniense, mas em outro momento: no processo de formação destas elites enquanto efebos. A efebia ateniense foi profundamente reformulada entre o final do século IV e início do III, tornando-se não mais obrigatória e passando a ter um custo que limitava seus membros às famílias mais ricas da cidade. $\mathrm{O}$ marco da associação entre a efebia como formação das elites e o evergetismo parece ter sido a dedicação do santuário do Demos e das Graças, no final do século III, quando passou a fazer parte do circuito de atividades efébicas: o sacerdote do Demos e das Graças participava da gestão das atividades junto dos cosmetes, em particular na organização dos sacrifícios em agradecimento aos evergetas de Atenas, e, a partir de meados do século II, expressamente ao povo romano. Para além do local de boa parte das atividades atléticas 
e intelectuais dos efebos serem realizadas do Ptolemaion, observa-se na associação entre o culto ao Demos e as Graças - ele próprio um culto de agradecimento às práticas evergéticas - o nascimento de uma cultura do evergetismo, que estará na base da formação das elites atenienses.

A importância desta cultura evergética para as estratégias atenienses na geopolítica mediterrânica é evidente. Os edifícios e monumentos doados pelos monarcas helenísticos são ao mesmo tempo produtos e vetores de diplomacia fundada no desnível entre Atenas e as monarquias nos planos militar e cultural. No plano militar, Atenas não tem mais qualquer potência comparável aos grandes contingentes das monarquias helenísticas ou da república romana. Em contrapartida, nenhuma capital das destas potências tinha o prestígio cultural de Atenas, de base tanto material quanto literária. Este desequilíbrio era o fundamento da busca por Atenas como espaço de exposição e propaganda da dinastia, cuja importância era muito maior do que qualquer facilidade de ordem militar (como o uso do Pireu como base); Atenas, como cidade símbolo da helenidade, poderia ser um fiadora das alegações de helenidade de reinos cujas populações eram multi-étnicas. A relevância desta alegação se torna evidente com as constantes associações, feitas por atenienses, entre macedônios e persas, ou entre pergamenos e os próprios atenienses. Os atenienses, conscientes de sua posição no cenário cultural helênico justamente por conta da supervalorização de sua tradição literária em centros como Alexandria e Pérgamo, poderiam, pelo aluguel de seus espaços para a propaganda dinástica, assegurarem sua autonomia em um contexto estruturalmente anárquico e particularmente instável com a entrada de Roma e o colapso ou enfraquecimento das dinastias dos Sucessores, a partir do início do século II. A busca por potências que fossem ao mesmo tempo suficientemente distantes para impedir a anexação territorial (como poderia acontecer com a Macedônia) e suficientemente fortes para assegurar os tratados que concediam autonomia às cidades como Atenas (como era o caso de Roma) foi a linha norteadora da diplomacia ateniense, perseguida com êxito por mais de um século.

O evergetismo construtivo, que havia se estabelecido na lógica da produção do espaço urbano ateniense como elemento estruturante, era parte fundamental do concerto diplomático geral que os atenienses desenvolveram no período tardo-helenístico, após a libertação da Macedônia e antes da dominação incontestável de Roma. A hierarquia da comemoração espacial do evergetismo em Atenas era clara: aos monarcas eram concedidas honras relacionadas às estruturas da vida cívica, religiosa e agonística 
ateniense, tais como a inclusão entre os Heróis Epônimos, a associação a divindades centrais nos cultos cívicos, ou a nomeação de edifícios monumentais em regiões centrais da cidade; aos embaixadores, bastavam decretos honoríficos e estátuas colocadas no santuário do Demos e das Graças, assim como proclamações e concessões de coroas durante os festivais. Uma figura intermediária era Diógenes, protagonista do fim da presença militar macedônica na cidade, que foi incorporado à religião e ao calendário agonístico cívico mas não foi incorporado como herói epônimo. Esta hierarquiazação permitia uma gramática urbana do evergetismo, que teria na procissão panatenaica um momento dramático de leitura (em particular do evergetismo atálida), do santuário do Demos e das Graças na entrada da ágora à Dedicação Atálida no final do percurso. Percursos por outras regiões de Atenas não deixariam de destacar seja a presença selêucida no projeto não concluído de reconstrução do Olympiion, seja a atálida na concluída Stoa de Eumenes, emoldurando por baixo a encosta sul da acrópole que era, neste ponto, encabeçada pela Dedicação Atálida.

Curiosamente, pouquíssimas intervenções urbanas do século II podem ser associadas com segurança a Roma; será preciso o advento da grande destruição de 86 para o aparecimento de intervenções cada vez mais visivelmente romanas, que rediscutirão as lógicas do programa tardo-helenístico e estabelecerão a nova lógica que dominará, junto da comemoração dinástica, o programa augustano: o urbanismo antiquário.

\section{Urbanismo antiquário e comemoração monárquica}

O período de formação da lógica das intervenções romanas da ágora pode ser dividida em alguns período definidos.

Um primeiro período inclui todas as intervenções espaciais associadas a Roma antes do saque de 86. Como vimos, a documentação de um eventual Rhomaion não é conclusiva, assim como a incorporação do culto a Roma no santuário do Demos e das Graças não pode ser atribuída com segurança ao século II; o mesmo problema na datação aparece para a instalação do bema romano. Apesar disso, é bastante provável que tais intervenções já estivessem em pauta na segunda metade do século II, diante das transformações da própria estrutura geopolítica no Mediterrâneo Oriental: a destruição de Corinto em 146 certamente foi determinante na percepção da hegemonia romana, 
coincidindo, do ponto de vista ateniense, com o início do enfraquecimento da posição de Pérgamo e dos reinos helenísticos como protetores relevantes.

No caso do Rhomaion e do santuário do Demos, das Graças e de Roma, é perceptível a estratégia da mediação religiosa como suporte para a intervenção: a ligação dos dois santuários com mitos fundadores atenienses, em particular com o cico mítico de Teseu, apontam para um movimento local de interpretação do contexto e ao mesmo tempo de incorporação do novo (a hegemonia romana) dentro de estruturas já conhecidas. A rotatividade dos magistrados romanos responsáveis pela gestão do império, no entanto, impedia a criação de laços comparáveis ao dos monarcas helenísticos; dessa forma, a solução encontrada foi o estabelecimento do culto à própria cidade, na forma da deusa Roma, ao mesmo tempo mais genérica e mais evasiva do que a propaganda dinástica helenística. A estrutura republicana da dominação romana está na base da inexistência de um programa coerente de intervenção espacial romana sobre Atenas; as intervenções ligadas à atividade religiosa partem da população local e é realizada a partir de seus próprios critérios.

O bema na ágora, no entanto, aponta para outra direção. O caráter utilitário da intervenção - permitir a comunicação não institucional com a massa - se manifesta na ausência de um programa ornamental de destaque: as marcas romanas estavam mais na utilização da plataforma por generais romanos do que por qualquer elemento de natureza estética. Sua instalação marca uma ruptura nas práticas de reunião política atenienses, o que se explica pela posição extraordinária ocupada por Roma no cenário geopolítico do Mediterrâneo oriental na segunda metade do século II.

O marco fundamental da ruptura é o saque de 86 , no qual, como vimos, as representações sobre o passado ateniense tiveram um papel central, tanto na tentativa (frustrada) de evitar o saque quanto na decisão de não destruir inteiramente a cidade. $\mathrm{O}$ impacto do saque, para além dos danos materiais causados no processo de invasão, deve ser compreendido nos termos da construção de uma nova atitude em relação ao espaço. A possibilidade da destruição total, que arrasasse a densidade histórica associada aos locais, promoveu justamente o reforço da consciência da historicidade do espaço. Em 86, Atenas entra definitivamente no coração das transformações pelas quais passam Roma e todo o Império; o paralelismo de Roma e Atenas, ambas parcialmente destruídas por Sula, aponta para a construção de uma modalidade de integração nova ao Mediterrâneo romano, sem a mediação das monarquias helenísticas. 
Esta historicidade do espaço é a marca do segundo período, que se estende do saque em 86 até o final da década de 50. Neste período, a ênfase é dada na restauração e preservação. A restauração se dá tanto por razões práticas (no caso do Tholos e do Asklepieion, por exemplo) quanto pela conjugação de razões práticas e elementos propagandísticos, como na reconstrução do Odeion de Péricles e das restaurações de Pompeu. No caso do Odeion de Péricles, a dinastia capadócia em certa medida recupera o programa tardo-helenístico por meio da reafirmação da comemoração anti-bárbara, situando-se, por meio da intervenção na encosta da acrópole ateniense, como oposição à alternativa persa/pôntica/parta. No entanto, à diferença do programa tardo-helenístico, a intervenção no Odeion é uma restauração, que só encontra paralelo na (possivelmente datada no século II) restauração do Erechtheion; não está no horizonte, neste período, grandes implantações arquiteturais visando a construção de novas paisagens. A preservação, por sua vez, mesmo que conhecida para apenas um caso - a casa de Epicuro - é extremamente rica na medida em que revela a construção de uma rede preservacionista composta por atenienses e estrangeiros, que tem, para com o espaço, uma atitude mediada pelo conhecimento erudito. As décadas entre 80 e 50 são, justamente, o período de formação de uma atitude propriamente antiquária em relação ao espaço, que terá na figura de Ático um de seus personagens principais - mesmo que nenhuma intervenção em Atenas seja associada a ele. Os interesses antiquários que Ático ajudará a construir em Roma certamente consolidou a estratégia ateniense da valorização erudita de suas próprias tradições, cada vez mais reconhecidas pelos romanos.

Um terceiro período se inicia no final da década de 50 e vai até o final da década de 40, quando é atestada a demanda por um edifício radicalmente novo - o novo mercado ao leste da Stoa de Átalo II, que seria terminado apenas no período augustano (a chamada Ágora Romana). A existência desta demanda aponta para a retomada da atividade construtiva ateniense ligada ao desenvolvimento da própria cidade, para além do museu a ser visitado por romanos e outros. No entanto, as vicissitudes da guerra civil impedem tal retomada, e acabam por reforçar, mais ainda, a estratégia antiquária: este será novamente o argumento que salvará a cidade da destruição sob César, assim como será a estratégia adotada na comemoração dos tiranicidas Bruto e Cássio.

Um quarto período, finalmente, equivale à década de 30, dominado pela figura de Marco Antônio. A relativa estabilidade na cidade faz com que a estratégia antiquária vá para o segundo plano; os longos períodos de estadia de Antônio na cidade, por sua 
vez, promovem um resgate de um dos elementos do programa tardo-helenístico até então latente: o culto ao soberano. Infelizmente, a exiguidade da documentação impede uma determinação precisa dos modos pelos quais se manifestou no espaço a presença de Antônio; a referência à rededicação de um monumento atálida, entretanto, é uma indicação suficiente da incorporação do novo Dioniso no contexto de práticas de comemoração estabelecidas ainda no século II. Mais do que às tradições e mitos fundadores da identidade políade - como na assimilação de Bruto e Cássio aos tiranicidas - o posicionamento de Antônio como novo Dioniso significava sua interpretação como monarca helenístico, o que era, no século I, já uma tradição antiga na cidade. A ausência de vestígios do evergetismo construtivo de Antônio não pode ser tomada de modo absoluto; não é improvável que as intervenções augustanas tenham sido implantadas justamente sobre as eventuais intervenções antonianas.

Do ponto de vista da produção do espaço, no período entre meados do século II e o início do principado, Atenas passou da integração indireta à integração direta ao sistema romano de dominação. Até 86, as intervenções ocorriam na cidade, normalmente, pela iniciativa de monarcas gregos; Roma era a potência hegemônica, mas sua posição não se manifestava de modo monumental na cidade (ainda que a posição do santuário do Demos, das Graças e de Roma na entrada da ágora não seja desprezível). Em 86, a intervenção destrutiva de Sula inauguraria o período da integração direta, pela qual as transformações no espaço urbano ateniense estariam intimamente ligadas às vicissitudes da política romana; Atenas se consolidaria na paisagem cultural mediterrânica como berço e símbolo da civilização contra a barbárie (visível nas intervenções de Pompeu, Cícero e Ariobarzanes) e símbolo dos valores republicanos (visível na comemoração de Sula, Bruto e Cássio como tiranicidas); a circulação de livros (como a biblioteca peripatética adquirida por Sula), estátuas (como as encomendas de Cícero a Ático) e elementos arquitetônicos (como as colunas do Olympieion levadas ao Capitólio) são indícios desta consolidação.

A integração direta significa, entre outras coisas, a necessidade de acomodação diante das novas estruturas de poder da republica romana, cada vez mais concentradas nos grandes generais (Sula, Pompeu, César, Antônio), assim como nas novas estruturas cognitivas romanas, marcadas pela verdadeira revolução iniciada com a adoção de formas literárias e estéticas gregas (Wallace-Hadrill, 2008) que deslegitimariam a aristocracia tradicional romana em nome de um conhecimento mediado pelas técnicas de pesquisa e pela erudição de natureza antiquária que visava restabelecer, justamente, 
as "verdadeiras" tradições. Este duplo e ambíguo processo de ruptura (poderes sem precedentes) e continuidade (valorizaçãoda tradição) resulta, para Atenas, no desenvolvimento de duas atitudes em relação ao espaço já existentes, mas cuja relação ainda não havia sido desenvolvida: o urbanismo antiquário e a comemoração monárquica. A ascenção da primeira após o saque de 86 a tornou uma alternativa viável à comemoração monárquica na relação com os potentados, e uma se sobreporá à outra ao sabor das circunstâncias: mais monarquia com Antônio, mais antiquarianismo com Bruto e Cássio. A vitória de Augusto em 31, no entanto, reforçando a ambiguidade deste processo (concentração sem precedentes do poder e valorização das tradições), promoverá a grande síntese entre as duas atitudes que alterá radicalmente, em nome das tradições, a paisagem urbana ateniense.

\section{As lógicas do programa augustano}

As intervenções augustanas são muitas e variadas; produzir uma explicação geral a partir de um fator, tal como a propaganda imperial ou a resistência local, como discutido para cada uma das intervenções, não dá conta da multiplicidade de soluções e da ambiguidade de cada caso. Antes, seguindo a sugestão de A. Winterling (2009, p. 1), a síntese proposta aqui discutirá a simultaneidade dos não-simultâneos, ou, em outras palavras, procurará identificar as lógicas e padrões do programa urbano augustano como um modo de melhor esclarecer o jogo de relações entre os elementos de continuidade e os elementos de ruptura. Ao invés de uma interpretação geográfica (Roma x Atenas), procuraremos apresentar uma interpretação temporal (continuidade x ruptura).

As diversas intervenções são documentadas de modo desigual: para algumas, há indicação clara do financiamento (Ágora Romana), enquanto para outras não há nem se quer menção literária ou epigráfica (reformas no Tholos). Considerando os diferentes momentos do programa urbano a partir da documentação disponível, é possível estabelecer que no projeto, são utilizados repertórios tanto italianos e/ou microasiáticos (Agrippeion, Templo Noroeste) quanto locais (monópteros). Na manufatura, as diferentes intervenções apresentam técnicas e materiais variados, que vão do mármore importado da Eubéia (Stoa Nordeste) a blocos de reuso de edifícios em ruínas (Arsenal - Stoa Noroeste), de inovações na cobertura de grandes áreas (Agrippeion) à remontagem de edifícios antigos (templo de Ares). O uso também apresenta uma grande 
variação: artístico (Agrippeion), comercial/administrativo (Ágora Romana, complexo do Tholos-Strategion), religioso (templos, anexo), propagandístico (monópteros) etc. O descarte é um caso especial: não há destruições de edifícios antigos para a construção de novos, exceto no caso bastante peculiar da transposição do templo de Ares, onde o templo original foi "destruído" para ser remontado na ágora; de resto, os novos edifícios se adequam aos espaços anteriores, ou, se há alteração de algum elemento, a fachada é mantida na forma original (anexo à Stoa de Zeus). Este último aspecto é um dos mais característicos do programa augustano, e será retomado mais adiante.

O conjunto das intervenções também apresenta diversos padrões de implantação. O padrão de restauração, entendida tanto num sentido amplo, incorporando novos elementos, quanto no sentido estrito, de retorno à forma original, pode ser encontrado no Asklepieion, no Tholos-Strategion, no templo de Ares e, acima de tudo, no decreto IG II2 1035. O padrão de ampliação pode ser encontrado na Ágora Romana (que amplia a área comercial murada, independente dos usos anteriores da área) e no Agrippeion, que pode ser interpretado como uma ampliação do ginásio (Praça Sul). O padrão de adequação aparece na articulação de novos edifícios a orientações determinadas anteriormente, como é o caso do Agrippeion e do templo de Ares, que respeitam estritamente a orientação cardeal das stoas helenísticas, ou na implantação do monóptero, orientado pelo eixo longitudinal do Pártenon. O padrão da duplicação ágora/acrópole aparece na criação de monumentos a Augusto na acrópole e na ágora, ambos relacionados espacialmente a santuários de Zeus (Polieus na acrópole, Eleutherios na ágora), assim como de Agrippa (pilar diante do propileu da acrópole, teatro coberto na Ágora). Finalmente, o padrão da apropriação é estruturante no monóptero (que se apropria da narrativa anti-bárbara condensada no Pártenon e na Dedicação Atálida), no templo de Ares (que se apropria dos cultos de Ares com provável ligação ao culto imperial), e também no conjunto Agrippeion-templo de Ares, que se apropria da procissão panatenaica criando eixos diagonais que reforçam sua monumentalidade.

Tais padrões são estruturados, por sua vez, por duas lógicas dominantes: a comemoração monárquica e o urbanismo antiquário, que se fundem em uma síntese característica do principado augustano. O templo de Ares, por exemplo, é uma manifestação extrema do antiquarianismo: a transposição integral de um templo clássico para o centro da ágora, remontado e restaurado; simultaneamente, as inscrições que associam Caio César a Ares indicam claramente para a lógica da comemoração 
dinástica presente na implantação de Ares no centro da ágora. Os exemplos se multiplicam: o monóptero, cuja arquitetura é quase academicamente inspirada no Erechtheion, estava ligado à comemoração monárquica de Augusto contra os bárbaros; o Agrippeion, cujo uso apontava para o antiquarianismo das temáticas sofistas, também realizava a comemoração monárquica por meio da conotação dinástica de sua articulação com o templo de Ares.

A convivência entre urbanismo antiquário e comemoração monárquica/dinástica em Atenas se resolve diante do contexto geopolítico: celebrar as tradições locais e comemorar os poderosos de então era a forma encontrada pelos atenienses para garantirem sua segurança em um mundo só recentemente estabilizado. Mas é preciso ter em mente o fundamento material desta convivência: por um lado, o saque de 86 e o reforço de uma consciência antiquária do espaço, a partir de então compartilhado pelos romanos, e por outro, a formação da autocracia augustana pela eliminação de um rival particularmente próximo de Atenas, Antônio. Ademais, o programa augustano operou uma seleção na memória condensada no espaço: a supervalorização da tradição antibárbara no monóptero, da tradição literária no Agrippeion, e da tradição religiosa no templo de Ares é diretamente proporcional à relativa marginalização da tradição tiranicida (protagonista no episódio de 44) e dos cultos dionisíacos, particularmente associados a Antônio.

Isto não significa um retorno a uma visão excessivamente romanizante do programa augustano; a discussão demonstrou não apenas a participação ativa das elites locais, ávidas por demonstrar sua adesão à causa augustana e expor aos cidadãos sua proximidade com a casa imperial, mas também enfatizou a multiplicidade de interpretações disponíveis em cada intervenção e em seus conjuntos. A nova paisagem urbana de Atenas tornava a cidade simultaneamente mais romana e mais ateniense - sua interpretação deve dar conta da ambiguidade do programa, que reitera, a todo momento, padrões espaciais tardo-helenísticos e tardo-republicanos. Atenas se tornava uma pólis imperial, incorporando em sua paisagem todas as ambiguidades de um sistema ao mesmo tempo republicano e monárquico, local e mediterrânico.

Da mesma maneira, a visão que enfatiza excessivamente a ruptura das intervenções augustanas deve ser rejeita: as rupturas augustanas se inserem em um quadro mais amplo definido a partir de 200, o quadro do evergetismo construtivo. Mesmo que nem todas as intervenções estivessem relacionadas às práticas evergéticas (da doação ao agradecimento), sua hegemonia na atividade construtiva é inegável. Esta 
é a estrutura a partir da qual as intervenções augustanas - e depois, adriânicas - poderão variar.

Em suma: o espaço urbano ateniense entre os anos 200 a.C. e 14 d.C. foi locus privilegiado para a integração mediterrânica, e algumas consequências desta mediterranização - tais como a cristalização da imagem de Atenas como o berço da civilização e como bastião antibárbaro - ainda paira sobre nossas cabeças. 


\section{Bibliografia}

\section{Fontes literárias:}

ANTIFONTE. Antiphon, the sophist: the fragments / edited with introduction, translation, and commentary by Gerard J. Pendrick. Cambridge : Cambridge University Press, 2009.

APIANO. Appian's roman history. 4 vols. Edited by G. Goold, translated by Horace White. London: William Heinemann, 1982

APOLODORO. The Library. London : William Heinemann, 1921.

ARISTOFANES. Os acarnenses. Coimbra : Inic, 1988.

ARISTÓTELES. A Política. Rio de Janeiro : Nova Fronteira, 2011.

ARRIANO. Arrian. London: William Heinemann, 195-.

ATHENAEUS. The Deipnosophists. Cambridge: Harvard University Press, 1963.

DEMÓSTENES. Demosthenes. Cambridge, Mass. / London: Harvard University Press / W. Heinemann, 1986-1994.

DIO CÁSSIO. Dio’s Roman History. London / Cambridge (Mass.): W. Heinemann / Harvard University Press, 1954-55.

DIODORO SÍCULO. Biblioteca histórica. Madrid : Gredos, 2001-2004.

DIÓGENES LAÉRCIO. Lives of eminent philosophers. Cambridge: Cambridge university press, 2013.

HERACLIDES. Die Reisebilder des Herakleides. Wien : Rudolf M. Rohrer, 1951.

HORÁCIO. Orazio, Tutte le poesie. Torino : G. Einaudi, 2009.

JUSTINO. Justin, Philosopher and Martyr: Apologies. Oxford: Oxford University Press, 2009.

LUCANO. La guerre civile. Paris: Société d'édition "Les Belles-Lettres,", 1967.

MALALAS. Chronographia. Berlin : De Gruyter, 2000.

PAUSANIAS. Description de la Grèce. Paris : Les Belles Lettres, 2002.

FILÓSTRATO. Lives of the sophists. London : William Heinemann, 1952.

PÍNDARO. Selected odes. Ann Arbor : University of Michigan Press, 1968. 
PLUTARCO. Lives. 11 vols. Cambridge / London: Harvard University Press / W. Heinemann, 1954-62.

. Moralia. Cambridge : Harvard University Press, 1976.

POLYBIUS. The Histories. Cambridge : Harvard University Press, 1992.

ESTRABÃO. The Geography. Cambridge / London: Harvard University Press / W. Heinemann, 1954-1961.

SUDA. Suda on line. Disponível em : http://www.stoa.org/sol/.

SUETONIUS. Vies des douze Césars. Paris : Société d'édition "Les Belles Lettres", 1961.

TÁCITO. Histoires. [Paris] : Gallimard, 1997.

TITO-LÍVIO. Histoire romaine. Paris : Belles Lettres, 1998.

TUCÍDIDES. La guerre du Péloponnèse. Paris : Les Belles Lettres, 1995.

VALÉRIO MÁXIMO. Faits et dits mémorables. 2 vols. Paris : Les Belles Lettres, 2003.

VITRÚVIO. Tratado de Arquitetura. São Paulo : Martins Fontes, 2007.

\section{Estudos:}

ABRANSON, H. The Olympieion in Athens and Its Connections with Rome. California Studies in Classical Antiquity, v. 7, pp. 1-25, 1974.

ADAMS, A. The Arch of Hadrian at Athens. In: WALKER, S.; CAMERON, A. (eds.). The Greek Renaissance in the Roman Empire. London: University of London, 1989, pp. 10-15.

AGER, S. An Uneasy Balance: from the Death of Seleukos to the Battle of Raphia. A Companion to the Hellenistic World. Oxford: Blackwell, 2003, pp. 35-49.

AJOTIAN, A. A Roman Athena from the Pnyx and the Agora in Athens. In: Hesperia, v. 78, n. 4, pp. 481-499, 2009.

ALCOCK, S. Tomb Cult and the Post-Classical Polis. In: American Journal of Archaeology, v. 95, n. 3, pp. 447-467, 1991.

. Graecia Capta: the landscapes of Roman Greece. Cambridge: Cambridge University Press, 1993. . (ed.). The Early Roman Empire in the East. Oxford: Oxbow Books, 1997. 
Roman Greece: landscape of resistance? In: MATTINGLY, D. (ed). Dialogues in Roman Imperialism: Power, discourse, and discrepant experience in the Roman Empire. Portsmouth: Journal of Roman Archaeology (Supplementary series, n. 23), 1997, pp. 103-15.

- Archaeologies of the Greek Past: landscape, monuments, and memories. Cambridge: Cambridge University Press, 2002.

. The reconfiguration of memory in the eastern Roman Empire. In: ALCOCK, S.; D’ALTROY, T.; MORRISON, K.; SINOPOLI, C. (eds). Empires. Perspectives from Archaeology and History. Cambridge: Cambridge University Press, 2001, pp. 323-350.

.; CHERRY, J.; ELSNER, J. (eds.). Pausanias: travel and memory in Roman Greece. Oxford: Oxford University Press, 2001.

; D'AlTROY, T.; MORRISON, K.; SINOPOLI, C. (eds). Empires. Perspectives from Archaeology and History. Cambridge: Cambridge University Press, 2001.

ALFEN, P. G. (ed). Agoranomia. New York: The American Numismatic Society, 2006.

ALESHIRE, S.; LAMBERT, S. Making the "Peplos" for Athena: A New Edition of "IG" II² 1060 + "IG" II² 1036. In: Zeitschrift für Papyrologie und Epigraphik, Bd. 142, pp. 65-86, 2003.

ALLEN, R. E. Attalos I and Aigina. In: The Annual of the British School at Athens, v. 66, pp. 1-12, 1971. The Attalid Kingdom: a Constitutional History. Oxford: Clarendon Press, 1983.

ANDERSON, G. The Second Sophistic. A Cultural Phenomenon in the Roman Empire. London and New York: Routledge, 1993.

ANDRADE, M. M. A vida comum. Rio de Janeiro: DP\&A, 2002.

ANDREAU, J.; SCHNAPP, A. ; SCHMITT-PANTEL P. Paul Veyne et l'évergétisme. In: Annales, 33, n.2, pp. 307-325, 1978.

ANTELA-BERNÁRDEZ, B. Alejandro Magno o la demostración de la divinidad. Faventia, 29/1, pp. 89-103, 2007.

. Vencidas, Violadas, Vendidas: Mujeres Griegas y Violencia Sexual en Asedios Romanos. Klio, v. 90, n. 2, 307-322, 2008.

- Metween Medeios and Mithridates: the Peripatetic Constitution of Athens (Agora I 2351). Zeitschrift für Papyrologie und Epigraphik, Bd. 171, pp. 105108, 2009a. 
Entre Delos, Atenas, Roma y el Ponto: Medeo del Pireo In: Faventia, 31, pp. 49-60, 2009b.

. Sila no vino a aprender Historia Antigua. El asedio de Atenas en 87/6 A.C. $R E A$, v. 111, n. 2, p. 475-491, 2009c.

ARAFAT, K. W. Pausanias' Greece. Cambridge: Cambridge University Press, 1996.

ARCHIBALD, Z.; DAVIES, J.; GABRIELSEN, V.; OLIVER, G. (eds). Hellenistic economies. London and New York: Routledge, 2001.

ARCHIBALD, Z.; DAVIES, J.; GABRIELSEN, V. (eds). Making, moving and managing. The New World of Ancient Economies, 323-31 BC. Oxford: Oxbow Books, 2005.

ARENZ, A. Herakleides Kritikos »Über die Städte in Hellas«. Eine Periegese Griechenlands am Vorabend des Chremonideischen Krieges. München: Herbert Utz Verlag, 2006.

ATHANASSOGLOU-KALLMYER, N. Excavating Greece: Classicism between Empire and Nation in Nineteenth-Century Europe. Nineteenth-Century Art Worldwide, v. 7, n. 2, pp. 1-27, 2008.

BADIAN, E. Sulla's Cilician Command: The Evidence of Apollinaris Sidonius. Athenaeum, v. 37, 1959, pp. 279-303.

. Rome, Athens and Mithridates. In: American Journal of Ancient History, 1, pp. 105-128, 1976.

BALDASSARRI, P. Augusto Soter. Ipotesi sul monóptero dell'Acropoli ateniense. Ostraka, anno 4, n. 1, pp. 69-84, 1995.

. Sebastoi soteri: edilizia monumentale ad Atene durante il Saeculum Augustum. Roma: G. Bretschneider, 1998.

BALlESTEROS PASTOR, L. Atenión, tirano de Atenas. Studia histórica (Historia antigua), v. 23, pp. 385-400, 2005.

BARRINGER, J. Alkamenes' Prokne and Itys in Context. In: BARRINGER, J.; HURWIT, J. (eds). Periklean Athens and Its Legacy: Problems and Perspectives. Austin: University of Texas, 2005, pp. 163-176.

BEARD, M.; NORTH, J.; PRICE, S. Religions of Rome. v.1: A History. Cambridge: Cambridge University Press, 1998.

BEAZLEY, J. D.; ASHMOLE, B. Greek Sculpture and Painting. Cambridge: Cambridge University Press, 1932. 
BENJAMIN, A. The Altars of Hadrian in Athens and Hadrian's Panhellenic Program. Hesperia 32, pp. 57-86, 1963.

BENJAMIN, A.; RAUBITSCHEK, A. Arae Augusti. Hesperia, v. 28, n. 1, 1959, pp. 65-85.

BÉRENGER, A.; PERRIN-SAMINADAYAR, É. (éd). Les entrées royales et impériales. Paris: De Boccard, 2009.

BERGER, S. Revolution and society in Greek Sicily and Southern Italy. Stuttgart: Franz Steiner Verlag, 1992.

BOEGEHOLD, A. (ed.). The Lawcourts of Athens. Literary and Epigraphic Testimonia, (The Excavations the Athenian Agora, vol. 28). Princeton: American School of Classical Studies at Athens, 1996.

BOGH, B. Mother of the Gods: Goddess of Power and Protector of Cities. Numen, v. 59, pp. 32-67, 2012.

BORG, B. (ed). Paideia: The World of the Second Sophistic. Berlin / New York: Walter de Gruyter, 2004.

BOURAS, C. The city of Athens during the Hellenistic period. In: Akten des XIII. Internationalen Kongresses für klassische Archäologie. Berlin: Mainz and Rhein, 1990, pp. 267-274.

BOURDIEU, P. Espace social et pouvoir symbolique. In : Choses dites. Paris: Éditions de Minuit, 1987, pp. 147-166,

BOWERSOCK, G. Augustus and the Greek World. Oxford: Clarendon Press, 1965. Greek Sophists in the Roman Empire. Oxford: Clarendon Press, I969.

BOWIE, E. Greeks and Their Past in the Second Sophistic. Past \& Present, n. 46, pp. 341, 1970. . Inspiration and Aspiration: Date, Genre, and Readership. In: ALCOCK, S.; CHERRY, J.; ELSNER, J. Pausanias: Travel and Memory in Roman Greece. Oxford: Oxford University Press, 2001, pp. 21-32.

. The geography of the Second Sophistic: Cultural variations. In: BORG, B. (ed.). Paideia: the World of Second Sophistic. Berlin, Walter de Gruyter, 2004, pp..

BRAUND, D.; WILKINS, J. (eds). Athenaeus and his world: Reading Greek Culture in the Roman Empire. Exeter: University of Exeter Press, 2000.

BREHME, S. Die Blibliothek von Pergamon. In: Pergamon. Panorama der Antiken Metropole. Berlin, Michael Imhof Verlag, 2011, pp. 194-198. 
BREITENBERGER, B. Aphrodite and Eros. The Development of Erotic Mythology in Early Greek Poetry and Cult. New York and Abingdon: Routledge, 2007.

BRINGMANN, K. Poseidonios and Athenion: a study in Hellenistic Historiography. In: CARTLEDGE, P.; GARNSEY, P.; GRUEN, E. (eds). Hellenistic constructs: essays in Culture, History, and Historiography. Berkeley: University of California Press, 1997, pp. 145-158.

Grain, timber and money: Hellenistic kings, finance, buildings and foundations in Greek cities. In: ARCHIBALD, Z.; DAVIES, J.; GABRIELSEN, V.; OLIVER, G. (eds). Hellenistic economies. London and New York: Routledge, 2001, pp. 155-162.

BROCK, R.; HODKINSON, S. (eds.). Alternatives to Athens. Varieties of Political Organisation and Community in Ancient Greece. Oxford: Oxford University Press, 2000.

BROONER, O. The Tent of Xerxes and the Greek Theater. Berkeley: University of California Press, 1944.

BRUNEAU, Ph. Recherches sur les cultes de Délos à l'époque hellénistique et à l'époque impériale. Paris : de Boccard, 1970.

- Quatre propos sur l'archéologie nouvelle. Bulletin de Correspondance Héllenique, v. 100, n. 100-1. pp. 103-135, 1976.

BRUNN, H. I doni di Atalo. Annali dell'Istituto di Corrispondenza Arqueologica, 292$323,1870$.

BUCHER, G. The Origins, Program, and Composition of Appian's Roman History. Transactions of the American Philological Association, v. 130, pp. 411-458, 2000 .

BUGH, G. The Horsemen of Athens. Princeton: Princeton University Press, 1988.

BUGH, G. Athenion and Aristion of Athens. Phoenix, v. 46, n. 2, pp. 108-123, 1992.

BURDEN, J. Athens remade in the age of Augustus. Dissertation, University of California, 1999.

BURKERT, W. Homo Necans. The Anthropology of Ancient Greek Sacrificial Ritual and Myth. Berkeley: University of California Press, 1983. . Greek Religion: Archaic and Classical. London: Blackwell. 1985.

BUSTAMANTE, R. M. da C. Práticas religiosas nas cidades romano-africanas: identidade e alteridade. Phoînix (Rio de Janeiro), v. 5, p. 325-348, 1999. 
BYRNE, S. Early Roman Athenians. In: KIRCHNER, J.; TRAILL, J. JORDAN, D. Lettered Attica: a Day of Attic Epigraphy. Proceedings of the Athens symposium. Athens : Canadian Archaeological Institute of Athens, 2003a, pp. 120.

. Roman citizens at Athens. Leuven/Dudley: Peeters, 2003b.

CALDAS, P. ; SANT'ANNA, H. "Fixar a onda de luz": O problema da transição das épocas históricas no conceito de helenismo em Johann Gustav Droysen. História da historiografia, n. 1, pp. 88-101, 2008.

CALlATAY, F. de. L'histoire des guerres mithridatiques vue par les monnaies. Louvain-La-Neuve, Université Catholique de Louvain, 1997. .; DEPEYROT, G. ; VILLARONGA, L. L'argent monnayé d'Alexandre le Grand à Auguste. Bruxelles, Imprimerie Cultura, 1993.

CAMP, J. The Athenian Agora: Excavations in the Heart of Classical Athens. London: Thames \& Hudson, 1986. . Rectangular Peribolos. In: BOEGEHOLD, A. (ed.). The Lawcourts of Athens. Literary and Epigraphic Testimonia, (The Excavations the Athenian Agora, vol. 28). Princeton: American School of Classical Studies at Athens, 1996, pp. 99103.

. The archeology of Athens. New Haven/London: Yale University Press, 2001. . The Athenian Agora: a short guide. Athens: ASCSA, 2004. . The Athenian agora: Site Guide. Princeton: ASCSA, 2010. .; MAUZY, C. (eds). The Athenian Agora: new perspectives on an Ancient site. Mainz and Rhein and Athens, Ferlag Philipp von Zebern and ASCSA, 2009.

CARPENTER, J. R. The Propylon in Greek and Hellenistic architecture. Dissertation, University of Pennsylvania, 1971.

CARPENTER, T. H. Greek Religion and Art. In: OGDEN, D. (ed.). A companion to the Greek Religion. Oxford, Blackwell, 2007, pp. 398-420.

CARTLEDGE, P.; GARNSEY, P.; GRUEN, E. (eds). Hellenistic constructs: essays in Culture, History, and Historiography. Berkeley: University of California Press, 1997.

CARUSO, A. Akademia. Archeologia di una scuola filosofica ad Atene da Platone a Proclo (387 a.C.-485 d.C.). Studi di Archeologia e di Topografia di Atene e dell'Attica, 6. Athens / Paestum: Pandemos, 2013. 
CHAMPION, C.; ERSKINE, A. Introduction: the Study of Roman Imperialism. In: CHAMPION, C. (ed). Roman imperialism: Readings and Sources. Oxford: Blackwell, 2004, pp. 1-10.

CHAPLIN, J. Introduction. In: Livy. Rome's Mediterranean Empire : books 41-45 and the Periochae. A new translation by Jane D. Chaplin. Oxford, Oxford University Press, 2009, pp. ix-xxiv.

CHARADE, S. L'intégration politique, sociale et religieuse des Rhômaioi dans les cité d'Athènes et de Delos. Dissertation, Université du Quebec à Montréal, 2009.

CLARKE, M. L. The Garden of Epicurus. Phoenix, v. 27, pp. 286-287, 1973.

CLÍMACO, J. C. Cultura e poder na Alexandria romana. Dissertação, Universidade de São Paulo, 2007.

- A Alexandria dos antigos: entre a polêmica e o encantamento. Tese, Universidade de São Paulo, 2013.

CLINTON, K. The Eleusinian Mysteries: Roman Initiates and Benefactors, Second Century B.C. to A.D. 267. ANRW 18, no. (1989):1499-1539

. Eleusis and the Romans: Late Republic to Marcus Aurelius. In: HOFF, M. C.; ROTROFF, S. (eds.). The Romanization of Athens. Oxford, Oxford University Press, 1997, pp. 161-181.

COARELli, F. Le Tyrannoctone du Capitole et la mort de Tiberius Gracchus. Mélanges d'archéologie et d'histoire, v. 81, n. 81-1, pp. 137-160, 1969.

CONNOLLY, J. The New World Order: Greek Rhetoric in Rome. In: WORTHINGTON, I. (ed.). A Companion to Greek Rhetoric. Oxford: Blackwell, 2007, pp. 139-165.

COPETE, J. M. C. El fracasso del primer proyeto panhelénico de Adriano. Dialogues d'histoire ancienne, v. 25, n. 25-2, 1999, pp. 91-112.

COULTON, J. The architectural development of the Greek Stoa. Oxford: Clarendon Press, 1976.

CROSBY, M. Greek Inscriptions. Hesperia, v. 6, n. 3, pp. 442-468, 1937.

CUNIBERTI, G. La polis dimezzata. Immagini storiografiche di Atene ellenistica. Alessandria: Edizioni dell'Orso, 2006.

CURTIS, J.; SIMPSON, S. J. (eds.). The World of Achaemenid Persia. History, Art and Society in Iran and the Ancient Near East. London and New York: I. B. Tauris, 2010. 
CURTIS, V. The Iranian Revival in the Parthian Period. In: CURTIS, V.; STEWART, S. The Idea of Iran II: the Age of the Parthians. London: Tauris, 2007, pp. 1-25.

CURTIS, V.; STEWART, S. The age of the Parthians. London / New York: Tauris, 2007.

DALLY, O. Athen in der frühen Kaiserzeit - ein Werk des Kaisers Augustus? In: VLIZOS, S. (ed.). Athens during the Roman period: recent discoveries, new evidence. Athens, Mouseio Benaki, 2008, pp. 43-54.

DAY, J. An economic history of Athens under Roman domination. New York: Columbia University Press, 1942.

DEENE, M. Proleptic Honours in Classical Athens? A Short Note on IG II $^{2} 212$ Zeitschrift fur Papyrologie und Epigraphik, v. 183, pp. 171-175, 2012.

DE RUYT, C. Macellum.

DIAZ-ANDREAU, M. A World History of Nineteenth-Century Archaeology. Nationalism, Colonialism, and the Past. Oxford: Oxford University Press, 2007.

DICKENSON, C. On the Agora. Power and public space in Hellenistic and Roman Greece. (Tese) Rijksuniversiteit Groningen, 2012.

DIHLE, A. Greek and Latin Literature of the Roman Empire: From Augustus to Justinian. London: Routledge, 1994.

DINSMOOR, W. B. The monument of Agrippa at Athens (abstract). In: American Journal of Archaeology, 24, p. 83, 1920.

. The Athenian Archon List in the Light of Recent Discoveries. New York: Columbia University Press, 1939.

DMITRIEV, S. City Government in Hellenistic and Roman Asia Minor. Oxford: Oxford University Press, 2005.

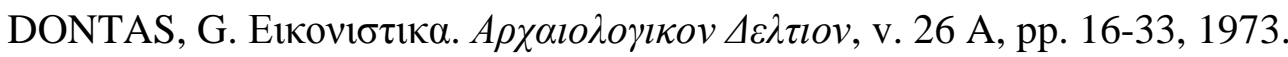
The true Aglaureion. Hesperia, v. 52, n. 1, pp. 48-63, 1983.

DÖRPFELD, W. Alt-Athen und seine Agora. Osnabrück: Otto Zeller, 1937.

DOW, S. A Leader of the Anti-Roman Party in Athens in 88 B. C. Classical Philology, v. 37, n. 3, pp. 311-4, 1942.

DYSON, S. In Pursuit of Ancient Pasts: A History of Classical Archaeology in the Nineteenth and Twentieth Centuries. New Haven: Yale University Press, 2006.

ECKSTEIN, A. Conceptualizing Roman Imperial Expansion under the Republic: An Introduction. In: ROSENSTEIN, N. ; MORSTEIN-MARX, R. (eds.). A Companion to the Roman Republic. Oxford: Blackwell, 2006a, pp. 567-589. 
Mediterranean Anarchy, Interstate War, and the Rise of Rome. Berkeley: University of California Press, 2006b.

. From Anarchy to Hierarchy in the Hellenistic Mediterranean, 230-170 BC.

Oxford: Blackwell, 2008.

EDWARDS, K. Captive Gods. Romans and Athenian Religion from 229 B.C. to the Age of Augustus. Diss. University of Virginia, 1997.

EILERS, C. Roman Patrons of Greek Cities. Oxford, Oxford University Press, 2002.

ELSNER, J. Pausanias: A Greek Pilgrim in the Roman World. Past \& Present, v. 135, pp. 3-29, 1992.

. Structuring “Greece': Pausanias's Periegesis as a Literary Construct. In:

ALCOCK, S.; CHERRY, J.; ELSNER, J. Pausanias: Travel and Memory in Roman Greece. Oxford: Oxford University Press, 2001, pp. 3-20.

ENGEN, D. Honor and Profit: Athenian Trade Policy and the Economy and Society of Greece, 415-307 B.C.E.. Ann Arbor: University of Michigan, 2010.

ESHLEMAN, K. Defining the circle of sophists: Philostratus and the Construction of the second sophistic. Classical Philology, v. 103, pp. 395-413, 2008.

ERSKINE, A. A. Hellenistic Monarchy and Roman Political Invective. Classical Quarterly, vol. 41, n. 1, pp. 106-120, 1991.

. Greekness and Uniqueness. The Cult of the Senate in the Greek East. In: Phoenix, v. 51, n. 1, pp. 25-37, 1997.

. (ed.). A Companion to the Hellenistic World. Oxford: Blackwell, 2003.

ERSKINE, R. Search for a Saviour [review of Mikalson, 2000]. The Classical Review, v. 50, n. 1, pp 124-126, 2000.

ÉTIENNE, R. La politique culturelle des Attalides. Pallas, v. 62, pp. 357-377, 2003. . Athènes, espaces urbains et histoire. Paris: Hachette, 2004.

FAVERSANI, F. O Estado Imperial e os Pequenos Impérios. História (São Paulo), v. 26, n. 1, p. 53-62, 2007.

. Entre a República e o Império: apontamentos sobre a amplitude desta fronteira. Mare Nostrum, v. 4, pp. 100-111, 2013.

FAVRO, D. The urban image of Augustan Rome. Cambridge, Cambridge University Press, 1998.

- Making Rome a World City. In: GALINSKY, K. (ed.). The Cambridge Companion to the Age of Augustus. Cambridge: Cambridge University Press, 2007, pp. 234-263. 
FAYER, C. Il culto della dea Roma: origine e diffusione nell'Impero. Pescara: Trimestre, 1976.

FERRARY, J.-L. Philhellénisme et impérialisme : aspects idéologiques de la conquête romaine du monde hellénistique, de la Seconde Guerre de Macédonie à la Guerre contre Mithridate. Rome : École Française de Rome, 1988.

FERGUSON, J. The Religions of the Roman Empire. London, Thames and Hudson, 1970.

FERGUSON, W. S. Notes on Greek Inscriptions. Classical Philology, v. 2, n. 4, 1907, pp. 401-406. Hellenistic Athens. London: Macmillan's, 1911.

FERGUSON, W. S. The Salaminioi of Heptaphylai and Sounion. In: Hesperia, v. 7, n. 1, pp. 1-74, 1938.

FICUCIELLO, L. Le strade di Atene. Atene / Paestum: Pandemos, 2008.

FIGUEIRA, T. Excursions in Epichoric History. Aiginetan Essays. Lanham: Rowman \& Littlefield, 1993.

FINLAY, G. Greece under the Romans: a historical view of the condition of theGreek nation, from the time of its conquest by the Romans until the extinction of the Roman Empire in the East, B. C. 146 - A. D. 717. Edinburgh and London: William Blackwood and sons, 1844.

FONTANI, E. "Il filellenismo di Antonio tra realtà storica e propaganda politica: le ginnasiarchie ad Atene e ad Alexandria”. In: VIRGILIO, B. (a cura di). Studi Ellenistici XII. Pisa/Roma: Istituti Editoriali e Poligrafici Internazionali, 1999, pp. 193-210.

FOLLET, S. (éd.). L'Hellénisme d'époque romaine. Paris, De Boccard, 2004.

FORSYTHE, G. A Critical History of Early Rome: From Prehistory to the First Punic War. Berkley: University of California Press, 2005.

FOUNIER, J. Entre tutelle romaine et autonomie civique : 1'administration judiciaire dans les provinces hellénophones de l'Empire romain (129 av. J.-C. - 235 apr. J.-C.). Athènes / Paris, École Française d'Athènes / De Boccard, 2010.

FOX, R. The first Hellenistic man. In: ERSKINE, A.; JONES, L. (eds). Creating a Hellenistic World. Swansea: Classical Press of Wales, 2010, pp. 1-30.

FRANCISCO, G. da S. Grafismos Gregos: Escrita e Figuração na Cerâmica Ática do Período Arcaico (do século VII-VI a. C.). São Paulo: Suplemento da Revista do Museu de Arqueologia e Etnologia da USP, 2008. 
Panatenaicas: tradição, permanência e derivação. Tese, Universidade de São Paulo, 2012.

FUNARI, P.P.A.(org.) Repensando o Mundo Antigo. n. 47. Campinas, IFCH/UNICAMP, 2005.

GALINSKY, K. Introduction. In: GALINSKY, K. (ed). The Cambridge Companion to the Age of Augustus. Cambridge: Cambridge University Press, 2007, pp. 1-12.

GALSTERER, H. A Man, a Book, and a Method: Sir Ronald Syme's Roman Revolution after Fifty Years. In: RAAFLAUB, K.; TOHER, M. (eds). Between Republic and Empire: Interpretations of Augustus and its Principate. Berkeley, University of California Press, 1990, pp. 1-20.

GARNSEY, Peter e SALLER, Richard. The Roman Empire: economy, society and culture. London: Duckworth, 1987.

GAUTHIER, Ph. La cité grecque et leurs bienfaiteurs. Paris, BCH (supp. 12), 1985.

GEAGAN, D. The Athenian Constitution after Sulla. Princeton: The American School of Classical Studies at Athens, 1967.

. Roman Athens: some aspects of life and culture I. In: Aufstieg und Niedergang der römischen Welt, II, v. 7.1. Berlin and New York: Walter de Gruyter, 1979, pp. 371-437.

. A Family of Marathon and Social Mobility in Athens of the First Century B.C. Phoenix, v. 46, pp. 29-44, 1992.

GERDING, H. The Erechtheion and the Panathenaic Procession. American Journal of Archaeology, n. 110, pp. 389-401, 2006.

GINOUVÈS, R. ; MARTIN, R. Dictionnaire Méthodique de l'Architecture Grecque et Romaine. 3 vols. Athènes/Rome, EFA/EFR, 1985, 1992, 1998.

GLASS, S. Palaistra and Gymnasium in Greek Architecture. University of Pennsylvania (dissertation), 1967.

GLEW, D. The selling of the king: notes on Mithridates Eupator's propaganda in 88 B. C. Hermes, v. 105, 1977, pp. 253-6.

GOPNIK, H. Why Columned Halls? In: CURTIS, J.; SIMPSON, J. (eds). The World of Achaemenid Persia. London: British Museum Press, 2010, pp. 195-207.

GOODMAN, M. The Roman World. 44BC - AD180. London / New York: Routledge, 1997.

GORMAN, R.; GORMAN, V. The Tryphê of the Sybarites: A Historiographical Problem in Athenaeus. Journal of Hellenic Studies, v. 127, 38-60, 2007. 
GRACE, V. The Middle Stoa dated by Amphora Stamps. Hesperia, v. 54, n. 1, pp. 154,1985 .

GRAINDOR, P. Inscriptions attiques d'époque impériale. Textes inédits et corrections. Bulletin de correspondance héllenistique, v. 38, pp. 351-443, 1914.

. Chronologie des archontes athéniens sous l'empire. Bruxelles: Lamertin, 1922.

. Marbres et textes attiques d'époque impériale. Gand: Van Rysselberghe \& Rombaut, 1922.

. Album d'inscriptions attiques d'époque impériale. Gand / Paris: Van Rysselberghe \& Rombaut / Édouard Champion, 1924.

. Athènes sous Auguste. Cairo: Imprimerie Misr, 1927.

Athènes de Tibère à Trajan. Bonn: Habelt, 1927.

Athènes sous Hadrian. Cairo: Imprimerie Misr, 1934.

GRECO, E. (ed). Topografia di Atene - Sviluppo urbano e monumenti dalle origini al III secolo d. C. vol. 1. Atene-Paestum, Pandemos, 2010.

GROS, P. Aurea templa: recherches sur l'architecture religieuse de Rome à l'époque d'Auguste. Rome : École française de Rome, 1976.

. "Nouveux paysage urbain et cultes dynastiques: remarques sur l'idéologie de la ville augustéene à partir dês centres monumentaux d'Athènes, Thasos, Arles et Nîmes”. In: Les Villes augustéenes de Gaule. ColloqueAutun, 1991, pp. 127-40. .; TORELLI, M. Storia dell'urbanistica: il mondo romano. Roma, Laterza, 1988.

GRUEN, E. The Hellenistic World and the coming of Rome. Berkeley/Los Angeles/London: University of California Press, 1984.

. Culture as Policy: The Attalids of Pergamon. In: GRUMMOND, N.; RIDGWAY, B. (eds.). From Pergamon to Sperlonga: Sculpture and Context. Berkeley and Los Angeles, University of California Press, 2000, pp. 17-31.

GUARINELLO, N. Uma morfologia da História: as formas da História Antiga. Politeia, v. 3, n. 1, pp. 41-61, 2003.

. Ordem, integração e fronteiras no Império Romano. Um ensaio. Mare Nostrum, v. 1, pp. 113-127, 2010.

GUIDI, G. "Il muro Valeriano a S. Demetrio Katiphori e la questione del Diogeneion". Annuario della Scuola Archeologica di Atene, v. 4, pp. 33-54, 1921-1922. 
HABICHT, C. Zur Geschichte Athens in der Zeit Mithridates' VI., 1. Der eponyme Archon im Jahr der 'Anarchie' (88/7); 2. Die Darstellung der Tyrannenmörder auf den Silbermünzen Athens. Chiron, v. 6, 127-142, 1976. . Studien zur Geschichte Athens in hellenistischer Zeit. Göttingen: Vandenhoek \& Ruprecht, 1982.

. Pausanias and the Evidence of Inscriptions. In: Classical Antiquity, v. 3, n. 1, pp. 40-56, 1984.

. The Seleucids and their rivals. In: ASTIN, A.; WALBANK, F.; FREDERIKSEN, M.; OGILVIE, R. (eds). Cambridge Ancient History, volume VIII: Rome and the Mediterranean to 133 B. C. $2^{\text {nd }}$. ed. Cambridge: Cambridge University Press, 1989, pp. 324-387.

. Athens and the Attalids in the Second Century B. C. In: Hesperia, 59, 3, pp. 561-77, 1990.

. Was Augustus a visitor at the Panathenaia? In: Classical Philology, v. 86, n. 3, pp. 226-8, 1991.

. Athens and the Ptolemies. Classical Antiquity, v. 11, n. 1, pp. 68-90, 1992.

- Athens from Alexander to Antony. Cambridge-Massachucets: Harvard University Press, 1997.

. The Hellenistic monarchies. Ann Arbor, The University of Michigan Press, 2006.

HAHM, D. E. Posidonius' Theory of Historical Causation. In: Aufstieg und Niedergang der romischen Welt. t. II, v. 36.2. Berlin and New York: Walter de Gruyter, 1989, pp. 1325-1363.

HALL, J. Hellenicity: between Etnicity and Culture. Chicago and London: University of Chicago Press (2002).

HAMILAKIS, Y. The nation and its ruins: antiquity, archaeology, and national imagination in Greece. Oxford: Oxford University, 2007.

. Decolonizing Greek archaeology: indigenous archaeologies, modernist archaeology and the post-colonial critique. In: DAMASKOS, D.; PLANTZOS, D. (eds.). A Singular Antiquity: Archaeology and Hellenic Identity in TwentiethCentury Greece. Athens: Benaki Museum, 2008, pp. 273-284.

HANSEN, E. V. The Attalids of Pergamon. Ithaca and London: Cornell University Press, 1971. 
HANSEN, M. H. The Athenian Heliaia from Solon to Aristotle. Classica et Mediaevalia, v. 33, pp. 9-47, 1981-1982.

. The 'Autonomous City-State'.Ancient fact or modern fiction? In: HANSEN,

M. H.; RAAFLAUB, K. (eds). Studies in the Ancient Greek Polis. Stuttgart: Franz Steiner Verlag, 1995. pp. 21-43.

. Reflections on the number of citizens accommodated in the assembly place on the Pnyx. In: FORSÉN, B.; STANTON, G. (eds). The Pnyx in the history of Athens. Proceedings of an international colloquium organized by the Finnish Institute at Athens, 7-9 October 1994. B. Forsén and G. Stanton, (eds). Helsinki: Foundation of the Finnish Institute at Athens, 1996, pp. 23-33.

A Comparative Study of Thirty City-State Cultures. Copenhagen, The Royal Danish Academy of Science and Letters, 2000.

. A Comparative Study of Six City-State Cultures. Copenhagen, The Royal Danish Academy of Science and Letters, 2002.

.; NIELSEN, T. H. An inventory of archaic and classical poleis. Oxford / New York: Oxford University Press, 2004.

HARRIS, W. V. "The Mediterranean and Ancient History”. In: HARRIS, W. V. (ed.). Rethinking the Mediterranean. Oxford, Oxford University Press, 2005.

HARRISON, E. The Composition of the Amazonomachy on the Shield of Athena Parthenos. Hesperia, v. 35, n. 2, pp. 107-133, 1966.

Athena at Pallene and in the Agora of Athens. In: BARRINGER, J.; HURWIT,

J. (ed.). Periklean Athens and its Legacy. Problems and perspectives. Austin, University of Texas Press, 2005, pp. 119-131.

HASENOHR, C. Les italiens à Délos : entre romanité et hellénisme. Pallas, v. 73, pp. 221-232, 2007.

HEGEL, G. W. A razão na História. Lisboa : Edições 70, 1995.

HEKSTER, O.; RICH, J. Octavian and the thunderbolt: the temple of Apollo Palatinus and Roman traditions of temple building. Classical Quaterly, v. 56, n. 1, pp. 149-168, 2006.

HELLER, A. La cité grecque d'époque impériale : vers une société d'ordres?. Annales. Histoire, Sciences Sociales, année 64, n. 2, pp. 341-373, 2009.

HELLMANN, M.-C. L'architecture grecque, 3. Habitat, urbanisme et fortifications (Les manuels d'art et d'archéologie antiques). Paris: éd. Picard, 2010. 
HENIG, M. (ed). Architecture and Architectural Sculpture in the Roman Empire. Oxford, Oxford University Committee for Archaeology, 1990.

HERES, H. The Myth of Telephos in Pergamon. In: DREYFUS, R.; SCHRAUDOLPH, E. (eds.). Pergamon. The Telephus frieze from the Great Altar. vol. 2. San Francisco: Fine Arts Museums of San Francisco, 1997, pp. 23-57.

HERZFELD, E. Iran in the Ancient East. Archaeological Studies presented in the Lowell lectures at Boston. London and New York, Oxford University Press, 1941.

HINGLEY, R. Roman Officers and English Gentlemen. The Imperial Origins of Roman Archaeology. Londres: Routledge, 2000.

. Globalizing Roman Culture. Unity, diversity and empire. Londres:Routledge, 2005.

. Struggling with a Roman inheritance. A response to Versluys. Archaeological Dialogues, v. 21, n. 1, pp. 24-30, 2014.

HODDER, I. (ed.). Archaeology Theory Today. Cambridge: Polity Press, 2001.

HODDER, I. Entangled: An Archaeology of the Relationships between Humans and Things. West-Sussex, Wiley-Blackwell, 2012.

.; HUTSON, S. Reading the Past: Current approaches to interpretation in archaeology. Cambridge: Cambridge University Press, 2003.

HOFF, M. The Roman Agora at Athens. Dissertation, Boston University, 1988.

Civic Disobedience and Unrest in Augustan Athens. Hesperia, v. 58, n. 3, julset. 1989 , pp. 267-76.

- The Early History of the Roman Agora at Athens. In: WALKER, S.; CAMERON, A. (eds.). The Greek Renaissance in the Roman Empire. London: University of London, 1989, pp. 1-8.

. Augustus, Apollo and Athens. Museum Helveticum, v. 49, pp. 223-232, 1992.

. The So-Called Agoranomion and the Imperial Cult in Julio-Claudian Athens. Archäologische Anzeiger, v. 109, pp. 93-117, 1994.

. The politics and architecture of the Athenian imperial cult. In: SMALL, A. Subject and Ruler: The Cult of the Ruling Power in Classical Antiquity. Ann Arbor: Journal of Roman Archaeology (supp. 17), 1996, pp. 185-200.

. Laceteratae Athenae: Sulla's siege of Athens in 87/6 B. C. and its aftermath.

In: HOFF, M. C.; ROTROFF, S. (eds.). The Romanization of Athens. Oxford, Oxford University Press, 1997, pp. 33-51. 
An equestrian statue of Lucius Caesar in Athens Reconsidered. Archäologischer Anzeiger (DAI), h. 4, pp. 583-599, 2001.

. Greece and the Roman Republic: Athens and Corinth from the Late Third Century to the Augustan Era. In: EVANS, J. (ed). A Companion to the Archaeology of the Roman Republic. Oxford: Blackwell, 2013, pp. 559-578.

.; ROTROFF, S. (eds.). The Romanization of Athens. Oxford: Oxford University Press, 1997.

HOJTE, J. M. Cultural Interchange? The Case of Honorary Statues in Greece. In: OSTENFELD, E. N. (ed). Greek Romans and Roman Greeks. Studies in Cultural Interaction. Copenhagen, Aarhus University Press, 2002, pp. 55-63.

. Roman Imperial Statue Bases: from Augustus to Commodus. Aarhus: Aarhus University Press, 2005.

. Portraits and Statues of Mithridates VI. In: HOJTE, J. M. (ed.). Mithridates VI and the Pontic Kingdom. Aarhus: Aarhus University Press, 2009, pp. 145-162.

HOWARD, S. The Dying Gaul, Aigina Warriors, and Pergamene Academicism. American Journal of Archaeology, vol. 87, n. 4, pp. 483-487, 1983.

HORDEN, P. and PURCELL, N.The Corrupting Sea: a study of Mediterranean history. Oxford/Massachusetts: Blackwell Publishers, 2000.

HURWIT, J. The Athenian Acropolis. History, Mythology, and Archaeology from the Neolithic Era to the Present. Cambridge: Cambridge University Press, 1999.

HUS, A. Préface. In: TITE LIVE. Histoire Romaine. t. XXI, 1. XXXI. Paris: Les Belles Lettres, 1977, pp. i-cxliv.

JONES, A. H. M. The Greek City from Alexander to Justinian. Oxford, 1940.

. The Greeks under the Roman Empire. Dumbarton Oaks Papers, v. 17, pp. 1+319, 1963.

JONES, C.P. The Roman World of Dio Chrysostom. Cambridge, Massachussets and London: Harvard University Press, 1978.

JONES, C. An Athenian Document Mentioning Julius Nicanor. In: Zeitschrift für Papyrologie und Epigraphik, Bd. 154, pp. 161-172, 2005.

JUDEICH, W. Topographie von Athen. 2a. ed. Munich, 1931.

KAJAVA, M. Vesta and Athens. In: SALOMIES, O. (ed.). The Greek East in the Roman Context. Helsinki: Suomen Ateenan-Instituutin Säätiö, 2001, pp. 71-94.

KALLENDORF, C. A companion to the Classical Tradition. Oxford: Blackwell, 2007. 
KALLET-MARX, R. Hegemony to Empire. The Development of the Roman Imperium in the East from 148 to 62 B.C. Berkeley / Los Angeles / Oxford: University of California Press, 1996.

KANTIRÉA, M. Les Dieux et les dieux augustes: Le culte impérial en Grèce sous les Julio-claudiens et les Flaviens - Études épigraphiques et archéologiques (Meletemata 50). Athènes : De Boccard, 2007.

KEARNS, E. The heroes of Attica. London: University of London, 1989.

KEAVENEY, A. Sulla's Cilician Command: The Evidence of Apollinaris Sidonius. Historia: Zeitschrift für Alte Geschichte. bd. 44, h. 1, 1995, pp. 29-36.

KEAY, S.; TERRENATO, N. Italy and the West: comparative Issues in Romanization. Oxford: Oxbow, 2001.

KEEN, T. 'Undoing the wineskin's foot': Athenian slang?. Classical Quaterly, v. 59, pp. 626-31, 2009.

KELLOG, D. Marathon fighters and Men of Maple. Ancient Acharnai. Oxford: Oxford University Press, 2013.

KELLY, L. Identity and cult in Roman Athens. Dissertation. University of Pennsylvania, 2010.

KELLUM, Barbara. The City Adorned: Programmatic Display at the Aedes Concordiae Augustae. In: RAAFLAUB, K.; TOHER, M. (eds.). Between Republic and Empire: Interpretations of Augustus and its Principate. Berkeley: University of California Press, 1990, 276-307.

KENNELL, N. Review of The Romanization of Athens. Bryn Mawr Classical Review 1998.10.08.<http://bmcr.brynmawr.edu/1998/1998-10-08.html>

KEPPIE, L. Understanding Roman Inscriptions. Baltimore, The John Hopkins University Press, 1991.

KIDD, B. The doric revival under the Attalids of Pergamon. Dissertation, University of Missouri, 2003.

KLEINER, Semblance and Storytelling in Augustan Rome. In: GALINSKY, K. (ed.). The Cambridge Companion to the Age of Augustus. Cambridge: Cambridge University Press, 2007, pp. 197-233.

KLEINER, F. The Agora Excavations and Athenian Bronze Coinage, 200-86 B. C. In: Hesperia, v. 45, n. 1, pp. 1-40, 1976.

KOHL, M. La genèse du portique d'Attale II. Origine et sens des singularités d'un batîment construit dans le cadre de la nouvelle organisation de l'agora d'Athènes 
au IIe siècle av. J.-C. In : MARC, J.-Y. ; MORETTI, Ch. (ed.). Constructions publiques et programmes édilitaires en Grèce : entre le IIe siècle av. J.-C.et le Ier siècle ap. J.-C. Athènes/Paris : École Française d'Athènes/De Boccard, 2001, pp. 237-266.

KORRES, M. Stoa tou Evmenous. Archaiologiko Deltio, n. 35, pp. 18-19, 1988 [1980]. - Vorfertigung und Ferntransport eines athenischen Grossbaus und zur Proportionierung von Säulen in der Hellenistischen Architektur. In: Hoepfner, W. (Hrsg.). Bauplanung und Bautheorie der Antike. Berlin: DAI, 1984, pp. 201207.

. "Apo tons travo stinachaia agora". Horos 10-12, p. 83-104, 1992-1998.

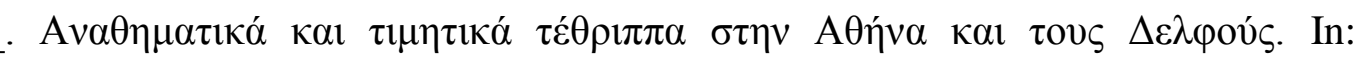
JAQUEMIN, A. (ed.). Delphes cent ans après la Grande fouille. Essai de bilan. Actes du colloque organisé par l'EFA, 17-20 septembre1992. Athènes: EFA, 2000, pp. 293-329.

Athinaiki poleodomia - Arkhaios oikistikos khoros. Aksia oraton martyrion. In: GOETTE, H. (ed.). Ancient Roads in Greece. Athen, Deutsches Archäologisches Institut, 2002, pp. 1-33 and pl. 1-2.

. Essay. The Pedestals and the Akropolis South Wall. In: STEWART, A. Attalos, Athens and the Akropolis. The Pergamene "Little Barbarians" and their Roman and Renaissance Legacy. Cambridge: Cambridge University Press, 2004, pp. 242-286.

. Topographic Issues of the Acropolis. In: MOSCHONAS, N. (coord.). Archaeology of the City of Athens (Digital Edition). 2008. Disponível em: http://www.eie.gr/archaeologia/En/chapters.aspx. Acessado em novembro de 2014.

KOSMETATOU, E. The Attalids of Pergamon. In: ERSKINE, A. (ed.). A Companion to the Hellenistic World. Oxford: Blackwell, 2003, pp. 159-174.

KRAUS, C. S. Historiography and biography. In: HARRISON, S. A Companion to Latin Literature. Oxford, Blackwell, 2005, pp. 241-256.

KREUZ, P. A. Monuments for the King: Royal Presence in the Late Hellenistic World of Mithridates VI. In: HOJTE, J. M. (ed.). Mithridates VI and the Pontic Kingdom. Aarhus: Aarhus University Press, 2009, pp. 131-144.

KROLL, J. The Eleusis Hoard of Athenian Imperial Coins and Some Deposits from the Athenian Agora. In: Hesperia, v. 42, n. 3, pp. 312-333, 1973. 
LALONDE, G. Horoi. In: LALONDE; G.; LANGDON, M.; WALBANK, M. Inscriptions: Horoi, Poletai Records, Leases of Public Lands (The Athenian Agora, v. 19). Princeton: The American School of Classical Studies, 1991, pp. 51.

. IG I3 1005b and the boundary of Melite and Kollytos. Hesperia, v. 75, 2006, pp. 83-119.

LAMBERT, S. D. The Attic genos Salaminioi and the island of Salamis. In: Zeitschrift für Papyrologie und Epigraphik, v. 119, pp. 85-106, 1997.

LANCASTER, L.; ULRICH, R. Materials and techniques. In: ULRICH, R.; QUENEMOEN, C. (eds.). A Companion to Roman Architecture. Oxford: Blackwell, 2014, pp. 157-192.

LASAGNI, C. IG II2 958 e la Stoa tou Rhomaiou. In: Annuario della Scuola Archeologica di Atene, v. 96, pp. 57-67, 2008.

LEACH, E. The Rhetoric of Space: Literary and Artistic Representations of Landscape in Republican and Augustan Rome. Princeton: Princeton University Press, 1988.

LEFEBVRE, H. La production de l'espace. Paris: Éditions Anthropos, 1974.

LENDON, J. The Empire of Honour: the art of government in the Roman world. Oxford: Oxford University Press, 2001.

LE GUEN, B. L'association des Technites d'Athènes ou les ressorts d'une cohabitation réussie. In : COUVENHES, J.-C. ; MILANEZI, S. Individus, groupes et politique a Athènes de Solon à Mithridate. Actes du colloque international de Tours 7 et 8 mars 2005. Tours: Presses universitaires François-Rabelais, 2007, pp. 339-364.

LE ROUX, Patrick. La romanisation en question. Annales, Histoire, Sciences Sociales, $59^{\mathrm{e}}$ année, n. 2, pp. 287-311, 2004.

LESK, B. A Diachronic Examination of the Erechtheion and its Reception. Dissertation, University of Cincinnati, 2004.

LEVENSORN, M.; LEVENSOHN, E. Inscriptions on the South Slope of the Acropolis. Hesperia, v, 16, n. 2, pp. 63-74, 1947.

LEWIS, D. Persians in Herodotus. In: Selected Papers in Greek and Near Eastern History. Cambridge: Cambridge University Press, 1997, pp. 345-361.

LINDSAY, H. The Biography of Atticus : Cornelius Nepos on the Philosophical and Ethical Background of Pomponius Atticus. Latomus, t. 57, fasc. 2, 1998, pp. 324-336. 
LIPPOLIS, E. “Tra il ginnasio di Tolomeo ed il Serapeion: La ricostruzione topografica di un quartiere monumentale di Atene. Ostraka, anno 4, pp. 43-68, 1995. . Apolo Patroos, Ares, Zeus Eleutherios. Annuario della Scuola Archeologica di Atene, v. 76-78, pp. 139-218, 2001.

LOZANO, F. La religion del poder: el culto imperial em Atenas em época de Augusto y los emperadores Julio-Claudios. Oxford, British Archaeology Reports, 2002. Un dios entre los hombres: la adoración a los emperadores romanos en Grecia. Barcelona: Universitat de Barcelona, 2010.

LUCE, T. Livy: the composition of his history. Princeton : Princeton University Press, 1977.

MA, J. Antiochos III and the Cities of Western Asia Minor. Oxford, Oxford University Press, 1999.

MACKENDRICK, P. Athenian aristocracy, 339 to 31 B.C. Cambridge, Harvard University Press, 1969.

MACREADY, S. ; THOMPSON, F. H. (eds.) Roman architecture in the Greek world. London, Thames and Hudson, 1987.

MADSEN, J. The Ambitions of Mithridates VI: Hellenistic Kingship and Modern Interpretations. In: HOJTE, J. M. (ed.). Mithridates VI and the Pontic Kingdom. Aarhus: Aarhus University Press, 2009, pp. 191-202.

MAIDMENT, K. Minor Attic orators I (Antiphon and Adocides). London / Cambridge: Willian Heinemann / Harvard University Press, 1941.

MALKIN, I. "Introduction". In: Mediterranean Paradigms and Classical Antiquity. London and New Youk: Routledge, 2005.

MANGO, E. Tanta vis admonitionis inest in locis - Zur Veränderung von Erinnerungsräumer im Athen des 1. Jahrhunderts v. Chr. In: KRUMEICH, R.; WITSCHEL, Chr. Die Akropolis von Athen im Hellenismus und in der römischen Kaiserzeit. Wiesbaden: Reichert Verlag, 2010, 117-155.

MARC, J.-Y. ; MORETTI, Ch. (ed.). Constructions publiques et programmes édilitaires en Grèce : entre le IIe siècle av. J.-C.et le Ier siècle ap. J.-C. Athènes/Paris : École Française d'Athènes/De Boccard, 2001.

MARCHETTI, P. Rapport de synthese: edifices et complexes monumentaux. In : MARC, J.-Y. ; MORETTI, Ch. (ed.). Constructions publiques et programmes édilitaires en Grèce : entre le IIe siècle av. J.-C.et le Ier siècle ap. J.-C. Athènes/Paris : École Française d'Athènes/De Boccard, 2001, pp. 137-154. 
Métamorphoses de l'agora d'Athènes à l'époque augustéenne. In: CAVALIER,

L.; DESCAT, R.; DES COURTILS, J. (eds). Basiliques et Agoras de Grèce et d'Asie Mineure. Bordeaux : Ausonius, 2012, pp. 207-223.

MARQUES, J. Tradição e renovações da identidade romana em Tito Lívio e Tácito.

Tese de Doutorado. Faculdade de Filosofia, Letras e Ciências Humanas, Universidade de São Paulo, 2008.

MARSZAL, J. Ubiquitous Barbarians: Representations of the Gauls at Pergamon and

Elsewhere. In: GRUMMOND, N.; RIDGWAY, B. (eds). From Pergamon to Sperlonga. Sculpture and Context. Berkeley: University of California Press, 2000, pp. 191-234.

MARTIN, R. Recherches sur l'Agora grecque. Paris : De Boccard, 1951. . L'Urbanisme dans la Grèce Antique. 2. ed. Paris: A. \& J. Picard, 1974. . Agora et forum. In: Architecture et urbanisme. Rome : École Française de Rome, 1987. pp. 155-185.

MASTROCINQUE, A. Studi sulle guerre Mitridatiche. Stuttgart : Steiner, 1999.

MATHYS, M.; STAPPMANS, V.; HOFF, R. “Das Gymnasion -Architektur, Nutzung und Bildwerke". In: Pergamon. Panorama der Antiken Metropole. Berlin, Michael Imhof Verlag, 2011, pp. 270-277.

MATTINGLY, D. (ed). Dialogues in Roman Imperialism: Power, discourse, and discrepant experience in the Roman Empire. Portsmouth: Journal of Roman Archaeology (Supplementary series, n. 23), 1997.

MATTINGLY, H. Some Third Magistrates in the Athenian New Style Silver Coinage. Journal of Hellenic Studies, v. 91, pp. 85-93, 1971.

MAVROJANNIS, T. 'Apollo Delio, Atene ed Augusto'. Ostraka, anno 4, n. 1, pp. 85102, 1995.

MCALLISTER, M. The temple of Ares: review of the evidence. Hesperia, v. 28, n. 1, pp. 1-64, 1959.

MCGING, B. C. The foreign policy of Mithridates VI Eupator King of Pontus. Leiden: Brill, 1986.

. Mithridates VI Eupator: Victim or Aggressor? In: HØJTE, J. (ed.). Mithridates VI and the Pontic Kingdom. Århus, Aarhus University Press, 2009, pp. 203-216.

MCINERNEY, J. Heraclides Criticus and the problem of taste. In: SLUITER, I.; ROSEN, R. Aesthetic value in Classical Antiquity. Leiden and Boston, Brill, 2012, pp. 243-264. 
MEIER, C. C. Caesar Diviu filius and the Formation of the Alternative in Rome. In: RAAFLAUB, K.; TOHER, M. (eds). Between Republic and Empire: Interpretations of Augustus and its Principate. Berkeley: University of California Press, 1990, pp. 54-70.

MELLOR, R. $\Theta \varepsilon \alpha P \omega \mu \eta$ : the Worship of the Goddess Roma in the Greek World. Göttingen: Vandenhoeck \& Ruprecht, 1975.

- The Goddess Roma. In: HAASE, W. (ed). Aufstieg und Niedergang der romischen Welt. t. II, v. 17.2. Berlin and New York: Walter de Gruyter, 1981, pp. 950-1030.

MENESES, U. T. B. de. "A cultura material no estudo das sociedades antigas". In: Revista de História, n. 115, 1983.

. Introdução ao estudo histórico da iconografia urbana. Revista USP, v. 30, pp. 144-155, 1996.

MERCURI, L. Programmi pergameni ad Atene: la "stoa" di Eumene. Annuario della Scuola Archeologica Italiana di Atene e dele missioni italiane in Oriente, v. 82, s. 3, n. 4, t. 1, pp. 61-79, 2004.

. Immagini e potere. Note di scultura pergamena attraverso nuovi studi e proposte interpretative. Annuario della Scuola Archeologica Italiana di Atene e dele missioni italiane in Oriente, v. 82, s. 3, n. 4, t. 2, pp. 511-531, 2004.

MERITT, B. D. The Athenian Year. Berkeley and Los Angeles: University of California Press, 1961. . Greek inscriptions. Hesperia, v. 32, n. 1, pp. 1-56, 1963. Athenian Archons 347-6 - 48-7 B. C. In: Historia, 26, pp. 161-191, 1977.

MEYER, E. A. Explaining the epigraphic habit in the Roman Empire. The evidence of epitaphs. In: The Journal of Roman Studies, v. 80, pp. 74-96, 1990.

MICHELS, C. Dionysos Kathegemon und der attalidische Herrscherkult: Überlegungen zur Herrschaftsrepräsentation der Könige von Pergamon. In: GÜNTHER, L.-M.; PLISCHKE, S. (eds.). Studien zum vorhellenistischen und hellenistischen Herrscherkult. Verdichtung und Erweiterung von Traditionsgeflechten. Oikumene. (Studien zur antiken Weltgeschichte 9). Berlin: Verlag Antike, 2011, pp. 114-140.

MIKALSON, J. Religion in Hellenistic Athens. Berkeley: University of California Press, 1998. 
MILlAR, F. Cornelius Nepos, 'Atticus' and the Roman Revolution. Greece \& Rome, vol. 35 , n. 1, pp. 40-55, 1988.

.; SEGAL, E. Caesar Augustus. Seven Aspects. Oxford: Clarendon Press, 1984.

MILLER, S. Architecture as Evidence for the Identity of the Early Polis. In: HANSEN, M. (ed.). Sources for the Ancient Greek City-State. Copenhagen: Munksgaard, 1995, pp. 201-244.

MILLETT, M. The Romanization of Britain: an essay in archaeological interpretation. Cambridge: Cambridge University Press, 1990.

MITCHELL; LEVENSOHN, E. Inscriptions on the South Slope of the Acropolis. Hesperia, v. 16, n. 2, pp. 63-74, 1947.

MITCHELL, L. G. Greeks Bearing Gifts: The Public Use of Private Relationships in the Greek World, 435-323 BC. Cambridge, Cambridge University Press, 1997.

MOMIGLiANO, A. Os limites da helenização. Rio de Janeiro: Jorge Zahar Editor, 1991.

MONACO, M. C. Contributi allo studio di alcuni santuari ateniesi I: il temenos del Demos e delle Charites. Annuario della Scuola Archeologica Italiana di Atene e dele missioni italiane in Oriente, v. 79, s. 3, n. 1, pp. 103-150, 2001.

MORALES, F. A. “A polis de seus outros: os metecos atenienses e a historiografia da polis”. In: Revista do MAE, São Paulo, 18: 183-197, 2008.

. Resenha de Unthinking the Greek Polis, de K. Vlassopoulos. Revista Mare Nostrum, v.1, pp. 129-133, 2010.

. Quem é o dono da topografia ateniense? As escolas estrangeiras de atenas e os grandes projetos editoriais nos séculos XX e XXI. Revista de Arqueologia Pública (UNICAMP), número especial, pp. 1-14, 2013a.

. Resenha de Greece and the Augustan Cultural Revolution, de A. Spawforth.

Politeia: História e Sociedade, v. 13, n. 1, pp. 253-259, 2013 b.

MORKHOLM, O. Studies in the Coinage of Antiochus IV of Syria (Hist. Filos. Medd.

Dann. Vid. Selsk, 40, no.3). Copenhagen, 1963.

. Antiochus IV of Syria. Copenhagen, 1966.

. The chronology of the New Style Coinage of Athens. The American Numismatic Society Museum Notes, v. 29, pp. 29-42, 1984.

MORRIS, I. Mediterranization. Mediterranean Historical Review, v 18, 30-55, 2003.

MOSCONI, G. La democrazia ateniese e la 'nuova' musica: l'Odeion di Pericle. CASSIO, A.; MUSTI, D.; ROSSI, L. (edd.). Synaulía: cultura musicale in 
Grecia e contatti mediterranei. Annali dell'Istituto Orientale di Napoli, Sezione filologico-letteraria, quaderni 5, pp. 217-316, 2000.

MUSTI, D. Il dionisismo degli Attalidi : antecedenti, modelli, sviluppi. L'association dionysiaque dans les sociétés anciennes (Actes de la table ronde, Rome, 24-25 mai 1984). Rome : Collection de l'École française de Rome, 1989, pp. 105-128.

NULTON, P. The Sanctuary of Apollo Hypoakraios and Imperial Athens. Providence: Brown University, 2003.

OBER, J. The Athenian Revolution. Princeton, Princeton University Press, 1998.

OGDEN, D. Greek bastardy in the Classical and Hellenistic periods. Oxford: Clarendon Press, 1996.

OLBRYCHT, M. Mithridates VI Eupator and Iran. In: HOJTE, J. (ed). Mithridates VI and the Pontic kingdom. Aarhus: Aarhus University Press, 2009, pp. 163-190.

OLIVER, G. Foreign Names, Inter-Marriage and Citizenship in Hellenistic Athens. In: CATLING, R.; MARCHAND, F.; KANAVOU, N. (eds). Onomatologos. Studies in Greek Personal Names presented to Elaine Matthews. Oxford: Oxbow Books, 2010, pp. 155-69.

OLIVER, J. H. "The MOUSEION in Late Attic Inscriptions". In: Hesperia, v. 3, n. 2 , 1934, pp. 191-6. . Inscriptions from Athens. In: American Journal of Archaeology, v. 40, n. 4, 1936, pp. 460-465.

. New Evidence on the Attic Panhellenion. In: Hesperia, v. 20, n. 1, pp. 31-33, 1951.

. Livia as Artemis Boulaia at Athens. In: Classical Philology, v. 60, n. 3, p. 179, 1965.

. The Civilizing Power: A Study of the Panathenaic Discourse of Aelius Aristides against the Background of Literature and Cultural Conflict, with Text, Translation and Commentary by James H. Oliver. Philadelphia: American Philosophical Society, 1968.

."Roman Emperor at Athens". In: Historia: ZeitschriftfürAlte Geschichte, v. 30, n. 4, pp. 412-423, 1981.

ONIANS, J. Art and Thought in the Hellenistic Age. London, Thames and Hudson, 1979. 
OSANNA, M. Il problema topografico del santuario di Afrodite Urania ad Atene. Annuario della Scuola Archeologica Italiana di Atene e dele missione in Oriente, v. 66-67, pp. 77-95, 1988-89 (1993).

OSBORNE, M. Naturalization in Athens. Brussels: Paleis der Academien, 1981-1983.

OSBORNE, R. Did democracy transform Athenian space? In: British School at Athens Studies, v. 15 (Building Communities: House, Settlementand Society in the Aegean and Beyond), pp. 195-199, 2007.

OSTENFELD, E. N. Greek Romans and Roman Greeks. Studies in Cultural Interaction. Copenhagen, Aarhus University Press, 2002.

PALAGIA, O. Classical encounters: Attic sculpture after Sulla. In: HOFF, M. C.; ROTROFF, S. (eds.). The Romanization of Athens. Oxford: Oxford University Press, 1997, pp. 81-95.

PAPAZARKADAS, N. Sacred and Public Land in Ancient Athens. Oxford: Oxford University Press, 2011.

PARKER, R. Athenian Religion: a History. Oxford, Oxford University Press, 1997. Polytheism and Society at Athens. Oxford, Oxford University Press, 2005.

PATTERSON, J. The City of Rome: From Republic to Empire. The Journal of Roman Studies, v. 82, pp. 186-215, 1992.

PAYNE, M. J. Aretas eneken: honors to Romans and Italians in Greece, from 260 to 27

B. C. Dissertation, Michigan State University, 1984.

PHANG, S. E. Roman Military Service. Ideologies of Discipline in the Late Republic and Early Principate. Cambridge : Cambridge University Press, 2008.

PELEKIDIS, Chr. Histoire de l'éphébie attique des origines à 31 avant Jésus-Christ. Paris : Éd. De Boccard, 1962.

PELLING, C. Fun with fragments. In: BRAUND, D.; WILKINS, J. (eds). Athenaeus and his world: Reading Greek Culture in the Roman Empire. Exeter: University of Exeter Press, 2000, 171-190.

PEPPAS-DELMOUSOU, A statue base for Augustus. AJP, 1979.

PEREIRA, M H. R. Pausanias and the Roman conquerors. Humanitas, v. 63, pp. 17584, 2011.

PERRIN, E. Héracleidès le Crétois à Athènes : les plaisirs du tourisme culturel. Revue des Études Grecques, t. 107, f. 509-510, pp. 192-202, 1994.

PERRIN-SAMINADAYAR, É. Images, statut et accueil des étrangers à Athènes à l'époque hellénistique. In : NOURRISSON, D. ; PERRIN, Y. (ed). Le barbare, 
l'étranger: images de l'autre. Saint-Étienne: Publications de l'Université de Saint-Étienne, 2005, pp. 67-91.

PIPPIDI, D. (éd.). Assimilation et résistance à la culture gréco-romaine dans le monde ancien. Bucurest/Paris, Editura Academiei/Les Belles Lettres, 1976.

PINTO, R. Arqueologia e romanização: os discursos arqueológicos e a cultura material da Bretanha romana. Dissertação. Universidade de São Paulo, 2003.

POLACCO, L. Cronologia del portico presso l'Odeo di Erode Attico e i porticus eumenicae. Memorie (Istituto veneto di scienze, lettere ed arti), n. 3, pp. 4-53, 1954.

POLINSKAYA, I. A Local History of Greek Polytheism. Gods, People and the Land of Aigina, 800-400 BCE. Leiden: Brill, 2013.

PONDER, R. A Hellenistic Arsenal in Athens. Hesperia, v. 52. n. 3, pp. 233-256, 1980.

PRETZLER, M. Travel and Travel Writing. In: BOYS-STONES, G.; GRAZIOSI, B.;

VASUNA, Ph. (eds.). The Oxford Handbook of Hellenic Studies. Oxford, Oxford University Press, 2009, pp. 352-362.

PRICE, S. R. F. Rituals and Power. The Roman Imperial Cult in Asia Minor. Cambridge, Cambridge University Press, 1984.

PRICHETT, W. K. An Unfinished Inscription, IG II2 2362. Transactions and Proceedings of the American Philological Association, v. 85, pp. 159-167, 1954.

PURCELL, N. "Roman Forum (The Republican Period). In: Lexicon Topographicum Urbis Romae. Vol. 2. Rome. 1995a.

. Roman Forum (Imperial Period). In: Lexicon Topographicum Urbis Romae. Vol.2 Rome, 1995.

RAAFLAUB, K.; TOHER, M. (eds). Between Republic and Empire. Interpretations of Augustus and his principate. Berkeley and Los Angeles, University of California Press, 1990.

RADT, W. Pergamon: Geschichte und Bauten einer antiken Metropole. Darmstadt, Primus Verlag, 1999.

RAUBITSCHEK, A. E. "Hadrian as the son of Zeus Eleutherios". In: American Journal of Archaeology 49, pp. 128-133, 1945.

. Octavia's Deification at Athens. Transactions and Proceedings of the American Philological Association, v. 77, pp. 146-150, 1946. 
Sylleia. In: COLEMAN-NORTON, P.; BOURNE, F.; FINE, J. (eds). Studies in

Roman economic and social history in honor of Allan Chester Johnson.

Princeton, Princeton University Press, 1951, pp. 49-57.

. Demokratia. Hesperia 31, 238-243, 1962.

RAWSON, E. Caesar's Heritage: Hellenistic Kings and Their Roman Equals. Journal of Roman Studies, vol. 65, pp. 148-159, 1975a.

Architecture and Sculpture: The Activities of the Cossutii. Papers of the British School at Rome, v. 43, pp. 36-47, 1975.

. Cicero and the Areopagus. Athenaeum, v. 63, a. 73, pp. 44-67, 1985a.

Intellectual life in the Late Roman Republic. London, Duckworth, 1985b.

REINMUTH. An ephebic text of ca. 43/2 b.c. Hesperia, v. 34, n. 4.

REPÚBLICA DA GRÉCIA. Navigating the routes of art and culture: Athens, suburbs, attica, cultural events. Athens: Hellenic Republic Ministry of Culture and Sports Archaeological Receipt Funds ; ICOM Hellenic National Committee, 2014.

REVELL, L. Roman imperialism and local identities. Cambridge, Cambridge University Press, 2009.

RICOEUR, P. Interpretação e Ideologias. Rio de Janeiro: Francisco Alves, 1990.

RIDGWAY, B. S. Roman Copies of Greek Sculpture. The Problem of the Originals. Ann Arbor, The University of Michigan University Press, 1984.

. Hellenistic Sculpture I: The Styles of ca. 331-200 B.C. Madison: The University of Wisconsin Press, 2001.

ROBERT, L.; ROBERT, J. Bulletin épigraphique. In: Revue des Études Grecques, t. 86, fasc. 409-410, pp. 48-211, 1973.

ROBERTS, E. S.; GARDNER, E. A. An Introduction to Greek Epigraphy: The Inscriptions of Attica. Cambridge, 1905.

ROBERTSON, N. The Ancient Mother of the Gods. In LANE, L. (ed.). Cybele, Attis and Related Cults. Leiden: Brill, 1996, 239-304. . The City Center of Archaic Athens. Hesperia, v. 67, n. 3, pp. 283-302, 1998.

ROCHETTE, B. 'PSMAIA. Maia, v. 50, n. 2, pp. 253-256, 1998.

RODDAZ, J.-M. Marcus Agrippa. Paris: Boccard, 1984.

RÖDEL, C. Von Lucius Aemilius Paulus zu Augustus. Stiftungen von Römern in Athen. In: KRUMEICH, R. ; WITSCHEL, C. (eds.). Die acropolis von Athen im Hellenismus und in der römischen Kaizerzeit. Düsseldorf, Reichert Verlag Wiesbaden, 2010, pp. 95-115. 
ROMAN, D.; ROMAN, Y. Rome et l'hellénisme. IIIe-Ier siècle av. J.-C. Paris: Ellipses, 2005.

ROMANO, D. The Panathenaic Stadium and Theater of Lykourgos: A Re-Examination of the Facilities on the Pnyx Hill. American Journal of Archaeology, v. 89, n. 3, pp. 441-454, 1985.

ROSE, C. “The Imperial Image in the Eastern Mediterranean”. ALCOCK, S. (ed). The Early Roman Empire in the East. Oxford: Oxbow, 1997, pp. 108-120. . The Parthians in Augustan Rome. American Journal of Archaeology, v. 109, n. 1, pp. 21-75, 2005.

ROSTOVTZEFF, Michael I. Historia Social y Econômica del Império Romano. 2 vols. Madrid: Espasa-Calpe, S.A., 1937.

_. Social \& Economic History of the Hellenistic World. 3 vols. Oxford: Clarendon Press, 1941.

ROSTROFF, S. An Anonymous Hero in the Athenian Agora. Hesperia, v. 47, n. 2, pp. 196-209, 1978.

ROUSSEL, P. Délos, colonie athénienne. Paris: de Boccard, 1916.

RUBENSTEIN, L. HANSEN, M.; NIELSEN, T. VESTERGAARD, T.; BJERTRUP, L. Adoption in Hellenistic and Roman Athens. Classica et Mediaevalia, vol. 42, p. 139-151, 1991.

RUTHERFORD, I. Tourism and the Sacred: Pausanias and the Traditions of Greek Pilgrimage. In: ALCOCK, S.; CHERRY, J.; ELSNER, J. Pausanias: Travel and Memory in Roman Greece. Oxford: Oxford University Press, 2001, pp. 40-52.

SANTANGELO, F. Sulla, the Elites and the Empire. A Study of Roman Policies in Italy and the Greek East. Leiden/Boston: Brill, 2007.

SAPRYKIN, S. J. The Religion and Cults of the Pontic Kingdom: Political Aspects. In: HOJTE, J. M. (ed.). Mithridates VI and the Pontic Kingdom. Aarhus: Aarhus University Press, 2009, pp. 249-276.

SARTRE, Maurice. Le Haute-Empire Romain. Les provinces de Méditerranée orientale d'Auguste aux Sévères. Paris : Seuil, 1991.

. El Oriente Romano. Provincias y sociedades provinciales del Mediterráneo Oriental. De Augusto a los Severos (31a.C. - 235 d.C.). Madrid: Akal Ediciones, 1994.

SAURON, G. Les propylées d'Appius Claudius Pulcher à Éleusis : 1'art neo-attique dans les contradictions idéologiques de la noblesse romaine à la fin de la 
République. In: MARC, J.-Y. ; MORETTI, J.-C. (éds). Constructions publiques et programmes édilitaires en Grèce, Paris / Athènes, De Boccard / École Française d'Athènes, 2001, pp. 267-283.

SCHÄFER, T. (1998). Spolia et signa: Baupolitik und Reichskultur nach dem Parthererfolg des Augustus. Göttingen: Vandenhoeck \& Ruprecht 1998.

SCHALLES, H.-J. Die Hellenistische Umgestaltung der Athener Agora im 2. Jh. V. Chr. - Ausdruck von Rationalität oder Entpolitisierung? In: Hephaistos, v. 4, pp. 97-116, 1982.

SCHIFFER, M. Archaeological context and Systemic context. American Antiquity, v. 37, pp. 156-165, 1972.

. Formation Processes of the Archaeological Record. Salt Lake City: University of Utah Press 1987.

SCHLAIFER, R. Notes on Athenian Public Cults. Harvard Studies in Classical Philology, v. 51, pp. 233-260, 1940.

. The Cult of Athena Pallenis: (Athenaeus VI 234-235). Harvard Studies in Classical Philology, v. 54, pp. 35-67, 1943.

SCHMALZ, G. Public Building and civic identity in Augustan and Julio-Claudian Athens. Dissertation, University of Michigan, 1994.

. Athens, Augustus, and the Settlement of 21 B.C. Greek, Roman and Byzantine Studies, v. 37, pp. 381-398, 1996.

. The Athenian Prytaneion Discovered? Hesperia, v. 75, n. 1, pp. 33-81, 2006. . Inscribing a ritualized past: restoration decree IG II2 1035 and cultural memory in Augustan Athens. Eulimene (Rethymno-Grécia), v. 8-9, pp. 9-46, 2007-2008. . Augustan and Julio-Claudian Athens. A New Epigraphy and Prosopography. Leiden / Boston, Brill, 2009.

SCHUBERT, P. Strabon et le sort de la bibliothèque d'Aristote. Les Études Classiques (Namur), v. 70, n. 3, 2002, pp. 225-237.

SEBASTIANI, B. Bélica lição polibiana. Tese de doutorado, Universidade de São Paulo, 2006.

SHAW, B. Chalenging Braudel: a new vision of the Mediterranean. In: Journal of Roman Archaeology, 14, pp. 419-453, 2001.

SHEAR, J. L. Polis and Panathenaia: The history and development of Athena's festival. Dissertation, University of Pennsylvania, 2001. 
. Reusing statues, rewriting inscriptions and bestowing honours in Roman Athens. In: NEWBY, Z.; LEADER-NEWBY, R. E. Art and inscriptions in the Ancient World. Cambridge: Cambridge University Press, 2007, pp. 221-46.

SHEAR, T. L. The campaign of 1936. In: Hesperia, v. 6, n. 3, pp. 333-381, 1937. . The campaign of 1937. In: Hesperia, v. 7, n. 3, pp. 311-362, 1938.

SHEAR JR., T. L. The Monument of the Eponymous Heroes in the Athenian Agora. Hesperia, v. 39, n. 3, pp. 145-222 e pl. 41-58, 1970.

. The Athenian Agora: Excavations of 1971. Hesperia, v. 42, n. 2, pp. 121-179, 1973.

. Athens: from city-state to provincial town. Hesperia, v. 50, n. 4, pp. 356-77, 1981.

. The Athenian Agora: Excavations of 1980-1982. Hesperia, v. 53, n. 1, pp. 1$57,1984$.

SHERWIN-WHITE, A. N. Ariobarzanes, Mithridates, and Sulla. The Classical Quarterly, v. 27, n. 1, 1977, pp. 173-183.

SIELHORST, B. "Hellenistic agorai. Formation, Reception and Semantics of an Urban Space”. In: The Agora in the Mediterranean, from Homeric to Roman Times. Athens, Ministry of Culture and Tourism / Archaeological Institute of Aegean Studies, 2011, pp. 31-46.

SILVA, B. Romanização e os séculos XX e XXI: a dissolução de um conceito. Mare Nostrum, n. 2, pp. 1-19, 2011.

SILVA, M. Plutarco e Roma: o mundo grego no Império. Tese de doutorado. Universidade de São Paulo, 2007.

SILVA, U. G. A Antiguidade Tardia como forma da História. Anos 90, v. 16, n. 30, pp. 77-108, 2009.

SILVA, T. (org). Identidade e Diferença: a perspectiva dos Estudos Culturais. Trad. Tomaz Tadeu da Silva. 10. ed. Petrópolis, RJ: Vozes, 2011.

SKIBO, J.; SCHIFFER, M. People and Things. A Behavioral Approach to Material Culture. New York: Springer-Verlag, 2008.

SIMONETTA, B. Notes on the Coinage of the Cappadocian kings. The Numismatic Chronicle and Journal of the Royal Numismatic Society (seventh series), v. 1, pp. 9-50, 1961.

SMELAKOVA, T. N. The Earliest Application of Brass and "Pure" Copper in the Hellenistic Coinages of Asia Minor and the Northern Black Sea Coast. In: 
HOJTE, J. M. (ed.). Mithridates VI and the Pontic Kingdom. Aarhus: Aarhus University Press, 2009, pp. 233-248.

SMITH, R. R. R. Greeks, Foreigners, and Roman Republican Portraits. In: The Journal of Roman Studies, v. 71, pp. 24-38, 1981.

. "Cultural Choice and Political Identity in Honorific Portraits Statues in the Greek East in the Second Century A.D.". In: The Journal of Roman Studies, v. 88, 1998, pp. 56-93.

SNODGRASS, A. An Archaeology of Greece: The Present State and Future Scope of a Discipline. Berkeley and Los Angeles, University of California Press, 1987.

SOLIN, H.; COARELLI, F. MUSTI, D. (ed.). Delo e l'Italia.(Opuscula Instituti Romani Finlandiae, II, 1982). Rome: Bardi, 1983.

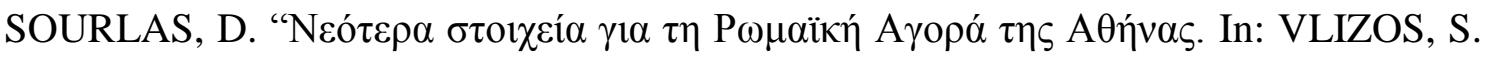

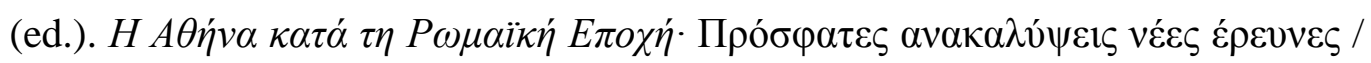
Athens During the Roman Period: Recent Discoveries, New Evidence. Athens, Mouseio Benake, 2008, pp. 99-114.

. L'Agora romaine d'Athènes. Utilisation, fonctions et organisation interieure.

In : CHANKOWSKI, V.; KARVONIS, P. (eds). Tout vendre, tout acheter.Structures et équipementsdes marchés antiques. Actes du colloque d'Athènes, 16-19 juin 2009. Paris : De Boccard, 2012, pp. 119-138.

SOURVINOU-INWOOD, C. Athenian myths and festivals: Aglauros, Erechtheus, Plyntheria, Panathenaia, Dionysia. Oxford: Oxford University Press, 2011.

SPAWFORTH, A. The early cult reception of the imperial cult in Athens: problems and ambiguities. In: HOFF, M. C.; ROTROFF, S. (eds.). The Romanization of Athens. Oxford: Oxford University Press, 1997, pp. 183-201.

. Greece and the Augustan Cultural Revolution. Cambridge: Cambridge University Press, 2012.

; WALKER, S. «The World of Panhellenion 1: Athens and Eleusis ». In: Journal of Roman Studies, 75, pp. 78-104, 1985.

STADTER, Ph. (ed). Plutarch and the Historical Tradition. London: Routledge, 1992.

STAVROPOULOS. 1930-1931. Lozano (livro).

STEFANIDOU-TIVERIOU, Th. Tradition and Romanization in the monumental landscape of Athens. In: VLIZOS, S. Athens during the Roman period. Athens: Mouseio Benaki, 2008, pp. 11-42. 
STEIN-HÖLKESKAMP, E. The Tyrants. In: RAAFLAUB, K.; VAN WESS, H. A Companion to Archaic Greece. Oxford: Blackwell, 2009, pp. 100-116.

STEWART, A. Attalos, Athens and the Akropolis. The Pergamene "Little Barbarians" and their Roman and Renaissance Legacy. Cambridge: Cambridge University Press, 2004.

. Hellenistic Art: Two Dozen Innovations. In: BUGH, G. (ed.). The Cambridge Companion to the Hellenistic World. Cambridge: Cambridge University Press, 2006, pp. 158-185.

STRASBURGER, H. Poseidonios on Problems of the Roman Empire. Journal of Roman Studies, v. 55, n. 1/2, pp. 40-53, 1965.

STROOTMAN, R. The Hellenistic Royal Court. Court Culture, Ceremonial and Ideology in Greece, Egypt and the Near East, 336-30 BCE. Dissertation, University of Utrecht, 2007.

STROUD, R. Inscriptions from the North Slope of the Acropolis (I). In: Hesperia, v. 40, n. 2, pp. 146-204, 1971.

. The Aiakeion and Tholos of Athens in POxy 2087. In: Zeitschrift für Papyrologie und Epigraphik, Bd. 103, pp. 1-9, 1994.

The Athenian Grain-Tax Law of 374/3 B. C. (Hesperia Supplements, vol. 29).

Princeton: The American School of Classical Studies at Athens, 1998.

STUART, E.; REVETT, N. Antiquities of Athens. London: John Haberkorn, 1787.

SUlliVAN, R. The Dinasty of Cappadocia. In: Aufstieg und Niedergang der römischen Welt, II.7.2. Berlin and New York: Walter de Gruyter, 1980, pp. 1159-1161.

SYME, R. The Roman Revolution. Oxford, Clarendon Press, 1939.

TAMURA, T. Les artistes dionysiaques et la première guerre de Mithridate. In: YUGE, T.; DOI, M. (ed). Forms of control and subordination in Antiquity. Tokyo: The Society for Studies on Resistance Movements in Antiquity, 1988.

TITCHENER, F. Cornelius Nepos and the Biographical Tradition. Greece \& Rome, s. 2, v. 50, n. 1, 2003, pp. 85-99.

THAKUR, S. Identity under Construction in Roman Athens. In: YOFFEE, N. (ed). Negotiating the Past in the Past. Identity, Memory, and Landscape in Archaeological Research. Tucson: The University of Arizona Press, 2008, pp. 104-127. 
THEOCHARAKI, A. M. The Ancient Circuit Wall of Athens: Its Changing Course and the Phases of Construction. Hesperia, v. 80, n. 1, pp. 71-156, 2011.

THOMPSON, H. The Pnyx in Athens. Hesperia, v. 1, pp. 90-217, 1932.

. "Buildings on the West Side of the Agora". Hesperia, v. 6, n. 1, pp. 1-226, 1937.

. The Excavation of the Athenian Agora Twelfth Season: 1947. Hesperia, v. 17, pp. 149-196, 1948.

. The Odeion in the Athenian Agora. Hesperia, v. 19, n. 2, 31-141, 1950.

Excavations in the Athenian Agora: 1951. Hesperia, v. 21, pp. 83-113, 1952a.

. The Altar of Pity in the Athenian Agora. Hesperia, v. 21, n. 1., pp. 47-82, $1952 b$.

. The Agora at Athens and the Greek Market Place. Journal of the Society of Architectural Historians, v. 13, n. 4, pp. 9-14, 1954.

. The Annex to the Stoa of Zeus in the Athenian Agora. Hesperia, v. 35, n. 2, pp. 171-187, 1966.

Activity in the Athenian Agora: 1966-1967. In: Hesperia, v. 37, n. 1, pp. 36-72, 1968

.; WYCHERLEY, R. The agora of Athens: the History, Shape and Uses of an Ancient city center (The Athenian Agora XIV). Princeton: The American School of Classical Studies at Athens, 1972.

THOMPSON, M. The New Style Silver Coinage of Athens. New York, The American Numismatic Society, 1961.

TOFI, M. L'Odeion di Pericle. In: GRECO, E. (a.c.). Topografia di Atene : sviluppo urbano e monumenti dalle origini al III secolo d.C. Tomo 1. Atene / Paestum: Pandemos, 2010, pp. 161-163.

TÖLlE-KASTENBEIN, R. Das Olympieion in Athen. Wien: Böhlau Verlag, 1994.

TORELLI, M. L'immagine dell'ideologia augustea nell'agora de Atene. In: Ostraka, anno 4, n. 1, pp. 9-32, 1995.

Attorno al Chalcidicum : problemi di origine e diffusione. In: LAFON, X. ;

SAURON, G. Théorie et pratique de l'architecture romaine. Etudes offertes à Pierre Gros. Aix-en-Provence : Publications de l'Université de Provence, 2005, p. 23-37.

TOWNSEND, R. The East Side of the Agora: the remains beneath the Stoa of Attalos. Princeton, The American School of Classical Studies at Athens, 1995. 
TRACY, S. Athens in 100 B.C. Harvard Studies in Classical Philology, v. 83, pp. 213235, 1979.

IG II2 2336. Contributors of the First Fruits for the Pythais. Königstein/Ts.: Hain, 1982.

. Athens and Macedon: Attic Letter-Cutters of 300 to 229 B.C. Berkeley: University of California Press, 2003.

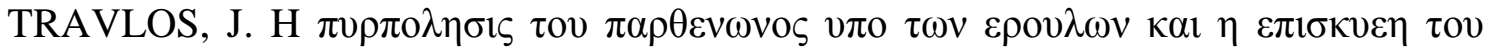

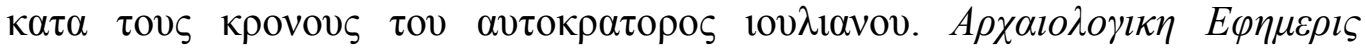
(Atenas), pp. 218-236, 1973.

. Pictorial dictionary of Ancient Athens. New York: Praeger, 1971. . Athens after the Liberation: Planning the New City and Exploring the Old. In: Hesperia, v. 50, n. 4 (Greek Towns and Cities: A Symposium), pp. 391-407, 1981.

.; THOMPSON, H. The West side of the Athenian Agora restored. In: Hesperia Supp.v. 8, pp. 382-490, 1949.

VAN BERCHEM, D. Les Italiens d'Argos et le déclin de Délos. In: Bulletin de correspondance hellénique. v 86, 1. 1, pp. 305-313, 1962.

VANDERPOOL, E. “Athens Honor the Emperor Tiberius”. In: Hesperia, 28, pp. 86-90, 1959.

VAN DOMMELEN, P. Fetishizing the Romans. Archaeological Dialogues, v. 21, n. 1, pp 41-45, 2014.

VAN NIJF, O. ; ALSTON, R. Political culture in the Greek city after the classical age: introduction and preview. In: VAN NIJF, O.; ALSTON, R.; WILLIAMSON, C. (eds). Political culture in the Greek city after the Classical age. Leuven, Paris, Walpole: Peeters, 2011, pp. 1-26.

VERDEJO MANCHADO, J.; ANTELA-BERNARDEZ, B. IG II2 1334: a Crown for Onaso and the Archon Athenion. Zeitschrift für Papyrologie und Epigraphik, v. 177, pp. 91-962011.

. Medeios at the Gymnasium. Zeitschrift für Papyrologie und Epigraphik, v. 186, pp. 134-140, 2013.

VERMEULE, C. C. Roman Imperial Art in Greece and Asia Minor.Cambridge, 1968.

VERSLUYS, M. Understanding objects in motion. An archaeological dialogue on Romanization. Archaeological Dialogues, v. 21, n. 1, pp 1-20, 2014. 
. Getting out of the comfort zone. Reply to responses. Archaeological Dialogues, v. 21, n. 1, pp 50-64, 2014.

VEYNE, P. Panem et circensis. L'évergétisme devant les sciences humaines. Annales, 24, n. 3, pp. 785-825, 1969.

. Le pain et le cirque : sociologie historique d'un pluralism politique. Paris : Le Seuil, 1976.

. L'hellénisation de Rome et la problématique des acculturations. Diogène, n. 106, pp. 3-29, 1979.

. L’Empire Gréco-Romain. Paris: Éditions du Seuil, 2005.

VIAL, C. Les Grecs, de la paix d'Apamée à la bataille d'Actium. Paris, Seuil, 1995.

VIAN, F.; MOORE, M. Gigantes. In: Lexicon Iconographicum Mythologiae Classicae. (Eros-Herakles). Zürich, München, Düsseldorf: Artemis \& Winkler Verlag, 1988, pp. 191-270.

VLASSOPOULOS, K. Unthinking the Greek Polis: Ancient Greek History beyond the Eurocentrism. Cambridge: Cambridge University Press, 2007. . Greeks and Barbarians. Cambridge: Cambridge University Press, 2013.

VLIZOS, S. (ed.). He Athene kata te Romaike epoche: Prosphates anakalypseis, nees ereunes / Athens During the Roman Period: Recent Discoveries, New Evidence. Athens, Mouseio Benake, 2008.

WALBANK. Polybius, Rome and the Hellenistic World: Essays and Reflections.

Cambridge: Cambridge University Press, 2002.

Fortune (Tyché) in Polybius. In: MARINCOLA, J. (org.). A Companion to Greek and Roman Historiography. Oxford: Blackwell, 2007, pp. 349-355.

WALKER, H.J. Theseus and Athens. Oxford: Oxford University Press, 1995.

WALKER, S. A Sanctuary of Isis on the South Slope of the Athenian Acropolis. In: The Annual of the British School at Athens, v. 74, pp. 243-258, 1979.

Athens under Augustus. In: HOFF, M. C.; ROTROFF, S. (eds.). The Romanization of Athens. Oxford: Oxford University Press, 1997, pp. 67-80.

. The Moral Museum: Augustus and the city of Rome. In: COULSTON, J.; HAZEL, D. (eds.). Ancient Rome. The Archaeology of the Eternal City. Oxford: Oxford University School of Archaeology, 2000, pp.61-75.

.; CAMERON, A. (eds.). The Greek Renaissance in the Roman Empire. London:

University of London, 1989. 
WALlACE-HADRILL, A. Rome's Cultural Revolution. Cambridge: Cambridge University Press, 2008.

WATSON, J. Rethinking the Sanctuary of Aphaia. In: FEARN, D. (ed.). Aegina: Contexts for Choral Lyric Poetry. Oxford: Oxford University Press, 2011, pp. $79-113$

WELCH, K. T. Pomponius Atticus: A Banker in Politics? Historia: Zeitschrift für Alte Geschichte, vol. 45, n. 4, pp. 450-471, 1996.

WILKINS, J. Athenaeus the Navigator. Journal of Hellenic Studies, v. 128, pp. 132152 , nov/2008.

WILKINSON, L. P. Cicero and the relationship of oratory to literature. In: KENNEY, E. J.; CLAUSEN, W. V. The Cambridge history of Classical Literature. V. 2 (Latin Literature). Cambridge, Cambridge University Press, 1982, pp. 230-267.

WILL, E. Histoire politique du monde hellénistique : 323-30 av. J.-C. 2 vols. Paris, Seuil, 2003. [1 ${ }^{\mathrm{a}}$. ed.1966-1967, 2a . ed. 1979-1982].

WILLIAMS, K. A re-evaluation of Temple E and the West End of the Forum of Corinth. In: WALKER, S.; CAMERON, A. (eds). Greek Renaissance in the Roman Empire. Papers from the Tenth British Museum Classical Colloquium. London : University of London, Institute of Classical Studies, 1989, pp. 156162.

WINSTEDT, E. Chronological Order of the Letters. In: CICERO, M. T. Letters to Atticus, v. 3. London / Cambridge: William Heinemann / Harvard University Press, 1961, pp. 44-448.

WINTER, F. Studies in Hellenistic Architecture (Phoenix Supplementary Volumes). Toronto: University of Toronto, 2006.

WINTERLING, A. Politics and Society in Imperial Rome. Malden, MA/Oxford/Chichester: Wiley-Blackwell, 2009.

WHITTAKER, H. Some reflections on the temple to the Goddess Roma and Augustus on the Acropolis of Athens. In: OSTENFELD, E. (ed). Greek Romans and Roman Greeks: Studies in Cultural Interaction. Aarhus: Aarhus University Press, 2002, pp. 25-39.

WOLF, M. Appian, the Rise of Rome, and Monarchy: An Analysis of the Romaika through the Portrayal of Africanus and Aemilianus. Thesis, Willians College (Massachusetts), 2004. 
WOOLF, G. Becoming Roman, Staying Greek: culture, identity and the civilizing process in the Roman East. Proceedings of the Cambridge Philological Society; 40:116-43, 1994. . Becoming Roman: The Origins of Provincial Civilization in Gaul. Cambridge: Cambridge University Press, 1998. . Inventing empire in Ancient Rome. In: ALCOCK, S.; D’ALTROY, T.; MORRISON, K.; SINOPOLI, C. (eds). Empires. Perspectives from Archaeology and History, Cambridge, Cambridge University Press, 2001, pp. 311-322. Romanization 2.0 and its alternatives. Archaeological Dialogues, v. 21, n. 1, pp 45-50, 2014.

WYCHERLEY, R. E. Literary and Epigraphical Testimonia (The Athenian Agora, v. 3). Princeton: The American School of Classical Studies, 1957. . The garden of Epicurus. Phoenix, v. 13, 1959, pp. 73-77. . How the Greek built cities. 2a. ed. London: MacMillan Press, 1962. . The Olympieion at Athens. Greek, Roman, and Bzyantine Studies, v. 5, n. 3, 161-179, 1964. . The stones of Athens. Greece \& Rome, v. 21, n. 1, pp. 54-67, 1974. . The stones of Athens. Princeton: Princeton University Press, 1978.

YOUNG, R. An industrial district of Ancient Athens. Hesperia, v. 20, n. 3, pp. 135-288 1951.

ZANKER, P. The power of images in the age of Augustus. Ann Arbor, University of Michigan Press, 1988.

ZORIDI, P. Two New Roman Portraits from Athens. American Journal of Archaeology, v. 88, n. 4, pp. 592-594, 1984.

ZUIDERHOEK, A. The politics of munificence in the Roman Empire. Cambridge, Cambridge University Press, 2009. 